Universidade de São Paulo

FaCuldade de Filosofia, Letras e CiênCias Humanas

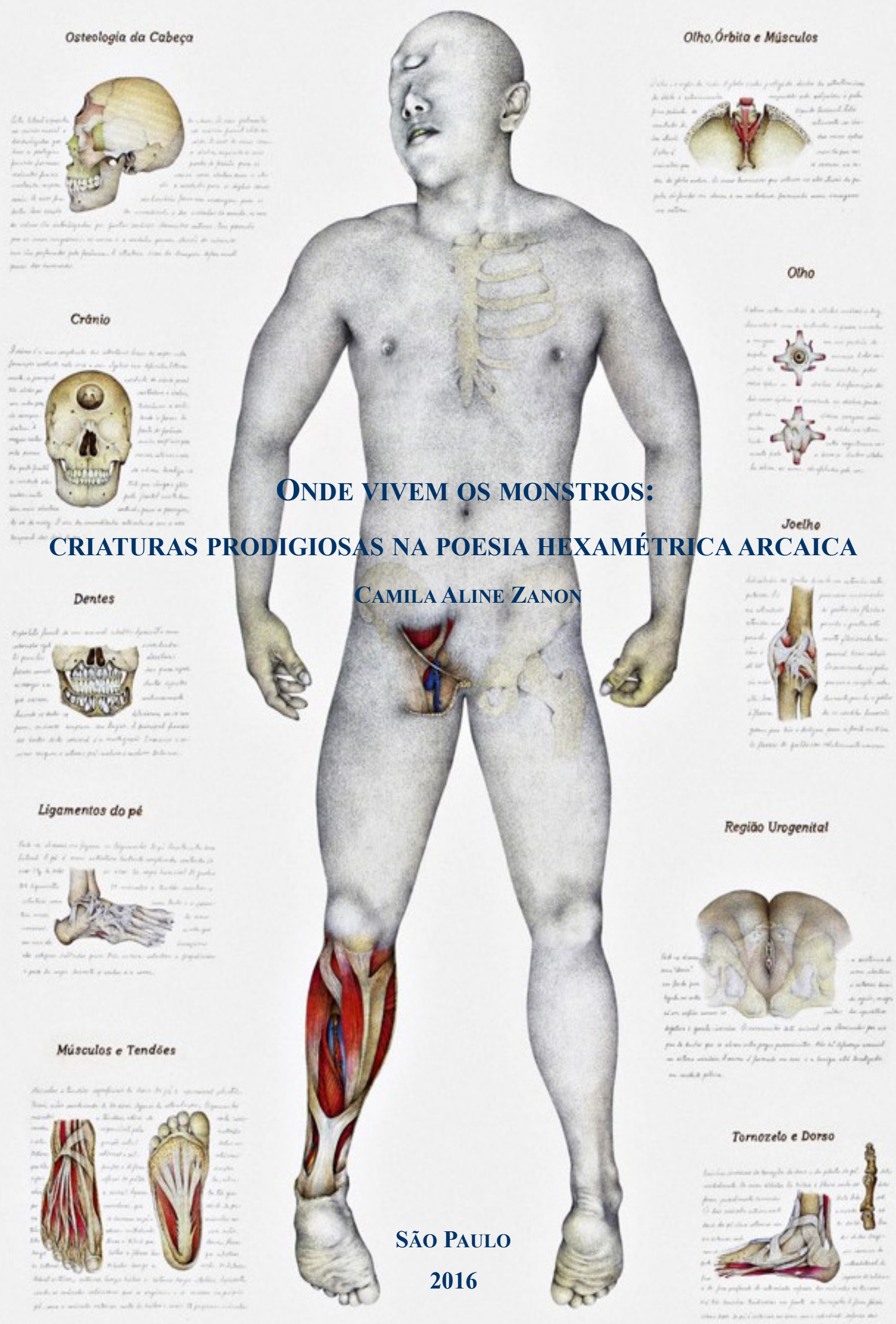




\section{Universidade de São Paulo}

Faculdade de Filosofia, Letras e Ciências Humanas

ONDE VIVEM OS MONSTROS:

CRIATURAS PRODIGIOSAS NA POESIA HEXAMÉTRICA ARCAICA

CAMila Aline ZANON

Tese apresentada à Faculdade de Filosofia, Letras e Ciências Humanas da Universidade de São Paulo para obtenção do título de Doutor em Letras Clássicas

Orientador: Prof. Dr. Christian Werner

SÃo PAUlo 
Autorizo a reprodução e divulgação total ou parcial deste trabalho, por qualquer meio convencional ou eletrônico, para fins de estudo e pesquisa, desde que citada a fonte.

Catalogação na Publicação

Serviço de Biblioteca e Documentação

Faculdade de Filosofia, Letras e Ciências Humanas da Universidade de São Paulo

Z330

Zanon, Camila Aline

Onde vivem os monstros: criaturas prodigiosas na poesia hexamétrica arcaica / Camila Aline Zanon ; orientador Christian Werner. - São Paulo, 2016. $312 \mathrm{f}$.

Tese (Doutorado)- Faculdade de Filosofia, Letras e Ciências Humanas da Universidade de São Paulo. Departamento de Letras Clássicas e Vernáculas. Área de concentração: Letras Clássicas.

1. Literatura grega clássica. 2. Antiguidade clássica. 3. Poesia Épica. 4. Monstros. I. Werner, Christian, orient. II. Título. 
ZANON, Camila Aline. Onde vivem os monstros: criaturas prodigiosas na poesia hexamétrica arcaica. Tese de doutorado em Letras Clássicas. São Paulo: Universidade de São Paulo, 2016. 312 p.

\author{
Banca Examinadora
}

Prof. Dr. Christian Werner (USP)

Prof. Dr. Adriane da Silva Duarte (USP)

Prof. Dr. Norberto Luiz Guarinello (USP)

Prof. Dr. Gilberto da Silva Francisco (UNIFESP)

Prof. Dr. Carlos Henrique Barbosa Gonçalves (USP)

Prof. Dr. Breno Battistin Sebastiani (USP) - suplente

Prof. Dr. André Malta Campos (USP) - suplente

Prof. Dr. Flavio Ribeiro de Oliveira (UNICAMP) - suplente

Prof. Dr. Maria Beatriz Borba Florenzano (USP) - suplente

Prof. Dr. Paulo Sérgio de Vasconcellos (UNICAMP) - suplente de de 2016. 
A minha mãe (em memória) e a meu pai, exemplos de honestidade, generosidade e resiliência.

A Uiran Gebara da Silva, companheiro que nunca perde a ternura ao longo de nossa jornada pelo multiverso. 


\section{AGRADECIMENTOS}

Ao longo dos quatro anos dedicados a esta tese, muitos foram os que com ela colaboraram, seja direta ou indiretamente. Agradeço a meu orientador, Christian Werner, por todo o apoio ao longo da pesquisa, pelas inúmeras sugestões, pela leitura sempre atenta, sua crítica contumaz, disponibilidade e capacidade de preservar e estimular minha independência intelectual como pesquisadora. Tê-lo como orientador foi um privilégio pelo qual serei sempre grata. Qualquer qualidade que se possa notar nesta tese não teria sido possível sem suas contribuições e sem o grande respeito com que ele tratou este trabalho.

Agradeço ao professor Jim Marks pelas preciosas sugestões e pelo entusiasmo que mostrou diante do tema. Foi também um privilégio ter a oportunidade de assistir à disciplina de pós-graduação acerca dos Hinos Homéricos que ministrou na Faculdade de Filosofia, Letras e Ciências Humanas (FFLCH-USP), a convite do professor Christian Werner, em 2012.

Aos professores André Malta Campos e Adriane da Silva Duarte expresso minha gratidão por terem constituído a banca de qualificação em 2014, propondo questões importantes acerca do assunto. O interesse que demonstraram pelo trabalho foi um grande estímulo para o desenvolvimento desta tese.

Aos professores Breno Battistin Sebastiani e Adriano Ribeiro, por terem participado da banca avaliadora do projeto que originou esta tese e por terem-no julgado merecedor do primeiro lugar dentre os projetos então selecionados.

Ao professor Adrian Kelly, que não apenas possibilitou minha estadia de seis meses em Oxford, mas garantiu que eu tivesse o melhor ambiente de pesquisa possível, providenciando o acesso à Sackler com seu acervo especializado em Clássicas, à Bodleian, com seu andar inteiro dedicado a esta área, e à biblioteca particular do Balliol College. Graças ao professor Kelly, pude desfrutar do status de Research Associate no Holywell Manor, centro de pós-graduandos do Balliol College, bem como o de Academic Visitor no Ioannou Centre for Classical and Byzantine Studies (Faculty of Classics). A ele devo minha primeira experiência de longo prazo em um ambiente acadêmico internacional, do qual esta tese se beneficiou enormemente. Sua generosidade ímpar aliada a sua competência acadêmica e a seu humor inteligente o tornam uma figura rara no mundo acadêmico. Sua contribuição transcende o conteúdo deste trabalho e certamente me acompanhará pela vida inteira.

À Capes (Coordenação de Aperfeiçoamento de Pessoal de Nível Superior) por ter possibilitado minha estadia de seis meses em Oxford por meio do Programa de Doutorado 
Sanduíche no Exterior (PDSE) e pelos três meses de bolsa no país no início do doutorado, e à FAPESP, que financiou 33 dos 48 meses totais de pesquisa.

Não poderia deixar de agradecer ao pessoal do Balliol Hall, onde pude usufruir de um menu caprichado ao longo dos meses que permaneci em Oxford: ao Alexander, à Alma, e às gêmeas Blanca e Lidia, pela atenção e pelo carinho com que me trataram sempre. Aos funcionários da Sackler, Andrea e Len, por terem sido tão solícitos e bem-humorados.

Ao pessoal do Nooc (North Oxford Overseas Centre) por ter me abrigado e me tratado com muita gentileza: Elita, Daniel, Tim, Lesley e Julie. Ao mau humor do Dave, que fazia companhia para o meu mau humor todas as manhãs. Às pessoas que conheci no Nooc, que, como eu, estavam lá desfrutando das maravilhas oxfordianas: a Suelen Carls (Santa Catarina) e a Louise (Bélgica), pela doçura e pelo carinho, a Lakshmy Venkatesh (Índia), pelo carinho e por ter me ensinado a cozinhar cogumelos crocantes por fora e macios por dentro, a Paola Solimena (Ítalo-Germano-Americana) e a Rosa Stopler (Holanda) pelas prazerosas conversas inteligentes. Às grandes amizades de Wasim Khalid (Cachemira), Fernando (Pernambuco), Rodrigo Carro (Rio de Janeiro), Santiago (Galícia). Um agradecimento especial e cheio de saudade a Nilüfer Peker e Hülya Cosgunaras Sahna (ambas da Turquia) e a Pinelopi Flaouna (Grécia), amizades para a vida inteira.

Ao Juca e à Thais Rocha, pelos jantares no St. Benet's College e por terem sido meu porto seguro em Oxford. Vocês são sensacionais, meus caros.

Minha experiência em Oxford foi, sem dúvida, muito enriquecida por todas essas pessoas que me permitiram fazer parte de suas vidas e que passaram a ser parte da minha.

Aos meus amigos daqui, aqueles que, mesmo longe estão sempre por perto: Livia Oushiro; Pedro Toledo; Tiago Attorre; Tiago Pessoa; Veruska Guimarães; Ranulpho Souza; Carol Spinelli; Marta Maria, amiga de infância e muito querida; e Carla Hermann que, além de ter me visitado em Oxford, me apresentou a fantástica obra de Walmor Corrêa.

Aos queridos Luciano Ferreira, Gilberto da Silva Francisco e Lucia Sano, amizades que são um enorme incentivo para a minha permanência na área de Estudos Clássicos.

Aos colegas do LEIR-MA (Laboratório de Estudos do Império Romano e Mediterrâneo Antigo): Juliana Monzani, Sarah Azevedo, Gaya Gicovate, Aline Saes, Pedro Piza, Gabriel Cabral, Renan Teruya, Fabrício Sparvoli, Fabio Morales, Bruno dos Santos e, especialmente, Gustavo Junqueira, homerista sempre entusiasmado e disposto a escandir hexâmetros. Um agradecimento enorme ao professor Norberto Luiz Guarinello, por ter me aceito em seu laboratório, dando-me a oportunidade de participar do fértil ambiente de debate 
acadêmico que o LEIR-MA proporciona. Esta tese certamente não teria sido possível sem o diálogo com eles.

Ao meu avô (em memória), a meus tios Nelson e José, a minha tia Maria Elizabete, a meu pai e minha irmã, por seu amor incondicional e por me permitirem existir no sentido mais pleno do termo. As minhas avós Clélia e Ana, a tia Dora e a minha mãe, mulheres que, embora tenham partido muito cedo, ainda conferem sentido a minha existência.

A Nádia Gebara da Silva e a Laila Spinelli por terem me acolhido e me feito parte de sua família. A Maíra Gebara e Guilherme Zambelli por estarem sempre dispostos a compartilhar um vinho.

A Uiran Gebara da Silva, companheiro sem o qual a vida seria pobre em fadas, elfos e dragões. Esta tese é a materialização de seu apoio incondicional e sob muitas formas e de seu incentivo sempre presente. Um companheiro de vida cotidiana, de vida acadêmica, de vida oxfordiana, de vida fantástica.

Por fim, a todos os gigantes a cujos ombros nos alçamos para poder observar mais longe, principalmente aos monstros sagrados cuja estatura me permitiram vislumbrar o que eu não conseguiria sozinha: Haiganuch Sarian, a quem devo grande parte de minha formação como helenista junto com tantos outros que ela formou ao longo de toda a sua carreira dedicada aos Estudos Clássicos no Brasil, e Jenny Strauss Clay, cujo interesse pelos monstros constitui mais uma de suas inúmeras qualidades como classicista. 
Aquele que combate monstros deve cuidar para que ele próprio não se torne um. E se olhar tempo demais para o interior de um abismo, o abismo olha de volta para você.

Friedrich Nietzsche, Além do Bem e do Mal, aforismo 146. 


\section{RESUMO}

ZANON, C. A. Onde vivem os monstros: criaturas prodigiosas na poesia hexamétrica arcaica. 2016. [312 p.]. Tese (Doutorado) - Faculdade de Filosofia, Letras e Ciências Humanas, Universidade de São Paulo, São Paulo, 2016.

O objetivo desta tese é analisar as criaturas amiúde consideradas monstruosas bem como os termos geralmente traduzidos por "monstro" presentes em três poemas da tradição de poesia hexamétrica arcaica, a saber, a Teogonia de Hesíodo, o Hino Homérico a Apolo e a Odisseia de Homero. A análise dessas criaturas tem como foco o modo como são descritas e o papel que desempenham nas narrativas contidas nesses poemas, para a qual são utilizadas como abordagem teórico-metodológica a referencialidade tradicional proposta e desenvolvida por John Miles Foley ao longo da década de 1990 bem como a perspectiva de que os poemas que constituem a tradição hexamétrica arcaica compõem uma história do cosmo, conforme desenvolvida por Barbara Graziosi e Johannes Haubold na década de 2000. Como resultado da análise das criaturas, de um lado, e dos termos traduzidos por "monstro", de outro, questiona-se a pertinência da categoria "monstro" como geralmente pressuposta para essas criaturas no mundo moderno, tendo-se em vista que ela possa não existir na poesia hexamétrica arcaica, já que fazem parte de um sistema de pensamento em um mundo ainda não desencantado em termos weberianos, no qual a realidade empírica e a esfera divina enquanto representativa do sobrenatural estão profundamente imbricadas. Como instrumental teórico-metodológico para o questionamento acerca da existência ou não do monstro enquanto categoria em tal tradição poética, lançou-se mão das teorias de categorização de Wittgenstein, desenvolvida nas décadas de 1940 e 1950, daquelas desenvolvidas por Eleanor Rosch e sua equipe durante a década de 1970, bem como as presentes nas obras de George Lakoff a partir da década de 1980. A proposição de que a categoria "monstro" como pressuposta e entendida no mundo moderno é inexistente para a poesia hexamétrica arcaica tem implicações na compreensão moderna dessas criaturas, que devem ser percebidas enquanto integrantes de um cosmo que não separa o sobrenatural, o maravilhoso e o divino nos mesmos termos que o faz a sociedade moderna ocidental, revelando a necessidade de compreender essas criaturas sob o ponto de vista da tradição que as criou ou as incorporou e ressignificou.

Palavras-chave: Hesíodo; Teogonia; Homero; Odisseia; Hinos homéricos; Hino Homérico a Apolo; poesia hexamétrica arcaica; monstros. 


\begin{abstract}
ZANON, C. A. Where the monsters are: prodigious creatures in archaic hexametric poetry. 2016. [312 pp.]. Thesis (Ph.D.) - Faculdade de Filosofia, Letras e Ciências Humanas, Universidade de São Paulo, São Paulo, 2016.
\end{abstract}

The aim of this thesis is to analyse the creatures often considered monstrous as well as the words generally translated as "monster" in three poems belonging to the tradition of archaic hexametric poetry, namely, Hesiod's Theogony, the Homeric Hymn to Apollo, and Homer's Odyssey. The analysis of the creatures focuses on the ways they are described and the role they play in the narratives presented in those poems. The theoretical and methodological approach used to such analysis is the traditional referenciality proposed and developed by John Miles Foley in the 1990's in addition to the perspective that such poems that inform the archaic hexametric tradition constitute a history of the cosmos, as developed by Barbara Graziosi and Johannes Haubold during the 2000's. The analysis of the creatures, in one hand, and of the words translated by "monster", in the other, results in questioning the validity of the "monster" category as usually taken for granted in the modern world, considering that it might not exist in archaic hexametric poetry, since those creatures are part of a system of thought in a world not yet disenchanted in Weberian terms, in which the empirical reality and the divine sphere as representative of the supernatural are deeply entangled. As theoretical and methodological framework for questioning the existence of "monster" as a category in such poetical tradition, this thesis adopted the theories of categorization formulated by Wittgenstein during the 1940's and 1950's, as well as the theories developed by Eleanor Rosch and her team during the 1970's, along with the ones presented by George Lakoff from 1980's onward. The proposition that the category of "monster" as pressuposed and understood by the modern world is non-existent in archaic hexametric poetry has consequences to the modern understanding of those creatures which must be perceived as part of a cosmos that does not separate the supernatural, the wonderful, and the divine in the same terms as the modern western world does, revealing the need to understand those creatures under the point of view of the tradition that created them or incorporated and ressignified them.

Keywords: Hesiod; Theogony; Homer; Odyssey; Homeric Hymns; Homeric Hymn to Apolo; archaic hexaemtric poetry; monsters. 


\section{Lista de Abreviaturas e Siglas}

Brill's New Pauly $\quad$ CANCIK, H.; SCHNEIDER, H.; \& SALAZAR, C. F. (2002). Brill's New Pauly: encyclopaedia of the ancient world (English ed. / managing editor, Christine F. Salazar.). Leiden: Brill.

Chantraine

CHANTRAINE, Pierre. (1968-1977). Dictionnaire etymologique de la langue grecque. Tomes I-IV. Paris: Éditions Klincksieck.

Cunliffe

CUNLIFFE, Richard John. (1963). A Lexicon of the Homeric Dialect. University of Oklahoma Press.

FGrH

MÜLLER, Karl Otfried et al. (1841-1883) Fragmenta Historicorum Graecorum. 5 vols. Parisiis: Editore Ambrosio Firmin Didot.

GH CHANTRAINE, Pierre. (1958). Grammaire Homérique. Tome 1: Phonétique et Morphologie. Paris: Librarie C. Klincksieck.

LfgrE SNELL, Bruno (ed.). (1955-2010). Lexikon des frühgriechischen Epos. 25 vols. Göttingen: Vandenhoeck und Ruprecht.

LH HOFINGER, M. (1975-1978). Lexicon Hesiodeum cum indice inverso (Tomes I-IV). Leiden: Brill.

LIMC Lexicon Iconographicum Mythologiae Classicae. (1981-). ACKERMANN, H. C., GISLER, J.-R., \& KAHIL, L. Zürich: Artemis.

LSJ

LIDDELL, Henry George. SCOTT, Robert. (1940). A GreekEnglish Lexicon. Revised and augmented throughout by Sir JONES, Henry Stuart with the assistance of MCKENZIE, Roderick. Oxford: Clarendon Press, 1940.

Pauly-Wissowa PAULY, A. F. von. (1894). Paulys Real-Encyclopädie der classischen Altertumswissenschaft. (Neue Bearbeitung / unter Mitwirkung zahlreicher Fachgenossen herausgegeben von G. Wissowa.). Stuttgart; Munchen: JBMetzler; Alfred Druckenmuller.

\section{LiSTA DE SíMbolos}

$\dagger \quad$ texto corrompido

$<>\quad$ inserção editorial

[ ] texto restaurado

[...] supressões 


\section{SUMÁRIO}

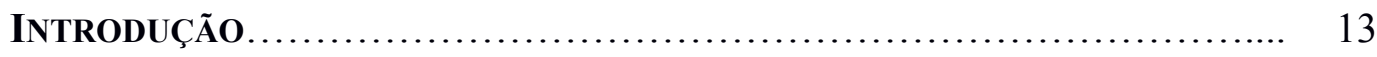

1. MONSTRO: DEFINIÇÕES E INDEFINIÇÕES............................... 20

$1.1 \mathrm{O}$ monstro teratológico......................................... 29

1.1.a) Aristóteles: o monstro natural............................... 29

1.1.b) Dos filósofos naturalistas a Foucault: do monstro antinatural ao monstro interior............................................... 32

1.2 O monstro, o prodígio, o portento: sinais dos deuses................. 38

1.2.a) Cícero: monstrum entre natureza e retórica.................... 39

$1.3 \mathrm{O}$ maravilhoso.................................................. 43

1.3.a) O maravilhoso etnográfico............................... 44

1.3.b) O monstro antropológico.................................... 46

$1.4 \mathrm{O}$ monstro metafórico.............................................. 49

1.4.a) O monstro cultural e os Monster Studies...................... 50

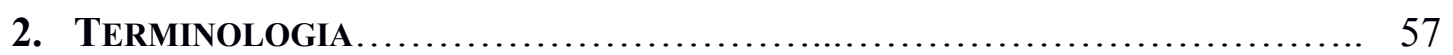

2.1 Problematização................................................. 59

2.2 O substantivo $\tau \dot{\varepsilon} \rho \alpha \varsigma$ na poesia hexamétrica arcaica................... 65

2.2.a) Ilíada..................................................... 66

2.2.b) Odisseia............................................... 70

2.2.c) Teogonia e Hino Homérico a Apolo............................. 71

2.3 Variantes do substantivo épico $\pi \varepsilon \dot{\lambda} \lambda \omega \rho$ e $\pi \varepsilon \dot{\varepsilon} \lambda \omega \rho o v$ e do adjetivo épico

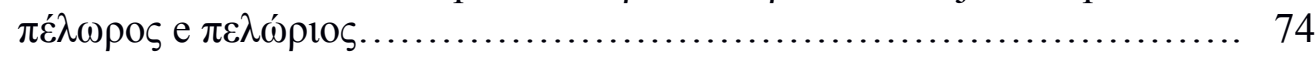

2.3.a) Ilíada................................................... 76

2.3.b) Odisseia................................................. 79

2.3.c) Hino Homérico a Apolo e Hino Homérico a Hermes............... 82

2.3.d) Teogonia, Escudo de Héracles e Catálogo das Mulheres........... 84

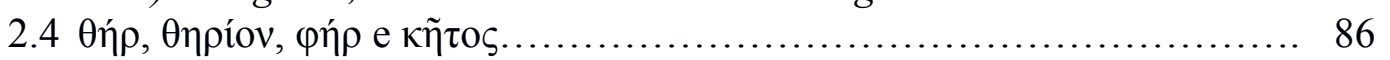

2.5 Conclusões...................................................... 90

3. Criaturas consideradas monstruosas na Teogonia de Hesíodo..... 91

3.1 A Teogonia e seu programa........................................ 95

3.2 Ciclopes e Centímanos............................................. 101

3.2.a) Ciclopes em foco......................................... 104

3.2.b) Centímanos em foco...................................... 114

3.2.c) Os Centímanos na Titanomaquia.............................. 125

3.2.d) Estrutura narrativa e estrutura de poder...................... 130

3.3 Tífon/Tifeu.................................................... 133

3.4 Progênie de Fórcis e Cetó........................................... 140

3.5 Conclusões................................................... 153

4. Criaturas Consideradas monstruosas no Hino Homérico a Apolo... 155

4.1 A serpente......................................................... 158

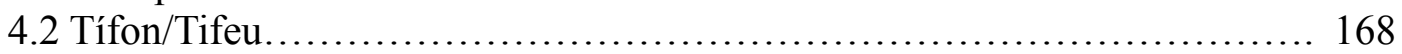

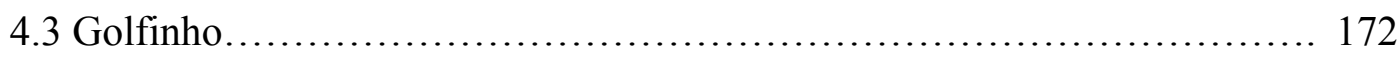

4.4 Conclusões........................................................ 175 
5. Criaturas consideradas monstruosas na OdisSEIa de Homero....... 177

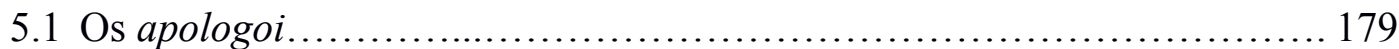

5.2 Os ciclopes......................................................... 183

5.2.a) Os ciclopes nos apologoi..................................... 186

5.2.b) Polifemo e Odisseu............................................. 192

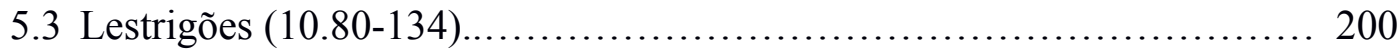

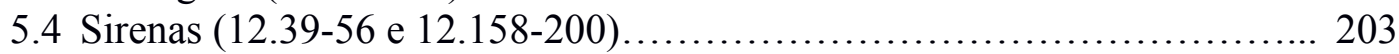

5.5 Cila e Caríbdis $(12.72-126$ e 12.234-259)........................... 208

5.6 Conclusões....................................................... 214

6. CONCluSÕES: O MONSTRO COMO CATEgORIA E SUA INEXISTÊNCIA NA POESIA HEXAMÉTRICA ARCAICA ........................................... 219

$\begin{array}{ll}\text { REFERENCIAS } & 234\end{array}$

OBRAS DE REFERÊNCIA: DICIONÁRIOS, LÉXICOS E ENCICLOPÉDIAS 235

FONTES: EDIÇÕES, TRADUÇÕES E COMENTÁRIOS 237

$\begin{array}{ll}\text { BIBLIOGRAFIA SECUNDÁRIA } & 242\end{array}$

APÊNDICES 262

Apêndice A - Verbetes 263

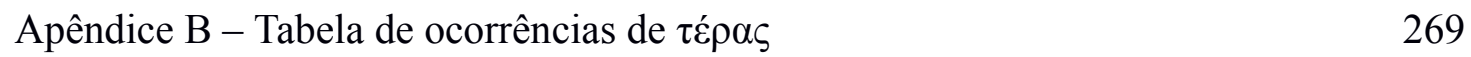

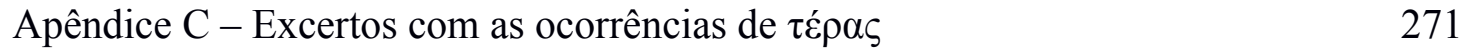

Apêndice D - Tabela de ocorrências de $\pi \varepsilon ́ \lambda \omega \rho$ e derivados 278

Apêndice E - Excertos com as ocorrências de $\pi \varepsilon ́ \lambda \omega \rho$ e derivados 281

Apêndice F - Excertos da Teogonia 295

Apêndice G - Excertos do Hino Homérico a Apolo 302

Apêndice H - Excertos da Odisseia 305

Apêndice I - Grande Cadeia de Seres $\quad 311$ 


\section{INTRODUÇÃO}

Everyone is a monster to someone. Since you are so convinced that I am yours, I will be it.

Captain Flint, Black Sails. 
INTRODUÇÃO

Dunstan Lowe, na introdução a seu livro sobre monstros e monstruosidade na poesia augustana, publicado em 2015, apontou (p. 2) a recente inserção dos Estudos Clássicos no campo moderno e interdisciplinar dos estudos da monstruosidade. Embora receba ainda um número consideravelmente menor de contribuições comparado a períodos históricos mais recentes, nos últimos anos o tema da monstruosidade tem suscitado um interesse crescente do estudioso da Antiguidade em geral, refletindo-se no aumento do número de eventos e da produção bibliográfica acerca do assunto. Publicações como o Monstres e Monstruosités dans le Monde Ancien (Mazoyer e Pérez Rey, 2007) e Monstra: Costruzzione e percezione delle entità ibride e mostruose nel Mediterraneo antico (Baglioni, 2013) - esta última resultado de um encontro de mesmo título promovido pelo Museo delle Religioni "Raffaele Pettazzoni" (Velletri, Roma) em colaboração com a Sapienza Università di Roma em junho de 2011 - não se restringem à Antiguidade Clássica, trazendo artigos sobre Egito, Oriente Próximo, Índia e Mesoamérica.

Como exemplo de publicações voltadas exclusivamente para a Antiguidade Clássica está Monsters and Monstrosity in Greek and Roman Culture, volume editado em 1998 por Catherine Atherton, então Tutorial Fellow em Classical Philology no New College em Oxford. Em 2000, Adrienne Mayor publicou The First Fossil Hunters: Paleontology in Greek and Roman Times, obra na qual a autora oferece uma perspectiva, diga-se, quase evemerista dos monstros das mitologias grega e romana, em que muitos deles seriam criações que se fundamentam na observação de fósseis ou ossadas de animais extintos. Em 2007, Paul Murgatroyd, professor do Department of Classics na McMaster University (Ontário, Canadá), publicou um livro intitulado Mythical Monsters in Classical Literature, em que apresenta os monstros da mitologia partindo estritamente das fontes literárias. Marianne Govers Hopman (2012a) dedicou um livro inteiro à figura da Cila presente tanto em obras poéticas como iconográficas. Vejam-se também os workshops sob organização de Samantha Newington (University of Aberdeen) e Sian Lewis (University of St. Andrews) realizados na University of St. Andrews, na Escócia, intitulados respectivamente "Sacred Animals and Monsters in Greek and Near-Eastern Religions" (janeiro de 2014) e "Animals, Monsters and Demons: a Comparative Approach" (janeiro de 2015). ${ }^{1}$ Acredita-se, assim, que a presente tese venha se

1 As respectivas páginas das duas edições do evento estão em: https://www.st-andrews.ac.uk/classics/events/conferences/animals/ (2014); http://www.st-andrews.ac.uk/classics/events/conferences/amd/ (2015). 
somar a esses exemplos que refletem o crescente interesse pela questão do monstro na Antiguidade Clássica, embora se circunscreva aos poemas da tradição oral hexamétrica, mais precisamente a Teogonia de Hesíodo, a Odisseia de Homero e o Hino Homérico a Apolo (h.Ap.).

Quanto a tais poemas, adota-se nesta tese a perspectiva oralista, ou seja, de que eles são parte de uma tradição de poesia em verso hexamétrico transmitida oralmente. ${ }^{2}$ Denominados $\tau \grave{\alpha}$ Ě $\pi \varepsilon \alpha$ (tá epea) pelos antigos, expressão entendida modernamente como "o conjunto da poesia épica", tal designação, a partir de certa época, passou a se referir sobretudo ao metro em que tais poemas foram compostos, o hexâmetro dactílico, em detrimento do gênero ao qual possam eventualmente ter pertencido. Entretanto, como bem nota Thalmann, "[m]etro não é um meio artificial ou arbitrário de amontoar poemas que talvez tenham senão poucas similaridades. [...] ele serve genuinamente para definir um padrão poético", pois os compositores desses poemas "[...] baseavam-se em um repositório de expressões formulares herdadas que, qualquer que fosse sua origem, foi gradualmente se acumulando para o uso no verso do hexâmetro dactílico. [...]". ${ }^{3}$

Tais expressões formulares são um dos elementos na poesia arcaica de verso hexamétrico que compõem aquilo que Thalmann denomina convenção. ${ }^{4}$ Por atingir o público por meio de uma performance oral, a poesia hexamétrica faz uso do que é convencional não apenas para aquele que a enuncia mas também para a plateia, já que, “[...] [s]ob essas condições [as da performance oral], não havia espaço para a obscuridade. Tudo tinha de ser entendido fácil e imediatamente, e convenções serviam a esse propósito".5 Portanto, pressupondo-se o conhecimento comum entre poeta e público desses mecanismos convencionais dos quais se vale tal poesia, o verso hexamétrico e as expressões formulares, de um lado, operam como instrumentos facilitadores da compreensão da poesia apresentada oralmente, e de outro, tais expressões ressoam em uma rede de significações tradicionais que o público é capaz de reconhecer de imediato (Foley, 1991 e 1999).

Quanto ao conteúdo dessa poesia hexamétrica arcaica, uma característica fundamental é "seu tratamento de narrativas sobre ambos homens e deuses como fragmentos em um

2 Os precursores principais dessa perspectiva são Parry (1987 [1971]) e Lord 1971 [1960]).

3 Thalmann (1984, p. xiii): "Meter is not an artificial or arbitrary means of lumping together poems that might otherwise have few similarities. [...] it genuinely serves to define a poetic type. [...], the composers of these poems drew on a store of inherited formulaic phrases that, whatever their origin, had gradually accumulated for use in dactylic hexameter verse. [...]". Acerca da relação entre o corpus hexamétrico e a poesia elegíaca, tendo em vista o parentesco métrico e o uso comum da denominação epos, cf., entre outros, Nagy (2009b).

4 Posteriormente, na década de 1990, Foley (1991 e 1999) usará a expressão "referencialidade tradicional", uma reelaboração do que Thalmann denominou "convenção" mais fortemente embasada na Estética da Recepção.

5 Thalmann (1984, p. xiv): “[...] Under these conditions there was no room for obscurity. Everything had to be easily and immediately intelligible, and conventions served this purpose.". 
contínuo narrativo e temático e, portanto, como reflexos do que é essencialmente uma visão única do mundo", 6 uma concepção a partir da qual Graziosi e Haubold (2005) desenvolveram a noção de "história do cosmo". Assim, seja o conteúdo da poesia hexamétrica arcaica relativo aos deuses ou ao âmbito heroico, ela apresenta, em certa medida, um contínuo narrativo que se inicia com a origem dos deuses e do cosmo e segue até a última geração de heróis representada por aqueles que combateram em Troia. Assim, ${ }^{7}$

[...] O que parece ser mais importante sobre essa poesia é que ela era um meio de vir a conhecer e de explicar o mundo e o lugar do homem nele: a história e o arranjo do mundo físico; o curso da história divina e humana; as condições que governam as relações dos homens com os deuses e uns com os outros; e a significância e o valor da civilização humana e das instituições sociais. Convenções poéticas, como veículos de significado, favoreceram esse objetivo de modos cruciais e assim habilitaram a poesia a apresentar uma visão de mundo coerente. [...]

Conquanto a perspectiva de Thalmann implique uma coerência da tradição oral de épica hexamétrica maior do que se assume nesta tese, mantêm-se aqui a perspectiva de que essa poesia é um meio de conhecer e explicar o mundo e o lugar do homem nele e, ao mesmo tempo, o produto de uma visão do homem sobre o mundo e sobre si próprio. Esse mundo, ou cosmo, entretanto, não é visto de maneira separada da figura divina, pois todo ele é percebido em termos de divindades: Terra, Céu, Mar e Montanhas não são apenas elementos da paisagem, mas deuses que compõem e configuram o mundo enquanto tal. Esse modo de perceber o cosmo, e de viver nele, tem implicações diretas para a compreensão das criaturas com as quais esta tese tenta lidar, aquelas sob a classificação de monstros mitológicos.

Essas criaturas que nós, modernos, denominamos "monstros", vistos como integrantes desse cosmo percebido como divino, colocam em xeque essa nossa denominação. ${ }^{8}$ A palavra "monstro" chegou ao português a partir do termo latino monstrum, que está ligado ao verbo moneo, significando, grosso modo, “avisar", “advertir". Originalmente, monstrum, como prodigium ("prodígio") e portentum ("portento"), denotava uma mensagem enviada pelos deuses ou, mais precisamente, um fenômeno que se constituía em um aviso ou advertência

6 Thalmann (1984, p. xii): "[...] its treatment of stories about both men and gods as fragments in a narrative and thematic continuum, and therefore as reflections of what is essentially a single view of the world. [...]".

7 Thalmann (1984, p. xiv): "What seems to be most important about this poetry is that it was a means of coming to know and of explaining the world and man's place in it: the history and arrangement of the physical world; the course of divine and human history; the conditions that govern men's relations with the gods and with each other; and the significance and value of human civilization and social institutions. Poetic conventions, as vehicles of meaning, furthered this aim in crucial ways and thus enabled the poetry to present a coherent worldview. [...] The original audience's responses were conditioned by the cultural environment and ingrained by long habit of hearing just this type of poetry. [...]".

8 O termo "moderno" é usado nesta tese de forma ampla para designar o período da história ocidental que segue o mundo medieval. Desse modo, "moderno" ou "Modernidade" abrange também o mundo contemporâneo e a pós-modernidade. Para uma crítica dessas "Formas da História”, cf. Guarinello (2003). 
emitido pela divindade, sendo, portanto, algo de natureza profética. Para nós, "monstro" é geralmente, embora nem sempre, um termo pejorativo que designa algum tipo de mal ou ameaça e pode assumir uma pluralidade de sentidos que não se encontram nas fontes antigas. Do mesmo modo, a relação de "monstro" como algo que tem origem divina é totalmente ausente, senão ao menos inteiramente prescindível, para a concepção contemporânea de "monstro". Portanto, "monstro" é tratado nesta tese como uma categoria historicamente definida e, sendo assim, necessita ser entendida de acordo com os parâmetros da sociedade que lhe deu origem ou que dela se apropriou, adaptando-o ao seu próprio sistema de significações. No caso da poesia hexamétrica arcaica, a categoria "monstro" como concebida no mundo moderno é, ouso afirmar, inexistente: por um lado, aquilo que se concebe como "monstro" é entendido como um prodígio, ou seja, algo ligado à manifestação da divindade no mundo, um sentido ausente do nosso "monstro"; por outro, a pluralidade de sentidos que a nossa categoria “monstro" assume não está presente na concepção apresentada nos poemas analisados.

Tal concepção moderna de monstro e sua distinção em relação às concepções "antiga" e medieval" são exploradas no primeiro capítulo. Essa diferenciação entre moderno, de um lado, e antigo e medieval, de outro, encontra sua razão de ser na distinção que ocorre na própria noção de monstro, que, durante a Antiguidade e o período medieval, é parte de um mundo ainda não "desencantado", no sentido estritamente weberiano do termo, e ainda não sofreu com o processo de "desendeusação do mundo", nas palavras de Pierucci (2013, p. 3031), iniciado com a Modernidade. E, como será visto, a categoria "monstro" não prescinde da categoria "divindade" seja no mundo antigo seja no medieval. Essa é a grande mudança em relação a tal categoria no mundo moderno: a secularização da noção de monstro, um processo que a despoja de sua estreita relação com o âmbito divino, ou seja, com aquilo que talvez lhe seja mais intrínseco no mundo antigo.

O capítulo 2 se debruça sobre os termos utilizados na poesia hexamétrica arcaica amiúde traduzidos e entendidos como "monstro". Nele, a análise contextual mostra que "monstro" é uma palavra que não somente falha em expressar a ideia transmitida pelos termos gregos em questão, como também impinge uma concepção equivocada sobre eles, afetando sobremaneira a nossa compreensão dos termos em si bem como dos seres aos quais remetem.

O capítulo 3 inicia as análises dos seres que consideramos monstruosos nos poemas propriamente ditos. Ele se dedica aos seres presentes na Teogonia e é seguido do capítulo 4, que explora as figuras de Tifeu, da serpente e do golfinho presentes no Hino Homérico a Apolo (h.Ap.). O último capítulo de análise, o capítulo 5, é dedicado ao estudo das criaturas 
presentes nos cantos 9 a 12 da Odisseia, usualmente denominados apologoi de Alcínoo. Cada um desses capítulos apresenta uma breve introdução em que são apresentadas sua organização e uma problematização inicial.

Essa ordenação nos capítulos de análise encontra sua justificativa na "história do cosmo", desenvolvida por Graziosi e Haubold (2005): a Teogonia, primeiro poema a ser analisado, discorre sobre o nascimento do cosmo, enquanto o Hino Homérico a Apolo (h.Ap.) apresenta um episódio da história do cosmo, que é o nascimento e a conquista da timē de Apolo; por fim, a Odisseia, que remete à fase heroica dessa história. A Ilíada, conquanto faça parte dessa fase heroica, não se constitui como um dos poemas analisados, pois não apresenta nenhuma criatura considerada monstruosa que desempenhe um papel importante para a narrativa principal: os heróis que lutaram em Troia não enfrentaram qualquer dessas criaturas; são os heróis da geração precedente, por vezes chamados "matadores de monstros", como Hércules, Perseu, Teseu e Belerofonte, que as tiveram como antagonistas (Mackie, 2008). Contudo, algumas criaturas são brevemente mencionadas na Ilíada e essas passagens servirão como aportes à argumentação principal dos capítulos de análise. O Escudo de Héracles, de modo semelhante, também contribui tangencialmente para as análises dos outros poemas e não recebe um capítulo pela mesma razão apresentada para a Ilíada. Entretanto, no capítulo acerca da terminologia, levou-se em consideração as obras supérstites da poesia hexamétrica arcaica homérica e hesiódica, o que inclui a Ilíada, os demais Hinos Homéricos, o Escudo de Héracles e o Catálogo das Mulheres. Trabalhos e Dias, que não apresenta criaturas consideradas monstruosas nem faz uso da terminologia analisada, é evocado apenas oportunamente.

Os capítulos de análise se estruturam fundamentalmente pelas criaturas presentes nos respectivos poemas. No capítulo acerca da Teogonia, são estudados os Ciclopes e os Centímanos, seguidos de Tifeu e, por fim, as criaturas que compõem a progênie de Fórcis e Cetó, pertencentes à denominada "linhagem do Mar". O capítulo 4 é composto pela análise das figuras da serpente morta pelo deus Apolo, de Tifeu, que é gerado por Hera no h.Ap. e não por Terra, como na Teogonia, e do golfinho no qual Apolo se transforma na parte final do h.Ap. O capítulo 5, por sua vez, explora a raça dos ciclopes e a figura de Polifemo, os lestrigões, as Sirenas e, por fim, Cila e Caríbdis. Cada um dos capítulos se encerra com uma breve conclusão.

No último capítulo, são tecidas as conclusões a que o estudo dos termos e das criaturas conduziu, problematizando a própria noção de "categoria" e expondo algumas diferenças entre a percepção do cosmo expresso pela poesia hexamétrica arcaica e a compreensão do 
cosmo no mundo moderno ocidental por meio do esquema da Grande Cadeia de Seres, conforme utilizado por Lakoff e Turner (1989). Com base nesse esquema, problematiza-se também a tríade "deuses, heróis e monstros" enquanto categorias que falseiam a compreensão da visão de mundo explicitada na tradição poética em questão. Na conclusão é brevemente discutida a questão do antropomorfismo como baliza para a categorização do que é ou não monstruoso, mostrando-se que o emprego dessa noção para a definição das divindades gregas é feito de forma bastante limitada, e limitadora, estando aquém das discussões atuais sobre antropomorfismo e antropomorfização nas ciências humanas e sociais.

Quanto às referências bibliográficas, elas foram separadas em três seções: a primeira apresenta as obras de referência como dicionários e enciclopédias; a segunda, contém as edições, traduções e comentários organizados por sobrenome do editor, tradutor ou comentador e não pelo nome do autor antigo - portanto, a Teogonia de Hesíodo, por exemplo, é referenciada por Torrano (1995) e Werner (2013a) -; a terceira e última seção contém a bibliografia secundária, que segue o sistema autor-data, como as demais.

As referências são seguidas de uma série de apêndices: reproduções e respectivas traduções próprias dos verbetes do LSJ e de Cunliffe para os termos analisados no capítulo 2; tabelas com as ocorrências dos termos traduzidos como "monstro/monstruoso"; excertos organizados por poema, que auxiliam tanto na leitura do capítulo 2 como na dos capítulos de análise; e, por fim, a reprodução do esquema da Grande Cadeia de Seres encontrada em Swanepoel (2010, p. 1421) acompanhada de um esboço mais geral da Grande Cadeia de Seres representada pela poesia hexamétrica arcaica.

É necessário esclarecer de antemão que se evitou o uso do nós majestático, tomandose a liberdade de adotar o pronome pessoal de primeira pessoa do singular quando é exposta uma perspectiva particular da pesquisadora, consequentemente assumindo para si a responsabilidade de qualquer equívoco, ao passo que o uso da primeira pessoa do plural se restringe a duas situações: quando se refere a "nós" que vivemos no mundo moderno e contemporâneo, cuja noção de monstro difere daquela de outras épocas; e quando designa a proponente desta tese em conjunto com o leitor, um recurso retórico cuja função é aproximálo e incluí-lo como partícipe da tese, já que ela se desenvolveu em um diálogo constante com alguns leitores reais e outros imaginários. ${ }^{9}$

9 Imagem da capa: Curupira, de Walmor Corrêa, 2005 (Série Unheimlich, imaginário popular brasileiro). 


\section{Capítulo 1}

\section{MONSTRO: DEFINIÇÕES E INDEFINIÇÕES}

[...] Daí, vieram me chamar. Causa dum bezerro: um bezerro branco, erroso, os olhos de nem ser - se viu -; e com máscara de cachorro. Me disseram; eu não quis avistar. Mesmo que, por defeito como nasceu, arrebitado de beiços, esse figurava rindo feito pessoa. Cara de gente, cara de cão: determinaram - era o demo. Povo prascóvio. Mataram. $[\ldots]$

Riobaldo, em Grande Sertão: Veredas, p. 3., de Guimarães Rosa. 
Monstro: sm. 1. Ser de conformação anormal, cujo estudo pertence à teratologia: monstro de duas cabeças. 2. Ser fantástico e de aparência assustadora, ger. colossal (monstro mitológico). 3. Fig. Pej. Pessoa muito feia, horrorosa; MONSTRENGO. 4. Fig. Pessoa muito cruel, desumana. 5. Fig. Pessoa que causa assombro; PRODÍGIO: Ela é um monstro no piano. a2g2n. 6. Enorme, colossal, gigantesco: Pegamos um engarrafamento monstro. [F.: Do lat. monstrum, i. Ideia de 'monstro': terat(o)(teratológico).] Monstro sagrado: 1. Pessoa de grande talento em sua atividade, por isso admirado e renomado. 2. P. ext. Irôn. Pessoa que, por ter fama e prestígio, tornou-se um mito inatacável, sempre louvado e nunca criticado. ${ }^{1}$

Conquanto não se deva esperar que dicionários gerais de língua deem conta da amplitude e da complexidade de conceitos, eles podem funcionar como uma baliza razoável dos sentidos mais comuns em que um termo é utilizado pelos falantes de uma determinada língua. No caso do dicionário Aulete digital, do qual procede o verbete acima, é possível, ainda, ter uma noção da mudança ou permanência de sentido das palavras porque ele disponibiliza, além do verbete atual, o verbete originalmente publicado na edição portuguesa do final do século XIX:

\begin{abstract}
Monstro: s. m. || tudo o que é contra a ordem regular da natureza. || (Fisiol.) Animal que no todo ou em algumas das suas partes se afasta da estrutura ou da conformação natural dos da sua espécie ou sexo, e cujo estudo pertence à teratologia. \| (Fig.) Figura gigantesca e colossal: Mais ia por diante o monstro horrendo. (Camões.) O cocheiro transporta-me até junto do monstro preso à muralha do cais por fortes amarras. (Samuel Maia, Por Terras Estranhas, p. 133.) || (Fig.) Pessoa cruel, feroz, desumana, perversa. || Indolente; estafermo. || Pessoa muito feia, horrorosa; mostrengo. || Portento, prodígio, assombro: Um monstro de ingratidão, de crueldade. $\|-$, adj. (Bras.) (fam.) muito grande, basta. F. lat. Monstrum.
\end{abstract}

Ao se comparar as duas versões, chama a atenção que a primeira acepção apresentada pelo verbete original ("tudo o que é contra a ordem regular da natureza") tenha sido omitida do verbete atual e que a segunda acepção apresentada pelo verbete atual ("ser fantástico") não apareça no verbete original. Embora todas essas acepções, apresentadas em ambas as versões, estejam presentes nas tentativas de conceituar o que vem a ser um monstro, conforme será visto ao longo deste capítulo, é possível perceber que algumas são privilegiadas durante um determinado período, enquanto outras desaparecem ou se tornam menos comuns. Isso implica que a acepção de "monstro" e sua conceituação variam diacronicamente. E, como é possível

1 Verbete "monstro", em Aulete digital. Disponível em: http://www.aulete.com.br (último acesso: 20 out. 2015). 
depreender com base nos verbetes acima, também variam sincronicamente, pois diferentes áreas do conhecimento, dentre as quais a teratologia serve como exemplo, conceituam o monstro de acordo com seus interesses particulares centrados em aspectos do conceito que lhe sejam mais pertinentes.

A despeito de, em geral, não captarem a complexidade de conceitos, dicionários de língua são, de certo modo, bem-sucedidos em oferecer um vislumbre do senso comum acerca de um termo, tendo por senso comum aqui a ideia que se tem de forma geral e corriqueira acerca de determinado objeto concreto ou abstrato. Via de regra, os dicionários atuais de língua portuguesa fornecem definições para o substantivo "monstro" que podem ser reduzidas a basicamente três sentidos principais: seres que são objeto de estudo científico, geralmente da teratologia, campo da fisiologia que se dedica à malformação embrionária; seres fantásticos, geralmente oriundos de sistemas mitológicos, como o greco-romano, o egípcio, o nórdico etc; e seres de grande dimensão. ${ }^{2}$ Os demais sentidos são considerados figurados e denotam feiura, crueldade, ameaça ou, de modo diverso, genialidade. Em seu uso enquanto adjetivo, como em "engarrafamento monstro", a acepção mais comum é a de enormidade.

Por apresentar uma pluralidade de sentidos, pode-se dizer que a noção de "monstro" encontrada no senso comum, representado aqui pelas definições de dicionários, é polissêmica, e esses múltiplos sentidos agrupam concepções distintas e independentes entre si do que é um “monstro". Por exemplo, o sentido de enormidade é distinto e independente do sentido de "criatura fantástica", e o primeiro não implica necessariamente no outro: uma criatura enorme não é por pressuposto uma criatura fantástica, nem esta apresenta a enormidade como imprescindível. Do mesmo modo, um "ser de conformação anormal” não necessita ser fruto da imaginação nem a "conformação anormal" está indispensavelmente ligada a uma enorme dimensão. Além de distintas e independentes, essas acepções são o resultado de um processo de produção de sentido do termo que não encontram obrigatoriamente a mesma origem no tempo ou no espaço. Elas são uma acumulação de diversos sentidos que o termo "monstro" assumiu ao longo do tempo e são também uma seleção operada, muitas vezes, de acordo com o campo do conhecimento que o tem como objeto de estudo.

Essa polissemia da categoria "monstro", encontrada tanto em português quanto em outras línguas modernas, como o inglês, por exemplo, foi granjeada ao longo da história do

2 Além do Aulete digital, foram consultados o dicionário Michaelis online (disponível em: http://michaelis.uol.com.br/moderno/portugues/index.php. Último acesso: 05 jan. 2016) e o Dicionário Priberam da Língua Portuguesa (disponível em: https://www.priberam.pt/DLPO/. Último acesso: 05 jan. 2016). Optou-se por privilegiar os dicionários que podem ser facilmente acessados online em detrimento daqueles que ou requerem o pagamento de uma assinatura para o acesso online, como é o caso do Grande Dicionário Houaiss da Língua Portuguesa, ou que estão disponíveis em forma de softwares a serem comprados, como é o caso do Dicionário Eletrônico Aurélio. 
termo "monstro", sendo bastante possível que um ou outro sentido não esteja presente em determinada língua, ou que, alternativamente, mais sentidos sejam atribuídos ao termo. Portanto, a transposição direta do termo para sociedades pré-modernas pode ocasionar uma projeção da noção para períodos e lugares nos quais tal polissemia não necessariamente existia. É comum encontrar, por exemplo, obras de referência sobre a Antiguidade (e aqui Antiguidade abrange Antigo Oriente Próximo) nas quais há um verbete para "monster", como se a nossa concepção contemporânea fosse diretamente transponível para as noções antigas.

Um caso curioso ocorre com a Brill's New Pauly: encyclopaedia of the ancient world (Cancik, Schneider \& Salazar, 2002). Seu verbete "monster" é dividido em três partes: Oriente Antigo e Egito, regiões celtas e Antiguidade Clássica. ${ }^{3} \mathrm{O}$ problema se torna aparente logo no início do verbete ao se perceber que a concepção de "monstro" delineada ali é estritamente a de "seres de forma híbrida". Essa equiparação sem ressalvas entre "monstros" e "híbridos" é problemática fundamentalmente em relação ao Egito antigo, que opera o hibridismo entre animais e a forma humana como uma das maneiras canônicas de representar suas divindades. No entanto, a New Pauly se limita à consideração de que "[n]o Egito os próprios deuses são, com frequência, representados como monstros híbridos". ${ }^{4}$ Essa sinonímia entre "hibridismo" e "monstruosidade" causa um estranhamento mais forte no tocante ao Egito antigo porque sobrepõe as noções de "deuses" e de "monstros", tornando evidente o equívoco que a projeção da nossa concepção pode causar. ${ }^{5}$

$\mathrm{Na}$ continuação do verbete, percebe-se que a mesma dissonância ocorre na arte babilônica, ao se afirmar que "[n]a arte do período Antigo da Babilônia (c. 2000 a 1600 a.C.), monstros aparecem pela primeira vez como elementos positivos que afastam o mal", uma positividade contrastante em relação às características que se atribui a um monstro na acepção moderna. ${ }^{6}$ No caso do que o verbete denomina de "arte celta", há uma honesta explicitação da incerteza acerca do que "monstros" significariam, com a exceção de apenas um caso mais tardio, datado entre o III e o I século a.C., que diz respeito às representações masculinas com chifres de veado, identificadas com o deus celta Cernunnos. Tal sobreposição entre "deus" e "monstro", que a New Pauly não hesita em fazer para as divindades egípcias e para o deus

3 Os autores das partes do verbete são: Anthony Green (“Ancient East and Egypt"), Volker Pingel (“Celtic Regions") e Lutz Käppel (“Classical Antiquity”).

4 Cancik, Schneider \& Salazar (2002, vol. 9 [2006], p. 182, verbete de Anthony Green): "In Egypt the gods themselves are often represented as hybrid monsters [...].".

5 Cf. a afirmação de Aufrere (2007, p. 11), para quem "[...] uma tradição de ignorância das crenças egípcias decidiu a priori acerca do caráter monstruoso de seus deuses, quando eles não são grotescos" (“[ [...] une tradition de méconnaissance des croyances égyptiennes a décidé a priori du caractère monstrueux de ses dieux, quand ceux-ci ne sont pas grotesques. [...]").

6 Cancik, Schneider \& Salazar (2002, vol. 9 [2006], p. 183): “[...] In Old Babilonian art (c. 2000-1600 BC) monsters appear for the first time as positive elements which fend off evil. [...]". 
celta, desaparece na próxima seção que trata da Antiguidade Clássica, em relação à qual os monstros são definidos como "criaturas fabulosas míticas, frequentemente metade humanas, metade animais [...], com igual frequência híbridos de diferentes animais”, sendo classificados como "demons" ("demônios"), categoria talvez tão inadequada quanto "monstro"?

Ao se consultar, contudo, Der Neue Pauly, o original alemão do qual a New Pauly é uma tradução, percebe-se que o verbete original de "monster" é "Mischwesen", termo que significa "seres híbridos", não necessariamente "monstro", que em alemão encontra "Monster", "Ungeheuer" ou "Ungetüm" como vocábulos mais próximos. Disso, torna-se evidente que o equívoco não está na concepção do verbete em si tanto quanto na tradução para a língua inglesa: enquanto o verbete original se propõe tratar de seres híbridos, o que certamente inclui os deuses egípcios, a tradução por "monster" acaba evidenciando o malentendido que a projeção da nossa noção de monstro pode causar. ${ }^{8}$ Em suma, essa dissonância criada pela sobreposição de "deuses" e "monstros" evidencia quão inadequada pode ser a transposição da nossa noção de "monstro" para uma sociedade que representava seus deuses de forma híbrida. ${ }^{9}$

Espera-se que a construção de verbetes em enciclopédias seja pautada por uma bibliografia especializada no assunto em questão; contudo, mesmo em obras que tratam do tema da monstruosidade especificamente, o termo "monstro" é usado na maioria das vezes sem uma definição mínima, deixando para o leitor a inferência do sentido de "monstro" que está sendo utilizado. Essa ausência corriqueira de uma definição de "monstro" acaba por ocasionar a transposição acrítica dessa noção, que não expressa de maneira adequada o modo como outros povos se relacionam ou se relacionavam, no caso das sociedades antigas, com figuras ou criaturas possivelmente percebidas dentro de um âmbito divino, cuja compreensão nós enviesamos com o termo "monstro", que, para nós, nada expressa de divino.

Duas outras enciclopédias dedicadas ao mundo antigo, recentemente publicadas, chamam a atenção pelo tratamento dispendido ao verbete "monster". Em uma delas, The Oxford Encyclopedia of Ancient Greece and Rome (Gagarin e Fantham, 2010), o foco do verbete recai sobre a poesia hexamétrica arcaica, principalmente a Teogonia de Hesíodo. ${ }^{10}$

7 Cancik, Schneider \& Salazar (2002, vol. 9 [2006], p. 183): “[...] Mythical fabulous creatures, frequently half human, half animal $[\ldots]$, equally frequently a hybrid from different animals [...]. They're demons and originate in Minoan [I], and probably earlier, in oriental [2] religion".

8 Digno de nota é que nem a Paulys Real-Encyclopädie der classischen Altertumswissenschaft (Pauly et al., 1894), comumente Pauly-Wissowa ou RE, nem a Der Kleine Pauly (Ziegler e Sontheimer, 1964) apresentam um verbete para "Michwesen".

9 Cf. Mander (2013) e Verderame (2013), que discutem acerca do caráter híbrido de figuras divinas na Mesopotâmia e da inadequação do conceito de "monstro" para essas figuras.

10 O verbete "monster" se encontra no vol. 4, p. 457-459. 
Embora o verbete não tenha sido elaborado por uma especialista no assunto da "monstruosidade", é evidente o esforço de Susan C. Shelmerdine em produzir um texto afinado com os recentes estudos sobre a figura do monstro, principalmente aqueles do campo dos estudos culturais denominados "monster studies" ("estudos da monstruosidade"). A predileção de Shelmerdine pelas fontes poéticas em hexâmetro, talvez decorrente dos próprios interesses e publicações da pesquisadora, diferencia-se da tendência em privilegiar fontes como a Biblioteca de Apolodoro ou o Metamorfoses de Ovídio. Contudo, ainda que as escolhas de Shelmerdine na elaboração do verbete sejam salutares, tanto no que diz respeito às fontes como no que concerne à abordagem teórica, a noção subjacente de monstro não deixa de ser anacrônica, e a sua tradução por "monstruosa" do adjetivo épico na forma feminina $\pi \varepsilon \lambda \omega ́ \rho \eta$, atribuído a Terra na Teogonia, é denunciativa da transposição direta e acrítica de uma noção própria da contemporaneidade para o poema hesiódico, como será visto no capítulo 2.

O outro exemplo fornece um contraponto de interesse. Publicada em 2012, The Encyclopedia of Ancient History apresenta um verbete "monster" elaborado por David Engels, especialista em portentos e prodígios do período romano. $\mathrm{O}$ verbete, bem mais curto do que o elaborado por Shelmerdine, dedica-se quase exclusivamente à noção romana de monstrum, "uma importante categoria de prodígios", que Engels afirma corresponder ao grego

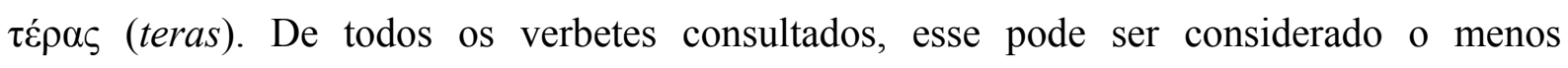
anacrônico deles, pois tenta expressar uma noção elaborada pelos próprios antigos, no caso, os romanos. ${ }^{11}$

O termo latino monstrum, apesar de ser a origem do português "monstro", não expressa a mesma noção que "monstro" no mundo contemporâneo. Assim, ao se traduzir o termo monstrum do latim por “monstro", não se está operando uma tradução adequada, porque o termo latino não reflete a polissêmica noção do que é um monstro no mundo contemporâneo, e nem a noção de monstro no mundo contemporâneo em toda a sua polissemia expressa o sentido de monstrum, que remete a um sinal enviado pelos deuses, um presságio, ou seja, uma mensagem divina que demanda um intérprete. ${ }^{12}$ De modo semelhante, aspectos que o mundo moderno e contemporâneo ocidental considera monstruosos, como o

11 Talvez seja oportuno ressaltar aqui que poucas obras de referência acerca do mundo antigo apresentam um verbete "monstro". É bastante comum deparar com a ausência do verbete em obras recentes como a Encyclopedia of Ancient Greece (Wilson, 2006), The Cambridge Dictionary of Classical Civilization (Shipley et. al., 2006) e The Oxford Companion to Classical Civilization (Hornblower e Spawforth, 1998). Essa ausência pode ser indicativa ou da consciência do anacronismo por parte de seus editores e organizadores ou da simples falta de interesse pelo tema.

12 Em Sobre a adivinhação, 42.93, Cícero coloca monstrum junto com os termos prodigium, portentum e ostendum e os define de acordo com os diferentes métodos de adivinhação (Schultz, 2014). Cf. adiante, p. 39. 
hibridismo e a multiplicidade de membros inferiores ou superiores, não são necessariamente considerados monstruosos em outras culturas: como já apontado, as divindades egípcias, por exemplo, são geralmente representadas em forma híbrida de animal com figura humana, e divindades hindus, como Shiva, apresentam uma multiplicidade de membros superiores sem serem considerados monstruosos. ${ }^{13}$

O termo "monstro" assume uma polissemia também nas várias modalidades de seu uso metafórico. No mundo contemporâneo, a noção de monstruosidade é comumente usada em seu sentido figurado relacionado à crueldade para se referir a assassinos em série ou a ditadores reconhecidamente cruéis. Esse lugar, o do monstro como metáfora moral, o pensamento medieval reservava ao herege, como bem representou Umberto Eco em sua obra ficcional Baudolino (originalmente de 2000), que narra as aventuras do herói homônimo enquanto cruzado durante sua viagem ao Oriente à época da terceira cruzada, no século XII.

"Monstro" para nós também designa alguém que apresenta alguma grande habilidade, um sinônimo de "prodígio" no sentido de alguém que é extremamente bom em executar alguma atividade, uma pessoa genial e extremamente talentosa. Contudo, a nossa sinonímia entre "monstro" e "prodígio", conquanto ambos os termos possam expressar algo extraordinário, não carregam o sentido de uma mensagem divina, como os termos latinos que lhes deram origem. ${ }^{14}$

"Monstro" pode, ainda, designar algo enorme, cujas dimensões ultrapassam o que se considera dentro da normalidade. Esse é, talvez, o sentido de "monstro" no mundo contemporâneo que pode estar mais próximo de uma das noções expressas pelo termo $\pi \varepsilon ́ \lambda \omega \rho$ e seus derivados, como será exposto no capítulo 2, que explora a terminologia dos poemas hexamétricos.

De todas as acepções fornecidas pelos dicionários de língua portuguesa consultados, a que menos pertence àquilo que se está denominando aqui como "senso comum" é aquela que remete ao campo da teratologia. Contudo, a noção de "monstro" com o qual esse campo científico opera é definida por parâmetros corporais, que, por sua vez, são constituintes do

13 Cf. Ferrara (2013, p. 191): "[...] Tentare di parlare del mostruoso e dell'ibrido come categorie interpretative nell'amito delle esegesi religiose del Sudasia antico rischia di presentarsi come un'operazione dalle tinte vagamente orientalistiche, perché si tratta di categorie elaborate a partire da ambiti storici e geografici precisi - greco e romano - che potrebbero assumere una vita própria e piegare i dati storici alla metastoria.".

14 Cf., por exemplo, o verbete "prodígio" do Aulete digital: "(s[ubstantivo] m[asculino].) 1. Coisa ou feito fora do comum ou sobrenatural; MARAVILHA; PORTENTO: os prodígios dos heróis mitológicos. 2. Pessoa extremamente talentosa; GÊNIO; PORTENTO: Ele é um prodígio no saxofone. (a[djetivo]) 3. Diz-se de criança excepcionalmente inteligente, precoce (menino prodígio). [F.: Do lat. prodigium, ii.]". Cf. também o verbete "portento": (sm.) 1. Pessoa, ocorrência ou coisa prodigiosa, extraordinária; MARAVILHA; MILAGRE; PRODÍGIO: Ela é um portento de eficiência. 2. Pessoa dotada de inteligência ou de talento extraordinários; GÊNIO [F.: Do lat. portentum, i.]. Disponível em: http://www.aulete.com.br/prod \%C3\%ADgio (último acesso: 16 jun. 2016). 
senso comum acerca do monstro. Baseada fundamentalmente no exame de seres presentes na natureza e em sua comparação com o que se considera dentro dos parâmetros estabelecidos pela generalidade de ocorrências, essa disciplina científica, em sua origem, retomou as observações feitas por Aristóteles, resgatadas pelos estudos modernos de história ou filosofia natural, e teve um grande impacto na filosofia e antropologia do século XX, principalmente no que diz respeito às reflexões acerca do que é "normal" e "anormal" dentro de uma determinada cultura, ou acerca daquilo que uma determinada sociedade incorpora como dentro da normalidade ou tenta expulsar enquanto anomalias que interferem em seu bom funcionamento.

Essa filosofia e antropologia, imbuídas dos sentidos do monstro presentes no senso comum, serviram-se desses parâmetros culturais em seu entorno para pensar instituições sociais, práticas culturais e as próprias cognição e epistemologia. Ao fazê-lo, costumeiramente prescindiram de definir o monstro e recorreram muitas vezes a elementos desconjuntados do senso comum. Este capítulo busca mostrar que aquilo que vem a ser considerado um monstro, uma monstruosidade ou monstruoso muda de acordo com os contextos histórico, social e cultural. Ele também aponta determinados elementos constitutivos das concepções do que é um monstro no mundo moderno e contemporâneo. Esses elementos, já apresentados nessa breve descrição de certas noções de senso comum, serão também investigados por meio da análise de noções utilizadas por alguns estudiosos, dentre antropólogos, filósofos e historiadores. No que diz respeito a esses estudiosos, não há uma sistematização das diferentes noções de monstro produzidas ou reelaboradas por eles. Há, em vez disso, uma seleção que, apesar de não esgotar todos aqueles que eventualmente tenham se apropriado de alguma modalidade da polifônica noção de monstro, reflete o esforço de produzir uma síntese preliminar.

Da Antiguidade Clássica até o mundo contemporâneo, o termo "monstro" e a noção do que um monstro vem a ser tiveram uma longa história cujas minúcias extrapolam em muito o escopo desta tese de doutoramento. Há, contudo, momentos dessa história que são cruciais para a constituição da nossa noção de monstro. Como não poderia deixar de ser, é em Aristóteles que se encontra uma formulação que estará no centro de uma das "direções" que compõem a polissemia da concepção moderna de monstro. ${ }^{15}$ É da conceituação aristotélica de monstruosidade que derivará a tradição do monstro teratológico, ou seja, aquele que é objeto de estudo das ciências médicas e biológicas desde o período do Renascimento.

15 Tomo a expressão "direções" utilizada por Ceárd (1977) para expressar os diferentes rumos tomados pela noção de monstro ao longo de seu desenvolvimento. Por vezes, utilizarei como sinônimo de "direções" a expressão “ordens de discurso", de Cuny-Le Callet (2005). 
A formulação aristotélica, no entanto, não é a predominante no mundo antigo, nem entre os escritores gregos, nem entre os romanos. O que Aristóteles define como " $\tau \varepsilon ́ \rho \alpha \varsigma^{\prime}$ " não expressa o senso comum, ou o que conseguimos vislumbrar do senso comum, presente na mentalidade da abstração moderna que denominamos "o homem grego". ${ }^{16}$ Como o termo

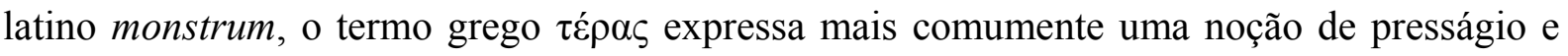
prodígio. ${ }^{17}$ Essa noção será mais bem explicitada por Cícero (infelizmente não há uma elaboração dessa noção em textos gregos preservados), principalmente em sua obra $D e$ divinatione ("Sobre a adivinhação"), cujo tema se centra na prática da "leitura" de nascimentos de animais ou de seres humanos com algum tipo de deformidade enquanto sinais enviados pelos deuses. Essa acepção de augúrio perdurará por toda a Idade Média e o monstro só começará a perder seu significado como presságio a partir do Renascimento, com a retomada do estudo da natureza bem como o da anatomia humana.

Além dessas duas direções, a que denomino "monstro teratológico" e a do monstro enquanto prodígio, há uma terceira, que talvez anteceda as outras duas: a da

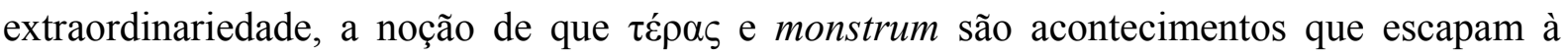
ordem corriqueira das coisas. ${ }^{18}$ Essa direção, contudo, será estudada mais adiante e, com ela, o seu desdobramento etnográfico, que também está no âmbito do fora do comum, do extraordinário, do fantástico.

16 Contra, Lenfant (1999). Lenfant projeta a noção aristotélica para toda a "sociedade grega": "[...] Monsters in Greek society are defined in a negative way, as beings who do not resemble their parents, in that they deviate from the characteristics of their species [...]" (p. 197). Ela afirma que essa definição está presente em textos (Platão, Crátilo, 394a, e Aristóteles, Geração dos animais, $769 \mathrm{b8}$ and 770b5) e maldições em "juras oficiais" ("official oaths"), para os quais cita o juramento dos Anfictiônidas citado por Ésquines em Contra Ctesifonte e uma inscrição cuja autenticidade é altamente questionável. O juramento dos Anfictiônidas seria datado do início do século VI a.C., após a Primeira Guerra entre a liga de Delos e a cidade de Cirra, na Fócida. O problema é que o texto de Ésquines não é confiável em relação ao juramento: o trecho presente no texto é uma citação de outro juramento, que nada tem a ver com o juramento dos Anfictiônidas. Além disso, Ésquines (390-314 a.C.) pode ter se inspirado na definição de Aristóteles (384322 a.C.), seu contemporâneo, para compor seu discurso.

17 Contra, Lenfant (1999). O texto de Lenfant tenta mostrar a raridade documental acerca da exposição de crianças com deformidades na Grécia antiga. Para ela, a nossa compreensão das práticas gregas em relação à deformidade física é distorcida pelo conhecimento que temos das práticas romanas: "Generally speaking, understanding of Greek practices and beliefs in relation to monsters seems to have been distorted by knowledge of Roman ones. It is striking how often modern statements on prodigies 'in antiquity' rest in fact on Latin sources and Roman instances." (p. 205). Concordo com Lenfant acerca do cuidado que se tem de tomar a fim de não se projetar para os gregos práticas que conhecemos dos romanos. Contudo, a noção de algo extraordinário ou sobrenatural expressa por $\tau \dot{p} \rho \alpha \varsigma$ (teras) está mais próxima da expressa por monstrum do que da expressa pela moderna noção de "monstro", sendo o monstrum talvez o ponto de referência mais

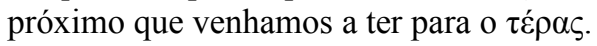

18 Com base em Céard, Davies (2013, p. 49-50) considera que o Renascimento tenha herdado três tradições interpretativas do monstro: a primeira corresponde à formulação de monstro aristotélica; a segunda, à do presságio de Cícero; e a terceira, ao monstro como maravilha da natureza, encabeçada pelos textos de Plínio, o Velho. Embora essa formulação de Davies pareça bastante adequada no que concerne as concepções renascentistas e suas origens nos textos da tradição clássica, a distinção entre o monstro como presságio e o monstro como maravilha da natureza se torna cada vez menos nítida quanto menos secularizado é o discurso, até chegar ao ponto em que são indistintas, como o são para a poesia hexamétrica arcaica, proposta defendida aqui. 
Este capítulo se debruça sobre essas três concepções, duas das quais se encontram elaboradas por autores antigos, e suas implicações para as formulações do monstro dentro de diversos campos do conhecimento científico no mundo moderno e contemporâneo.

\subsection{O MONSTRO TERATOLÓGICO ${ }^{19}$}

A acepção de "monstro" como uma anomalia da natureza encontra sua primeira elaboração (senão a primeira, ao menos a mais antiga que temos) em Aristóteles. Embora não seja mais tão usual definir anomalias ou deformidades anatômicas como monstruosidades, principalmente as presentes em seres humanos - uma prática comum até meados do século $\mathrm{XX}$, que vem sendo abandonada em razão dos avanços nos estudos de fisiologia, que, por sua vez, provocaram uma conscientização cada vez maior acerca da diversidade da natureza humana e da natureza em geral -, essa acepção ainda figura nos dicionários de língua portuguesa, sendo contudo a mais técnica dentre elas, por remeter ao objeto de estudo de um

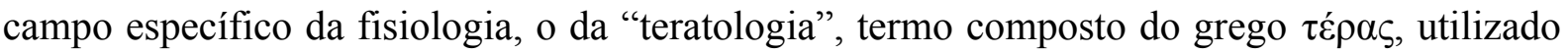
por Aristóteles para remeter a seres que apresentam algum tipo de anomalia ou deformidade. ${ }^{20}$

\section{1.a) Aristóteles: o monstro natural}

É em Geração dos animais, texto no qual Aristóteles examina os processos do desenvolvimento embrionário, que ele trata do tema da anomalia observável em corpos não normatizados, geralmente referida como deformidade e, cada vez menos, como monstruosidade. Por refletir seus interesses naturalistas, a definição de monstro encontrada em Geração dos animais é, portanto, elaborada com base na observação da natureza, não apresentando nenhuma relação com o âmbito mitopoético.

Ao discorrer sobre os diferentes níveis de semelhança esperada entre progenitores e sua prole, Aristóteles comenta que, por vezes, os filhos nascem com uma aparência tão

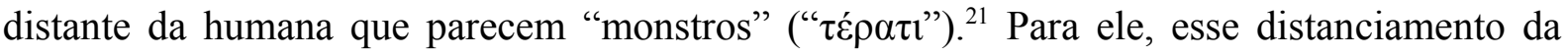

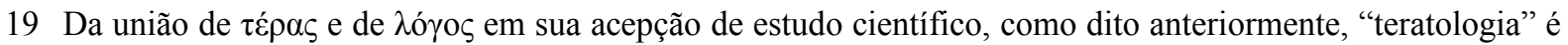
o termo que designa o ramo das ciências médicas que se dedica ao estudo da malformação embrionária. Que se entenda, portanto, "monstro teratológico" como a concepção de monstro que é objeto de estudo das ciências biológicas.

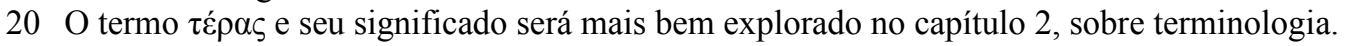

21 Embora nesta tese o termo "monstro" e correlatos sejam evitados para traduzir as ocorrências de $\tau \dot{\varepsilon} \rho \alpha \varsigma$ na poesia hexamétrica arcaica, preferindo-se "prodígio" ou "portento", toma-se aqui certa licença para se

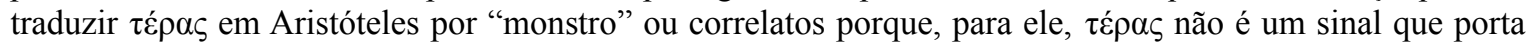
uma mensagem divina, mas um acontecimento puramente natural, desprovido de qualquer conexão com o mundo divino. Assim, o uso de $\tau \dot{\varepsilon}$ pas por Aristóteles articula-se com, ao menos, um dos sentidos modernos do termo "monstro", que encontra sua origem, possivelmente, nos textos do próprio Aristóteles. 
aparência humana e qualquer dessemelhança entre progenitores e prole são indícios de que a natureza sofreu um desvio: ${ }^{22}$

\begin{abstract}
As causas disso se devem a alguns rebentos se assemelharem a seus pais e outros não, alguns a seu pai e outros a sua mãe, de acordo com a totalidade do corpo e com cada parte, e se assemelharem mais aos pais do que aos ancestrais, e mais aos ancestrais do que a qualquer outro. Os homens se assemelham mais ao pai e as mulheres mais à mãe. Alguns não se assemelham a nenhum de seus parentes, conquanto se assemelhem a um ser humano. Outros não se assemelham a um ser humano em sua forma, mas a um monstro. Por isso, aquele que não se parece com seus genitores é, na verdade e de algum modo, um monstro, já que a natureza se desviou nesses casos, de algum modo, de sua ordem. [...]
\end{abstract}

É possível depreender desse trecho que a noção fundamental que subjaz à concepção aristotélica de monstruosidade é a de um desvio da natureza. Aristóteles, contudo, ressalta que tal desvio não deve ser entendido como algo contrário à natureza em si, pois tudo o que ocorre nela, mesmo que de forma contrária à generalidade dos casos ou a seu curso ordinário, ocorre de acordo com ela..$^{23}$ Ele circunscreve, portanto, a noção de $\tau \dot{\rho} \rho \alpha \varsigma$ ao âmbito exclusivamente natural, destituindo-o de seu caráter divino ou religioso enquanto sinal dos deuses, isto é, ele realiza uma desmistificação de $\tau \dot{\varepsilon} \rho \alpha \varsigma$ e da noção que o termo encerra. Essa operação de desmistificação da noção de monstro vem acompanhada pela desmitificação (sem "s") da possibilidade de existência de criaturas híbridas como as que frequentemente figuram nas narrativas mitológicas. Baseando-se ainda na observação empírica dos períodos de gestação de diferentes animais, Aristóteles afirma a impossibilidade de um animal, ou de um humano, ter a cabeça de outro animal. ${ }^{24}$ Para ele, ainda que um animal nasça com uma parte

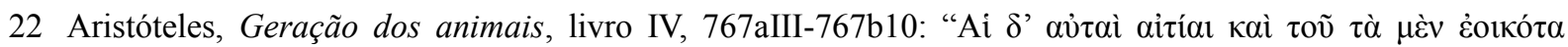

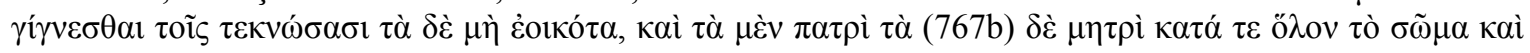

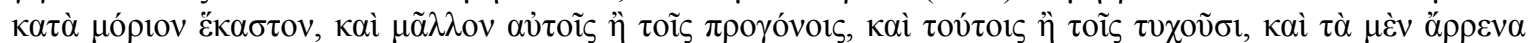

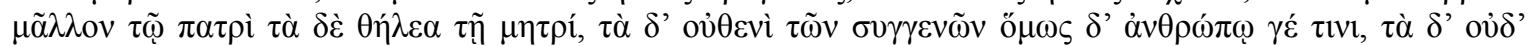

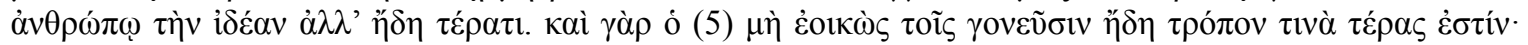

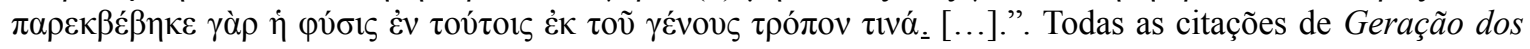
animais são provenientes da edição presente na tradução de Peck (1943) e as traduções são próprias. Como não sou especialista em Aristóteles, cujas particularidades conceituais são muitas, baseei-me nas soluções oferecidas por Peck principalmente em relação à terminologia.

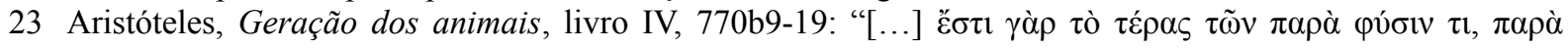

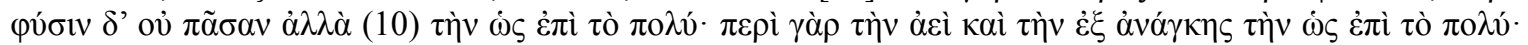

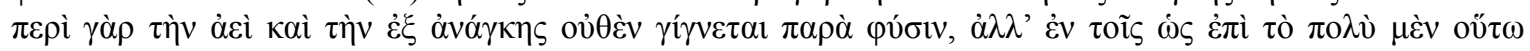

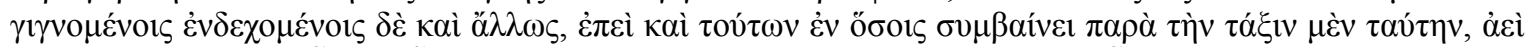

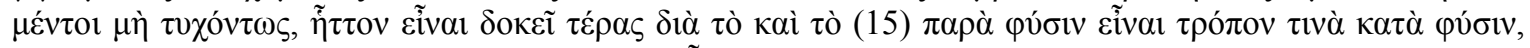

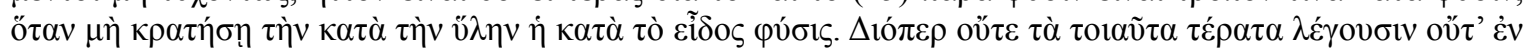

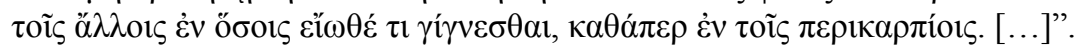

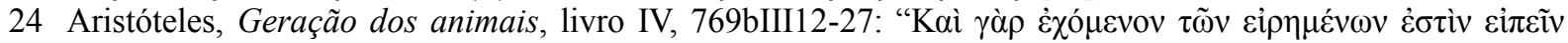

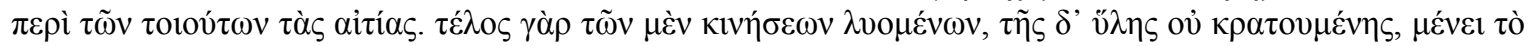

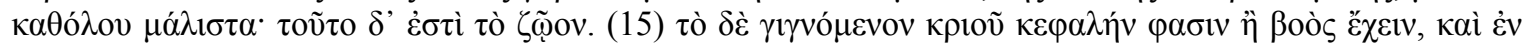

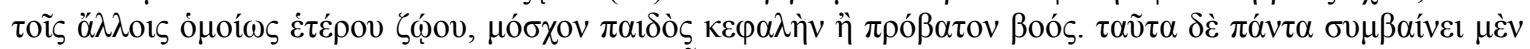

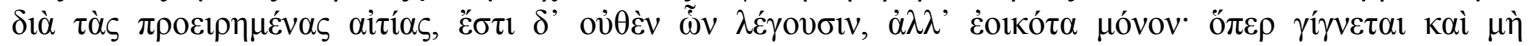

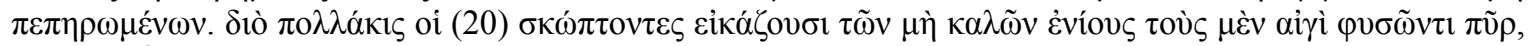

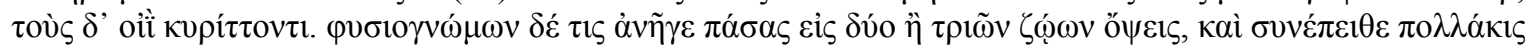


do corpo que se assemelhe a outro animal, isso não é mais que aparência. A esse hibridismo entre diferentes tipos de animais ou entre animais e o ser humano, Aristóteles acrescenta a multiplicidade de membros, embora não distinga claramente este último tipo de monstruosidade enquanto possibilidade real em contraposição à ficcionalidade dos seres híbridos. ${ }^{25}$ Sua equiparação entre as causas de monstruosidades e de deformidades o leva a concluir que "uma monstruosidade é, na verdade, um tipo de deformidade". ${ }^{26}$

No âmbito das preocupações naturalistas de Aristóteles, pode-se encontrar, portanto, duas noções fundamentais para o desenvolvimento futuro da noção de "monstro". Primeiro, uma definição desmistificada de monstruosidade, ou seja, estritamente relacionada ao mundo natural, na qual o monstro pertence às coisas que são contrárias à ordem da natureza, embora não contrária a ela em si; segundo, uma desmitificação do monstro híbrido ao demonstrar, pela observação empírica, a impossibilidade de animais nascerem com partes de outros. ${ }^{27}$ Esse exame de cunho racionalista, digno de um naturalista do século XVIII, preconiza, cerca de 1500 anos, o que Weber designa como segunda fase no processo de desencantamento do mundo, aquela em que a ciência reduz o mundo natural ao mero mecanismo causal. ${ }^{28}$

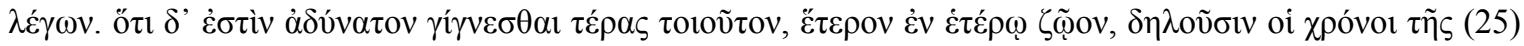

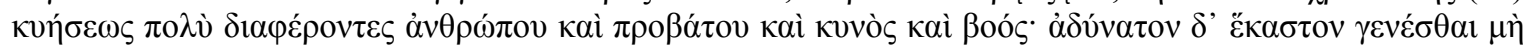

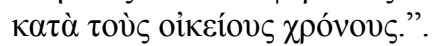

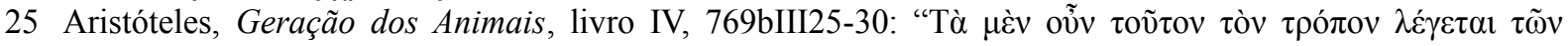

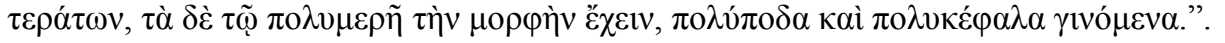

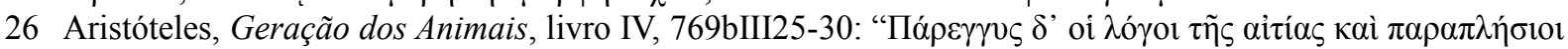

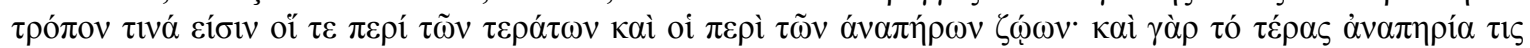

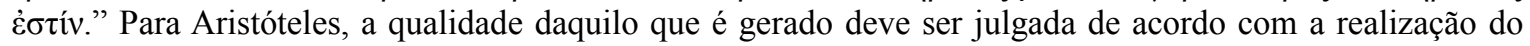
fim visado. O monstro, em sua forma imperfeita, é a não realização do fim visado e, portanto, da essência de um determinado ser. É como se, ao contrário do que ocorre quando a Natureza está dentro de seu curso, a matéria dominasse a forma impedindo-a de cumprir sua essência. Como no processo embrionário, segundo Aristóteles, é a parte masculina que provê a "forma" e a feminina que fornece a "matéria", decorre que ele atribui a geração de $\tau \dot{\varepsilon} \rho \alpha \tau \alpha$ à ocasião em que a parte masculina é dominada pela parte feminina, ou seja, Aristóteles acaba por atribuir a geração de crianças com deformidades às mulheres. Para uma crítica dessa visão das mulheres por parte de Aristóteles, cf. Horowitz (1976). Para uma tentativa de resgate de Aristóteles em relação à acusação, agora frequente, de misoginia, cf. Mayhew (2010).

27 É preciso ressaltar que, conquanto Aristóteles forneça uma definição de monstro calcada na observação da natureza e ainda recuse a existência de animais compostos de partes de animais diferentes, como o são alguns dos que figuram na poesia hexamétrica arcaica, não se pode considerar que essa dimensão racionalista predomine no pensamento nem mesmo de sua época. A definição de Aristóteles é particular de um filósofo naturalista e empirista, baseada em sua observação da physis, e não pode ser projetada para os séculos anteriores sem se correr o risco de cometer anacronia.

28 Cf. Pierucci (2013, p. 141-142). Ao explicar o conceito weberiano de "desencantamento do mundo", isto é, o processo pelo qual toda a magia é removida do mundo cedendo cada vez mais lugar à racionalização, Pierucci (p. 30-31) a chama sabiamente de "desendeusação do mundo". Para Weber, há dois momentos cruciais no longo processo de desencantamento do mundo: o primeiro é o desencantamento do mundo pela religião - e aqui a religião se refere estritamente à religião monoteísta - e o segundo, o desencantamento por meio da ciência. Penso que "monstro" é uma dessas noções com base nas quais esse processo pode ser observado com surpreendente clareza, pois o desencantamento pelo qual o termo e a noção "monstro" passam reflete esses dois momentos cruciais, principalmente no tocante à "desendeusação do mundo": no primeiro, à medida que há menos deuses no mundo, há menos remetentes das mensagens que o monstro porta e ele acaba carregando a mensagem unívoca de uma punição enviada por um único deus; no segundo, o monstro é desprovido de todo o sentido religioso, sendo excluído de qualquer relação com o mundo divino. 
Não obstante o tratamento empírico dispensado por Aristóteles à noção de $\tau \varepsilon ́ p \alpha \varsigma$ e a influência que teve sobre Lucrécio, Cícero, Plínio, o Velho, ou mesmo Santo Agostinho, a concepção desmistificada de monstro como produto da natureza só vai encontrar outros portavozes nos filósofos ou historiadores naturalistas a partir do século XVI. Portanto, no que

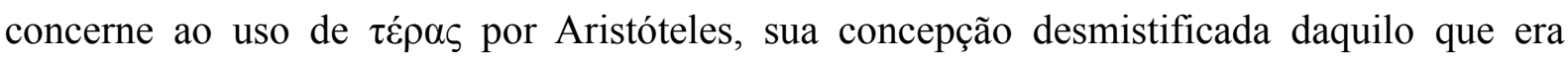
usualmente concebido como um sinal ou mensagem de origem divina é um tanto particular e não deve ser projetada sobre a poesia hexamétrica arcaica. ${ }^{29}$

\section{1.b) Dos filósofos naturalistas a Foucault: do monstro antinatural ao monstro interior}

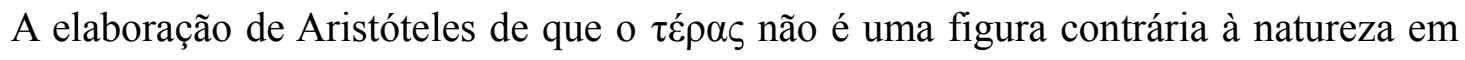
si, porque nada pode lhe ser contrário enquanto parte dela, mas uma figura que contraria a generalidade dos casos que podem ser encontrados nela vai ecoar na concepção epicurista do orador e filósofo romano Cícero que, em De Divinatione (II.28,60), ou "Sobre a adivinhação", utilizando o termo latino monstrum, expressa a mesma ideia ao declarar que este não é contrário à natureza (praeter naturam) conquanto contrário ao que é habitual (praeter consuetudinem).$^{30}$ De sua elaboração por Aristóteles no século IV a.C., passando pela apropriação por Cícero no século I a.C., essa contestação da noção de monstro como contrário à natureza ganhará uma nova nuança na reelaboração de Isidoro de Sevilha (566-636), certamente influenciado por Santo Agostinho: monstra não são contrários à natureza porque existem por vontade divina, e a vontade do Criador é a natureza de cada coisa que existe (Etimologias, XI.3). ${ }^{31}$ Ainda que portentos e prodígios nunca tenham deixado de ocupar um lugar na reflexão dos filósofos da teologia cristã durante a Idade Média, como Santo Agostinho e Isidoro de Sevilha, por exemplo, as considerações naturalistas de Aristóteles não encontraram lugar no sistema de pensamento então vigente, seja porque o acesso a seus textos era possível apenas em árabe, seja porque as preocupações de ordem teológica tinham primazia no pensamento medieval. ${ }^{32}$ Assim, é apenas na Idade Moderna, mais precisamente a partir do século XVI, que é possível perceber uma verve naturalista orbitando novamente o

29 Para um estudo da concepção de monstro de Aristóteles em relação à sua noção de incompletude (aquilo que não realizou sua essência) e ao conceito estético do inacabado, ver o capítulo de Eugénie Matthis, "Aristote, l'incomplet, le monstrueux et l'inachevé", (em Mazoyer e Pérez Rey, 2007, p. 203-217).

30 A edição utilizada de De divinatione é a que se encontra em Falconer (1923).

31 Cf. a noção de Santo Agostinho de que a natureza é a vontade de Deus em De civitate Dei, xxi.8 e De Trinitate, iii.2. A edição de Isidoro de Sevilha utilizada é a de Lindsay (1911).

32 Alberto Magno (ca. 1200-1280), considerado o principal seguidor de Aristóteles durante o período medieval, talvez seja a exceção mais conhecida. Sobre as traduções dos textos de Aristóteles nos séculos XII e XIII e da influência que tiveram sobre os filósofos naturalistas, inclusive Alberto Magno, cf. os capítulos 6 e 7 de Grant (2009). 
tema da monstruosidade, ou, mais precisamente, o da deformidade.

Ambroise Paré (1510-1590), que serviu quatro monarcas franceses como cirurgião (Henrique II, Francisco II, Carlos IX e Henrique III), pode ser considerado uma figura de transição entre a perspectiva estritamente teológica, predominante em sua época, e a naturalista, precursora da nossa perspectiva científica racionalista, ao adotar uma abordagem empirista caracterizada pela prática da observação direta dos corpos por meio da dissecação, um tanto similar à praticada por Aristóteles em animais. Não obstante, sua explicação para a existência de deformidades fisiológicas estava ainda profundamente enraizada na superstição e na crença religiosa. Em sua obra intitulada Des monstres et prodiges (1573), Paré oferece uma lista de possíveis causas para monstruosidades, dentre as quais a primeira é a glória de Deus e a segunda é sua ira. ${ }^{33}$ Assim, embora sua prática metodológica estivesse próxima da de um empirista como Aristóteles, sua elaboração teórica estava mais para a de Isidoro de Sevilha.

Emblemática desse "pensamento híbrido" de Paré é sua atitude desmistificadora, de certo modo, diante das criaturas híbridas de animal e ser humano: ele nega a essas criaturas o caráter de portento afirmando que elas não são portadoras de qualquer mensagem divina ou sinal, pois são simplesmente o resultado da relação sexual de sodomitas e ateus com animais. $^{34}$ Portanto, se, por um lado, Paré desmistifica o que ele próprio chama de "monstruosidade" porque suprime, em alguma medida, uma causa sobrenatural ou divina que é geralmente atribuída a ela, por outro, o mecanismo de causalidade aplicado por ele é ainda imbuído do tipo de julgamento pautado pela crença cristã e não pela comprovação empírica.

Uma distinção, contudo, chama a atenção no texto de Paré: uma elaboração que diferencia monstros de maravilhas e prodígios. Para ele, “[m]onstros são coisas que aparecem fora do curso da Natureza (e muito frequentemente são signos de um mal iminente), como uma criança que nasce com apenas um braço, outra que tem duas cabeças e membros em uma quantidade acima do ordinário", ou seja, monstros são desvios da norma. Contudo, "prodígios" vão muito além das anormalidades que os monstros apresentam: "Prodígios são coisas que acontecem [de modo] que são completamente contra a Natureza, como quando uma mulher dá à luz uma serpente ou um cachorro [...]". Talvez seja no texto de Paré que se encontre pela primeira vez uma distinção entre "prodígio" e "monstro". 35

33 Essa lista se encontra na p. 4 da tradução de Céard (cf. Paré, 1971).

34 Paré (1971, p. 62).

35 Paré (1971, p. 3): "Monstres sont choses qui apparoissent outre le cours de Nature (et sont le plus souvent signes de quelque malheur à devenir) como un enfant qui naist avec un seul bras, un autre qui aura deux testes, et autres membres, outre l'ordinaire. Prodiges, se sont choses qui viennent du tout contre Nature, comme une femme qui enfantera un serpent, ou un chien, ou autre chose du tout contre Nature, [...]". 
Ao final do século XVI, tratados sobre "monstros" tinham se tornado praticamente um gênero, do qual o volume de Paré é provavelmente o mais bem conhecido. ${ }^{36}$ Tais tratados, contudo, não se distinguem muitas vezes dos livros de curiosidades da época, geralmente denominados Book of Wonders (literalmente "Livro de Maravilhas"). A terminologia também não apresentava uma distinção marcada entre "monstro", "prodígio", "portento" e "maravilha" e, em vez de uma distinção entre elas, o que se percebe mais fortemente é que remetem ao mesmo campo semântico do extraordinário. Embora Paré opere uma distinção entre "monstros" e "prodígios", a compreensão geral desses termos na literatura francesa bem como na inglesa pende mais para uma sinonímia entre eles do que para uma distinção precisa e marcada.

A ideia de "monstros" como sinais enviados por Deus, compartilhada tanto pela cultura popular quanto pela erudita, começa a se retirar gradualmente do cenário intelectual inglês e francês a partir do começo do século XVII, como pode ser observado pelo programa de Francis Bacon para a reforma geral do conhecimento humano. Bacon julgava necessário catalogar todo tipo de "monstruosidades", pois, como parte da ordem da natureza, elas poderiam ser usadas para melhorar as explicações causais. ${ }^{37}$ Contudo, as feiras, como a Bartholomew Fair em Londres, e os gabinetes de curiosidade atraíam o mais variado tipo de público ao exibir seres humanos com algum tipo de deformidade junto com criaturas marinhas, artefatos ou indivíduos de sociedades não europeias como indígenas nativos das Américas. Conforme observa Davies (2013, p. 72-73), entre a obra de Paré e meados do século XVIII, "a categoria de monstro se expandiu enormemente, enquanto suas subdivisões se tornaram menos pronunciadas". ${ }^{38}$

É na França do século XIX, trezentos anos depois de Ambroise Paré, que Isidore Geoffroy Saint-Hilaire (1805-1861), dando seguimento aos trabalhos de seu pai, Étienne

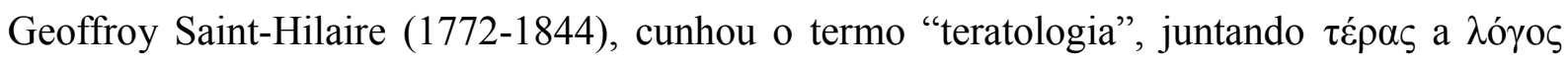
$(\log o s)$, em sua acepção oitocentista de “discurso científico". Isidore Geoffroy Saint-Hilaire é considerado o primeiro a fornecer uma definição científica para a categoria da monstruosidade em sua obra Histoire générale et particulière des anomalies de l'organisation

36 Cf. a introdução de Pallister (Paré, 1982) em sua tradução de Des monstres et prodiges para o inglês e a introdução de Céard (1971) à edição suíça. Pallister chama a atenção para o fato de que, apesar de afirmar não conhecer o grego antigo, Paré tem uma atitude empirista de valorização da experimentação muito próxima da de Aristóteles. Ambos chegaram ao tema da monstruosidade por intermédio da questão da reprodução. $\mathrm{O}$ fato de não saber grego, contudo, não deve ter impedido Paré de ter tido contato com traduções e comentários da obra de Aristóteles; cf. a afirmação de Céard (1971, p. xxxiii) de que Paré conhecia muito bem o texto Problemas, de Aristóteles, atualmente considerado pseudoaristotélico.

37 Cf. o artigo de Park e Daston (1981, p. 43 e ss.). As ideias de Bacon para a reforma do conhecimento podem ser encontradas em suas obras Novum Organum e The Advancement of Learning.

38 Davies (2013, p. 72-73): “[...] between Paré's Des monstres et prodiges of 1573 and the mid-eighteenth century, the category of monster expanded enormously, while its subdivisions became less pronounced". 
chez l'homme et les animaux, ou traité de tératologie. Nela, ele distingue quatro categorias de anomalias de acordo com seu nível de severidade: a primeira, denominada "hémitéries" ("semimonstruosas"), abrange as anomalias ditas simples, que não impõem obstáculo ao indivíduo, como lábio leporino ou o nanismo, por exemplo; a segunda, ou "heterotaxias" (“outra organização”), é composta de anomalias complexas que não são identificadas externamente, como o situs inversus, a inversão de posição dos órgãos internos; a terceira é denominada "hermafroditismo", incluindo anomalias que dificultam a diferenciação sexual; por fim, a quarta é a categoria das "monstruosidades", definidas como anomalias muito complexas e graves que não são compatíveis com a vida após o nascimento e frequentemente culminam em um aborto espontâneo. ${ }^{39}$

A definição elaborada por Isidore Geoffroy Saint-Hilaire coloca a monstruosidade no plano daquilo que pode ser considerado objeto de conhecimento científico, portanto, analisável, categorizável e explicável de um ponto de vista que prescinde da crença religiosa ou da atribuição de uma função ou explicação sobrenatural. Com Isidore Geoffroy SaintHilaire, portanto, completa-se o círculo: o "monstro", que era natural para Aristóteles, pois sua ocorrência não se dá senão na natureza, e que passou a maior parte de sua história imbuído de um caráter sobrenatural em uma relação muito próxima com o divino, fosse para o bem fosse para o mal, volta a ser concebido como produto da natureza novamente no século XIX.

Em 1880, Ernest Martin, com a publicação de Histoire des monstres: depuis l'antiquité jusqu'a nos jours, que traça uma história dos monstros em sentido estritamente teratológico desde a Antiguidade até o século XIX, coloca Étienne e Isidore Geoffroy SaintHilaire como fundadores definitivos da "ciência dos monstros". Segundo Martin, é com a obra dos Geoffroy Saint-Hilaire que "se dissipará o caos inextricável que durante tanto tempo confundiu mitos, ficções e realidades: o espírito agora mede a distância que separa o maravilhoso do verdadeiro, os seres fantásticos daqueles criados pela natureza" ${ }^{40}$ A obra de Ernest Martin, portanto, explicita a distinção entre o monstro do qual ela trata, ou seja, o ser humano portador de um corpo não normatizado em decorrência de deformidades e anomalias, e as concepções ficcionais e mitológicas do monstro. Martin inicia sua obra com o status legal do monstro na Antiguidade, em que "monstro" é claramente sinônimo para seres humanos

39 Apud Cuny-Le Callet (2005, p. 14-15). Isidore justifica o uso do termo "monstro" e "monstruosidade" pelo seu sentido no senso comum da época: "[...] Un monstre est, pour le vulgaire, un être dont l'aspect étonne et, presque toujours mème, offense les regards. [...]" (Saint-Hilaire, 1837-1838, p. 16).

40 Martin (1880, p. 380): "Désormais va se dissiper cet inextricable chaos où s'étaient si longtemps confondus les mythes, les fictions et les réalités: l'esprit mesure maintenant la distance qui sépare le merveilleux du vrai, les êtres fantastiques de ceux que crée la nature". 
com algum tipo de deformidade e termina com um capítulo sobre indivíduos "monstruosos" célebres à sua época. Tal obra é tão emblemática da atitude do século XIX em relação aos avanços das ciências médicas e suas implicações para as noções de normalidade e anomalia, que Foucault a utiliza como fonte em sua análise da figura do monstro para o curso que proferiu no Collège de France entre 1974 e 1975, publicado sob o título Les Anormaux em 1999, cujo tópico é a emergência do indivíduo anormal no século XIX. ${ }^{41}$ A aula de 22 de janeiro de 1975 é centrada na distinção entre o "monstro", o "indivíduo a ser corrigido" e o "masturbador", principalmente a criança que se masturba, como figuras centrais da anormalidade no século XIX.$^{42}$ É nesse curso que o filósofo francês delineia a transição entre a monstruosidade física ou morfológica para a monstruosidade no âmbito do comportamento, que ele localiza no século XIX.

No que concerne o tratamento do tema da monstruosidade, Foucault foi bastante influenciado por seu orientador, o epistemólogo e historiador da ciência Georges Canguilhem. Formado na École Normale Supérieure, tendo entrado no mesmo ano e feito parte da mesma turma de Jean-Paul Sartre, Canguilhem complementou sua formação humanística ao se graduar também médico. Sua obra Le normal et le pathologique contém um importante ensaio baseado em uma conferência proferida em Bruxelas em 1962 sobre o monstro e a monstruosidade ("Monstre et Monstruosité").

Tanto Canguilhem como Foucault resgatam essa tradição denominada aqui de "monstro teratológico" e a integram em suas respectivas reflexões filosóficas sobre normas, normalidade e normalização. Ambos localizam na obra de Isidore Geoffroy Saint-Hilaire o momento crucial da mudança de atitude em relação ao monstro e à monstruosidade. Para Canguilhem, com a descrição das causas e com a classificação da monstruosidade, realizadas principalmente por Saint-Hilaire, o monstro se tornou "transparente" ao pensamento científico, que relegou toda forma de monstruosidade ao reino do mito e da imaginação, uma ideia resumida em sua frase "A vida é pobre em monstros. O fantástico é um mundo [de monstros]".

Para Foucault, opera-se, no século XIX, uma transição da figura do monstro enquanto uma noção do discurso legal, porque transgressora seja das leis da natureza seja das leis da sociedade, para a figura do sujeito anormal, objeto do discurso médico-legal e, depois, do psiquiátrico. Não é difícil imaginar a sobreposição da deformidade física do monstro com a anormalidade do paciente psiquiátrico. Ao final do século XIX, a "monstruosidade" exterior, como a de gêmeos xifópagos ou de portadores de neurofibromatose, caso de Joseph Carey 
Merrick, o famoso homem-elefante, era cada vez mais desmistificada pela recém-criada teratologia e cedia espaço para outro tipo de monstruosidade, um tipo que não é reconhecido imediatamente ao se observar a compleição física de um indivíduo, mas que se traduz eventualmente em seus atos, como o canibalismo, por exemplo.

Esse movimento da monstruosidade perceptível em sua dimensão corpórea para a monstruosidade interior, muitas vezes oculta ao observador externo e que se mostra apenas quando traduzida em ações consideradas monstruosas, pode ser bastante sentido na literatura inglesa ao longo do século XIX. O início do século testemunha o surgimento do romance Frankenstein ou Prometeu moderno, de Mary Shelley, no qual o monstro, cujo corpo é um agregado de partes de cadáveres de indivíduos de baixa estirpe, é, ao fim, mais nobre em suas ações do que o bem-educado doutor que o criou, abandonou-o à sua sorte e o renegou em todas as oportunidades que teve de se redimir. A criatura de Frankenstein frustra as expectativas de monstruosidade do leitor e revela a atitude desumana do criador, não da criatura, colocando em perspectiva a figura do monstro e relativizando a concepção de humanidade. Ao final do século XIX, Robert Louis Stevenson publica Dr. Jekyll and Mr. Hyde, traduzido para o português como $O$ médico e o monstro, cujo protagonista, também um respeitado doutor, encerra em si próprio a figura do monstro: o duplo médico e monstro, figuras distintas na obra de Shelley, juntam-se em uma única pessoa na novela de Stevenson, e o hibridismo prescinde de ser uma característica reconhecidamente exterior, passando a ser também interior. Quatro anos depois da publicação de Dr. Jekyll and Mr. Hyde (1886), Oscar Wilde lança seu único romance, The Picture of Dorian Gray (1890), em que o resultado das ações do protagonista é mantido oculto ao ser projetado no quadro do belo jovem, e sua monstruosidade é visível apenas no momento de sua morte.

Essa foi uma tentativa de traçar, em linhas bastante gerais, a trajetória de uma das direções tomadas pela noção de "monstro", mais precisamente, aquela que encontra sua primeira elaboração com Aristóteles e que foi denominada aqui de "monstro teratológico". A

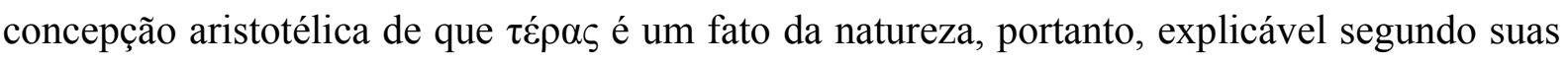
leis ou sua ordem, destitui do termo a intenção ou o desejo dos deuses de comunicação com a esfera humana. Com isso, Aristóteles subtrai a noção de $\tau \dot{\varepsilon} \rho \alpha \varsigma$ do universo da adivinhação: ele não é uma mensagem dos deuses porque suas causas são naturais e não divinas. Essa não é, contudo, a concepção predominante na Antiguidade, seja na que denominamos "grega", seja 
na romana, nem será durante toda a Idade Média e grande parte da Modernidade. Não há, contudo, uma elaboração da noção de $\tau \dot{\varepsilon} \rho \alpha \varsigma$ enquanto uma mensagem divina por autores da Antiguidade helênica. O que há é a elaboração da concepção de monstrum, prodigium, portentum, todos termos usados no âmbito da adivinhação, por autores romanos, dentre os quais o principal talvez seja o orador Cícero.

\subsection{O MONSTRO, O PRODÍGIO, O PORTENTO: SINAIS DOS DEUSES}

A afirmação de Aristóteles de que um $\tau \dot{\varepsilon} \rho \alpha \varsigma$ apresenta causas estritamente naturais é uma contraposição à noção de que aqueles seres, animais ou humanos, portadores de deformidades ou anomalias transmitem alguma mensagem dos deuses. O $\tau \dot{\varepsilon} \rho \alpha \varsigma$ enquanto mensagem divina não se restringe, contudo, a seres viventes; ele abrange fenômenos diversos, que hoje denominamos "naturais", como um arco-íris ou a erupção de um vulcão, com base nos quais um adivinho decifra a mensagem que está sendo enviada pelos deuses. Portanto, $\tau \varepsilon ́ p \alpha \varsigma$ é um tipo de $\sigma \tilde{\eta} \mu \alpha$, um sinal que precisa de interpretação, seja ele um fenômeno como o arco-íris ou o nascimento de um animal com duas cabeças. ${ }^{43}$

Embora Aristóteles tenha lançado mão de uma explicação para o $\tau \varepsilon \dot{\varepsilon} \rho \alpha \varsigma$ enquanto ser vivo baseada puramente na observação da physis, a visão comum durante toda a Antiguidade Clássica é de que esses seres tinham causa divina. E apesar da elaboração de Aristóteles, como visto anteriormente, essa concepção de que o nascimento de seres com alguma anomalia era uma mensagem dos deuses ou de Deus predominou, de uma forma ou de outra, até os séculos XVIII e XIX, quando encontrou sua desmistificação final com os Saint-Hilaire. Assim, o estudo do monstro enquanto prodígio se relaciona com o estudo do monstro teratológico, não enquanto compreensão em paralelo do mesmo fenômeno, mas enquanto explicação prevalente durante grande parte da história que foi, subsequentemente e em grande medida, suplantada pela noção de monstro teratológico.

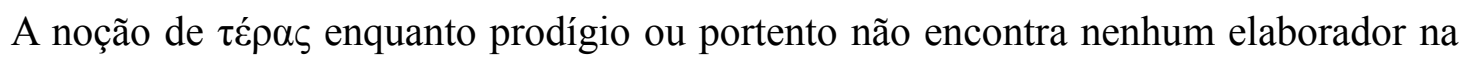
Antiguidade helênica como a do monstro teratológico encontrou em Aristóteles. É em Cícero que se pode encontrar uma formulação entre os antigos da noção de monstrum em conjunto com prodigium, portentum e ostendum. Tanto Aristóteles quanto Cícero defendem a causa

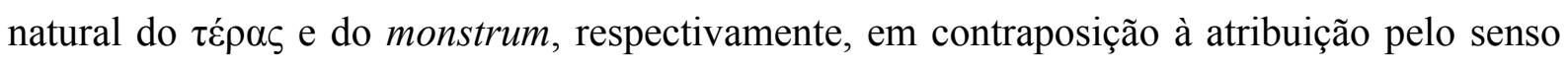
comum de uma causa estritamente divina. Esse debate entre a causa divina ou natural do $\tau \varepsilon ́ p \alpha \varsigma$ ou do monstrum perpassa grande parte da história da noção de monstruosidade, como

43 Cf. Colombo (2012) e também o capítulo 2, p. 66 e ss. 
apontou Blandine Cuny-Le Callet (2005) já no prefácio de seu estudo sobre "Roma e seus monstros" (Rome et ses monstres): "A história da monstruosidade no pensamento ocidental é a da confrontação - e por vezes da conjunção - de uma visão religiosa do monstro e de uma visão 'científica', que exclui a ideia de uma origem divina ou demoníaca da criatura monstruosa". ${ }^{44}$ Em Aristóteles se encontra a formulação dessa visão científica em contraposição a uma visão mística e em Cícero, sem dúvida leitor de Aristóteles, encontra-se a apropriação dessa formulação em um contexto de reflexão sobre a atividade divinatória, ou seja, o orador romano junta em um só texto, o De divinatione ("Sobre a adivinhação"), os argumentos que advogam em favor e contra ambas as concepções.

\section{2.a) Cícero: monstrum entre natureza e retórica}

Para Cuny-Le Callet (2005, p. 39) e Moreau (2014, p.44-47), o uso do termo monstrum associado a inimigos políticos de Cícero, como Catilina e Marco Antônio, embasa a noção de que nos discursos do orador romano nasce a figura do "monstro político". Contudo, ao se deter nos textos, é possível observar que essa compreensão é tanto uma derivação quanto uma projeção da nossa própria noção de monstro. Parece-me que a noção de monstrum em Cícero é estritamente aquela de sinonímia com portentum e prodigium, ou seja, termos do campo divinatório. Ainda que Cícero, em seu diálogo Sobre a adivinhação, exponha uma visão ambígua ou contraditória da atividade divinatória, colocando argumentos em seu favor nas falas de seu irmão Quinto, que representa a perspectiva estoica, e apresentando os argumentos academicistas contra tal atividade por meio de sua própria figura como persona do diálogo, os termos monstrum, prodigium, portentum e ostendum são usados dentro do campo semântico da adivinhação.

Veja-se, por exemplo, que, em um de seus primeiros discursos, Em defesa de Sexto Róscio Amerino, Cícero utiliza os termos portentum, prodigium e monstrum para definir o crime do parricídio. Ao defender Sexto Róscio da acusação de ter matado seu próprio pai, Cícero desenvolve parte de seu argumento se baseando na gravidade desse tipo de crime. Segundo ele próprio, o parricídio é "tão atroz, tão singular e tão raramente cometido", que, quando se ouve a respeito, é considerado um "portento ou prodígio" (portenti ac prodigi). ${ }^{45}$

44 Cuny-Le Callet (2005, p. 13): L'histoire de la monstruosité dans la pensée occidentale est celle de la confrontation - et parfois de la conjugaison - d'une vision religieuse du monstre et d'une vision 'cientifique', excluant l'idée d'une origine divine ou démoniaque de la créature monstrueuse. [...]".

45 Cícero, Pro Roscio, 13[38]: "[...] in hoc tanto, tam atroci, tam singulari maleficio, quod ita raro exstitit ut, si quando auditum sit, portenti ac prodigi simile numeretur [...].". Todas as citações do latim de Pro Roscio de Cícero são da edição de Clark e Peterson (1905-1918, vol. 1). 
Um pouco mais adiante nesse mesmo discurso, Cícero repete a construção da sinonímia entre "parricídio" e "portento" ao usar a expressão portentum atque monstrum ("portento e monstro") para remeter àqueles que, pertencendo à espécie humana, assassinam os que lhe deram a vida, ultrapassando os animais em selvageria. ${ }^{46}$

Embora seja bastante tentador compreender o parricida como um "monstro", o termo latino remete não à figura de um monstro em si, mas ao "mau augúrio" que o crime do parricídio anuncia. Perceba-se que Yonge, o tradutor do discurso para a língua inglesa, sensível à estranheza que "monster" teria causado na passagem, teve a sensibilidade de traduzir "monstrum" por "prodigy" em lugar de "monster". ${ }^{47} \mathrm{O}$ parricida, nessa passagem, não deve ser entendido como um "monstro" no sentido moderno, mas como o prenúncio de eventos desastrosos: por ser raro entre os romanos, o crime do parricídio é um dos eventos sinalizadores de que algo ruim recairá sobre toda a cidade. ${ }^{48}$

Uma confusão semelhante é possível na leitura de outro discurso, Em defesa de Marco Célio, em que Cícero recorre ao mesmo recurso de aproximação entre monstrum e uma figura humana, e no qual Yonge traduz novamente o termo "monstrum" por "prodigy".49

[...] neque ego umquam fuisse tale monstrum in terris ullum puto, tam ex contrariis diversisque atque inter se pugnantibus naturae studiis cupiditatibusque conflatum. (Cícero, Pro Caelio, 5[11].)

Nor do I believe that there ever existed so strange a prodigy up on the earth, made up in such a manner of the most various, and different and inconsistent studies and desires.

Nessa passagem, monstrum se refere a Catilina, um dos inimigos mais famosos de Cícero e, por isso, a tendência de se traduzir o termo latino por "monstro" pode ser ainda mais difícil de evitar. Cícero descreve Catilina como um "monstrum" de natureza variada e inconsistente em seus desejos, remetendo à natureza híbrida (ou "quimérica") que um monstrum pode apresentar, o que pode ser um elemento forte para induzir a tradução por "monstro". Yonge, contudo, escolhe "prodigy" em detrimento de "monster", não traindo sua sensibilidade para a diferença que há entre o "monstrum” latino e o "monster" moderno.

46 Cícero, Pro Roscio, 22[63]: "[...] portentum atque monstrum certissimum est esse aliquem humana specie et figura qui tantum immanitate bestias vicerit ut, propter quos hanc suavissimam lucem aspexerit, eos indignissime luce privarit, cum etiam feras inter sese partus atque educatio et natura ipsa conciliet.".

47 Yonge (1913-1921, vol. 1): "[...] it is a most undeniable portent and prodigy, for any one to exist in human shape, who so far outruns the beasts in savageness, as in a most scandalous manner to deprive those of life by whose means he has himself beheld this most delicious light of life; when birth, and bringing up, and nature herself make even beasts friendly to each other."

48 Cf. comentário e referências em Dyck (2010, p. 110 [38] e p. 130 [63]).

49 Texto em latim da edição de Clark e Peterson (1905-1918, vol. 1) e tradução para o inglês de Yonge (19131921, vol. 3). 
Há ainda outra circunstância de uso de monstrum em Cícero que pode levar a uma interpretação ou tradução equivocada de monstrum por "monstro". Na décima terceira filípica ou décimo terceiro discurso contra Marco Antônio, Cícero associa os Antonii aos três termos latinos: "monstrum", "portentum" e "prodigium":50

[...] 'prius undis flamma,' ut ait poeta nescio quis, prius denique omnia quam aut cum Antoniis res publica aut cum re publica Antonii redeant in gratiam. monstra quaedam ista et portenta sunt et prodigia rei publicae. [...]. (Cícero, Filípicas, $13[21]$.

[...] 'Sooner shall fire and water mingle,' as some poet or other says; sooner shall any thing in the world happen than either the republic become reconciled to the Antonii, or the Antonii to the republic. Those men are monsters, prodigies, portentous pests of the republic. [...].

Conquanto nessa passagem Yonge tenha traduzido "monstra" por "monsters", "monstra", "portenta" e "prodigia" expressam mais um prenúncio de que a conciliação entre os Antonii e a República simboliza a ruína que recairá sobre a república romana, ou seja, um mau augúrio, em detrimento de uma sinonímia entre os Antonii e a figura de um "monstro" no sentido moderno.

Com base nessas três ocorrências de "monstrum" em discursos de Cícero, é compreensível que Cuny-Le Callet (2005) e Moreau (2014) depreendam um sentido de "monstro político" para a noção em Cícero. O que se contesta aqui não é a aplicação do adjetivo "político" ao monstrum de Cícero, mas a projeção mesma da noção de "monstro" como concebida atualmente.

Esse uso dos termos monstrum, portentum e prodigium pelo orador romano indica o sentido que eles recebem no senso comum, ou em seu uso cotidiano, de augúrio ou presságio. Não obstante, na obra de Cícero que se centra especificamente em torno do tema da adivinhação, é possível observar a herança aristotélica da concepção do monstrum ( $\tau \dot{\varepsilon} \rho \alpha \varsigma$ em Aristóteles) enquanto contrário não à natureza em si (praeter naturam), mas à generalidade dos casos ou, em termos ciceronianos, "ao habitual" (praeter consuetudinem). ${ }^{51}$ Nessa obra em forma de diálogo entre Cícero e seu irmão Quinto, este apresenta os argumentos estoicos

50 Texto em latim da edição de Clark e Peterson (1905-1918, vol. 2) e tradução para o inglês de Yonge (19131921, vol. 4).

51 Cícero, Sobre a adivinhação, 2.60 [28] (edição e tradução para o inglês em Falconer, 1923): "An vero illa nos terrent, si quando aliqua portentosa aut ex pecude aut ex homine nata dicuntur? quorum omnium, ne sim longior, una ratio est. quicquid enim oritur, qualecumque est, causam habeat a natura necesse est, ut, etiamsi praeter consuetudinem extiterit, praeter naturam tamen non possit existere. causam igitur investigato in re nova atque admirabili, si poteris; si nullam reperies, illud tamen exploratum habeto, nihil fieri potuisse sine causa, eumque terrorem, quem tibi rei novitas attulerit, naturae ratione depellito. ita te nec terrae fremitus, nec caeli discessus, nec lapideus aut sanguineus imber, nec traiectio stellae, nec faces visae terrebunt." 
em favor da atividade divinatória no livro I e as falas de Cícero apresentam os argumentos academicistas contra tal atividade predominantemente no livro II. ${ }^{52} \mathrm{Na}$ passagem citada em nota, é possível observar não apenas o discurso em favor de uma desmistificação do portento, mas uma pequena lista de eventos que fazem parte do que se considera um portento, como terremotos, estrelas cadentes ou cometas. Monstra, portenta e prodigia não se referem apenas a nascimentos de crianças disformes ou a criaturas que modernamente consideramos monstruosas, mas a qualquer fenômeno que se conceba como uma manifestação portadora de uma mensagem enviada pelos deuses.

Em 42.93, Cícero explicita uma diferenciação entre os tipos de augúrio de acordo com a ação expressa pelo verbo originário do termo:

[...] Quorum quidem vim, ut tu soles dicere, verba ipsa prudenter a maioribus posita declarant. Quia enim ostendunt, portendunt, monstrant, praedicunt, ostenta, portenta, monstra, prodigia dicuntur. [...].

[...] Indeed, the inherent force of these means of divination, as you like to observe, is clearly shown by the very words so aptly chosen by our ancestors to describe them. Because they 'make manifest' (ostendunt), 'portend' (portendunt), 'intimate' (monstrant), 'predict' (praedicunt), they are called 'manifestations,' 'portents,' 'intimations, and 'prodigies.'[...].

Note-se que Falconer (1923) traduziu o verbo latino "monstrant" por "intimate" no inglês em detrimento de "show" ("mostrar", "revelar"), privilegiando o sentido do verbo monere ("admoestar", "avisar"), uma das etimologias possíveis do substantivo "monstrum" e do verbo "monstrare". Apesar dessa distinção apontada por Cícero entre os termos que designam atividades divinatórias, em seus textos ela não parece ser rigidamente seguida, já que ele frequentemente usa um ou outro termo indistintamente, como pode ser percebido pelas passagens dos discursos citados acima. ${ }^{53}$

O fato de Cícero argumentar em Sobre a adivinhação contra a noção de que monstra, portenta, prodigia e ostenda carregarem mensagens divinas é em si indicativo de que essa era a crença comum e, portanto, a noção predominante entre os seus contemporâneos.

52 Há interpretações diversas e divergentes relativas à posição de Cícero no tocante à atividade da adivinhação. Céard (1977, p. 3 e 7-11) considera que Cícero seja favorável à atividade da adivinhação e contrário à perspectiva totalmente naturalista de Aristóteles; Cuny-Le Callet (2005, p. 229-230) declara que a reflexão filosófica de Cícero "implica uma necessária desconstrução da noção religiosa de monstruosidade"; Schultz, (2014, p. 13), por sua vez, defende a neutralidade de Cícero.

53 Cf. Céard (1977, p. 11-12), nas quais ele aponta o uso indistinto dos termos divinatórios por parte de Cícero. 
Embora a prática da adivinhação tenha sido colocada em posição de marginalidade no mundo cristão medieval, o vocabulário relacionado a ela, principalmente os termos prodigium, portentum e monstrum continuaram a aparecer nas obras de autores cristãos como Santo Agostinho e Isidoro de Sevilha (Céard, 1977, p. 32). Esses termos, contudo, ao longo da Idade Média, deixaram de designar uma mensagem dos deuses que precisava ser decifrada pelo áugure a fim de ser revelado um acontecimento futuro. Os prodigia, portenta ou monstra passaram a ser vistos como sinais da vontade divina (Friedman, 1981, p.108-130) e, em certos casos, especificamente como punições de Deus contra atos já realizados (Wilson, 1993, p. 22). Portanto, apesar de manterem um valor indicial, o tempo ao qual remetem deixa de ser o futuro, sobre o qual transmitiam um aviso, e passa a ser o passado, o tempo de um pecado já cometido para o qual o monstrum é uma punição.

Era de se esperar que essa noção arrefecesse à medida que o discurso científíco ganhava força no século XVIII, principalmente depois dos estudos dos Saint-Hilaire, pois, se a monstruosidade apresentava causas naturais, como já defendia Aristóteles, ela não precisaria ser explicada em termos sobrenaturais ou divinos nem ter significado extrínseco à ordem da natureza. Enquanto essa "direção" ou "ordem do discurso" sobre o "monstro" como portento predominou durante a Antiguidade e a Idade Média em relação aos nascimentos de crianças ou de animais com anomalias, ou mesmo de fenômenos naturais não usuais, há outra que seguiu a tradição de narrativas de terras distantes com descrições de povos de raças ditas monstruosas. Essas raças são geralmente localizadas no longínquo Oriente ou são representadas visualmente em mapas como habitantes das bordas do universo conhecido. As raízes clássicas dessa tradição serão apresentadas a seguir como uma das concepções daquilo que nós modernos costumamos pensar que os antigos consideravam monstruoso.

\subsection{O MARAVILHOSO}

Um elemento importante do maravilhoso na Antiguidade Clássica é aquele composto por figuras que denominamos monstruosas. Elas podem figurar no discurso poético do epos homérico, como aquelas que Odisseu diz encontrar na Odisseia, nas narrativas de Heródoto em suas Histórias, nos fragmentos de Ctésias de Cnido ou de Megástenes, nas mitografias como a Biblioteca de Apolodoro ou no grande projeto enciclopedístico de Plínio, o Velho. Antes de prosseguir com o monstro, contudo, é necessário ressaltar que o adjetivo "maravilhoso" usado aqui não deve ser tomado pelo "fantástico" enquanto gênero literário: "maravilhoso" serve fundamentalmente para indicar que a direção do sentido de "monstro", 
ou ordem do discurso acerca dele, decorre do efeito de "maravilhamento" ou, para usar um termo talvez mais neutro, de "espanto" que ele causa. É nesse efeito, deveras, que todas as noções de monstro exploradas anteriormente se interseccionam: tanto o prodígio divino,

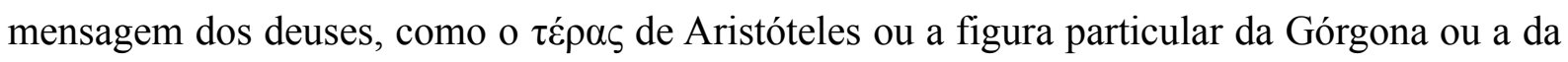
Quimera ou, ainda, a raça dos ciclopes na Odisseia. Todas essas instâncias do que pode ser

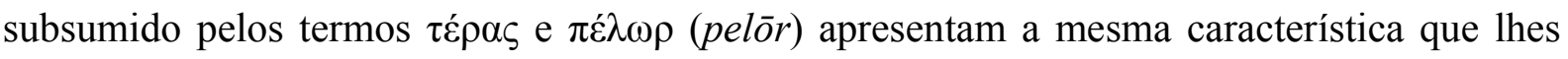
possibilita causar esse efeito de maravilhamento: seu caráter extraordinário. No entanto, nesta direção ou ordem do discurso sobre o monstro, a ênfase recai não na busca pelas causas naturais ou nos significados divinos do prodígio, mas precisamente no efeito de maravilhamento causado por meio de sua representação verbal.

\section{3.a) O maravilhoso etnográfico}

Carol Dougherty (2001), logo na introdução de seu livro The Raft of Odysseus: Ethnographic Imagination of Homer's Odyssey, coloca o protagonista Odisseu como protótipo da figura do "viajante-observador". ${ }^{54}$ Seu objetivo nesse livro é explorar o que ela denomina "imaginação etnográfica" da Grécia arcaica, que a própria autora define nos seguintes termos: “[...] a visão, como articulada na Odisseia, de um mundo fabuloso distante no tempo e no espaço [...]". ${ }^{55}$ É evidente que Dougherty não quer dizer que Odisseu é um etnógrafo à moda de Levi-Strauss no século XX. Seu paralelo entre o discurso etnográfico e as narrativas de Odisseu, guardadas as devidas proporções, tem como objetivo apontar que tanto Odisseu no épico homérico quanto o etnógrafo no mundo moderno constroem o discurso sobre o outro como produto de observação em primeira mão. O viajante que narra suas aventuras entre povos desconhecidos ao voltar para casa é um tópos literário recorrente na literatura ocidental. Diferente do que ocorre com o discurso etnográfico moderno, contudo, esse tópos literário prescinde totalmente de uma distinção entre o que é "real" e o que é "fantástico" ou "imaginário".

Heródoto (segunda metade do século $\mathrm{V}$ a.C.), que geralmente recebe a alcunha de "historiador" ou, mais atualmente, de "primeiro etnógrafo", fornece em sua obra Histórias descrições de raças como os Arimaspos, seres humanos com apenas um olho que habitavam o

54 O que Dougherty (2001, p. 4) denomina "traveler-observer" Hartog (1999) havia denominado "homensfronteira" ("Hommes-frontières"). Para Hartog, esses homens incorporam a marca da fronteira ao mesmo tempo que mantêm grande mobilidade.

55 Dougherty (2001, p. 8): “[...] In this book, I set out to explore what I call the 'ethnographic imagination' of early archaic Greece - the vision, as articulated in the Odyssey, of a fabulous world long ago and far away and the ways in which that vision helps accommodate and articulate particular issues pertaining to the early archaic Greek world. [...]". 
norte da Cítia (3.116.2). ${ }^{56}$ Apesar de declarar que não acredita na existência de uma raça de humanos com apenas um olho ou com pés de cabra ou que durmam durante metade do ano (4.25.1), seu ceticismo é menor quando se trata de raças de animais como as formigas que encontram ouro na Índia (3.102), ou as cobras voadoras da Arábia (3.102) ou os grifos guardiões de ouro (3.116).$^{57} \mathrm{~A}$ abertura de Heródoto para comentar acerca da existência ou não dessas criaturas é um sinal de que seus critérios não são exatamente os mesmos dos historiadores modernos, que pressupõem a inexistência delas.

As criaturas consideradas monstruosas, contudo, aparecem de maneira incidental na obra de Heródoto, diferente do que ocorre com o tratado de Ctésias de Cnido, que teria trabalhado como médico na corte do rei persa Artaxerxes II e, ao retornar à Hélade, teria escrito suas memórias das ideias que os persas tinham da Índia. ${ }^{58}$ É à Indika de Ctésias que se atribui o papel de ter moldado uma concepção de Índia enquanto uma terra distante, exótica e habitada por raças de seres fantásticos, que vai prevalecer no mundo ocidental por toda a Idade Média. Isso não ocorre, decerto, sem a intermediação do autor romano Plínio, o Velho, e sua História Natural. Segundo o historiador da arte Rudolph Wittkower (1944), em seu artigo considerado seminal acerca do manuscrito medieval Marvels of the East (séc. XII), Ctésias e Plínio são cruciais para a concepção de Índia ou de “Oriente” que se tornou lugarcomum nas narrativas de viagens ou no gênero de descrição das "maravilhas", um dos favoritos do período medieval. ${ }^{59}$

No mundo romano, o monstro como elemento do maravilhoso também figurou no discurso poético como o de Ovídio em Metamorfoses, na Eneida de Virgílio e em outros poemas latinos. ${ }^{60}$ No entanto, a direção do monstro como "mirabilia" no mundo medieval encontra no projeto enciclopedístico de Plínio, o Velho, uma fonte segura acerca da existência dessas criaturas. A História Natural de Plínio, obra que lhe valeu a alcunha de "naturalista", é composta de 37 livros nos quais são descritas raças como a dos cinocéfalos, homens com cabeça de cachorro, e a dos ciápodas, cujo único pé funcionava como um guarda-sol. É muito provável que Plínio tenha tido Ctésias e Megástenes - este embaixador de Seleuco Nicátor na Índia - como fontes para suas descrições de raças maravilhosas (Friedmann, 1981, p. 5-25), que não incluem apenas seres que denominamos monstruosos, mas raças de homens como os

56 Para a presença do maravilhoso em Heródoto, cf. Morais (2004).

57 Cf. a discussão no comentário de Asheri, Lloyd, Corcella et al. (2007, p. 504).

58 Fragmentos da obra Indika de Ctésias sobrevivem em citações feitas por outros autores. Há também o resumo presente na Bibliotheka de Fócio de Constantinopla. Cf. McCrindle (1882) e a recente tradução dos trechos de Ctésias por Nichols (2011).

59 Wittkower está preocupado em traçar uma genealogia do discurso que coloca a Índia como lugar do exótico ou do maravilhoso e, nesse sentido, essa concepção helênica, e depois romana, de Índia teria moldado a concepção ocidental.

60 Cf. Lowe (2015). 
que se alimentam exclusivamente de odores ou os que habitam em cavernas e não têm fala, denominados "trogloditas". 61

Raças como essas, mencionadas por Heródoto ou descritas por Ctésias e depois por Plínio, e apropriadas no mundo medieval pelo discurso das mirabilia, são colocadas dentro de uma espacialidade distante, para fora ou para o limiar do mundo conhecido. Durante o período medieval, essa espacialidade foi muitas vezes traduzida em cartografia, ou seja, na produção de mapas nos quais era comum representar figuras monstruosas em suas bordas. $\mathrm{O}$ monstro "etnográfico", portanto, acaba sendo também "geográfico/cartográfico" (Friedman, 1981, p. 37-58). Com as grandes navegações e com o mapeamento do globo terrestre, essas narrativas de povos exóticos ou raças fantásticas são deslocadas ou para o gênero literário da fantasia ou para o discurso antropológico/etnográfico como elaborado cientificamente, que se ocupa, dentre outras práticas sociais, das mitologias dos povos que são seu objeto de estudo.

\section{3.b) O monstro antropológico}

De modo semelhante ao que ocorre com o monstro enquanto prodígio, o monstro maravilhoso também passa por um processo de exclusão da possibilidade de existência na realidade empírica. Enquanto no mundo antigo e no mundo medieval a existência empírica desses seres maravilhosos é tida como uma possibilidade verossímil, o mundo moderno os relega ao âmbito do imaginário, seja o imaginário ocidental veiculado por obras ficcionais ou o imaginário não ocidental tido fundamentalmente como objeto de estudo pelo discurso antropológico/etnográfico.

Os parâmetros para se distinguir a possibilidade real do nascimento de uma criança com ciclopia, por exemplo, e a impossibilidade de existência de uma raça de seres com apenas um olho só é delineado a partir do século XVIII com os Saint-Hilaire e com o mapeamento definitivo do mundo a partir do século XIX ou, em termos weberianos, quando foi atingida a segunda fase do processo de desencantamento do mundo, aquela operada pelo conhecimento científico (Pierucci, 2013).

Ao final do século XIX, as narrativas de viagem a lugares distantes e a descrição de hábitos peculiares de povos que habitavam tais lugares continuavam a exercer fascínio. De

$61 \mathrm{Na}$ obra Baudolino, já mencionada anteriormente, o semioticista e romancista italiano Umberto Eco reproduz com maestria uma dessas narrativas de viagem ao Oriente. Nela figuram criaturas e raças de seres fantásticos que povoam o imaginário medieval, como, por exemplo, a manticora, os cinocéfalos, os sátiros e as blêmias, muitas das quais são herdadas das obras antigas, principalmente a História Natural de Plínio. Para a História Natural como um projeto político-pedagógico em sua relação com questões de identidade romana e processos de romanização e integração multiétnica no Mediterrâneo Antigo, cf. a tese de Teixeira (2013). 
objeto da curiosidade, muitos dos povos e culturas que figuravam nessas narrativas passaram a ser objeto de estudo dos viajantes e colonizadores europeus, o que levou ao desenvolvimento do campo da antropologia.

Com a investigação de sistemas culturais de povos não ocidentais ou não europeus, os principais estudos antropológicos do século XX foram os que se dedicaram fundamentalmente à compreensão de sistemas mitológicos e práticas rituais. Dentre os antropólogos que se dedicaram aos sistemas mitológicos, Lévi-Strauss se sobressai como o fundador da antropologia estrutural com sua investigação da estrutura do mito, na qual ele aplica os conceitos de langue e parole da linguística saussureana. Na conclusão de seu artigo fundante de 1955, no qual apresenta seu método estrutural de análise do mito, Lévi-Strauss defende que o tipo de lógica usada no pensamento mítico é tão rigorosa quanto aquela da ciência moderna, posicionando-se abertamente contra a concepção de que o mito é expressão de uma mente primitiva. Ao utilizar o mito de Édipo para exemplificar seu método de análise, com a justificativa de que é bem conhecido de todos, Lévi-Strauss acaba aproximando os mitos de povos indígenas, com os quais ele e sua mulher Dina Lévi-Strauss trabalharam, aos mitos que herdamos da Antiguidade helênica, uma aproximação que, por um lado, emparelhava narrativas consideradas primitivas e narrativas consideradas da alta cultura ocidental e que, por outro, abria as portas para que futuros classicistas como Jean-Pierre Vernant utilizassem o método de análise de Lévi-Strauss.

Apesar de não ter se preocupado com a figura do monstro particularmente, LéviStrauss, em sua análise estrutural do mito de Édipo, conclui que os monstros dessa narrativa, a serpente e a esfinge, apresentam a característica comum da negação da origem autóctone do homem e serão derrotados por Cadmo e Édipo, respectivamente. ${ }^{62}$ Com sua análise e conclusão, Lévi-Strauss não está propondo uma interpretação geral do papel do monstro nas narrativas mitológicas dos antigos ou em seu sistema de pensamento como um todo, mas o contrário: que o papel da figura do monstro, ou de qualquer figura, na verdade, está circunscrita à sua função dentro da narrativa, uma posição que fazia frente à perspectiva psicologizante e universalizante de Freud, com sua análise do mito de Édipo como representação do desejo sexual do filho pela mãe, e de Jung, com sua teoria dos arquétipos.

Contemporâneos de Lévi-Strauss, os antropólogos Victor Turner e Mary Douglas, que, por sua vez, voltaram-se mais para o rito do que para o mito, usaram ambos a figura do

62 Lévi-Strauss (1955, p. 434): “[...] The dragon is a chthonian being which has to be killed in order that mankind be born from the earth; the Sphinx is a monster unwilling to permit men to live. [...] Since the monsters are overcome by men, we may thus say that the common feature [...] is the denial of the autochthonous origin of man.”. A análise pode ser encontrada nas p. 433-436 de Lévi-Strauss (1955). 
monstro de modo tangencial em seus estudos de religião e ritual.

Mary Douglas (2012, p. 54-55), em sua obra Pureza e perigo (originalmente de 1966), observa que toda cultura engendra meios de lidar com as ambiguidades e anomalias produzidas pelos seus próprios sistemas classificatórios. Como exemplo ela utiliza uma narrativa etnográfica de Evans-Pritchard, presente em Nuer Religion (1956, p. 84), na qual o criado nuer do antropólogo lhe chega uma manhã com alguma alegria e lhe conta que uma mulher tinha dado à luz uma criança e um hipopótamo natimortos, sendo o hipopótamo o animal totêmico da vila onde o nascimento havia acontecido. Douglas observa que toda vez que há o nascimento de uma criança com algum tipo de deformidade, a linha demarcatória entre o que é humano e o que é animal se torna ameaçada, só se restabelecendo quando é atribuído um nome ou um rótulo para o fenômeno. No caso dessa vila nuer, a ameaça do natimorto com deformidade é neutralizada ao se rotulá-lo de "hipopótamo" e, por conseguinte, recolocá-lo no rio, que é seu devido lugar.

Douglas, portanto, atribui um valor transgressor ao que ela denomina "monstro" não apenas da realidade empírica (nascimento do feto deformado), mas do próprio sistema classificatório, que falha em reconhecer o natimorto enquanto humano. A posição do "monstro" dentro desse sistema é intersticial até ser reincorporado por ele: o natimorto disforme não está entre as categorias taxonômicas operantes no sistema classificatório dos nuer e só volta a fazer parte delas quando eles o enquadram no esquema mental no qual se baseiam para explicar o mundo.

Victor Turner também observou a posição intersticial e, por isso, liminar do monstro, adotando o conceito de "fase liminar" dos ritos de passagem elaborado por Van Gennep no início do século XIX. Van Gennep propôs que os ritos de passagem são divididos em três grandes fases: o da separação, o da margem ou liminar (do latim limen, em sentido concreto "soleira de porta", em sentido derivado "limiar") e, por fim, o da agregação. A fase intermediária da liminaridade se caracteriza pela ambiguidade do sujeito que não faz mais parte de um grupo mas ainda não foi integrado a outro. Em O processo ritual (originalmente de 1969), Turner comenta que essa ambiguidade também se manifesta pelo fato de o sujeito do ritual muitas vezes usar uma máscara ou ser disfarçado de monstro, demonstração de que ele deixou de possuir um determinado status e ainda não possui outro (Turner, 1969, p. 95).

Durante grande parte do século XX, o estudo do monstro ficou relegado ao estudo do outro, seja ele o outro antropológico, isto é, das culturas de sociedades geralmente tribais, ou mesmo agrárias, que não se encaixam na lógica ocidental de produção e reprodução material ou cultural, seja ele o outro do passado remoto, investigado pelo campo da História, 
representado também pelas culturas do Mediterrâneo antigo. Ainda que tenha sido demonstrado pela antropologia que sistemas de organização social pré-industriais não deixam a desejar em termos de complexidade cultural, o pensamento científico moderno, que considera os monstros meros construtos ficcionais sem correspondentes na realidade material, relega ao pensamento pré-industrial a "crença" na realidade material desses construtos ficcionais, como uma criança acredita no bicho-papão embaixo da cama. ${ }^{63}$

\subsection{O MONSTRO METAFÓRICO}

De acordo com o que tem sido exposto, o monstro no mundo antigo e medieval, enquanto percebido como uma mensagem dos deuses ou de deus, isto é, possuindo um valor indicial, é um signo que veicula uma mensagem. Dito de outra forma, o monstro é algo que significa uma coisa outra. Em seu processo de secularização, o monstro tem esse valor indicial reduzido ao mínimo, ou seja, indica apenas que a natureza se desviou de seu curso. Todavia, ao mesmo tempo em que é despido desse valor indicial do divino, o monstro no mundo moderno granjeia sentidos figurados que ajudam a construir o valor polissêmico que possui na contemporaneidade. Nela, o monstro recupera também seu valor indicial, entretanto, não mais como mensagem divina, mas enquanto metáfora.

O campo filosófico fez uso recorrente do monstro em seu sentido figurado ou metafórico. Além de Hegel e sua monstruosidade de Cristo (mencionado na nota 63), Georges Bataille com frequência conecta a experiência do sagrado ao monstruoso, pensando-o como uma metáfora para a experiência da contradição entre vida e morte (Biles, 2007). Outros célebres usos metafóricos do monstro são feitos por Derrida, que primeiro o relaciona ao futuro como a temporalidade da differance ("diferência"), ou seja, o futuro percebido como um acontecimento não derivado das estruturas estabelecidas no presente, que não é mero reprodutor do passado e, portanto, é um rebento que não tem os traços de seu progenitor (Derrida, 2011, p. 249, original de 1967) e, acrescentando a esse primeiro sentido, relaciona-o ao próprio processo da escrita filosófica como geradora da instância crítica da normalidade (Derrida, 1995).

A metáfora talvez possa ser considerada uma outra direção do monstro ou ordem do discurso sobre ele, uma que lhe confere a versatilidade de um conceito "guarda-chuva" sob o qual muitos outros se abrigam: o do assassino, do alienígena, do híbrido, do outro etc. É dessa multiplicidade ou dessa capacidade de ter seu sentido multiplicado, muitas vezes como uma

63 A propósito da crença, Hegel, como apontado por Slavoj Zizek (2011, p. 74), classifica Cristo como monstruoso em razão do hibridismo entre homem e deus. 
hidra, que vão se originar os Monster Studies ("Estudos da Monstruosidade”), campo dos estudos culturais que tenta entender as culturas por meio dos monstros que elas concebem.

\section{4.a) O monstro cultural e os Monster Studies}

O recente aumento nos estudos sobre a figura do monstro reflete o interesse que ela tem causado dentro e fora do âmbito acadêmico. Conquanto tenha sido uma figura contumaz nas obras literárias e cinematográficas produzidas ao longo do século XX, é apenas no final dele e no início do XXI que ela começa a receber um pouco mais de atenção do mundo acadêmico. Asa Mittman, na introdução ao Ashgate Research Companion on Monsters and the Monstrous, publicado em 2013, conta que, em uma entrevista de emprego há alguns anos, foi aconselhado por um membro do departamento a "largar essa história de monstros e começar a fazer pesquisa de verdade". ${ }^{64}$ Apesar do descrédito inicial, os Monster Studies, que traduzo aqui por "Estudos da Monstruosidade", têm ganhado cada vez mais espaço no mundo acadêmico como subcampo dos estudos culturais.

Importante para esse aumento do interesse acadêmico na figura do monstro foi a obra de 1996 de Jeffrey Jerome Cohen, Monster Theory: Reading Culture, considerada fundadora do campo da Monster Theory ou, atualmente, Monster Studies. ${ }^{65}$ Nessa reunião de estudos de autoria variada, Cohen propôs um "esboço de um novo modus legendi: um método para ler culturas por meio dos monstros que elas engendram". ${ }^{66}$ Para tanto, ele lança mão do que denominou "sete teses" sobre o monstro, que se tornaram bastante influentes no meio dos Estudos da Monstruosidade: a primeira é a de que "o corpo do monstro é um corpo cultural", porque ele é a "corporificação de um momento cultural" (p. 4); a segunda é a de que "o monstro sempre escapa", porque ele é tão corpóreo quanto incorpóreo (p. 4-5); a terceira é a de que o monstro é o "prenúncio da crise da categoria", recusando-se a ser facilmente categorizado (p. 6-7); a quarta é a de que o "monstro habita nos portões da diferença", ou seja, ele é "a diferença em carne e osso, que veio habitar no meio de nós" (p. 7-8); a quinta é a de que "o monstro vigia as bordas do possível”, porque está na fronteira do conhecimento (p. 12-); a sexta é a de que "o medo do monstro é, na verdade, um tipo de desejo", porque ele amedronta, mas também atrai (p. 16-17); e, por fim, a sétima é a de que "o monstro permanece no limiar do... tornar-se", porque nos questionam sobre as nossas próprias

64 Em Mittman e Dendle (2013, p. 2).

65 Cf. Mittman (em Mittman e Dendle, 2013, p. 2).

66 Cohen (1996, p. 3). Cf. trecho original na nota 70 adiante. 
assunções culturais (p. 20). ${ }^{67}$ Lançadas como um instrumento para se ler culturas (aparentemente, qualquer cultura), as sete teses sobre o monstro não têm a finalidade de defini-lo, mas de instrumentalizá-lo como chave de leitura para ser usada pelos estudos culturais.

Apesar das dezenove ocorrências da expressão "the monster is" dentre a introdução e o primeiro capítulo, ambos de autoria de Cohen, enquanto há apenas outras duas no restante do livro, a ausência de definições do que seja o monstro não é acidental: para Cohen o monstro é "uma categoria que não está limitada a estruturações classificatórias" e, para o espanto de historiadores, "muito menos uma [categoria] tão mal-arranjada e inadequada como o tempo". ${ }^{68}$ Sua postura diante do monstro é, portanto, a de entendê-lo como indefinível e atemporal. Tal posicionamento, todavia, entra em contradição com a primeira tese, a de que o monstro é "a corporificação de um momento cultural”, pois circunscrever o monstro a um momento é submetê-lo ao tempo. De todo modo, o texto de Cohen é considerado fundador do campo dos Monster Studies ou Monster Theories e suas "sete teses" são amiúde evocadas.

Além de nascerem já órfãos do tempo, os Estudos da Monstruosidade também surgem da perspectiva pós-moderna de que "[...] pós de Man, pós Foucault, pós Haydn-White, é necessário se ter em mente que a história é apenas um texto em uma procissão deles e não é garantidor de qualquer significação singular". ${ }^{69}$ Ao propor seu modus legendi, Cohen declara que violará "duas das máximas sagradas dos estudos culturais recentes: a compulsão por especificidade histórica e a insistência de que todo conhecimento (e, portanto, todas as

67 As "sete teses" compõem o primeiro capítulo do livro, intitulado "Monster Culture (Seven Theses)", em Cohen (1996, p. 3-25).

68 O monstro de Cohen está claramente aludindo ao monstro de Derrida (2011, p. 249): "Há portanto duas interpretações da interpretação, da estrutura, do signo e do jogo. Uma procura decifrar, sonha decifrar uma verdade ou uma origem que escapam ao jogo e à ordem do signo, e sente como um exílio a necessidade da interpretação. A outra, que já não está voltada para a origem, afirma o jogo e procura superar o homem e o humanismo, sendo o nome do homem o nome desse ser que, através da história da Metafísica ou da ontoteologia, isto é, da totalidade da sua história, sonhou a presença plena, o fundamento tranquilizador, a origem e o fim do jogo. Esta segunda interpretação da interpretação, cujo caminho nos foi indicado por Nietzsche, não procura na Etnografia, como o pretendia Lévi-Strauss, cuja Introduction à l'oeuvre de Mauss cito novamente, a 'inspiração de um novo humanismo'. Poderíamos hoje entrever por mais de um sinal que estas duas interpretações da interpretação - que são absolutamente inconciliáveis mesmo se as vivemos simultaneamente e as conciliamos numa obscura economia - partilham entre si o campo daquilo que se denomina, de maneira tão problemática, as ciências humanas. Pelo que me diz respeito, não creio, muito embora estas duas interpretações devam acusar a sua diferença e aguçar a sua irredutibilidade, que hoje haja alguma coisa a escolher. Em primeiro lugar porque aí estamos numa região - digamos ainda, provisoriamente, da historicidade - em que a categoria de escolha parece bem frágil. Em seguida porque é preciso tentar primeiro pensar o solo comum, e a diferência desta diferença irredutível. E porque temos aí um tipo de questão, digamos ainda histórica, cuja concepção, formação, gestação, trabalho, hoje apenas entrevemos. E digo estas palavras com os olhos dirigidos, é certo, para as operações da procriação; mas também para aqueles que, numa sociedade da qual não me excluo, os desviam perante o ainda inominável que se anuncia e que só pode fazê-lo, como é necessário cada vez que se efetua um nascimento, sob a espécie da não espécie, sob a forma informe, muda, infante e terrificante da monstruosidade.".

69 Cohen (1996, p. 3): “[...] post de Man, post Foucault, post Hayden White, one must bear in mind that history is just another text in a procession of texts, and not a guarantor of any singular signification. [...]". 
cartografias daquele conhecimento) é local". ${ }^{70}$ Não é de se entranhar, portanto, a postura de indefinição do monstro que tem se perpetuado nos Estudos da Monstruosidade. Mittman, em sua introdução ao Ashgate Research Companion, publicado 17 anos após o Monster Culture de Cohen, declara: “[...] Por definição, o monstro está fora de tais definições; ele desafia o desejo humano de subjugar por meio de categorização. Essa é a fonte, de muitas maneiras, de seu poder. [...]". ${ }^{71}$ Stephen Asma (2011), em seu livro sobre o monstro como incorporação dos medos e terrores desde a Antiguidade até a Contemporaneidade, também lança mão do mesmo artifício da não definição: “[...] Alguém tentará em vão encontrar nesse livro uma definição única e convincente de monstro. Isso não é porque eu me esqueci de incluí-la, mas porque não acredito que haja uma. [...]". ${ }^{72}$

Essa postura de indefinição diante do monstro chega a ser compreensível dada a natureza variada dos membros que podem compor essa categoria. Por outro lado, além da solução que parte da "inerente" indefinição do monstro, há tentativas de lidar com determinados tipos de monstros, tornando o escopo de algumas obras mais circunscrito. É o caso de The Origins of Monsters: Image and Cognition in the First Age of Mechanical Reproduction, de David Wengrow (2014), por exemplo, que, apesar de anunciar em seu título que trata da "origem de monstros", na verdade, discorre especificamente sobre imagens de figuras compósitas, que se tornam mais abundantes ao longo do processo de surgimento dos centros urbanos do crescente fértil, mais especificamente na região da Mesopotâmia. ${ }^{73}$ Outros exemplos são o livro de Wright (2013) e de Murgatroyd (2007). Em Monstrosity: the human monster in visual culture, Wright delimita já no título de seu livro o tipo de monstro sobre o qual se centrará, aquele que ela chama de monstro "humano" ou "real", desde as criaturas em "Monstrous Races of the World", um fólio do século XII com imagens de dezessete tipos de raças monstruosas que se acreditava habitarem o mundo e serem reais, passando por Joseph Merrick, o Homem Elefante, que viveu no final do século XIX, até a figura de alguns

70 Cohen (1996, p. 3):"What I will propose here by way of a first foray, as entrance into this book of monstrous content, is a sketch of a new modus legendi: a method of reading cultures from the monsters they engender. In doing so, I will partially violate two of the sacred dicta of recent cultural studies: the compulsion to historical specificity and the insistence that all knowledge (and hence all cartographies of that knowledge) is local. [...]".

71 Mittman (em Mittman e Dendle, 2013, p. 7): “[...] By definition, the monster is outside of such definitions; it defies the human desire to subjugate through categorization. This is the source, in many ways, of their power. [...]".

72 Asma (2011, p. 281-282): "[...] One will search in vain through this book to find a single compelling definition of monster. That's not because I forgot to include one, but because I don't think there is one. [...]". Asma, ao menos, explicita a razão pela qual, para ele, não há uma definição para monstro. Como adepto da teoria cognitiva dos protótipos, ele entende que uma categoria é construída a partir de um exemplo prototípico e se estende como uma família. Voltarei a esse conceito no capítulo 6 porque o adoto para pensar o monstro como categoria.

73 Essa obra de Wengrow foi resenhada por mim e publicada na Revista Mare Nostrum, cf. Zanon (2014b). 
assassinos em série, cuja monstruosidade não é externada em seus corpos, mas em seu comportamento. ${ }^{74}$ Já, Murgatroyd, em seu livro Mythical Monsters in Classical Literature, explora as criaturas mitológicas consideradas monstruosas que figuram na literatura grecoromana.

Além de "tipos" de monstros ou aquilo que chamo de "direções do monstro", algumas obras fazem recortes por períodos históricos. Para a Antiguidade, por exemplo, além do mencionado livro de Murgatroyd, há o volume organizado por Atherton (1998), Monsters and Monstrosity in Greek and Roman Culture, uma reunião de artigos que foram apresentados durante o "Sixth Symposium of the Nottingham Classical Literature Seminar", realizado em maio de 1997. Os dois volumes recentemente organizados por Baglioni (2013) expõem um excelente panorama das figuras ditas monstruosas nas culturas antigas, com artigos de especialistas em Egito, Mesopotâmia, Grécia e Roma, fazendo um esforço para incluir trabalhos sobre literatura védica e povos mesoamericanos e africanos. Há também a recente obra Monsters and Monstrosity in Augustan Poetry, de Lowe (2015). Para o período Medieval, o livro de Williams (1999), Deformed Discourse: The Function of the Monster in Mediaeval Thought and Literature, é talvez um dos mais conceituados. ${ }^{75}$

Há, ainda, os que se debruçam sobre a figura do monstro e da monstruosidade especificamente na literatura e no cinema. No Brasil, conta-se com as publicações organizadas pelo professor Julio Jeha, da Universidade Federal de Minas Gerais: Monstros e monstruosidades na literatura e Da Fabricação de Monstros (Jeha, 2007 e 2009, respectivamente). Jackson (2013), em seu Technology, monstrosity, and reproduction in twenty-first century horror, trata da figura do monstro no cinema de terror. Confira-se também a obra de divulgação Monsters in the Movies, do cineasta John Landis (Landis, 2011), abundante em imagens dos mais icônicos monstros que estrelaram no cinema.

Por ser considerado com frequência uma figura de alteridade, o monstro é amiúde utilizado para pensar questões de identidade e gênero, principalmente por meio de abordagens dos estudos psicanalíticos. Em seu Strangers, Gods and Monsters: interpreting otherness, Kearney (2003) se vale da figura do monstro, junto com a de deuses e de estrangeiros (que inclui a noção de alienígena), como criaturas liminares dentro da fragmentária psique humana, compondo uma tríade fundamental para a construção da identidade. Creed (1993), em The

74 Wright, 2013. Para o fólio medieval de "Monstrous Races" (Harley 2799 f.243r), cf. o site da British Library. Para o registro detalhado:

http://www.bl.uk/catalogues/illuminatedmanuscripts/record.asp?MSID=7862\&CollID=8\&NStart=2799.

Para a imagem: http://www.bl.uk/learning/images/medieval/monstrous/large96488.html (último acesso: 16 jun. 2016).

75 Veja-se também a publicação organizada por del Priori (1998), Monstros e Monstrengos do Brasil, dedicada à "zoologia fantástica brasileira" nos séculos XVII e XVIII. 
monstrous-feminine: film, feminism, psychoanalysis, argumenta que a construção da figura feminina como monstruosa está sempre relacionada a seus órgãos sexuais bem como às suas funções reprodutoras; ela faz uso da figura da vagina dentata para contrariar a proposição freudiana de que a mulher é temida porque o homem a percebe como uma figura castrada para propor que a mulher é uma figura temida pelo homem porque ela é capaz de castrar. ${ }^{76}$

A abordagem psicanalítica é uma das mais frequentes nos estudos da monstruosidade. A obra de Gilmore (2003), Monsters, Evil Beings, Mythical Beasts, and All Manner of Imaginary Terrors, mencionada e citada com frequência nas obras que se voltam para o monstro, talvez seja uma das mais emblemáticas dessa abordagem, que considera o monstro uma sublimação das repressões contidas em nossa psiquê, formando uma zona cinza entre ego e id, que ele denomina "super-id" (Gilmore, 2003, 194). ${ }^{77}$ Apesar de bastante criticável por ser uma abordagem que subsume as diferenças histórico-culturais a uma característica que seria “inerente" ao ser humano, aquela de criar monstros, Gilmore, como Asma (2011), oferece um panorama das figuras (que nós consideramos) monstruosas, desde a Antiguidade até a Contemporaneidade.

Não obstante o volume de publicações que tem surgido nos últimos anos, dentre livros, periódicos, websites, além dos encontros organizados em nível local e internacional, sejam eles centrados na figura do monstro ou que instrumentalizem a figura do monstro para pensar alguma outra questão, é raro encontrar uma definição do monstro enquanto uma categoria do pensamento. ${ }^{78} \mathrm{~A}$ resistência ou simples recusa em definir o monstro pode, às vezes, dar a impressão de que há um certo comodismo por parte dos estudiosos da monstruosidade, que se habituaram a considerar o monstro como uma figura indefinível e tomam isso como pressuposto. Gostaria de ressaltar que não considero a ausência de definição do monstro nas obras mencionadas um fator que comprometa a qualidade do trabalho realizado por seus autores. Todos eles se voltam para questões importantes e instigantes e são bem-sucedidos no tratamento de seu respectivo tema de acordo com a abordagem que

76 Creed fundamenta seu livro na obra de Kristeva (1984, original fracês de 1980), The Power of Horror: an essay on abjection, que se tornou seminal para os estudos de gênero e da "queer theory".

77 Conquanto essas abordagens psicologizantes digam muito mais sobre o indivíduo que está operando a análise do que acerca do objeto analisado, o conceito de "Unheimlich", geralmente traduzido para o inglês como "uncanny" e que traduzirei aqui como "inquietante", pode ser útil para uma compreensão do monstro. $\mathrm{O}$ "Unheimlich" ou "inquietante" é o sentimento no qual a familiaridade e a estranheza simultâneas criam um paradoxo que levam à rejeição do objeto.

78 Talvez o grupo de maior destaque seja o Inter-disciplinary.net, com sua base em Oxford, na Inglaterra, que promove o projeto "Monsters and the Monstrous: Myths \& Metaphors of Enduring Evil", organizando encontros anuais desde 2003 (cf. website em: http://www.inter-disciplinary.net/at-theinterface/evil/monsters-and-the-monstrous/. Último acesso: 30 nov. 2015). Além dos encontros anuais e das publicações em formato de livro físico e digital, eles dirigem o periódico virtual Monsters and the Monstrous (disponível em: http://monstersjournal.net/. Último acesso: 30 nov. 2015). 
escolheram. Todavia, não se faz ciência sem questionar pressupostos e, ultimamente, este de que o monstro é uma categoria indefinível tem sido repetido ad nauseam.

No universo da pós-modernidade, contudo, o monstro acaba por ter seu caráter polissêmico radicalizado. Ele passa a ser um conceito por vezes tão abrangente, que é difícil dizer o que não pode ser considerado um monstro ou monstruoso. Isso contribui de modo fundamental para a ausência de definição do monstro. De qualquer modo, é perceptível nos Estudos da Monstruosidade, principalmente naqueles que se dedicam aos aspectos socioculturais do assunto, uma predileção pela fluidez e permissividade da(s) perspectiva(s) pós-modernas. Esta(s) apresenta(m) a grande vantagem de permitir a incorporação de outras perspectivas que ocasionalmente venham a calhar para a compreensão proposta, tornando possível ao investigador lançar mão de teorias antropológicas, da psicanálise, dos estudos culturais, dos estudos de gênero, para citar apenas alguns exemplos, ou de todas essas perspectivas teóricas em conjunto, e ainda outras.

Note-se que a crítica aqui não está endereçada à pós-modernidade, mas à perspectiva de que conceitos ou ideias possam ser a-históricos ou atemporais. O que se entendia por “monstro" na Idade Média certamente não é o que se entende por “monstro" após o século XIX, porque, como está implicada na proposta do próprio Cohen de que é possível estudar uma cultura por meio dos monstros que engendra, cada cultura, época ou sociedade engendrará monstros que refletirão suas concepções particulares, não podendo ser transpostas de maneira automática para outras culturas, épocas ou sociedades. Na transposição acrítica é que habita o perigo do anacronismo e do uso de categorias nem sempre existentes enquanto tais para a compreensão do "outro", seja ele um "outro" na diacronia ou na sincronia.

O problema de se estudar as culturas pelos monstros que elas engendram é que essa categoria pode não estar presente em uma dada cultura. E aqui discordo veementemente de Gilmore (2003) e de Wittkower (1942) de que todas as culturas engendram monstros. Nós modernos (ou pós-modernos) é que classificamos ou categorizamos como parte da nossa categoria "coheniana" de "monstros" criaturas ou seres produzidos por outras culturas que não eram assim considerados naquele sistema cultural. Contudo, entender esses seres depende fortemente da compreensão das definições e concepções que cada uma dessas culturas desenvolveu para classificá-los. Isso fica muito claro no caso do objeto desta tese. Colocado de outra forma, o que defendo aqui é que criaturas que entendemos como tipicamente integrantes do rol greco-romano de "monstros", como Cérbero, Centauro, Quimera, Cila etc. podem nem ter sido concebidas enquanto tais no que concerne à poesia hexamétrica arcaica. No próximo capítulo, exploro do ponto de vista filológico os termos utilizados nessa poesia 
que são geralmente traduzidos como "monstro", de forma a demonstrar a inadequação de tal tradução. Adicionalmente, analiso essas criaturas que denominamos monstros em seu contexto poético, verificando se são utilizadas formas tradicionais de descrevê-las. 


\section{Capítulo 2}

\section{TERMinOLOGIA}

- Mas eu não posso dizer esse tipo de coisa num pedido de financiamento, se quiser ser levada a sério. Não faz sentido. Não pode existir. É impossível, e se não for impossível é irrelevante, e se não for qualquer dessas coisas, então é embaraçoso.

Mary Malone, em A Faca Sutil, p. 87, de Philip Pullman. 


\section{CAPÍTULO 2}

Este capítulo se dedica ao estudo dos termos presentes na poesia hexamétrica homérica e hesiódica traduzidos como "monstro", "monstruosidade" ou "monstruoso/monstruosa". Seu objetivo é mostrar que tais vocábulos não expressam uma ideia correspondente à noção moderna de "monstro", mas estão relacionados a três noções básicas: primeiro, a noção de algo extraordinário e, por isso, espantoso e impressionante, podendo ou não infundir o sentimento do terror; segundo, e derivada da primeira, a noção de portento ou prodígio enquanto manifestação do ato comunicativo da divindade com o âmbito humano, considerado, portanto, uma mensagem enviada pelos deuses; terceiro, uma noção de enormidade espantosa (especificamente no caso do substantivo $\pi \varepsilon ́ \lambda \omega \rho / \pi \varepsilon ́ \lambda \omega \rho \circ v$ e das formas do adjetivo correspondente $\pi \varepsilon ́ \lambda \omega \rho \circ \varsigma$ e $\pi \varepsilon \lambda \omega ́ \rho ı \varsigma)$.

O capítulo tem início com uma problematização que abrange as definições encontradas no dicionário grego-inglês LSJ e em léxicos especializados em poesia hexamétrica, juntamente às traduções dessa poesia em línguas modernas. Em seguida, realizase a análise dos termos em seu contexto no interior dos poemas hesiódicos e homéricos. $\mathrm{O}$ primeiro dos termos a ser estudado é o substantivo $\tau \dot{\varepsilon} \rho \alpha \varsigma$, aproveitando-se a proximidade com a exposição feita no capítulo 1 acerca da noção que ele apresenta em Aristóteles. Segue-se,

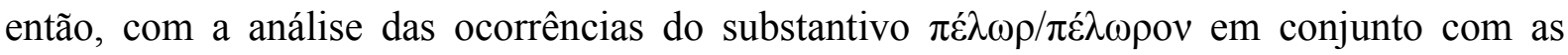

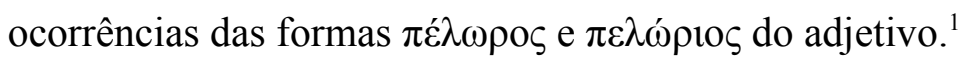

Outros termos, ainda, são também traduzidos por "monstro" com alguma frequência,

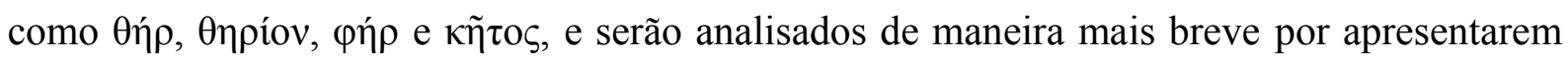
menos dificuldades em ter seu campo semântico delimitado do que os substantivos

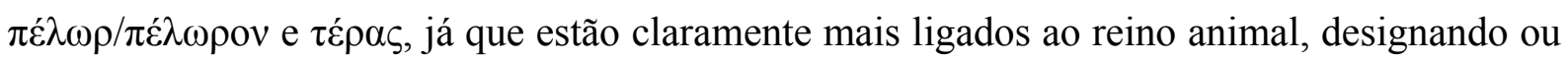

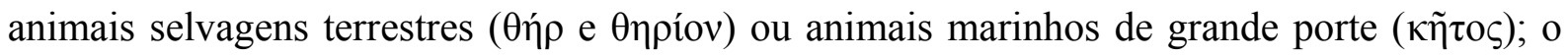
caso de $\varphi \eta ́ \rho$, contudo, é um tanto especial, como será visto adiante.

O capítulo se encerra com uma breve recapitulação das conclusões acerca do significado dos termos na poesia hexamétrica arcaica.

1 Utiliza-se aqui $\pi \varepsilon ́ \lambda \omega \rho$ e $\pi \varepsilon ́ \lambda \omega \rho \nu$ separados por barra (“`”) por serem considerados nesta tese variantes de um mesmo substantivo, e não dois substantivos distintos, sendo indistinguíveis quando estão declinados. Cf.

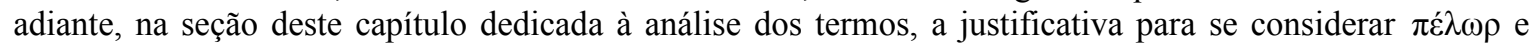
$\pi \varepsilon ́ \lambda \omega \rho o v$ variantes de um mesmo substantivo. 


\subsection{Problematização}

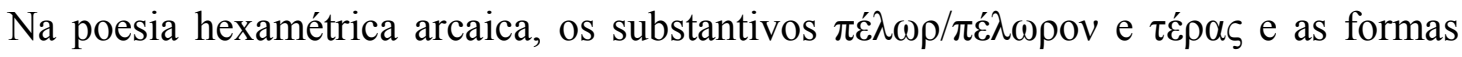
$\pi \varepsilon \dot{\varepsilon} \omega \rho \rho \varsigma$ e $\pi \varepsilon \lambda \omega ́ \rho \operatorname{sos}$ do adjetivo aparecem associados a seres que a tradição sagrou monstruosos, mais precisamente, Polifemo (Odisseia 9.428, 9.257, 9.187 etc.), Cila (Odisseia 12.87), Górgona (Ilíada 5.741; Odisseia 11.634 etc.), Équidna (Teogonia v. 295) e Tifeu (Teogonia v. 845 e 856). Entretanto, esses mesmos termos aparecem igualmente associados a uma variedade de outros seres como deuses, dentre os quais Hefesto (Ilíada 18.410) e Terra (Teogonia v. 159, 173 etc.), e heróis, como Aquiles (Ilíada 21.527 e 22.92) e Heitor (Ilíada 12.229); eles aparecem também associados a objetos, como a lança do deus Ares (Ilíada 5.594) e a de Atena (Ilíada 8.424) ou a foice usada por Crono para castrar Céu (Teogonia v. 179), e a fenômenos naturais, como as ondas do mar (Odisseia 3.286-290) ou um arco-íris (Ilíada 17.548). Quando observada a multiplicidade de referentes desses termos - seres, objetos e fenômenos que não consideramos "monstros" ou "monstruosos" a priori -, suspeitase que "monstro" possa ser uma tradução que não reflete adequadamente o que eles expressam nesses poemas.

Não obstante a natureza variada de seus referentes, os termos supramencionados são amiúde traduzidos por "monstro" e correlatos. Essa acepção é recorrentemente sugerida pelos dicionários de grego em línguas modernas, dentre os quais o LSJ, um dos mais usados tanto por estudantes como por pesquisadores da área de Estudos Clássicos. ${ }^{2}$ A grande abrangência do LSJ, que é uma das características que torna seu uso tão comum entre helenistas, pode conduzir, por vezes, a uma compreensão anacrônica de termos que adquirem determinada acepção ao longo do tempo, conquanto não a apresentem em contextos literários mais recuados, como aquele da poesia hexamética arcaica.

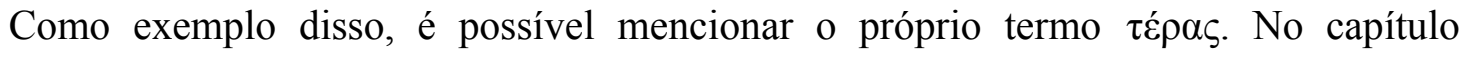
anterior, foi exposto que Aristóteles usa $\tau \dot{\varepsilon} \rho \alpha \varsigma$ em sua obra Geração dos animais como sinônimo de um ser, humano ou animal, portador de alguma anomalia ou deformidade, um sentido contemplado no verbete $\tau \dot{\varepsilon} \rho \alpha \varsigma$ do dicionário LSJ. Contudo, apesar da separação hierárquica das diferentes acepções apresentadas pelo dicionário, é possível que o usuário

2 Os verbetes $\pi \dot{\lambda} \lambda \omega \rho, \pi \varepsilon \dot{\varepsilon} \omega \rho o v, \pi \varepsilon \dot{\varepsilon} \omega \rho \rho \varsigma, \pi \varepsilon \lambda \omega ́ \rho ı \varsigma$ e $\tau \varepsilon \dot{\varepsilon} \rho \varsigma$ fornecidos pelo LSJ se encontram reproduzidos e acompanhados de tradução própria para o português no Apêndice A. Atualmente, o LSJ está disponível gratuitamente online: http://stephanus.tlg.uci.edu/lsj/\#eid=1\&context=lsj (último acesso em 19 fev. 2016). Dá-se preferência aqui ao LSJ em detrimento do dicionário grego-francês de Anatole Bailly em razão de este não apresentar diferença significativa em seus verbetes em relação ao LSJ e também por ser um dicionário com uma proposta mais voltada para estudantes secundaristas do que para pesquisadores e especialistas, conforme explicitado em seu prefácio. 
entenda equivocadamente que $\tau \dot{\varepsilon} \rho \alpha \varsigma$ pode assumir qualquer dos sentidos ali expostos independentemente da época ou do gênero ao qual pertence a fonte textual. Ao se analisar as ocorrências de $\tau \varepsilon ́ p \alpha \varsigma$ na poesia hexamétrica arcaica, entretanto, percebe-se que nela o termo nunca é usado com o sentido aristotélico, como será visto adiante.

A fim de evitar anacronismos ao se trabalhar com a poesia hexamétrica arcaica, é fundamental a utilização de dicionários especializados, como o léxico homérico de Cunliffe e os volumes do LfgrE, por exemplo. A despeito do trabalho vultoso e sistemático dedicado à confecção dos verbetes ao longo de mais de 50 anos (de 1944 a 2010), com uma equipe internacional de pesquisadores de alto nível, o LfgrE fornece "monstro" ("Monstrum", “Ungeheur") como acepção de $\tau \dot{\rho} \rho \alpha \varsigma$ e também de $\pi \varepsilon ́ \lambda \omega \rho / \pi \varepsilon ́ \lambda \omega \rho o v .{ }^{3}$ Quando um léxico do calibre do $\operatorname{LfgrE}$ indica tal acepção, ela se torna quase inquestionável. O léxico de Cunliffe, todavia, uma empreitada bem mais humilde e solitária, tem o cuidado de não indicar tal acepção. ${ }^{4}$ Não é intenção aqui desmerecer essa ou aquela obra de referência - todas são muito úteis e resultantes de anos de muito esforço e diligência -, e sim indicar o quanto determinada acepção pode estar enraizada a ponto de escapar ao escrutínio de especialistas renomados.

Um reflexo direto das acepções propostas pelos dicionários é sentido nas traduções das obras antigas para línguas modernas que, por serem um dos principais meios pelos quais essas obras são acessadas pelo leitor moderno, podem veicular uma compreensão distorcida de determinado termo.

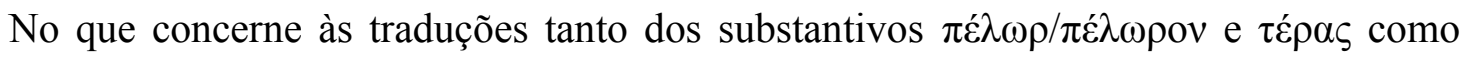
das formas $\pi \varepsilon ́ \lambda \omega \rho o \varsigma$ e $\pi \varepsilon \lambda \omega ́ \rho ı \varsigma \varsigma$ do adjetivo, constata-se certa variação de acordo com o referente, optando-se, em geral, por "monstro" e "monstruoso" quando ele é um ser considerado monstruoso a priori, conquanto se prefira "portento" ou "prodígio" quando o

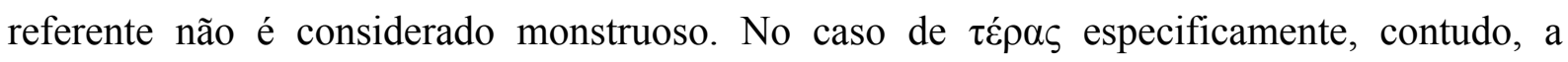
variação é menor, preferindo-se traduzi-lo por "prodígio" ou "portento" na maior parte dos casos. Na Ilíada e na Odisseia, $\tau \dot{e} \rho \alpha \varsigma$ é predominantemente traduzido por "portent" (“portento"), "sign" (“sinal”) e “omen" ("augúrio") na tradução de Murray (1919 e 1924), uma escolha mantida na tradução portuguesa da Ilíada feita por Lourenço (2013a), que traduz todas as ocorrências por "portento(s)", e na tradução da Odisseia de Werner (2014), que escolhe predominantemente "prodígio", usando "presságio" em uma única ocorrência

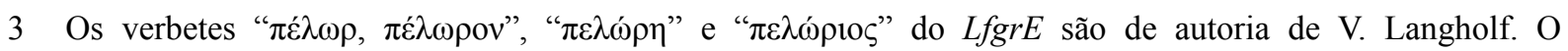
responsável por " $\tau \varepsilon \dot{\rho} \rho \varsigma$ ” é G. Markwald.

4 Os verbetes do léxico de Cunliffe se encontram reproduzidos e acompanhados de tradução própria para o português no Apêndice A. 


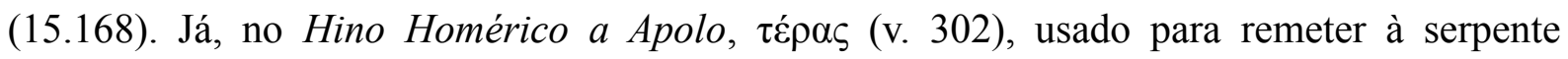
opositora do deus Apolo, é traduzido por “monster" na tradução de Evelyn-White (1982, originalmente de 1914), acepção adotada unanimemente nas traduções brasileiras de Cabral (2004) e Massi (em Ribeiro Jr., 2010). Em sua única ocorrência na Teogonia (v. 744), que

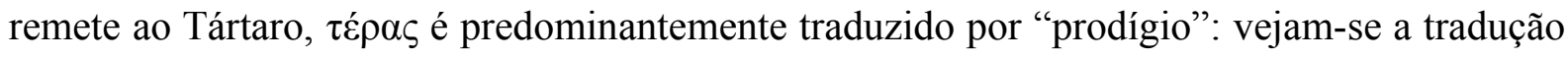
para o francês de Mazon (1928), que escolhe "prodige", a tradução para o italiano de Arrighetti, que traduz por "prodigio", e as traduções para o português de Torrano (2005) e Werner (2013a), que optam por "prodígio" e "portento", respectivamente. Contudo, para esta ocorrência, Most (2006) a traduz por “monstrosity", destoando, por um lado, das traduções nas demais línguas modernas e, por outro, da tradução de Evelyn-White (1982), que opta por "wonder" ("maravilha").

No caso do substantivo $\pi \varepsilon ́ \lambda \omega \rho / \pi \varepsilon ́ \lambda \omega \rho o v$, a variação de acordo com o referente se mantém, embora predomine a noção de "monstro" nas traduções. Vejam-se, por exemplo, as traduções da Teogonia. Nesse poema, o substantivo $\pi \dot{\lambda} \lambda \omega \rho / \pi \dot{\varepsilon} \lambda \omega \rho o v$ aparece três vezes no total, uma remetendo a Équidna (v. 295) e as outras duas, a Tifeu (v. 845 e 856): Équidna é descrita no poema como metade moça, metade serpente, e Tifeu, com cem cabeças de serpente. Tanto a tradução para o inglês de Evelyn-White (1982), que foi publicada originalmente em 1914, sendo, portanto, anterior à publicação do léxico de Cunliffe (primeira edição de 1924) e do $L f g r E$, quanto a tradução de Most (2006), publicada quase um século depois da de Evelyn-White, ambas sob a chancela da Loeb Classical Library, traduzem essas ocorrências por "monster". A escolha se repete na tradução para o francês ("monstre") realizada por Mazon (1928) para o volume da conceituada coleção Les Belles Lettres bem como na recente tradução para o italiano ("mostro") de Arrighetti (1998).

Para as ocorrências das variantes do adjetivo, contudo, que são mormente remissivas à deusa Terra no poema, os tradutores abandonam o termo "monstro" em detrimento da expressão de enormidade especificamente. Evelyn-White, que traduziu o substantivo por "monster", oscila entre "vast" e "huge" para a variante triforme do adjetivo ( $\pi \varepsilon \dot{\lambda} \omega \rho \circ \varsigma)$, que é epíteto de Terra, e traduz a variante biforme ( $\pi \varepsilon \lambda \omega \operatorname{\rho lo} \varsigma)$, que remete à foice criada por Terra (v. 179), como "great long". Most, que também verteu o substantivo usando "monster", escolhe "huge" nas ocorrências em que o adjetivo é epíteto de Terra, alternando para “monstrous", porém, na única vez em que o referente é a foice. Mazon, que traduziu a forma

5 A tradução da Teogonia de Evelyn-White é a que está disponível na biblioteca digital Perseus Project em: http://www.perseus.tufts.edu/hopper/text?doc=Perseus\%3atext\%3a1999.01.0130 (último acesso: 02 dez. 2015). Para essa amostragem, optou-se por privilegiar as traduções mais acessíveis, principalmente as disponíveis online, ou aquelas consideradas mais fiéis ao texto grego. 
do substantivo por "monstre", prefere "énorme" como epíteto de Terra e "grande" para a foice. Arrighetti, que optou pelo substantivo "mostro" em sua tradução para o italiano, escolhe "prodigiosa" como epíteto de Terra, mas "terribile" para a foice.

Contrariando, contudo, essa tendência geral, no Brasil, as traduções da Teogonia realizadas por Torrano (1995) e por Werner (2013a) adotam "prodígio” (v. 295 e 856) / "prodigioso ser" (v. 845) e "portento" (v. 845 e 856) / "ser portentoso" (v. 295), respectivamente, destacando-se por uma escolha lexical que, conforme se defende aqui, é mais adequada do que a opção por "monstro". No caso da única ocorrência de $\pi \varepsilon ́ \lambda \omega \rho / \pi \varepsilon ́ \lambda \omega \rho o v$ presente no Escudo de Héracles (v. 223), porém, Torrano (2000) acaba optando por "monstro", muito provavelmente por se tratar da cabeça da Górgona, uma escolha que também se verifica nas traduções para o inglês de Evelyn-White (1982) e Most (2007), que a traduzem por "monster", bem como na tradução francesa de Mazon (1928), que opta por "monstre", e na italiana de Arrighetti (1998), que traduz por "mostro".

Nos Hinos Homéricos, apesar de haver ocorrências em apenas dois deles, a saber, o Hino Homérico a Apolo (h.Ap.) e o Hino Homérico a Hermes (h.Merc.), a variação persiste. No h.Ap., há três ocorrências do substantivo, uma delas no v. 374 remetendo à serpente que será morta por Apolo, e que a tradição posterior sagrará com o nome Pito (Pitó ou Píton), enquanto as outras duas ocorrências (v. 401 e 416) remetem ao deus transformado em golfinho. No h.Merc. há duas ocorrências do substantivo (v. 225 e 349) e uma do adjetivo triforme $\pi \dot{\varepsilon} \lambda \omega \rho o \varsigma$ (v. 342), todas remetendo a pegadas deixadas pelo deus Hermes para enganar Apolo. Na tradução do começo do século XX de Evelyn-White, "monster" é a escolha unânime para as três ocorrências do h.Ap., embora ele varie no h.Merc., traduzindo

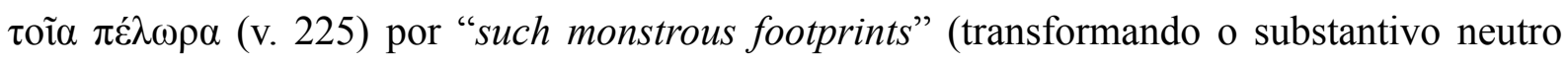

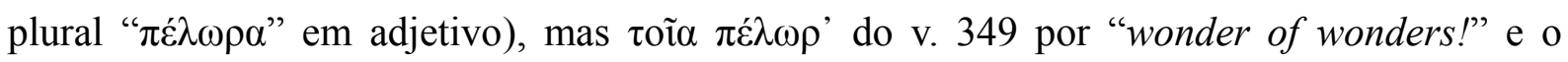
adjetivo $\pi \varepsilon ́ \lambda \omega \rho \alpha$ no v. 342 por "wonderful", talvez para deixar explícito o espanto de Apolo diante das estranhas e extraordinárias pegadas deixadas por Hermes. Observe-se, contudo, que Evelyn-White mantém certa coerência no h.Ap. ao traduzir $\pi \varepsilon ́ \lambda \omega \rho / \pi \varepsilon ́ \lambda \omega \rho o v$ por "monster" também quando remete ao deus Apolo transformado em golfinho (v. 401 e 416), não apenas em remissão à serpente morta pelo deus (v. 374), o que não acontece na tradução para o italiano de Càssola (1975), que usa "mostro" para traduzir $\pi \varepsilon ́ \lambda \omega \rho$ do v. 374, referindo-se à serpente, variando entre "prodigio" (v. 401) e "mostro" (v. 416) quando remete ao deus Apolo transformado em golfinho. Quanto às ocorrências no h.Merc., Càssola varia entre "passi cosi smisurati" (v. 225), transformando o substantivo neutro plural " $\pi \varepsilon ́ \lambda \omega \rho \alpha$ " em adjetivo, como Evelyn-White, e os adjetivos "straordinarie" (v. 342) e "singolare" (v. 349) para qualificar as 
pegadas do deus Hermes, esta última uma escolha também bastante "singular" como tradução

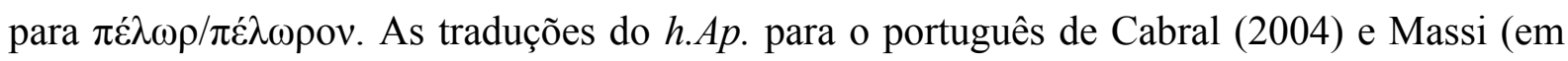
Ribeiro Jr., 2010) mantêm a mesma coerência de Evelyn-White, traduzindo por "monstro" inclusive quando $\pi \dot{\lambda} \lambda \omega \rho / \pi \varepsilon ́ \lambda \omega \rho o v$ remete ao golfinho. Já, a tradução do h.Merc. de Dezotti (em Ribeiro Jr., 2010) varia entre "prodigiosas passadas" (v. 225), "medonhas" (v. 342) e “tamanho prodígio!" (v. 349).

Nas traduções da Ilíada, particularmente, acontece algo curioso quanto às três ocorrências do substantivo $\pi \varepsilon ́ \lambda \omega \rho / \pi \varepsilon ́ \lambda \omega \rho o v ~(2.321,5.741,18.410)$, pois são geralmente traduzidas de forma bastante diferente entre si. $^{6} \mathrm{Na}$ passagem do canto 2, o neutro plural $\pi \varepsilon ́ \lambda \omega \rho \alpha$ é traduzido em geral por "portentos" ou "prodígios"; ${ }^{7}$ na passagem do canto 5, o genitivo singular $\pi \varepsilon \lambda \omega ́ \rho \rho$ é traduzido predominantemente por "monstro" (ou "monster" em inglês), embora Lourenço (2013a) o traduza por "prodígio", enquanto Butler (1898) e Murray (1924) traduzem por "monster"; e no canto 18.410, é possível encontrar "monster" (Butler, 1898), "huge" (Murray, 1924) e "colosso" (Lourenço, 2013a). Essa variação decorre

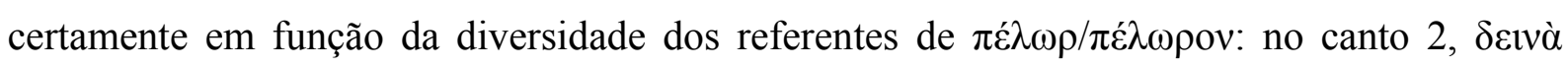
$\pi \varepsilon ́ \lambda \omega \rho \alpha \theta \varepsilon \tilde{\omega} v$ remete especificamente aos prodígios que interrompem a hecatombe oferecida

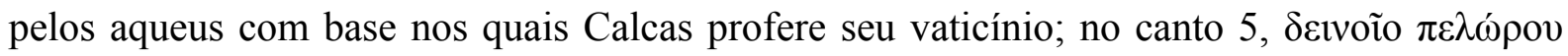
remete especificamente à cabeça da Górgona no escudo de Palas Atena; e no canto 18, $\pi \varepsilon ́ \lambda \omega \rho$ remete ao deus Hefesto.

Na Odisseia também é possível encontrar essa variação: traduz-se em geral por “monstro" quando $\pi \varepsilon ́ \lambda \omega \rho / \pi \varepsilon ́ \lambda \omega \rho o v$ remete a Polifemo $(9.428,9.257)$, a Cila (12.87) e à cabeça da Górgona (11.634), mas por "prodígio" ou "portento" em contexto de vaticínio (15.161); já, quando os animais encantados de Circe são o referente, as traduções variam entre "monstro" e "portento/prodígio" (10.168 e 10.219). ${ }^{8}$

Como é possível perceber, há uma variação de campo semântico atribuído aos termos em questão que reflete uma ideia preconcebida do referente, sendo a escolha lexical dos

6 Para a Ilíada e para a Odisseia, limita-se aqui a mencionar uma variedade menor de traduções por se acreditar que expõem suficientemente o ponto principal da argumentação, ou seja, o da variação na tradução dos termos ser decorrente de uma concepção prévia do referente.

7 Cf. as traduções para o inglês de Butler (1898) e Murray (1924), que traduzem por "portent", ambas disponíveis no portal Perseus Project. A tradução de Butler (1898) se encontra em: http://www.perseus.tufts.edu/hopper/text?doc=Perseus\%3atext\%3a1999.01.0217 (último acesso: 24 mai. 2016). A tradução de Murray está disponível em: http://www.perseus.tufts.edu/hopper/text?doc=Perseus \%3atext\%3a1999.01.0134 (último acesso: 24 mai. 2016).

8 Cf., as traduções para o inglês também da Odisseia de Butler (1900) e Murray (1919), igualmente disponíveis no portal Perseus Project. Para a tradução de Butler (1900): http://www.perseus.tufts.edu/hopper/text?doc=Perseus\%3atext\%3a1999.01.0218 (último acesso: 24 mai. 2016). Para a tradução de Murray (1919): http://www.perseus.tufts.edu/hopper/text?doc=Perseus\%3atext \%3a1999.01.0136 (último acesso: 24 mai. 2016). 
tradutores pautada por uma concepção de "monstro" estabelecida a priori e não de uma efetiva compreensão de $\pi \varepsilon ́ \lambda \omega \rho / \pi \varepsilon ́ \lambda \omega \rho o v$.

É notável também que haja uma preferência por se traduzir as variantes do adjetivo por "enorme" enquanto há uma tendência em se traduzir as variantes do substantivo por "monstro", como exposto acima para a Teogonia. Nos épicos homéricos, a variação "monstro"

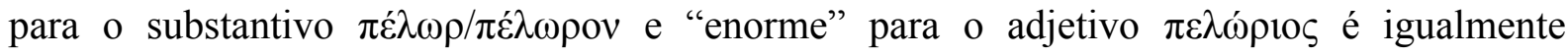
predominante. Embora seja traduzido com maior frequência para o inglês por "vast" e "huge", $\pi \varepsilon \lambda \hat{\rho} \cos$ também apresenta uma variação em sua tradução de acordo com uma ideia preconcebida do referente. Conquanto o adjetivo seja usado para qualificar heróis, deuses ou armas na Ilíada, sendo traduzido em geral com a noção de enormidade, quando remete a Polifemo na Odisseia (9.187 e 9.190), ele é predominantemente traduzido por "monstruoso". A tradução da Ilíada para o inglês de Murray (1924) oscila entre "huge" e "mighty", porém usa "monstrous" duas vezes: em 5.395, ao qualificar o deus Hades e em 21.527 ao adjetivar o herói Aquiles, uma escolha interessante do uso de "monstrous" porque geralmente esse adjetivo é evitado para qualificar deuses e heróis. Em sua tradução da Odisseia, Murray (1919) traduz duas das cinco ocorrências por "huge" (3.290 e 11.594) e as outras três, por “monstrous", das quais duas remetem a Polifemo (9.187 e 9.190); em 11.594, ele adota "monstrous" para adjetivar uma rocha, muito possivelmente com sentido de enormidade e não para expressar monstruosidade propriamente. Talvez seja esse sentido de enormidade que ele deseja atribuir ao adjetivo "monstrous" ao usá-lo para qualificar Aquiles (Ilíada 21.527) e Hades (Ilíada 5.395). É certo que "enorme" é uma das acepções do adjetivo "monstruoso" nas

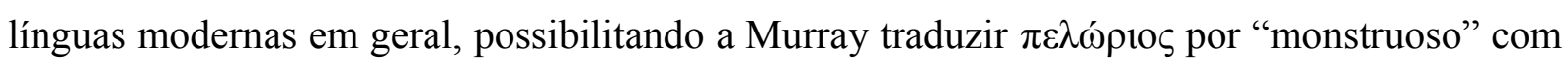
tal sentido; entretanto, este adjetivo evoca um campo semântico nas línguas modernas que extrapola em muito o da "enormidade".

Diante de tal variação de referentes, é compreensível que os tradutores tivessem de buscar diferentes soluções. No entanto, tais soluções ocorrem muito em função da compreensão de $\pi \varepsilon ́ \lambda \omega \rho / \pi \varepsilon ́ \lambda \omega \rho o v$ predominantemente como sinônimo de "monstro", um termo que, nas línguas modernas, assume um sentido majoritariamente pejorativo, desprovido de qualquer relação com o âmbito divino. A solução por "portento" ou "prodígio", como nas traduções brasileiras da Teogonia, expressa com mais adequação o campo semântico de $\pi \varepsilon ́ \lambda \omega \rho / \pi \varepsilon ́ \lambda \omega \rho o v$. O sentido de enormidade pode ser atribuído a quase todas as ocorrências tanto do substantivo quanto do adjetivo, a única exceção talvez seja a que está na Ilíada 2.231 (cf. adiante). Como será visto, o sentido de "portento"/"prodígio" e o de "enormidade" não são excludentes entre si, ou seja, os referentes, quer sejam do substantivo $\pi \dot{\varepsilon} \lambda \omega \rho / \pi \varepsilon ́ \lambda \omega \rho o v$ 
quer sejam das formas $\pi \varepsilon ́ \lambda \omega \rho o v$ e $\pi \varepsilon \lambda \omega ́ \rho ı \varsigma \varsigma$ do adjetivo, são percebidos como portentos e prodígios porque apresentam uma enormidade extraordinária. Dito de outro modo, a enormidade também é um elemento que torna algo passível de ser considerado um portento ou prodígio.

Apesar de $\pi \varepsilon \dot{\varepsilon} \lambda \omega \rho / \pi \varepsilon ́ \lambda \omega \rho o v$ possivelmente apresentar a mesma raiz etimológica de

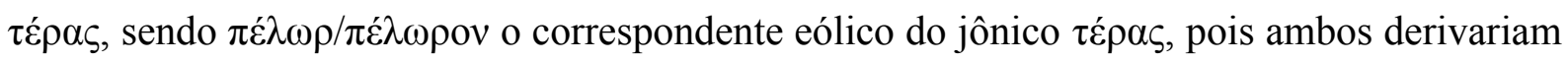
da mesma raiz indo-europeia $\mathrm{k}^{\mathrm{w}}$ er- ${ }^{9}$ Pizzani (2000, p. 534-535) defende que, enquanto $\tau \dot{\varepsilon} \rho \alpha \varsigma$ nos poemas homéricos apresenta um sentido de "advertimento divino", " $\pi \varepsilon ́ \lambda \omega \rho$ e derivados designam sempre unicamente e tout court o caráter enorme e excepcional do referente". ${ }^{10}$ Mesmo que o sentido de enormidade possa ser atribuído a todos os referentes de $\pi \varepsilon ́ \lambda \omega \rho$, defende-se aqui que o termo não designe enormidade física pura e simplesmente. Isso será mais bem explorado nas seções a seguir, que se dedicam a estudar cada um dos termos usualmente traduzidos por "monstro/monstruoso/monstruosidade". Passemos, então, ao primeiro deles a ser analisado.

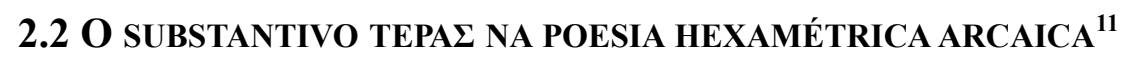

As ocorrências de $\tau \varepsilon ́ p \alpha \varsigma$ na poesia hexamétrica arcaica se concentram nos dois épicos homéricos, com apenas uma ocorrência na Teogonia (v. 744) e outra no Hino Homérico a Apolo (v. 302). ${ }^{12}$ Em função disso, prefere-se analisar primeiro as ocorrências na Ilíada e na Odisseia, que são em maior número e, portanto, oferecem mais oportunidades de observação contextual para a compreensão do termo.

9 Cf. os verbetes $\pi \varepsilon ́ \lambda \omega \rho$ e $\tau \varepsilon ́ \rho \alpha \varsigma$ nos dicionários etimológicos de Chantraine (1974, tomo III, p. 878-879 para

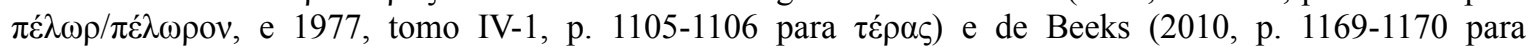

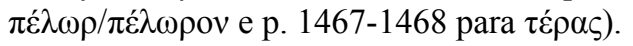

10 Pizzani (2000, p. 534-535): “[...] nei poemi omerici $\tau \dot{\varepsilon} \rho \alpha \varsigma$, anche quando fa riferimento a entità o ad eventi assumenti i caratteri del mostruoso nel senso usuale del termine, è sempre esplicitamente usato per evidenziarne il carattere di avvertimento divino; per converso $\pi \dot{\varepsilon} \lambda \omega \rho$ e i derivati designano sempre unicamente e tout court il carattere abnorme ed eccezionale del referente, quand'anche 'di fatto' assumesse nel contesto i caratteri di avvertimento divino.".

11 No Apêndice B, encontra-se uma tabela com as ocorrências de $\tau \dot{p} \rho \alpha \varsigma$ e no Apêndice C estão os excertos nos

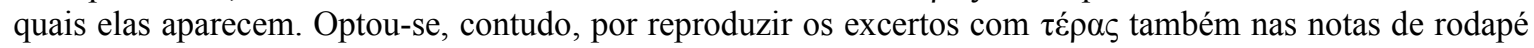
deste capítulo para a comodidade do leitor.

12 Veja-se, contudo, o fragmento do Catálogo das Mulheres, frag. 141, linha 28, reproduzido ao final do Apêndice C. 


\section{2.a) Ilíada}

Logo no início da Ilíada (2.299-330), no episódio em que os aqueus estão reunidos em assembleia tentando decidir se continuam o cerco à Troia ou se retornam para os seus, Odisseu recorda ao exército o momento em que faziam sacrifícios em Áulis, antes de partirem rumo à Troia, pedindo aos deuses que lhes enviassem ventos propícios. O herói relembra que, durante o sacrifício, uma serpente apareceu e devorou oito filhotes de pardal mais a mãe, aninhados na árvore sob a qual os aqueus realizavam o sacrifício, e logo em seguida foi transformada em pedra por Zeus. Ele reproduz a fala de Calcas na ocasião, na qual o adivinho

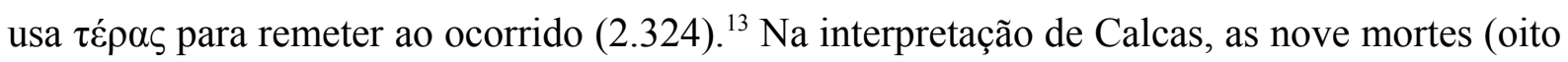
filhotes mais a mãe) sinalizavam o número de anos que duraria o cerco dos aqueus à Troia, seguido da vitória contra os troianos. Note-se que a expressão $\tau \dot{\varepsilon} \rho \alpha \varsigma \mu \varepsilon ́ \gamma \alpha$ utilizada nessa passagem remete não à serpente em si, e sim ao portento como um todo revelado diretamente

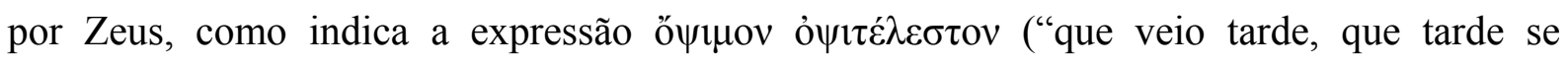

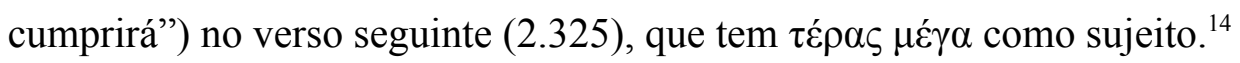

Nessa fala de Odisseu (reproduzida mais longamente no Apêndice C), há dois

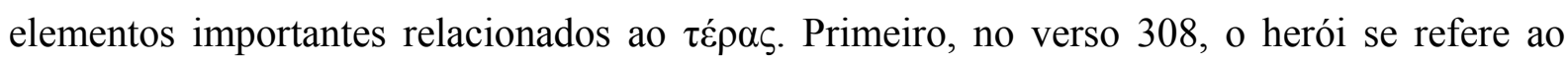

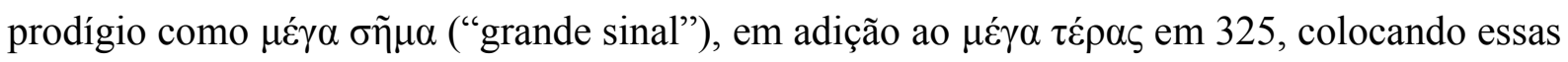
duas expressões em uma relação de sinonímia. Segundo, no verso 320, Odisseu diz que todos se "espantaram" ( $(\theta \alpha \mu \alpha \alpha \zeta \zeta \mu \varepsilon v)$ com o que acontecera, um efeito frequente, como se verá,

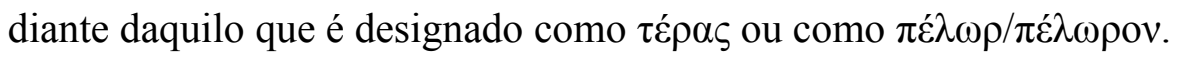

As demais passagens da Ilíada (e também as da Odisseia) corroboram essa leitura de $\tau \varepsilon ́ p \alpha \varsigma$ enquanto um portento enviado por uma divindade. No canto 4 (75-84), ao traçar um símile entre a deusa Palas Atena, que rapidamente se lança em direção à terra entre os

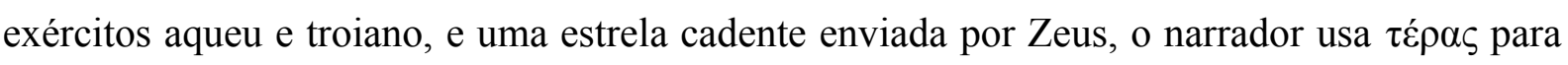
designar a passagem da estrela como um portento aos marinheiros e aos povos (4.76). ${ }^{15}$

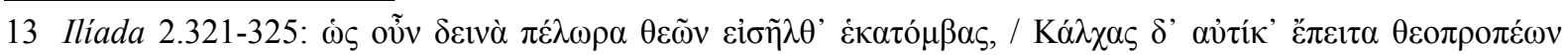

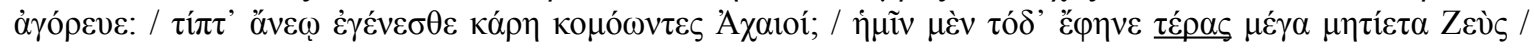

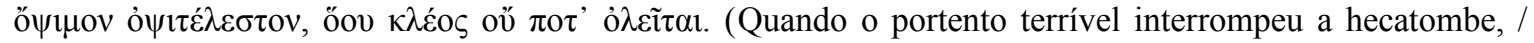
imediatamente nos deu Calcas o seguinte vaticínio: / 'Por que vos mantendes em silêncio, ó Aqueus de longos cabelos? / A vós mostrou este grande prodígio Zeus conselheiro, / que veio tarde, que tarde se cumprirá, mas cuja fama nunca morrerá.). Todas as traduções da Ilíada para o português citadas neste capítulo e nos subsequentes são de Lourenço (2013a). A edição é a de Allen-Monro (1920) para os cantos 112 e Allen (1920) para os cantos 13-24. Cf. o Apêndice C, para o excerto de 2.999-325.

14 Nesta passagem é também usado o substantivo $\pi \varepsilon ́ \lambda \omega \rho / \pi \varepsilon ́ \lambda \omega \rho o v ~(2.321)$. Cf. adiante.

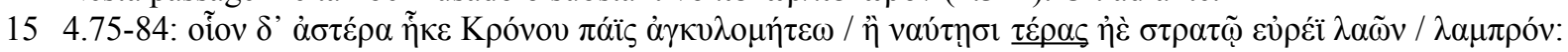

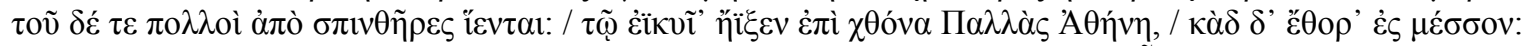

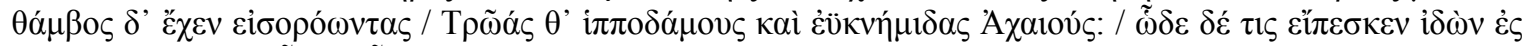

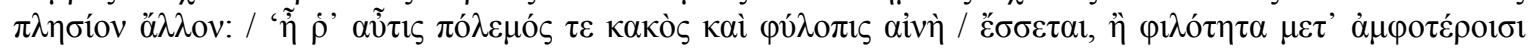


Assim, tanto o fato de uma serpente aparecer durante um sacrifício, devorar nove pardais e desaparecer em forma de pedra, quanto o fato de uma estrela cadente cruzar o céu são entendidos como um portento enviado por Zeus (cf. 2.324 e 4.75). Observe-se que, quando Atena aterrissa no meio do campo de batalha, o "espanto" ( $\theta \dot{\alpha} \mu \beta o \varsigma, 4.79)$ toma conta de ambos os exércitos, aqueu e troiano. Diante de tal evento espantoso, comenta-se a dupla possibilidade de interpretação do ocorrido: Zeus estabelecerá a guerra ou a amizade entre as partes.

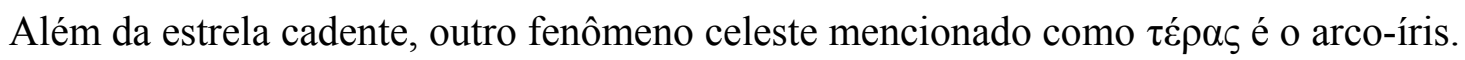
$\mathrm{Na}$ descrição da couraça de Agamêmnon, em 11.28, as serpentes entrelaçadas que a adornam são comparadas a um arco-íris, e em 17.548, o arco-íris é um presságio de guerra ou de

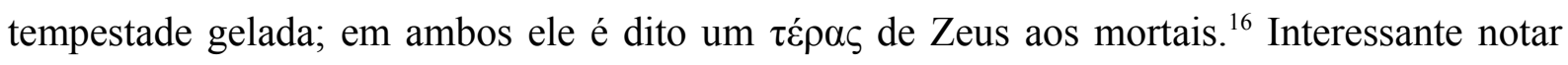
que, nessa passagem do canto 17, o arco-íris é usado como símile também de Atena, que agora se insere no exército aqueu para encorajar os combatentes.

No canto 4 (4.398 e 4.408), a expressão $\tau \varepsilon \rho \alpha ́ \varepsilon \sigma \sigma ı ~ \theta \varepsilon \tilde{\omega} v$ (“portento dos deuses”), usada por Agamêmnon e por Estênelo, respectivamente, atribui o envio de um portento aos deuses em geral. ${ }^{17}$ Note-se que na mesma fala de Agamêmnon, um pouco antes em 4.381, o termo $\sigma \tilde{\eta} \mu \alpha$ ("sinal", "signo") é usado para remeter aos "portentos desfavoráveis" mostrados por Zeus, o que reitera a sinonímia entre $\tau \dot{\varepsilon} \rho \alpha \varsigma$ e $\sigma \tilde{\eta} \mu \alpha$.

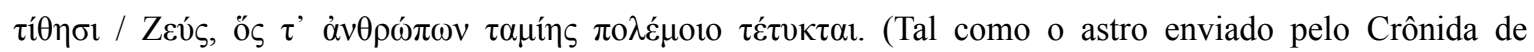
retorcidos conselhos / como portento a marinheiros ou ao vasto exército de povos, / estrela brilhante, de que se projetam abundantes centelhas - / assim se lançou em direção à terra Palas Atena, aterrando / no meio deles com um salto; e o espanto dominou quem olhava, / Troianos domadores de cavalos e Aqueus de belas cnêmides. / E assim dizia um deles, olhando de soslaio para o outro: / "Virá de novo a guerra maligna e o fragor tremendo / da refrega, ou então entre ambas as partes estabelece / Zeus a amizade, ele que dispensa a guerra aos homens.")

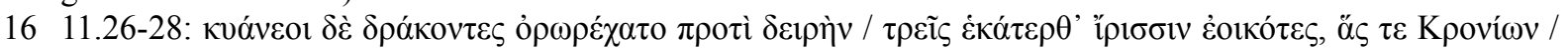

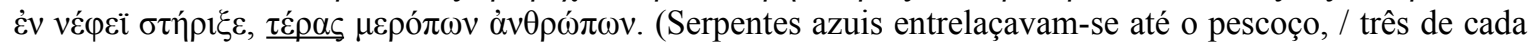
lado, semelhantes ao arco-íris que o Crônida / põe no meio das nuvens, como portento para os mortais.)

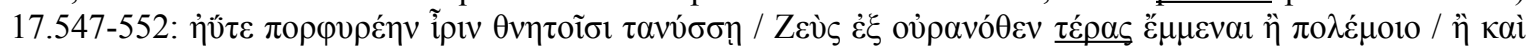

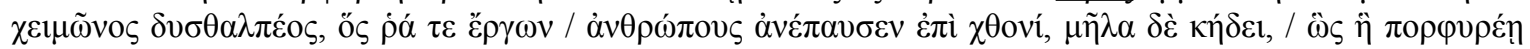

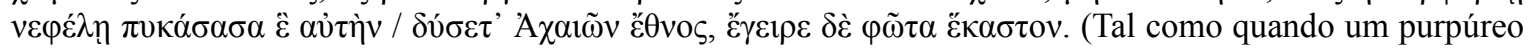
arco-íris para os mortais / Zeus estica do céu, como portento quer da guerra, / quer da gélida tempestade que obriga os homens / a parar a lavoura nos campos e prejudica rebanhos - / assim Atena, envolta numa nuvem purpúrea, entrou / na chusma dos Aqueus e encorajou cada homem.)

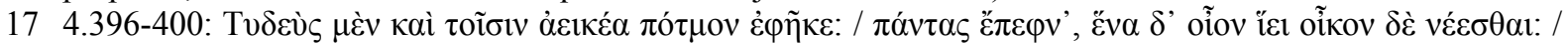

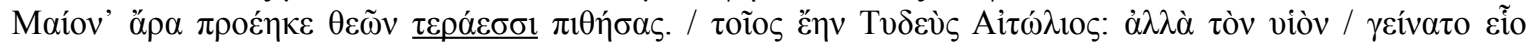

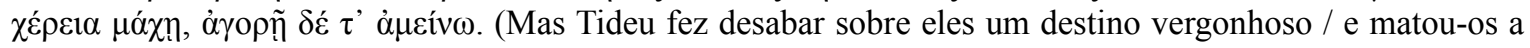
todos; só a um deixou que regressasse a casa - / mandou embora Méon, obedecendo aos portentos dos deuses. / Tal era Tideu da Etólia; mas o filho que gerou é pior / que ele na guerra, embora seja melhor na

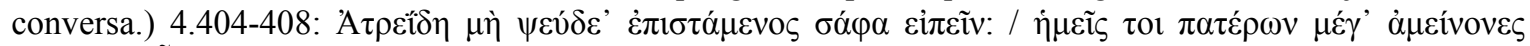

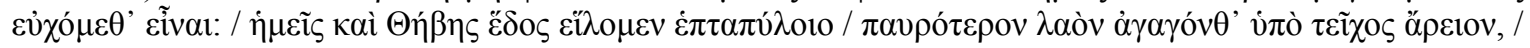

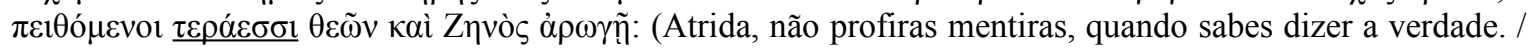
Nós declaramo-nos de longe melhores que os nossos pais. / Conquistamos a sede da heptápila Tebas, quando ambos / juntamos uma hoste menor sob uma muralha mais forte, / tendo acreditado nos portentos divinos e na ajuda de Zeus.) 
Enquanto $\sigma \tilde{\eta} \mu \alpha$, ou seja, enquanto "sinal" ou "signo", $\tau \dot{\varepsilon} \rho \alpha \varsigma$ tem um valor indicial em que uma coisa indica outra: uma serpente que devora nove pardais indica a vitória dos aqueus contra os troianos após nove anos de cerco à Troia; uma estrela cadente pode indicar a guerra ou a paz; um arco-íris pode indicar a guerra ou uma tempestade gelada. A única ocorrência na Ilíada da qual se poderia dizer que $\tau$ śpaৎ não designaria exatamente um presságio, mas uma figura considerada monstruosa é em 5.742, em que o narrador usa $\tau \varepsilon ́ p \alpha \varsigma$ tendo como referente a cabeça da Górgona representada no escudo de Atena. ${ }^{18}$ Entretanto, ao descrever o escudo, o narrador diz que nele está “a cabeça monstruosa da Górgona, terrível / e medonha, portento de

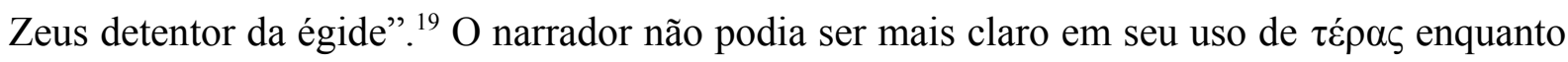

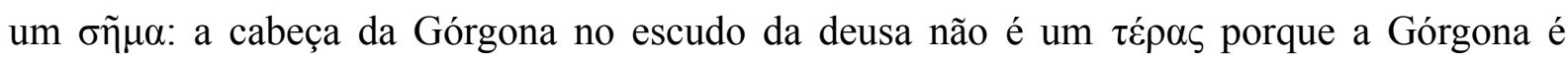
considerada um "monstro", e sim porque é um portento de Zeus em seu aspecto de "portador do escudo": ela é um $\tau \varepsilon \dot{\varepsilon} \rho \alpha \varsigma$ ou um $\sigma \tilde{\eta} \mu \alpha$ que indica o aspecto defensivo e protetor de Zeus, presente na égide da deusa. Outro caso em que uma divindade traz consigo um portento no sentido de um símbolo ou uma insígnia está nos primeiros versos do canto 11: Zeus envia ao acampamento dos aqueus a deusa Éris (ou "Discórdia"), que carrega nas mãos um "portento de guerra". ${ }^{20}$

Tal aspecto defensivo ou protetor de Zeus é evocado, ainda na Ilíada, por outro portento. Em 12.200-209, uma serpente que cai no meio do exército troiano, contorcendo-se toda, é dita pelo narrador "um portento de Zeus portador do escudo". ${ }^{21}$ Nessa passagem em que o exército troiano faz um cerco às naus dos aqueus, no momento em que Polidamante e Heitor estão na iminência de cruzar a vala para chegar ao muro que protege os barcos inimigos, uma águia sobrevoa pela esquerda com uma serpente nas garras. ${ }^{22}$ A serpente morde a águia no peito e esta a deixa cair no meio do exército troiano. Polidamante, então, aproximase de Heitor e lhe pede que não avancem contra os barcos, interpretando o ocorrido como um

18 No verso 5.741 é usado também o substantivo $\pi \varepsilon ́ \lambda \omega \rho / \pi \varepsilon ́ \lambda \omega \rho o v$ para remeter à cabeça da Górgona. Cf. adiante.

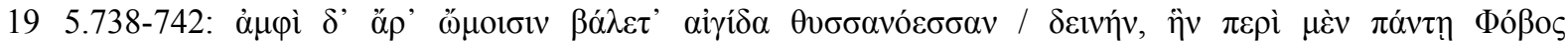

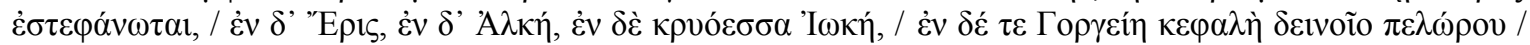

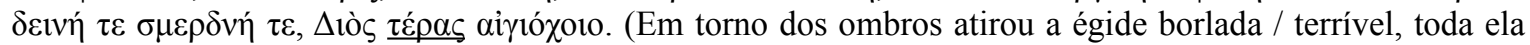
engalanada de Pânico: nela / está a Discórdia, está a Sanha, está o gélido Assalto, / está a cabeça monstruosa da Górgona, terrível / e medonha, portento de Zeus detentor da égide.)

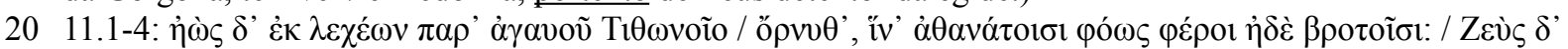
”Е deitava junto do orgulhoso Titono / surgiu a Aurora, para trazer luz aos homens. / Zeus enviou a Discórdia para junto das naus velozes dos Aqueus, / a medonha Discórdia, que segurava nas mãos um portento de guerra.)

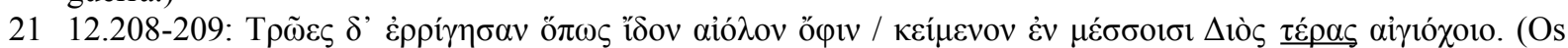
Troianos horrorizaram-se ao ver a cobra a contorcer-se, / ali jazente no meio deles - portento de Zeus detentor da égide!)

22 Acerca de presságios protagonizados por pássaros na Ilíada, cf. Kelly (2007, p. 254-255). 
aviso de que, ainda que consigam transpor e destruir os muros que protegem as naus, os aqueus matarão muitos troianos. ${ }^{23}$ Embora a interpretação de presságios requeira o conhecimento especializado de um adivinho, Polidamante se arrisca a interpretá-lo e sua interpretação não agrada a Heitor, que o rechaça afirmando que não dá importância para o voo das aves, mas obedece apenas à deliberação do próprio Zeus (cf. 12.231-250), muito possivelmente se referindo à fala da deusa Íris em 11.200-210, que lhe diz entregar uma mensagem de Zeus, na qual o deus lhe promete vitória (cf. Hainsworth e Kirk, 1993, p. 342).

Sabemos que esse cerco às naus aqueias, que perdurará até o canto 15 , não tem um fim favorável aos troianos, confirmando a interpretação do presságio por parte de Polidamante e o equívoco de Heitor. Essas mensagens desencontradas constituem a estratégia de Zeus para fazer os troianos pensarem que obterão a vitória. Veja-se que, logo após a fala de Heitor, Zeus faz levantar uma rajada de vento do Ida lançando poeira contra as naus aqueias, confundindo os aqueus, por um lado, e indicando glória para os troianos, por outro (12.251-255), que se mantinham na tentativa de arrasar a muralha "confiantes em portentos" ( $\varepsilon \varepsilon \rho \alpha ́ \varepsilon \sigma \sigma 1 \pi \varepsilon \pi 01 \theta$ ó $\tau \varepsilon \varsigma$, 12.256). ${ }^{24} \mathrm{O}$ problema é que os portentos nos quais confiaram tinham o objetivo de enganálos.

Quanto à serpente ser dita um portento de Zeus em seu aspecto de detentor do escudo (12.209), como a cabeça da Górgona no escudo de Palas Atena, é possível que a expressão

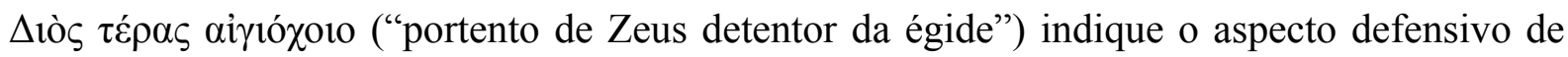
Zeus evocado no presságio, já que os aqueus serão bem-sucedidos na defesa de seus barcos contra o ataque troiano.

Por fim, há também os portentos dos deuses mencionados por Glauco no canto 6 (178183), no contexto da narrativa acerca de seus ancestrais, dentre eles seu avô, Belerofonte. Glauco diz que Belerofonte matou Quimera "obedecendo aos portentos dos deuses" (6.183). ${ }^{25}$ Tendo se recusado a deitar com Anteia, esposa do rei Proito, Belerofonte foi enviado por Proito para a Lícia portando $\sigma \tilde{\eta} \mu \alpha \tau \alpha ~ \lambda v \gamma \rho \alpha ́$ (“sinais ominosos”, 12.168), que o herói devia

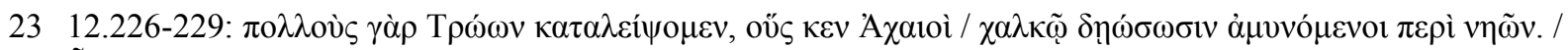

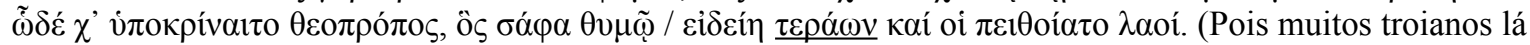
deixaremos, a quem os Aqueus / matarão com o bronze em defesa das naus. / Esta seria a interpretação de um adivinho, que no ânimo / tem conhecimento de portentos e no qual o povo confia.)

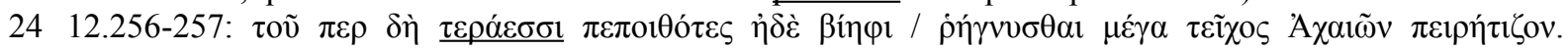
(Confiando em portentos e na sua força, os Troianos / procuravam arrasar a grande muralha dos Aqueus.)

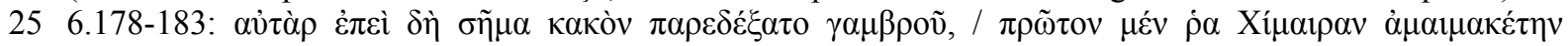

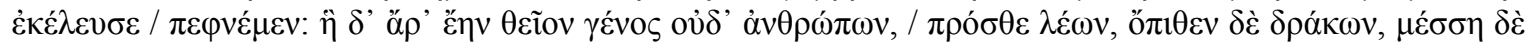

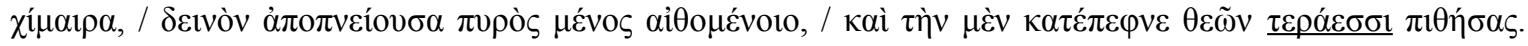
(Porém quando recebeu o sinal maligno de seu genro, / primeiro mandou-o matar a terrífica Quimera. / Ela é de raça divina - não pertence à dos homens: / à frente tem forma de leão, atrás de dragão, no meio de cabra; / seu sopro é a fúria terrível do fogo ardente. / Mas Belerofonte matou-a, obedecendo aos portentos dos deuses.) 
mostrar ao sogro de Proito para que ele o matasse (12.168-170). Depois de mostrar o $\sigma \tilde{\eta} \mu \alpha$ какóv (“sinal maligno”), o sogro de Proito o enviou para matar Quimera (12.178-179), o que

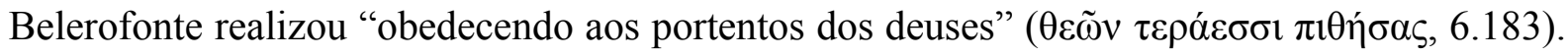
Talvez não seja despropositado sugerir que os $\sigma \tilde{\eta} \mu \alpha \tau \alpha$ $\lambda v \gamma \rho \alpha ́$ contidos na tabuinha de aba dupla (12.169) que Belerofonte transportou consigo pudessem ser, na verdade, "portentos dos deuses" ( $\theta \varepsilon \tilde{\omega} \nu \tau \varepsilon \rho \alpha ́ \varepsilon \sigma \sigma 1,6.183)$ que Proito teria forjado e registrado na tabuinha para justificar enganosamente a morte de Belerofonte. ${ }^{26}$

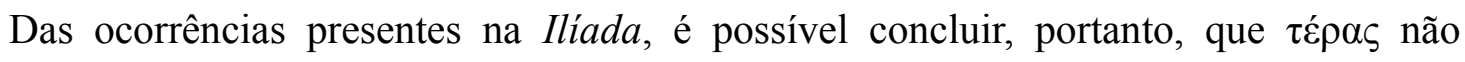
designa "monstro" ou "monstruosidade", mas portentos, ou seja, presságios enviados pelos deuses ou por Zeus especificamente e, como $\sigma \tilde{\eta} \mu \alpha$, pode designar, inclusive, uma insígnia. Conforme afirma Pizzani (1997, p. 2), para que a vontade divina se manifeste e seja reconhecível enquanto tal, ela tem de se apresentar como algo fora do ordinário. Tal evento fora do comum, que amiúde causa espanto, é, assim, um sinal comunicativo da esfera divina com o âmbito humano.

\section{2.b) Odisseia}

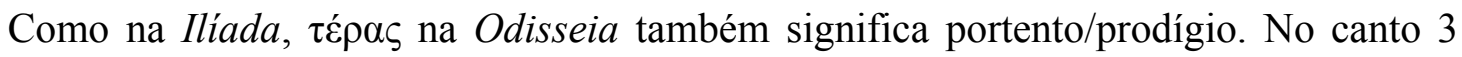

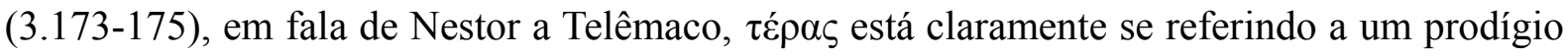
como mensagem dos deuses..$^{27}$ No canto 15, Pisístrato, filho de Nestor, pede a Menelau que interprete um $\tau \dot{\varepsilon} \rho \alpha \varsigma$ (15.168). ${ }^{28}$ Vejam-se também: a fala de Telêmaco a Odisseu no canto 16, perguntando se o herói sabe de algum portento ( $\tau \dot{\varepsilon} \rho \alpha \varsigma, 16.320$ ) de Zeus portador do escudo, ${ }^{29}$

26 Evidentemente, essa sugestão não passa de pura especulação, não havendo nada que possa comprová-la. Interessante notar, contudo, que a menção a essa tabuinha era considerada um elemento da poesia homérica que remetia mais possivelmente a uma prática do século VIII a.C. do que a uma do período micênico, fundamentalmente por fazer referência à escrita, pois ainda que os palácios micênicos fizessem uso da Linear B, esta é considerada uma escrita estritamente administrativa. Entretanto, a tabuinha de Uluburun, um díptico proveniente de um naufrágio datado do final do século XIV a.C., no sudoeste da Turquia, é muito semelhante à descrita nessa passagem da Ilíada, principalmente por se constituir de duas tabuinhas conectadas por um mecanismo que possibilita seu fechamento e abertura. Fechos e dobradiças encontrados no palácio de Micenas e Pilos tiveram sua função esclarecida apenas com a descoberta da tabuinha de Uluburun. Coincidentemente, a região na qual foi encontrado esse naufrágio se localiza exatamente na costa do que era a antiga Lícia, região para onde Belerofonte foi enviado com a tabuinha dupla. Cf. Shear (1998) e Mellink (1998).

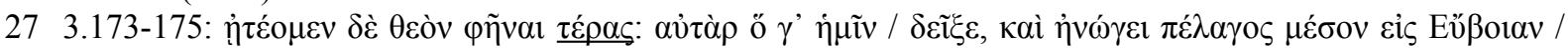

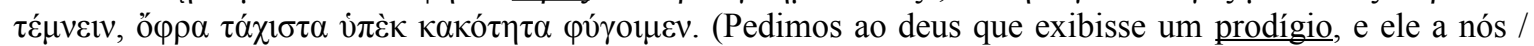
mostrou e ordenou que, rumo a Euboia, o meio do mar / cortássemos, para bem rápido escapar do nefasto.) Todos os excertos da Odisseia são da edição de Allen (1917 e 1919) e as traduções são de Werner (2014).

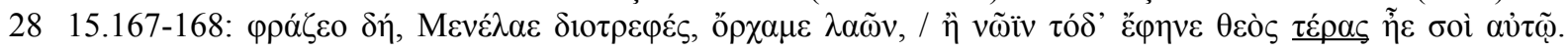
(Analisa, Menelay criado-por-Zeus, líder de tropa, / se o deus mostrou o presságio a nós dois, ou a ti.)

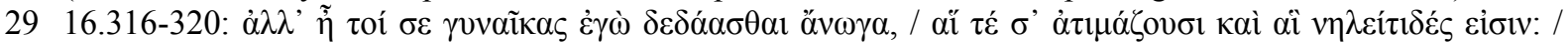

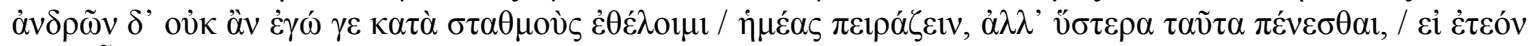

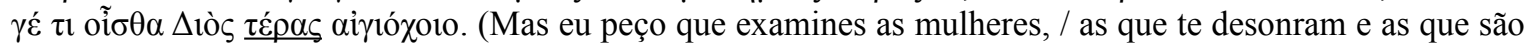


a prece de Odisseu a Zeus no canto 20, que pede ao deus que prenuncie um $\tau \dot{\varepsilon} \rho \alpha \varsigma(20.101) ;{ }^{30}$

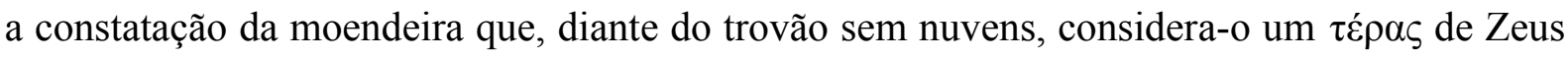
(20.114); ${ }^{31}$ e, por fim, o trovão que Odisseu entende como sinal do apoio de Zeus no canto 21

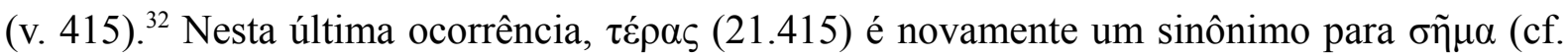
21.413).

Uma passagem da Odisseia, contudo, chama a atenção pelo aspecto extraordinário envolvido. No canto 12, na narrativa de Odisseu aos feácios, Odisseu menciona que os deuses exibiram um $\tau \varepsilon ́ p a \varsigma$ a ele e a seus companheiros, referindo-se ao episódio em que as peles das vacas do deus Sol, que ele e seus companheiros mataram e comeram, caminhavam como se estivessem vivas e as suas carnes mugiam. ${ }^{33}$ Nessa passagem, um tanto diferente das demais em que há um contexto claro de vaticínio no qual o deus envia uma mensagem a ser

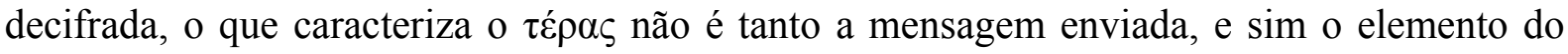
extraordinário ou fantástico, que é em si um indício de que aqueles animais não são de estirpe humana, sugerindo o ultraje cometido por Odisseu e seus companheiros ao se alimentarem deles. $^{34}$

\section{2.c) Teogonia e Hino Homérico a Apolo}

As duas ocorrências de $\tau \dot{p} \rho \alpha \varsigma$ fora dos épicos homéricos, contudo, parecem apresentar sentidos que se distanciam um pouco daquele constatado na Ilíada e na Odisseia, em uma

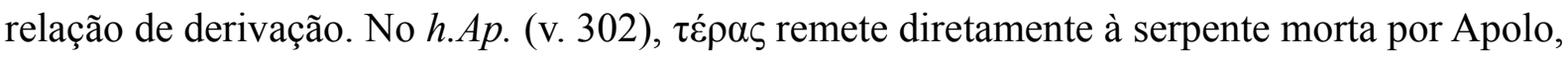

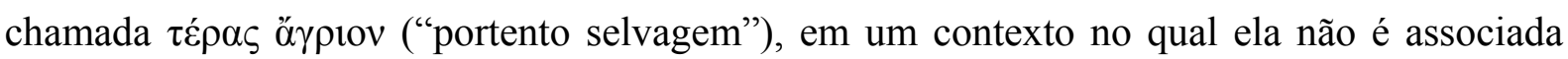
diretamente a qualquer sinal ou mensagem enviada por uma divindade. ${ }^{35}$ Nada impede, no

inocentes; / aos varões eu não quereria, pela quinta, / que os testássemos, isso faremos depois, / se de verdade sabes de prodígio de Zeus porta-égide.)

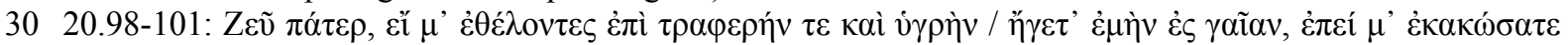

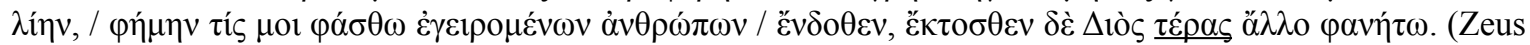
pai, se a mim, com intenção, à firme e úmida / terra, à minha, trouxestes, após me lesardes demais, / prenúncio pronuncie um dos homens que desperta / dentro, e, fora, prodígio de Zeus, ademais, apareça.)

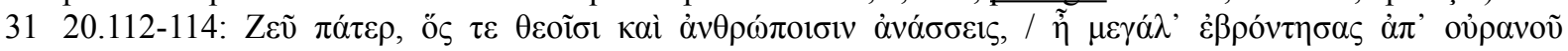

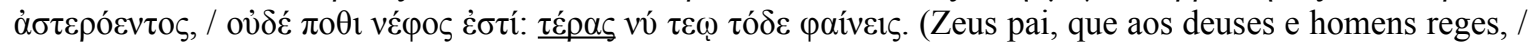
com vigor trovejaste do páramo estrelado, / onde nuvem não há; é prodígio que mostras a alguém.)

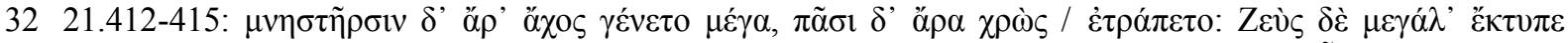

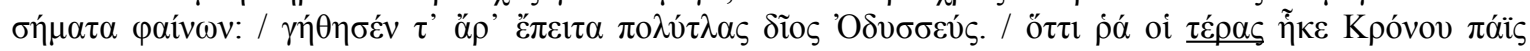
$\grave{\alpha} \gamma \kappa v \lambda о \mu \eta \dot{\tau} \varepsilon \omega$ : (Grande angústia se apossou dos pretendentes, e sua cor / mudou. E Zeus ribombou forte, revelando sinais. / Então alegrou-se o muita-tenência, divino Odisseu, / pois prodígio enviou-lhe o filho de Crono curva-astúcia.)

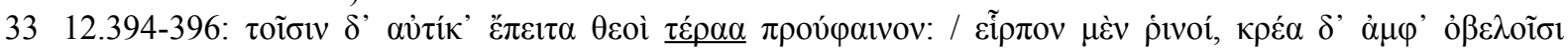

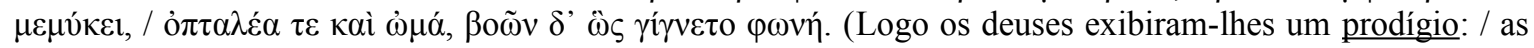
peles caminhavam as carnes nos espetos mugiam, / cozidas ou cruas; e o som era como o das vacas.)

34 Acerca das funções narrativas dos presságios na Odisseia, cf. Werner (2011).

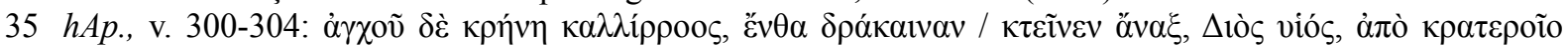




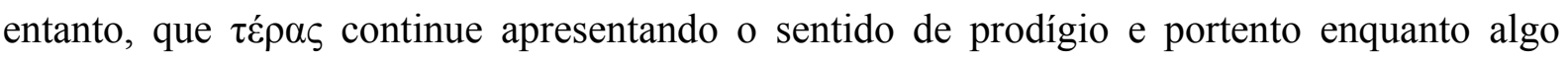
extraordinário, já que a serpente não é descrita como uma serpente comum. Todavia, é preciso apontar para a diferença entre o uso nos épicos, cujas ocorrências estão associadas estritamente a um sinal enviado por um deus ou a uma insígnia (como a cabeça da Górgona no escudo de Atena enquanto insígnia de Zeus portador do escudo), e o uso no h.Ap, que remete à serpente no momento em que é descrita de modo a evidenciar sua natureza destrutiva em relação aos mortais (cf. v. 300-306). É possível pensar, entretanto, que a serpente seja um $\tau \varepsilon ́ p \alpha \varsigma$ no sentido de portento/prodígio na medida em que é um indício da presença de Hera, principal opositora de Apolo no h.Ap., pois ela tomou conta de Tifeu, filho de Hera. Porém, isso ainda representaria certo distanciamento, no caso, penso, uma derivação, do sentido de

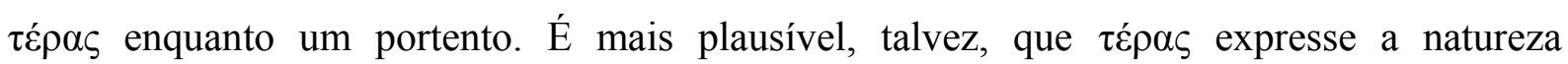
extraordinária da serpente, como parece ser o caso de sua única ocorrência na Teogonia. Nesse poema hesiódico, $\tau \varepsilon ́ \rho \alpha \varsigma$ (v. 744) também não está relacionado diretamente a um sinal enviado por um deus; ele remete ao Tártaro e o contexto é claramente o de assombro, evocando o sentido de extraordinariedade, que espanta até mesmo os deuses (v. 743-744). ${ }^{36}$

Embora Aristóteles use o substantivo $\tau \dot{p} \rho \alpha \varsigma$ para se referir a seres com algum tipo de anomalia ou deformidade, seu emprego em Geração dos animais não coincide com o

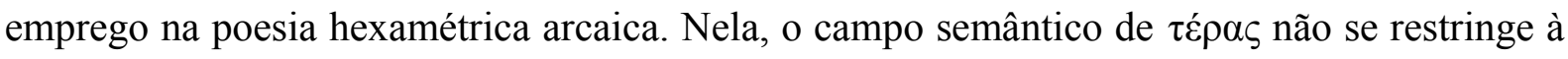
definição aristotélica, podendo abranger eventos ou fenômenos considerados fora do comum, como o aparecimento de um arco-íris, por exemplo (cf. Ilíada 17.548). Talvez se possa dizer, portanto, que Aristóteles não apresenta tanto uma definição de $\tau \dot{\varepsilon} \rho \alpha \varsigma$ quanto uma delimitação

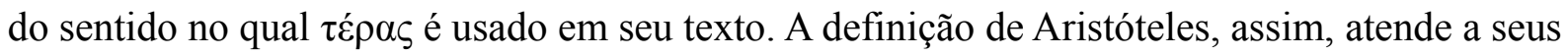
interesses naturalistas e muito possivelmente às necessidades de circunscrição de seu objeto de estudo na obra Geração dos animais especificamente. ${ }^{37}$

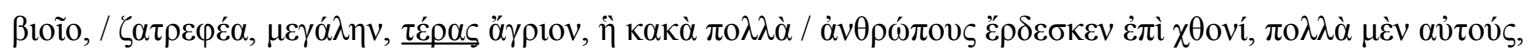

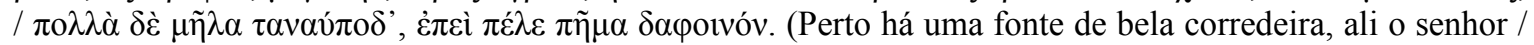
filho de Zeus, matou, com seu arco enérgico, uma serpente / robusta, grande, um monstro feroz que fazia muitos males / aos homens sobre a terra; muitos males a eles, / e muitos males aos carneiros de patas finas. Era um tormento de sangue.) Edição de Allen-Haliday-Sikes (1936) e tradução de Massi (em Ribeiro Jr., 2010).

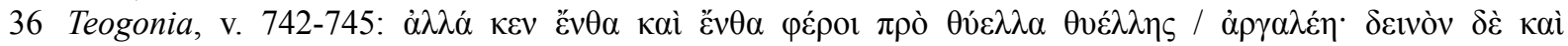

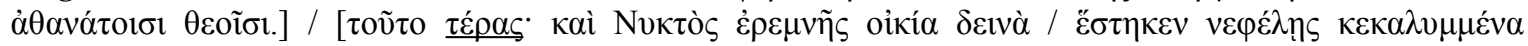

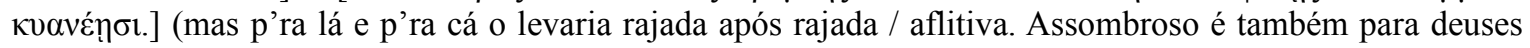
imortais / esse prodígio; também a morada assombrosa de Noite /encontra-se escondida em nuvem cobalto. Edição de West (1997 [1966]) e tradução de Werner (2013a).

37 Essa delimitação de sentido de $\tau \varepsilon ́ p \alpha \varsigma$, observada em Aristóteles, não significa, contudo, que esse fosse o 
Nesse campo semântico mais amplo, que inclui fenômenos considerados fora do comum ou algo espantoso, um arco-íris pode ser designado pelo termo $\tau \dot{\varepsilon} \rho \alpha \varsigma$ tanto quanto a cabeça da Górgona no escudo da deusa Palas Atena (Ilíada 11.28 e 5.742, respectivamente). A amplitude desse campo semântico, que permite juntar sob um mesmo termo referentes tão diversos, deve-se ao fato de que eles são entendidos como portentos e prodígios, ou seja, como sinais enviados pela divindade aos mortais ou insígnias que correspondem a uma determinada divindade. Tanto o arco-íris como a cabeça da Górgona no escudo de Palas Atena são explicitados no poema como prodígios ou portentos de Zeus (Ilíada 11.27-28 e 5.741-42, respectivamente), e no caso específico da cabeça da Górgona, de um aspecto bastante particular de Zeus: aquele que porta o escudo. Assim, tanto o arco-íris como a cabeça da Górgona são prodígios/portentos de Zeus porque são indícios de sua presença, quer seja por meio de uma mensagem a ser decifrada, quer seja por meio de uma imagem que o evoque, ainda que de maneira indireta.

Disso, é possível concluir que, primeiro, $\tau \varepsilon ́ p \alpha \varsigma$ pressupõe a característica da extraordinariedade, sendo essa extraordinariedade o meio pelo qual uma divindade se comunica com o âmbito humano; segundo, que $\tau \dot{\rho} \rho \alpha \varsigma$, sendo uma mensagem divina comunicada por um ser/coisa/evento extraordinário, apresenta um significado outro que não o próprio ser/coisa/evento, ou seja, tem valor indicial em que, por exemplo, um arco-íris pode indicar guerra iminente ou uma tempestade gelada (Il. 17.547-552).

Enquanto "signo" ( $\sigma \tilde{\eta} \mu \alpha)$, há uma arbitrariedade entre o significante (i.e., arco-íris) e o significado (i.e., guerra iminente ou tempestade gelada), em termos saussureanos, que amiúde torna necessário o conhecimento especializado do adivinho para que a mensagem contida em

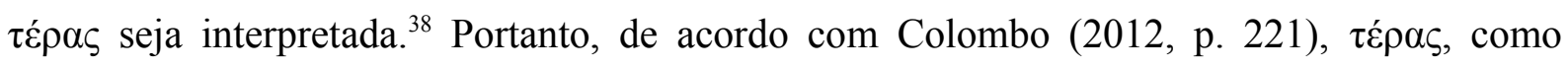
designativo de uma mensagem identificável com base no elemento extraordinário, é um "signo de exceção". É esse caráter de "exceção", contudo, que permanece com força em Geração dos animais de Aristóteles.

único sentido à sua época nem que ele ignorasse os outros.

38 Sobre a arbitrariedade do signo linguístico conforme proposto pelo linguista suíço, cf. Saussure (2008). 


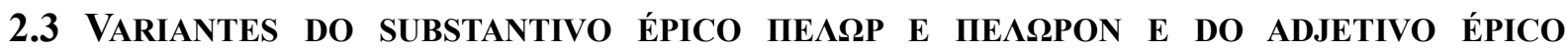

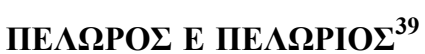

As formas $\pi \varepsilon ́ \lambda \omega \rho$ e $\pi \varepsilon ́ \lambda \omega \rho o v$ do substantivo épico, encontradas em verbetes separados no LSJ e no léxico homérico de Cunliffe (cf. Apêndice A), não são consideradas aqui dois

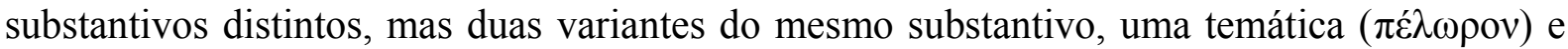
outra atemática $(\pi \varepsilon ́ \lambda \omega \rho)$. Considera-se que sejam variantes de um mesmo substantivo porque esta pesquisa não constatou diferenças de sentido entre essas duas formas na poesia hexamétrica arcaica, sendo a escolha de uma ou de outra não decorrente de qualquer distinção semântica entre elas e sim da exigência métrica do hexâmetro. ${ }^{40}$ Sendo assim, as duas variantes serão analisadas conjuntamente.

No caso de $\pi \varepsilon ́ \lambda \omega \rho o \varsigma$ e $\pi \varepsilon \lambda \omega ́ \rho ı \varsigma$, elas também são consideradas variantes do mesmo adjetivo por não apresentarem distinção de sentido. A variante triforme $\pi \varepsilon ́ \lambda \omega \rho \circ \varsigma, \pi \varepsilon \lambda \omega ́ \rho \eta$, $\pi \varepsilon ́ \lambda \omega \rho$ ov ocorre predominantemente na poesia hesiódica como epíteto da deusa Terra e a

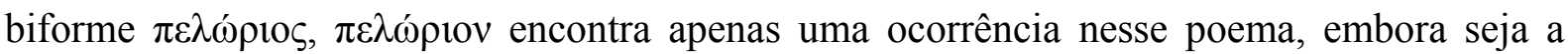
única usada nos épicos homéricos.

No mais recente estudo sobre monstros e monstruosidade no mundo antigo, que se dedica especificamente à poesia augustana, Dunstan Lowe (2015) distingue as variantes do substantivo, atribuindo a $\pi \varepsilon ́ \lambda \omega \rho$ um uso exclusivo para remeter a "seres vivos de aparência assustadora" e a $\pi \dot{\lambda} \lambda \omega \rho o v$, um uso mais amplo, remetendo a "coisas bem como criaturas sobrenaturais, perturbadoras, especialmente portentos divinos e híbridos, como a monstruosa prole de Terra". ${ }^{41}$ Conquanto essa distinção não encontre respaldo nos poemas homéricos e hesiódicos, como será visto adiante, é possível que Lowe esteja considerando o uso desses termos em poemas épicos posteriores, como o Argonáutica, de Apolônio de Rodes, escrito no século III a.C., ou mesmo poemas tardios, como o Pós-homérica, de Quinto de Esmirna, do século IV d.C., ou, ainda, o Dionisíaca, de Nono, do início do século V d.C.

A despeito de LSJ e Cunliffe disponibilizarem entradas individuais para $\pi \varepsilon ́ \lambda \omega \rho$ e $\pi \varepsilon ́ \lambda \omega \rho$ ov, eles são considerados sinônimos por ambas as obras de referência, com o sinal de igual no verbete $\pi \varepsilon \dot{\lambda} \omega \rho \circ v$, marcando a sinonímia entre os termos. Essa sinonímia está também

39 As ocorrências estão listadas em tabelas no Apêndice D. Para os excertos, consulte-se o Apêndice E.

40 As formas trissilábicas em geral, que compreendem o nominativo/acusativo temático $\pi \varepsilon ́ \lambda \omega \rho o v$ junto com as formas declinadas, são preferidas para compor final de verso (10 de 14 ocorrências). A forma dissilábica

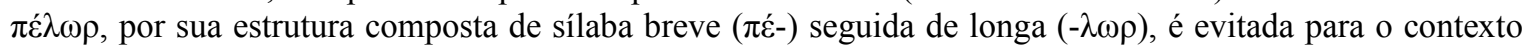
métrico de final de verso, que exige uma sílaba inicial longa no último dáctilo.

41 Lowe (2015, p. 8-9): “[...] living beings of frightening appearance [...]”; “[...] unsettling, supernatural things as well as creatures, especially divine portents and hybrids, such as the monstrous offspring of Earth. [...]”. 
marcada na própria estrutura do verbete $\pi \dot{\varepsilon} \lambda \omega \rho o v$, que se centra mais nas ocorrências do que no sentido, já exposto no verbete $\pi \varepsilon ́ \lambda \omega \rho$. Em algumas delas, contudo, não é possível distinguir se a variante usada é a temática $\pi \varepsilon ́ \lambda \omega \rho \circ v$ ou a atemática $\pi \varepsilon ́ \lambda \omega \rho$, pois elas apresentam a mesma forma quando declinadas nos casos que não são o nominativo/acusativo singular. Isso torna ainda mais questionável a tentativa de traçar uma distinção de significado entre elas, pois não há como saber qual das variantes está sendo usada na forma do genitivo ( $\pi \varepsilon \lambda \omega ́ \rho o v)$ ou do nominativo/acusativo plural ( $\pi \dot{\varepsilon} \lambda \omega \rho \alpha)$, por exemplo.

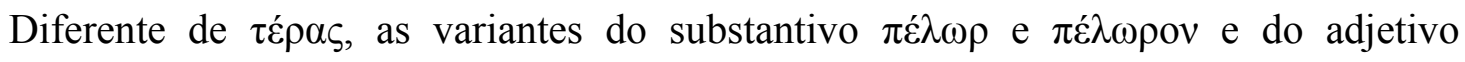
$\pi \varepsilon ́ \lambda \omega \rho \circ \varsigma$ e $\pi \varepsilon \lambda \omega ́ \rho ı \varsigma \varsigma$ são ditas "épicas" por serem usadas quase exclusivamente na poesia hexamétrica arcaica. ${ }^{42}$ Embora elas tenham sido usadas por autores posteriores - como Apolônio de Rodes em seu Argonáutica (cf. Argonáutica 1.996, 2.39, 4.143 e 4.1440) ou Teócrito, que utilizou o substantivo épico em sua poesia bucólica (Idílios, 24.13 e 24.59) no mesmo século de Apolônio, ou, ainda, Calímaco, em seu Hino a Diana (v. 51 e v. 84) -, elas não apresentam um uso contínuo em textos que não sejam de poesia. Sabe-se, entretanto, que, à época de Aristóteles (séc. IV a.C.), esses termos deviam ser arcaísmos, pois ele menciona na

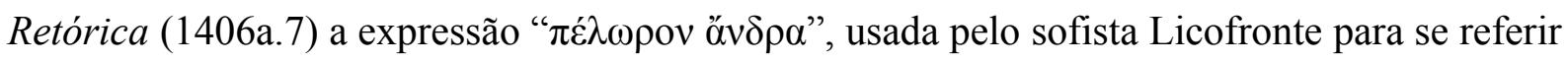
a Xerxes, como exemplo de expressão arcaica que torna um discurso ineficaz.

Enquanto o LSJ apresenta "portent", "prodigy" e "monster" como sinônimos para as variantes do substantivo $\pi \varepsilon ́ \lambda \omega \rho$ e $\pi \varepsilon ́ \lambda \omega \rho o v$, apontando para um uso "sempre" referente a seres vivos e, na maioria das vezes, com um sentido pejorativo, Cunliffe apresenta uma definição mais neutra dessas variantes, indicando que remetem a "um ser de tamanho ou força incomum" ou, ainda, com um "aspecto particularmente intimidante ou portentoso". Por sua vez, o verbete $\pi \dot{\varepsilon} \lambda \omega \rho$ do $\operatorname{Lgr} E$, que, como o léxico de Cunliffe, é circunscrito à poesia épica arcaica, indica "Monstrum" e "Ungeheur" (ambos significam "monstro" em alemão). Apesar da maior cautela por parte de Cunliffe, o mais comum é encontrar "monstro" como proposta de tradução para as variantes do substantivo $\pi \varepsilon \dot{\lambda} \omega \rho$ e $\pi \dot{\lambda} \lambda \omega \rho \circ$, principalmente se o referente delas é um ser considerado monstruoso a priori.

Quanto às variantes do adjetivo, LSJ oferece "monstrous", "prodigous", formas adjetivas dos substantivos que ofereceu como sinônimos para as variantes $\pi \varepsilon \dot{\lambda} \lambda \omega \rho / \pi \varepsilon \dot{\varepsilon} \lambda \omega \rho \circ$, adicionando "huge" e o sentido colateral de "terrible". A sinonímia entre as duas variantes do

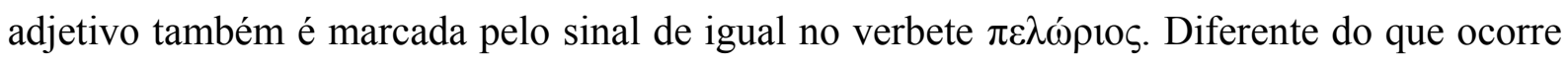
com o substantivo, entretanto, os adjetivos encontram referentes considerados monstruosos com menos frequência, sendo traduzidos geralmente por algum termo que expresse

42 Veja-se, contudo, o fragmento de ditirambo 70db verso 8 de Píndaro (Snell-Maehler, 1975, p. 79). 
enormidade. Todavia, nem as variantes do adjetivo nem as do substantivo deixam de obedecer ao critério da monstruosidade estabelecida a priori.

Para a análise, decidiu-se separar as ocorrências das variantes por poema, como na análise de $\tau \varepsilon ́ p a \varsigma$, começando-se com os épicos homéricos, seguidos dos hinos homéricos e, por fim, os poemas atribuídos a Hesíodo.

\section{3.a) Ilíada}

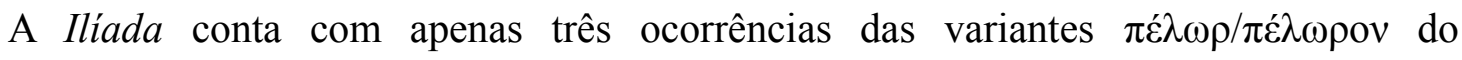

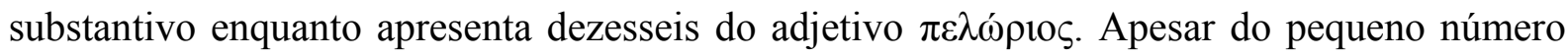
de vezes em que elas aparecem, as variantes do substantivo encontram referentes bastante diversos em cada uma delas. No canto 2 (v. 321-322), no contexto do vaticínio de Calcas, narrado por Odisseu, já apresentado acima, $\delta \varepsilon ı v \alpha ̀ ~ \pi \varepsilon ́ \lambda \omega \rho \alpha \theta \varepsilon \tilde{\omega} \nu$ ("assombrosos prodígios dos deuses") é usado para remeter às manifestações de Zeus que interrompem o sacrifício

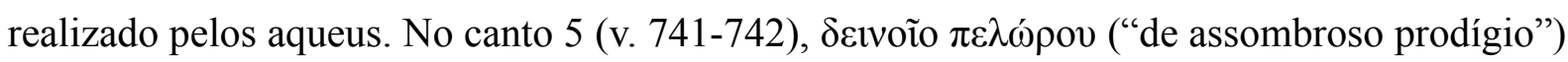
é usado para caracterizar a cabeça da Górgona no escudo da deusa Palas Atena, uma passagem

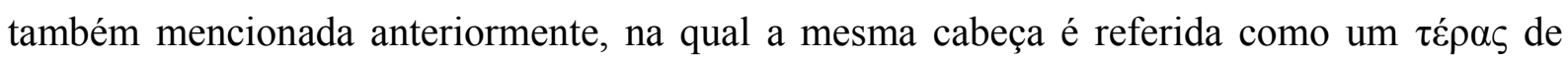
Zeus portador do escudo. ${ }^{43}$ Nesses dois contextos, é possível perceber a proximidade

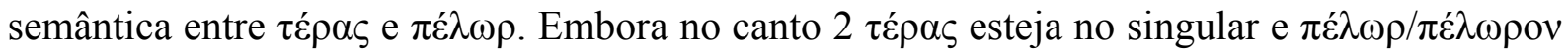

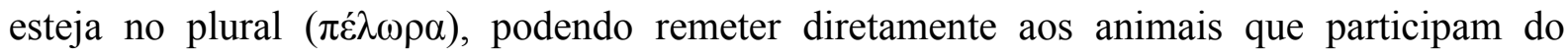
presságio, ambos fazem remissão ao sinal ou sinais enviados por Zeus.

A última ocorrência, no canto 18 (v. 410), tem como referente o deus Hefesto, o que

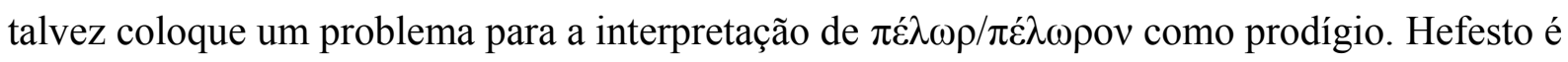
chamado $\pi \varepsilon ́ \lambda \omega \rho$ na ocasião em que a deusa Tétis vai pedir a ele que confeccione novas armas para seu filho, Aquiles. Ao ver Tétis, Hefesto profere um discurso (18.394-409) relembrando quando foi salvo por ela e por Eurínome, filha de Oceano, depois de ser arremessado do Olimpo por sua mãe, Hera. Além de louvar a atitude de Tétis em seu discurso, Hefesto manifesta o desejo de poder lhe retribuir o feito. Sentado diante de sua bigorna, o deus se levanta para recebê-la adequadamente e é nesse momento que o narrador o descreve como

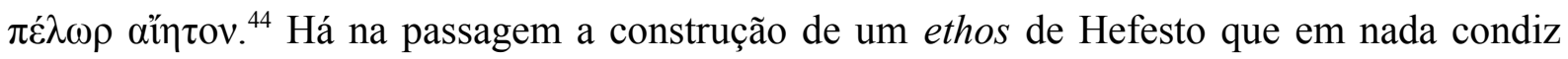

43 Cf. a reprodução da passagem do canto 2 e do canto 5 nas notas 13 e 19, respectivamente, ou no Apêndice C ou, ainda, no ApêndiceApêndice $\mathrm{E}$.

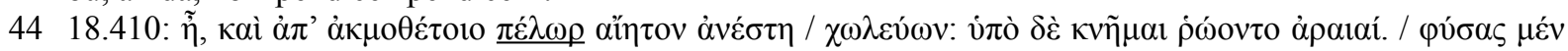

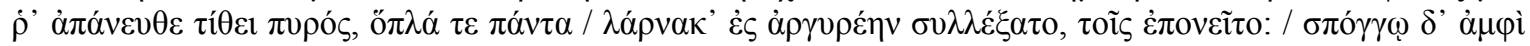

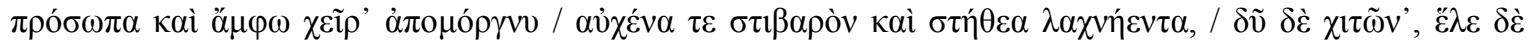

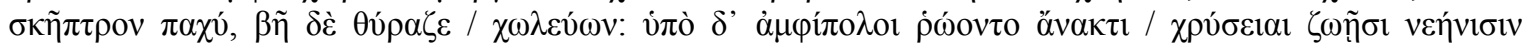


com o sentido moderno de "monstro". O que ocorre, na verdade, é uma contraposição, nos versos 18.410-411, estabelecida entre a parte superior do corpo de Hefesto (18.410), que é forte e enorme, e a fragilidade dos seus membros inferiores, em consequência de o deus ser coxo, característica cuja causa acabou de ser aludida no discurso de boas-vindas a Tétis (18.394-409). Os versos seguintes dão continuidade a uma caracterização de Hefesto que mantém esse contraste: enquanto seu pescoço é “ $\sigma \tau \imath \beta \alpha \rho o ́ \varsigma$ " ("forte”), ele precisa se apoiar em um "cetro robusto" ( $\sigma \kappa \tilde{\eta} \pi \tau \rho o v ~ \pi \alpha \chi v ́, 18.416)$ e ser ajudado por donzelas esculpidas em ouro

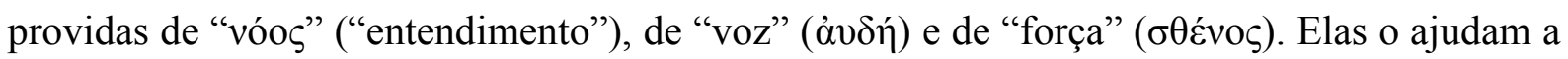
seguir "lentamente" (cf. ع̌ $\rho \rho \omega v, 18.421$ ) até o assento próximo a Tétis, a quem ele acaricia e trata pelo nome. Portanto, a caracterização do deus nada evoca de monstruoso, ao contrário: a força da parte superior de seu corpo contrasta com a fragilidade da parte inferior tanto quanto a sua gratidão para com Tétis contrasta com o tratamento que recebeu de sua mãe. ${ }^{45}$

No caso dos épicos homéricos, contudo, pode-se contar com uma importante ferramenta para a compreensão de determinados termos. Os escólios e as glosas feitos pelos editores e comentaristas antigos são preciosos para a compreensão de termos mais obscuros ou mal compreendidos (embora não se deva transformá-los em veredito sobre qualquer sentido que possam oferecer.) Os Scholia Minora (ou Scholia Didymi, assinalados = D), considerados mais antigos e que em geral são mais simples, porque se limitam a oferecer sinônimos ou explicar o sentido de alguma palavra, são praticamente categóricos quanto ao

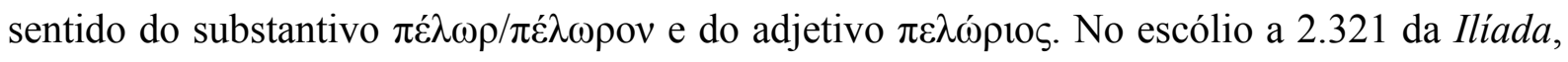

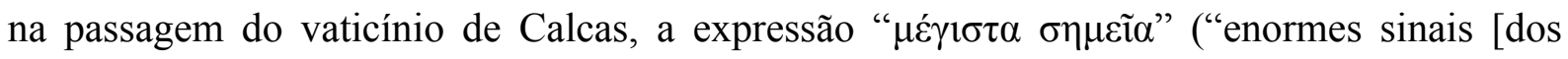
deuses]") é apresentada como sinônimo do substantivo no neutro plural $\pi \varepsilon ́ \lambda \omega \rho \alpha$ e, de modo semelhante, no escólio a 5.741, em que o genitivo $\pi \varepsilon \lambda \omega ́$ pov remete à cabeça da Górgona, o

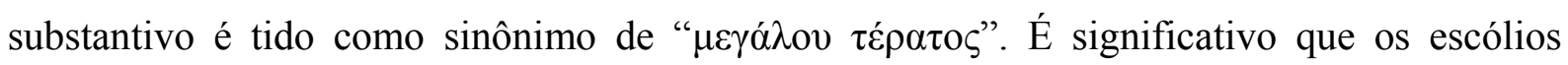

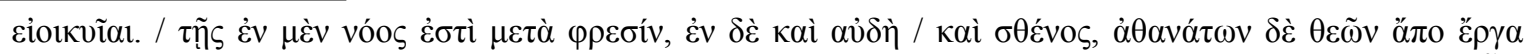

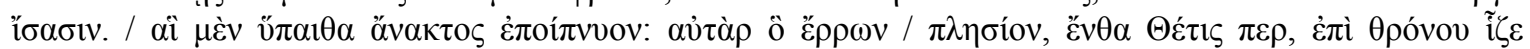

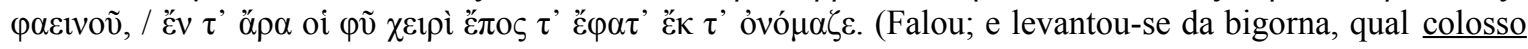
ofegante, / coxeando; mas as pernas por baixo dele eram ágeis / Colocou os foles longe do fogo e toso os instrumentos / reuniu numa arca de prata, todos de que se servira. / Com uma esponja limpou a cara e os dois braços, / assim como o pescoço possante e o peito hirsuto; / depois vestiu uma túnica e agarrou num cetro robusto; / saiu porta fora a coxear. Para dar apoio ao soberano correram / duas servas douradas, semelhantes a moças vivas. / Nelas há entendimento no espírito; são dotadas de voz / e de força e conhecem os trabalhos dos deuses imortais. / Foram estas que se apressaram a apoiar o amo, que foi a / coxear até onde estava Tétis e sentou-se num trono luzente. / Acariciando-a com a mão assim lhe disse, tratando-a pelo nome.). O sentido

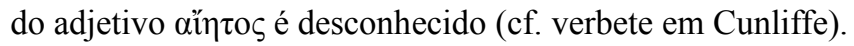

$45 \mathrm{O}$ caso de Hefesto na Ilíada é, sem dúvida, o mais emblemático do desacordo entre a nossa noção de "monstro" e o que está sendo expresso por $\pi \varepsilon ́ \lambda \omega \rho$. Hefesto certamente não é um monstro na nossa concepção do termo, e sim uma vítima: ele é lançado ainda bebê ao Hades por sua própria mãe, em razão do que se torna coxo; é salvo pela deusa Tétis e Eurínome, e em gratidão confecciona as armas de Aquiles; é motivo de riso quando aparece mancando no Olimpo (certamente, uma vítima de bullying); e, depois de tudo isso, é ainda traído por sua esposa Afrodite. 


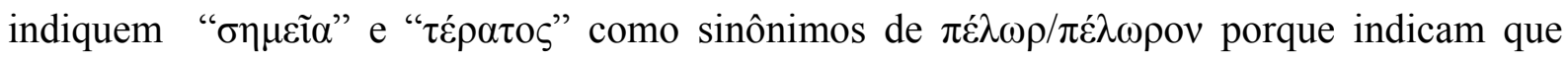
esses termos compartilham ao menos uma parte de seus respectivos campos semânticos. Note-

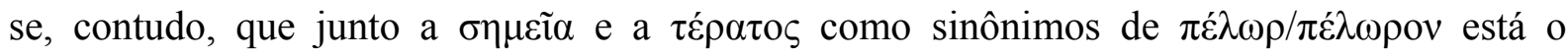

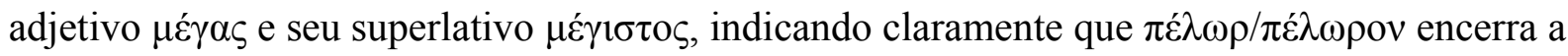
noção de enormidade juntamente com o sentido de "sinal" e de "portento".

Outros escólios que não são os Scholia Minora, mas que também fazem parte dos Scholia Vetera, fornecem acepções igualmente iluminadoras, embora não sejam tão antigos quanto os Minora possam ser. Em relação a Hefesto, um deles (18.410b) menciona que se diz

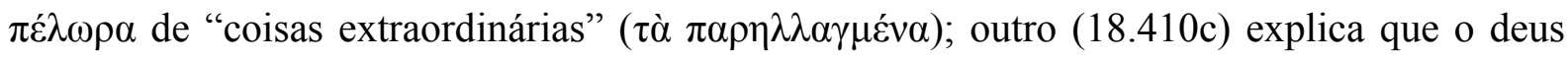

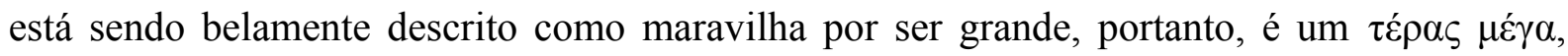
estabelecendo que $\pi \varepsilon \dot{\varepsilon} \omega \rho$ é relativo ao "tamanho" ( $\mu \varepsilon \gamma \varepsilon \dot{\varepsilon} \theta 0 v \varsigma) .{ }^{46}$

Nesse uso de $\pi \dot{\lambda} \lambda \omega \rho / \pi \varepsilon ́ \lambda \omega \rho o v$ é possível perceber claramente que seu campo

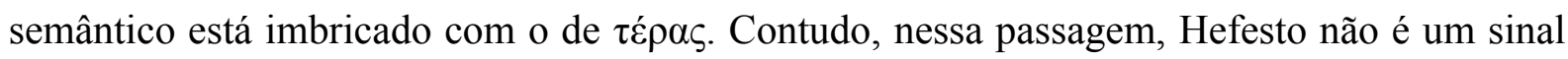
ou portento enviado como mensagem pelos deuses, embora se constitua em algo extraordinário. Pizzani (2000, p. 533) não poderia estar mais equivocado ao apresentar como solução o fato de que todos os referentes de $\pi \varepsilon \dot{\lambda} \omega \rho / \pi \varepsilon ́ \lambda \omega \rho o v$ são monstros "tout court", inclusive o "zoppicante e goffo" ("coxo e deselegante") deus Hefesto. ${ }^{47}$ Todavia, Pizzani não é o único a incluir o deus Hefesto na categoria “monstro": Lowe (2015, p. 9) também o faz.

Esse sentido de enormidade extraordinária está presente em todas as ocorrências do adjetivo $\pi \varepsilon \lambda \omega ́ p ı$ na Ilíada, seja ao qualificar heróis, deuses ou armas. ${ }^{48}$ Príamo se refere a Agamêmnon ao inquirir Helena sobre quem seria aquele ő $v \delta \rho \alpha \pi \varepsilon \lambda \omega ́ \rho ı v v ~(3.166)$, utilizando a expressão que Aristóteles condena como arcaísmo, e o caracteriza no verso seguinte (3.167) como "tão forte" e "tão grande". Helena (3.229) e o narrador (7.211) utilizam a expressão

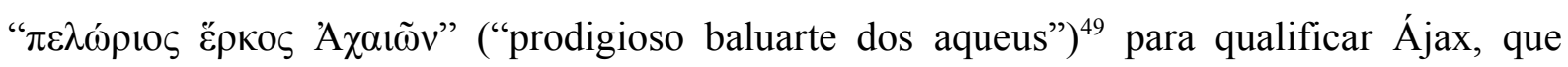

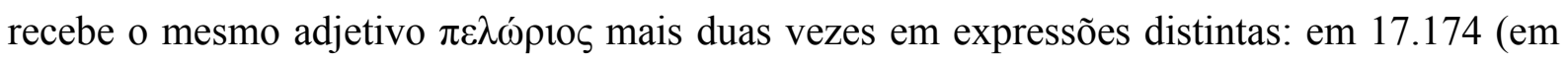
fala de Heitor) e em 17.360 (pelo narrador). ${ }^{50}$ Outros heróis incluem Perifante (5.842 e 5.847),

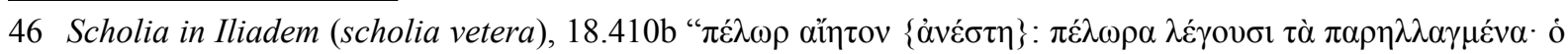

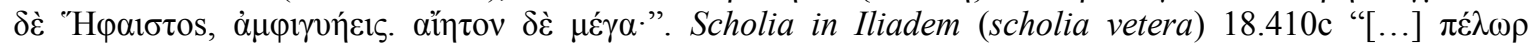

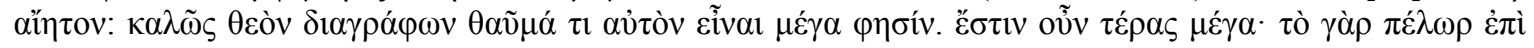
$\mu \varepsilon \gamma \varepsilon \dot{\theta} \theta 0 \varsigma^{\prime} \tau \alpha ́ \sigma \sigma \varepsilon \tau \alpha 1 .[\ldots] "$.

47 Veja-se, contudo, a tradução para o português de Lourenço (2013a). Talvez vexado de traduzir o termo por "monstro" nessa ocasião em que remete ao deus Hefesto, ele o verte por "colosso", solução que contempla o sentido de "algo enorme" sem necessariamente impingir um tom pejorativo.

48 Cf. as ocorrências na tabela D.2 no ApêndiceApêndice D e a reprodução das passagens no ApêndiceApêndice E.

49 Lourenço (2013a) traduz por "enorme baluarte dos aqueus".

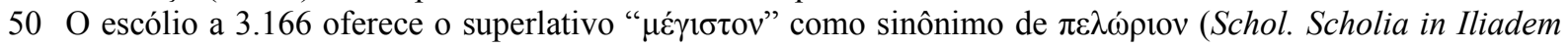
(scholia vetera) (= D scholia), 3.166 linha 1); e o escólio a 3.229 fornece o adjetivo no grau zero " $\mu \varepsilon ́ \gamma \alpha \varsigma$ " (Schol. Scholia in Iliadem (scholia vetera) (= D scholia), 3.229 linha 1). 
Heitor (11.820) e Aquiles (21.527 e 22.92). Além do deus Hefesto, Hades (5.395) e Ares

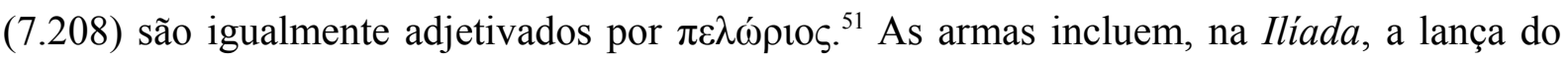
deus Ares (5.594) e a de Atena (8.424), as armas de ouro de Reso (10.439) e as armas de Aquiles (Il. 18.83). Para esses dois conjuntos de armamento, o de Reso vestido por Diomedes e o de Aquiles vestido por Pátroclo, o narrador usa a expressão “ $\pi \varepsilon \lambda \omega \dot{\rho} \alpha \theta \alpha \alpha \tilde{v} \mu \alpha$ i $\delta \varepsilon \dot{\varepsilon} \sigma \alpha \iota$ ” (“prodigiosas maravilhas de se ver”). O escólio a 10.439, relativo às armas do rei Reso,

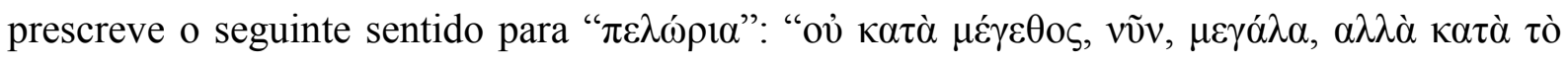
$\kappa \alpha ́ \lambda \lambda o \varsigma$ ", "não relativo à grandeza, portanto, enormes, mas relativo à beleza". Outro escólio,

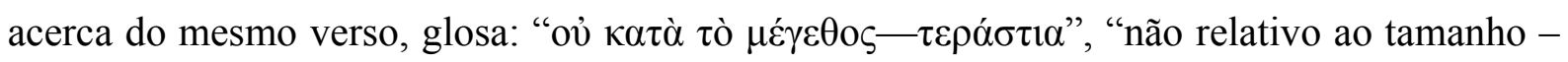
portentosas". ${ }^{52}$ Tanto o uso de $\theta \alpha \tilde{v} \mu \alpha$ i $\delta \varepsilon ́ \sigma \theta \alpha \iota$ junto com $\pi \varepsilon \lambda \omega ́ \rho ı$ quanto a anotação do

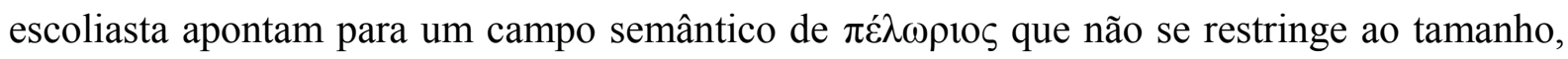
contrariamente ao que afirma Pizzani (2000). A expressão homérica relaciona o adjetivo não apenas ao âmbito do extraordinário, mas igualmente à esfera daquilo que é maravilhoso.

Vejamos que para a Odisseia as conclusões não são diferentes.

\section{3.b) Odisseia}

Na Odisseia, o número de ocorrências do substantivo e do adjetivo é mais equilibrado do que na Ilíada: sete ocorrências do substantivo e cinco do adjetivo. O ciclope Polifemo aparece como referente em quatro das doze ocorrências totais: duas do substantivo (9.257 e 9.428) e duas do adjetivo (9.187 e 9.190), bastante próximas entre si e todas no canto 9, no qual é narrado o episódio em que é antagonista de Odisseu. Outros dois seres amiúde

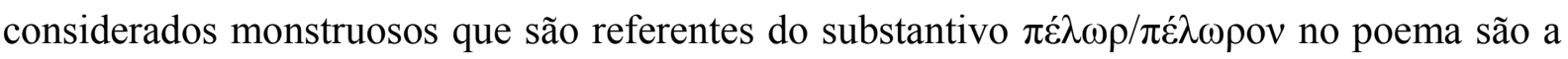
Górgona (11.634, mais precisamente, sua cabeça) e a Cila (12.87). Essas ocorrências (para Polifemo, Górgona e Cila) somam a metade do total encontrado no poema. A outra metade tem como referentes do substantivo o cervo do qual Odisseu e seus companheiros se alimentam na ilha de Circe (10.168) bem como os outros animais encontrados lá (10.219), que na verdade são homens transformados por Circe, além do presságio no canto 15 no qual uma águia voa com uma gansa nas garras (15.161). Qualificados pelo adjetivo estão as ondas do mar infladas pelo forte vento enviado por Zeus (3.290), o deus Órion (11.572) e a enorme pedra carregada por Sísifo (11.594). ${ }^{53}$

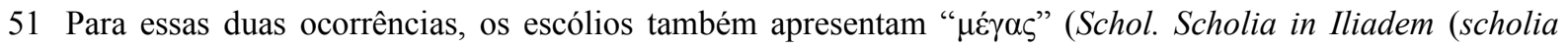
vetera) (= D scholia), 5.395 linha 2 e 7.208 linha 1).

52 Scholia in Iliadem (Scholia Recentiora Theodori Meliteniotis) (e cod. Genevensi gr. 44), 10.439 linha 1.

53 Todas as ocorrências estão listadas nas tabelas do ApêndiceApêndice D e nos excertos reproduzidos no 
É bastante digno de nota que quase todas as ocorrências se concentram entre os cantos 9 e 12, que compõem os denominados apologoi, ou narrativas de Odisseu a Alcínoo, rei dos feácios, podendo haver uma forte focalização no uso desses termos por parte de Odisseu. ${ }^{54} \mathrm{As}$ duas exceções são: a que está no canto 3 (v. 290), em enunciação de Nestor, e a que está no canto 15 (v. 161), proferida pelo narrador principal.

A única ocorrência que não está em enunciação de personagem, a do canto 15 (v. 161), é da variante $\pi \varepsilon ́ \lambda \omega \rho o v$ do substantivo e está sendo usada em um contexto que é explicitamente

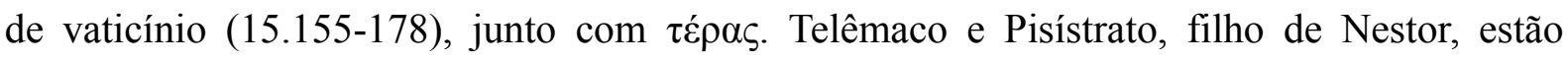
prontos para partir de Esparta após sua estadia na casa de Menelau e Helena. Ao despedir-se, Telêmaco expressa o desejo de que, quando chegar em casa na ilha de Ítaca, possa encontrar o pai, Odisseu, e lhe falar dos presentes e da amizade que recebeu de Menelau. Nesse momento, uma águia voa em sua direção, à direita, com uma gansa nas garras. Pisístrato pede, então, a Menelau que analise o presságio, referindo-se a este com a palavra $\tau \dot{\varepsilon} \rho \alpha \varsigma$. Helena se adianta e declara que, como a águia que veio da montanha e agarrou uma gansa doméstica, Odisseu, depois de sofrer muitos males e de muito vagar, retornará à casa e se vingará dos pretendentes, ou é possível que o herói já esteja em casa tramando contra eles. Novamente, como no canto 2 da Ilíada, $\pi \varepsilon ́ \lambda \omega \rho / \pi \varepsilon ́ \lambda \omega \rho o v$ e $\tau \varepsilon ́ p \alpha \varsigma$ ocorrem no mesmo contexto de vaticínio, designando um presságio. Aqui, contudo, $\pi \varepsilon \dot{\varepsilon} \lambda \omega \rho o v$ não está no plural: o fato de estar no singular e em posição apositiva sugere que $\pi \varepsilon \dot{\varepsilon} \lambda \omega \rho / \pi \varepsilon ́ \lambda \omega \rho o v$ remete ao fenômeno do prodígio como um todo e não aos animais que o constituem.

No canto 3, Nestor, dirigindo-se a Telêmaco e à deusa Atena disfarçada de Mentor, ao narrar sobre o retorno dos aqueus após o fim da guerra de Troia, conta como um vento forte enviado por Zeus inflou as ondas do mar e separou a frota. Nessa passagem, $\pi \varepsilon \lambda \omega ́ \rho ı ~(3.290)$ é usado por Nestor para adjetivar essas ondas. Um escólio a esse verso oferece o sentido de

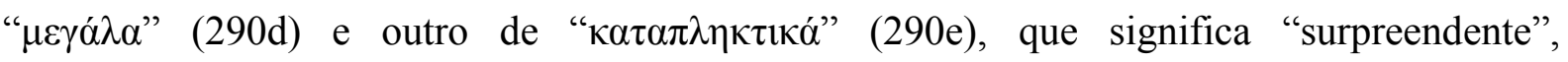
"espantoso". 55

No canto 9, todas as quatro ocorrências remetem a Polifemo. Ao descrever para os

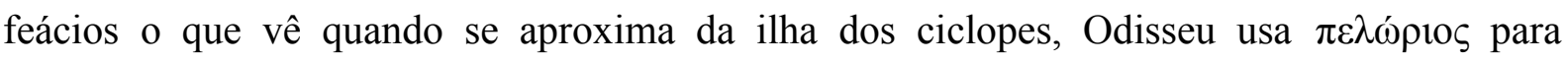

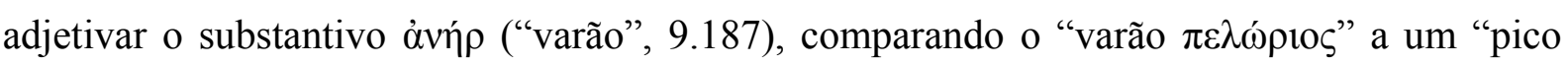

ApêndiceApêndice E.

54 "Focalização" é um termo comumente empregado pelos estudos de narratologia (cf. De Jong, 1992 e 2004 [2001]), servindo para marcar uma distinção entre o que é narrado pelo narrador principal e o que é dito (“enunciação de personagem") ou narrado (narrador secundário) pelos personagens. Essa diferença de focalização geralmente implica em maior subjetividade expressa nas enunciações de personagens em geral ou por parte dos narradores secundários.

55 Scholia in Odysseam (libri $\gamma-\delta$ ) Book 3 hypothesis-verse 290d line 1 (290d) $\pi \varepsilon \lambda \omega ́ \rho 1 \alpha: ~ \mu \varepsilon \gamma \alpha ́ \lambda \alpha$; (290e)

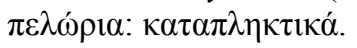




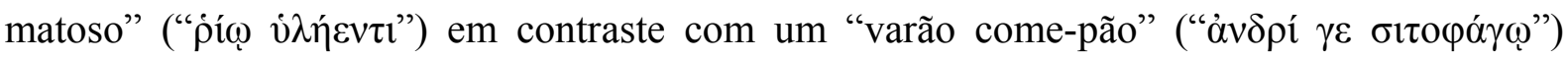
(9.190-192). Tal comparação não indica que Polifemo seja um monstro ou uma montanha, mas que ele se distingue de "varões" em sua enormidade física, sendo esta característica que o torna motivo de assombro a Odisseu e a seus companheiros, sentimento a que são acometidos novamente quando o ciclope lhes dirige a palavra em 9.256-257. Note-se que em 9.190, o adjetivo $\pi \varepsilon \lambda \omega ́ p ı s \varsigma$ qualifica $\theta \alpha \tilde{u} \mu \alpha$ ("maravilha", "assombro") em remissão ao ciclope (9.190). Além de ter seu campo semântico novamente relacionado à maravilha, $\pi \varepsilon ́ \lambda \omega \rho$ e $\pi \varepsilon ́ \lambda \omega \rho$ ov são ambos usados por Odisseu em relação ao ciclope (cf. 9.257 e 9.428), o que advoga em favor de serem variantes do mesmo substantivo e não dois substantivos distintos.

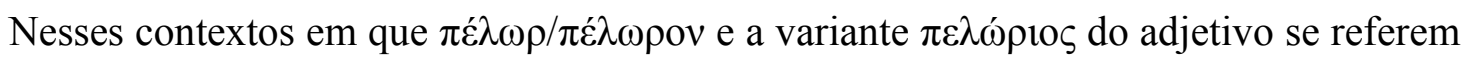
a Polifemo, eles estão claramente relacionados à enormidade do ciclope e ao espanto que ela causa. Outro ser também denominado $\pi \varepsilon ́ \lambda \omega \rho / \pi \varepsilon ́ \lambda \omega \rho o v$ que causa espanto por sua enormidade fora do comum é o cervo abatido por Odisseu, na ilha de Circe, do qual ele e seus

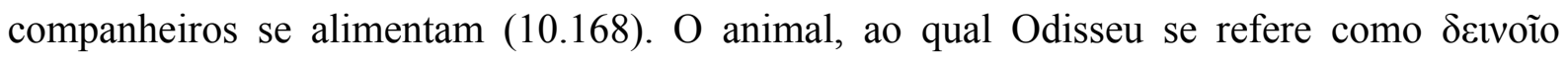
$\pi \varepsilon \lambda \omega ́ p o v$ (“do assombroso prodígio”), era grande $(10.158,171$ e 180) a ponto de o herói declarar que era impossível carregá-lo com apenas um braço.

No canto 10 , o substantivo $\pi \varepsilon ́ \lambda \omega \rho / \pi \varepsilon ́ \lambda \omega \rho o v$ é usado também para os outros animais encantados de Circe. Odisseu declara que os companheiros sentiram medo ao ver os "terríveis

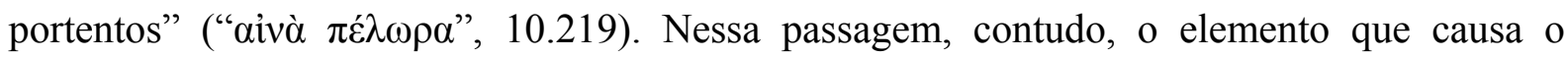
assombro parece ser o fato de lobos e leões, animais tipicamente selvagens, comportarem-se como animais domésticos, abanando docilmente a cauda. Eles são designados $\pi \varepsilon ́ \lambda \omega \rho \alpha$ porque são espantosos, talvez não por sua dimensão física, da qual o poema nada declara, e sim pelo comportamento fora do comum, ou seja, daquilo que é esperado de animais selvagens e geralmente ferozes, como leões e lobos.

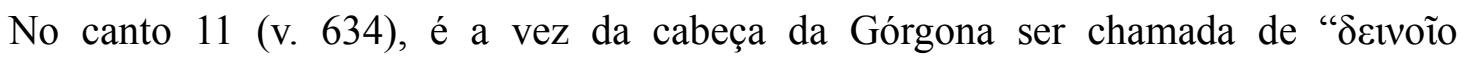
$\pi \varepsilon \lambda \omega ́ \rho o v "$, exatamente como o cervo em 10.168. Ainda na narrativa do herói aos feácios, Odisseu relata sua viagem ao Hades. Ao final do canto, com medo de que estivesse se demorando por lá, quando grupos de mortos começaram a se ajuntar em torno dele, Odisseu diz que foi tomado por um "medo amarelo" de que Perséfone enviasse a cabeça da Górgona,

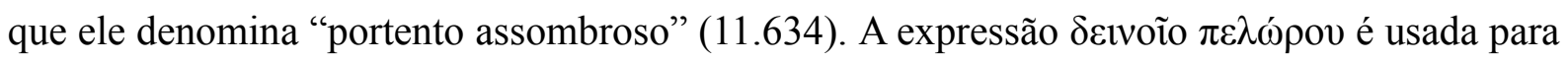
caracterizar a cabeça da Górgona tanto na passagem que descreve o escudo de Palas Atena na Ilíada (5.741) como também no Escudo de Héracles (v. 223). Se na Ilíada, como visto, a cabeça da Górgona é dita um portento de Zeus em seu aspecto de portador do escudo, nessa passagem da Odisseia a cabeça é um instrumento da deusa Perséfone que pode ser enviado 
para afugentar Odisseu. Por ser amedrontadora, a cabeça da Górgona tem a função de repelir aquilo que é indesejável, seja um visitante um tanto inoportuno como Odisseu em sua passagem pelo Hades, seja um inimigo no campo de batalha. ${ }^{56}$ Ela é um elemento que assume recorrentemente uma função apotropaica, representada em frontão de templos e em outros elementos arquitetônicos, como acrotérios e antefixas. ${ }^{57}$

Outro ser aterrorizador chamado $\pi \varepsilon ́ \lambda \omega \rho$ é Cila. No canto 12 , Odisseu reproduz a fala de Circe, que o aconselha acerca dos perigos que enfrentará depois de partir de sua ilha (12.36-110 e 116-141). Um desses perigos é Cila, criatura de doze pés e seis cabeças cheias de dentes que vive em uma gruta e que, ao fim, arrebata seis dos companheiros de Odisseu. Cila

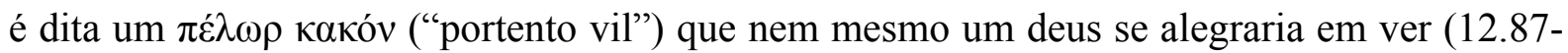
$88) .58$

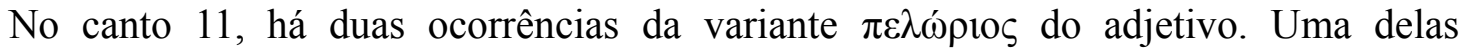
qualifica Órion (11.572), que Odisseu observa ajuntando "feras" (“ $\theta \tilde{\eta} \rho \alpha \varsigma$ ") que o próprio deus matou, e a outra qualifica a pedra carregada por Sísifo (11.594), que Odisseu diz observar em

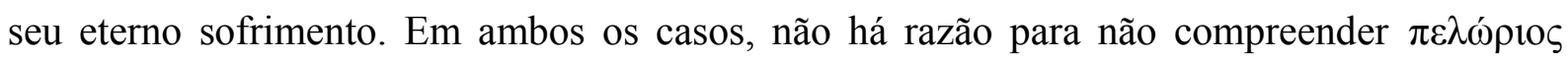
como expressão de enormidade e/ou de extraordinariedade. Como será visto a seguir, nos demais poemas analisados esses sentidos se mantêm.

\section{3.c) Hino Homérico a Apolo e Hino Homérico a Hermes}

No h.Ap, há apenas três ocorrências que se limitam às variantes do substantivo (v. 374, 401 e 416), e no h.Merc., duas ocorrências também do substantivo (v. 225 e 349) e uma do adjetivo (v. 342). A todas elas é possível atribuir um sentido de enormidade, bem como de prodígio e portento enquanto algo extraordinário.

No h.Ap., tanto a serpente morta pelo deus Apolo, como o próprio deus Apolo transformado em golfinho são referidos por $\pi \varepsilon \dot{\varepsilon} \lambda \omega \rho / \pi \varepsilon ́ \lambda \omega \rho o v$. No caso do h.Merc., as duas ocorrências do substantivo bem como a do adjetivo remetem às pegadas deixadas pelo deus

56 Cf. Vernant (1988), que examina a figura da Górgona enquanto uma máscara que exprime uma monstruosidade oscilante "entre dois polos: o horror do que é terrificante, o risível do grotesco" (p. 40). Em relação ao "risível do grotesco", Vernant considera que a máscara da Górgona, de um lado, e os Silenos ou Sátiros, de outro, apresentam "afinidades manifestas com a representação crua, brutal, do sexo, feminino ou masculino - representação que, da mesma forma que a face monstruosa à qual sob certos aspectos equivale, pode provocar igualmente o pavor de uma angústia sagrada e a gargalhada libertadora.". No caso dos poemas épicos, acredito que a figuração da Górgona esteja mais para o lado do pavor do que para o riso.

57 Cf., por exemplo, o verbete "Gorgo, Gorgones" no LIMC (vol. IV, t. 1, p. 285-330), de autoria de Ingrid Krasukopf (fontes arqueológicas) e Stephan-Christian Dahlinger (fontes literárias). Para as Górgonas na Etrúria, cf. "Gorgones in Etruria", p. 330-345, de autoria de Ingrid Krasukopf, e para as Górgonas romanas, cf. "Gorgones Romanae”, p. 345-362, de autoria de Orazio Paoletti.

58 Polifemo e Cila são analisados mais extensamente no capítulo 5. 
Hermes com o intuito de enganar Apolo. Na primeira ocorrência no h.Merc. (v. 225), o deus

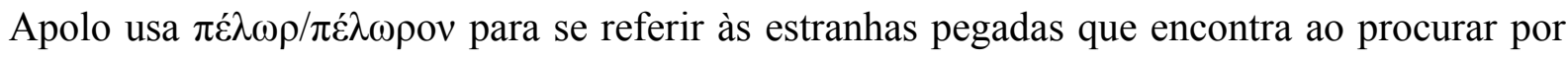
seu gado roubado: elas são tão estranhas que não se parecem nem mesmo, segundo o deus, com as que deixa um centauro. Adiante no poema (v. 349), em seu diálogo com Zeus, Apolo descreve as pegadas como se tivessem sido deixadas por alguém calçando ramos de carvalho,

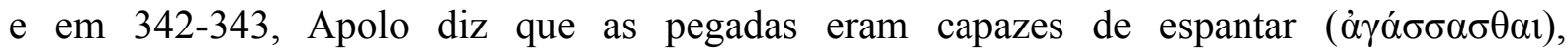

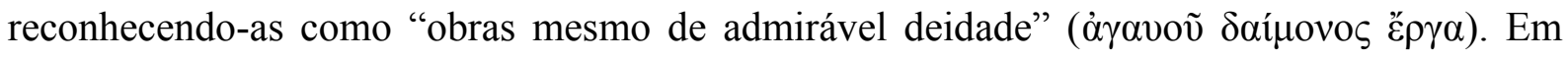

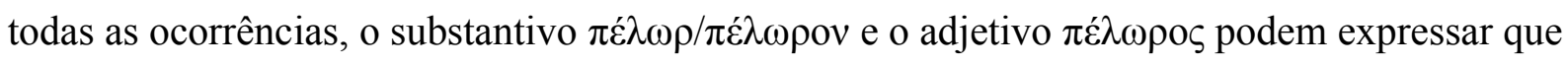
as pegadas são de um tamanho avantajado, todavia, o espanto de Apolo parece residir mais no formato e na natureza estranha das pegadas do que no tamanho em si.

No h.Ap., a serpente é caracterizada de modo bastante negativo: ela causa muitos males aos seres humanos e a seus rebanhos (v. 302-304); é chamada "desgraça sanguínea"

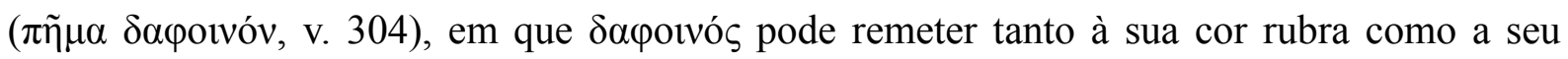
caráter sanguinário; ela não é apenas um mal em si, mas foi responsável por nutrir outro mal, Tifeu, filho de Hera no h.Ap., que ela concebeu por estar agastada com Zeus em razão de ele ter gerado sozinho Palas Atena (v. 354); quem deparasse com a serpente encontraria morte

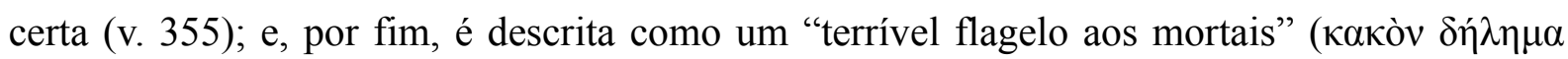

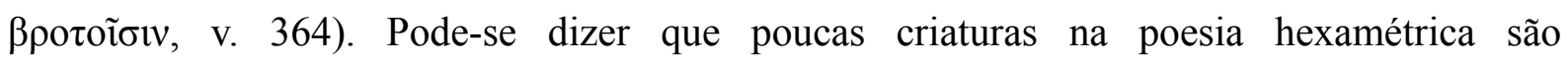
caracterizadas de modo tão negativo. Contudo, o golfinho no qual Apolo se transforma, também é descrito como $\pi \varepsilon ́ \lambda \omega \rho \mu \varepsilon ́ \gamma \alpha \tau \varepsilon \delta \varepsilon ı v o ́ v \tau \varepsilon$ ("prodígio grande e terrível”). Sua presença dentro do barco cretense, além de chacoalhá-lo para todos os lados, faz com que a tripulação se assuste e fique emudecida. O espanto é tal, que eles queriam desembarcar e ficar observando o "grande espanto" ou "grande maravilha" ( $\mu \varepsilon \dot{\gamma} \alpha \theta \alpha \tilde{v} \mu \alpha)$ para ver se o "prodígio"

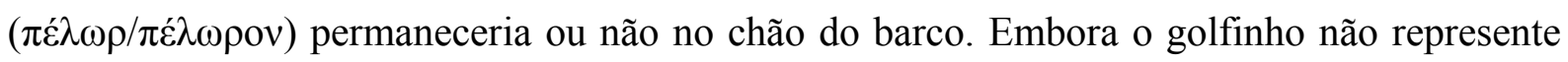
uma ameaça à vida humana para além do susto, ele causa tanto espanto quanto a fatal serpente, porque aqueles que o observam não sabem de antemão suas intenções. A serpente bem como o golfinho são $\pi \varepsilon ́ \lambda \omega \rho$ não porque sejam monstros, mas porque são extraordinários em relação às demais serpentes (cf. supra) e aos outros golfinhos, tanto no que diz respeito à sua grande dimensão, quanto às suas respectivas atitudes. Veja-se que a tripulação do barco no

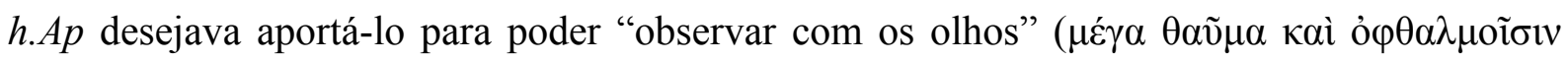

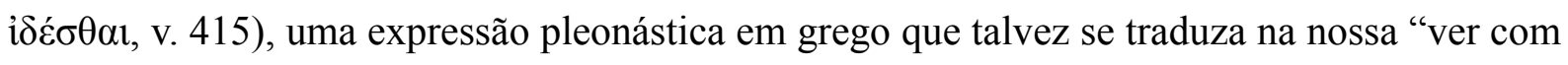
os próprios olhos", remetendo a algo tão extraordinário que mal se pode conceber estar diante de si E aqui $\pi \varepsilon ́ \lambda \omega \rho o v$ está novamente relacionado ao $\theta \alpha \tilde{u} \mu \alpha$ ("assombro", "maravilha"). Portanto, serpente e golfinho não são designados $\pi \dot{\lambda} \lambda \omega \rho / \pi \varepsilon ́ \lambda \omega \rho o v$ porque são "monstros", 
ainda que a serpente seja um mal aos mortais, e sim porque ambos se destacam por serem extraordinários, talvez até mesmo "incríveis".

\section{3.d) Teogonia, Escudo de Héracles e Catálogo das Mulheres}

Na Teogonia, as variantes do substantivo ocorrem três vezes (v. 295, 845 e 856) e as do adjetivo, dez vezes (v. 159, 173, 179, 299, 479, 505, 731, 821, 858, 861). No Escudo e no Catálogo, há apenas uma ocorrência do substantivo (Sc., v. 223) e uma do adjetivo (frag. 150, v. 11), respectivamente. ${ }^{59}$

Na Teogonia, o substantivo remete a Équidna (v. 295) e a Tifeu (v. 845 e 856), e no Escudo, à cabeça da Górgona, todos os três considerados "monstros" tout court segundo critérios modernos. Entretanto, o adjetivo biforme $\pi \varepsilon ́ \lambda \omega \rho \circ \varsigma$ serve quase exclusivamente como epíteto à divindade primordial Terra, na forma do feminino ( $\pi \varepsilon \lambda \omega ́ \rho \eta)$, usado oito vezes na Teogonia e uma vez no Catálogo. A única ocorrência do adjetivo em sua forma neutra

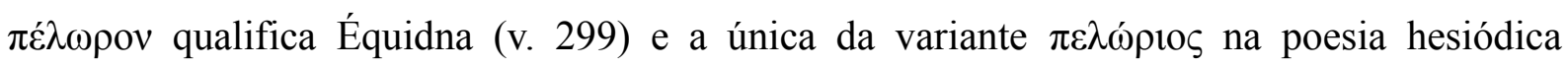
adjetiva a foice concebida por Terra e entregue por ela a seu filho Crono, com a qual ele castrará seu pai, Céu.

Enquanto o substantivo se concentra na remissão a seres que consideramos monstruosos, sendo difícil argumentar com base apenas nelas contra a acepção de $\pi \varepsilon ́ \lambda \omega \rho / \pi \varepsilon ́ \lambda \omega \rho$ ov como "monstro", o adjetivo $\pi \varepsilon ́ \lambda \omega \rho o v$, com um número muito maior de ocorrências do que o substantivo, tem seu uso quase exclusivamente como epíteto da deusa Terra e talvez seja possível encontrar aí um argumento forte em favor da interpretação tanto do adjetivo como do substantivo enquanto expressões de enormidade extraordinária.

Ainda que os tradutores, em geral, não hesitem em traduzir as ocorrências do substantivo por "monstro" (cf. supra), há uma predominante preferência por não se traduzir $\pi \varepsilon \lambda \omega ́ \rho \eta$ como epíteto de Terra por "monstruosa" e essa preferência é compreensível dado o estranhamento que esse adjetivo causa em referência à deusa. ${ }^{60}$ Observando-se outros adjetivos de Terra na Teogonia, percebe-se que eles indicam predominantemente sua solidez e

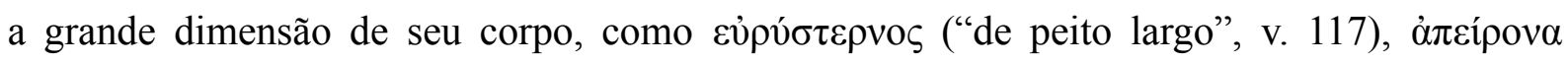
(“ilimitada", v. 187) e $\mu \varepsilon \gamma \alpha \dot{\lambda} \eta$ (“enorme”, v. 622), portanto, não seria descabido que $\pi \varepsilon \lambda \omega ́ \rho \eta$ também remetesse à sua característica de enormidade. ${ }^{61}$

59 Cf. Apêndice E.

60 Torrano prefere "prodigiosa" e Werner, "portentosa"; Evelyn-White varia entre "vast" e "huge", Most adota "huge", Mazon, "énorme" e Arrighetti, "prodigiosa".

61 Perceba-se ainda que a fórmula $\gamma \alpha \tilde{\alpha} \alpha \pi \varepsilon \lambda \omega ́ \rho \eta$, que só aparece nos poemas hesiódicos, tem o mesmo valor 
Calame, em um artigo de 1985, intitulado "Les figures grecques du gigantesque", explora como a enormidade é parelha da noção de monstruosidade no sistema de pensamento

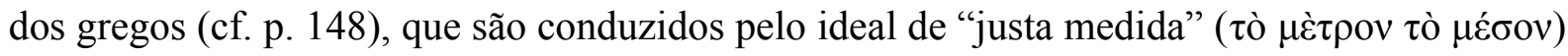

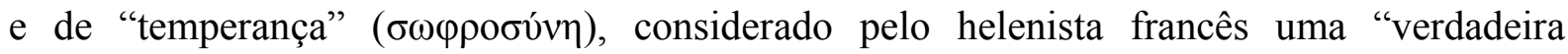
categoria do pensamento grego". ${ }^{62} \mathrm{Na}$ contramão dessa perspectiva de Calame, Porter (2015), em um artigo recentemente publicado sobre Homero e o sublime, coloca a grande dimensão em outros termos, mais precisamente no campo do sublime, cuja representação se fundamenta no grandioso, naquilo que apresenta dimensões extraordinárias e, portanto, desafia os limites do pensamento e da representação. Na Teogonia, Terra, com sua enorme dimensão, enquanto divindade primordial originária de grande parte do cosmo, desafia precisamente tais limites da representação. Sua existência em si é um desafio a esses limites. Como representar algo do

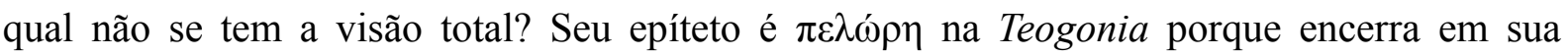
essência mesma a enormidade incomensurável que lhe confere o caráter prodigioso ou portentoso de seu ser. Como ela própria, a foice que produz com o intuito de se livrar de Céu, seu filho e consorte, também é prodigiosamente enorme ( $\pi \varepsilon \lambda \omega ́ \rho \operatorname{\rho } \varsigma)$ ).

Équidna e Tifeu também são criaturas enormes. Ela é dita "terrível e grande" (" $\delta \varepsilon v v o ́ v$ $\tau \varepsilon \mu \varepsilon ́ \gamma \alpha \nu \tau \varepsilon$ ", v. 299) e ele, embora não seja dito que é grande no poema, sua capacidade destrutiva e as consequências de sua derrota o colocam como um ser de proporções

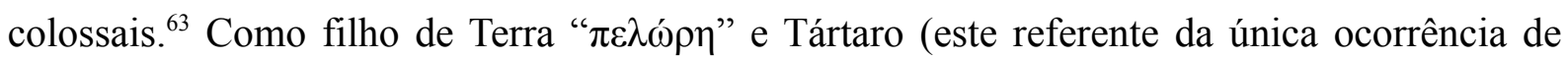

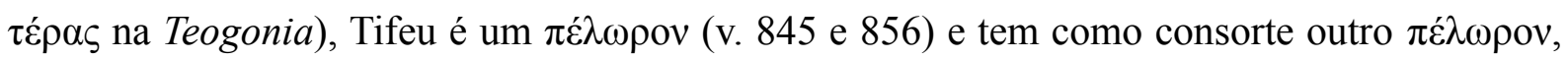
Équidna. Além de enormes, Équidna e Tifeu são criaturas que, como é característico do sublime, desafiam a capacidade de representação. Perceba-se que o poeta descreve Équidna em termos de negação ou privação, tornando mais claro o que ela não é ou as características que ela não tem em detrimento de uma descrição que contribua para compor sua

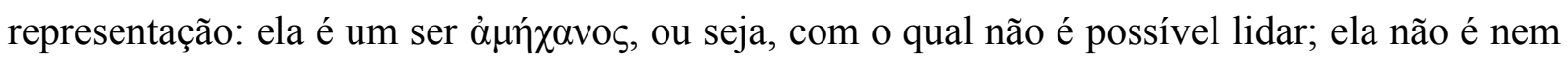
parecida com os mortais nem com os imortais; apesar dessa dessemelhança com os deuses, ela é imortal e não tem velhice; por fim, sua morada é no interior de uma gruta, ou seja, distante

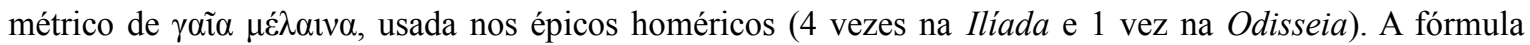
homérica aparece uma vez na Teogonia (v. 69), o que atesta seu conhecimento por parte de Hesíodo e certa infração do princípio da economia, que se caracteriza pela rejeição de duas expressões de mesmo sentido

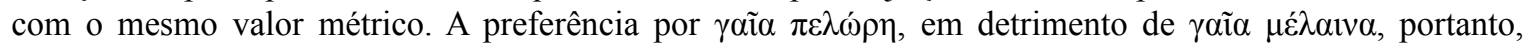
talvez indique que o sentido contido em $\pi \varepsilon \lambda \omega ́ \rho \eta$ seja mais conveniente à caracterização de Terra na Teogonia do que $\mu \varepsilon ́ \lambda \alpha \imath v \alpha$.

62 Perceba-se que Calame reproduz uma noção de "gregos" que não leva em consideração a especificidade de diferentes períodos nem as particularidades inerentes a cada fonte textual, como se compusessem um todo único e homogêneo. Cf., por exemplo, p. 153 e ss.

63 Quanto ao adjetivo $\delta \varepsilon \imath v o ́ s$, prefere-se o sentido de "assombroso" em detrimento de "terrível", como utilizado por Werner (2012), em sua tradução da Teogonia (v. 745 e 746). 
dos olhos mortais. A única caracterização que não ocorre pela negação é seu aspecto físico de metade moça, com um belo rosto e olhos ágeis, e metade serpente, "grande e assombrosa".

Por mais estranho que possa nos parecer, um escólio ao verso 845 da Teogonia, em

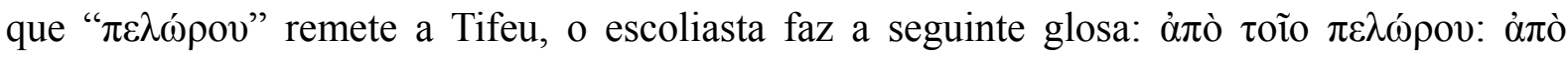

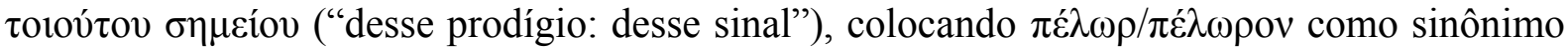
de $\sigma \eta \mu \varepsilon i ̃ o v ~(=\sigma \tilde{\eta} \mu \alpha)$ inclusive quando se trata, para nós, de um "monstro tout court". ${ }^{64}$

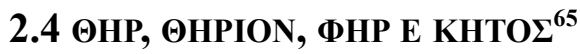

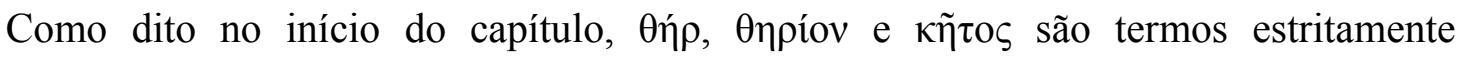

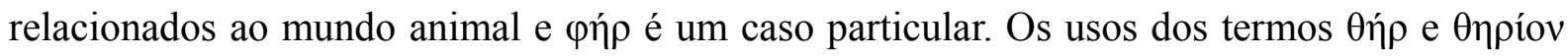
indicam que eles sejam variantes de um mesmo substantivo.

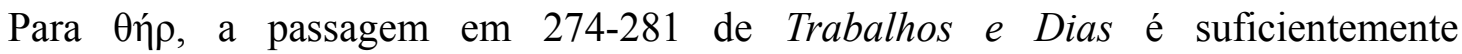
iluminadora ${ }^{66}$ Ao aconselhar Perses a evitar a violência, o narrador contrasta os humanos

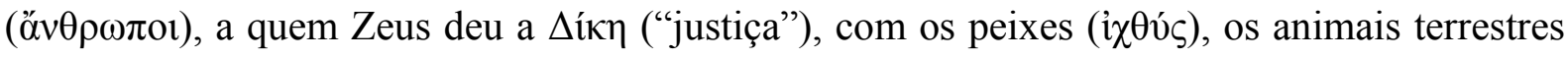

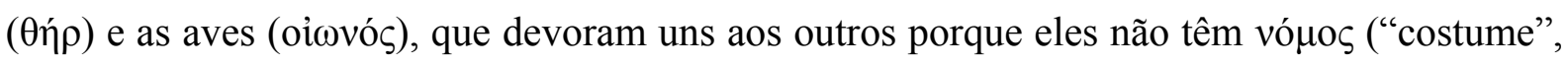
"lei"). ${ }^{67}$ A passagem sugere uma totalidade tripartite de animais de acordo com seu habitat, muito semelhante à que ocorre na fala de Laerte, na Odisseia, acerca do paradeiro de Odisseu (Odisseia 24.290-296), que expressa seu receio de que o filho possa ter sido devorado por peixes no mar ou, em terra firme, ter sido presa de feras ou de aves de rapina. ${ }^{68} \mathrm{Em}$ geral, tanto na Ilíada quanto na Odisseia, $\theta$ ń remete a animais selvagens principalmente em

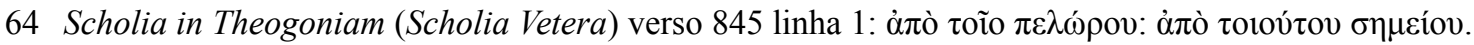

65 Para 甲ท́ $\rho$, cf. Ilíada: 1.268 e 2.743.

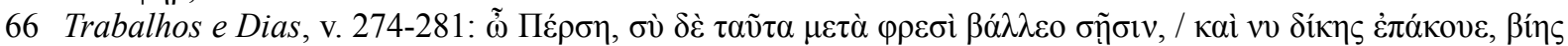

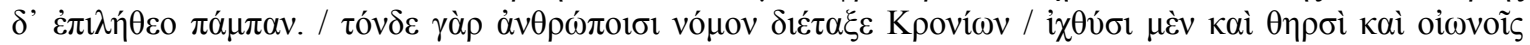

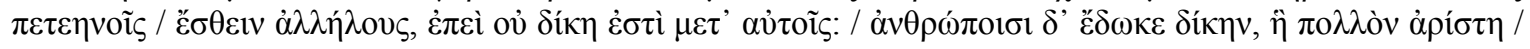

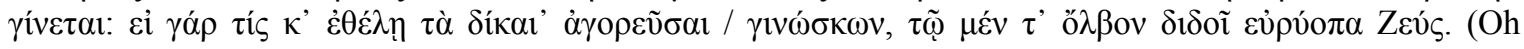
Perses, tu essas coisas em tua mente lança / ouve Justiça e a força de todo esquece. / Essa norma para os homens o Cronida ordenou, / para peixes, feras e aladas aves / se entredevorarem, pois Justiça não está entre eles. / Aos homens deu Justiça, que de longe o melhor / é: se alguém quiser anunciar o que é justo / ao reconhecê-lo, fortuna dar-lhe-ia Zeus ampla-visão.). Edição de West (1978) e tradução de Werner (2013b).

67 Em Trabalhos e Dias v. 512, Өń que vivem na floresta.

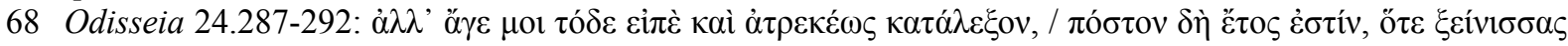

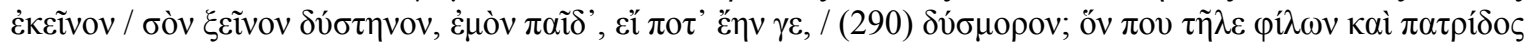

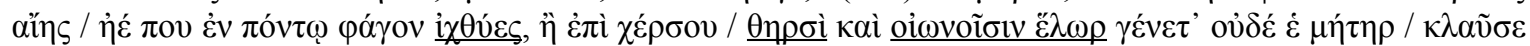

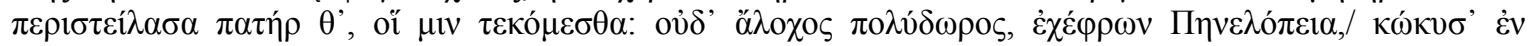

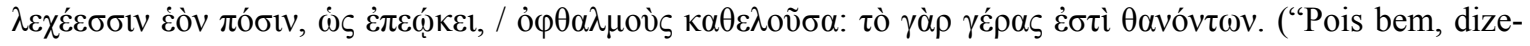
me isto e conta com precisão / qual já é o ano desde que o hospedaste, / teu hóspede infeliz, meu filho, se um dia existiu, / desventurado, que, longe dos caros e do solo pátrio, / ou no mar comeram-no os peixes ou em terra firme / tornou-se presa de feras e aves de rapina. A ele mãe não / amortalhou e chorou, nem o pai, esses que o geramos; / nem a esposa muita-dádiva, a prudente Penélope, / ululou pelo marido junto ao leito, como convém, / após cerrar os olhos: essa é a honraria dos mortos.) 


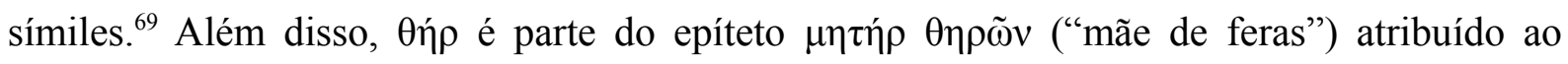

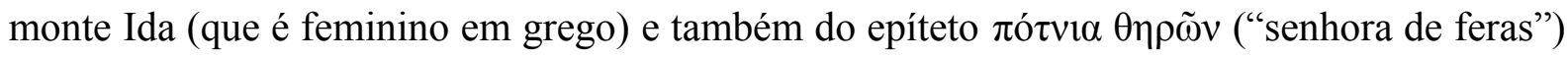
da deusa Ártemis. ${ }^{70}$ Portanto, $\theta \dot{\rho} \rho$ na poesia hexamétrica arcaica é usado estritamente para animais selvagens que vivem em ambiente terrestre. O mesmo ocorre com $\theta \eta \rho i ́ o v:$ no Hino Homérico a Afrodite (v. 4) ele designa os animais, que, como os humanos, são também subjugados pela força da deusa, e na Odisseia (10.171 e 180) é usado para o enorme cervo que Odisseu caça para alimentar os companheiros na ilha de Circe.

No caso de $\kappa \tilde{\tau} \tau o \zeta$, talvez uma parte de seu campo semântico coincida com o de "monstro" no mundo moderno, já que denominamos "monstros marinhos" alguns animais que vivem no mar. ${ }^{11}$ Contudo, $\kappa \tilde{\eta} \tau o \varsigma$ registra qualquer animal marinho de médio e grande porte, como focas ou tubarões, por exemplo (Odisseia, 4.443, 4.446 e 4.452), não exatamente aqueles que nós consideramos "monstros marinhos", que são, em geral, animais que habitam

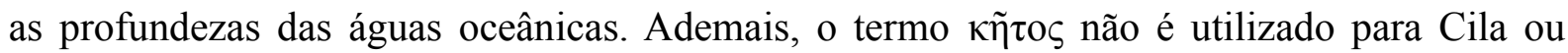
Caríbdis na Odisseia, embora as consideremos "monstros marinhos da mitologia grega". ${ }^{72}$ Ele é usado, em vez disso, para os grandes animais aquáticos dos quais Cila se alimenta (Odisseia 12.95-96).

Considerada a forma eólica de $\theta \eta \dot{\rho}$, o substantivo $\varphi \eta ́ \rho$ encontra apenas duas ocorrências, ambas na Ilíada (1.268 e 2.743), e designam os centauros em alusões ao combate

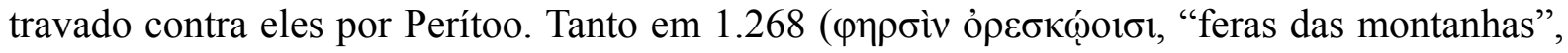

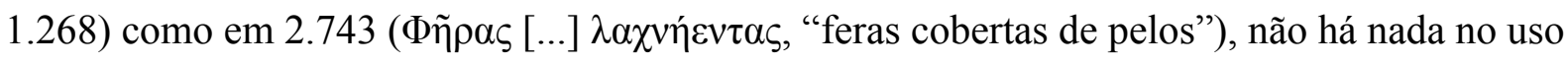

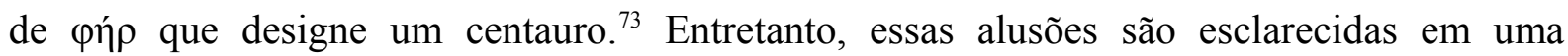
passagem da Odisseia (21.288-310), na qual Antínoo, dirigindo-se a Odisseu disfarçado de mendigo, usa a narrativa da desavença entre Perítoo e o centauro Eurítion como exemplo de comportamento a ser evitado pelo hóspede: enquanto hospedado na casa de Perítoo, o

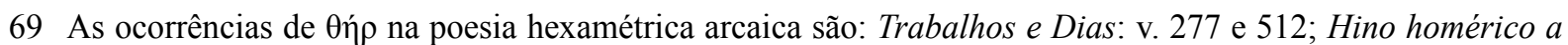
Afrodite: v. 18, 68 e 123; Hino homérico a Pan: v. 13; Hino homérico a Hefesto: v. 4; Hino homérico a Artemis (27): v. 8 e 10; Ilíada: 3.449, 8.47, 10.184, 11.119, 11.546, 14.283, 15.151, 15.324, 15.586, 15.633, 21.470 e 21.485; Odisseia: $5.473,11.573,14.21$ e 24.292 .

70 Epíteto do monte Ida: Ilíada 8.47, 14.283 e 15.151; também no Hino Homérico a Afrodite v. 68; epíteto de Ártemis: 21.470 .

71 Note-se que este é o único verbete de Cunliffe, dentre os analisados aqui, em que ele oferece uma acepção que contém a noção de monstro ("sea-monster").

72 Vejam-se os verbetes "Cila" e "Caríbdis" na Wikipédia: ambas são referidas como "monstro marinho". O uso da Wikipédia aqui não tem a finalidade de instruir o leitor quanto a essas figuras mitológicas, mas indicar o modo como são representadas em um verbete que, além de ser construído coletivamente, é usado como referência por milhares de pessoas com acesso à internet atualmente. Para Cila: https://pt.wikipedia.org/wiki/Cila (último acesso: 28 mai. 2016). Para Caríbdis: https://pt.wikipedia.org/wiki/Car\%C3\%ADbdis (último acesso: 28 mai. 2016).

73 Essas duas traduções são próprias e literais, diferindo da de Lourenço (2013a), que as traduz por "centauros das montanhas" e "centauros hirsutos", respectivamente. 
centauro se embriagou com vinho e acabou aprontando vilezas, em razão do que foi arrastado para fora da casa e teve uma orelha e o nariz decepados. Isso ocasionou a querela entre

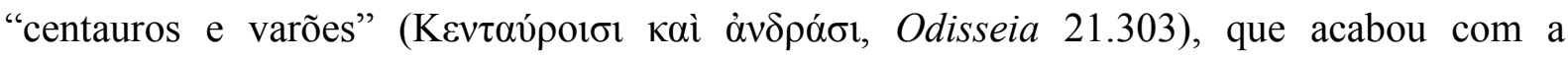
aniquilação daqueles por parte destes (Ilíada 1.268). De todo modo, eles são aludidos por $\varphi \eta ́ \rho$ não por serem considerados monstruosos, mas por serem considerados habitantes do mundo

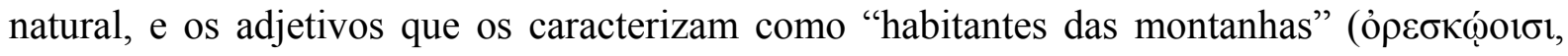
1.268) e "cobertos de pelos" ( $\lambda \alpha \chi v \eta ́ \varepsilon v \tau \alpha \varsigma, 2.743)$ ressaltam sua natureza animal. Ademais, as ações desumanas praticadas por Perítoo nesse episódio aterrorizam mais pela crueldade do que qualquer eventual monstruosidade que se atribua aos centauros.

Conforme tem sido mostrado, nenhum dos termos mencionados é totalmente assimilável ao nosso conceito contemporâneo de monstro, e o contrário também é verdadeiro, pois o nosso conceito de monstro não encontra paralelo nos poemas hexamétricos arcaicos, e possivelmente não encontre no mundo antigo greco-romano. ${ }^{74}$ Os substantivos

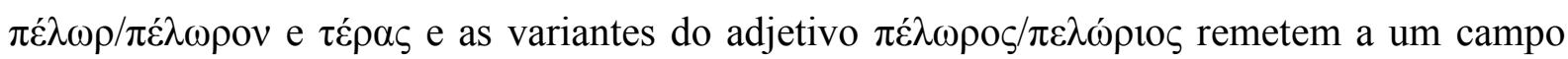
semântico mais próximo da origem do termo "monstro", ou seja, do campo semântico do termo latino monstrum, conquanto não deva ser igualado a ele, pois monstrum percorre seu próprio trajeto semântico ao longo de sua história particular. Apesar de o vernáculo "monstro" vir do latim monstrum, ele passou por um longo processo histórico no qual a noção original, imbuída de uma relação com o mundo religioso e o âmbito divino, sofreu um processo de secularização, ou seja, foi despida dessa relação com o sagrado. Esse substantivo neutro latino, junto com outros, como prodigium e portentum, que, por sua vez, deram origem a "prodígio" e "portento" em português, fazem parte do vocabulário de presságios e vaticínios e estão intimamente ligados à esfera da divinação romana. Monstrum, prodigium e portentum designam revelações enviadas pela divindade aos mortais que funcionam como uma mensagem ou um aviso acerca de algum acontecimento futuro ou uma razão para um evento passado. Eles designam, em geral, uma intervenção divina no mundo dos mortais.

Benveniste (1995, vol. II, p. 257-265) dedica um capítulo à exploração e distinção dos termos latinos relacionados a presságios e augúrios. Baseando-se no estudo do indo-europeu, e também em Cícero e no gramático Festo, ele traça uma diferenciação entre os termos em que "portentum" designaria presságios que revelam uma sequência de acontecimentos

74 Veja-se, contudo, a obra de Cuny-Le Callet (2000), que explora a noção de monstro em Cícero e Lucrécio. 
mostrando um panorama do futuro (por-tendo, "aquilo que se estende diante de"); "prodigium" estaria relacionado à emissão de uma voz divina que se faz ouvir (prod e -agium, do verbo aio, "dizer", "proferir"); e "monstrum" remete a um conselho ou advertência mostrado pela divindade, representando um ensinamento divino (do verbo moneo, "advertir", “instruir”). Essas distinções não estão presentes nos termos gregos aqui analisados, uma razão importante para que não se estabeleça uma igualdade plena entre tais termos e os latinos.

Ainda que haja certa distância entre o monstrum latino e os termos gregos, há um campo semântico relativo ao âmbito divino compartilhado entre eles do qual o nosso moderno termo "monstro" está desprovido. Talvez "portento" e "prodígio" ainda apresentem um resquício da relação com o âmbito divino em sua possível remissão a um "milagre" (cf. verbete "portento" no dicionário Aulete Digital), contudo, "milagre" deve ser evitado em razão da profunda relação que tem com o monoteísmo cristão. De todo modo, a relação intrínseca do monstro com o universo divino se perdeu ao longo da história entre o início do mundo moderno até a contemporaneidade. O momento exato é difícil precisar, já que essa perda é principalmente fruto do contínuo processo de desenvolvimento científico que marca os mundos moderno e contemporâneo. Talvez se possa atribuir a Isidore Geoffroy de SaintHillaire, no século XIX, o marco de elaborar uma noção de "monstro" secularizada, porém, é preferível tomá-la como resultante, em termos weberianos, do processo de "desencantamento do mundo", do qual Saint-Hillaire também faz parte. Conforme visto no capítulo 1, essa noção weberiana tem se mostrado bastante útil para entender o processo sob o qual o termo "monstrum" perdeu seu lastro com a presença divina no mundo, que, por sua vez, cedeu lugar à presença do conhecimento científico do mundo.

Disso tudo, é possível concluir que as escolhas de traduções que expressem ou não o caráter de monstruosidade dos substantivos e adjetivos tratados aqui é fundamentalmente pautada pela noção moderna preconcebida do caráter monstruoso da figura em questão. É certo que essa escolha é amparada pelos dicionários de grego antigo em línguas modernas, que ou oferecem tal acepção de modo totalizante, isto é, como uma tradução segura para qualquer época ou texto, ou não são explícitos o suficiente quanto às diferenças de sentido que o termo pode assumir em diferentes épocas ou em diferentes autores. 


\subsection{CONCLUSÕES}

Do que foi exposto, fica evidente que, na poesia hexamétrica arcaica, o substantivo

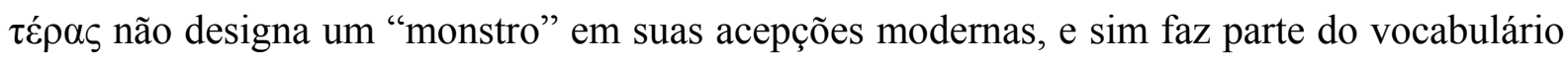
de presságios e vaticínios, designando um portento ou prodígio, que, como $\sigma \tilde{\eta} \mu \alpha$, apresenta um valor indicial, além de poder designar também uma insígnia. Tendo o extraordinário e não o monstruoso como condição sine qua non para ser reconhecido como portento ou prodígio, $\tau \varepsilon ́ p \alpha \varsigma$ pode ser usado para indicar extraordinariedade como a da serpente no h.Ap. e a do Tártaro na Teogonia. Esse elemento do extraordinário enquanto pressuposto para que algo seja denominado $\tau \dot{\varepsilon}$ pas tem como efeito o espanto, podendo resvalar para o terror, como diante da cabeça da Górgona, por exemplo.

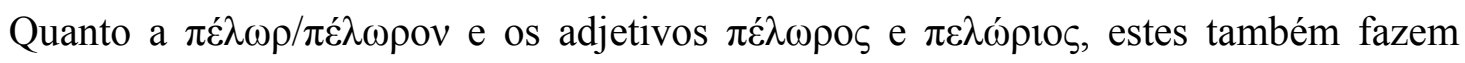
parte do vocabulário da adivinhação e têm parte de seu campo semântico compartilhado com $\tau \varepsilon ́ p \alpha \varsigma$. Eles, contudo, indicam amiúde a enormidade extraordinária do referente, embora não

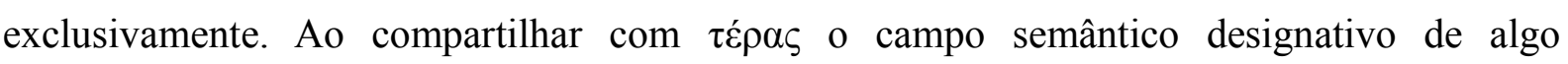
extraordinário e prodigioso, e como o extraordinário é um meio pelo qual os deuses se comunicam com os humanos, a relação com a esfera divina não está ausente do campo semântico de $\pi \varepsilon ́ \lambda \omega \rho$ e derivados. Como $\tau \dot{\varepsilon} \rho \alpha \varsigma$, o extraordinário expresso por $\pi \varepsilon ́ \lambda \omega \rho$ e derivados tem como efeito o espanto, podendo resvalar para o terror ou para o maravilhamento.

Diferente do que ocorre com $\pi \dot{\varepsilon} \lambda \omega \rho / \pi \varepsilon ́ \lambda \omega \rho o v$, contudo, $\tau \dot{\varepsilon} \rho \alpha \varsigma$ não se restringe aos poemas épicos, sendo uma palavra corrente na língua grega antiga. Por ser um termo usado por Aristóteles em Geração dos animais para designar seres com algum tipo de deformidade

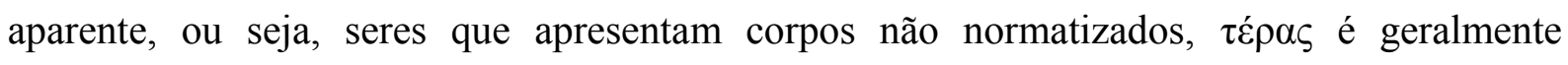
considerado o termo do grego antigo que designa um "monstro". Contudo, da análise realizada neste capítulo, conclui-se que esses termos estão ligados não à monstruosidade, e sim ao elemento do extraordinário e do espantoso, que, para a poesia hexamétrica, só pode ter origem no âmbito mesmo do divino. 


\section{Capítulo 3}

\section{CRIATURAS CONSIDERADAS MONSTRUOSAS NA TEOGONIA DE HESÍODO}

Se o inferno é uma casa, a casa de Hades, é natural que um cão a guarde; também é natural que esse cão seja imaginado como atroz. A Teogonia de Hesíodo lhe atribui cinquenta cabeças; para maior comodidade das artes plásticas, esse número foi reduzido, e as três cabeças do cão cérbero são de domínio público. [...]

Jorge Luis Borges, O livro dos seres imaginários, p. 52. 


\section{CAPÍTULO 3}

Este capítulo é dedicado à análise das figuras usualmente consideradas monstruosas na Teogonia de Hesíodo. ${ }^{1} \mathrm{O}$ critério para se estabelecer quais figuras são objeto de análise neste e nos capítulos subsequentes é pautado por aquele assumido na produção científica acerca da Teogonia, bem como dos outros dois poemas, a saber, o Hino Homérico a Apolo e a Odisseia. Isso significa ter de acompanhar, para depois problematizar, a utilização de uma noção de monstruosidade baseada no senso comum moderno para definir aquilo que se percebe como monstruoso nessa poesia, em geral envolvendo algum tipo de corporeidade não normatizada, seja relativa ao corpo humano ou à anatomia animal. O que se percebe é que, na produção científica acerca desses poemas, os critérios para se estabelecer o que é ou não monstruoso é norteado pela percepção do senso comum e, em certos casos, mesmo que a noção de monstruosidade seja elaborada dentro de um sistema teórico mais complexo, os pressupostos da definição permanecem não examinados. Um exemplo disso é o estudo de Jenny Strauss Clay, um dos poucos que explora essas figuras e ressalta os papéis importantes que elas assumem no cosmo apresentado na Teogonia. ${ }^{2}$ Pode-se considerar que a obra de Clay é fundante desta tese e, ainda que a noção de monstro utilizada por ela seja criticada e, de certo modo, desconstruída aqui, a estudiosa apresenta uma compreensão sólida e influente dessas figuras no tocante a seu papel no interior do cosmo hesiódico.

Dos três poemas que têm suas criaturas analisadas mais detidamente nesta tese, decidiu-se iniciar com a Teogonia por três razões. A primeira é decorrente de um número maior de seres considerados monstruosos presentes nesse poema do que nos outros dois, oferecendo, assim, mais oportunidade de análise. A segunda é a existência da obra de Clay que trata dessas figuras especificamente, diferente do que ocorre para os demais poemas: apesar de haver uma bibliografia razoável para a figura de Polifemo na Odisseia, por exemplo, as outras criaturas são pouco exploradas. ${ }^{3}$ A terceira é a ideia de "história do cosmo" de Graziosi e Haubold (2005), com base na qual os poemas atribuídos a Homero e a Hesíodo “descrevem o mesmo mundo, embora a partir de diferentes perspectivas e em diferentes estágios de desenvolvimento". ${ }^{4}$

1 Os questionamentos acerca da categoria "monstro" aplicada indistintamente a Ciclopes, Centímanos e Tifeu na Teogonia foram explorados em um paper apresentado em Oxford em 2014, durante o "12th Global Conference - Monsters and the Monstrous", e publicado no formato de ebook. Cf. Zanon (2014a).

2 Clay (1993 e 2003).

3 A recente obra de Hopman (2012a), dedicada à Cila, é uma exceção.

4 Graziosi e Haubold (2005, p. 35-36): “[...] We argue that the Homeric and the Hesiodic epics describe the 
De acordo com essa noção, dentre o corpus de poesia hexamétrica arcaica, a Teogonia, por apresentar o início do cosmo, ocupa a posição inicial; já os poemas atribuídos a Homero fornecem uma aproximação, como em um close, de algum momento crucial para essa história, explorando-o em detalhe. Ou seja, eles se detêm em episódios dessa história enquanto o corpus hesiódico a trata em linhas mais gerais. ${ }^{5}$ Os hinos homéricos, por exemplo, narram o nascimento de uma divindade em particular, como ela passou a integrar a ordem olímpica e adquiriu sua time $\bar{e}^{6}$ Os dois épicos homéricos, por sua vez, focam em narrativas heroicas que teriam se passado à época da guerra de Troia, fazendo parte de um momento na história do cosmo que o poeta de Trabalhos e Dias vincula com o fim da era dos heróis (v. 156-173).

Importante para este capítulo e para os subsequentes que se dedicam à análise das figuras consideradas monstruosas na poesia hexamétrica arcaica é a noção de referencialidade tradicional elaborada por John Miles Foley (1991 e 1999). Foley desenvolveu essa noção, que se tornou bastante influente nos estudos homéricos, em diversos livros publicados, sobretudo, nas décadas de 1980 e 1990. Trata-se, em linhas gerais, de um aperfeiçoamento da teoria oral desenvolvida por M. Parry (1987 [1971]) e A. B. Lord (1971 [1960]) incorporando certos pressupostos da Estética da Recepção. ${ }^{7}$

Adotando a perspectiva oralista, que ganhou fôlego com as teorias de Parry e Lord de que os poemas homéricos são o produto de uma longa tradição de composição e performance orais, com uso de expressões formulares dentro de um pé métrico fixo e construção de cenas típicas, Foley acrescentou as implicações da oralidade para o público desses poemas, que não é mero espectador mas agente da tradição ou das tradições a que esses poemas pertencem, concluindo o circuito poeta-perfomance-público. ${ }^{8}$

same world, albeit from different perspectives and at different stages of development. [...]". Cientes de que o termo "história" pode trazer implicações científicas para a expressão "história do cosmo" e de que os poemas épicos não são, evidentemente, expoentes do gênero historiográfico, Graziosi e Haubold justificam a escolha do termo "história" por expressar o desenvolvimento através do tempo no interior da tradição bem como por evocar certa confiabilidade (2005, p. 37).

5 A história do cosmo que se inicia com a Teogonia tem sua sequência no Catálogo das Mulheres, a despeito de seu estado fragmentário e das dúvidas acerca de sua atribuição, pois ele dá continuidade às genealogias presentes na Teogonia, apresentando as uniões de mulheres com imortais que dão origem a semideuses ou heróis. Por último, está Trabalhos e Dias, que apresenta o mundo mais ou menos como no presente. Para um recente estudo do Catálogo das Mulheres e seu possível contexto social de produção, cf. a obra de Ormand (2014). Tanto Ormand como Graziosi e Haubold (2005) defendem que, embora o Catálogo possa não ser genuinamente de Hesíodo, ele é hesiódico no que concerne suas características de épica genealógica por excelência. Cf. também o capítulo de Tsagalis, em Montanari, Rengakos e Tsagalis (2009), p. 131-179.

6 Embora a Teogonia narre o nascimento de Zeus em detalhe, isso não contradiz a concepção mais generalista dos poemas hesiódicos em relação aos hinos homéricos, pois o nascimento de Zeus é um episódio crucial para a narrativa desenvolvida na Teogonia e faz parte dos mitos de sucessão nela contidos. A passagem do nascimento de Hécate (v. 411-452), por vezes entendida como um hino à deusa, pode ser considerada um close-up dentro da Teogonia.

7 Para uma recente aplicação da referencialidade de Foley à Ilíada, cf. Kelly (2007), na qual o autor faz um "comentário referencial" ao canto 8.

8 Para uma boa discussão em português acerca do conceito de tradição relacionado à poesia hexamétrica 
A referencialidade tradicional consiste em uma rede de associações produzida ao longo do tempo e que poeta e público compartilham, tornando efetiva a comunicação da poesia e, consequentemente, da tradição que ela veicula. Expressões formulares como as de nomeepíteto (“Aquiles de pés rápidos" ou "Hera de alvos braços”, por exemplo), que para Parry e Lord tinham uma função mais subjugada à métrica dentro do verso hexamétrico, ganham com Foley o caráter de "palavra" ou "unidade cognitiva da expressão tradicional", ou seja, são consideradas uma unidade mínima de sentido, de modo que a expressão formular (e, portanto, tradicional) “Aquiles de pés rápidos" não caracteriza Aquiles como aquele que é veloz naquele determinado contexto poético; ela, em sua totalidade, é uma "palavra" dentro dessa tradição, um modo de remeter ao índice Aquiles, isto é, o herói e tudo o que ele evoca no interior da tradição de poesia hexamétrica. Ao ser enunciada dentro do verso, a expressão “Aquiles de pés rápidos" ressoa em uma rede de significações, referenciando significados implícitos dentro dessa tradição, compartilhados entre poeta e seu público, e criando uma rede de ressonâncias. O mesmo ocorre para as cenas típicas, que também são consideradas por Foley no nível da "palavra" para essa tradição, ou seja, uma unidade mínima de sentido para a compreensão da poesia hexamétrica.

Conquanto Foley tenha se dedicado aos poemas homéricos na elaboração de sua teoria, comparando-os com tradições orais ainda existentes, principalmente de poesia eslava, transpõe-se aqui sua noção de referencialidade tradicional para os poemas hesiódicos e para os hinos homéricos por serem integrantes dessa tradição de poesia hexamétrica arcaica e, portanto, submetidos às mesmas regras que nela operam.

Quanto a sua organização, este capítulo tem início com uma breve introdução à Teogonia e seu programa, seguido da análise das criaturas. Primeiro são analisados os Ciclopes e os Centímanos, que formam dois grupos de filhos de Terra e Céu, em seguida Tifeu, filho de Terra e Tártaro e opositor de Zeus no poema, e, por fim, as criaturas que compõem a progênie de Fórcis e Cetó, casal de filhos de Mar e Terra. O capítulo se encerra com uma breve retomada das conclusões a que se chegou ao longo das análises.

arcaica, cf. a tese de doutoramento recentemente defendida por Oliveira (2015). Para a presente tese, arriscome a esboçar uma definição mínima de tradição: um fenômeno em que se verifica a permanência de elementos operada por agentes sociais em um processo dialético de reprodução e recepção por meio de qualquer modalidade de comunicação, seja de natureza verbal ou visual. 


\subsection{A TEOGONIA E SEU PROGRAMA}

A Teogonia tem como tema geral o nascimento dos deuses e, por tais deuses serem concebidos como aspectos do cosmo, ela acaba por ser também uma cosmogonia, em que o nascimento dos deuses é em si o nascimento do cosmo. ${ }^{9}$ Entremeados ao nascimento dos deuses, isto é, às genealogias, são narrados no poema os eventos que levaram ao estabelecimento da ordem de Zeus sobre o cosmo, os chamados "mitos de sucessão", assim denominados modernamente por relatarem como cada governante foi destronado por seu filho e sucessor: primeiro Céu, depois Crono e, por fim, Zeus. ${ }^{10}$

Seus primeiros 115 versos constituem o proêmio (v. 1-115), no qual o poeta, nomeadamente Hesíodo (v. 22), pede às Musas que celebrem os deuses imortais, anunciando assim o objeto de seu canto. ${ }^{11}$ Em seguida, tem início a "história do cosmo", com o nascimento das divindades primordiais (v. 116-122): Caos, Terra, Tártaro e Eros. ${ }^{12}$ Desses quatro, apenas Caos e Terra terão linhagens que constituirão o cosmo definido na Teogonia. ${ }^{13}$ E dentre esses dois, apenas Terra gerará criaturas que são consideradas monstruosas, seja diretamente, como é o caso dos Ciclopes, dos Centímanos e de Tifeu, seja indiretamente, como é o caso da progênie de Fórcis e Cetó, casal de filhos gerados pelo Mar em união com sua mãe, Terra, uma das raras instâncias na Teogonia em que a prole é gerada pela parte masculina do casal, contrastando com as demais genealogias predominantemente matrilineares em que as fórmulas para descrever os nascimentos têm a mãe como sujeito gramatical. ${ }^{14}$ Portanto, é na linhagem de Terra que as análises apresentadas aqui se

9 O título Teogonia, de $\theta \varepsilon$ ć ("deus") + yóvoৎ ("origem”), só foi estabelecido mais tarde, possivelmente pelos editores e gramáticos alexandrinos (cf. West, 1997 [1966], p. 150).

10 West (1997 [1966], p. 31), talvez com a intenção de sublinhar a relação de organicidade entre as genealogias e os mitos de sucessão, tece uma analogia entre a Teogonia e um corpo vivo em que os mitos de sucessão são a espinha dorsal do poema e as genealogias, sua carne e sangue. Cf. Détienne e Vernant (2008 [1974], p. 62-66), que problematizam o fato de Céu (Urano) não ser nomeado soberano na Teogonia, com o tema da competição pela soberania surgindo apenas com Crono, de modo que os mitos de sucessão teriam início com Crono e não com Urano (Céu). Para eles, Urano não poderia ser rei de um cosmo que ainda não veio a existir e que só vai emergir quando seu filho castrá-lo e separá-lo de Terra, momento mesmo em que Crono ascende à soberania.

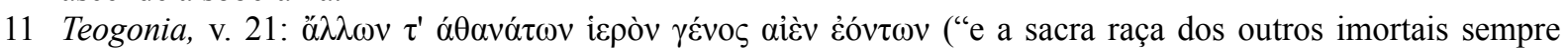

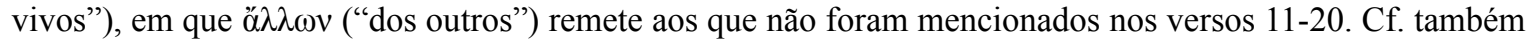
v. 105. Sobre o proêmio da Teogonia, cf. Minton (1970), Verdenius (1972), Rudhardt (1995), Pucci (2007) e Rijksbaron (2009). Pucci (2007, p. 9) denominou o proêmio (v. 1-115) de "Hino às Musas" por apresentar um estilo característico do gênero hínico e certa independência em relação aos motivos teogônicos predominantes no poema, e também por ser um elogio às Musas (e, consequentemente, à poesia).

12 A despeito da ambiguidade do texto hesiódico, esta tese considera que Tártaro se constitui como uma das divindades primordiais. Cf. discussão adiante.

13 Tártaro, contudo, será o pai de Tifeu, gerado por Terra, e Tifeu terá sua própria prole com Équidna (cf. adiante).

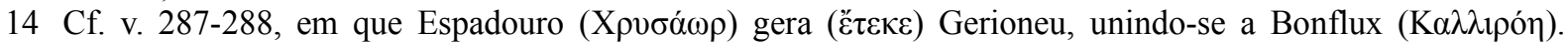
Contudo, veja-se o verso 981, no qual é Bonflux quem gera ( $\tau \varepsilon \varepsilon \varepsilon)$ Gerioneu, e não Espadouro. Cf. também o 
concentram. Todavia, a compreensão do cosmo hesiódico e, principalmente, das criaturas consideradas monstruosas como parte desse cosmo não pode prescindir de um entendimento geral, ainda que breve, da linhagem de Caos.

Primeiro, é necessário esclarecer que, embora seja muito comum encontrar "Caos" como tradução para Xáos, o sentido do vernáculo “caos” não corresponde ao termo grego. Tal tradução, equivocada mas canônica e por isso mantida aqui, faz pensar que o caos primordial hesiódico esteja em oposição a uma ordem posteriormente estabelecida porque o nosso vernáculo transmite esse sentido de “desordem”. Na verdade, Xáoৎ é um termo de difícil interpretação, pois além das quatro ocorrências na Teogonia (v. 116, 123, 700, 814), não há outra no corpus de poesia hexamétrica arcaica e as poucas encontradas em textos posteriores dependem direta ou indiretamente do uso do termo no poema hesiódico. ${ }^{15}$ West (1997 [1966], p. 192-193), Bussanich (1983, p. 213), Muellner (1996, p. 55) e Pucci (2009, p. 45), por

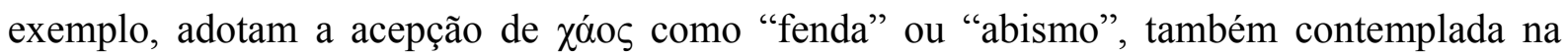
tradução da Teogonia para o português de Werner (2013a). ${ }^{16}$ Essa acepção decorre

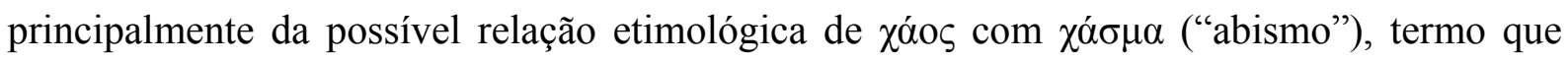
aparece no verso 740, na passagem da descrição do Tártaro (v. 720-819). Torrano (2012, p. 30 ), inclusive, aponta para uma correspondência maior da noção de "abismo" com Tártaro do que com Caos no texto hesiódico. Já Mondi (1989) entende qóos como a ausência de uma forma rígida e definida e, de acordo com o que será explorado adiante, esse aspecto de indefinição do primordial Caos parece se encaixar melhor no programa da Teogonia do que a ideia de "fenda" ou "abismo", pois, como afirma Clay, "[...] Esse movimento a partir do indefinido para a crescente definição é característico da cosmogonia hesiódica. [...]". ${ }^{17}$ Clay aponta também que a noção de "boundedness" (“delimitação"), ligada à concepção de Terra, parece tornar mais compreensível a noção de Caos como algo "unbounded" ("ilimitado", “irrestrito"). Além disso, a ideia de Caos como "fenda" parece contradizer o texto da

episódio no qual Zeus dá à luz Atena após engolir a Métis (v. 886-900 e 924-926). Para os nomes próprios, segue-se aqui aqueles propostos pela tradução de Werner (2013a), com exceção dos Centímanos, cujo nome

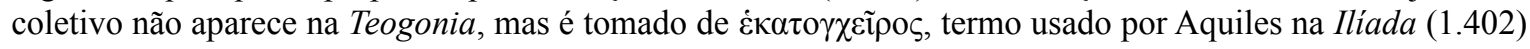
para se referir a Briareu. Para Tifeu, o poeta também usa a forma Tífon. Cf. adiante.

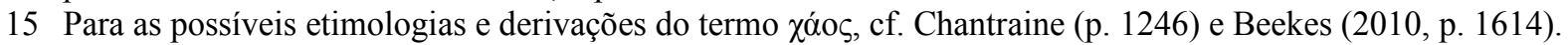

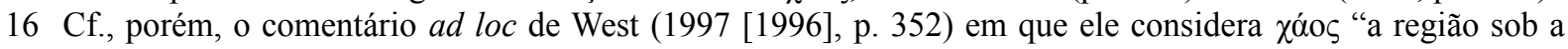

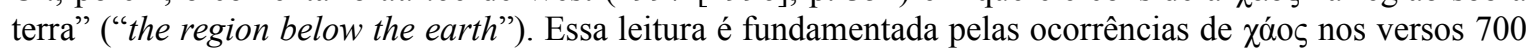
e 814: o primeiro está no contexto da Titanomaquia em que os raios de Zeus atingem todo o cosmo, inclusive o Xáoc; o segundo está em referência ao local onde foram presos os Titãs, que fica "para lá do

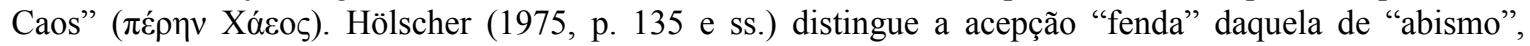
descartando a primeira porque ela coloca "la cavità prima dell'involucro", mas defendendo a segunda com base em comparações com as cosmogonias próximo-orientais, das quais a poesia hesiódica seria em grande parte herdeira.

17 Clay (2003, p. 15): “[...] This movement from undefined to increasing definition is characteristic of Hesiod's cosmogony. [...]”. 
Teogonia, já que uma fenda, como notado por Hölscher (1975, p. 135 e ss.), necessita de algo que exista antes dela para defini-la, e Xóos é a "primeiríssima" divindade a nascer (cf. o superlativo $\pi \rho \omega ́ \tau 1 \sigma \tau \alpha$ no v. 116). ${ }^{18}$

Um aspecto da linhagem de Caos que está bastante de acordo com essa noção de algo "ilimitado" ou "irrestrito" é a marcada ausência de tangibilidade ou corporeidade dessa linhagem se comparada à de Terra. ${ }^{19}$ Abrindo o programa genealógico do poema, Caos gera sozinho Escuridão (ou Érebo) e Noite, irmãos que se unem e, por sua vez, geram Éter (ou “Claridade”) e Dia (v. 123-125). ${ }^{20}$ Logo em seguida, entre os versos 126-210, está a linhagem de Terra e o primeiro episódio do mito de sucessão, que será, por sua vez, seguido dos filhos de Noite (v. 211-232), um catálogo de seres intangíveis em sua maioria, com personificações como Morte (v. 212) e Esquecimento (v. 217), por exemplo. ${ }^{21}$ Assim, a primeira geração de filhos de Terra, quer sejam dela sozinha ou gerados com seu filho Céu, uma sequência de rebentos com extrema força física, é precedida e sucedida na estrutura do poema (não necessariamente em sua cronologia) pelos entes predominantemente intangíveis da linhagem de Caos.

Como Caos, que gera sozinho Escuridão e Noite, Terra também produz seus primeiros rebentos sozinha: Céu, depois Montanhas e, por fim, Mar (v. 126-132), uma tríade que define e delimita em termos gerais os contornos de sua progenitora. Céu, o primogênito, foi gerado "a fim de cobri-la por inteiro" e, como ela própria, para ser sede dos deuses (que ainda estão por vir).

Caos e Terra, portanto, sendo as divindades primordiais originárias de praticamente todo o cosmo apresentado no poema, têm já em sua prole inicial a descendência de aspectos que definem esse cosmo em termos daquilo que é intangível (Caos e sua linhagem), por um lado, e daquilo que apresenta solidez e corporeidade (Terra e sua linhagem), por outro. E

18 Para boas conduções da discussão acerca do significado de Xóo (1989) e Torrano (2012) e o capítulo dedicado à sequência narrativa na Teogonia em Muellner (1996, p. 593).

19 Cf. West (1997 [1966], p. 35).

20 Com o nascimento de Escuridão e Noite e de seus filhos, o poema revela, em um momento bem próximo do início do cosmo, aquilo que Thalmann $(1984$, p. 2) chamou de "princípios básicos" da estrutura e do conteúdo da visão de mundo expressa pela poesia hexamétrica arcaica: a semelhança, nesse caso, entre Caos e seus filhos Escuridão e Noite, e a antítese, que se faz entre o casal Escuridão e Noite e seus filhos Éter e Dia, no que concerne o par antitético escuridão/luz.

21 As Hespérides, contudo, são ditas cuidar de maçãs e de árvores frutíferas para lá do Oceano (v. 215-216). Às Perdições (Kñ $\rho \varepsilon \varsigma)$ também são atribuídas atividades: dão aos mortais seu bem e mal e punem transgressões de mortais e deuses (v. 217-222). Em razão de exercerem "atividades", pode haver alguma corporeidade implícita na concepção dessas divindades. Isso não contradiz, porém, a ideia geral subjacente à linhagem de Caos dentro do programa da Teogonia, pois não se defende que haja uma exclusividade do elemento corpóreo por parte da linhagem de Terra nem uma exclusividade incorpórea por parte de Caos, mas uma predominância de um e de outro. 
perceptivelmente, todas as figuras arroladas no poema consideradas monstruosas podem ter sua origem traçada até Terra, nenhuma delas pertencendo à genealogia de Caos, o que faz jus à corporeidade por vezes exacerbada dessas figuras, algumas delas descendentes diretas de Terra, como os Ciclopes, os Centímanos e Tifeu.

É necessário, contudo, justificar a interpretação adotada aqui de que Tártaro é uma das divindades primordiais. O texto da Teogonia não deixa claro se ele é uma das primeiras divindades ou apenas um local em contraposição ao Olimpo (cf. v. 117-119). Há, portanto, essas duas possibilidades interpretativas e a questão é debatida desde a Antiguidade. West, cuja edição do texto é adotada aqui, considera Tártaro uma das divindades primordiais (1997 [1966], p. 194-195), embora nessa passagem o tome como uma inserção posterior feita por Hesíodo. Em virtude da análise proposta nesta tese da figura de Tifeu, que é filho de Terra e Tártaro no poema, entende-se que o derradeiro inimigo de Zeus na Teogonia tem como origem duas divindades primordiais. Além disso, é difícil compreender a razão pela qual a origem de Tártaro seria omitida nos quase cem versos dedicados à sua descrição no poema (v. 721-819), a não ser que já tivesse sido mencionada, e a única possibilidade de referência à sua origem é o verso 119, cuja ambiguidade possibilita a leitura de Tártaro como uma das divindades primordiais.

Conforme declarado acima, as criaturas que são habitualmente consideradas “monstros" na Teogonia pertencem à linhagem de Terra. Clay (1993 e 2003) as separa em, de um lado, as criaturas que pertencem ao chamado "catálogo de monstros" (v. 270-336), composta pela progênie de Fórcis e Cetó, casal de irmãos gerados por Mar em união com sua mãe Terra, e, de outro lado, as criaturas "de fora do catálogo", a saber, os Ciclopes, os Centímanos e Tifeu. Essa separação é condizente com a estrutura geral da Teogonia, porque os chamados "monstros de fora do catálogo" assumem papéis relevantes na narrativa desenvolvida no poema, enquanto os "monstros do catálogo" estão "enclausurados" ("enclosed") ou encapsulados em um determinado trecho e não se inserem na narrativa de ascensão de Zeus ao trono, apresentando papéis em episódios de cunho heroico aludidos brevemente no poema, como Medusa sendo decapitada por Perseu (v. 274-285), um e outro dos feitos de Héracles (v. 289-294, 313-318 e 326-332) e a morte de Quimera por Belerofonte (v. 319-325). Adoto essa separação para a análise das criaturas porque tanto o estudo de Clay quanto este está grandemente pautado pela narrativa hesiódica de modo geral, o que não poderia ser diferente, já que ambos tentam entender o papel delas nessa narrativa e o modo como são concebidas pela tradição de poesia hexamétrica arcaica.

Os Ciclopes e os Centímanos nascem bem cedo na história do cosmo, da união de 
Terra com seu primogênito Céu (v. 139-153). Eles são irmãos dos outros doze filhos também engendrados por essa união e que receberão a alcunha de "Titãs" no poema. Tifeu, de sua parte, é um filho extemporâneo de dois primordiais, Terra e Tártaro, engendrado logo após a derrota dos Titãs, abatidos pela união de forças entre Zeus, seus irmãos e os Centímanos (v. $820-822)$.

O papel dos Ciclopes e dos Centímanos como aliados de Zeus na Teogonia e o de Tifeu como seu opositor foram bem analisados por Détienne e Vernant (2008 [1974]) na segunda parte de seu livro Métis - As astúcias da inteligência, intitulada "A conquista do poder” (p. 55-117), da qual este capítulo é, em parte, devedor. Lá, Détienne e Vernant mostram a importância dos Ciclopes e dos Centímanos para a consolidação da supremacia de Zeus: de um lado, os Ciclopes como forjadores do raio, a arma suprema com a qual Zeus primeiro combate os Titãs no episódio da Titanomaquia (v. 617-721), depois derrota Tifeu no episódio da Tifonomaquia, pondo um fim à ameaça de usurpação que ele representa (v. 820880), e com a qual governa entre mortais e imortais; e, de outro, os Centímanos como a artilharia que garante a derrota dos Titãs na Titanomaquia.

Quanto aos ditos "monstros do catálogo", o artigo de Clay (1993) é uma das únicas publicações que apresentam uma análise mais detida deles, aparecendo sempre como pano de fundo para o estudo proposto aqui. Para Clay o "catálogo de monstros representa um anticosmo que explode toda a concepção da Teogonia" (p. 115) porque subverte o processo de individuação que perpassa todo programa do poema, já que, em vez de dar continuidade a ele, o frequente hibridismo das criaturas que o compõem mistura categorias como "divino", "humano" e "bestial" (p. 106 e 108). Embora o nascimento desses seres ocorra em uma fase relativamente inicial do cosmo, o poema conta como algumas delas são derrotadas por heróis, remetendo a narrativas que ocorrem em uma fase bem posterior na história do cosmo. Clay chama a atenção para essa operação realizada com frequência por Hesíodo na Teogonia, que ela denomina de "colapsar a cronologia", dando ao poema "uma dupla perspectiva na qual ser e vir a ser são entrelaçados”. Para ela, o catálogo também explicita essa característica.

Conquanto a leitura de Clay seja uma das mais relevantes em relação ao denominado "catálogo" e sua proposta de entendê-lo como um anticosmo seja bastante coerente com sua leitura da Teogonia como um todo, a compreensão da progênie de Fórcis e Cetó argumentada para a tese é de que ela não é em si um anticosmo, mas dá continuidade ao processo de definição do cosmo apresentando as primeiras criaturas mortais do poema bem como os primeiros animais. As categorias fundamentais para a compreensão da Teogonia, portanto, não são "deuses", "heróis" e "monstros", como a leitura de Clay (1993 e 2003) pode fazer pensar, 
mas as de "imortal" e "mortal", como nota Stoddard (2004), para quem o poeta da Teogonia, ao enfatizar a diferença entre o tempo divino e o tempo humano, enfatiza também a importância de seu papel como uma ponte entre os dois.

Não obstante a relevância da análise de Détienne e Vernant bem como a de Clay, é preciso ressaltar que eles pressupõem a categoria "monstro" a todos esses seres. Essa categoria é fundamental para a análise de Clay e é usada no título mesmo de seu artigo de 1993 (“The Generations of Monster in Hesiod”). Em Hesiod's Cosmos, sua obra de 2003, a categoria "monstro" integra a de "híbrido". No capítulo intitulado "Hybrids" (p. 150-174), tanto heróis como monstros são considerados os híbridos da poesia hesiódica: os heróis por serem resultado da união entre deuses e mortais e os monstros por frequentemente serem uma mistura de diferentes espécies de seres. Percebe-se, contudo, que há aí uma confusão entre tipos diferentes de hibridismo: os heróis são híbridos em decorrência de sua origem mista e os monstros são, por vezes, anatomicamente híbridos. ${ }^{22}$ Essa característica de hibridismo, entretanto, está ausente dos Ciclopes e dos Centímanos, que, para Clay, são monstros por ausência de uma característica anatômica que geralmente ocorre em pares, como a presença de apenas um olho nos Ciclopes, ou pelo excesso, como é o caso dos cem braços e cinquenta cabeças dos Centímanos. Tifeu, contudo, parece ser uma mistura das duas formas: ele tem cinquenta cabeças de serpente, mas apresenta braços, pés e ombros (cf. Teogonia v. 823-826), características entendidas como antropomórficas.

Fundamentalmente, para Clay, os Ciclopes, os Centímanos, Tifeu e as criaturas do catálogo são monstros por desviarem de um padrão ao mesmo tempo "teomórfico" e antropomórfico, porque, segundo ela, para Hesíodo "os seres humanos são antropomórficos porque se parecem com os deuses" (Clay, 2003, p. 17). Embora o antropomorfismo seja amiúde considerado o principal critério em geral para a categorização de um ser como "monstruoso", a delimitação de seus limites encerra enormes dificuldades, como será discutido no capítulo 6. Além disso, ele deixou de ser o único critério de monstruosidade, quando esta ganhou nuanças psicológicas e comportamentais, como discutido no capítulo 1 (p. 36-37).

Por ora, é necessário ter em mente que as análises a seguir são uma tentativa de explorar o modo como são verbalmente representadas essas criaturas tanto do ponto de vista

22 Clay, contudo, é consciente dessa distinção (1993, p. 116), que ela considera "tipos diferentes de $\mu$ íłıı": "[...] in setting the hybrid heroes against the other hybrid monsters, Hesiod calls attention to the different kinds of $\mu i \xi 1 \zeta$, the one positive and controlled, the other, destructive and disordered. As a necessary aberration, the catalogue of monsters constitutes, by way of counter-example, the most compelling argument for an ordered cosmos under Zeus' hegemony.". 
do vocabulário usado para descrevê-las como do papel que representam no interior do poema. Isso vale também para a análise das criaturas no Hino Homérico a Apolo (capítulo 4) bem como para a análise das que figuram na Odisseia (capítulo 5).

\subsection{Ciclopes e Centímanos}

É da união de Terra com seu próprio filho, Céu, que são engendradas as primeiras criaturas consideradas monstruosas da história do cosmo: os Ciclopes e os Centímanos (v. 139-153). ${ }^{23}$ Gerados com seus outros doze irmãos (v. 132-138), eles são os únicos a receber uma descrição. ${ }^{24} \mathrm{Na}$ verdade, os quinze versos que descrevem esses dois grupos (v. 139-153) contrastam com a brevidade dos seis versos (v. 133-138) que praticamente apenas nomeiam seus doze irmãos, dentre eles Crono. Esse trecho que os descreve já foi considerado, inclusive, uma interpolação em consequência de sua extensão e por causar uma impressão de interrupção no encadeamento lógico do poema: precedida pelos versos do nascimento de Crono (v. 137-138), em que é expresso o ódio que sentiu por seu pai, Céu, e sucedida pelos versos que expõem o ódio sentido por Céu contra todos os seus filhos (v. 154-156), bem como pela narrativa de castração de Céu por parte de Crono (v. 157-210), ela parece estorvar a sequência narrativa, o que levou Arthur Meyer (1887, p. 60, apud West, 1997 [1966], p. 206) a concluir que os versos 139-153 seriam uma interpolação. Além disso, os Ciclopes e os Centímanos não são libertados com a castração de Céu, como seus irmãos, mas por Zeus em momentos diferentes da narrativa. Dada a importância, contudo, que os Ciclopes e os Centímanos assumem no decorrer do poema como aliados de Zeus, a exclusão da passagem que os descreve seria inviável e incorreria no obscurecimento do texto. Assim, H. Buse (1937, p. 27-28, apud West, 1997 [1966], p. 206) propôs que Hesíodo teria concebido a narrativa da castração imediatamente após a lista dos filhos de Terra e Céu e quando chegou ao episódio da Titanomaquia, percebendo que os Ciclopes e os Centímanos não tinham sido mencionados, ele teria inserido os versos 139-153 sem perceber a dificuldade que essa inserção causara, pois a libertação dos Titãs por meio da castração de Céu libertaria também os Ciclopes e os Centímanos. Apesar de ter sido aceita por West (1997 [1966], p. 206) em seu comentário à Teogonia, já que tanto Buse quanto West pensam os poemas hesiódicos como textos concebidos na forma escrita, essa proposta pressupõe certa inépcia que não condiz com a habilidade do poeta da Teogonia (cf. Thalmann, 1984, p. 13 e Muellner, 1996, p. 77) e dá

23 Para Ciclopes e Centímanos considerados como monstros, cf., por exemplo, Clay (1993 e 2003), Vergados (2013), Felton (2013) e Pucci (2009, p. 57 e 65).

24 Cf. a passagem entre os versos 126-160 no Apêndice F. 
conta apenas da inserção dos Centímanos, não dos Ciclopes, que não participam diretamente do episódio da Titanomaquia.

Em contraposição a esse tipo de solução, e partindo da noção de que a poesia hexamétrica arcaica é primordialmente oral e, por isso mesmo, convencional, Thalmann (1984) lançou mão da noção de composição anelar para compreender e justificar a posição em que se encontra a descrição dos Ciclopes e dos Centímanos na Teogonia, revelando sua centralidade no interior de um anel, posição de destaque geralmente ocupada por algo relevante para a passagem ou para o poema como um todo. ${ }^{25}$ Desse modo, os versos dedicados ao nascimento de Crono (v. 137-138), nos quais é dito que ele odiou o pai, e aqueles em que é dito que todos os filhos de Céu foram odiados por seu pai (v. 154-156), circundam a descrição dos Ciclopes e dos Centímanos (v. 139-153), colocando-os no interior de um anel e conferindo a eles uma centralidade que encontra sua razão não no episódio imediatamente seguinte, ou seja, na castração de Céu, do qual não tomam parte, mas na importância que assumem para o programa da Teogonia como um todo, contribuindo de modo fundamental para que se instaure a soberania de Zeus. ${ }^{26}$

Quanto à sua libertação, os Ciclopes e os Centímanos serão soltos por Zeus em momentos distintos no poema. Em troca eles forjarão para ele o raio, sua arma por excelência, aquela que garantirá, em grande parte, sua supremacia (v. 501-506). Já os Centímanos serão libertados por Zeus em troca de auxílio no combate contra os Titãs, e funcionarão como a artilharia pesada de Zeus, lançando pedras contra seus próprios irmãos com seus cem braços em cada um dos três, Coto, Giges e Briareu (v. 639-675). Portanto, o nascimento dos Ciclopes e dos Centímanos no ponto em que se apresenta na Teogonia, não é uma interpolação nem fruto da inépcia do poeta, mas antecipa e ajuda a esclarecer a configuração posterior do poema (Thalmann, 1984, p. 14): ${ }^{27}$

25 A convencionalidade da poesia oral parte da necessidade de compreensão mútua entre poeta e plateia no momento da performance, e reside em grande parte em suas características formais que propiciam a repetição e a consequente fixação como, por exemplo, o metro, a construção de cenas típicas ou a utilização de temas recorrentes (cf. Thalmann, 1984, p. xiii-xiv). A técnica de composição anelar é uma dessas características formais que fazem parte da convencionalidade da poesia oral; ela consiste, grosso modo, em iniciar e terminar um trecho com a mesma informação ou com uma informação semelhante, circunscrevendo tal trecho no interior de um chamado "anel" (por isso, "composição anelar") e conferindo a ele certo destaque. Muitos dos argumentos apresentados por Thalmann (1984) contra a proposta de adição posterior da passagem dedicada aos Ciclopes e aos Centímanos foram retomados em um recente artigo por Vergados (2013).

26 Cf. a análise de Fränkel (1975, apud Rowe, 1983, p. 131-132), publicada originalmente em 1962, para quem a ascensão de Zeus ao poder é narrada por Hesíodo em três fases: a primeira é a narrativa dos Ciclopes forjando o raio para ele (v. 139-46 e 501-6); a segunda é a narrativa dos Centímanos e seu papel na Titanomaquia (v. 147-53, 617-63, 713 e ss., 734-5); e a terceira é o mito dos filhos de Estige (v. 383-403).

27 "[...] Just when Kronos is about to triumph over his father, his defeat by his own son Zeus is anticipated, both implicitly, by the mention here of Zeus's future partisans, and explicitly, by the reference in line 141 to the Kyklopes's gift of the lightning bolt to Zeus (cf. 11.504-5). Krono will pay for his deed by falling victim 
[...] Exatamente quando Crono está para triunfar sobre seu pai, sua derrota por seu próprio filho, Zeus, é antecipada, tanto implicitamente, pela menção aqui dos futuros parceiros de Zeus, quanto explicitamente, pela referência no verso 141 ao raio como presente a Zeus por parte dos Ciclopes (cf. v. 504-5). Crono pagará por seu feito sendo vítima do processo que ele mesmo iniciou [...]. Hesíodo, assim, alude ao real significado da vitória de Crono sobre Céu ao nos permitir vislumbrar as consequências finais daquele ato - não apenas a própria punição de Crono, mas o que é mais importante, a supremacia final de Zeus. Esse é o foco da Teogonia como um todo, com suas várias antecipações da vitória de Zeus. Assim, os três estágios do mito de sucessão são colocados juntos aqui, com uma prévia do resultado fornecido no início da sequência inteira.

Em consequência de sua castração por Crono, Céu chamou seus filhos de "Titãs" (v.

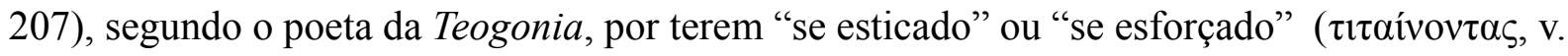

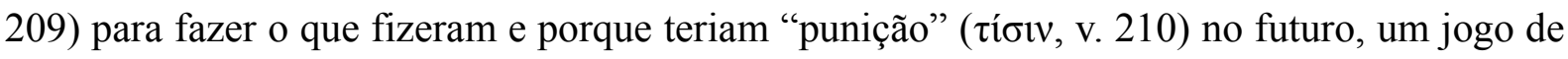
palavras que anuncia uma espécie de maldição contra eles e também funciona como uma antecipação da derrota que sofrerão sob as mãos dos deuses olímpicos e de seus irmãos, os Centímanos. ${ }^{28}$ Como os Ciclopes e os Centímanos são libertados por Zeus posteriormente no poema, é razoável supor que eles não tenham sido libertados pela castração de Céu. Sendo assim, eles não fariam parte do grupo formado por seus irmãos, os Titãs.

Uma hipótese explicativa para a não libertação dos Ciclopes e dos Centímanos no momento da castração de Céu é que apenas Zeus teria a inteligência necessária para explorar a força desses dois grupos e incorporá-los em sua ordem (Clay, 2003, p. 18, n. 16). De fato,

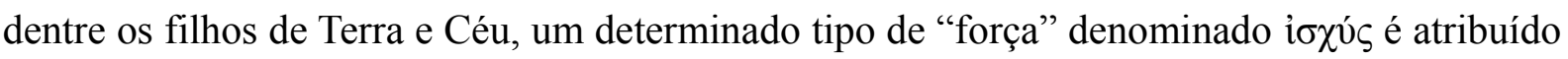
exclusivamente a esses dois grupos (v. 146 e 153). Outro argumento contra a inclusão especificamente dos Centímanos dentre os Titãs é que os três irmãos combaterão os outros doze ao lado de Zeus no episódio da Titanomaquia. Além disso, o fato de o poema atribuir nomes coletivos distintos a cada um dos grupos advoga contra a incorporação dos Ciclopes e dos Centímanos aos Titãs. Thalmann (1984, p.14) sugere que Hesíodo teria pensado os Ciclopes e os Centímanos como pertencentes a uma categoria diferente da de seus irmãos e Arrighetti (1998, p. 328) afirma que eles “[...] são apresentados como categorias um pouco à parte no complexo da prole de Céu e Terra [...]". ${ }^{29}$ Não há dúvida de que eles são

himself to the process that he is starting [...]. Hesiod thus hints at the real significance of Kronos's overthrow of Ouranos by letting us glimpse the ultimate consequences of that act - not merely Kronos's own punishment, but what is far more important, the ultimate supremacy of Zeus. That is the focus of the Theogony as a whole, with its several anticipations of Zeus's victory. Thus the three stages in the succession myth are brought together here, with a preview of the outcome given at the start of the entire sequence."

28 Sobre as (para)etimologias em Hesíodo, cf. Tsagalis (2006), p. 88-89, que as entende como uma forma de "comentário" revelador de um conhecimento que Hesíodo não teria não fosse a inspiração das Musas, indicando assim a autoridade do poeta como repositório da palavra inspirada pela divindade. Cf. adiante.

29 “[...] I Ciclopi e i Centimani sono presentati come categorie um po' a parte nel complesso della prole di Urano e Gaia [...]." 
particularizados em relação a seus irmãos, contudo, não é evidente que pertençam a uma categoria à parte ou diferente. Uma análise da descrição dos Ciclopes e dos Centímanos, de um lado, e, do outro, da ação de que tomam parte no interior da narrativa da Teogonia indica que, se de fato pertencem a uma categoria à parte, esta não é a de "monstro". Analisemos primeiro o caso dos Ciclopes.

\section{2.a) Ciclopes em foco}

No verso que introduz os Ciclopes (v. 139), nota-se a combinação de partículas $\delta$ ' $\alpha \tilde{\text { }}$ que, como demonstrado por Bonifazi (2008) em relação ao discurso homérico, apresenta uma função pragmática, ou seja, seu significado se relaciona com o contexto da enunciação em detrimento da relação semântica que possa apresentar com o enunciado em si. Tal combinação é empregada como marcador discursivo que carrega uma função visual: durante a performance, esses marcadores auxiliam o público na percepção da mudança de "foco visual" (visual shift). Essa mudança é enfatizada por partículas compostas principalmente por $\alpha \tilde{\text { e }}$, no caso de $\delta$ ' $\alpha \tilde{v}$, ela ocorre entre focos paralelos em uma sequência, conduzindo a atenção do público para sujeitos específicos, sem perder de vista o início dessa sequência.

Assim, se a proposição de Bonifazi for transposta para o discurso hesiódico, no caso dos Ciclopes (e dos Centímanos, como será visto adiante), a combinação de partículas $\delta$ ' $\alpha \tilde{\text { }}$ aponta para o paralelismo desse grupo com os demais filhos de Terra e Céu, orientando a atenção do público especificamente para esse trio, mas sem perder de vista nem a quem se emparelham fraternalmente nem sua origem genealógica. É possível perceber que essa marcada mudança de foco é acompanhada por uma descrição mais detalhada dessas figuras em detrimento dos filhos anteriores, como se esse trio recebesse um close-up por parte do poeta. Vergados (2013, p. 4, n. 9), de acordo com o que propôs Thalmann (1984, p. 14), entende esse "privilégio" dos Ciclopes (e dos Centímanos) em função do importante papel que terão posteriormente na narrativa como aliados de Zeus.

A primeira característica que o poema apresenta para os Ciclopes está na expressão

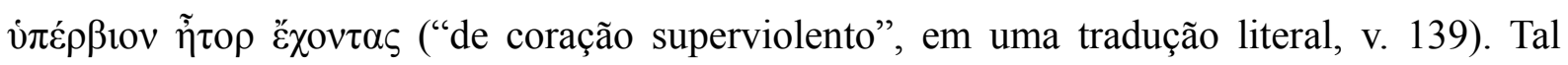
expressão é por vezes entendida como indicativa da natureza violenta dos Ciclopes: Most (2006) a traduz como "who have very violent hearts" ("que têm corações muito violentos") e Calame (1985, p. 150) afirma que os Ciclopes se caracterizam por ter sentimentos violentos. ${ }^{30}$ Uma característica frequentemente atribuída a criaturas monstruosas (mas não exclusivamente

30 Bem como pelo vigor e pela capacidade de invenção $(\mu \eta \chi \alpha v \alpha i ́)$, cf. adiante. 
a elas) é a violência ou a força extrema, que é difícil de ser contida e representa uma ameaça à vida humana (ou à divina). Essa expressão aparecerá na Teogonia apenas mais uma vez (v. 898, na mesma posição no interior do verso), mas no singular, referindo-se ao filho que Métis geraria se não tivesse sido engolida por Zeus, um possível usurpador do poder e do reino deste

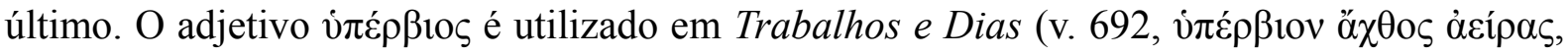
ocupando a mesma posição no interior do verso) remetendo a uma carga de tal modo excessiva que causa o rompimento do eixo de um carro.

Cunliffe apresenta a ocorrência de $\dot{\pi} \varepsilon \dot{\rho} \rho ß ı \varsigma$ na Ilíada 17.19 como um exemplo para o sentido "overweening, arrogant, wanton" ("presunçoso, arrogante, cruel”) e a ocorrência em 18.262 como exemplo para "headlong, headstrong, not to be restrained or turned aside" (“precipitado, obstinado, que não se pode restringir ou evitar"). A primeira ocorrência (Ilíada 17.19) está na resposta de Menelau a Pântoo: enquanto tenta proteger o corpo de Pátroclo da ameaça de Pântoo, que exige a primazia sobre o espólio, já que teria sido o primeiro a golpeálo, Menelau lhe diz que não é bom se vangloriar de modo vi $\pi \hat{\varepsilon} \rho \beta ı v$ (aqui o adjetivo é usado adverbialmente). A segunda ocorrência está na fala de Polidamas a Heitor; Polidamas, imediatamente após dizer que teme Aquiles, usa vi $\varepsilon$ $\rho ß ı \varsigma$ para qualificar o $\theta v \mu o ́ \varsigma$ ("ânimo") do herói. Note-se que em ambas as ocorrências o termo é usado por um personagem, não pelo narrador, o que se configura como uma expressão de "character-language" ("enunciação de personagem"), em termos narratológicos. ${ }^{31} \mathrm{Na}$ primeira passagem (17.19), v́ $\pi \varepsilon ́ \rho \beta ı \varsigma$ é usado para caracterizar um comportamento ou atitude repreensível de um guerreiro, de modo que Menelau repreende Pântoo. E, na segunda (18.262), é usado em relação a um traço ameaçador, e por isso temível, da personalidade de um herói.

Com exceção talvez de "headstrong” (“obstinado"), esses significados, contudo, não parecem ser muito adequados aos Ciclopes, já que em nenhum momento tomam qualquer ação que permita qualificá-los quer como presunçosos, arrogantes, cruéis ou precipitados. Quanto ao sentido de algo que "não se pode restringir ou evitar", o contrário pode ser considerado verdadeiro, já que permaneceram aprisionados no interior de Terra quando Crono castrou seu pai e só saíram de lá quando Zeus os libertou. ${ }^{32}$

Já o verbete apresentado pelo $L f g r E$ divide as acepções de vi $\pi \dot{\varepsilon} \rho \beta 1$ ı em duas de acordo com a classe gramatical. Para o adjetivo, oferece "übergewaltig" ("superpoderoso",

31 A enunciação do "character-language" se diferencia do "narrator-text" por expressar opiniões ou julgamentos realizados pelas personagens que o narrador homérico raramente expressa. Os conceitos da narratologia e sua aplicação à poesia épica hexamétrica, principalmente a homérica, podem ser encontrados na obra de De Jong (2004 [1987]) para a Ilíada e em De Jong (2004 [2001]) para a Odisseia.

32 Para o tema do aprisionamento, em geral, cf. a análise de Détienne e Vernant (2008 [1974]), no capítulo “Os combates de Zeus", p. 57-96. 
"superforte"); para a forma adverbial, "arrogante, ousado" (com o [falso] sentido de superforte, prepotente)". ${ }^{33}$

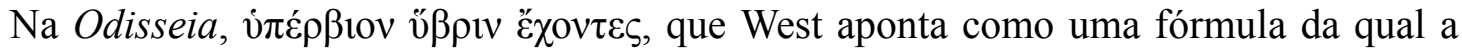
expressão hesiódica seria uma variação, é empregada para caracterizar os pretendentes de Penélope (1.368, 4.321 e 16.410). Em 1.368, Telêmaco se dirige a eles utilizando a expressão e em 4.321 a repete para caracterizá-los a Menelau. Até mesmo o narrador a emprega em 16.410. ${ }^{34}$ Jasper Griffin (1986) demonstrou que o narrador dos dois épicos homéricos evita expressar julgamentos morais acerca das ações narradas e que a expressão desses julgamentos acontece por meio das falas das personagens. Entretanto, Griffin notou que na segunda metade da Odisseia, o poeta acaba sendo mais parcial na linguagem utilizada, como sugere o

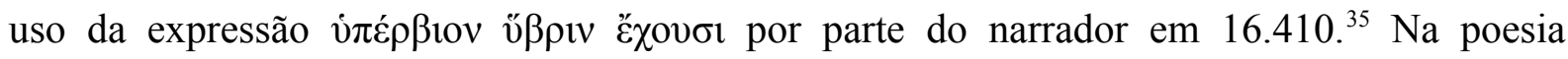
hesiódica o narrador faz um uso menos restrito de enunciações que expressam um "julgamento de valor" ("evaluative language") ou que lancem mão de termos "emotivos" ("emotional terms"), típicos de enunciação de personagem. ${ }^{36}$

À parte a expressão, vi $x$ $\rho \beta 1 o \varsigma$ é usado em relação aos pretendentes também pelo porqueiro Eumeu em sua fala a Odisseu (14.92 e 95), embora o adjetivo esteja sendo usado de modo adverbial para caracterizar a maneira em que comem e bebem. Esse uso adverbial aparecerá novamente em relação ao modo excessivo de consumir dos pretendentes na fala de Telêmaco a Odisseu (16.315). Ele também aparecerá na fala do deus Hélio Hipérion (12.379) a Zeus para caracterizar o assassinato de suas vacas por parte dos companheiros de Odisseu.

Apesar dessa predominância do uso do adjetivo para caracterizar os pretendentes ou seu modo de agir, o ânimo $(\theta v \mu o ́ \varsigma)$ do velho Nestor também é caracterizado por v́ $\pi \varepsilon ́ p \beta 1 o \varsigma$ na Odisseia (15.212), exatamente como o de Aquiles na Ilíada $18.262 .{ }^{37}$

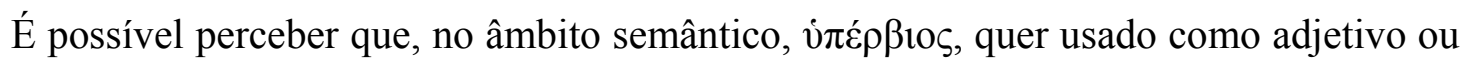
como advérbio, parece expressar em geral e com mais frequência um caráter intenso ou

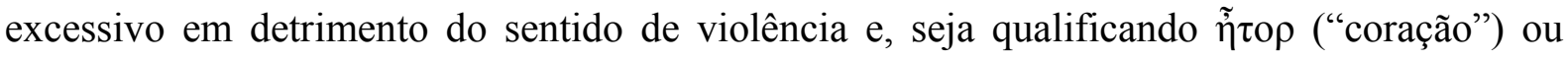
$\theta v \mu$ ó ("ânimo"), não expressa uma característica que se restrinja a um ser que

33 LfgrE: “'mit dem [trügerischen] Gefühl von Überstärke', 'präpotent': überheblich, vermessen”. O verbete vं $\pi \dot{\varepsilon} \rho \beta 1$ so é de autoria de V. Langholf.

34 Com uma pequena modificação na forma verbal, que passa da forma participial para o indicativo presente na

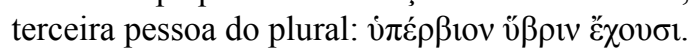

35 De Jong observa que esse uso daquilo que é típico da enunciação de personagem por parte do narrador tem como consequência o aumento do pathos (cf. De Jong 2004 [2001], p. 145).

36 Cf. Rengakos, em Montanari, Rengakos e Tsagali (2009), p. 211-212; e Nünlist em De Jong, Nünlist e Bowie (2004), p. 29.

37 Esses dois versos (Ilíada 18.262 e Odisseia 15.212), que se referem a Aquiles e a Nestor respectivamente,

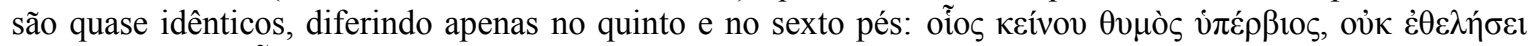

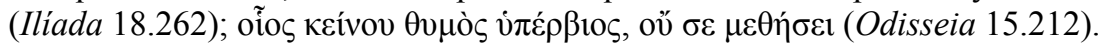


consideraríamos monstruoso, já que tanto o herói Aquiles e até mesmo o velho Nestor na Odisseia são ditos possuírem um $\theta v \mu$ ò

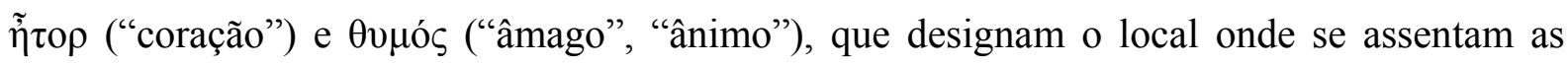
emoções e podem ser entendidos como sinônimos nas situações apresentadas acima, o adjetivo em questão revela uma característica que os Ciclopes da Teogonia teriam em comum com Aquiles na opinião de Polidamas e com Nestor na opinião de seu próprio filho. No caso

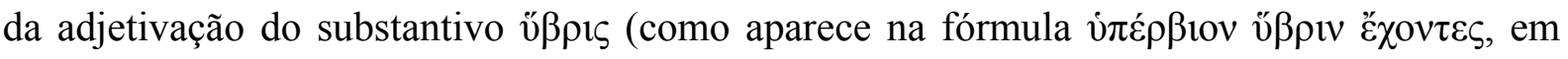
Odisseia 1.368, 4.321 e 16.410), que designa ele próprio a desmesura dos pretendentes, o adjetivo vi $x \varepsilon \beta 1 o \zeta$ acentuaria ainda mais o sentido de excesso já contido no substantivo.

Se pensarmos em termos de referencialidade, e considerarmos a fórmula vi $\pi \varepsilon ́ p \beta 10 v$

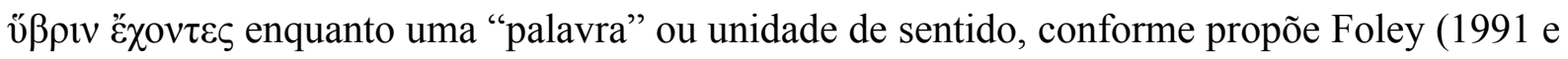

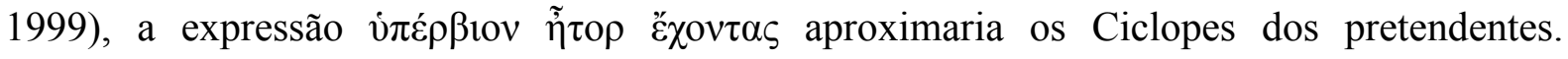

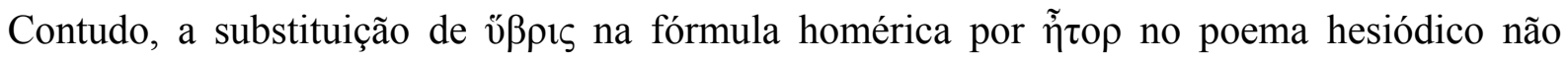
parece ser fortuita: como ű $\beta \rho ı \varsigma$ denota excesso, uma característica enfatizada ou amplificada pelo adjetivo $\dot{\pi} \varepsilon \dot{\rho} \beta 10 \varsigma$ na fórmula homérica, é possível que o poeta da Teogonia tenha operado a substituição exatamente por não atribuir aos Ciclopes a mesma característica dos pretendentes de Penélope na Odisseia.

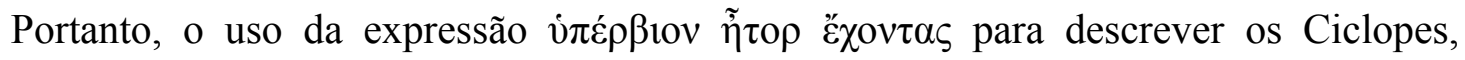
diferente do que geralmente se interpreta, não implica necessariamente uma disposição violenta ou para a violência por parte deles, uma interpretação muito literal de vi $\varepsilon_{\varepsilon} \beta \beta 1$ ov, por ser composto do termo ßín, que é um tipo de força (cf. adiante) geralmente traduzida por "violência". Ela também não revela uma característica que seja suficiente para classificá-los como monstruosos ou mesmo para indicar um traço monstruoso de sua personalidade. Mais do que com a v̋ßpis dos pretendentes e do que com o modo excessivo com o qual eles

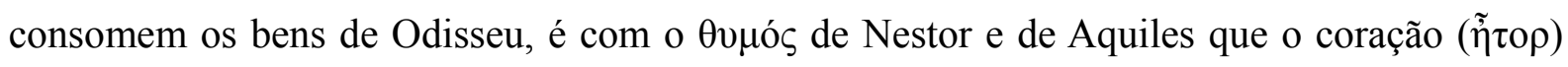
dos Ciclopes é comparável: o ânimo resoluto e forte que Heitor atribui a Aquiles dizendo que o teme, já que o herói mirmidão ao retornar à batalha há de combater com todo o ímpeto, e o ânimo de Nestor que seu próprio filho lhe atribui ao dizer a Telêmaco que o ancião não o deixaria partir sem antes recebê-lo em casa.

O verso 140, seguinte ao que caracteriza os Ciclopes como vं $\pi \varepsilon \rho \beta 10 v \tilde{\eta} \tau o \rho ~ \varepsilon ้ \chi o v \tau \alpha \varsigma$

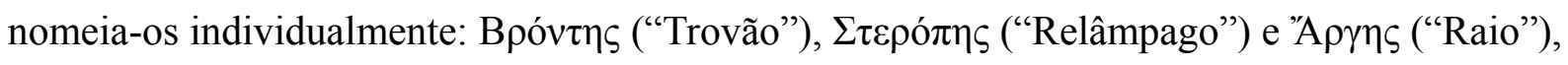
cada um deles remetendo a um aspecto do fenômeno que será a arma de Zeus forjada por eles próprios - respectivamente, o que se ouve (derivado de $\beta \rho \varepsilon ́ \mu \omega$, "rugir", cf. Beeks, 2010, p.

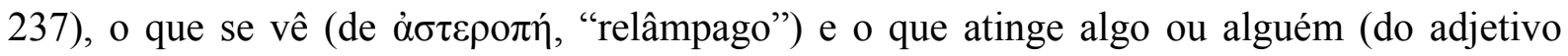




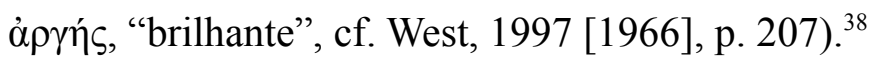

Raio, o aspecto tátil, recebe ainda um adjetivo, ỏ $\beta \rho \mu o ́ \theta v \mu o \zeta$, literalmente, de "ânimo

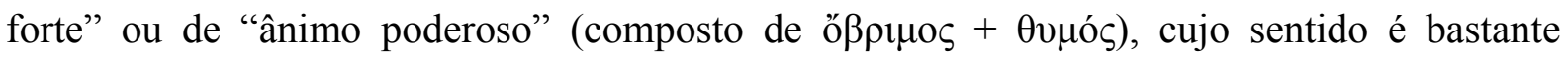

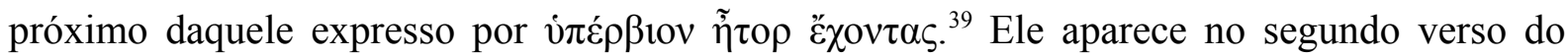
Hino Homérico a Ares (h.Hom.8), referindo-se a essa divindade (observe-se a semelhança

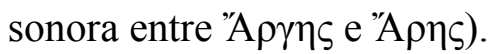

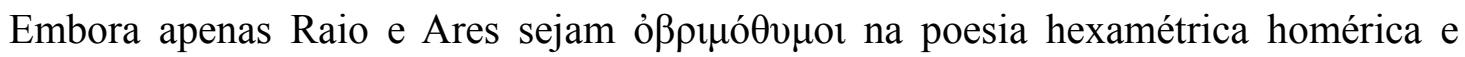

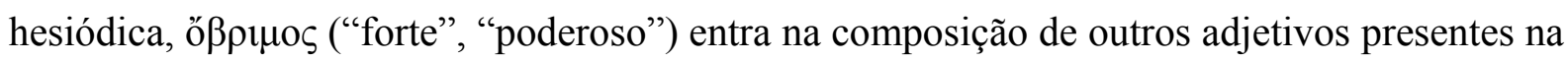
Teogonia, um deles remetendo ao próprio Zeus: o epíteto ỏ $\rho \mu$ но $\alpha \dot{\tau} \tau \eta$ (composto de ő $\beta \rho \mu о \varsigma$ $+\pi \alpha \tau \eta ́ p)$, literalmente "de pai forte" ou "de pai poderoso", que é atribuído à deusa Atena na Teogonia (v. 587), conferindo também a Zeus a característica expressa pelo adjetivo őßpıos. Esse epíteto da deusa também ocorre na Ilíada (5.747 e 8.391) e na Odisseia $(1.101 ; 3.135$ e 24.540), predominantemente na enunciação do narrador. ${ }^{40}$

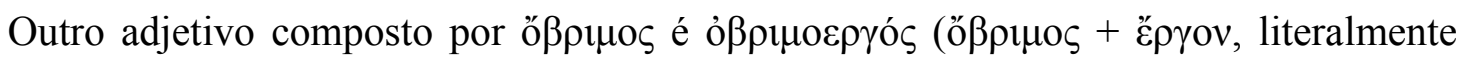
“ação/trabalho forte/poderoso"), usado no verso 996 da Teogonia para se referir a Pélias, rei

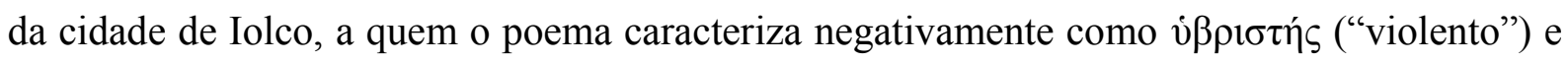

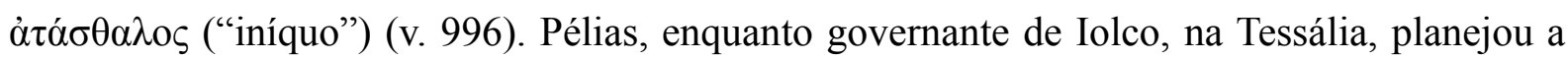
expedição em busca do velo de ouro para se livrar de Jasão e de sua reivindicação ao trono. O adjetivo também ocorre na Ilíada (5.403), em uma fala de Dione a Afrodite na qual

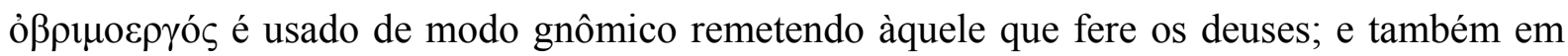
22.418, em uma fala de Príamo para se referir a Aquiles no momento em que o rei anuncia aos troianos sua resolução de ir ao acampamento aqueu com a finalidade de recuperar o corpo de

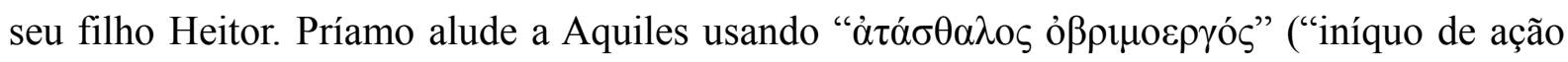
poderosa"), dois dos termos usados na Teogonia para se referir a Pélias. ${ }^{41}$ Em todas essas

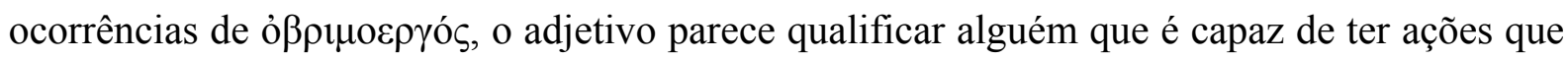
produzem efeitos consideráveis, por isso elas são "fortes" ou "poderosas". Essa noção de força e de poder também está presente no uso adverbial de ő $\beta \rho \mu \rho \varsigma$, no verso 839 da

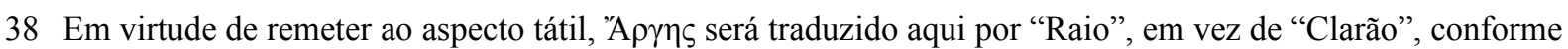
vertido por Werner (2013), conquanto a tradução de Werner possa ser mais exata, já que o nome do Ciclope

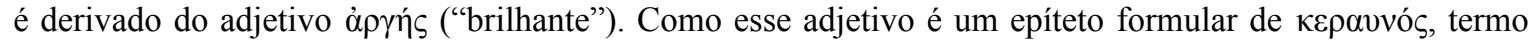
frequentemente usado para o raio na Teogonia (504-505, 690-691, 707, 845-846) (cf. West (1997 [1966], p. 207), talvez não seja equivocado tomá-lo por "raio".

39 Essa é a única ocorrência desse adjetivo na Teogonia, se desconsiderarmos o verso 501a, adicionado por Merkelbach, que é idêntico ao 140 (apud West, 1997 [1966], p. 304); não há ocorrência em Trabalhos e Dias, nem nos épicos homéricos.

40 Com exceção de $O d .3 .135$, que está em uma fala de Nestor a Telêmaco.

41 Os dois adjetivos aparecem compondo o segundo hemistíquio tanto na Teogonia (v. 996) quanto na Ilíada

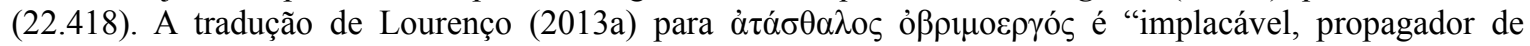
violência". 


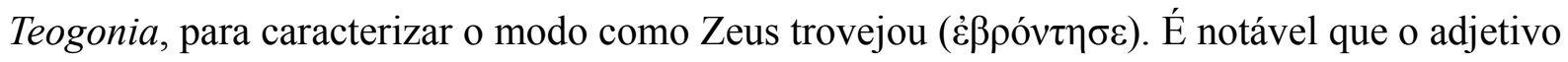

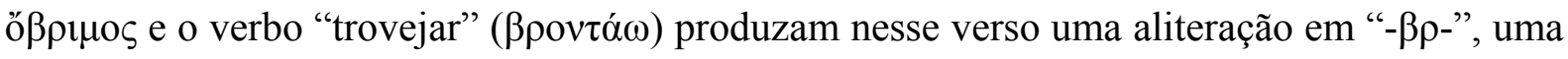

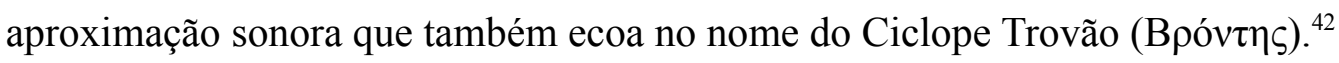

O adjetivo ő $\beta \rho \mu$ s pode ainda revelar uma relação mais estreita do que parece haver inicialmente entre Zeus, Ares e os Ciclopes, especificamente o Raio ('A $\rho \gamma \eta \varsigma$ ). A proximidade

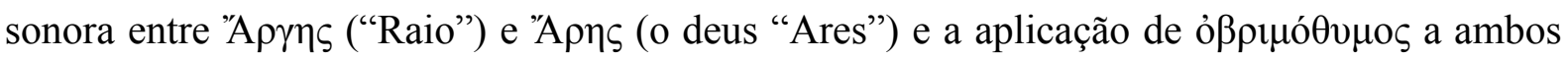
talvez indiquem uma possível associação semântica entre as duas figuras. Na Ilíada, o adjetivo őßpıнऽ é um epíteto formular para Ares $(5.845 ; 13.444$ e 521; 15.112; 16.613; 17.529), usado predominantemente na enunciação do narrador, com exceção de 15.112, que ocorre na enunciação da deusa Hera, mas também o é para a lança, ह̌ $\gamma \chi o \varsigma ~(3.357 ; 5.790$; $7.251 ; 11.435$ e 456; 13.294, 519 e 532; 14.451 e 498; 20.259 e 267). Como arma de guerra, a lança tem uma relação de grande proximidade com o deus Ares, que na Ilíada é expressa por

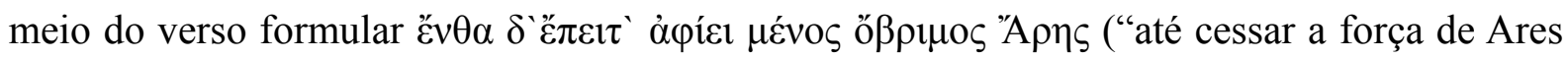
poderoso", que ocorre em 13.444, 16.613 e 17.529), remetendo à contínua vibração da lança ao atingir seu alvo ou ao fincar-se no solo até que cesse a força do deus Ares nela contida. A lança, como arma de arremesso, guarda semelhanças tanto em sua forma como em seu modo de utilização com o raio, a arma de Zeus por excelência, cujo aspecto tátil (que remete ao

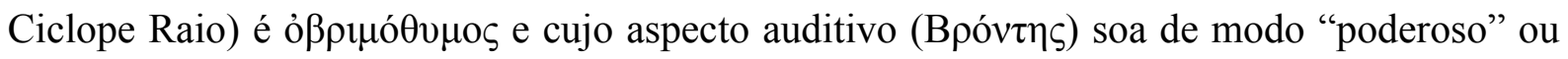
“forte" (ő $\beta \rho \mu \nu v)$, sem mencionar que o próprio Zeus é caracterizado como ő $\beta \rho \mu o \varsigma$ por meio

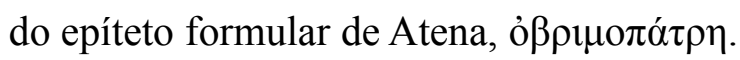

No âmbito heroico, Heitor é o único mortal que recebe esse adjetivo com certa frequência (Ilíada 8.473; 10.200; 11.347; 14.44); Aquiles o recebe uma única vez, em 19.408, na fala de seu cavalo Xanto, provocada por Hera. Entretanto, de modo oposto ao que acontece com as ocorrências relativas a Ares, a maior parte daquelas que se referem a Heitor está em enunciação de personagem (8.473 está na fala de Zeus a Hera; 11.347 na fala de Diomedes a Odisseu; e 14.44 na fala de Agamêmnon a Nestor; 10.200 é a única exceção). Ao colocar na fala das personagens, humanas ou divinas, uma atribuição a Heitor de uma característica que o narrador sabe ser um epíteto formular para Ares, ele acaba por aproximar o herói troiano do deus Ares, a divindade que está intimamente relacionada à carnificina guerreira. Heitor mata

$42 \mathrm{Na}$ Teogonia, őßpıо s será usado apenas mais uma vez, para adjetivar os Centímanos, irmãos dos Ciclopes,

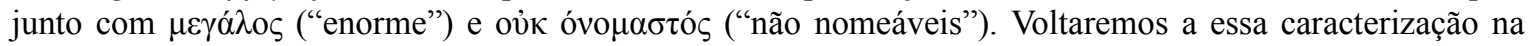
seção dedicada aos Centímanos. Será deixada para a mesma seção uma das duas ocorrências de ö $\beta \rho \mu$ o Trabalhos e Dias (v. 145), já que esta se refere à raça de bronze, à qual se atribuem semelhanças com os Centímanos (como já notara Clay, 2003, p. 91 e 107). Na outra ocorrência de őßpuos em Trabalhos e Dias

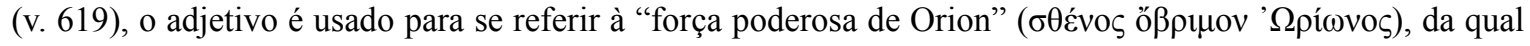
as Plêiades fogem. 
muitos heróis nas batalhas, sendo o guerreiro mais poderoso do lado troiano, mas não necessariamente o mais violento ou cruel.

Como o adjetivo vizépß1os, que aparece em Trabalhos e Dias (v. 692) para qualificar uma carga como excessiva, őßpıн também é usado para caracterizar o mesmo substantivo (ä $\chi 0$ o $\varsigma$ ), mas na Odisseia (9.233). Na verdade, ö $\beta \rho \mu о \varsigma$ ocorre apenas três vezes nesse poema e em todas elas relacionado ao episódio de Polifemo, mas não à sua figura. Além da

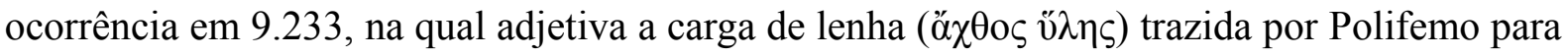
preparar o jantar, as outras duas (em 9.241 e 9.305) se referem à pedra ( $\theta 0 \rho \varepsilon o ́ \varsigma$ e $\lambda i ́ \theta o \zeta$, respectivamente) que cobre a entrada da caverna de Polifemo. ${ }^{43}$ Nessas ocorrências, os sentidos de "forte" e de "poderoso" talvez não se encaixem perfeitamente à carga de lenha ou à pedra, mas é possível inferir que o adjetivo se relaciona à dimensão ou ao volume descomunal de ambos, necessitando grande força para serem movidos ou transportados, uma força que, sabemos, Odisseu não possui, já que ele não conseguirá mover a pedra da entrada da caverna de Polifemo. Em uma ocorrência na Ilíada (4.453), tanto o sentido de "forte" ou "poderoso" quanto o de "grande volume" podem estar expressos: ő $\beta \mu \mu$ o qualifica a água (v̌ $\delta \omega \rho)$ no momento de um degelo, quando ela desce as montanhas atingindo um vale e causando estrondo (v. 452-456), um símile para o sangue e o barulho decorrentes da batalha (v. 446-449). ${ }^{44}$

É possível perceber, portanto, que ő $\beta \rho \mu o \varsigma$ é um adjetivo relacionado à força, ao ímpeto: de Ares, de Zeus, de Heitor, da lança que não cessa de balançar, da água do degelo que desce as montanhas. Expressa, ainda, a robustez ou um grande volume: da água do degelo, da carga de lenha e da pedra de Polifemo. Assim, o Ciclope Raio, o aspecto tátil, ou seja, fulminante, da arma de Zeus, possui um $\theta v \mu$ ó ("ânimo") forte como o $\theta 0 \mu$ ó do deus $^{\circ}$ Ares, que, por sua vez, faz muitas vítimas no campo de batalha. Essa característica expressa

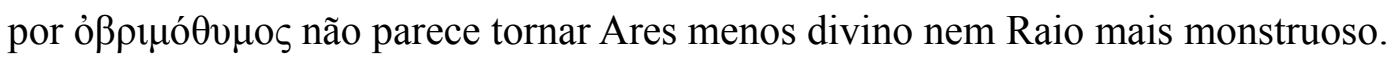

Como observado por Thalmann (1984, p. 14, cf. supra), ao informar que foram os

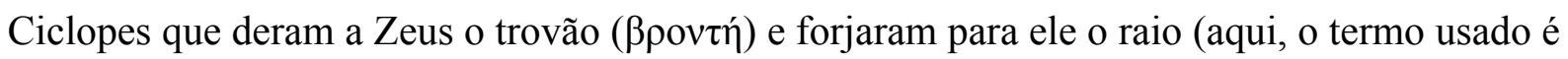

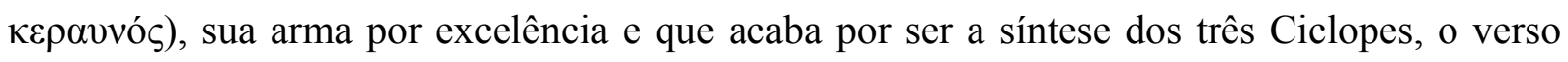
141 é uma antecipação não apenas da confecção do raio e da incorporação dos Ciclopes à ordem de Zeus, mas da própria supremacia final do filho de Crono. A importância dos Ciclopes para o estabelecimento do poder de Zeus é tão fundamental que, ao nascer (v. 453-

$43 \mathrm{Na}$ Ilíada, ő $\beta \rho \mu$ os está sempre compondo o dáctilo do quinto pé. Na Odisseia, ő $\beta \rho \mu o \varsigma$ varia entre o quinto pé (9.233), o primeiro (9.241), constituindo enjambement com o verso anterior, e o quarto (9.305).

44 Todas as ocorrências na Odisseia estão na narrativa tecida por Odisseu aos feácios, diferentemente da passagem da Ilíada, que está em um símile enunciado pelo narrador. 
506), além do embuste que leva Crono a vomitar todos os filhos, Zeus toma duas ações: cravar a pedra vomitada por Cronos em Delfos (v. 488-500) e libertar seus tios paternos (v. 501-505), os Ciclopes, que, em troca dessa ação benéfica, confeccionam para ele o raio.

Nessa passagem de resgate ou libertação dos Ciclopes (v. 501-505, cf.

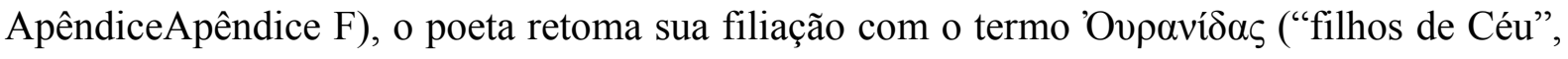
v. 502), lembrando não apenas sua ascendência direta, mas o momento da história do cosmo no qual nasceram, e acrescenta que o pai os aprisionou "por conta de cego juízo"

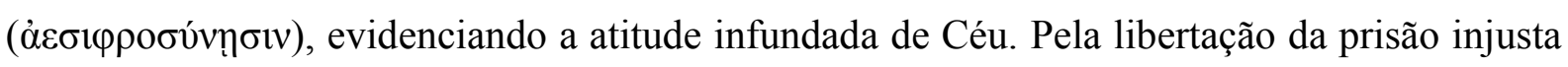
à qual lhes acometeu o pai, eles deram a Zeus o raio, aqui lembrado em seus três aspectos, embora o vocabulário se diferencie um pouco dos nomes individuais dos Ciclopes: [...]

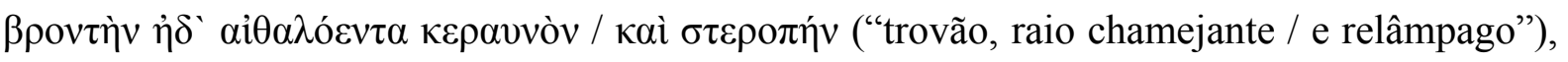
aspectos da arma de Zeus e dos próprios Ciclopes que estavam até então encobertos por Terra (v. 504-505), o que sugere sua permanência no interior da deusa, sem que tivessem sido libertados pela castração de Céu. ${ }^{45}$

O último verso dessa passagem (v. 506) conclui com a importância fundamental que os Ciclopes assumem para a ordem de Zeus, que, "com o apoio deles, rege sobre mortais e

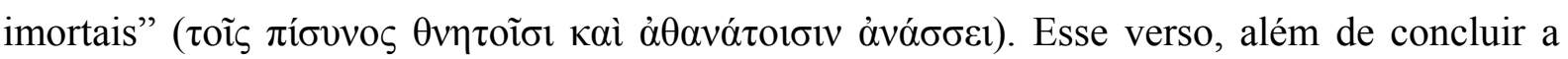
passagem da libertação dos Ciclopes, antecipa, com a menção aos mortais, o episódio que virá a seguir no poema: o de Prometeu, que roubará o fogo de Zeus em nosso benefício.

Imediatamente após sua associação com Zeus, no verso 141, por intermédio da arma que forjam para ele, o poeta informa que os Ciclopes eram semelhantes aos deuses em todas as outras coisas exceto por uma característica (v. 142-145): possuírem um único olho na

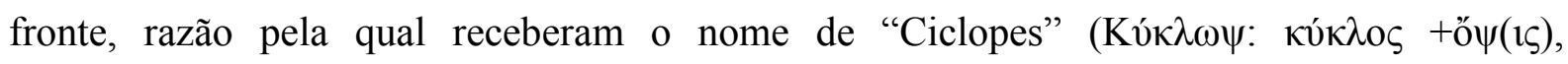
literalmente, "olho circular"), e é certamente em virtude dela que os Ciclopes são percebidos como figuras monstruosas. Todavia, se eles se diferenciam dos deuses somente sob esse aspecto (cf. v. 142), conclui-se, portanto, que sejam imortais como as demais divindades (cf.

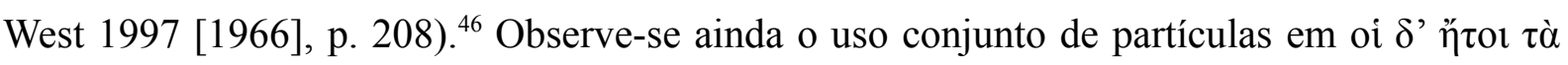

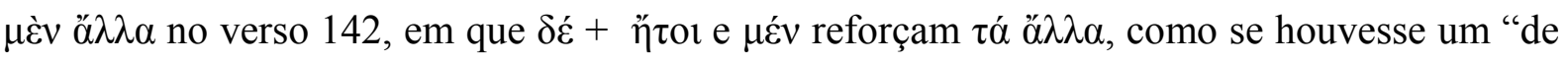
fato" antes de "nas outras coisas", enfatizando a semelhança entre os Ciclopes e os deuses.

45 Esse aspecto da libertação dos Ciclopes por Zeus também é explorado por Détienne e Vernant (2008 [1974]) em seu capítulo sobre os combates de Zeus para atingir a supremacia sobre o cosmo.

46 Contudo, o escólio ao verso 142 afirma que Crates de Mallos aponta um trecho do Catálogo das Mulheres em que é relatado que os Ciclopes foram mortos por Apolo em retaliação pela morte de Asclépio e, portanto, não poderiam ser imortais como os deuses (fr. 52 de M.-W.). Essa afirmação, entretanto, coloca mais questões para a genuinidade do Catálogo como obra de Hesíodo do que suscita dúvidas sobre o caráter imortal dos Ciclopes na Teogonia. Cf. as hipóteses e as implicações dessa afirmação de Crates para o Catálogo no capítulo de D'Alessio em Hunter (2005), p. 209 e ss. 
O poeta oferece em seguida uma explicação ou etimologia do nome "Ciclope": "Ciclopes era seu nome epônimo, porque deles / circular o olho, um só, que na fronte jazia"

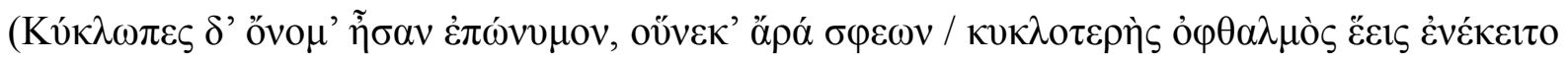

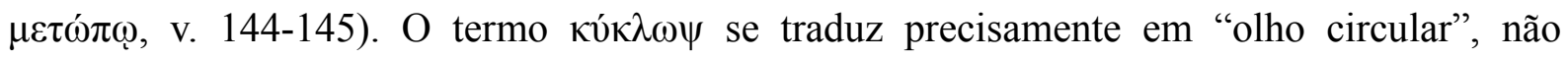
remetendo ao número mas à forma do olho; a unicidade desse órgão, entretanto, é claramente expressa tanto no verso 143 quanto no 145. Essa repetição da mesma informação em versos tão próximos encontra paralelos no restante do poema (cf. 65 e 67, por exemplo) e, dado que ambos os versos expressam a singularidade dos Ciclopes em relação aos demais deuses, tal repetição talvez cumpra um propósito de enfatizar tal especificidade. Tsagalis (2006, p. 88-89) apresenta uma compreensão enriquecedora da (para)etimologização em Hesíodo enquanto um dos recursos que confere a autoridade do conhecimento inspirado pela Musas. Para ele ${ }^{47}$

[...] Em composição oral diante de um público em tempo real, nomes simplesmente não funcionam como um texto escrito. Ao relembrar criaturas do passado ou evocar criaturas de um tempo e um lugar não humano para o tempo e o lugar do presente, o narrador os torna realidades tangíveis no momento mesmo da performance de seu canto. Sob essa perspectiva, etimologizar reforça a existência deles no presente da performance. O poeta mostra a seu público que "sua" versão teogônica da criação do mundo divino é a que tem mais autoridade, pois não se refere simplesmente a alguns deuses ou criaturas semidivinas, mas reaviva por intermédio da língua partes integrantes da existência e da forma deles. Quando o público ouve que os Ciclopes adquiriram seu nome por causa de um enorme e redondo olho em sua testa (Th. 144-

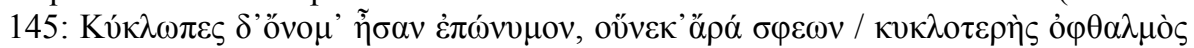

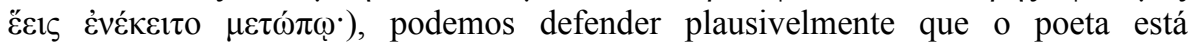
mostrando a seus ouvintes não apenas sua habilidade de se referir aos Ciclopes, mas também que ele é consciente da conexão inquebrável entre a língua e o significado, já que o nome Ciclope é um ícone na diç̧ão de uma característica anatômica dos Ciclopes, seu olho redondo. Não é necessário dizer que a imagem mental de um enorme gigante com um olho redondo na testa viria facilmente à mente do público, que apreciaria a habilidade do poeta de fazê-los visualizar o conteúdo de sua narrativa.

Portanto, a (para)etimologização em Hesíodo não encontra sua importância no fato de ser precisa ou verdadeira. A chave de sua compreensão está na capacidade de fazer com que o

47 " [...] In oral composition in front of a real-time audience, names do not simply function as a written text. By recalling creatures of the past or summoning creatures of a non-human time and place in present time and place, the narrator makes them tangible realities at the very moment of the performance of his song. Under this scope, etymologizing reinforces their existence in the present of the performance. The singer shows to his audience that 'his' theogonic version of the creation of the divine world is the most authoritative, since it does not simply refer to some gods or semi-divine creatures but revives through language integral parts of their existence and shape. When the audience hears that the Cyclopes had acquired their name because of a

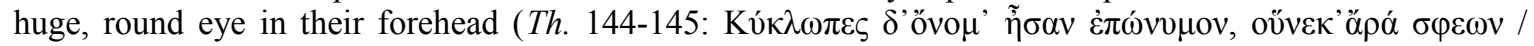

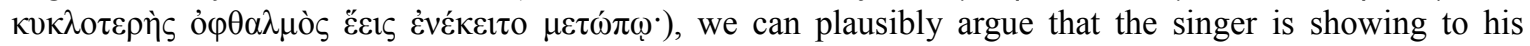
listeners not only his ability to refer to the Cyclopes, but also that he is aware of the unbreakable link between language and meaning, since the name Cyclops is a dictional icon of an anatomic characteristic of the Cyclopes, their round eye. Needless to say, the mental image of a huge giant with a round eye in the forehead would easily come to the audience's mind, who would appreciate the singer's ability to make them visualize the content of his narrative." 
poeta as transforme em "realidades tangíveis no momento mesmo da performance de seu canto", em um processo que estabelece uma ligação entre significante e significado que traz à mente do público a visualização do conteúdo da sua narrativa.

O último verso da passagem em 139-146, concernente aos Ciclopes, refere-se ao modo como executavam seu trabalho, que certamente tem como produto principal o raio de Zeus:

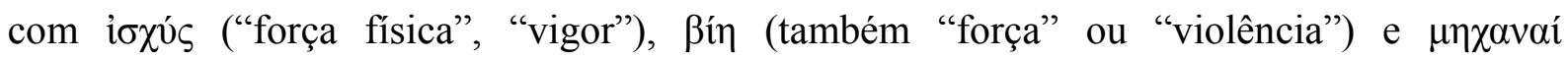
(“engenho"). ${ }^{48} \mathrm{O}$ substantivo i̇ $\chi v ́ \varsigma$, que designa força física, é atribuído somente aos Ciclopes, aos Centímanos (v. 153) e a Tifeu (v. 823) no poema, as criaturas ditas monstruosas que se encontram fora do denominado catálogo de monstros (Clay, 1993, p. 106 e 2003, p. 151) e que representam papéis fundamentais para a ordem de Zeus, quer como aliados (Ciclopes e Centímanos) quer como inimigo (Tifeu). O substantivo ßín também designa força

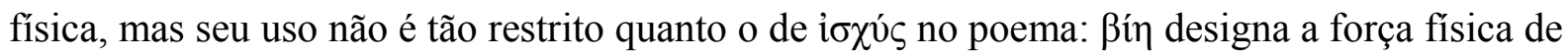
Héracles em 289, 315, 332, 943 e 982; é personificada como uma divindade em 385; designa a força de Hécate em 437, de Zeus em 490, 496 e 689, dos Centímanos em 649, 670, dos combatentes de ambos os lados da Titanomaquia em 677 e dos deuses todos que lutaram contra os Titãs em 882 .

Segundo Chantraine, em seu dicionário etimológico, i $\sigma \chi v ́ \varsigma$ designa força física, assim como ßín, entretanto, este último também designa violência e se distingue de outros substantivos que designam força porque exprime uma violência desejada, consciente, voluntária. Portanto, no que concerne aos Ciclopes, eles executam seu trabalho com ambos os tipos de força física, tanto aquela expressa por i $\chi \chi u ́ s$, significando talvez um tipo de força bruta, quanto aquela expressa por ßín, uma força mais consciente e controlada. Além delas, em seus feitos ou trabalhos havia $\mu \eta \chi \alpha v \alpha i ́$ ("artifícios", "recursos" ou "engenho"), característica atribuída unicamente a eles no poema (mais precisamente a suas ações) e que os contrasta com criaturas como Équidna (v. 295), seu filho Cérbero (v. 310) e Pandora (v. 589), todos referidos como $\alpha \mu \eta ́ \chi \alpha \nu$ os. Também adjetivado como $\alpha \mu \eta ́ \chi \alpha \nu o \varsigma$ é o possível feito de Tifeu (v. 836), caso tivesse se tornado governante no lugar de Zeus. ${ }^{49}$

Vergados (2013, p. 5-6) aponta que a existência de algumas peculiaridades linguísticas nessa passagem que descreve os Ciclopes, como o alongado ह̌દı (v. 145), o uso do incomum

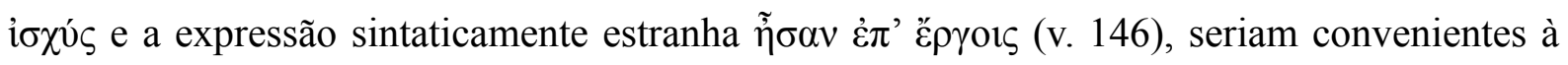

48 Os substantivos i̇ $\chi \dot{\zeta} \varsigma$ e $\mu \eta \chi \alpha v \eta ́$ não são encontrados nos poemas homéricos.

49 Diferentemente da maioria dos adjetivos com alfa privativo, $\dot{\alpha} \mu \eta$ ๆ $\chi$ ovo não exprime uma negação direta ou ausência da característica expressa pelo substantivo $\mu \eta \chi \alpha v \eta ́$. Richard Martin (1983) fez um estudo dos sentidos de $\dot{\alpha} \mu \eta \chi_{\chi} \alpha v o \varsigma$, dentre eles o de helplessness ("impotência", "desamparo") e o de impossible to be dealt with ("impossível de se lidar"). Esse adjetivo será mais bem explorado na seção dedicada às criaturas que são caracterizadas por ele. 
aparência dessas figuras que são "extremely odd-looking monsters" ("monstros de aparência extremamente estranha") e que, portanto, o uso dessas peculiaridades linguísticas não seria acidental por parte do poeta, que transfere para a linguagem a estranheza contida nas próprias criaturas. De fato, essa conveniência entre a forma e o conteúdo talvez tenha a função de chamar a atenção para a aparência singular que essas figuras apresentam. Entretanto, é necessário lembrar que o poema os considera semelhantes aos deuses em tudo, exceto pela unicidade de seu olho, desafiando a noção de "monstro" expressa por Vergados. ${ }^{50}$

Apesar dessas peculiaridades linguísticas apontadas por Vergados, há muito pouco na caracterização dos Ciclopes que não possa ser relacionado a uma divindade ou a um herói: talvez a força denominada iَðús, com a qual executam seus trabalhos e que compartilham apenas com seus irmãos Centímanos e seu meio-irmão Tifeu (v. 153, 823 respectivamente).

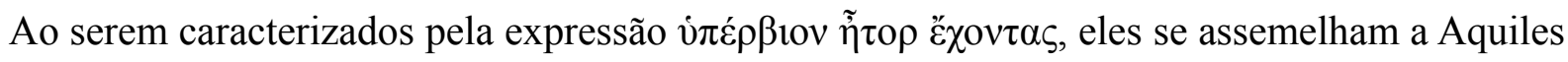

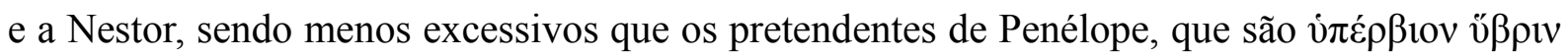

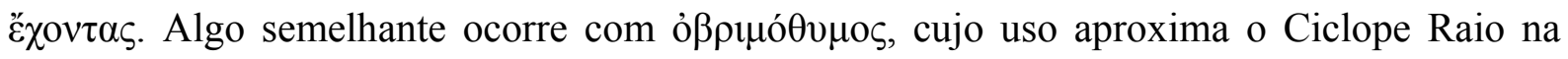
Teogonia do deus Ares no Hino Homérico a Ares (h.Hom.8). Ademais, os Ciclopes são os responsáveis por confeccionar a arma que garantirá a supremacia de Zeus sobre o cosmo. Fruto de sua gratidão a Zeus, por terem sido libertados da prisão a que o pai lhes condenou irrefletidamente (v. 501-502), a arma mais poderosa do cosmo deve ser confeccionada por divindades também poderosas, que conseguem aplicar a força e o engenho necessários para produzi-la. Enfim, os Ciclopes, com exceção da característica que lhes dá o nome, são semelhantes aos deuses em tudo, como o poema deixa claro (v. 142), portanto, acredita-se aqui que devam ser compreendidos como tais. ${ }^{51}$

\section{2.b) Centímanos em foco}

Como os Ciclopes, os Centímanos também compõem uma tríade de filhos de Terra e Céu que não será libertada pela castração deste por parte de Crono. Contudo, enquanto os

50 Em seu artigo, Vergados está levando em consideração não somente os Ciclopes mas também os Centímanos como "monstros de aparência extremamente estranha".

51 Um escólio ao verso 139 da Teogonia afirma que Helânico (c. 490-405 a.C.) distinguia "[...] três raças de Ciclopes: aqueles que fortificaram Micenas, os da raça de Polifemo e os deuses eles próprios" ("[...]

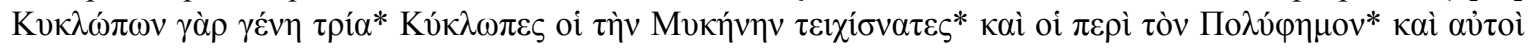
oi $\theta \varepsilon o$ í." (FGrH4 F 88)). A associação dos Ciclopes com Hefesto encontra sua fonte mais antiga em Calímaco (Hino 3, 36-86) e provavelmente decorre da atividade metalúrgica que têm em comum. A representação iconográfica dos três Ciclopes à forja não é atestada até o século I d.C. e se restringe à arte romana, na qual os Ciclopes não têm uma existência autônoma, mas são auxiliares de Vulcano (a versão romana de Hefesto) na confecção do raio de Zeus, e também das armas de Aquiles e das correntes que prendem Prometeu (cf. o verbete Kyklops, elaborado por Odette Touchefeu-Meynier, em LIMC, VI-1, p. 154-159; para as pranchas, ver LIMC, VI-2, p. 70-75). 
Ciclopes são libertados somente por Zeus em iniciativa própria, os Centímanos o serão por Zeus e seus irmãos em virtude de um conselho de Terra. A descrição dessa tríade segue imediatamente a dos Ciclopes, estando as duas circunscritas no interior de um anel (cf. supra a análise para a passagem referente aos Ciclopes), posição que reflete a importância que terão para a vitória de Zeus no poema: os Ciclopes como forjadores do raio e os Centímanos como a artilharia contra os Titãs no episódio da Titanomaquia.

Da mesma forma que seus irmãos Ciclopes, os Centímanos são introduzidos pela partícula $\delta^{\prime} \alpha \tilde{~(v . ~ 147), ~ c u j a ~ f u n c ̧ a ̃ o ~ p r a g m a ́ t i c a ~(c o m o ~ m a r c a d o r ~ d i s c u r s i v o ~ d a ~ m u d a n c ̧ a ~ d e ~}$ foco visual entre elementos paralelos em uma sequência, sem perder de vista seu início) indica o paralelismo com seus irmãos Titãs e Ciclopes, em uma sequência contínua de filhos de Terra e Céu. Também como no caso dos Ciclopes, os Centímanos receberão um close-up por parte do poeta, reforçando o paralelismo com os Ciclopes em relação ao papel instrumental que terão para a supremacia de Zeus.

Enquanto sabemos que os Ciclopes são um conjunto de três filhos por conta da nomeação individual que recebem, para os Centímanos o poema explicita seu número (v. 148). Na verdade, essa enumeração não é a única que ocorre na passagem dos Centímanos, já que o poema também revela o grande número de braços e de cabeças que apresentam (v. 150151). Também de modo diferente do que foi composto para os Ciclopes, para quem o segundo verso da respectiva descrição atribui um adjetivo a apenas um deles, o Raio, os Centímanos

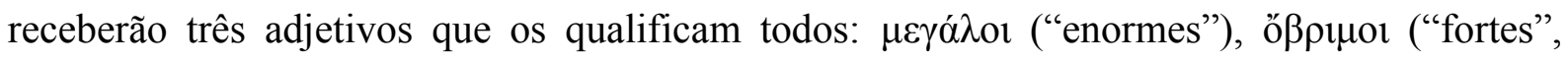
"poderosos", ou "brutais", em um sentido derivado que também valeria para a análise feita

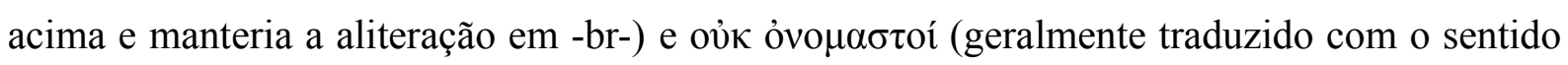
de "não nomeáveis", “que não devem ser nomeados ou mencionados").

Embora nada tenha sido dito da dimensão física dos Ciclopes, os Centímanos são “enormes" ( $\mu \varepsilon \gamma \alpha \dot{\lambda} \mathrm{ol})$, característica que lhes será novamente atribuída nessa mesma passagem (v. 153, no caso dativo). Conquanto o adjetivo $\mu \varepsilon_{\gamma} \alpha \varsigma$ seja bastante usual para qualificar quer substantivos comuns ou próprios, essa repetição em um número pequeno de versos reitera a característica que ele expressa, possivelmente ressaltando sua relevância, já que é um dos motivos pelos quais os Centímanos são odiados e aprisionados por seu pai Céu (v. 617-620).

Além de enormes, os Centímanos são őßpurol, adjetivo que foi explorado anteriormente e que está relacionado à força, à impetuosidade e à robustez. E de modo

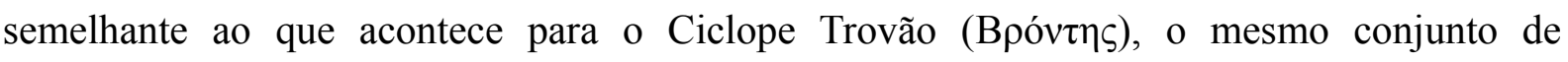

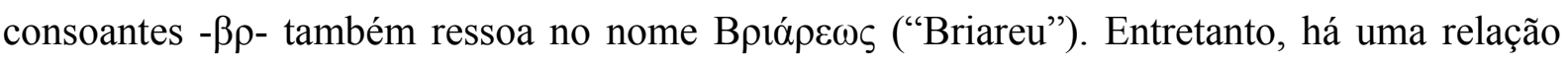
ainda mais estreita entre ő $\beta \mu \mu \varsigma_{\text {e }}$ B $\rho ı$ ó $\rho \varepsilon \omega \varsigma$, pois ambos são derivados de uma variação de 
origem pré-grega ỏ $\beta \rho \imath-/ \beta \rho t-$, designativa de algo grande, forte ou impetuoso (Beekes, 2010, p.

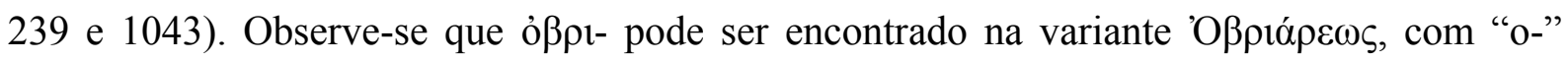
inicial, nos versos 617 e 734 da Teogonia.

A terceira e última adjetivação desse verso, oủк ỏvo $\mu \alpha \sigma \tau o$, literalmente "não nomeáveis", é um tanto singular. O dicionário LSJ oferece "abominable" (“abominável”) como um dos sentidos possíveis para essa expressão, que também aparece na Odisseia dentro

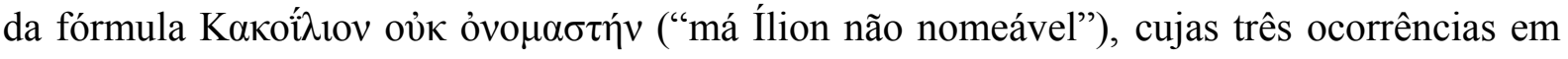
versos idênticos acontecem em falas de Penélope para se referir à Troia (19.260 e 597; 23.19). ${ }^{52}$ Todavia, tanto no caso de Troia quanto no caso dos Centímanos, eles são de certa forma nomeados. Na verdade, na Odisseia, Penélope altera o nome ílion ao prefixá-lo com

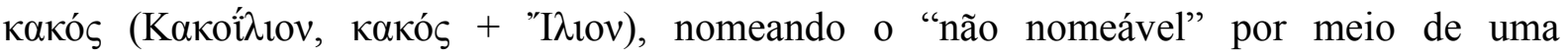
modificação no nome. No caso dos Centímanos, embora o poeta não os designe coletivamente como o faz para os Ciclopes, eles são nomeados individualmente no verso imediatamente

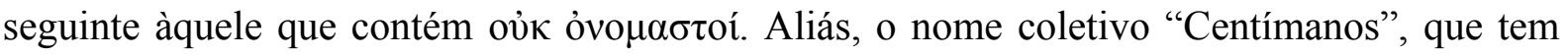
sido adotado aqui, não aparece nos poemas hesiódicos, embora ecoe no verso 150 , designando o número de braços ou mãos que apresentam, mas ocorre na Ilíada, 1.402, na forma adjetiva

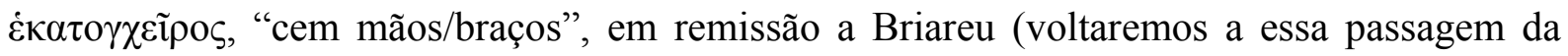
Ilíada adiante).

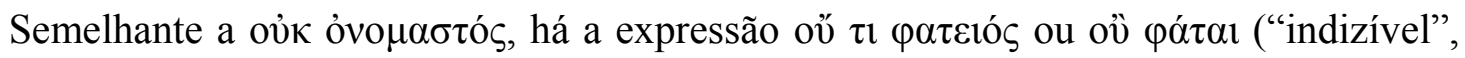
“do qual não se deve falar", equivalente ao latim nefandus), usada para qualificar Cérbero na Teogonia (v. 310), cão de Hades, que também apresenta cinquenta cabeças, como os Centímanos. ${ }^{53}$ No Escudo de Héracles, outro poema atribuído a Hesíodo, a expressão ov้ $\tau$ เ

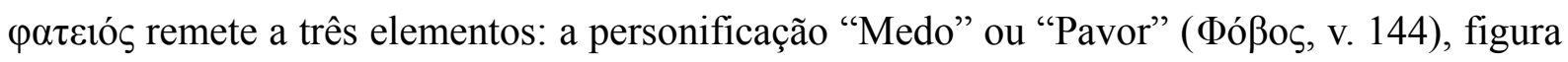
que ocupa o centro do escudo; as doze cabeças de serpente que adornam as vestes que Héracles leva nos ombros (v. 161); e, por fim, as Górgonas (v. 230). ${ }^{54}$ West (1997 [1966], p.

52 Werner (2014) traduz a expressão por “inominável Ruinosa-Ílion”.

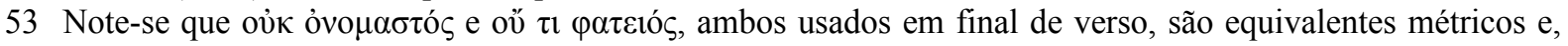
portanto, contradizem a regra da economia, a não ser que tenham significados diferentes (cf. Edwards, 1971, p. 69-70).

54 Acerca da autenticidade ou não do Escudo de Héracles como um poema atribuído a Hesíodo, cf. o capítulo de Cingano (em Montanari, Rengakos e Tsagalis, 2009, p. 91-130), no qual o autor aponta que o Escudo de Héracles é o único poema do corpus hesiódico que acompanha a Teogonia e Trabalhos e Dias na tradição manuscrita (p. 104): o códex Parisinus suppl. graec. 663, do século XI ou XII, embora fragmentário, apresenta partes da Teogonia e do Escudo; o Florentinus Laur. 32.16, do século XIII, reúne a Teogonia, Trabalhos e Dias e o Escudo de Héracles; e o Papiro Rainer, do século IV, contém fragmentos também dos três poemas (Edwards, 1971, p. 2, n. 5). Além da tradição manuscrita, o poeta siciliano Estesícoro atribui o Escudo a Hesíodo, conforme atestado no antigo Argumento do poema (T52), o que indica que ele era conhecido também fora da Ática já no início do século VI a.C. Outro indício da circulação do poema apresentado por Cingano (p. 99) é o considerável número de vasos áticos de figuras negras e alguns de figuras vermelhas datados entre c. 565 e 480 a.C. com representações iconográficas do combate entre 
209) aponta que a finalidade dessas expressões é aludir ao que não deve ser nomeado para que não seja conjurado, uma espécie de expressão apotropaica, já que nomear uma divindade é evocá-la; contudo, como essas criaturas são, ao fim e ao cabo, nomeadas, ele considera que essa crença já tinha se enfraquecido. ${ }^{55}$

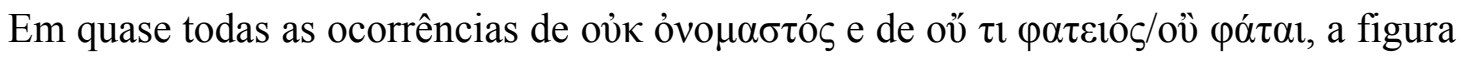
à qual se referem é nomeada, apesar de essas expressões indicarem que se deve fazer o exato oposto, a única exceção sendo as doze cabeças de serpente presentes no Escudo de Héracles que, de fato, não recebem nome próprio. ${ }^{56}$ Note-se, junto com Torrano (1995, p. 98), que todas as ocorrências mencionadas remetem a algo que infunde temor: os Centímanos com seus cem braços capazes de derrotar os Titãs; Cérbero, o cão com cinquenta cabeças que guarda os

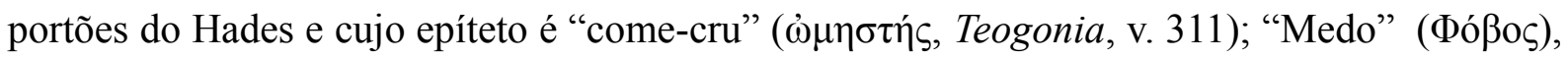
a própria personificação do pavor, com olhos de fogo, boca cheia de fileiras de dentes, tendo na fronte a "Discórdia" ("E que rangem os dentes e apavoram os homens (Escudo de Héracles, v. 161); as Górgonas (Escudo de Héracles, v. 230); e, por fim, Ílion, que, para Penélope, é a razão da interminável ausência do marido e de sua possível ruína. Com exceção de Troia, essas figuras apresentam aparência incomum (duas delas com grande número de cabeças), tornando-as indizíveis talvez no sentido de "indescritíveis", em razão de sua natureza múltipla e/ou numerosa. ${ }^{57}$ Há ainda um fragmento (MW 33a, 18; Most, 2007, p. 90-93, Fr. 31 v. 12-18), considerado parte do Catálogo das Mulheres, no qual é dito que as dádivas que Posêidon conferiu a seu neto

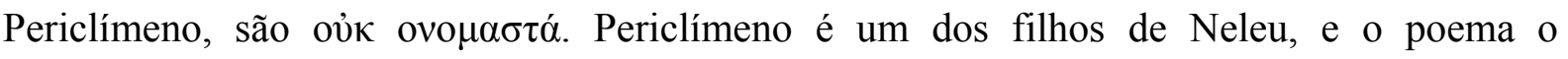
caracteriza como "afortunado" (ő $\lambda \beta 10 v)$ por ter recebido muitas dádivas do avô. Essas dádivas às quais o poema remete dizem respeito à capacidade de Periclímeno de mudar de forma: às vezes aparecendo como uma águia dentre os pássaros, outras, como uma formiga, uma abelha

Héracles e Cisne (Kúкvo $)$, episódio narrado no poema em questão (p. 98). Todas essas evidências, contudo, são indiretas. Análises estatísticas que comparam o Escudo com a Teogonia, Trabalhos e Dias e os dois épicos homéricos colocam o Escudo em uma relação de proximidade maior com os épicos homéricos do que com os poemas hesiódicos, principalmente no que diz respeito ao uso de formas não homéricas, praticamente ausentes no Escudo, e também ao digama inicial, cuja frequência o aproxima dos épicos homéricos (estas e outras características do Escudo que o distinguem da Teogonia e Trabalhos e Dias são resumidas em Edwards, 1971, p. 196-197).

55 Para uma explicação muito semelhante, cf. Torrano (1995, p. 98), para quem "o nome desses seres apavorantes é ne-fando [sic], e o que impede de pronunciar o nome desses Deuses é justamente o pavor que a presença deles infunde ou o mal que ela traz, pois o nome é a Presença". Entretanto, Torrano, diferente de West, não oferece justificativa para que esses deuses sejam nomeados apesar da advertência contida em

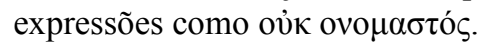

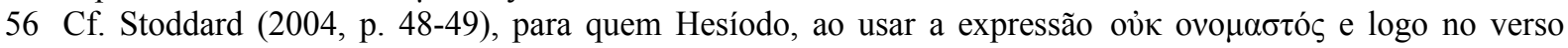
seguinte nomear os Centímanos, nomeia o inominável, direcionando nossa atenção para o fato de que ele tem total controle da apresentação da história e indicando que ele é consciente de seu papel como narrador.

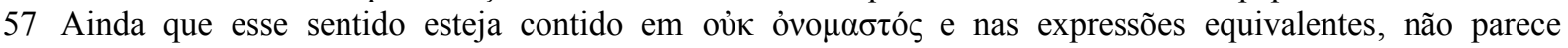
adequado estendê-lo a Troia. 
e uma cobra. J. N. O’Sullivan, no verbete ỏvo $\mu \alpha \sigma \tau o ́ \varsigma$ do $\operatorname{LfgrE}$, utiliza esse fragmento para

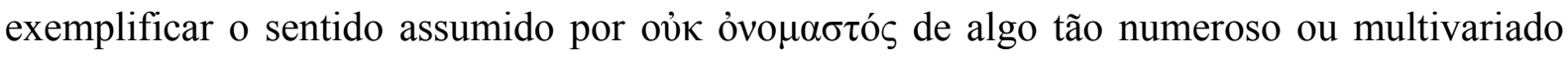
que desafia a enunciação, ou seja, algo "indescritível”, talvez até "inexplicável”. A extraordinariedade de Periclímeno é também descrita pela expressão $\theta \alpha \tilde{v} \mu \alpha ~ i ̂ ́ \varepsilon \sigma \theta \alpha \iota$ (“maravilha de ver").

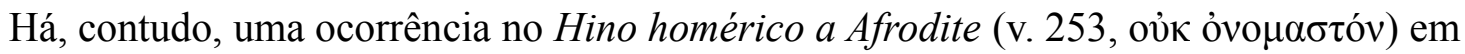
que a deusa Afrodite reclama de seus sofrimentos em virtude de sua paixão cruel e "oủ

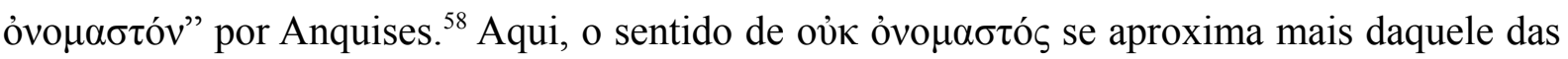

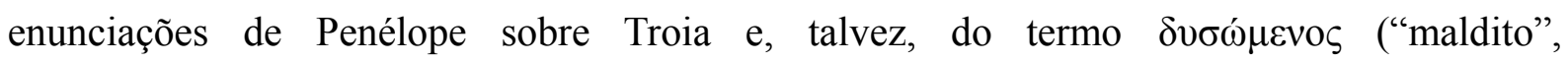
"amaldiçoado", "aquele que porta um nome agourento", cf. verbetes no LSJ e Cunliffe), usado na Teogonia na fala de Crono (v. 171) para adjetivar seu pai, Céu. ${ }^{59}$

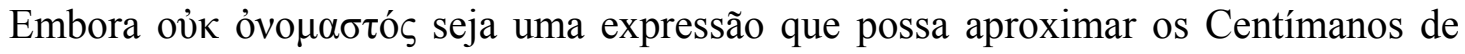
criaturas maléficas, ela parece tender mais para uma noção de algo que é "inexprimível” em razão de apresentar uma aparência bastante fora do comum, extraordinária. ${ }^{60}$ Além disso, o

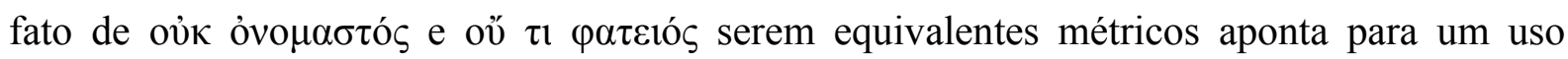
pautado em uma escolha entre diferentes sentidos, já que, de acordo com o princípio da economia, como proposto por Parry (1987), a linguagem do poeta é quase totalmente livre de expressões que têm o mesmo valor métrico contendo a mesma ideia.

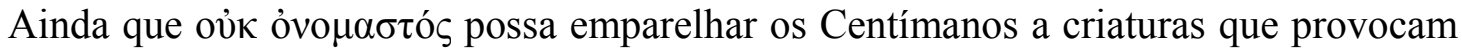
terror, há uma diferença significativa entre o vocabulário usado para descrevê-los nos versos 147-153 e aquele que se refere a eles no episódio da Titanomaquia, como será visto adiante, perceptivelmente mais próximo do que é usado para heróis e divindades.

De acordo com o que foi exposto, os nomes individuais dos Ciclopes indicam aspectos da arma que produzem para Zeus. No caso dos Centímanos, seus nomes não apresentam um significado claro, com exceção talvez de Briareu, que compartilha sua raiz com ö $\beta \rho \mu$ ("forte", "poderoso", "possante"). Coto e Giges são nomes de raiz e significado ainda obscuros. ${ }^{61}$

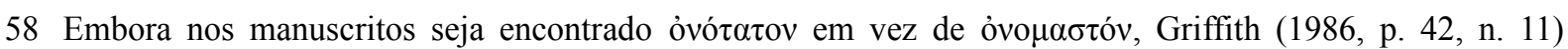
defende este último como o termo adequado já que não apenas seu sentido se encaixa, mas é uma expressão que ele considera parte do ethos feminino, sendo apropriado encontrá-lo na fala de Afrodite.

59 Para outras ocorrências de $\delta v \sigma \omega ́ v v \mu o \zeta$, cf. Ilíada 6.255 e 12.116 e Odisseia 19.571.

60 Cf. Arrighetti (1998, p. 327, v. 148): "L'inesprimibilitá è una caratteristica che viene menzionata altre volte a proposito di esseri eccezionali: cfr. per esempio, Th. 310 [passagem em que Cérbero é dito oủ $\tau \imath ~ \varphi \alpha \tau \varepsilon ı ́ c]$ ]; fr. 33 (a), 18 [fragmento acerca de Periclímeno]; [...]". Na continuação desse comentário ao verso 148, Arrighetti faz uma pequena troça da solução proposta por Blaise e Rousseau (em Blaise, Judet de la Combe e Rousseau, 1995, p. 230, nota 68): eles propõem que, em virtude de sua grande multiplicidade, os Centímanos estão além da possibilidade de serem nomeados; Arrighetti aponta jocosamente entre colchetes e com ponto de exclamação que os Centímanos são em número de três apenas.

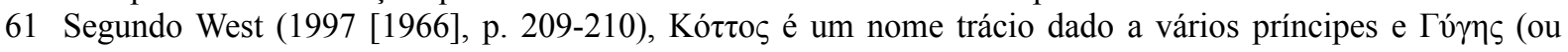




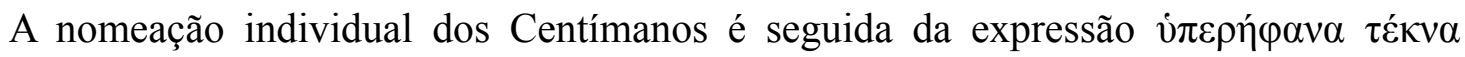
("filhos altivos"), que abrange todos os três, e não apenas um deles, como ocorre com os Ciclopes. O termo vi $\varepsilon \rho \eta ́ \varphi \alpha v o \varsigma$ é quase um hapax na poesia hexamétrica homérica e hesiódica. Em Hesíodo, ele é usado apenas essa vez, para caracterizar os Centímanos; em

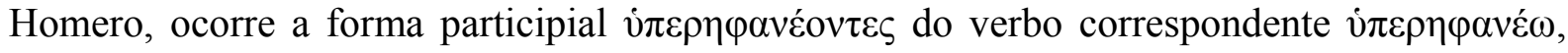
atribuído aos epeios (Ilíada, 11.694), habitantes da região de Elis, ao norte da Messênia, onde se localiza Pilos, cidade de Nestor. E é justamente Nestor quem atribui o particípio

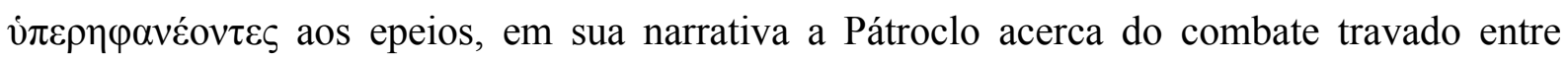
epeios e pílios. LSJ oferece overweening ("presunçoso", mesma tradução sugerida para

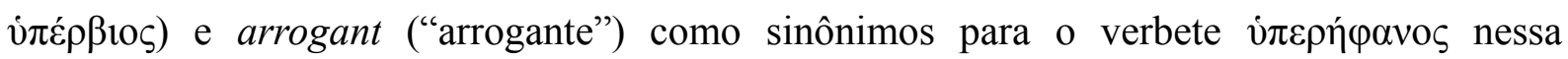
passagem da Teogonia, explicando que o termo é geralmente usado em sentido negativo, raramente com algum sentido positivo, embora o dicionário também aponte dois exemplos em Platão para o uso com sentido positivo de "magnífico", "esplêndido" (Fédon 96a; Banquete

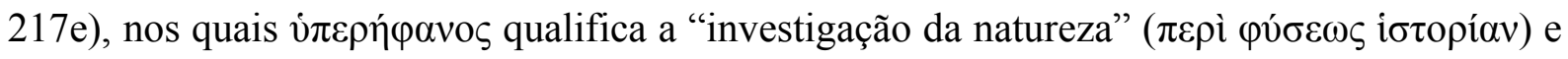

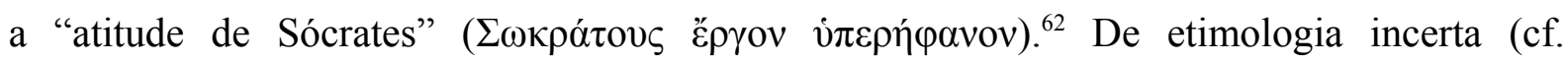
Chantraine, p. 1158; Beekes, 2010, p. 1533), o termo só pode ser entendido contextualmente e, ainda assim, de modo precário, dada a escassez de ocorrências. Embora não seja difícil encaixar o sentido de "presunçoso", "arrogante" aos epeios, principalmente porque está na enunciação do personagem Nestor, para os Centímanos essas acepções parecem conflitar tanto com o sofrimento decorrente de terem permanecido presos por tanto tempo, de um lado, como com a gratidão que sentem por terem sido libertados, de outro (cf. v. 621-623).

Os versos 150-152 descrevem a aparência dos Centímanos, semelhantes em função

Гúnৎ, embora ele não considere esta uma grafia correta) seria um reminiscente de ' $\Omega \gamma u ́ \gamma \eta \varsigma$, nome de um governante mítico da Ática. Contudo, há palavras em grego que mereceriam uma investigação mais detida

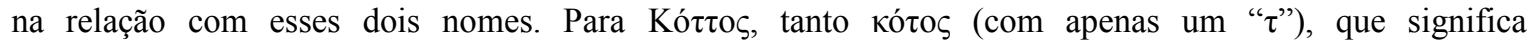

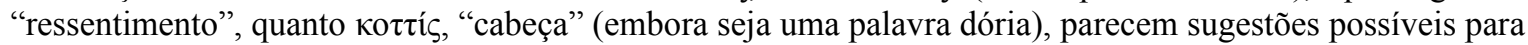
uma investigação etimológica, já que o significado de ambos os termos pode encontrar alguma relação com os Centímanos: os versos 621-623 informam que, por estarem aprisionados, os Centímanos "sofriam" (ä $\lambda \gamma \varepsilon$ '

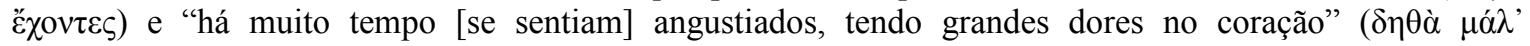

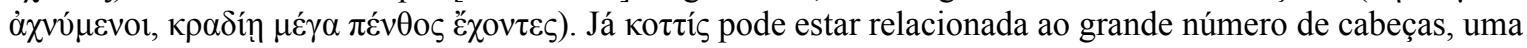
de suas principais características anatômicas. Quanto a Giges, talvez valesse a pena examinar uma

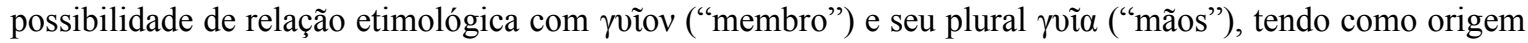
comum a raiz indo-europeia *gou- "mão". Essas sugestões são de caráter bastante especulativo, entretanto. Digno de nota é o escólio 148 do Scholia vetera (Di Gregorio, 1975, p. 35), no qual o escoliasta associa os

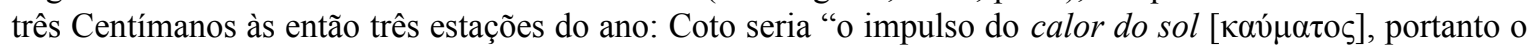

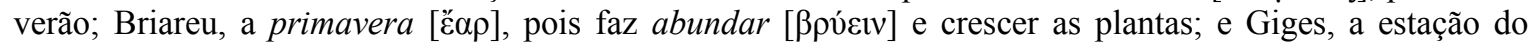

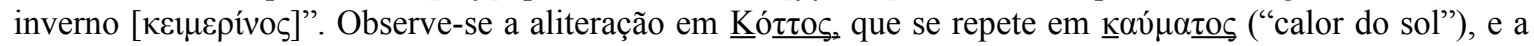

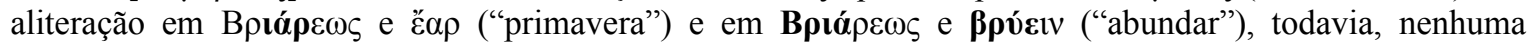

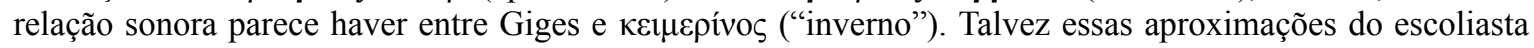
sejam tão ou mais arbitrárias do que as minhas especulações etimológicas.

62 LfgrE oferece "übermütig" ("pretensioso") para vं $\pi \rho \eta ́ \varphi \alpha v o s$, e Cunliffe, "to conceive arrogance, be led on to arrogance or wantonness" ("manifestar arrogância, ser levado à arrogância ou à crueldade"). 
aos quatro versos (142-145) dedicados aos Ciclopes, com exceção da explicação fornecida para o nome coletivo destes, já que para os Centímanos não há um nome coletivo no poema. Esses versos se repetirão em 671-673, que integram o episódio da Titanomaquia, com uma variação entre os versos 151 e 672. Eles os descrevem possuindo cem braços cada um que "se

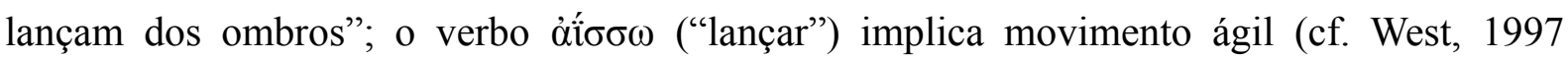
[1966], p. 211), o que está em conformidade com a atividade que desempenharão na Titanomaquia. Seus cem braços são ö $\lambda \lambda \alpha \sigma \tau o$ (“não moldáveis”, segundo LSJ), termo, no entanto, considerado equivalente de $\alpha \dot{x} \varepsilon \dot{\lambda} \alpha \sigma \tau o$ ("não aproximáveis", cf. West, ibidem), uma interpretação que West recusa, propondo que ö $\pi \lambda \alpha \sigma \tau o l$ (do verbo $\pi \lambda \alpha ́ \sigma \sigma \omega$, "moldar") signifique "a não serem copiados por artistas", ou seja, que não devem ser representados por imagem, já que representá-los teria o mesmo resultado que nomeá-los, isto é, evocá-los. Contudo, o adjetivo ö $\lambda \lambda \alpha \sigma \tau o \varsigma$ também aparece em Trabalhos e Dias (v. 148), referindo-se às mãos ou aos braços das figuras da raça de bronze. Essa relação com os membros, somada ao movimento ágil expresso pelo verbo áî́, $\sigma \omega$, tende a favorecer o sentido de "não aproximáveis" ou, como bem traduziu Werner (2013a), de “inabordáveis", em detrimento da interpretação proposta por West. ${ }^{63}$

Além de seus cem braços, os Centímanos apresentam, cada um deles, cinquenta cabeças, que "dos ombros nasceram sobre os membros robustos" (v. 152). Esse mesmo verso também é usado para a raça de bronze em Trabalhos e Dias (v. 149), mas relacionado aos seus “braços/mãos intocáveis” ( $\chi \varepsilon \tilde{\imath} \rho \varepsilon \varsigma ~ \alpha ̋ \alpha \pi \tau o \imath) .{ }^{64}$ Ademais, essa expressão ( $\left.\chi \varepsilon \tilde{\imath} \rho \varepsilon \varsigma \alpha ̋ \alpha \pi \tau o \imath\right)$, por seu turno, será utilizada também para os Centímanos na Teogonia (v. 649), em um verso que é quase idêntico ao 148 de Trabalhos e Dias. ${ }^{65}$ Para Clay (2003, p. 90, n. 31), a semelhança entre os Centímanos e a raça de bronze pode não ser fortuita, embora ela não ofereça uma justificativa para tal afirmação. Entretanto, apesar de compartilharem os adjetivos ő $\beta \rho \mu o \varsigma$ e

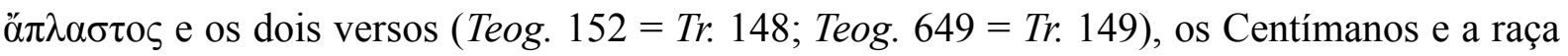

63 Note-se que a raça de bronze, além do adjetivo ő $\pi \lambda \alpha \sigma \tau o \varsigma$, também tem em comum com os Centímanos o adjetivo ő $\beta$ puos.

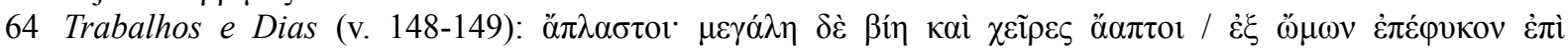
$\sigma \tau \imath \beta \alpha \rho \tilde{\sigma} \sigma \iota) \mu \varepsilon ́ \lambda \varepsilon \sigma \sigma ı v$ ("inabordáveis: grande força e mãos intocáveis / dos ombros nasceram sobre os membros robustos"). Wilamowitz suprimiu esses versos em Trabalhos e Dias, mas os manteve na Teogonia (v. 152 e 649). West (1997 [1966], p. 211) em sua edição da Teogonia, adota a mesma postura de

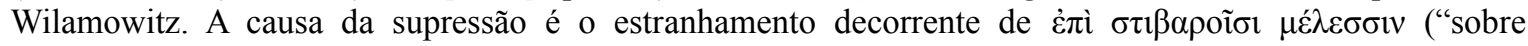
robustos membros"), que se encaixa no verso da Teogonia, pois se refere às cinquenta cabeças dos Centímanos que saem dos ombros que, por sua vez, estão sobre membros robustos, mas não se encaixaria em Trabalhos e Dias, pois os braços sairiam dos ombros que estão sobre os membros robustos, ou seja, os mesmos braços, tornando difícil compreender a composição visual descrita ou simplesmente tornando a expressão redundante. Contudo, em sua edição de Trabalhos e Dias, West (1978, p 188) voltou atrás da decisão de suprimi-lo e o manteve, preferindo responsabilizar Hesíodo pela "infeliz alteração".

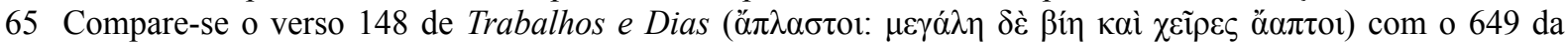

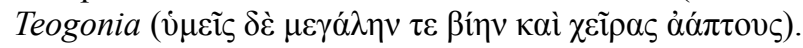


de bronze são diferentes entre si em relação a suas respectivas atitudes e a seus respectivos destinos. Como a própria Clay nota (2003, p. 91), a raça de bronze não consegue canalizar sua violência para "finalidades úteis" e seu excesso de força física é explorado por eles próprios apenas para fazer guerra entre si, diferentemente dos Centímanos, que são importantes aliados de Zeus contra os Titãs. O destino da raça de bronze é a autodestruição, enquanto aos Centímanos, após a vitória na Titanomaquia, é reservado o papel de carcereiros de seus irmãos Titãs, mantendo-se integrados à ordem de Zeus. De qualquer modo, é inegável que há uma semelhança no tratamento poético dispensado aos Centímanos e à raça de bronze.

Contudo, esses mesmos versos (148-149 de Trabalhos e Dias), que aproximariam a raça de bronze dos Centímanos em relação a sua grande força e a seus braços intocáveis, também aparecem no Escudo de Héracles (v. 75-76), com uma pequena variação, para remeter a Héracles e a Iolau, sobrinho e ajudante do herói. ${ }^{66}$ Assim, a "grande força" e "os braços intocáveis" são características que os Centímanos compartilham não apenas com a raça de bronze mas também com o herói Héracles e seu sobrinho Iolau.

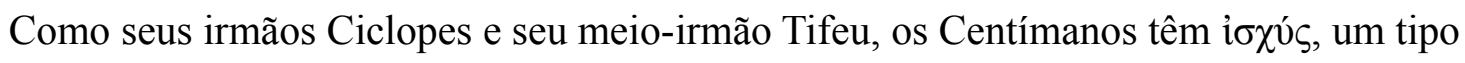
de força física, mas no caso dos Centímanos ela vem qualificada por ä $\pi \lambda \eta \tau o \varsigma$, forma jônica de

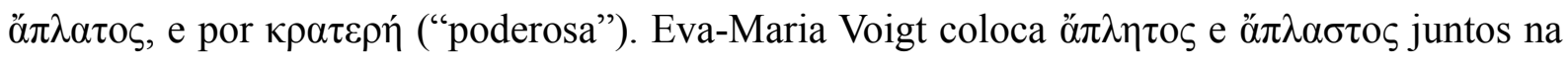
abertura do verbete elaborado por ela no $\operatorname{LgrE}$, considerando-os sinônimos, portanto. Ela oferece "unnahbar" (“inacessível”) como acepção principal para eles; uma acepção bastante próxima de ő $\pi \lambda \alpha \sigma \tau o \zeta$, se entendido como "inabordável”, “intocável”. Voigt aponta, ainda, o sentido derivado de "furchtbar" ("terrível"), também sugerido pelo LSJ, embora este último acrescente que o termo em questão "sempre [venha] com um sentido de terrível, monstruoso" ("always with a notion of terrible, monstrous").

$\mathrm{O}$ adjetivo ä $\pi \lambda \eta \tau$ oৎ é usado mais duas vezes na Teogonia: uma em 315, que pode

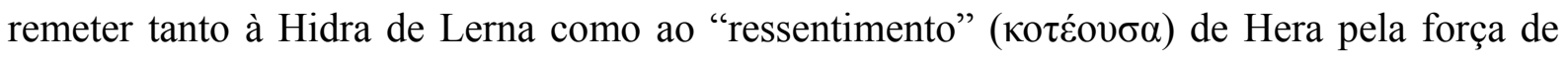
Héracles; e outra em 709 adjetivando ő $\tau$ oßos, o estrondo provocado pela luta de Zeus, seus irmãos e os Centímanos, de um lado, contra os Titãs, do outro. E é nessas duas ocorrências que o sentido de "inabordável" ou "inacessível” para ö $\lambda \lambda \eta \tau$ ç começa a não se encaixar e, como consequência, talvez não seja um possível sinônimo de ö $\pi \lambda \alpha \sigma \tau o \zeta$. Ao levar em consideração a multiplicidade tanto de braços/mãos dos Centímanos como de cabeças da

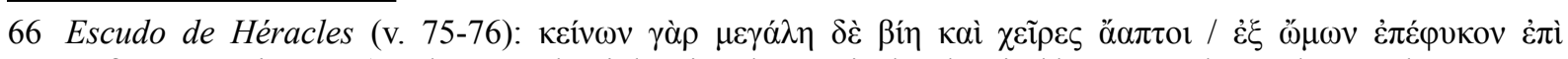

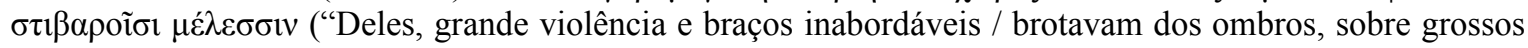
membros"). A tradução do Escudo de Héracles utilizada nesta tese é a de Torrano (2000). Note-se que West (1978, p. 188), apesar de ter mantido os versos 148-149 em Trabalhos e Dias, considera os versos 75-76 do Escudo uma interpolação, aparentemente pela mesma razão, atualmente rejeitada, que os havia anteriormente considerado interpolação em Trabalhos e Dias. 
Hidra de Lerna, faz sentido compreender $\alpha$ $\pi \lambda \eta \tau o \zeta$ como designativo de algo do qual não há como se aproximar, porque seriam muitas e ameaçadoras, embora Héracles tenha se aproximado de Hidra para matá-la. Mas quando o adjetivo qualifica algo abstrato como um barulho estrondoso ou um ressentimento, "inabordável” ou "inacessível” não parecem dar conta de tal adjetivação; principalmente "inacessível”, pois não faria sentido que um barulho estrondoso fosse inacessível. Segundo Voigt, ainda no verbete do $\operatorname{LggrE}$, escoliastas já haviam sugerido um sentido de "unersattlich" ("inexaurível”), "unaufhörlich" ("incessante”), para

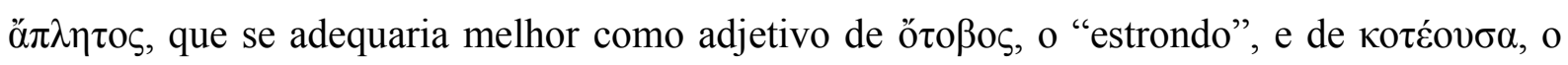
"ressentimento".

Embora com poucas ocorrências na Teogonia, o termo aparece quatro vezes no Escudo de Héracles: no verso 147, aparece em remissão às já mencionadas fileiras de dentes de Pavor; em 230, para adjetivar as Górgonas, que correm atrás de Perseu; em 250, é a vez das Cisões $(\mathrm{K} \tilde{\eta} \rho \varepsilon \varsigma)$, que massacravam os guerreiros caídos diante dos portões da cidade; e, por fim, em 268, para qualificar Névoa ('A $\chi \lambda \hat{\jmath} \varsigma$ ), que cobre os olhos dos moribundos. Como na Teogonia, o sentido de "inabordáveis" se encaixa em alguns contextos, mas não em outros. Ajusta-se às ameaçadoras fileiras de dentes de Pavor e talvez às Górgonas, apesar de Perseu abordar e matar uma delas (e de elas estarem correndo atrás de Perseu no Escudo, a propósito); mas em relação às Cisões e sua batalha às portas da cidade, tem-se a impressão de que o sentido de "inexaurível" ou "incessante" se ajusta melhor; o mesmo ocorre com Névoa, que, sendo uma névoa que cobre os olhos no momento da morte, não parece ter nada de “inabordável” ou “inacessível”.

Há dois outros exemplos, ainda, nos quais o sentido de "inabordável" aparenta inadequado. No fragmento 17a 16 (M.-W.; Most, 2007, 13 v. 16, p. 63), atribuído ao Catálogo das Mulheres, é reconstruída a forma dual ả $\lambda \lambda \eta \tau \omega ́$ para adjetivar os gêmeos Kteaton e Euryton, que têm Aktor (dos gêmeos siameses Aktor e Molione) como pai mortal e Posêdon como pai imortal. Kteaton e Euryton, como seu pai mortal Aktor, teriam quatro pés, quatro mãos e duas cabeças. Perceba-se que ö $\pi \lambda \eta \tau o \zeta$ está frequentemente ligado a criaturas que apresentam alguma multiplicidade: os Centímanos, a Hidra, as fileiras de dentes de Pavor e também os gêmeos siameses.

Por fim, ő $\pi \lambda \eta \tau o \varsigma$ é usado no Hino Homérico a Deméter (v. 83), na fala do deus Hélio

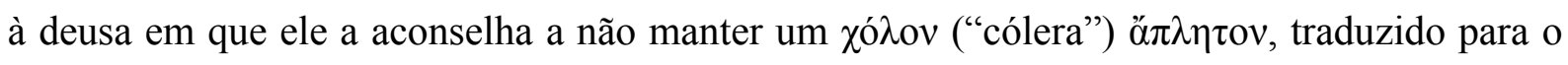
inglês como "unrelentingly" ("implacavelmente") por Allen-Sike-Halliday (1936), um contexto no qual "inabordável” parece, de fato, não funcionar.

Assim, é notável que ő $\pi \lambda \eta \tau$ o adjetiva, por um lado, seres que apresentam algum tipo 
de multiplicidade, quer uma característica anatômica que seja em maior número do que o esperado, como os Centímanos, possivelmente a Hidra, Pavor e os gêmeos siameses, quer seres que sejam múltiplos em seu conjunto, como as Górgonas, as Cisões e também os gêmeos siameses. Por outro lado, a̋ $\pi \lambda \eta \tau$ os também qualifica algo vasto, infindável, ou que simplesmente não é passível de ser mensurado, como um "estrondo" (őtoßoৎ) ou uma névoa

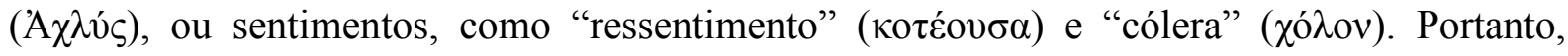

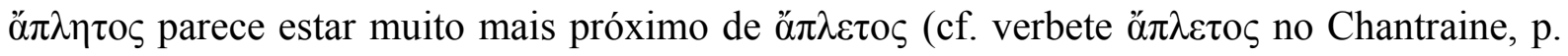
97), uma forma não atestada na poesia hexamétrica arcaica que significa "ilimitado", “imenso", "infinito", do que permite aproximar a vã etimologia. Desta feita, enquanto os

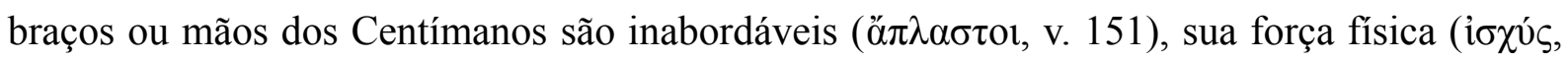

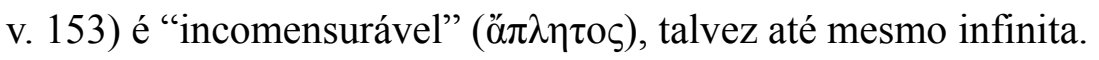

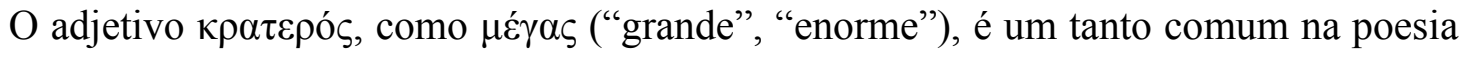

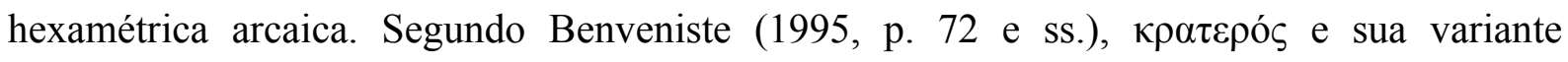

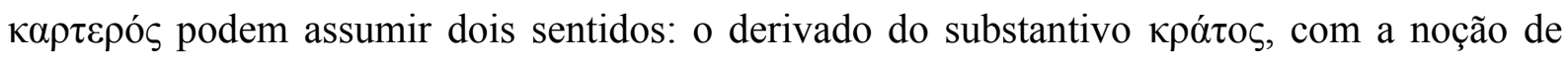

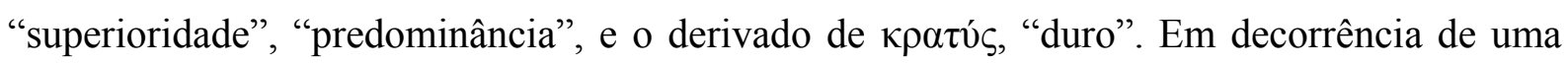
sobreposição lexical de duas raízes etimológicas diversas, uma de origem indo-europeia (kratu-), que designa "a virtude (mágica) do guerreiro", e outra de origem gótica (hardus),

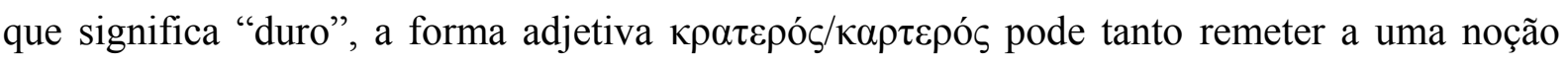
abstrata de "superior", "predominante", como à qualidade física do que é "duro". Nos poemas homéricos e nos hesiódicos são encontrados os dois usos do adjetivo, que Benveniste denomina "favorável”, ou seja, o sentido de "superior", e "desfavorável”, o sentido de "duro".

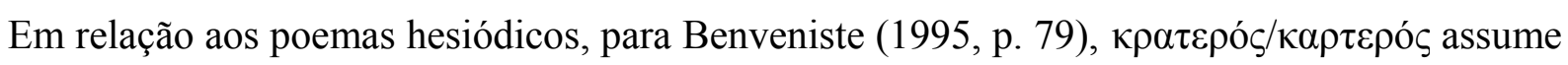
sua acepção "favorável", isto é, a de superior quando acompanha o substantivo $\alpha \mu v ́ \mu \omega v$ (“impecável”, Teogonia, v. 1013), e nesse caso específico tem a noção de "sem igual”. Mas quando adjetiva Ares no Escudo (v. 98 e 101), as Erínias ou Équidna na Teogonia (v. 185 e 297 respectivamente), o adjetivo assumiria sua acepção “desfavorável”, isto é, de algo duro.

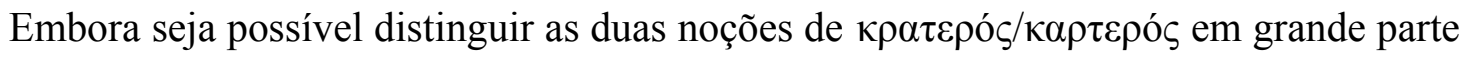
dos usos nos poemas homéricos, como demonstra Benveniste (1995, p. 76-77), principalmente aqueles em que assume sua acepção "favorável", nos poemas hesiódicos os casos em que a noção seria exclusivamente "desfavorável" não parecem ser tão evidentes, a não ser por um raciocínio tautológico no qual aquilo que se considera a priori desfavorável tenha necessariamente de receber um qualificador igualmente desfavorável. Tomemos um exemplo da Ilíada para esse tipo de raciocínio que pode ser encontrado no texto de

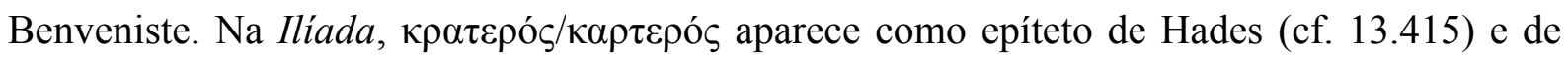


Ares (cf. 2.515) e, segundo o linguista (1995, p. 77-78), deve ser entendido na sua acepção "desfavorável"; entretanto, o adjetivo também aparece como epíteto de Diomedes e, nesse caso, deve ser entendido em sua outra acepção, a "favorável” (1995, p. 77). Não se pretende

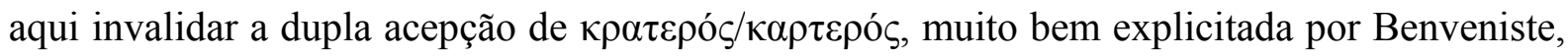
mas sugerir que em alguns casos haja possibilidade de a distinção de sentido não ser tão clara, como sugere o linguista. Outro exemplo de uma possível distinção duvidosa entre o sentido

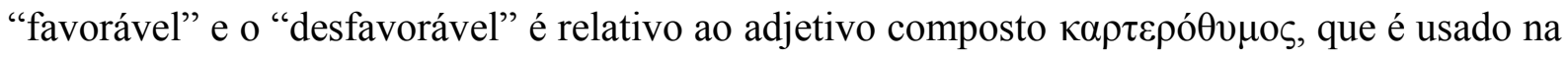
Ilíada por Licaonte para se referir a Diomedes (5.277) e pelo narrador para adjetivar Aquiles (13.350); na Odisseia, o adjetivo é usado pelo narrador para qualificar Héracles (21.25); na Teogonia, adjetiva a deusa Discórdia ('E Zeus (v. 476) e Espadouro (v. 979), amante de Afrodite e que surge junto com Pégaso do pescoço de Medusa ao ser decapitada por Perseu. Nessas ocorrências, a escolha de um sentido

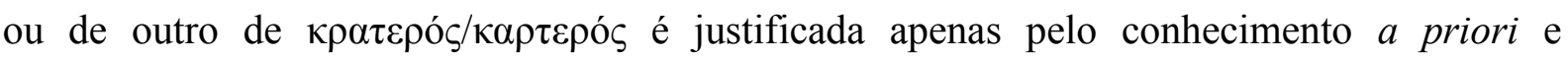
julgamento moral subsequente da índole de uma personagem heroica ou divina.

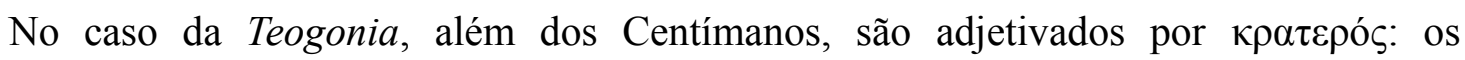

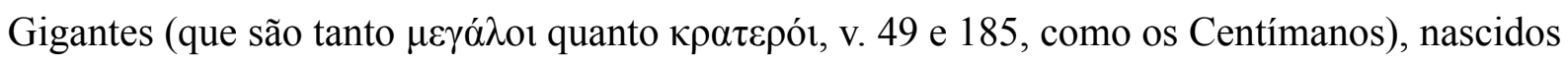
juntos com as Erínias a partir dos salpicos do esperma de Céu ao atingirem Terra; as Erínias elas mesmas (v. 185); Cérbero (v. 312); Quimera (v. 320, 322); Crono (v. 465); a ảvó $\gamma \kappa \eta$ (“obrigação") de Atlas, que sustenta o Céu na extremidade da Terra (v. 517); a "prisão"

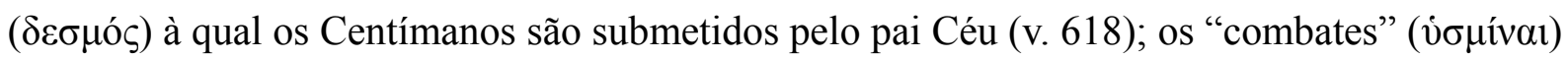
contra os Titãs (v. 631, 663, 712) e também os "golpes" ( $\beta$ oגaí) desferidos nesses combates (v. 683); os próprios Titãs (v. 670); Tifeu (v. 824); até mesmo Latino, fillho de Circe e Odisseu

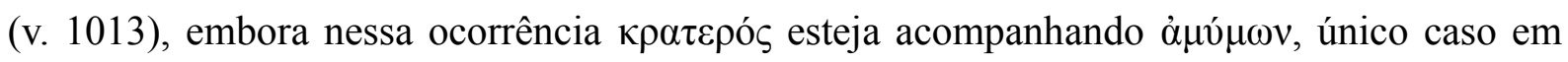

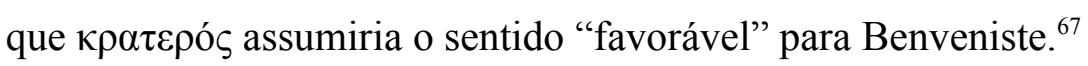

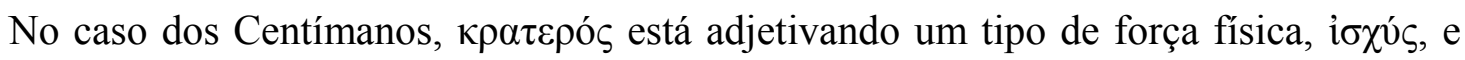
segundo o critério de Benveniste ela seria uma força "dura", com um sentido expandido de "cruel", "violenta", como o próprio linguista propõe para o adjetivo (1995, p. 78). Todavia, o sentido de "superior", “dominante", também expandido para "poder" por Benveniste (1975, p. 76-77), tomando a forma adjetiva "poderosa" ou "potente", parece do mesmo modo viável para a compreensão da força dos Centímanos. ${ }^{68}$

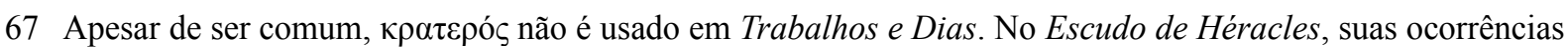
são: v. 43 referindo-se a $\delta \varepsilon \sigma \mu o ́ \varsigma$ ("prisão"); v. 52, a Héracles; v. 77 e 323, a Iolau; e v. 446, à "força" ( $\mu \varepsilon ́ v o \varsigma)$ de Ares.

68 Para os demais casos mencionados no parágrafo anterior também há a dupla possibilidade de compreensão

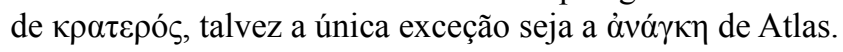




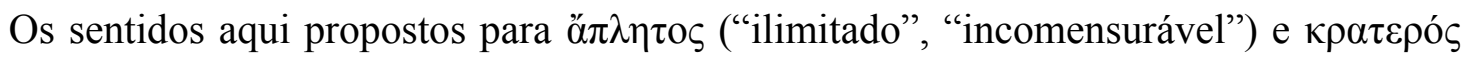
("poderoso") são, ainda, condizentes com o restante da descrição dos Centímanos no verso

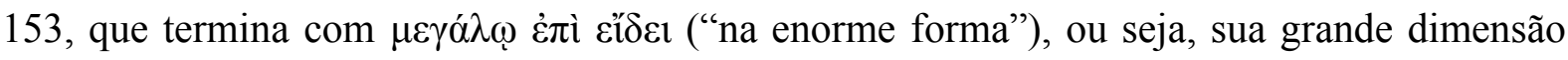

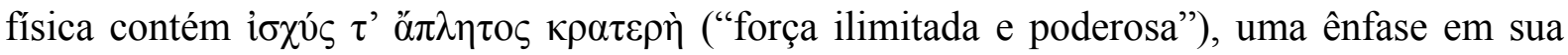

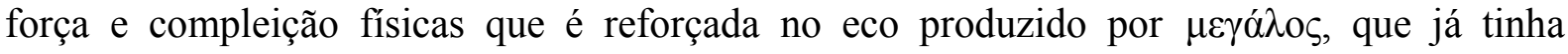
ocorrido no verso 148.

Há, por fim, outro eco reverberando nesse último verso, que encerra a passagem de

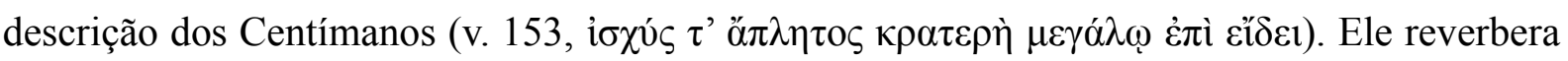

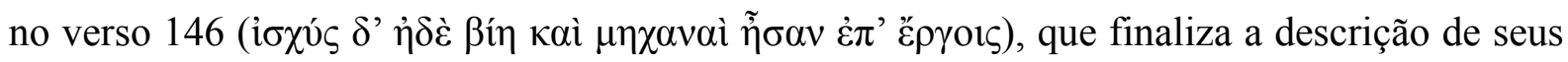
irmãos Ciclopes, traçando um paralelismo ainda mais evidente pelo uso peculiar de غ̇ंí com

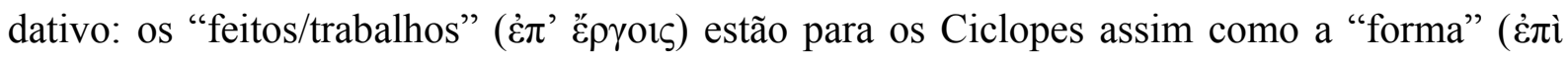

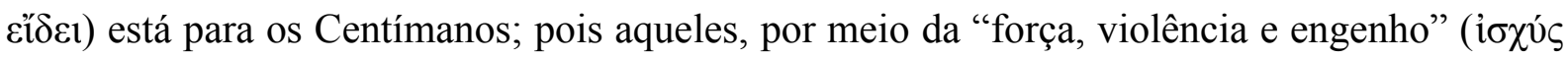

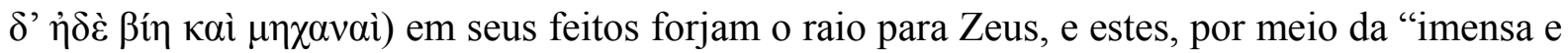

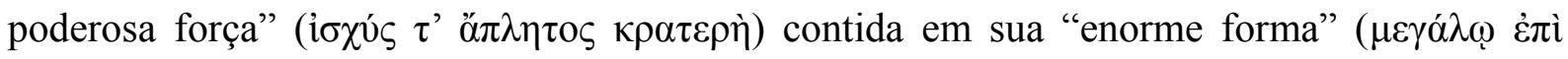

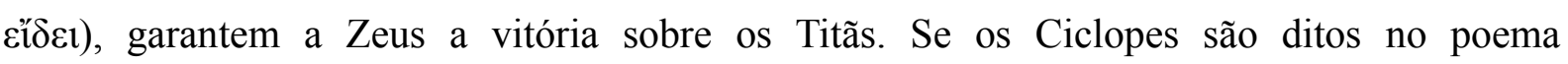
semelhantes aos deuses, o mesmo não é dito dos Centímanos; todavia, é justamente a singularidade de sua grande e múltipla conformação física que lhes garante um papel no cosmo regido por Zeus.

\section{2.c) Os Centímanos na Titanomaquia (v. 617-721)}

No início do episódio da Titanomaquia, o poeta retoma o ódio que Céu sentia por seus filhos e que ocasionou o aprisionamento deles. Nos versos 617-620, contudo, esse ódio é expresso apenas em relação aos Centímanos, tendo como motivos a sua "virilidade bem

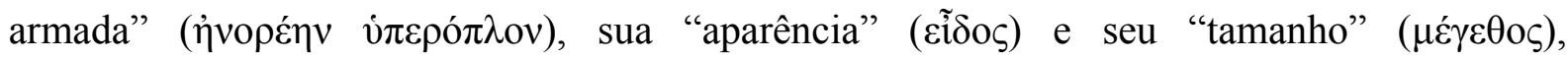

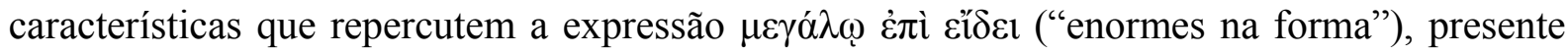
no último verso de sua descrição (153). Faz-se notar que as razões que levaram Céu a odiar os Centímanos são as mesmas que levaram Zeus a libertá-los.

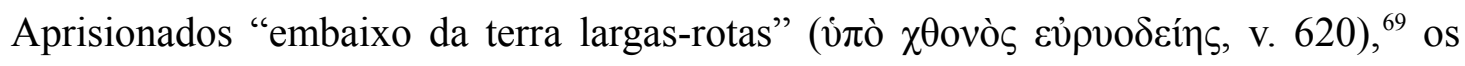

69 Essa expressão se repetirá em 717 em referência ao local para onde foram enviados os Titãs ao fim da Titanomaquia, indicando talvez que seja o mesmo local no qual estavam encerrados os Centímanos, e também em 787 para se referir ao local onde flui o rio Estige. West (1997 [1966], p. 338), em comentário ao verso 618, considera que o local no qual os Centímanos permaneceram aprisionados é Tártaro, embora Hesíodo evite afirmá-lo, já que Tártaro é o lugar reservado aos inimigos de Zeus. Interessante notar que a

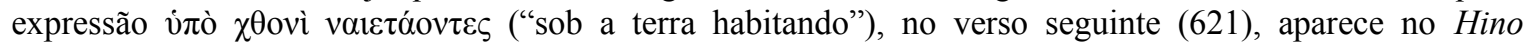
homérico a Apolo (v. 335), na evocação feita por Hera aos "Titãs que habitam sob o chão / ao redor do

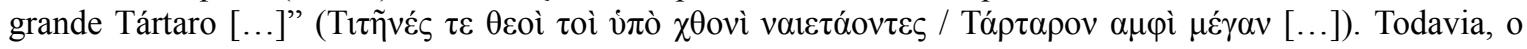




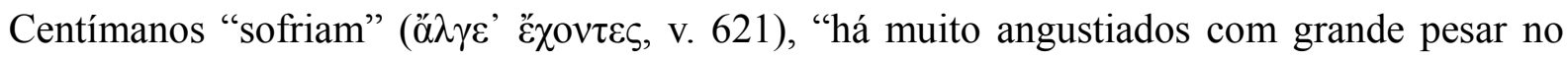

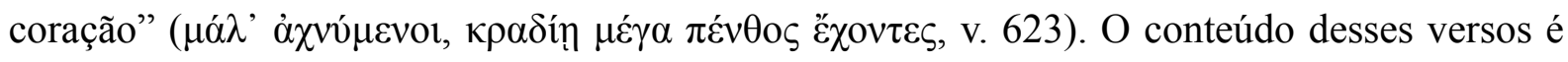
de certo modo desconcertante, se comparado à compleição física dos Centímanos. Esses três seres de cem braços e cinquenta cabeças cada um, tão enormes e fortes, "sentados na ponta,

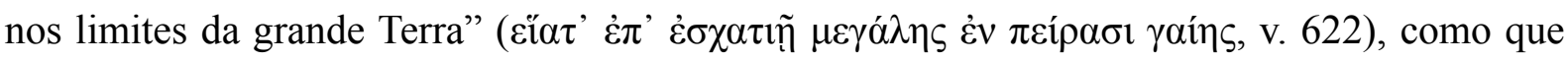
descorçoados da vida, compõem um belo quadro de contraste entre força e desalento. Talvez se pudesse acrescentar aí a sua solidão, já que todos os seus irmãos, inclusive os Ciclopes, foram libertados, quer por meio da castração de Céu, quer por Zeus. Quiçá nem mesmo Zeus os tivesse libertado, não fosse a difícil situação com os Titãs e, principalmente, o conselho de Terra.

Zeus, então, junto com seus irmãos, restitui os Centímanos à luz (v. 624-626), já que Terra lhes revela que teriam vitória sobre os Titãs, contra quem combatiam há dez anos, se obtivessem a ajuda dos Centímanos (v. 627-639). Zeus, à vista disso, oferece aos Centímanos

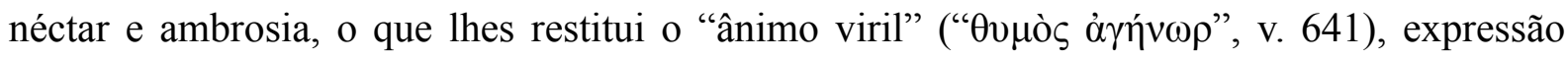
bastante usual na Ilíada e na Odisseia para se referir ao ânimo de figuras heroicas. ${ }^{70}$ Depois de

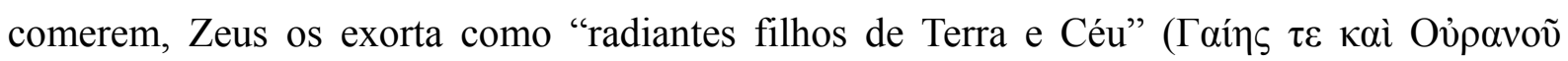

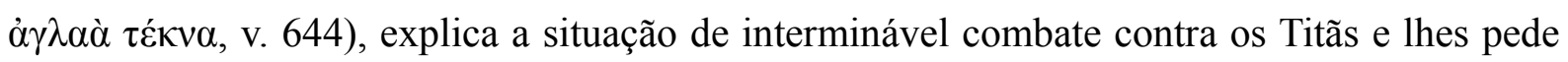

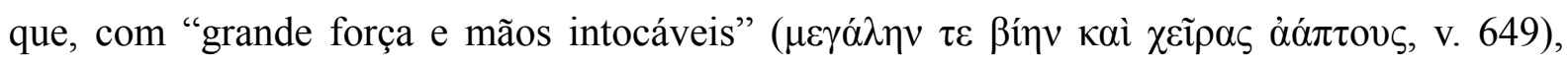

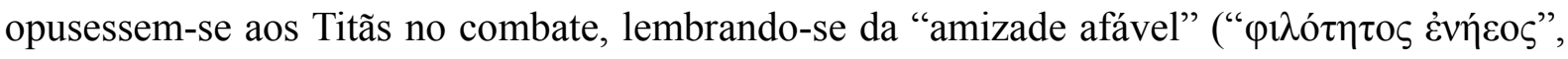
v. 651) e do quanto sofreram antes de serem libertados graças aos desígnios de Zeus e de seus irmãos (v. 642-653). É possível notar na enunciação de Zeus a focalização que os Centímanos recebem por parte da divindade olímpica, que os exorta como "radiantes filhos" ( $\alpha \gamma \lambda \alpha \grave{\alpha}$ $\tau \varepsilon ́ \kappa v \alpha$ ), uma focalização que introduz certa mudança no modo como os Centímanos são retratados. Com os versos iniciais da Titanomaquia (617-623) e com essa enunciação de Zeus, o vocabulário empregado em referência aos três irmãos se distancia daquele presente em sua descrição nos versos 147-153 e seguirá se aproximando de um vocabulário mais compatível com o que é usado para heróis e divindades, como será visto adiante. ${ }^{71}$

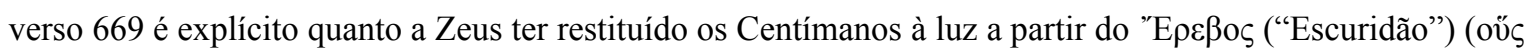

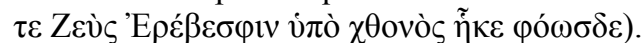

70 Cf, entretanto, Ilíada 2.276 , em que remete a Tersites, e 12.300, em remissão a um leão no interior de um símile. As ocorrências na Ilíada se referem, em sua maioria, a figuras heroicas: 9.398 (a Aquiles); 9.635 (em fala de Ájax em uso gnômico); 10.220 (a Diomedes); 10.244 (Diomedes acerca de Odisseu); 10.319 (a Dólon); 20.174 (narrador acerca de Aquiles); e 20.406 (narrador acerca da morte de Hipodamas). Na Odisseia, há um número maior de ocorrências: 2.103 (Antínoo acerca dos pretendentes); 4.548 (a Menelau); 4.658 (a Noemon e a Antínoo); 9.213, 10.406, 10.475, 12.28, 12.414, 14.219 e 18.61 (a Odisseu); 10.466 (a Odisseu e seus companheiros); 10.550 e 12.324 (aos companheiros de Odisseu); 19.148 e 24.138 (aos pretendentes). Werner (2013a) traduz a expressão por "ânimo arrogante".

71 Isso ocorre com exceção dos versos finais da Titanomaquia (671-675), nos quais o poeta retoma parte da descrição dos Centímanos feita nos versos 147-153. 
Zeus adota uma estratégia um tanto arriscada na libertação dos Centímanos. Em vez de propor a eles a libertação em troca de seu auxílio, o Cronida os liberta primeiro, alimentaos e lhes restituindo o ânimo, em um gesto de amizade e de hospitalidade, e depois lhes propõe a aliança, exortando-os. ${ }^{72}$ Com esse grande voto de confiança por parte de Zeus tanto em relação aos Centímanos quanto ao conselho de Terra, Zeus os persuade a combater a seu lado contra os Titãs, lembrando-os da amizade que acabaram de firmar e do sofrimento pregresso.

À fala de Zeus, Coto responde após ser qualificado pelo poeta como à $\mu v ́ \mu \omega v$ (“irrepreensível”, “impecável”, v. 654), epíteto honorário bastante comum na Ilíada e na Odisseia, embora nunca usado para divindades nesses dois poemas, mas cujo uso na passagem em questão parece manter a focalização de Zeus relativa aos Centímanos. ${ }^{73} \mathrm{Na}$ Teogonia, além de Coto, também recebem esse adjetivo Nereu (v. 263), o trabalho de suas cinquenta filhas (v. 264) e Latino, filho de Circe e Odisseu (v. 1013). ${ }^{74}$ Em sua resposta (v. 655-663), Coto declara que não é ignorante do coração e da mente de Zeus nem de que Zeus tenha se tornado protetor dos imortais, e atribui a sua libertação e a de seus irmãos à sagacidade do Cronida, parecendo nada saber da sugestão por parte de Terra, sua mãe. Coto encerra sua fala declarando que protegerão o poder de Zeus contra os Titãs, "com mente

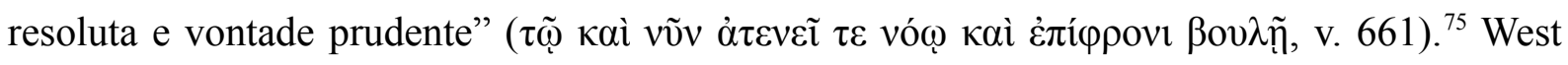
(1997 [1966], p. 345) já havia apontado que esse discurso de Coto ecoa o discurso de Zeus (v. 644-653), contudo, mais do que isso, a combinação $\tau \tilde{\omega}$ кaì vṽv no verso 661, enunciada por Coto, parece estabelecer um paralelismo entre as características de Zeus e de sua atitude, que o próprio Coto aponta nos versos 656-658, e a atitude que ele e seus irmãos tomarão agora. ${ }^{76}$

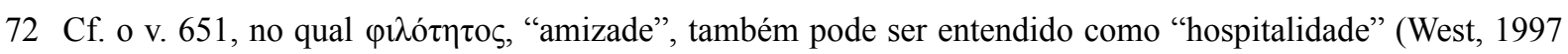
[1966], p. 344).

73 Esse epíteto foi objeto da obra inacabada de Anne Amory Parry, esposa de Milmann Parry, ambos mortos prematuramente em um acidente automobilístico. Anne Parry (1973) revisou todas as ocorrências de $\dot{\alpha} \mu v u_{\mu} \omega v$ nos poemas épicos, discordando do sentido de "impecável” ("blameless") geralmente atribuído a ỏ $\mu v ́ \mu \omega v$ em razão de uma possível etimologia com $\mu \tilde{\nu} \mu \alpha \rho$ ( $\mu \tilde{\omega} \mu \alpha \rho$ e $\mu \tilde{\omega} \mu \varsigma_{\zeta}$, "culpar", "reprovar"). Ela propôs um sentido relacionado à beleza que se estende para um sentido de excelência. Cf. Foley (1999, p. 211-213) para o caráter referencial de $\alpha \mu v ́ \mu \omega v$ enquanto um "sinal tradicional" que indica a complexidade das personagens a que se refere.

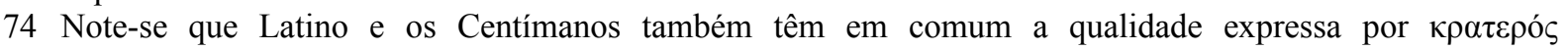
("poderoso", cf. supra). LSJ afirma que há apenas duas ocorrências de áuv́ $\mu \omega v$ em Hesíodo, entretanto, há quatro só na Teogonia e uma no Escudo de Héracles (v. 65), esta se referindo a Cisne (Kúкvos), oponente de Héracles.

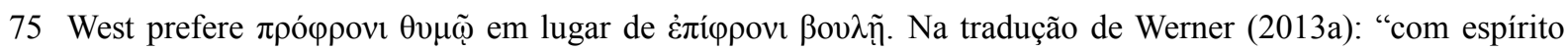
tenso e juízo solícito".

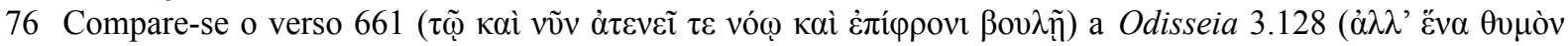

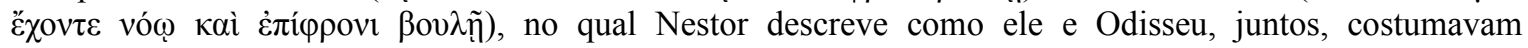
aconselhar os Aqueus. Edwards (1971, p. 175-176) aponta que “[...] Ainda assim, a contribuição que esses gigantes têm que fazer é, na verdade, de força bruta: Zeus por si só já tem todo o conhecimento que precisa

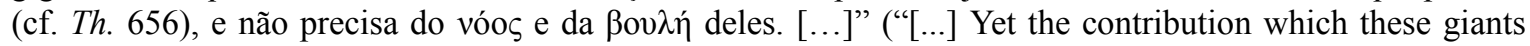
have to make is in facto ne of brute strength: Zeus himself already has all the wisdom he requires (cf. Th. 


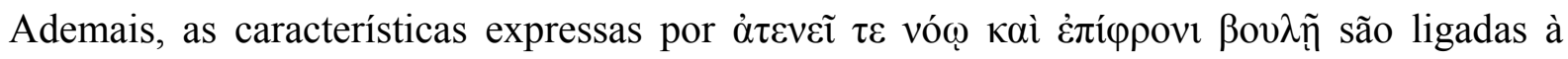
faculdade do pensamento e podem ressoar a atribuição de $\mu \eta \chi \alpha v \eta ́$ ao trabalho dos Ciclopes. ${ }^{77}$

A fala de Coto é aprovada pelos deuses e estimula o ânimo de todos a guerrear ainda mais do que antes. Então, todos se juntam para combater os Titãs e, nesse momento, o poeta retoma a descrição dos Centímanos (v. 669-675). Perceba-se que os versos 671-674 são

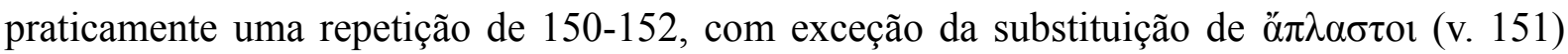
por $\pi \tilde{\alpha} \sigma ı v \dot{o} \mu \tilde{\omega}\left(\right.$ v. 672). ${ }^{78}$

Nesse trecho que introduz a participação dos Centímanos na batalha em si, a

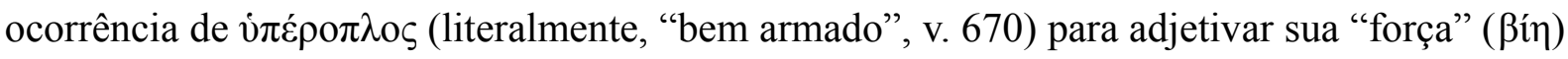

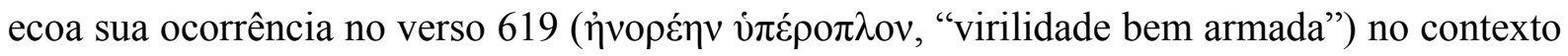
em que o poeta menciona as razões pelas quais Céu os odiou e os prendeu. Além disso, o verso 670 é imediatamente posterior ao que informa que Zeus os tirou do Érebo ou Escuridão lançando-os à luz, uma marcada relação de oposição entre a atitude de Céu, que os aprisiona por sua "bem armada virilidade", e a de Zeus, que os liberta. O uso de vं $\pi \varepsilon ́ \rho \circ \pi \lambda o \varsigma$ ainda

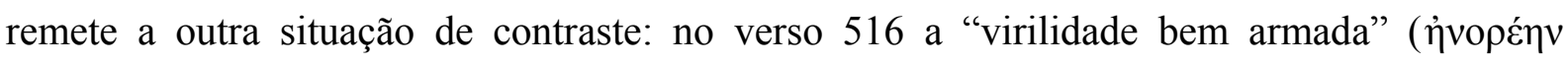
vं $\varepsilon$ po $\pi \lambda \circ v)$ é uma característica atribuída a Menécio, irmão de Prometeu e de Atlas, sendo uma das razões pelas quais Zeus o lança ao Érebo golpeando-o com o raio. A outra das duas razões para a atitude de Zeus em relação a Menécio é sua ḋं $\alpha \sigma \theta \alpha \lambda i ́ \alpha$ ("insensatez"), característica nunca atribuída aos Centímanos, mas sim aos Titãs (v. 209), que também serão aprisionados por Zeus e seus aliados. Assim, embora a "virilidade bem armada" seja uma das características dos Centímanos que suscita o ódio de Crono, ela será bem aproveitada por Zeus no contexto da Titanomaquia.

A retomada da descrição dos Centímanos entre os versos 670-673 é estratégica por evidenciar mais uma vez a dimensão física dos aliados dos deuses olímpicos imediatamente antes do início da batalha contra os Titãs. E ela se soma ao diálogo travado entre os

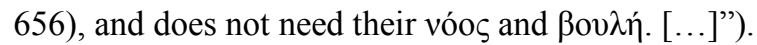

77 Observe-se que aos Ciclopes, diferentemente dos Centímanos, não é atribuída qualquer fala na Teogonia.

78 Nessa retomada da descrição dos Centímanos, é adicionada a característica expressa pelo adjetivo $\delta \varepsilon v v o ́ \varsigma$ ("terrível", "temível", "assombroso"), que não tinha aparecido no primeiro trecho relativo a eles, embora a

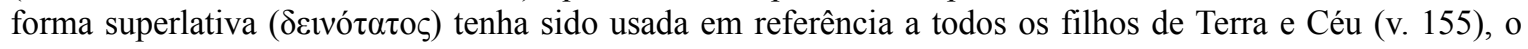

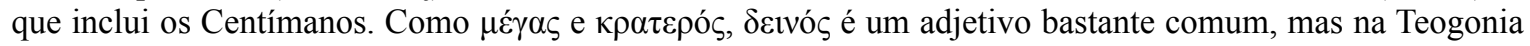
ele é predominantemente usado para qualificar algo ameaçador ou que causa medo: Cronos é qualificado por

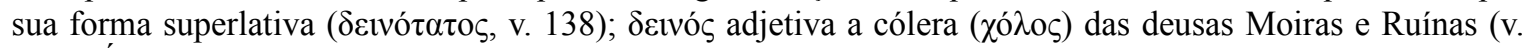
221); Équidna (v. 299); Tifeu (v. 307); Quimera (v. 320) e a força do fogo expelido por ela (v. 324); a serpente gerada por Fórcis e Cetó (v. 334); o modo como soava o mar durante a batalha contra os Titãs (v. 678); Tártaro (v. 743); a morada da Noite no Tártaro (v. 745); Morte e Sonho (v. 759); Cérbero (v. 769); o rio Estige (v. 776); as cabeças de Tifeu (v. 825 e 829) e o próprio Tifeu (v. 856); a deusa Atena (v. 925); Tritão (v. 933) e, por fim, Medo/Pavor e Terror (v. 935, Фóßos e $\Delta \varepsilon \tilde{\mu} \mu \circ$, traduzidos como "Afugentador" e "Susto" por Werner, 2013). Note-se que, além dos Centímanos, apenas Quimera é qualificada pela reunião dos

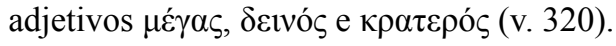


Centímanos e Zeus (v. 644-663), no qual Coto revela que combaterão com "mente resoluta e vontade prudente" (v. 661), características estas que, por sua vez, contrastam com a $\dot{\alpha} \tau \alpha \sigma \theta \alpha \lambda i ́ \alpha$ dos Titãs (v. 209). Desse modo, o poema não apenas retoma sua compleição física, estrategicamente relevante para o episódio, mas ela agora é somada a seus atributos intelectuais. O contraste com a $\alpha \tau \alpha \sigma \theta \alpha \lambda i ́ \alpha$ dos Titãs nesse episódio é relevante porque Céu, ao ser castrado, declara que os Titãs seriam punidos no futuro por terem cometido um ato de

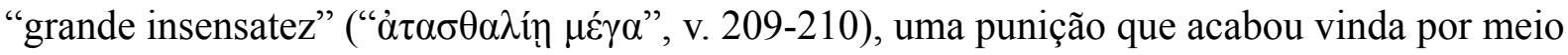
de seus próprios irmãos Centímanos. ${ }^{79}$

Os Centímanos, então, entram na batalha com pedras em suas mãos, armas que não são manufaturadas, mas naturais, contrastando com o raio de Zeus, obra do "engenho" ( $\mu \eta \chi \alpha v \alpha i ́$, v. 146) de seus irmãos Ciclopes, que será também crucial para a vitória sobre os Titãs; duas modalidades de força bélica que parecem se complementar. Ciclopes, com sua força e engenho, fabricam a arma mais poderosa do cosmo, e os Centímanos, com sua força, sua "mente resoluta e vontade prudente" (v. 661), tornam-se uma artilharia potente contra os Titãs. ${ }^{80}$ Embora Zeus use o raio durante a batalha (cf. v. 690-693 e 706-710), são os Centímanos que, por meio de seguidos arremessos, põem um fim ao combate, prendendo os Titãs no Tártaro (v. 714-721). Como apontam Blaise e Rousseau (em Blaise, de La Combe e Rousseau, 1995, p. 221), com a inserção dos Centímanos fazendo o papel de um batalhão, a luta contra os Titãs pôde ser finalmente definida em favor dos deuses olímpicos. Ao conferir uma utilidade à imensa força dos Centímanos, Zeus tem garantida sua primeira grande vitória em combate.

Encerrado seu papel na Titanomaquia, outro é atribuído aos Centímanos: tornam-se “guardiães fiéis" ( $\varphi v ́ \lambda \alpha \kappa \varepsilon \varsigma \pi i ́ \sigma \tau o 1)$ de Zeus no Tártaro (v. 734-735), uma relação enfatizada no verso 815 , que os qualifica por meio de uma fórmula homérica como seus "renomados

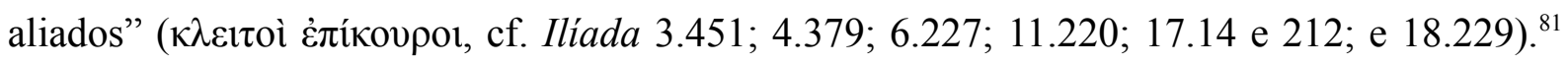
Como dito anteriormente, o vocabulário usado ao longo do episódio da Titanomaquia para remeter aos Centímanos é mais próximo daquele relacionado a divindades e figuras heroicas

79 Além da $\dot{\alpha} \tau \alpha \sigma \theta \alpha \lambda i ́ \alpha$ atribuída aos Titãs e a Menécio, o próprio Céu é dito $\alpha \tau \alpha ́ \sigma \theta \alpha \lambda o \varsigma$ por Terra (v. 164) e o rei Pélias também é caracterizado com esse adjetivo pelo poeta.

80 Poder-se-ia pensar que os Ciclopes incorporariam o engenho enquanto os Centímanos, a força. Contudo, tanto os Ciclopes quanto os Centímanos incorporam ambos: os Ciclopes também são fortes, como explicita o verso 146, embora não apliquem sua força diretamente no campo de batalha, mas em seus trabalhos; quanto aos Centímanos, além de Coto possuir fala bem articulada (cf. v. 655-663), o poema deixa claro, por meio do verso 661 e do diálogo travado com Zeus, que eles possuem a capacidade de reflexão (cf. v. 661).

81 Note-se que em Trabalhos e Dias, a despeito das possíveis semelhanças entre os Centímanos e a raça de bronze, o destino da raça de ouro, e não da raça de bronze, é tornar-se guardiã ( $\varphi v ́ \lambda \alpha \xi$ ) dos mortais (v. 121126) também por desígnios de Zeus. Entretanto, a função de guardiã da raça de ouro é de proteção dos mortais, enquanto a dos Centímanos é manter seus irmãos Titãs aprisionados. 
do que daquele que foi empregado em sua descrição (v. 147-153). Gige recebe o epíteto ő $\alpha$ to $\pi \mathrm{o} \lambda \varepsilon \dot{\mu} \mu \mathrm{oto}$ (“insaciável de guerra”), atribuído a Ares na Ilíada (5.388 e 863; 6.203) e no Escudo de Héracles (v. 59); Coto é à $\mu$ $\mu \omega v$ (v. 654), epíteto que expressa certa excelência

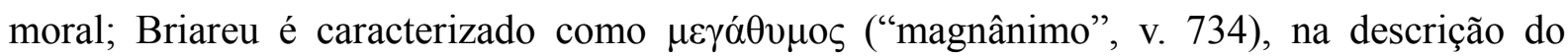

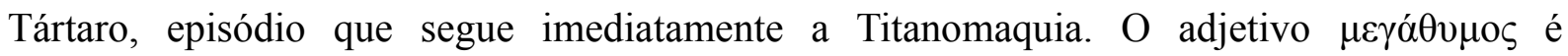
comumente usado para povos e heróis na Ilíada e na Odisseia, dentre os quais Aquiles (Il. 17.214; 18.226; 19.75; Od. 3.189), Heitor (Il. 18.335), Telêmaco (Od. 3.364 e 423), Odisseu (Od. 15.2) e também a deusa Atena (Od. 8.520 e 13.121). ${ }^{82}$

Após garantirem, então, a vitória sobre os Titãs, os Centímanos continuam sendo aliados de Zeus, que lhes garante um lugar em sua ordem, embora o lugar que passam a habitar talvez não seja muito diferente daquele no qual permaneceram aprisionados por tanto tempo. De acordo com Clay $(2003$, p. 25$):^{83}$

Os Centímanos, aprisionados sob o reinado tanto de Céu quanto de Crono como ameaças a seus regimes, retornam ao mundo das trevas, mas o ápice político de Zeus lhes assinala uma função que explora sua esmagadora força física. Como guardiães dos Titãs aprisionados, eles servem tanto à ordem de Zeus como são eliminados enquanto potenciais ameaças à sua concretização. [...]

Portanto, ao libertar os Ciclopes e os Centímanos, Zeus neutraliza duas possíveis e grandes ameaças à sua ordem. Ele se apropria de elementos da geração de seu pai não só para combatê-la e aprisioná-la, mas para governar (por meio do raio forjado por seus tios Ciclopes) sobre todas as gerações vindouras e pregressas.

\section{2.d) Estrutura narrativa e estrutura de poder}

A respeito da estrutura narrativa, as passagens relativas à libertação dos Ciclopes (v. 501-506) e à dos Centímanos (v. 617-663) flanqueiam o episódio de Prometeu. Acerca disso Clay (2003, p. 106-7) nota que: ${ }^{84}$

82 Stoddard (2001, p. 49) sugere que essa diferença na caracterização entre os versos 147-153, de um lado, e aquela ao longo do episódio da Titanomaquia e depois dele, de outro, decorre do fato de os Centímanos terem adquirido um papel bem definido e honrável na hierarquia olímpica.

83 "The Hundred-Handers, imprisoned under the reign of both Uranus and Cronus as threats to their regimes, return to the world of darkness, but Zeus's political acumen assigns them a function that exploits their overwhelming physical force. As guardians of the imprisoned Titans, they both serve Zeus's order and are removed as potential menaces to its realization. [...]"

84 " [...] In contrast to the punishment and binding of Prometheus, these two actions of unbinding prefigure Zeus's victory in the Titanomachy. Moreover, they share a common feature: a benefaction on the part of Zeus (his liberation of those previously imprisoned) elicits, so to speak, a counter-gift which ensures his final and permanent victory. These are, as Brown [1953, p. 20] has aptly put it, 'political deals' whereby 'Zeus secures the instruments of organized violence which are characteristic of political power: an armament 
[...] Em contraste com a punição e prisão de Prometeu, essas duas ações de libertação prefiguram a vitória de Zeus na Titanomaquia. Além disso, elas compartilham uma característica comum: uma benesse da parte de Zeus (a libertação daqueles emprisionados anteriormente) induz, por assim dizer, um contradom que assegura sua vitória final e permanente. Esses são, como Brown [1953, p.20] disse de modo sagaz, "acordos políticos" por meio dos quais "Zeus assegura os instrumentos da violência organizada que são característicos do poder político: uma indústria armamentista (os Ciclopes) e um exército de mercenários (os Centímanos).” [...]

[...] Em preparação para a Titanomaquia, Zeus se alia com os Ciclopes e os Centímanos, dando a eles o dom da liberdade. Por meio desse ato, Zeus ganha sua gratidão; eles, em contrapartida, ajudam Zeus contra seus inimigos e tornam possível sua vitória completa. A história de Prometeu está, portanto, emoldurada entre dois incidentes que enfatizam os princípios da reciprocidade e a importância das alianças políticas. A narrativa em si envolve repetidamente dons e o contradons.

Embora temíveis e odiados pelo pai, os filhos de Céu e Terra são divididos em dois diferentes grupos que recebem tratamento distinto por parte de Zeus, Titãs sendo aprisionados de um lado, Ciclopes e Centímanos sendo libertados de outro. Zeus, portanto, apresenta uma atitude muito diferente da de seu avô Céu e consegue discernir no cosmo aquilo que representa inevitavelmente uma ameaça à sua ordem daquilo que, ao contrário, pode ajudá-lo a firmá-la. Se os Titãs têm ḋं $\alpha \sigma \theta \alpha \lambda i ́ \alpha$, como enunciado pelo próprio Céu, os Ciclopes têm

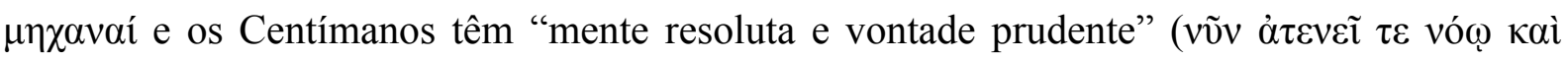

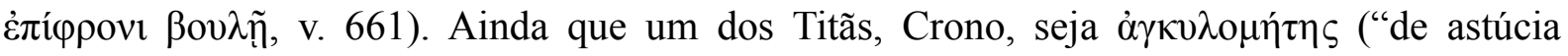
curva"), ele não soube tirar proveito da força e da capacidade de seus irmãos e não foi suficientemente páreo para Zeus e seus aliados. Portanto, a vitória de Zeus sobre os Titãs, sendo um golpe final contra a geração anterior, é também o golpe final de Zeus contra seu pai Crono e seu reinado. É essa vitória, obtida com a fundamental ajuda dos Centímanos, que garante o estabelecimento da derradeira geração olímpica no mito de sucessão.

E, ao atribuir aos Centímanos o papel de guardiães dos Titãs no Tártaro, Zeus parece firmar certo domínio também sobre essa região. Tal domínio parece ser corroborado se se levar em consideração a estrutura anelar que engloba a descrição Tártaro (v. 717-816): o anel tem início com a ação dos Centímanos em combate (713-717) e com o aprisionamento dos Titãs (717-720) e se encerra com a retomada desse aprisionamento (813-814), sendo finalizado com os Centímanos e o papel que agora desempenham como guardiães dos Titãs no

industry (the Cyclopes), and a mercenary army (the Hundred-Arms).' [...]

[...] In preparation for the Titanomachy, Zeus allies himself with the Cyclopes and the Hundred-Handers by giving them the gift of liberty. Through this act, Zeus gains their gratitude; they in turnhelp Zeus against his enemies and make possible his complete victory. The story of Prometheus is thus framed between two incidents that emphasize the principles of reciprocity and the importance of political alliances. The narrative itself repeatedly involves gifts and counter-gifts." 
Tártaro (v. 815-819) ${ }^{85}$ Portanto, o papel designado por Zeus aos Centímanos aponta para uma possível inserção de Zeus e sua ordem também nessa outra parte do cosmo.

Ao final da descrição do Tártaro, sabemos que Posêidon deu sua filha como esposa a Briareu por este ser valoroso (cf. v. 817, mais uma caracterização digna de atitudes heroicas), tornando-o seu genro. Dentre os três Centímanos, apenas Briareu parece ter recebido especial atenção de Posêdon - e também do poeta da Ilíada, já que é o único dos seus irmãos a ser mencionado neste poema. Lá, Briareu aparece como um protetor de Zeus. Na prece de Aquiles à sua mãe Tétis, o herói evoca o episódio (v. 1.396-406) no qual os deuses olímpicos tentaram acorrentar Zeus, e Tétis o socorreu ao chamar ao Olimpo o Centímano Briareu. É

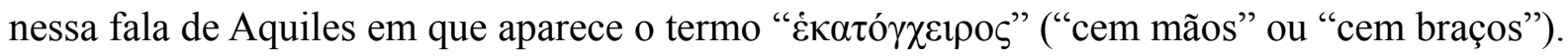
Segundo ela, "Briareu" é o nome sob o qual o Centímano é conhecido dos deuses, conquanto

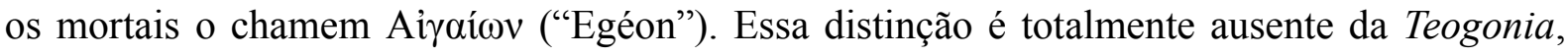
seja pelo desconhecimento do poeta, seja por não ser uma informação relevante para o poema, seja, ainda, em razão de a Teogonia narrar um tempo anterior ao nascimento dos mortais.

Nesse episódio mencionado na Ilíada por Aquiles, bastou Briareu sentar-se ao lado de Zeus para que os deuses desistissem da atitude que, talvez merecidamente, fizesse Zeus repensar no que fez a Prometeu. Essa breve menção a Briareu na Ilíada indica que a aliança firmada por Zeus, além de garantir sua vitória sobre os Titãs e a presença de seus representantes no Tártaro, protege-o da ação adversa dos próprios deuses olímpicos, seus irmãos, asseverando seu domínio sobre eles, não apenas por meio da posse de seu poderoso raio confeccionado pelos Ciclopes, mas também pela fundamental aliança firmada com os Centímanos. De acordo com Muellner (1996, p. 120): ${ }^{86}$

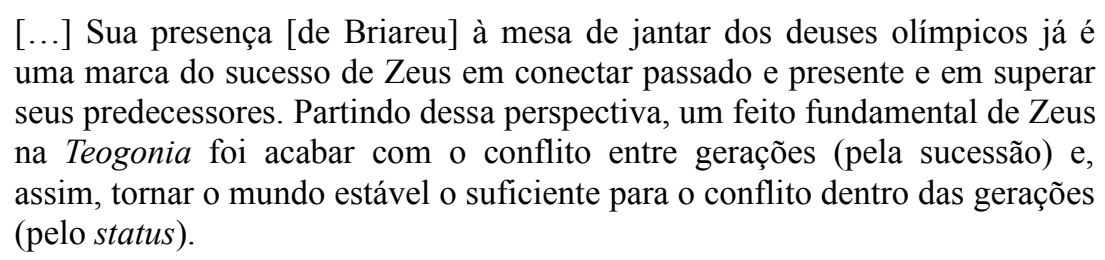

Porém, antes de chegar a ser ameaçado por seus próprios irmãos, Zeus terá de enfrentar seu derradeiro inimigo na Teogonia, Tifeu, filho dos primordiais Terra e Tártaro, e o fará sem o auxílio de qualquer aliado, embora munido da arma produzida pelos Ciclopes.

85 Sobre a estrutura anelar da descrição do Tártaro, cf. West (1997 [1966], p. 358).

86 " [...] His presence at the divine table is itself a mark of Zeus's success in bridging past and present, in outgoing his predecessors. From this perspective, a fundamental achievement of Zeus in the Theogony was to end conflict between generations (over succession) and so make the world stable enough for conflict within generations (over status)." 


\subsection{TíFON/TIFEU ${ }^{87}$}

Seguindo imediatamente a descrição do Tártaro, cujos últimos versos (v. 815-819) retomam os Centímanos e seu papel como aliados de Zeus, está o episódio do combate entre Zeus e Tifeu (v. 820-880). Gerado de Tártaro, Tifeu é o último filho de Terra no poema, fruto da única união da deusa presidida por Afrodite. Clay (2003, p. 25 n. 37) aponta que "a

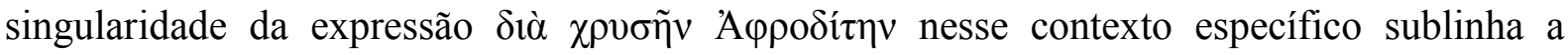
singularidade da união entre esses dois seres primordiais nesse estágio tardio da cosmogonia", tornando Tifeu um regresso literal a uma era mais antiga. ${ }^{88}$ Além disso, Tifeu é o único rebento em toda a Teogonia gerado diretamente da união de duas divindades primordiais, o que confere ainda mais força à sua origem e ao recuo ao passado apontado por Clay. Conforme Détienne e Vernant (2008 [1974], p. 107):

[...] por sua dupla hereditariedade, ele aparenta uma potência original; nascido tarde, mais jovem que Zeus, ele prolonga, num universo já diferenciado e ordenado, a linhagem daqueles "que foram antes", os seres primordiais que Hesíodo coloca nas raízes do mundo.

Portanto, é contra essa versão extemporânea das divindades ou potências primordiais que Zeus, filho dos Titãs Crono e Reia, terá de combater, dessa vez sozinho, sem aliados, munido apenas da arma confeccionada pelos Ciclopes. Esse combate entre Zeus e Tifeu é comumente chamado de "Tifonomaquia", considerado, por vezes, um duplo do episódio da Titanomaquia. Arthur Meyer (apud West 1997 [1966], p. 382-383) apontou as semelhanças estruturais entre esses dois episódios, reproduzidas a seguir. ${ }^{89}$

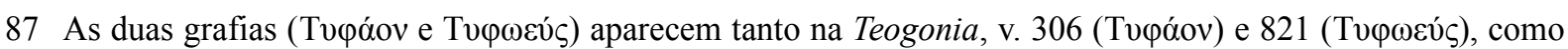

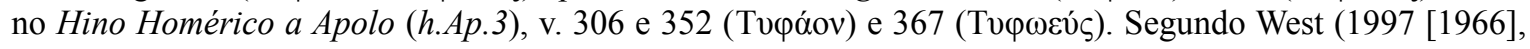
p. 252), a origem do nome e a razão de haver as duas variantes não apresentam explicação, embora tenham

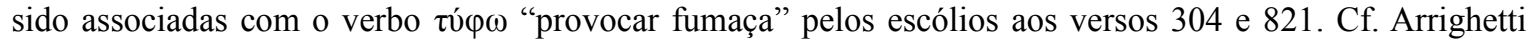
(1998, p. 338): “[...] c'è un' oscillazione del nome Typhaon/Typheo di cui non si trova una ragione plausibile; [...]". Por uma finalidade meramente prática, optou-se por utilizar apenas "Tifeu" ao longo do texto desta tese.

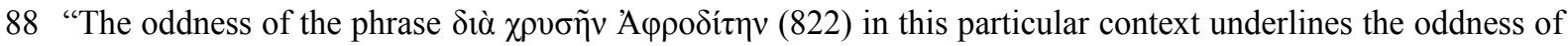
the union of these primordial beings at this late stage of cosmogony. Typhoeus is literally a throwback to an earlier era." Essa extemporaneidade de Tifeu já fora apontada por Détienne e Vernant (2008 [1974], p. 107).

89 Para uma análise comparativa entre os combates da Teogonia sob uma perspectiva semiótico-narrativa, cf. Pellizer (em Blaise, Judet de La Combe e Rousseau, 1995, p. 235-249) e a resposta de Ballabriga a Pellizer nas páginas 251-253. 


\begin{tabular}{|c|c|}
\hline Titanomaquia & Tifonomaquia \\
\hline v. 664 e ss.: descrição dos combatentes & v. 820 e ss.: descrição de Tifeu \\
\hline $\begin{array}{l}\text { v. } 678 \text { e ss.: descrição em termos gerais do } \\
\text { conflito contra os Titãs }\end{array}$ & $\begin{array}{l}\text { v. } 836 \text { e ss.: descrição em termos gerais do } \\
\text { conflito contra Tifeu }\end{array}$ \\
\hline $\begin{array}{l}\text { v. } 687 \text { e ss.: Zeus toma suas armas e exibe sua } \\
\text { força na Titanomaquia }\end{array}$ & $\begin{array}{l}\text { v. } 853 \text { e ss.: Zeus toma suas armas e exibe sua } \\
\text { força na Tifonomaquia }\end{array}$ \\
\hline $\begin{array}{l}\text { v. } 693 \text { e ss.: o inimigo é rechaçado e a } \\
\text { conflagração geral é elaborada por meio de um } \\
\text { símile }\end{array}$ & v. 855 e ss.: idem \\
\hline v. 717 e ss.: Titãs são arremessados ao Tártaro & v. 868 e ss.: Tifeu é arremessado ao Tártaro \\
\hline
\end{tabular}

Embora essa comparação mostre que os dois episódios obedecem a uma mesma ordenação narrativa, Clay (2003, p. 25-26), seguindo Blaise (1992), aponta que, diferentemente do que ocorre na Titanomaquia, a luta contra Tifeu é o único embate físico no qual Zeus luta sozinho e, ao derrotá-lo, o Cronida derrota também Terra, pondo "um fim à sua fecundidade e neutralizando sua estratégia de sempre apoiar a geração mais jovem contra a mais antiga para promover mudança a expensas da estabilidade cósmica". ${ }^{90}$ Ambos, Crono e Zeus, receberam conselhos de Terra e destronaram seus respectivos pais, episódios que compõem os mitos de sucessão. Talvez seja significativo que a primeira referência a Tifeu no episódio da Tifonomaquia seja pelo adjetivo ó $\pi \lambda$ ó $\alpha \alpha \tau o \varsigma$ ("caçula" ou "aquele mais bem armado", v. 821), que fora anteriormente atribuído a Crono (v. 137) e a Zeus (v. 478), sinalizando que Tifeu seja um potencial sucessor no domínio do cosmo.

Blaise (em Blaise, de La Combe e Rousseau, 1995, p. 256-257) oferece ainda outra justificativa para que a Tifonomaquia não seja um mero duplo da Titanomaquia: após combater os Titãs e ordenar o mundo "de cima" ("d'en haut"), Zeus deve ordenar o mundo “de baixo" (“d'en bas"), no qual já tinha iniciado sua inserção por meio dos Centímanos, conforme foi proposto acima. Assim, o episódio da Tifonomaquia é fundamental para que a ordenação do cosmo se complete e para que o poder de Zeus seja definitivamente instaurado.

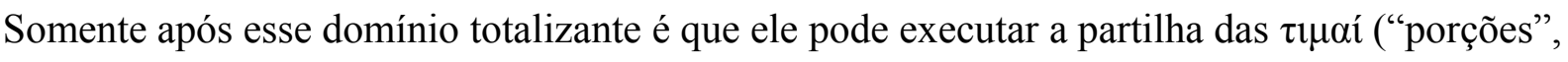
"honras") às divindades com quem compartilhará a administração do cosmo (v. 881 e ss.).

Como seus meio-irmãos Ciclopes e Centímanos, aliados de Zeus, Tifeu é portador do

90 “[...] To render his rule permanent, Zeus must here fight fire with fire and ultimately put an end to Earth's fecundity; he must neutralize her strategy of always siding with the younger against the older generation in order to promote change at the expense of cosmic stability." Cf. o princípio de "diferença e diferenciação" proposto por Pucci (em Montanari, Tsagalis e Rengakos, 2009, p. 68), no qual a fertilidade de Terra não cessa de produzir rebentos gerando diversidade e definição no interior do cosmo. 


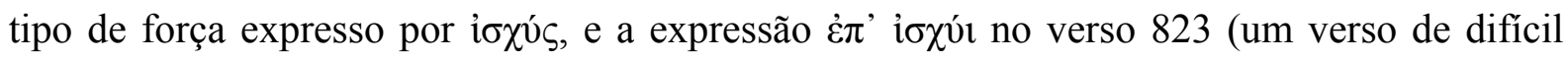
compreensão e, por isso, considerado corrupto [cf. West 1997 [1966], p. 384]) parece ecoar de

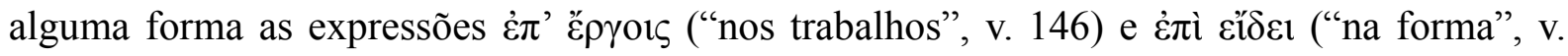
153), que fazem parte da descrição dos Ciclopes e dos Centímanos respectivamente, apresentando a incomum construção com غ̇ंí seguido de um substantivo no caso dativo. Conquanto Zeus tenha incorporado esse tipo de força a seu domínio por meio das alianças com os Ciclopes e os Centímanos, os únicos no poema a possuir esse tipo de força que é capaz de forjar um raio e de derrotar os Titãs - uma força que já não se encontra nas gerações posteriores aos filhos de Terra e Céu -, em Tifeu, ela constitui uma ameaça. ${ }^{91}$

Além de possuir essa força em seus braços (v. 823), ${ }^{92}$ Tifeu tem "pés incansáveis"

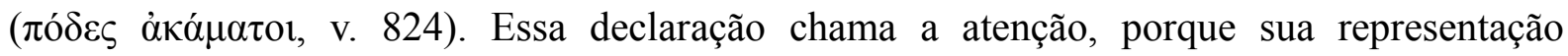
iconográfica, por vezes, apresenta a parte inferior do seu corpo composta por serpentes. ${ }^{93} \mathrm{Na}$ Teogonia, porém, as serpentes saem de seus ombros em número de cem (v. 825), o que também não se vê nas representações iconográficas. Na verdade, parece haver uma inversão: na iconografia, suas pernas são em geral de serpentes, com o torso antropomórfico (às vezes portando asas).

De suas cem cabeças de serpente, línguas escuras se conjugam com olhos flamejantes (v. 824-825). Contudo, a característica de Tifeu à qual o poeta dedica mais versos está relacionada à sua capacidade de produzir sons: dos treze versos dedicados à sua descrição (v. 823-835), sete se concentram na exposição dessa habilidade (v. 829-835). Tifeu produz sons que tanto podem ser compreendidos pelos deuses, supostamente uma fala articulada, quanto podem soar símeis a animais ferozes, como o touro e o leão, ou como inofensivos filhotes de cães, além de "assobiar" ou "sibilar" de modo que as montanhas o ecoavam. Essa multiplicidade sonora contrasta, de certo modo, com a fala bem articulada dos Centímanos em seu diálogo com Zeus (cf. v. 655-663).

Com toda a sua multiplicidade e capacidade destrutiva, Tifeu teria governado sobre mortais e imortais caso Zeus não tivesse intervindo (v. 836-838). O tipo de governante (cf. v.

91 Atualmente, embora se encontrem mais argumentos para a manutenção do episódio da Tifonomaquia do que para sua exclusão (cf. West, 1997 [1966], p.379-383), o verso 823 é considerado corrupto pelas dificuldades gramaticais que ele apresenta. Cf. o comentário de West (1997 [1966], p. 824, ad loc.). Consciente disso, levo em consideração esse verso em minha análise porque acredito fazer sentido que a Tifeu seja atribuída esse tipo de força bruta expresso por i̇ðú (para uma breve análise dessa força, cf. supra, p. 113-114).

92 Como dito na nota anterior, esse verso é de difícil compreensão. Entendo que ele expresse, contudo, a relação dessa força com os braços de Tifeu.

93 Para as representações iconográficas de Tifeu, cf. o verbete "Typhon" em LIMC, vol. VIII, 1997, Tomo I, p. 147-151 com texto de Odette Touchefeu-Meynier e p. 151-152 com texto Ingrid Krauskopf para a Etrúria, Tomo II (imagens), p. 112-113. Cf. especialmente a fig. 14. Clay (1993, p. 105) comenta que a proliferação de "monstros" na arte do período que se convencionou chamar de "Orientalizante" pode ser contemporânea a Hesíodo. 


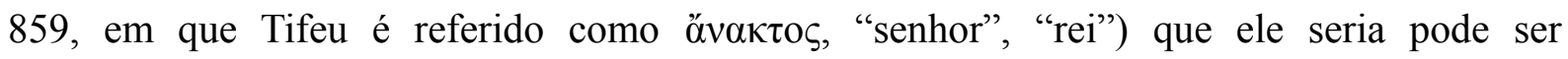
vislumbrado na passagem do "catálogo de monstros", na qual o poema o caracteriza como

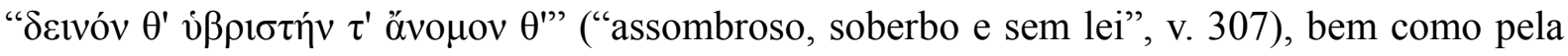

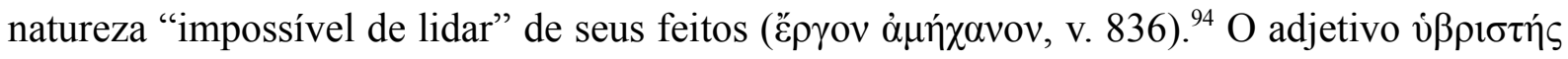
é usado na Teogonia para caracterizar Menécio (ou Menoitio), irmão de Prometeu e de Atlas, a quem Zeus fulmina com o raio e lança ao Érebo em razão de sua $\dot{\alpha} \theta \alpha \sigma \tau \alpha \lambda i ́ n$ (“iniquidade”) e

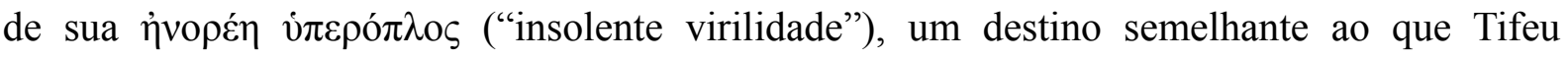
sofrerá..$^{95}$

Ao perceber Tifeu, Zeus troveja abalando Terra, Céu e Mar, e se lança do Olimpo, que estremece sob seus pés (839-843). O combate entre Zeus e Tifeu toma proporções de catástrofes meteorológicas, em que até mesmo o mar queima abaixo dos dois combatentes, resultado do trovão, do relâmpago, do fogo de Tifeu (aqui referido pela primeira vez por $\pi \varepsilon ́ \lambda \omega \rho / \pi \varepsilon ́ \lambda \omega \rho o v$, "prodígio"), dos ventos, dos tornados e do raio (v. 844-846). Com o estrondo, até Hades e os Titãs, estes no Tártaro, amedrontaram-se, indicando que o combate atinge todo o cosmo ao abalar desde o Olimpo até o Tártaro. Porém, o Cronida, com sua arma (compare-se a semelhança entre o v. 854 e o 140, retomando de certo modo a nomeação dos Ciclopes), desfere o golpe que expele Tifeu do Olimpo, queimando todas as cabeças do

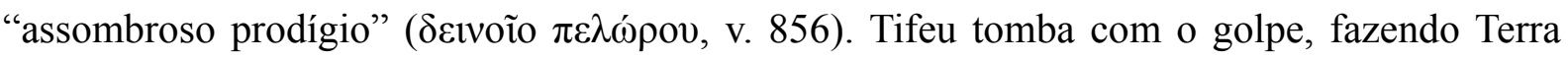

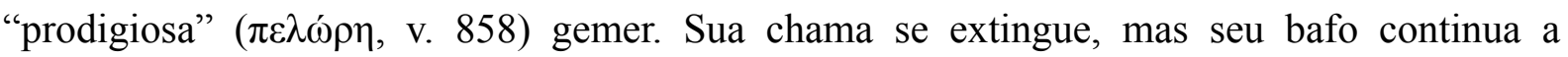

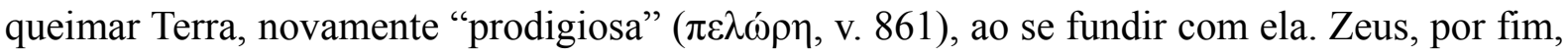
o arremessa ao Tártaro (v. 868), mesmo destino dos Titãs.

Nessa passagem estrondosa (v. 844-867), a repetição do substantivo $\pi \varepsilon ́ \lambda \omega \rho / \pi \varepsilon ́ \lambda \omega \rho o v$ atribuído a Tifeu (v. 845 e 856) e do adjetivo na forma do feminino $\pi \varepsilon \lambda \omega ́ \rho \eta$ a Terra (v. 858 e 861) opera uma aproximação entre as duas figuras tanto no tocante ao parentesco (Tifeu, filho de Terra) quanto em relação ao que esses termos expressam (cf. cap. 2): Tifeu é detentor de

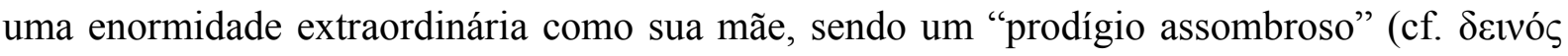
no v. 855).

Mesmo após seu encarceramento, Tifeu é ainda capaz de causar danos aos mortais. Apesar de derrotado, sua existência no cosmo é sentida pelos ventos que gera, caracterizados como "grande desgraça aos mortais" ( $\pi \tilde{\eta} \mu \alpha \mu \varepsilon \dot{\gamma} \gamma \alpha$ $\theta v \eta \tau o i ̃ \sigma l, ~ v . ~ 874)$. Portanto, sendo imortal

94 Como mencionado anteriormente, a ả $\mu \eta \chi \alpha v i ́ \alpha$ não é uma simples negação, por meio do " $\alpha$ " privativo, da $\mu \eta \chi \alpha v i ́ \alpha$ ("engenho"), uma das habilidades que os Ciclopes aplicam em seus trabalhos (cf. v. 146); a $\dot{\alpha} \mu \eta \chi \alpha v i ́ \alpha$, de acordo com Martin (1983), implica em uma ação diante da qual há um estado de desamparo ou total impotência porque é uma ação contra a qual é impossível de se lidar.

95 Ele também é usado para Pélias, rei de Iolco, que impôs os trabalhos a Jasão. Pélias é também caracterizado

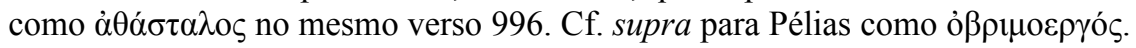




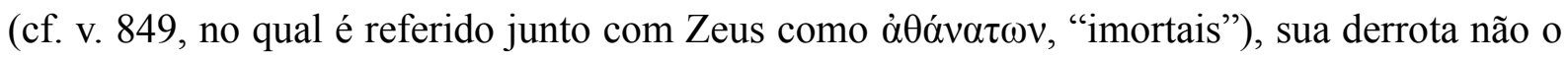
elimina do cosmo, apenas neutraliza a ameaça que representa contra a supremacia de Zeus.

Tais ventos gerados de Tifeu são contrastados com Noto, Bóreas e Zéfiro, que,

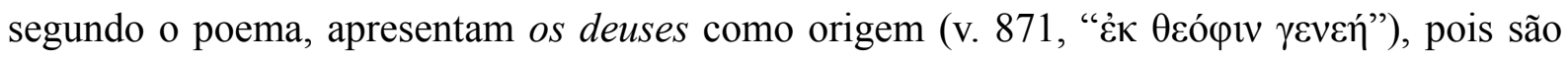

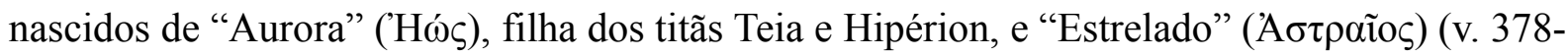
380), filho do titã Creio e de Euríbie, por sua vez, filha do Mar e de Terra (v. 234 239). Essa aparente contradição, colocada pela origem divina desses ventos em contraste com aqueles provenientes de Tifeu, é compreendida por West (1997 [1966], p. 384) nos termos de que Hesíodo não pode mais considerá-lo um deus por estar incapacitado, conquanto o considere uma divindade no contexto da batalha contra Zeus. Esse comentário de West é interessante para esta tese por entreter a possibilidade de que Hesíodo considere Tifeu um deus. ${ }^{96}$ Contudo, não acredito que Tifeu não seja mais considerado uma divindade por estar incapacitado, nem que ele deixe de ser considerado uma figura divina por Hesíodo. A declaração de que Notos, Zéfiro e Bóreas vêm "dos deuses" em oposição aos que vêm de Tifeu não marca uma oposição entre Tifeu e deuses, mas um contraste em que aqueles são benfazejos aos mortais,

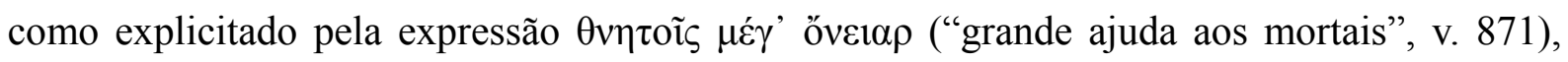
enquanto os que são provenientes de Tifeu causam "grande ruína aos mortais" ( $\pi \tilde{\eta} \mu \alpha \mu \varepsilon \dot{\gamma} \alpha$

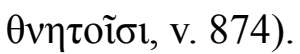

Com a derrota, mas não a eliminação, de Tifeu - o último recurso de Terra, que, desde que gerou Céu, governa indiretamente quer por meio de seus filhos quer por meio de seus conselhos -, Zeus agora está livre de ameaças para reinar sobre o cosmo e partilhar as honras entre seus pares, tema que compõe a última parte da Teogonia. Portanto, sendo o último a nascer de Terra e ao mesmo tempo sendo anterior ao ciclo de nascimentos sob a regência dos deuses olímpicos (cf. Thalmann, 1984, p. 40), Tifeu, na visão de Muellner (cf. 1996, p. 89) e Clay (2003, p. 26), encerra a história de Terra como um princípio procriador, tornando possível o reinado de Zeus. Assim, a derrota de Tifeu também seria uma derrota de Terra no cosmo hesiódico.

Calame (1985, p. 156-157), contudo, afirma que essa derrota "permite à soberania de Zeus se estabelecer de maneira definitiva sobre a negação do monstruoso" (grifo meu): ${ }^{97}$

96 No capítulo 6, será discutida essa questão da divindade em oposição aos mortais e o lugar das criaturas que denominamos "monstruosas" na visão do cosmo expressa pela poesia hexamétrica arcaica.

97 " [...] Ce parcours narratif complémentaire permet à la souveraineté de Zeus de s'établir de manière définitive sur la négation du monstrueux. Avec Typhée, il n'y a plus de place pour la médiation; cette figure conduit à l'assignation d'une place définitivement souterraine à la force purement physique et à une évaluation radicalement négative du monstrueux." 
[...] Esse percurso narrativo complementar permite à soberania de Zeus se estabelecer de maneira definitiva sobre a negação do monstruoso. Com Tifeu, não há mais lugar para a mediação; essa figura conduz à designação de um lugar definitivamente subterrâneo à força puramente física e a uma avaliação radicalmente negativa do monstruoso.

Com as vitórias ao longo da Teogonia, primeiro sobre os Titãs, depois sobre Prometeu e, por fim, sobre Tifeu, Zeus galga sua soberania se provando hábil e capaz de governar o cosmo. A primeira vitória, sobre os Titãs, já se constitui como uma vitória sobre a força puramente física, que ele combate com o auxílio da extrema força física dos Centímanos. Ao manter os Titãs aprisionados no Tártaro, tendo os Centímanos como seus guardiães, Zeus já designou "um lugar definitivamente subterrâneo à força puramente física". No duelo contra Prometeu, a vitória de Zeus consagra seu domínio sobre a $\mu \tilde{\eta} \tau ı \varsigma$ (“astúcia”) (cf. v. 613). Porém, com a vitória sobre Tifeu, não é a força puramente física ou o monstruoso que está em questão. Martin (1983, p. 20-23), em seu estudo sobre a ḋ $\mu \eta \chi \alpha v i ́ \alpha$ na poesia épica hexamétrica, traça um paralelo entre essa característica e a $\mu \tilde{\eta} \tau \iota \varsigma^{98}$

“[...] ao traçar associações de dicção nas descrições de outros monstros $\dot{\alpha} \mu \eta ́ \chi \alpha$ vo na obra de Hesíodo, podemos concluir que a própria multiplicidade, na forma e na voz, de tais monstros lhes confere o mesmo poder que a $\mu \tilde{\eta} \tau \iota \varsigma$ confere aos deuses e a alguns homens."

Assim, a vitória sobre Tifeu não é uma vitória sobre a força puramente física ou sobre o monstruoso, mas sobre a própria $\alpha \mu \eta \chi \alpha v^{\prime} \alpha$. O poema é explícito ao declarar que teria havido

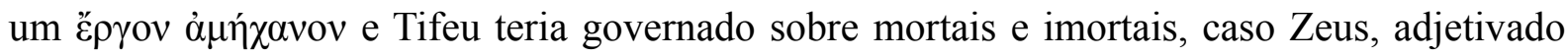
por ỏ ’́v ("afiado", de onde "arguto", v. 838), não tivesse notado. Com isso, Zeus, portanto, mostra-se capaz de evitar o inevitável e combater o incombatível: o aspecto múltiplo de Tifeu, seja em sua descrição física ou quanto aos sons que produz, soma-se à sua enorme capacidade destrutiva, e Zeus, sozinho, combate prontamente um fenômeno meteorológico com outro, seu raio, confeccionado pelos Ciclopes com $\mu \eta \chi \alpha v \alpha i ́$ (“engenho”). Segundo West (1997 [1966], p. 381), a associação de Tifeu com o fenômeno do tornado decorre da associação que os antigos

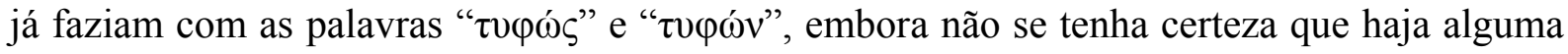
relação etimológica. De todo modo, ele sugere que essa etimologização popular tenha influenciado Hesíodo para que o poeta fizesse com que as tempestades de vento no mar tenham sido colocadas como originadas de Tifeu. ${ }^{99}$

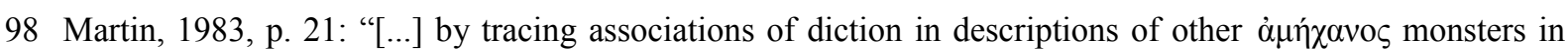
Hesiod's work, we can conclude that the very multiplicity, in form and voice, of such monsters gives them the same power as $\mu \tilde{\eta} \tau \iota$ does for gods and some men."

99 Veja-se a passagem da Ilíada 2.780-785: "Assim marcharam como se o fogo lavrasse na terra inteira; / a 
Blaise (1992, p. 369) considera que os ventos gerados de Tifeu são a "manifestação meteorológica das múltiplas e violentas vozes do monstro". ${ }^{100}$ Tifeu, portanto, como seus meio-irmãos Ciclopes, seria a personificação de um fenômeno natural. Para Blaise, "Hesíodo estabelece aqui uma genealogia negativa que reforça o caráter abstrato do monstro que os produz", em que os ventos gerados de Tifeu são exatamente como ele por também escaparem à representação. Contudo, penso que a multiplicidade de seu corpo e de sua voz não são indicativos de sua monstruosidade, mas o resultado de um modo de representação do mundo natural ou, mais precisamente, de representação da percepção de aspectos do mundo natural.

A imprevisibilidade e o caráter destrutivo dos ventos provenientes de Tifeu, junto com a segunda metade do hino a Hécate, enfatiza, para Stoddard (2004, p. 152-153), a inabilidade humana de controlar ou de predizer como uma divindade pode afetar o modo de vida do homem. Para ela: ${ }^{101}$

[...] Essa ênfase compartilhada no desamparo do homem diante do divino reflete a focalização humana que caracteriza as últimas seções dessas duas passagens. Ao discutir como deuses e homens interagem cotidianamente, seja para o bem ou para o mal, a impotência do homem na relação é tão inevitável para o narrador humano da Teogonia quanto o é para todos os humanos que oram. Hesíodo apresenta prolepticamente as ramificações que Hécate e Tifeu têm tido para a raça humana, e ao fazê-lo reitera o tema principal do poema que é o abismo que separa homens de deuses.

Assim, a derrota de Tifeu e a subsequente neutralização da ameaça que ele representa para a ordem de Zeus intensifica a diferença entre os imortais, que estão agora livres do filho de Terra e Tártaro, e os mortais, contra quem seus efeitos permanecem devastadores.

Como será visto em seguida, na descendência do casal Fórcis e Cetó, essa divisão entre mortal e imortal é reiterada para a maioria dos seres que deles descendem.

terra gemeu como que sob Zeus, que com o trovão se deleita, / encolerizado, quando fustiga o chão em torno de Tifeu / na terra dos Árimos, onde se diz ser o leito de Tifeu: / deste modo grandemente gemeu a terra sob os pés / dos que caminhavam; e depressa atravessaram a planície.”. West (1997 [1966], p. 380) acerca dessa passagem da Iliada: "[...] in no way [it] conflicts with Hesiod's account, but it represents the lashing of Typhoeus (Hes. 857) not as a historic event but as something that happens even now - evidently a mythical interpretation of some natural phenomenon, problably the earthquake. [...]".

100 “[...] Comme leur source, ces vents échappent à la représentation. [...] Hésiode établit ici une généalogie négative qui renforce le caractère abstrait du monstre qui les a produits. [...] Les vents de Typhée, eux, qui sont en fait la manifestation météorologique des voix multiples et violentes du monstre [...]."

101 "[...] This shared emphasis on man's helplessness in the face of the divine reflects the human-oriented focalization that characterizes these latter sections of the two passages. When discussing how gods and men interact on a daily basis, whether for good or ill, the fact of man's powerlessness in the relationship is as unavoidable to the human narrator of the Theogony as it is to all humans who pray. Hesiod proleptically presents the ramifications that Hecate and Typhoeus have had for the human race, and in doing so reiterates the poem's main theme of the gulf separating men from gods." 


\subsection{Progênie de Fórcis e Cetó}

Conforme dito anteriormente, a passagem entre os versos 270-336 da Teogonia é por vezes denominada "catálogo de monstros". Esses 67 versos concentram o nascimento de seres como as Górgonas, a Quimera, a Hidra de Lerna, dentre outras criaturas que geralmente são antagonistas de heróis como Héracles e Perseu. Elas compõem a descendência de Fórcis e Cetó, casal de irmãos gerado do Mar em união com sua mãe, Terra, uma das poucas instâncias na Teogonia em que a parte masculina do casal é o sujeito do verbo usado para indicar o ato de gerar a prole (cf. supra).

Em decorrência da concepção a priori de monstro, essa progênie é recorrentemente vista como monstruosa. West, em seu comentário à Teogonia (1997 [1966]), intitula o conjunto dos versos 270-336 de "The Monsters" (“Os monstros") e declara que "a progênie de Fórcis e Cetó é, sem exceção, monstruosa”. ${ }^{102}$ Pucci (em Montanari, Tsagalis e Rengakos, 2009 , p. 57) a chama de "Um zoológico monstruoso!". ${ }^{103}$ Clay se dedica a ela em um artigo intitulado "The Generation of Monsters in Hesiod" ("A geração de monstros em Hesíodo", 1993), que depois é retomado em sua obra de 2003, Hesiod's Cosmos. Como é possível perceber, nem mesmo renomados pesquisadores da poesia hesiódica, e da poesia hexamétrica em geral, escaparam à projeção da noção de monstro para tal poesia.

As criaturas do catálogo são consideradas parte da "linhagem do Mar", embora Terra participe da geração que resulta nessa prole. Antes de se unir à Terra, contudo, Mar, sozinho, gera Nereu, que é chamado também Ancião. De Nereu nascem as nereidas, cinquenta virgens que o poema diz serem “peritas em impecáveis trabalhos" (v. 264). Quando amante de Terra,

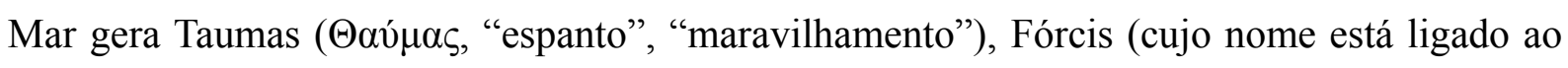

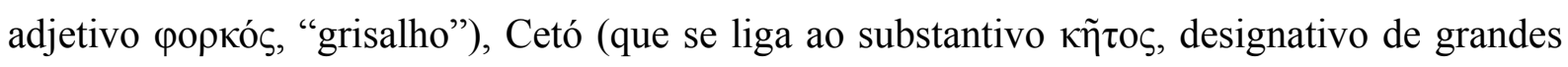

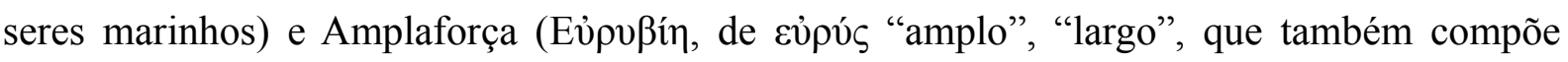

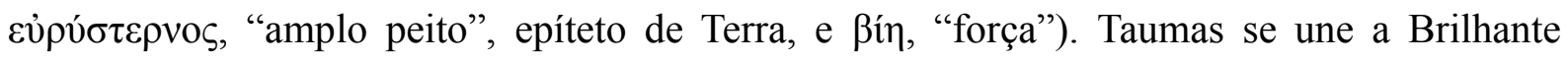

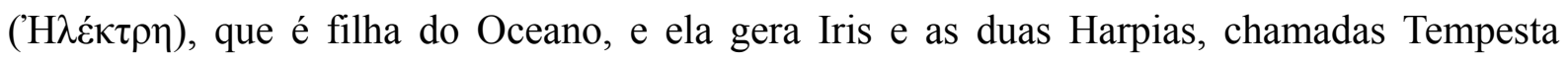

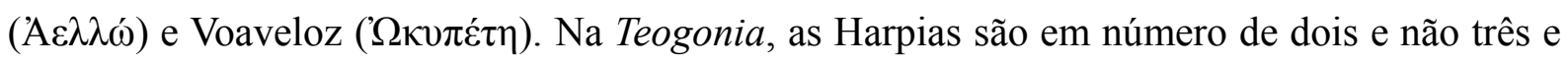
as únicas características atribuídas a elas são belos cabelos e o fato de voarem junto com aves e rajadas de vento (v. 267-269). Elas, portanto, não fazem parte do "catálogo de monstros" porque não são filhas de Fórcis e Cetó, mas de Taumas e Brilhante.

No verso seguinte à descrição das Harpias, o poema dá início à progênie de Fórcis e

102 West, 1997 (1966), p. 243: "The progeny of Phorkys and Keto are without exception monstrous. [...]". 103 "[...] A monstrous zoo! [...]". 


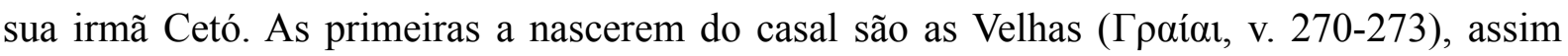

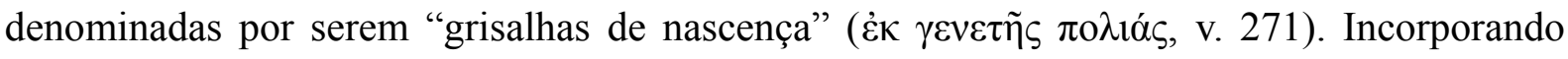

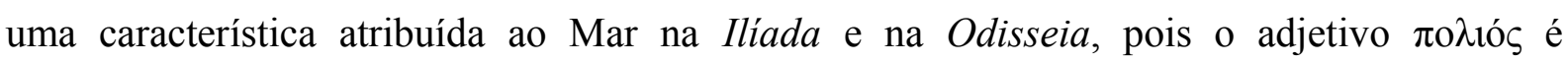
frequentemente usado em relação ele nesses dois poemas (cf., por exemplo, Ilíada 1.350, 4.248, 15.190 etc.; e Odisseia, 2.261, 4.580, 5.410 etc.), as Velhas são a personificação da velhice, associada também a seu tio Nereu por meio do nome "Ancião" (v. 234) bem como a seu pai Fórcis (de форкós, "grisalho"). Do lado materno, as Velhas herdam o epíteto "de belas

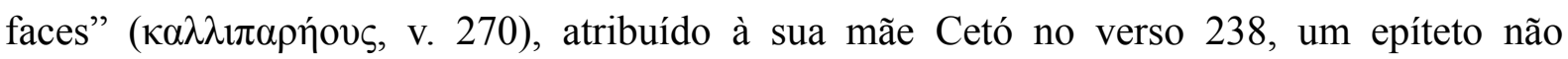
distintivo usado nos épicos homéricos para figuras femininas, mortais ou imortais, como Helena e as deusas Leto e Têmis. ${ }^{104}$ Note-se que as Velhas também recebem individualmente o epíteto de $\varepsilon \mho ̋ \pi \varepsilon \pi \lambda \circ \varsigma$ (“de belo peplo", Penfredó, v. 273) е крокó $\pi \varepsilon \pi \lambda \circ \varsigma$ (“de peplo cor de açafrão”, Enió, v. 273), sendo крокó $\varepsilon \varepsilon \pi \lambda \circ \varsigma$ epíteto da deusa Aurora na Ilíada. ${ }^{105}$

Por terem nascido apresentando uma característica que se atribui à velhice, as Velhas, segundo Clay (1993), incorporariam a combinação paradoxal entre juventude e velhice. Nada mais é dito na Teogonia acerca de suas características físicas, apenas que seus nomes são Penfredó e Enió e que "Velhas" é o nome que tanto os mortais quanto os imortais lhes atribuem. ${ }^{106}$ Não é de se ignorar, entretanto, que em Trabalhos e Dias (v. 181) o nascimento de bebês grisalhos é um dos sinais que indicam o momento no qual Zeus destruirá a raça de ferro.

Seguinte às Velhas, belas e grisalhas, Cetó dá origem às três Górgonas: Estenó, Euríale

$104 \mathrm{Na}$ Teogonia, esse epíteto é também atribuído a Équidna (v. 298), às Graças (v. 907) e a outras duas figuras femininas (v. 960, a Sapiente, filha de Oceano e mãe de Medeia; v. 976, a Agave, filha de Cadmo e Harmonia). Cf. Ilíada 1.184, 1.323, 1.346, 19.246 e 24.676 (referentes a Briseida); 1.143 , 1.310 e 1.369 (referentes a Criseida); 6.298, 6.302 e 11.224 (referentes a Teano, sacerdotisa troiana de Atena, esposa de Antenor); 9.665 (Diomeda, jovem que Aquiles trouxera de Lesbos e com quem se deita em sua tenda); 15.87 (deusa Têmis); 24.607 (deusa Leto). Cf. Odisseia 15.123 (Helena) e 18.321 (escrava Melanto). Arrighetti (1998, p. 337) considera o uso desse adjetivo em Hesíodo um caso raro de "dissemantização". Embora ele não explicite a razão, suponho que seja em virtude de ser usado para Cetó, para as Velhas e para Équidna que, julgadas monstros, não poderiam ter "belas faces".

105 Para $\varepsilon 0 \ddot{\pi} \varepsilon \pi \lambda$ os, cf. Ilíada 5.424, 6.372, 6.378, 6.383, 24.769 e Odisseia 6.49 e 21.160 . Para кроко́ $\pi \varepsilon \pi \lambda$ o , cf. Teogonia v. 358 (Telestó, filha de Oceano e Tétis) e Ilíada 8.1, 19.1, 23.227 e 24.695 (epíteto da deusa Aurora). Sobre кроко́ $\varepsilon \varepsilon \pi \lambda$, alguns escólios à Ilíada 8.1 relacionam a cor de açafrão do peplo da deusa Aurora ao momento do amanhecer quando ainda há pouca luz e, portanto, está mais escuro.

$106 \mathrm{O}$ poema não as descreve partilhando um único olho e um único dente, uma característica que aparece, por exemplo, em Ferecides (3 F 11, apud West, 1997 [1966], p. 245) e em Prometeu Acorrentado de Ésquilo (788 e ss. e 791 e ss.). Na Teogonia não há indicação de que o poema pressuponha tal versão. Outra diferença entre as versões é o número de irmãs, já que na Teogonia elas são duas, nomeadas individualmente Penfredó e Enió, enquanto em outras versões elas são três. Na tradição posterior, elas são também chamadas

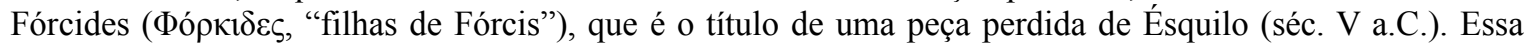
peça seria a segunda de uma trilogia que trataria de Perseu e sua busca pela cabeça de Medusa. Nela, as Velhas comporiam o coro. Em Prometeu Acorrentado (788 e ss. e 791 e ss.), além de serem três e compartilharem um olho e um dente, como já mencionado, é dito que elas têm a "forma de cisne"

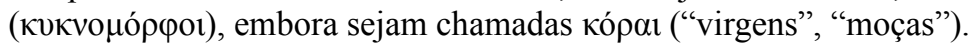


e Medusa. ${ }^{107}$ Em lugar de descrevê-las fisicamente, o poema indica o local em que habitam. A geografia de sua morada coincide com a das Hespérides (v. 275, cf. v. 215), filhas da Noite, que também habitam para lá do Oceano. ${ }^{108} \mathrm{O}$ poema esclarece que Estenó e Euríale eram "imortais e sem velhice" (v. 277), embora nada mais pronuncie sobre seu destino. Em razão de elas serem imortais e apenas Medusa ser mortal, Clay (1993, p. 108) considera que as Górgonas encerrariam a dicotomia mortalidade/imortalidade.

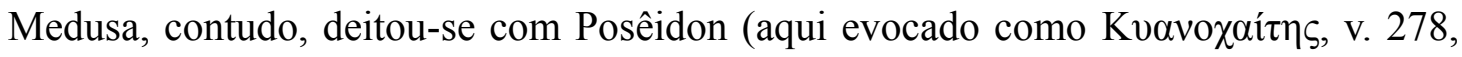
"aquele de cabelo ou crina de cor de cobalto"), "num prado macio com flores primaveris" (v. 279), uma paisagem idílica que, de certa forma, contrasta com a suposta natureza monstruosa de Medusa. ${ }^{109}$ Clay (1993, p. 109) sugere que a união entre o deus Posêidon e a mortal Medusa é uma primeira tentativa, frustrada, de produzir semideuses. É digno de nota que Medusa seja o primeiro ser mortal a nascer no poema e, ao gerar Espadouro (X $\rho v \sigma \alpha ́ \omega \rho)$ e

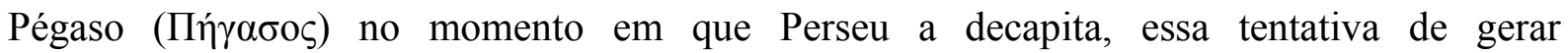
“semideuses”, mencionada por Clay, parece não ter sido tão frustrada, já que Pégaso recebe a função de levar o trovão e o raio a Zeus (v. 284-286). ${ }^{110}$ Para ambos os rebentos de Medusa, o poema fornece a etimologia de seus nomes: "Pégaso" em razão de ter nascido junto às “correntes" ou "fontes" ( $\pi \dot{\eta} \gamma \alpha \varsigma$, v. 282) do Oceano; "Espadouro" porque nasceu com "espadas

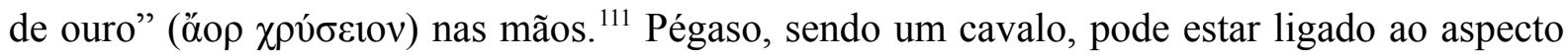
equino de seu pai, que é evocado no verso 278 pelo epíteto que alude ao cabelo ou à crina de

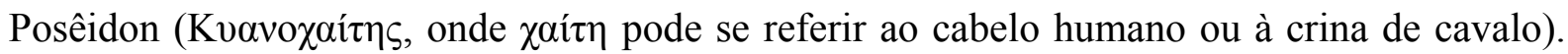

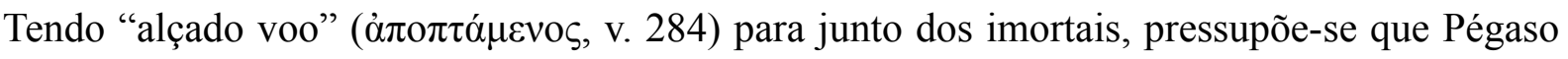
seja um cavalo alado, e a atividade que desempenha, de certo modo, complementa a dos Ciclopes, que forjaram o raio para Zeus.

Espadouro, por sua vez, une-se a uma filha do Oceano, "Bonflux" ou "Belaflui"

107 Na Teogonia, as Górgonas são em número de três. Nos épicos homéricos, contudo, a referência é sempre no singular (cf. Ilíada 8.349 e 11.36). No Escudo de Héracles (v. 223), na Ilíada (5.741) e na Odisseia (11.634),

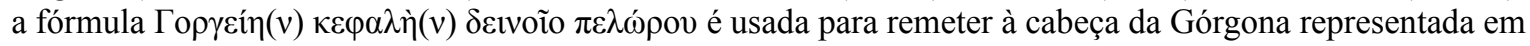

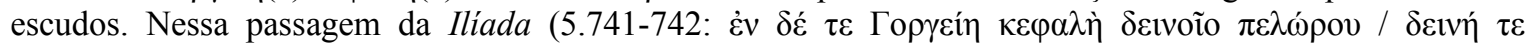

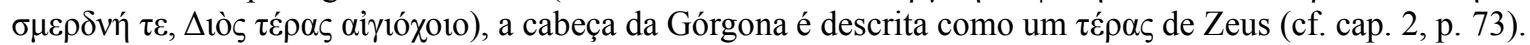

108 A expressão "para lá do glorioso Oceano" ( local onde Héracles matou Orto, filho de Équidna e cão de Gerioneu, e o vaqueiro Euritíon (v. 290-294).

109 Cf. a caracterização do locus das Sirenas na Odisseia (12.159) por parte de Odisseu, que se situam em um "prado florido".

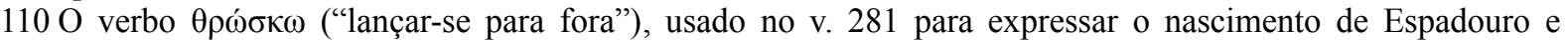
Pégaso, também é usado para o nascimento de Apolo no Hino Homérico a Apolo v. 119 e para o nascimento de Hermes no Hino Homérico a Hermes v. 20.

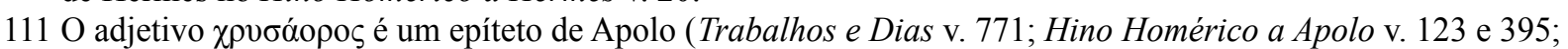
Hino Homérico a Ártemis v. 3; Ilíada 5.509 e 15.256) e também ocorre para se referir a Deméter (Hino Homérico a Deméter v. 4). Sobre a (para)etimologização em Hesíodo, cf. supra, p. 112-113. Compare o nascimento de Espadouro com o dos Gigantes, que nascem com longas lanças nas mãos (v. 185-186). 


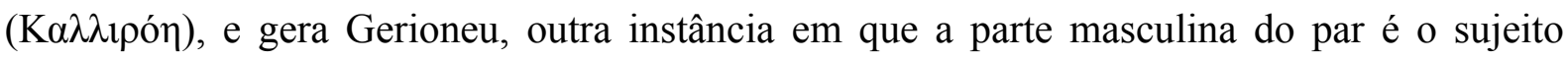
gramatical do verbo que designa a ação de gerar, como ocorre com Mar, seu bisavô, ao gerar Taumas, Fórcis, Cetó e Amplaforça (v. 234-239). ${ }^{112}$ Espadouro é mencionado novamente na Teogonia (v. 979) no decorrer do catálogo de deusas que se uniram com mortais, revelando que, diferente do que ocorre com seu irmão Pégaso, ele herdara a mortalidade de sua mãe. ${ }^{113}$ Essa mortalidade também é passada a seu filho, Gerioneu, que é morto pela "força heráclida"

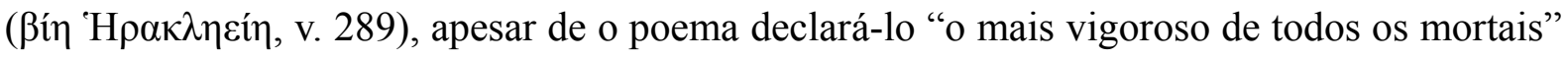

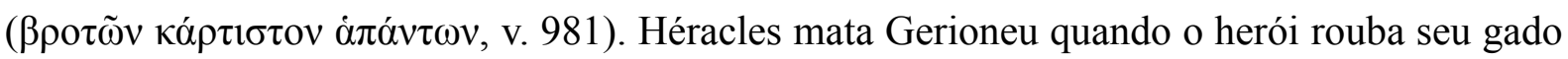
na ilha de Eriteia, que constitui o décimo dos doze trabalhos a serem executados por ele. ${ }^{114}$

Como informa o verso 387, Gerioneu é tricéfalo, uma característica também explicitada na Gerioneida de Estesícoro. ${ }^{115}$ Essa configuração anatômica, contudo, não impede o poeta da Teogonia de remeter a Gerioneu usando o substantivo ßpotós (v. 289), designativo de seres humanos mortais. Clay (1993, p. 109) sugere que Gerioneu, por ter um pai mortal e uma mãe imortal, manifesta certo paralelismo em relação à raça de heróis, cujos ancestrais também são compostos por um agente mortal e um imortal. Para ela, enquanto Gerioneu está fadado à destruição, a raça de heróis não apenas encontra sucesso, mas será o instrumento de aniquilação dos monstros. Veja-se que Gerioneu teve o mesmo destino que sua avó Medusa, ela, morta por Perseu, e ele, morto por Héracles. Contudo, esse sucesso indicado por Clay é, senão, temporário, já que a raça dos heróis também encontrará seu fim, com exceção de Héracles, que será imortalizado.

Depois de quase vinte versos dedicados à descendência de Medusa, o poema retorna aos rebentos de Fórcis e Cetó (v. 295 e ss.). ${ }^{116}$ É, então, introduzida Équidna (do substantivo

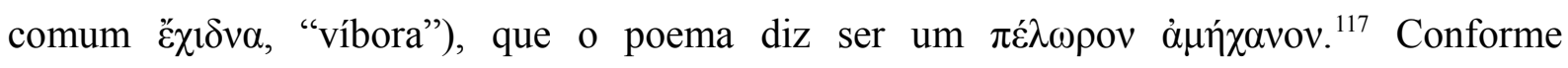
mencionado anteriormente, Équidna, junto com Tifeu, são os únicos seres aos quais o

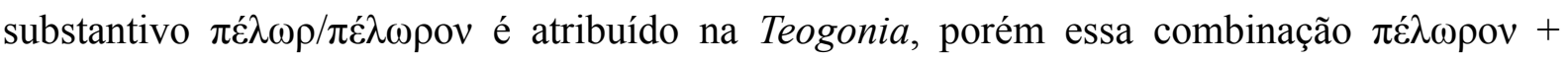

112 Veja-se, contudo, o verso 981, no qual é Bonflux quem gera ( $\tau \varepsilon \varepsilon \kappa \varepsilon)$ Gerioneu, e não Espadouro.

113 West questiona a autenticidade dos versos 979-983, que repetem o episódio da união entre Espadouro e Bonflux. Além da repetição, no verso 981, é Bonflux quem gera Gerioneu, e não Espadouro, como no verso 287.

114 Essa narrativa não está na Teogonia, que apenas menciona o episódio em 289-294 e 981-983; ela pode ser encontrada na Biblioteca de Pseudo-Apolodoro (Biblioteca, 2.5.10).

115 Frags. S 10 and 11 em Davies (1991, p. 155-56) e Frag. 10 em Curtis (2011, p. 82).

116 Considera-se, junto com West (1997 [1966], p. 249), que o $\dot{\eta} \delta$ ' no início do v. 295 remete a Cetó e não a Medusa ou a Belaflui. Arrighetti (1998, p. 338) considera que Équidna é filha de Cetó por partenogênese, não como fruto de sua união com Fórcis.

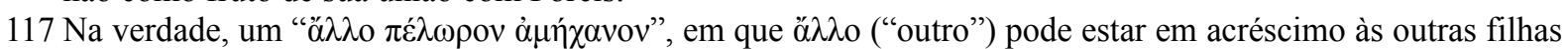
de Fórcis e Cetó, enunciadas anteriormente, as Górgonas e as Velhas, ou em acréscimo apenas às Górgonas ou, ainda, apenas à Medusa. Cf. Escudo de Héracles v. 223-224 em que a cabeça da Górgona (no singular) é

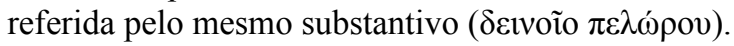


$\grave{\alpha} \mu \eta ́\{\alpha v o \varsigma$ é exclusiva de Équidna. Foi visto acima que Martin relaciona a $\alpha \mu \eta \chi \alpha v i ́ \alpha$ à multiplicidade. Tal multiplicidade, quer na forma, quer nos sons que eventualmente produzem, é um reflexo ou um indício de que, como aquele que é provido de $\mu \tilde{\eta} \tau \iota \varsigma$, , esses seres podem ser cheios de truques e de manhas e são, portanto, traiçoeiros (Martin, 1983, p. 22-23). Équidna (v. 295), seu filho Cérbero (v. 311), Pandora (v. 589) e a ação de Tifeu são

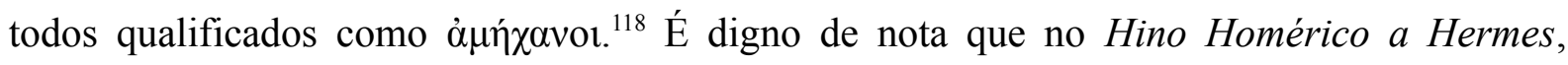

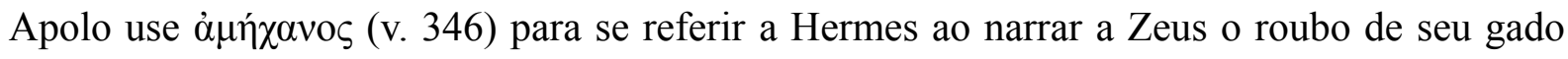
praticado pelo argifonte. ${ }^{119}$

Équidna não se parece com os mortais nem com os imortais (v. 295-296) e o mesmo é dito de Tifeu no Hino Homérico a Apolo (v. 351), seu consorte na Teogonia (v. 306-307). Essa dessemelhança contrasta com a semelhança, explicitada no poema, dos Ciclopes com os deuses (142-143). Contudo, o acúmulo de adjetivos como "divina” ( $\theta$ cínv, v. 297), "imortal”

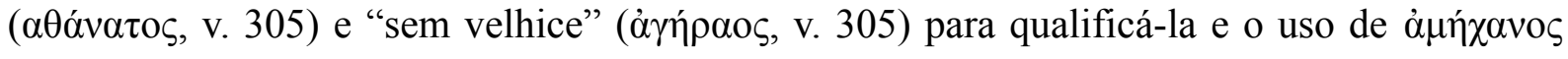
para adjetivar Hermes e $\pi \dot{\varepsilon} \lambda \omega \rho[\mathrm{ov}]$ para as pegadas do deus no Hino Homérico a Hermes parecem nublar uma separação rígida entre as ordens de seres às quais eles possam remeter.

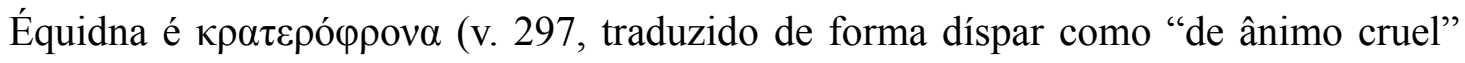
por Torrano e "juízo-forte" por Werner). ${ }^{120}$ Embora a tradução de Torrano esteja de acordo com o sentido "cruel" de $\kappa \rho \alpha \tau \varepsilon \rho o ́ \varsigma$ proposto por Benveniste, ao se olhar para os referentes de $\kappa \rho \alpha \tau \varepsilon \rho o ́ \varphi \rho \omega v$ na poesia hexamétrica arcaica é possível perceber que "juízo-forte” é mais adequado do que "ânimo cruel”. Na Teogonia, além de Équidna, única figura feminina a receber esse adjetivo em toda a poesia hexamétrica arcaica, e seus filhos (v. 308), Atlas (v. 509) recebe esse epíteto; em Trabalhos e Dias, a raça de bronze é dita ter "ânimo juízo-forte

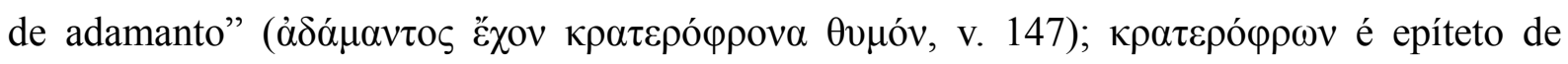
Héracles no Escudo (v. 458) e na Ilíada (14.324), poema no qual também adjetiva uma fera (10.184); e, por fim, Odisseu é assim caracterizado duas vezes na Odisseia (4.333 e 17.124) e também os heróis Castor e Polideuces (11.299). As ocorrências da Odisseia que remetem a

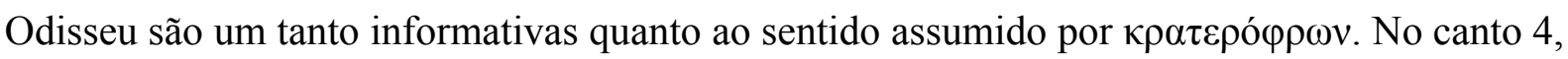
Menelau se dirige a Telêmaco remetendo aos pretendentes: ${ }^{121}$

118 No caso de Pandora, cuja multiplicidade está na variedade de dádivas divinas que recebe, tanto na Teogonia

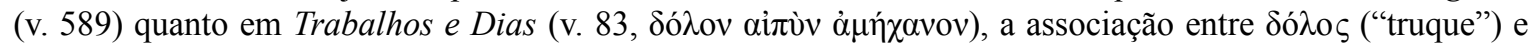

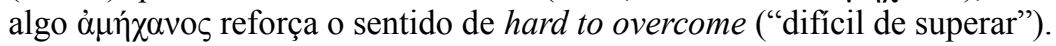

$119 \mathrm{E} \pi \dot{\varepsilon} \lambda \omega \rho / \pi \varepsilon \dot{\varepsilon} \lambda \omega \rho \circ v$ (v. 225 e 349) para remeter às pegadas deixadas por Hermes.

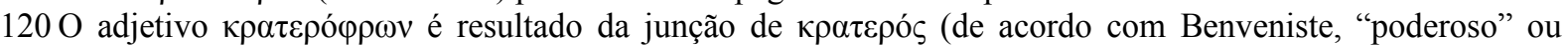
"cruel", discutido na seção dedicada aos Centímanos, cf. supra, p. 123-124) e possibilidades de tradução, usado em contextos que dizem respeito àquilo que por vezes se assinala como "racional" e, por vezes, "emocional").

121 No canto 17, esses versos são reproduzidos por Telêmaco, com algumas variações, para sua mãe, Penélope. 


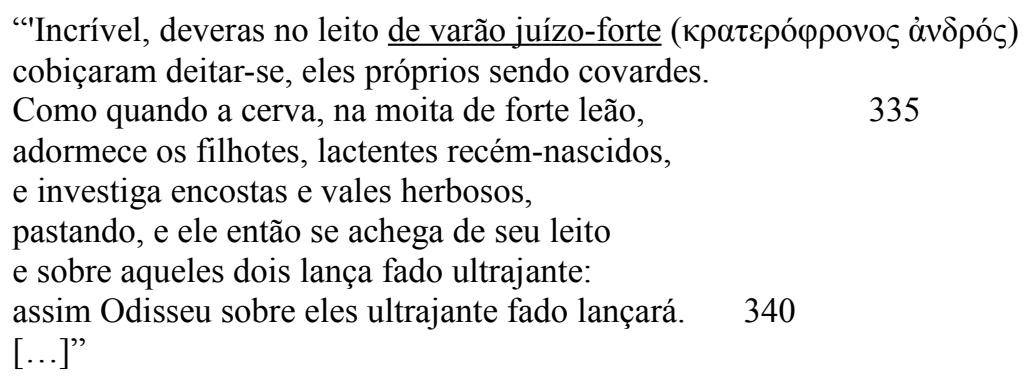

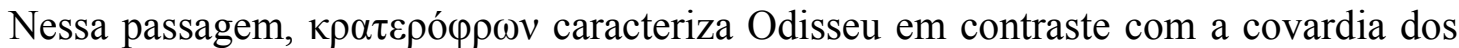

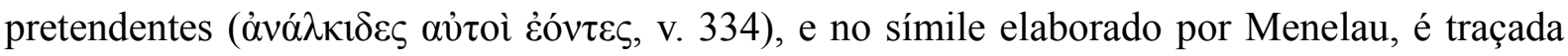
uma relação de paralelismo entre Odisseu e um leão, de um lado, e, de outro, os pretendentes e uma cerva que deixa os filhotes recém-nascidos dormindo na moita de um leão e sai para

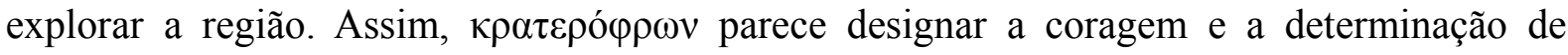
Odisseu, uma característica de intrepidez em contraposição à covardia dos pretendentes. É bastante notável que um adjetivo usado predominantemente para heróis seja usado também para Équidna, já que ela é apresentada com características marcadamente femininas no verso

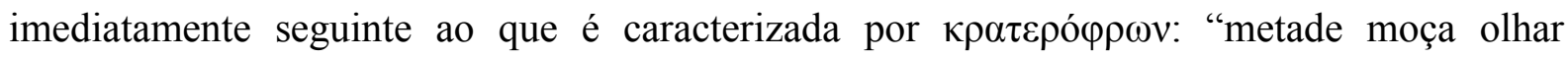

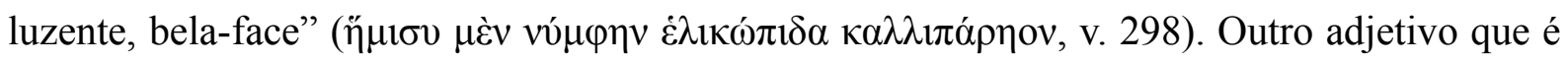
usado para referentes masculinos e também para Équidna é $\dot{\varepsilon} \lambda \hat{i} \kappa \omega \psi$, sendo um epíteto dos aqueus na Ilíada $(1.389,3.190,3.234,16.569=17.274,24.402)$ que expressa o movimento rápido dos olhos e que Cunliffe diz indicar vivacidade (cf. o verbete no léxico homérico de Cunliffe).

Sua metade superior de moça com um belo rosto, por sua vez, também contrasta com sua metade inferior de serpente ("metade serpente portentosa, terrível e grande, / dardejante

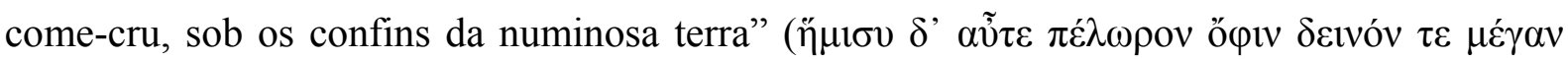

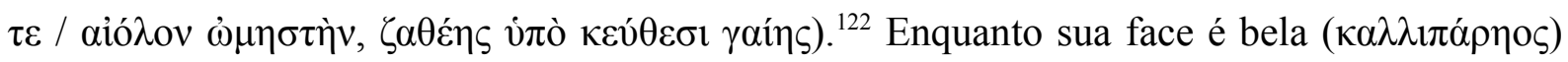
como a de sua mãe, Cetó, e as de suas irmãs, as Velhas (cf. supra), sua metade inferior é

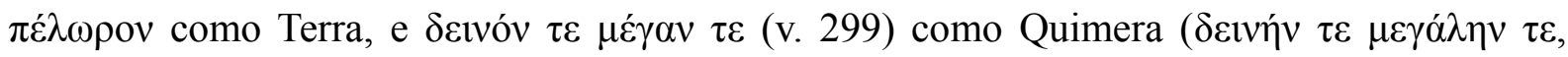
"assombrosa e grande", v. 320). Contudo, o conjunto de palavras para designar Équidna no

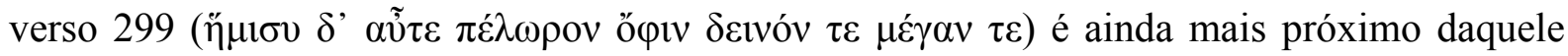
presente no verso 401 do Hino Homérico a Apolo referindo-se ao deus Apolo transformado

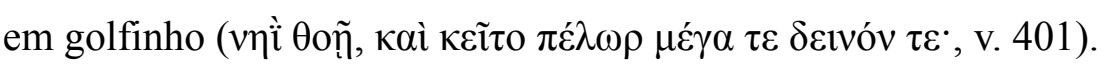

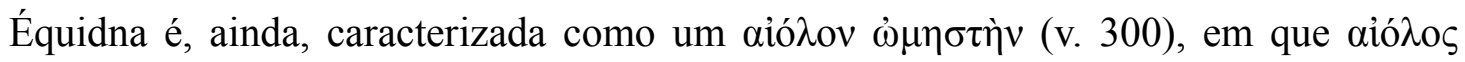




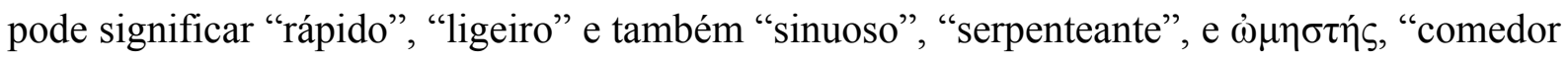
de carne crua", geralmente se referindo a animais como aves (Ilíada 11.454), cães (Ilíada 22.67) e peixes (Ilíada 24.82), mas também é usado por Hécuba para se referir a Aquiles (Ilíada 24.207), ressaltando o aspecto "cruento" do herói, que já matara tantos filhos de Príamo. ${ }^{123}$

Équidna nasceu em uma gruta profunda (v. 297) e continuou a habitá-la, morando

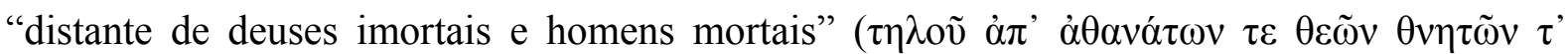
$\grave{\alpha} v \theta \rho \omega ́ \pi \omega v$, v. 302). ${ }^{124}$ Sua morada, embora sob a terra e distante dos deuses, foi-lhe dada por eles próprios (v. 303), em Arimos (ou “na terra dos arimos", v. 304), que na Ilíada (2.783) é onde se diz que Tifeu habita. ${ }^{125}$

Antes de o poema se dedicar à sua união com Tifeu, entretanto, Équidna é chamada $\lambda v \gamma \rho \eta ́$ ("lúgubre", "funesta" v. 304), um adjetivo que foi usado para designar o destino de Medusa (v. 276), o conhecimento de Hidra (v. 313) e a batalha contra os Titãs (v. 674). Em Trabalhos e Dias, o adjetivo qualifica as "agruras" ( $\kappa \eta ́ \delta \varepsilon \alpha$, v. 49) que Zeus armou contra os homens ao esconder o fogo bem como aquelas que saíram do jarro de Pandora (v. 95), os males que vagam entre os homens (v. 100 e 200), as ideias funestas dos reis (v. 261) e o modo como rangem os animais durante o inverno (v. 530). Sem dúvida, um adjetivo que explicita o caráter fatal de Équidna em relação aos mortais.

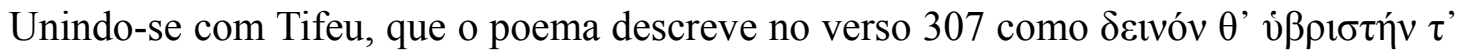
ăvouóv $\theta$ ' (“assombroso", "soberbo", "sem lei”), uma série de três adjetivos pejorativos que

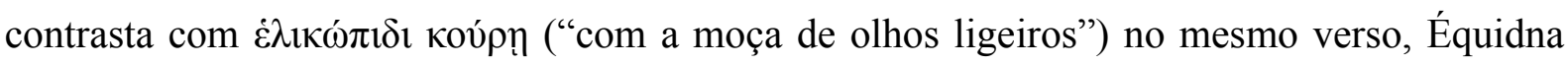

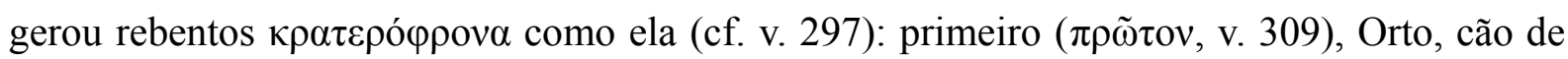

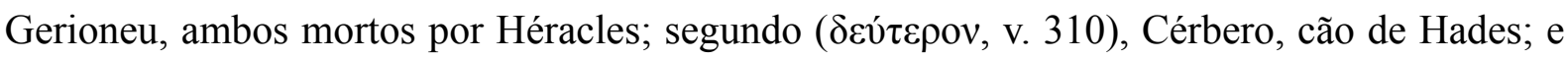
terceiro ( $\tau \rho i ́ \tau o v, 313)$, Hidra de Lerna. Embora apenas um verso seja dedicado ao nascimento de Orto (v. 309), o poema já o havia mencionado no verso 293 como vítima de Héracles junto

123 Cf. a observação de Vermeule (1979, p. 184): "Fish also eat their food raw, ômêstai and omophagoi, like lions, wolves and Achilles."

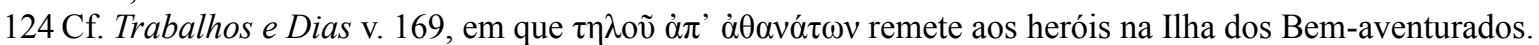

125 No verso 306, há um dos únicos casos em Hesíodo do uso do paбí impessoal ou indeterminado, que em Homero indica rumor (cf. Stoddard, 2004, p. 49-48). No caso da Teogonia, Stoddard sugere que "[f]ollowing Homeric usage, Hesiod employs $\varphi \alpha \sigma i$ to indicate the speaker's reliance on hearsay for the particular piece of information being related. The mingling of Typhoeus and Echidna is a subject on which the Muses cannot or will not - enlighten him.". E pouco adiante: "As Homer does in his three uses of unattibuted $\varphi \alpha \sigma i$ in narrator-text, in Th. 306 Hesiod reveals that he, while granted great knowledge by the Muses, is nevertheless still subject to some degree to the ignorance that characterizes the human race. The Muses made Hesiod a poet, not a god, and hence his knowledge, though greatly exalted above that of other men, remains limited. [...]." Stoddard nota ainda que na Ilíada 2.783 ocorre outro $\varphi \alpha \sigma i ́$ impessoal relacionado a Tifeu: "[...] Perhaps there is something inherent in the nature of chaotic, uncategorizable Typhoeus, whose voices even the gods cannot fully understand, that resists human knowledge?". 
com o pastor Eritíon.

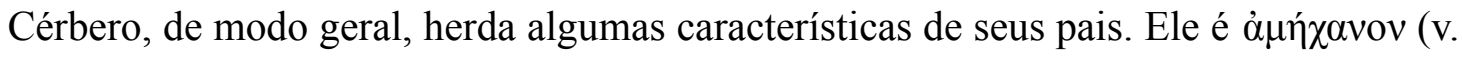

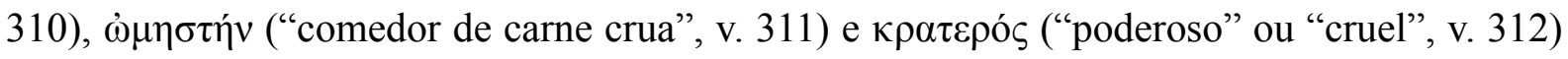

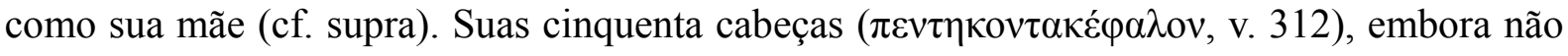
sejam de serpentes, fazem lembrar as cem cabeças de seu pai, Tifeu (v. 825). Tanto Orto quanto Cérbero, sendo cães, também remetem ao aspecto canino do som símil a filhotes produzido por Tifeu (v. 834), mas Cérbero, ao ser caracterizado por $\chi \alpha \lambda \kappa \varepsilon o ́ \varphi \omega v o v$ ("que soa como bronze", v. 311), um elemento sonoro, lembra também o aspecto sonoro de Tifeu. Na Ilíada (5.785), o mesmo adjetivo ( $\chi \alpha \lambda \kappa \varepsilon$ ó $\omega \nu$ o $)$ é usado para a fala da deusa Hera disfarçada de Estentor aos argivos, cuja voz equivale a de cinquenta homens, ficando evidente que o adjetivo remete à potência sonora: no caso de Cérbero, provavelmente do latido que suas cinquenta cabeças emitiriam. ${ }^{126}$

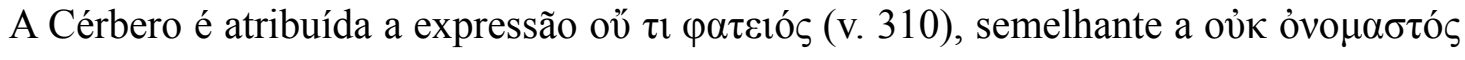
(v. 148), que foi usada para os Centímanos. ${ }^{127}$ Conforme dito anteriormente, o fato de essas expressões serem equivalentes métricos pode indicar que o poeta da Teogonia está contrariando a regra da economia ou pode advogar em favor de uma distinção de sentido entre elas. Contudo, em razão das poucas ocorrências de ambas, é difícil sustentar que tenham, de

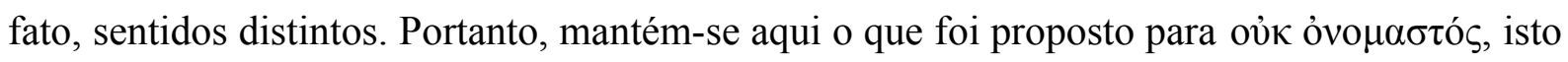
é, um sentido mais relacionado ao caráter extraordinário e indescritível das criaturas às quais remete, corroborado pela leitura de Arrighetti (1998, p. 327, v. 148, cf. supra, p. 118, nota 60), que entende essas expressões como indicativas do caráter inexprimível dessas figuras excepcionais.

O cão de Hades é ainda descrito por mais um termo de difícil tradução: o adjetivo

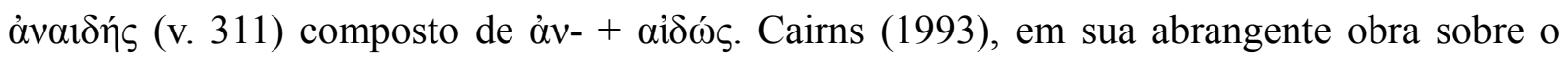
conceito de $\alpha i \delta \omega ́ \varsigma \varsigma$ na literatura grega antiga, que envolve as noções de honra, modéstia e respeito, entende o adjetivo ảvaı́ঠ́s como "shameless, ruthless, impudent" (“desavergonhado, impiedoso, impudente"). Para ele, $\alpha \mathfrak{i} \delta \omega ́ \varsigma$ em Homero, sendo uma "sensibilidade que regula o

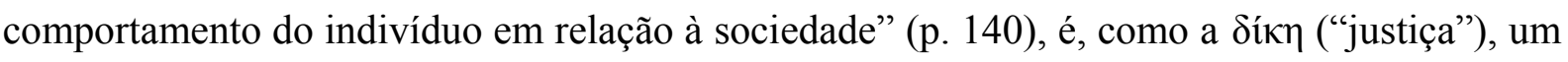
elemento que distingue homens dos animais (cf. Ilíada 24.40-45). ${ }^{128}$ Como exemplos de que em Hesíodo a noção de aỉó́s também separa homens de animais, Cairns (1993, p. 155, n. 29) menciona os dois versos na Teogonia em que àvaıঠ́n é usado: o verso 312 para Cérbero e o

126 É curioso que ambos os contextos nos quais o adjetivo $\chi \alpha \lambda \kappa \varepsilon$ $\varphi \omega v o \varsigma$ ocorre, ele está associado ao número cinquenta.

127 Para a exploração dessas expressões, cf. supra, p. 116-119.

128 Cf. Ilíada 1.158; Odisseia 1.254, 13.376, 17.449, 20.29, 20.39, 20.386 e 23.37. 


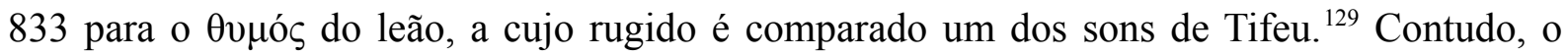

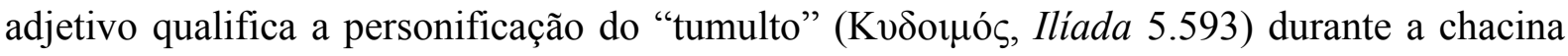
guerreira, trazido por Enió, deusa que acompanha Ares na Ilíada. ${ }^{130}$ Considerando-se que, como cão de guarda de Hades, a função de Cérbero é não permitir que ninguém escape de lá e consiga retornar ao mundo dos vivos, àvaı $\eta^{\prime} \varsigma$ no sentido de "impiedoso" parece uma característica não apenas adequada, mas necessária à sua função, assim como são também convenientes a ela suas cinquenta cabeças vigilantes.

Desse modo, a caracterização de Cérbero concentra um acúmulo de características ameaçadoras, condizentes com o papel que ele cumpre no cosmo, ou seja, o de guardar a passagem entre o mundo dos vivos e o mundo dos mortos. Assim, diferente do que ocorre com Orto, seu irmão, que também é um cão, Cérbero não é morto por um herói, cumpre, porém, a função de guardião, tal como os Centínamos.

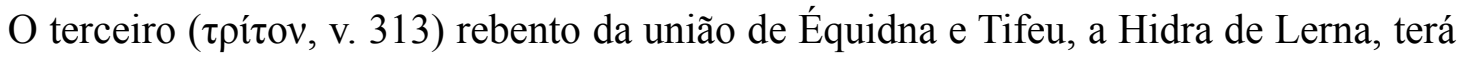
o mesmo destino de seu irmão Orto, ou seja, morrer pelas mãos de Héracles. A ela são dedicados seis versos (v. 313-318), nem todos descritivos, mas que mencionam sua morte pelas mãos do herói e o fato de ter sido nutrida por Hera em razão do rancor da deusa contra Héracles. Hidra é qualificada apenas de $\lambda v \gamma \rho \alpha \grave{~ i \delta v i ̃ \alpha v ~(" v e r s a d a ~ n o ~ f u n e s t o ", ~ v . ~ 313), ~ m e s m a ~}$ expressão usada por Agamêmnon para se referir à sua mulher, Clitemnestra, na Odisseia

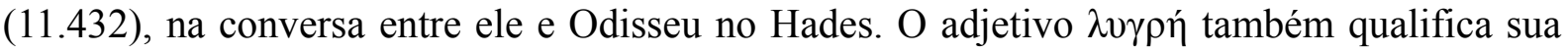
mãe, Équidna, em 304. Contudo, a Teogonia nada informa sobre a aparência de Hidra, preferindo dedicar quatro versos a Héracles e a Iolau, seu companheiro, mencionando que sua morte foi designada pela deusa Atena (v. 316-319).

No verso 319, o poema se volta para o nascimento de Quimera (do substantivo comum

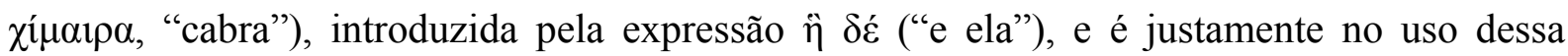
expressão que reside a imprecisão acerca de sua possível genitora. No verso 295, considero, junto com West, que î̀ $\delta \varepsilon ́$ retoma Cetó como mãe de Équidna, entretanto, nos versos 304 e 308 julgo que ĩ $\delta \varepsilon ́$ retoma Équidna, pois em ambos os versos é explicitada a relação de Équidna com Tifeu: em 304 é dito que "ela" vive nos Arimos, local em que Tifeu habita de acordo com a Ilíada (2.782-783); em 308 é introduzida sua prole. Nessa sequência, seria

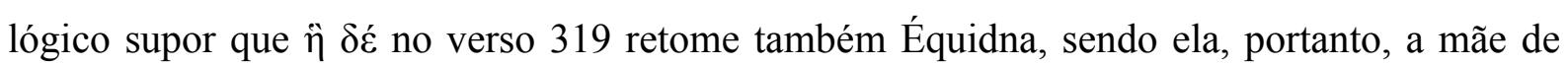

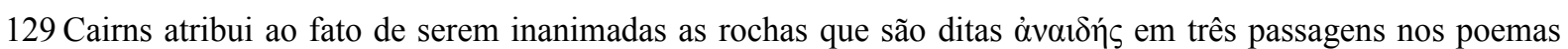
homéricos: na Ilíada 4.521, em que uma rocha esmaga um guerreiro, e 13.139, a uma rocha que se solta com a força do leito de um rio; na Odisseia, remete à rocha que sela a caverna de Polifemo ao se soltar e rolar. 130 Enió é o nome de uma das Velhas na Teogonia, mas na Ilíada o nome pertence a uma divindade guerreira. 
Quimera. ${ }^{131}$ Todavia, os rebentos de Équidna e Tifeu são articulados entre si por enumeração:

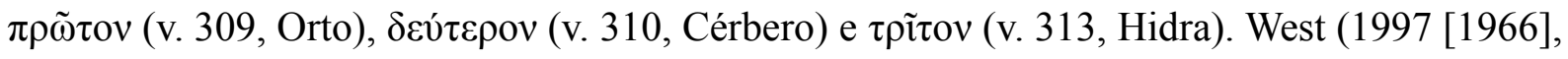
p. 254-255) argumenta que, nesse caso, a mãe é o último monstro (sic) mencionado, ou seja, a Hidra, e que esse argumento é corroborado, por analogia, pelo verso 326, em que o ì $\delta \varepsilon ́$ retoma a progenitora da Esfinge, que é Quimera, o último "monstro mencionado". Clay (1993, p. 113) comenta, jocosamente, que o consenso sobre essa passagem é tão quimérico quanto a própria criatura, possivelmente porque muitas e variadas soluções foram propostas por antigos e modernos. Não há, na Teogonia, uma passagem cujo texto obscureça tanto a relação genealógica expressa. ${ }^{132}$

No entanto, como uma das cabeças de Quimera é de serpente, essa natureza ofídica pode remeter tanto a Tifeu, que tem cem cabeças de serpente, quanto a Équidna, meio moça, metade serpente. Tanto Équidna quanto Quimera são ditas "grandes" e "terríveis" (v. 299 e 320). Outras características que também podem apontar o casal Équidna e Tifeu como seus prováveis genitores são o fato de Quimera soprar fogo, fazendo lembrar o fogo dardejante dos olhos de Tifeu e sua natureza ígnea em geral, e a multiplicidade que, em Quimera, está nas três cabeças de diferentes animais (cabra, serpente e leão) e que, em Tifeu, está na variedade de sons de animais que produz, inclusive o rugido de leão. Note-se que o poema caracteriza o olhar da cabeça de leão de Quimera ( $\chi \alpha \rho$ oлoĩo, v. 321) bem como os olhos de Équidna e de Tifeu, embora com adjetivos distintos.

Outra leitura possível, não contemplada pelo comentário ad loc. de West (1997 [1966]), é Quimera ser filha de Cetó e Fórcis, já que esse casal produziu filhos de características variadas como, as Velhas, as Górgonas e a própria Équidna.

Clay nota que as cabeças de leão e de serpente de Quimera contrastam com a cabeça de cabra, para a qual é usado o termo $\chi \mu \alpha i ́ \rho \alpha$, que designa um filhote de cabra do sexo feminino, colocando esse contraste em termos da ferocidade representada pelo leão e pela serpente em oposição a uma vítima sacrificial. Sendo uma das criaturas do catálogo a ser morta pelas mãos de um herói (como Gerioneu, Orto e Hidra), sua descrição se encerra com o poeta mencionando seu fim com o herói Belerofonte e Pégaso. Na Ilíada (6.183), contudo, Pégaso não é mencionado como ajudante de Belerofonte no assassinato de Quimera. Nessa passagem do poema homérico (6.178-183), Quimera é dita por Hipóloco ser de "raça divina" ( $\theta \varepsilon i ̃ o v ~ \gamma \varepsilon ́ v o \varsigma)$, não pertencente à dos homens. Tanto nessa passagem da Ilíada (6.179), bem

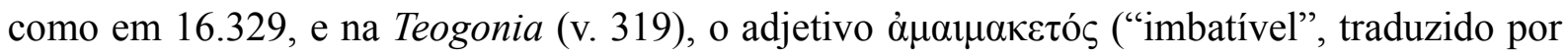


“indômito" por Werner, 2013a) está associado a ela: na Ilíada a adjetiva diretamente e na Teogonia qualifica o fogo expelido por ela. De sentido incerto, escoliastas e lexicógrafos forneceram termos equivalentes que significam "invencível”, “irresistível”, “imenso", “impetuoso", "penoso", “temível”, “inabordável”, “incansável”, "selvagem” (cf. verbete no léxico de Cunliffe). Ele aparece apenas uma vez na Odisseia (14.311), mas dito do mastro de

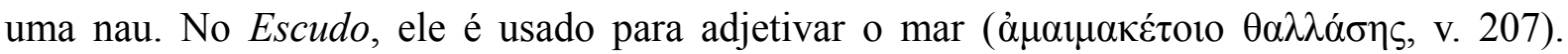
Cunliffe entende o adjetivo como possivelmente derivado de $\mu \alpha \kappa \rho o ́ \varsigma, ~ p o r t a n t o$, com sentido de algo "de grande tamanho ou altura". Já LSJ o entende como derivado de $\mu \alpha \mu \alpha ́ \omega$ ("apressar-se", "ser impetuoso"), o que conferiria um sentido de "furioso". 133

Embora tanto na Ilíada como na Teogonia, seja dito que ela expelia fogo, sua descrição difere um pouco. No poema hesiódico, ela apresenta três cabeças, como dito anteriormente, na Ilíada, contudo, parece possuir um corpo triforme: "à frente tem forma de

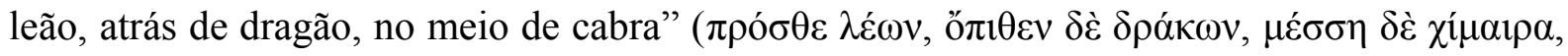
6.181). O poema homérico traz ainda outra informação: ela teria sido alimentada por Amisódaro (16.329), pai de Antímnio e Máris, dois combatentes do lado troiano.

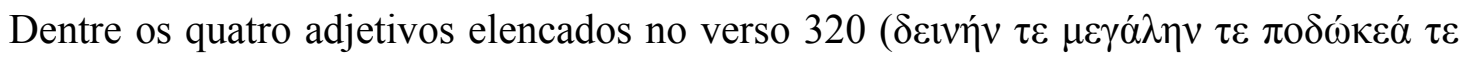
$\kappa \rho \alpha \tau \varepsilon \rho \eta ́ v ~ \tau \varepsilon$ ), $\pi$ о $\delta \omega ́ \kappa \varepsilon \alpha$ (“de pés rápidos”) chama a atenção por ser a forma feminina do epíteto particularizante de Aquiles na Ilíada e na Odisseia e também por ser a junção de $\pi$ ó

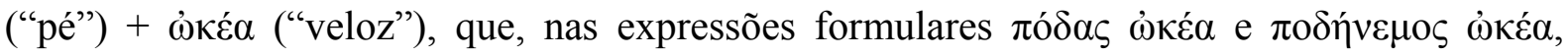

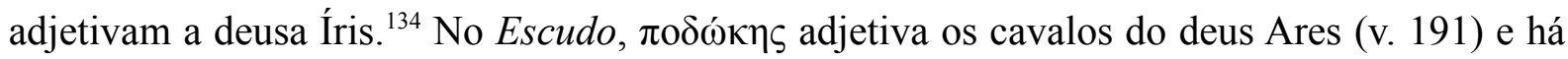
três fragmentos atribuídos a Hesíodo nos quais ele qualifica Atalanta (Fr. 73.2, 76.5 e 76.20), a virgem que vencia seus pretendentes na corrida a fim de evitar o casamento.

O problema acerca dos progenitores da Quimera persiste em relação à Esfinge, pois o mesmo î $\delta \varepsilon ́$ ocorre no início do verso 326. Todavia, quem quer que tenha dado a luz à Esfinge foi fecundada por Orto e também deu à luz o Leão de Nemeia (v. 327), fornecendo aqui um estranho caso de certeza da paternidade mas não da maternidade.

Embora a Esfinge não seja descrita, ela é adjetivada por ỏ $\lambda$ ớv ("ruinosa", v. 326) e

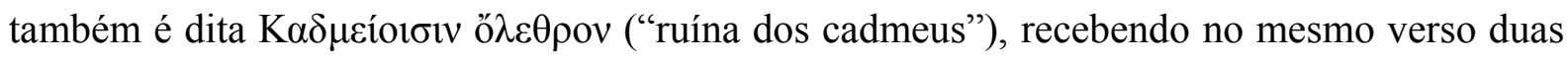

133 Hans-Joachim Mette, autor do verbete no LfgrE, assinala o verbete como de sentido "desconhecido" ("unbekannt").

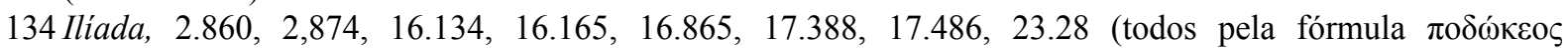

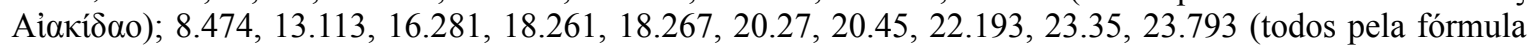

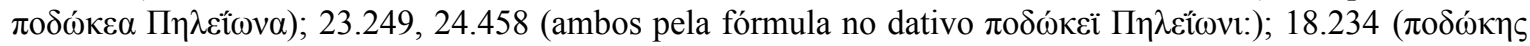

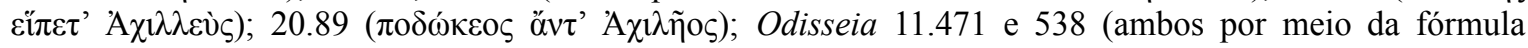

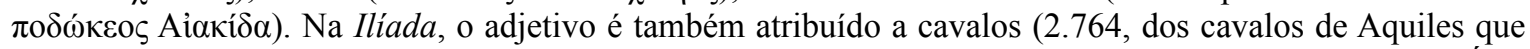
são "rápidos como aves"; 17.614; 23.376), a condutores de carro (23.262) e a Dólon (10.316). Deusa Íris:

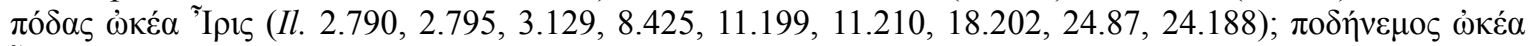
'I Ipıs (Il. 2.786, 5.368, 11.195, 15.168, 15.200, 18.166, 18.183, 18.196, 24.95) 
palavras (ỏoń e ő $\lambda \varepsilon \theta \rho o \varsigma)$ que expressam a ideia de ruína e destruição. Como ela é geralmente considerada como uma junção de figura feminina com leão, ambos os filhos de Orto apresentam características leoninas, um traço que pode ser ligado à Quimera, por uma de suas cabeças ser de leão, porém não há elementos textuais que garantam a maternidade de Quimera.

Tanto a Esfinge quanto o Leão de Nemeia são descritos em sua relação destrutiva com os mortais, ela, pelos termos ỏ $\lambda$ oń e ő $\lambda \varepsilon \theta \rho o \varsigma$ ("ruinosa" e "ruína", v. 326), ele, como uma “desgraça aos mortais" ( $\pi \tilde{\eta} \mu^{\prime} \dot{\alpha} v \theta \rho \omega ́ \pi 01 \zeta$, v. 329), de modo semelhante a Tifeu no v. 874 ( $\pi \tilde{\eta} \mu \alpha$

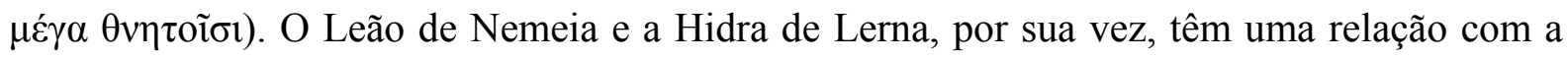
deusa Hera e foram destruídos por Héracles. ${ }^{135}$ Note-se que Héracles é o herói a quem o poema atribui o maior número de mortes dentre os heróis mencionados no catálogo: Gerioneu, Orto, Hidra de Lerna e Leão de Nemeia. Clay (1993, p. 112-113) comenta que cada sequência de geração de monstros culmina em um dos trabalhos de Héracles: Gerioneu e Orto (v. 270-294), Hidra (v. 295-318) e o Leão de Nemeia (v. 319-332).

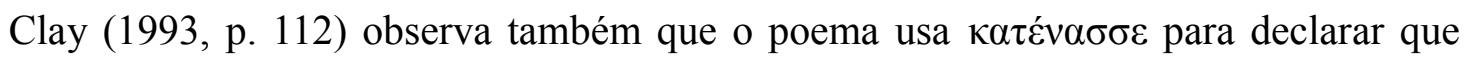

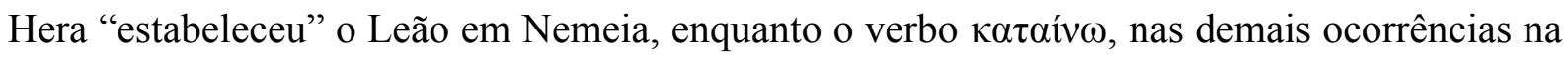
Teogonia, só possui Zeus e Crono como sujeito, “designando o governante dos deuses em sua capacidade como organizador do cosmo". ${ }^{136}$ Hera, portanto, estaria de certo modo usurpando o poder de Zeus ao alocar o Leão em Nemeia, exercendo uma atividade que é exclusiva de

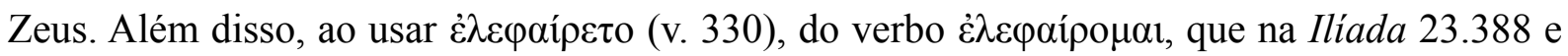
na Odisseia 19.565 tem o sentido de "enganar", Hesíodo, ao dizer que o Leão de Nemeia

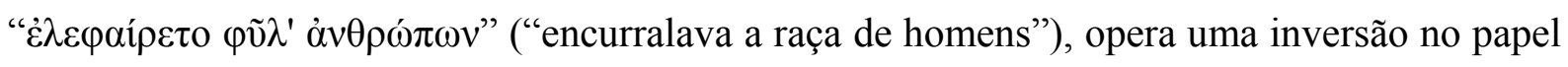
de homens e animais, já que são os homens que dominam os animais e os conduzem a armadilhas a fim de caçá-los. Segundo ela, ao derrotar o Leão e usar sua pele como emblema, Héracles restabelece a ordem hierárquica na qual homens reinam sobre animais.

No verso 333, o poema retoma a união de Fórcis e Cetó, encerrando sua progênie com o filho caçula do casal: a serpente que guarda as "maçãs" ou o "rebanho" de ouro. ${ }^{137}$ Sem lhe atribuir qualquer nome próprio ou oferecer qualquer de suas características, o poema apenas

135 No Hino Homérico a Apolo, Tifeu também tem uma relação com Hera, sendo seu filho (v. 305 e ss.). Cf. próximo capítulo.

136 "[...] Explicitly identified here as the wife of Zeus, Hera nursed the lion (as she did the Hydra) and

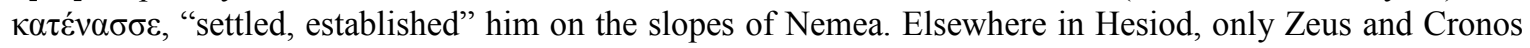

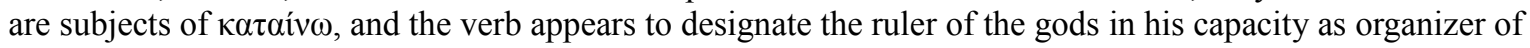
the cosmos. [...]"

137 Torrano (1995) traduz $\mu \tilde{\eta} \lambda \alpha$ no verso 335 por "maçãs" enquanto Werner (2013a) traduz por "rebanho". O

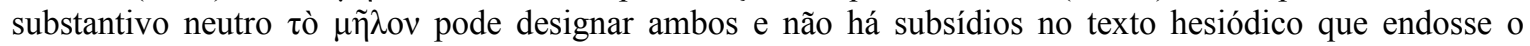
sentido de um ou de outro. 


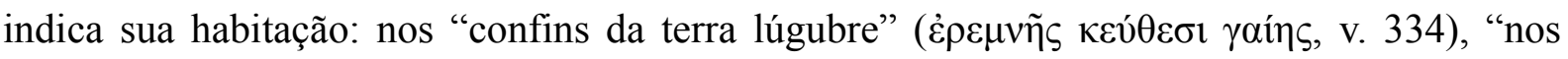

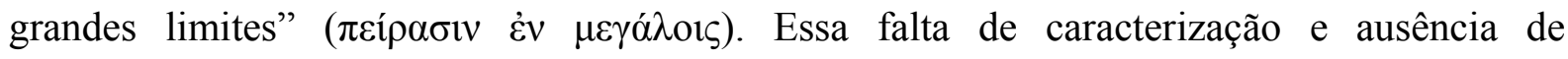
denominação é entendida por Clay (1993, p. 113-114) como parte do caráter "anticósmico" do catálogo, que, ao contrariar a crescente definição do cosmo, com a individuação e a nomeação dos entes que o compõem, conclui com uma figura que não é caracterizada e nem sequer nomeada. Clay afirma que Hesíodo chama a atenção para a importância da nomeação na Teogonia ao colocar a progênie de Fórcis e Cetó entre dois catálogos que são compostos fundamentalmente por nomes, o das Nereidas (v. 243-263) e o das Oceanidas (v. 349-361).

Segundo Philippson (1936, p. 9-10), a nomeação é um dos três modos de definição de uma divindade na Teogonia, os outros dois são por meio do epíteto ou descrição e pela genealogia. O catálogo, de maneira geral, segue esses três modos, em que alguns dos nomes são indicativos de uma característica definidora da própria criatura, como as Velhas, os irmãos Espadouro e Pégaso, a cujos nomes o poema oferece uma (para)etimologia, Équidna, Quimera e o Leão de Nemeia. Nem todas as criaturas do catálogo recebem um epíteto, mas as que recebem são geralmente caracterizadas por epítetos atribuídos a divindades ou heróis, como, por exemplo, as Velhas Penfredó e Enió, que recebem epítetos comumente usados para jovens

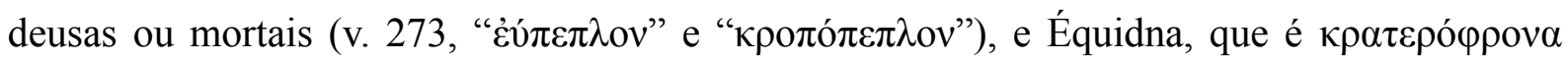
(“juízo-forte”, v. 297) como Atlas (v. 509), Odisseu (Od. 4.333 e 17.124), Castor e Polideuces (Od. 11.299). A maior parte das criaturas do catálogo, contudo, não recebe um epíteto, sendo brevemente descritas por expressões, frases explicativas ou comentários. Por sua vez, a genealogia das figuras do catálogo nem sempre é clara quanto aos genitores, principalmente a partir do trecho do nascimento de Quimera. É possível, entretanto, colocar todas as figuras do catálogo como descendentes de Fórcis e Cetó, filhos de Mar e Terra, o que, de modo geral, implica na importância do elemento da corporeidade para essas figuras, principalmente como descendentes de Terra (cf. supra). Por isso, para as figuras que compõem o catálogo, mais do que os três modos de definição propostos por Philippson, a descrição física é um dos elementos-chave em sua caracterização. Outro elemento que deve ser levado em consideração é a frequente localização geográfica atribuída a algumas dessas figuras.

A pressuposição do antropomorfismo (ou teomorfismo, segundo Clay, cf. supra) para as divindades e personificações na Teogonia está também pressuposta para alguns dos entes no "catálogo", como as Velhas e as Górgonas, ou mesmo Gerioneu, apesar de tricéfalo, e Espadouro. Équidna é um híbrido de moça e de serpente e Quimera apresenta cabeças de animais diferentes, enquanto os demais são predominantemente pertencentes ao reino animal, como os cães Orto e Cérbero, Pégaso, um cavalo alado, o Leão de Nemeia e a serpente não 
nomeada. Mais do que o hibridismo ou o excesso de alguma característica ou mesmo as disparidades entre velhice/juventude ou mortalidade/imortalidade, esses seres se apresentam como possuidores de um caráter extraordinário ou fantástico, que extrapola a observação da realidade imediata.

Pode-se considerar que a geografia do "catálogo" é também um indicador dessa extrapolação, em que a maior parte dos seres é colocado em uma localidade possivelmente inacessível ao público, embora não necessariamente externa ao mundo conhecido ou às suas bordas, como se costuma pensar para os monstros medievais. ${ }^{138}$ No "catálogo", alguns seres habitam os "confins" ou "para lá", uma localização geralmente marcada pelas palavras $\pi \varepsilon ́ \rho \eta v$

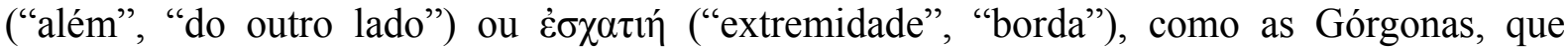
habitam para lá do Oceano, no limite perto da noite (v. 275-275), ou o local onde Héracles matou Orto, o pastor Euritíon e talvez Gerioneu (v. 293-294), este localizado na supostamente fantástica ilha de Eriteia, ou a serpente, situada "nos confins da terra lúgubre" (v. 335), "nos grandes limites" (v. 336). Équidna habita uma gruta, permanecendo longe dos deuses e dos homens (300-303) em Arimos, cuja localização é disputada desde a Antiguidade (cf. West, 1997 [1966], p. 250-251). Todavia, não se pode considerar que as criaturas que compõem o "catálogo" perfazem um périplo do mundo conhecido da poesia hexamétrica arcaica, situando-se sempre às bordas ou às margens dele, pois a Hidra, a Esfinge e o Leão são colocados bem no interior da geografia do Peloponeso. Lerna, o local onde Hidra foi nutrida pela deusa Hera, era um lago no leste da planície de Argos, no Peloponeso, próximo ao atual vilarejo de Míli. ${ }^{139}$ A Esfinge, por sua vez, aterrorizava os cadmeus, antigos habitantes de Tebas, na região da Beócia. Nemeia, onde habitava o Leão, situa-se no nordeste do Peloponeso, que, junto com Olímpia, Delfos e Istmo de Corinto, será um dos locais consagrados aos jogos pan-helênicos.

\subsection{CONCLUSÕES}

Com base no que foi exposto acerca das figuras comumente designadas como "monstros" na Teogonia, é possível que essa poesia não entretenha essa categoria de seres

138 Cf., contudo, Arrighetti (1998, p. 337). Ele considera que a progênie de Fórcis e Cetó é colocada no Ocidente, tomando como justificativa a referência às Hespérides no verso 215.

139 A localização do lago, hoje inexistente, contraria a noção comum quando se trata de monstros de que estes habitam as bordas do mundo conhecido, já que essa região foi habitada desde o período Neolítico, com os assentamentos mais antigos datando do $\mathrm{V}$ milênio a.C. Embora tenha havido um período no qual a região foi abandonada, ela voltou a ser ocupada no início da Idade do Bronze e continuou a sê-lo por todo o período micênico. Cf. Caskey (1960). 
como uma classe distinta de entes separada das categorias "mortal" e "imortal". A multiplicidade de seus corpos, sejam eles hibridizados ou caracterizados pela ausência ou pelo excesso de alguma característica anatômica, não se configura como mais relevante do que seu papel no interior do cosmo quer como antagonistas, que não depende de uma suposta monstruosidade, quer como aliados de Zeus ou de heróis.

Ao longo das análises da caracterização dessas criaturas, foi possível perceber que não há um modo tradicional de caracterização que seja exclusivo dessas criaturas. Elas são descritas por termos usados para variadas categorias de seres, como divindades, mortais, sejam eles homens comuns ou heróis, ou mesmo objetos. Dentro do escopo da referencialidade tradicional, as unidades mínimas de sentido, sejam elas palavras ou expressões inteiras, indicam que esses seres compartilham características com aqueles que chamamos heróis ou com divindades, inclusive as olímpicas. Em relação ao papel que desempenham na narrativa desenvolvida na Teogonia, seu aspecto anatômico não pode ser considerado um indicativo de uma função antagônica, já que Ciclopes, Centímanos e Pégaso não são antagonistas, mas apresentam papel de aliados e auxiliadores. Embora vários desses seres encontrem seu fim ou punição pelas mãos de Zeus ou de heróis, outros também têm o mesmo destino como Prometeu e seus irmãos Menécio e Atlas, revelando que não é a suposta monstruosidade que caracteriza o antagonista, mas, em sua maioria, a capacidade de abalar o domínio de Zeus sobre o cosmo. Ainda que algumas dessas criaturas sejam declaradas como “desgraça aos mortais”, a confecção de Pandora também é dita um "mal aos homens" (v. 570 e 593-594). Portanto, a dualidade que caracteriza o que é um "bem” ou um "mal” aos mortais não é um reflexo direto da composição anatômica dos seres apresentados na Teogonia.

Ciclopes, Centímanos, Tifeu, algumas das criaturas do chamado "catálogo de monstros", junto com Pandora são aquelas que recebem uma caracterização mais extensa na Teogonia. A capacidade do poeta de descrever essas criaturas, que se funde com a autoridade do seu conhecimento vindo diretamente das Musas, é um dos elementos que certamente reitera a autoridade desse conhecimento. Para o público, ouvindo uma descrição que torna possível visualizar seu conteúdo (cf. Tsagalis, supra), o poeta não apenas informa a existência dessas criaturas fantásticas e extraordinárias - uma existência garantida pela veracidade do canto como um todo -, pois não se limita a somente nomeá-las, ele as transporta dos confins do cosmo e as coloca diante do público, que, possivelmente espantado, e até mesmo aterrorizado, também se deleita com a maravilha que são criaturas e poeta. 


\section{Capítulo 4}

\section{CRIATURAS CONSIDERADAS MONSTRUOSAS NO HINO HOMÉRICO A APOLO}

Uma serpente grossa e alta com garras e asas talvez seja a descrição mais fiel do dragão. Pode ser negro, mas convém que também seja resplandecente; ao mesmo tempo se costuma exigir que exale baforadas de fogo e fumaça. O que antecede se refere, naturalmente, a sua imagem atual; os gregos parecem ter aplicado seu nome a toda serpente de bom tamanho. [...]

No livro XI da Ilíada lê-se que no escudo de Agamêmnon havia um dragão azul e tricéfalo; séculos depois os piratas escandinavos pintavam dragões em seus escudos e esculpiam cabeças de dragão na proa das embarcações. Entre os romanos, o dragão foi insígnia da coorte, como a águia da legião; essa é a origem dos atuais regimentos de dragões. Nos estandartes germânicos da Inglaterra havia dragões; o objetivo de tais imagens era infundir terror aos inimigos. [...]

O tempo desgastou consideravelmente o prestígio dos dragões. Acreditamos no leão como realidade e como símbolo; acreditamos no minotauro como símbolo, já que não acreditamos nele como realidade; o dragão talvez seja o mais conhecido, mas também o menos afortunado dos animais fantásticos. Parece-nos pueril e costuma contaminar de puerilidade as histórias em que está presente. Convém não esquecer, contudo, que se trata de um preconceito moderno, talvez provocado pelo excesso de dragões existentes nos contos de fadas. [...]

Jorge Luis Borges, O livro dos seres imaginários, p. 82-84. 
Em prosseguimento às análises das criaturas consideradas monstruosas na poesia hexamétrica arcaica, este capítulo examina três figuras presentes no Hino Homérico a Apolo (doravante, h.Ap.3): a serpente, que se caracteriza como antagonista do deus; Tifeu, nascido da deusa Hera no h.Ap.3; e o golfinho no qual Apolo se transforma. ${ }^{1}$

O h.Ap.3 é um dos 33 hinos compostos em verso hexamétrico em honra a divindades, sendo um dos quatro mais longos dentre os que alcançaram a modernidade. ${ }^{2}$ Esse hino narra o nascimento do deus em Delos e a fundação de seu templo e oráculo em Delfos, duas localidades de culto a Apolo bastante conhecidas. ${ }^{3}$ Ele é considerado, por alguns estudiosos, fruto da junção de dois hinos originariamente independentes, um a Apolo délio, cujo foco é o nascimento do deus, e outro a Apolo pítio, que tem como foco a fundação do oráculo em Delfos. ${ }^{4} \mathrm{Na}$ primeira parte, ou "seção deliana", Hera é a principal opositora de Apolo, tentando impedir o nascimento do deus e de sua irmã Ártemis ao reter no Olimpo a deusa Ilítia, responsável pelas contrações durante o parto (v. 97-100). Na segunda parte, ou seção pítica, Hera parece se manter como opositora de Apolo, conquanto sua atitude seja um pouco indireta: a antagonista direta de Apolo nessa seção é uma serpente a quem Hera entregou seu rebento, Tifeu, para que ela o nutrisse. Apesar de não antagonizar Apolo diretamente, são dedicados cinquenta versos ao episódio do nascimento de Tifeu (v. 305-354), quase dez por

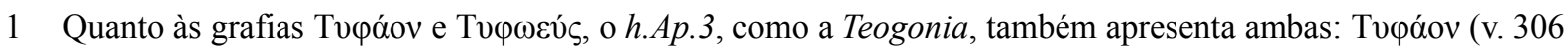

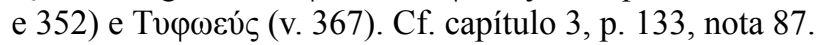

2 A maioria dos hinos é datada do período Arcaico (entre c.700-500 a.C.), entretanto, a referência explícita mais antiga a um desses hinos é de Tucídides (3.104) ao h.Ap.3, em que o autor cita duas passagens (v. 14650 e 165-72), o atribui a Homero e o denomina $\pi$ pooífıv. O uso desse termo por Tucídides sugere que os hinos tivessem sido preâmbulos a outros poemas. Para uma síntese da função, da estrutura e dos temas dos hinos homéricos, ver West (2003), Richardson (2010) e Clay (2006 [1989]).

3 Com exceção do h.Ap.3 e do Hino a Apolo de Alceu (Page, fr.142), em fontes posteriores Apolo sucede outras divindades, como Terra, Têmis, Poseidon e Dioniso, na posse do oráculo de Delfos (Píndaro, fr. 55; Ésquilo. Eumênides. 1-8; Eurípides. Ifigênia em Táuris, 1234-83, Orestes, 163-5, dentre outras posteriores). Entretanto, as evidências arqueológicas não apontam para a existência prévia de culto no santuário de Apolo em Delfos (Sourvinou-Inwood, 1988 [1987], p. 217-218). Contra cf., por exemplo, Clay (2006 [1989], passim).

4 O primeiro a sugerir a bipartição foi D. Ruhnken, Epistola critica I. In Homeridarum hymnos et Hesiodum (Leipzig, 1782). Wilamowitz, Die Ilias und Homer (Berlin, 1916), propunha que o h.Ap.3 fosse uma expansão de um hino originalmente a Apolo délio. Janko (1982, p. 102 e ss.), seguindo a proposição de dois hinos separados, datou a parte deliana em 655 a.C. e a pítica no início do século VI a.C. Aloni (1989, p. 1131), Martin (2000, p. 403-432) e Chappell (em Faulkner, 2011, p. 59-81) são partidários da divisão. Já Miller (1986, p. 111-117 e 174 nota 2), Clay (2006 [1989], p. 17-19) e Richardson (2010, p. 10-13) expressam uma visão unitarista do h.Ap.3 como uma composição coerente em sua totalidade. Embora a análise proposta aqui se concentre na segunda parte, ou seção pítica, adoto uma perspectiva unitarista em razão de a caracterização de Apolo na primeira parte, ou seção deliana, ser não apenas coerente com a da segunda, como também relevante para a análise proposta. 
cento do h.Ap.3, que tem ao todo 546 versos. É, portanto, nessa segunda parte que serão narrados os episódios de interesse para a presente tese: a morte da serpente por meio das flechas de Apolo, o nascimento de Tifeu e a transformação de Apolo em um golfinho, forma sob a qual o deus adentra uma embarcação cretense a fim de tornar os tripulantes sacerdotes e cuidadores de seu templo e santuário recém-fundados em Delfos.

Conforme o que foi proposto para o capítulo de análise das criaturas da Teogonia, continuam valendo para este capítulo o instrumental da referencialidade tradicional de Foley (1991 e 1999), principalmente no que concerne o modo de caracterizar as criaturas aqui estudadas, bem como a proposta de história do cosmo de Graziosi e Haubold (2005), na qual o h.Ap.3 se insere revelando episódios dessa história que se centram na vida de Apolo e na

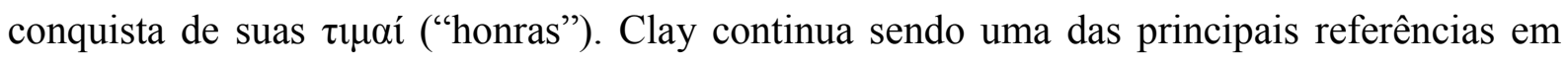
relação à análise narrativa, conquanto a obra principal que norteie este capítulo seja The Politics of Olympus (2006 [1989]), na qual ela explora a forma e o conteúdo dos quatro hinos homéricos de maior extensão.

Diferente da Teogonia, o h.Ap.3 não fornece tantos exemplares daquilo que se convencionou chamar "monstros da mitologia grega"; mesmo Tifeu não recebe uma caracterização ou descrição como aquela presente na Teogonia. Também diferente do que é narrado no poema hesiódico, Tifeu não é filho de Terra e Tártaro, mas da deusa Hera sozinha, que o entrega para ser criado por uma serpente. Tal serpente veio a ser referida pela tradição posterior como Pitó (Píton ou, ainda, Pito) e é com frequência considerada o "dragão" contra o qual Apolo lutou para estabelecer seu templo e oráculo em Delfos. Como será visto, essa serpente é caracterizada no h.Ap.3 de forma extremamente negativa. Talvez se possa dizer que poucas criaturas na poesia hexamétrica arcaica supérstite são caracterizadas tão negativamente. ${ }^{5}$ Embora não receba nenhuma descrição que a coloque como um ser híbrido ou como apresentando qualquer anomalia anatômica, sendo uma simples serpente, ou seja, um animal encontrado na natureza, ela não deixou de ser considerada um monstro, muito possivelmente por sua enorme dimensão e pela destruição que causa aos homens (cf. adiante). Remetida por $\tau \varepsilon \dot{\varepsilon} \rho \varsigma$ (v. 302) e por $\pi \varepsilon ́ \lambda \omega \rho$ (v. 374), dois termos que, como foi visto no capítulo 2, são geralmente traduzidos com o sentido de "monstro", a serpente é geralmente entendida como tal.

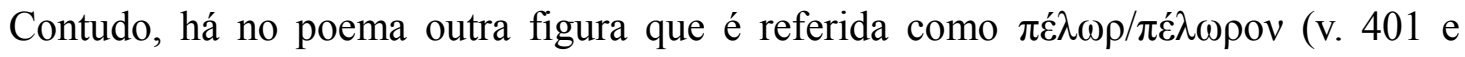
416): o golfinho no qual o deus Apolo se transforma. Será visto que a caracterização do

5 Cf. também a caracterização fortemente negativa de Cila e Caríbdis na Odisseia (cf. capítulo 5) bem como de Pandora e da "raça das mulheres" na Teogonia 585-612 e em Trabalhos e Dias 54-105 e 373-378. 
golfinho e a reação que sua aparição provoca na tripulação cretense é tal que parece nublar uma distinção precisa entre o comportamento de um deus e de uma criatura ameaçadora como a serpente.

Assim, a análise que segue se divide, grosso modo, entre as figuras da serpente, de Tifeu e do golfinho, embora não haja uma separação muito rígida, já que essas figuras se imbricam quer narrativamente, como a serpente e Tifeu, quer no modo como são caracterizadas, como a serpente e o golfinho. ${ }^{6}$

\subsection{A SERPENTE}

Após ser aceito no Olimpo, evento que compõe a narrativa da primeira parte do h.Ap.3 (1-175), Apolo parte em busca de um lugar para fundar seu templo e oráculo. Depois de vagar pelo Peloponeso, o deus encontra um lugar propício, em cujas redondezas depara com uma fonte chamada Telfussa, que não aprecia a intenção de Apolo e tenta demovê-lo, sugerindo outro local para que o deus instale seu santuário. Convencido pela fonte de que aquele local não era adequado para a construção de seu templo (v. 257-274), Apolo parte, por sugestão da própria fonte, para Crisa, no vale do Parnaso. Lá, nas proximidades de outra fonte, Apolo

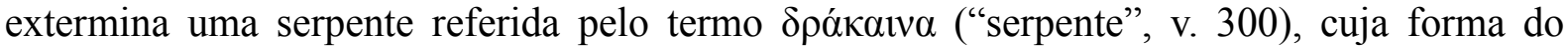

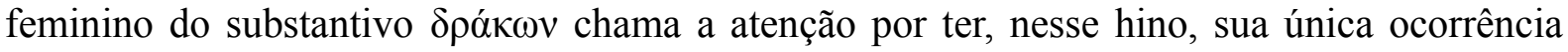
dentro do corpus de poesia hexamétrica arcaica. ${ }^{7}$

Alguns tradutores do h.Ap.3 usam o termo "dragão" em vez de "serpente", às vezes tomando o cuidado para marcar o gênero feminino, como Evelyn-White (1914) ao usar "shedragon", uma tradução um tanto inadequada, pois a figura de um dragão no mundo moderno evoca, por um lado, uma criatura do imaginário cristão combatida por São Jorge da Capadócia, e, por outro, a criatura do imaginário do extremo oriente, no qual ocupa um lugar de reverência, principalmente na China, por representar o imperador chinês, simbolizando poder, força e boa sorte. $^{8}$ Embora o termo "dragão" em português tenha sua origem

6 Uma análise preliminar das criaturas presentes no h.Ap.3 foi apresentada sob o título "Tífon, a serpente e o golfinho no Hino Homérico a Apolo" durante o XIX Congresso da Sociedade Brasileira de Estudos Clássicos (SBEC) realizado em 2013 e também foi discutida em um Seminário Mare Nostrum realizado pelo Laboratório de Estudos do Império Romano e Mediterrâneo Antigo (LEIR-MA) no mesmo ano. Agradeço ao público da SBEC por ter contribuído com questões relevantes e aos colegas do laboratório pelas sugestões oportunas.

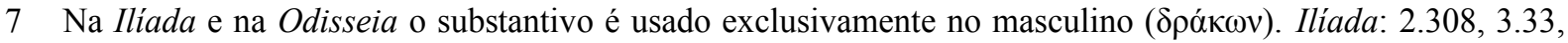
$6.181,11.26,11.39,12.202,12.220$ e 22.93; Odisseia: 4.457. Na literatura posterior, contudo, a forma do feminino $\delta \rho \alpha ́ \kappa \alpha ı v \alpha$ aparece na tragédia Eumênides, de Ésquilo, referindo-se às Erínias (v. 128) e Em Ifigênia em Táuris, de Eurípides, no v. 286, em remissão à Erínia de Clitemnestra. Nesta última tragédia, a serpente morta por Apolo é referida pelo termo no gênero masculino (v. 1245).

8 A origem da figura de São Jorge como matador do dragão e a narrativa de seu heroísmo é geralmente 
etimológica no termo grego via o latino draco, a tradução de $\delta \rho \alpha ́ \kappa \omega v$ e $\delta \rho \alpha ́ \kappa \alpha \iota v \alpha$ por "dragão" ou "dragoa" distorce a compreensão da criatura morta por Apolo, que não passa de uma serpente: um exagero poético que evoca um sentido ausente na língua de origem e provoca, no mínimo, um mal-entendido. ${ }^{9}$

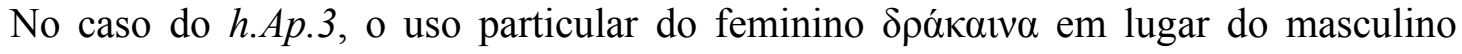
$\delta \rho \alpha ́ \kappa \omega v$ faz com que Apolo não encontre antagonistas do sexo masculino, sendo todos os opositores diretos do deus do sexo feminino: a deusa Hera, a fonte Telfussa e, por fim, a serpente. Isso é relevante porque, enquanto um símbolo ctônico, isto é, ligado a Terra, a serpente, ao ter seu sexo marcado pela estranha troca de gênero do substantivo, é colocada enfaticamente como um elemento feminino dentro de uma narrativa que dá seguimento à ordenação do cosmo, ensejada na Teogonia, em que a ordem olímpica estabelecida se configura predominantemente como masculina tanto sob o domínio de Zeus, cuja ascensão ao governo do cosmo foi narrado naquele poema, quanto por Apolo no h.Ap.3, que, ao derrotar a serpente enfaticamente do sexo feminino, estabelece um prolongamento da ordem de seu pai, Zeus, e também reitera a subjugação de uma ordem ligada a Terra e, portanto, feminina. ${ }^{10}$

Além do aspecto ctônico da serpente que a liga a Terra, há outros elementos que indicam uma configuração Terra-Hera-serpente enquanto representantes de uma ordem feminina e sobrepujada no h.Ap.3. Um elemento que aproxima Terra e Hera é o fato de ambas

associada ao mito de Perseu e Andrômeda, não à narrativa do h.Ap.3. Cf. Fontenrose (1980 [1959], p. 515520) e Ogden (2013, p. 249-255).

9 O combate de Apolo contra a serpente teria sido mencionado por Simônides (frag. 26A Bergk, apud Fontenrose, 1980 [1959], p. 15), que é citado na Epístola 24 de pseudo-Juliano. Nessa passagem de pseudoJuliano, a serpente é referida pelo substantivo masculino e é chamada Пú $\theta \omega v$. Contudo, não é possível ter certeza se Simônides de fato usou o nome Пú $\theta \omega v$ ou se se referiu à serpente usando apenas o substantivo comum $\delta \rho \alpha ́ \kappa \omega v$, à qual pseudo-Juliano poderia ter atribuído o nome próprio, que já tinha se tornado familiar à sua época, no século IV d.C. Depois do h.Ap.3 e, supostamente, de Simônides, uma menção ao combate entre Apolo e a serpente é encontrada na tragédia Ifigênia em Táuris (v. 1234-1259), de Eurípides. Após dar à luz Apolo em Delos, Leto leva o deus ao Parnaso, onde se celebravam honras a Dioniso. Lá Apolo, ainda

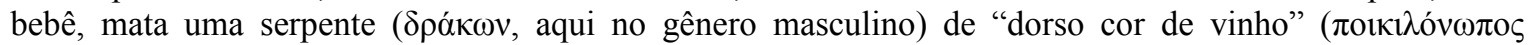

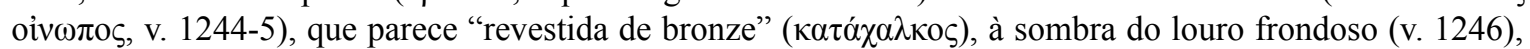

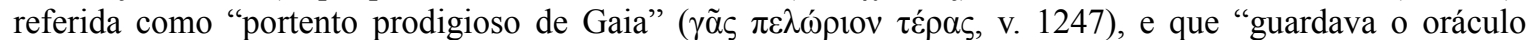

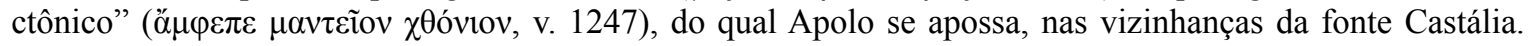
Essa versão da morte da serpente por um Apolo ainda bebê já circulava antes da peça de Eurípides, que é datada de 414-412 a.C., como se pode ver em um lécito branco de figuras negras, do início do século V a.C., em que, no colo de uma figura feminina, a figura de um bebê provido de um arco atira uma flecha em uma serpente escondida dentro do que aparenta ser uma rocha ou gruta. (Bibliothèque Nationale, Cabinet des Médailles, Paris. Corpus Vasorum Antiquorum, France 10, pl. 86.6-8; LM 3.3408, fig. 4.). Embora na peça de Eurípides a serpente também não seja nomeada, como no h.Ap.3, Eurípides parece se basear em uma versão diferente do mito. Fontenrose (1980 [1959], p. 21) lista cinco versões posteriores do embate entre Apolo e a serpente, conquanto a presente no h.Ap3 seja a única em que a serpente é marcadamente do gênero feminino.

10 Acerca do caráter ctônico de serpentes, relacionadas a fontes e ao caráter oracular, cf., por exemplo, Chappell (2006, p. 341): “[...] Serpents are regularly associated with springs; both rise from the earth and are chthonic powers. Prophecy and divination were from an early period associated with underworld powers and the dead; and so springs too, and the snakes that guard them, were thought to have prophetic powers.". 
darem à luz Tifeu, possível usurpador do poder de Zeus. ${ }^{11}$ Embora sejam consideradas versões conflitantes, cada uma cumpre seu determinado papel dentro da narrativa da qual fazem parte: na Teogonia, é Terra em sua união com Tártaro quem dá à luz Tifeu, gerando um possível usurpador do poder de Zeus, sendo ela, dentro do cosmo hesiódico, o princípio procriador feminino bem como um princípio que promove mudança (cf., por exemplo, Clay, 2003, p. 1718). No h.Ap.3, como será visto adiante, é Hera sozinha, mas com o assentimento de Terra, quem dá à luz Tifeu em uma tentativa de desafiar os princípios patriarcais do Olimpo estabelecidos com a ordem de Zeus (Clay, 2006 [1989], p. 67-70). ${ }^{12}$

Essa conexão entre Terra e Hera ocorre também por meio do termo $\varphi \rho \alpha \delta \mu o \sigma u ́ v \eta$ ("planos" ou "conselhos"). No contexto do nascimento de Apolo, narrado na seção deliana, diz-se que Ilítia, a deusa responsável pelas contrações do parto, permanecia no Olimpo em

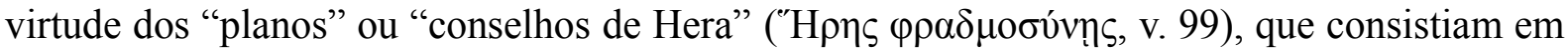
manter a deusa na ignorância acerca do parto de Leto, em razão da "inveja" ou do "ciúme"

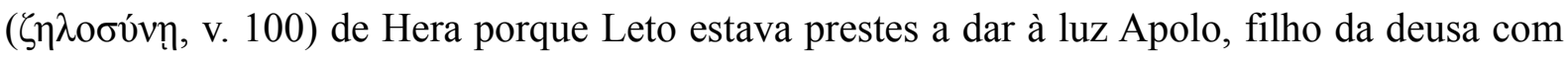
Zeus. ${ }^{13} \mathrm{O}$ termo $\varphi \rho \alpha \delta \mu \sigma \sigma v ́ v \eta$ é exclusivamente relacionado à Terra na Teogonia e nas três vezes em que ocorre nesse poema (v. 626, 884 e 891), o que está em questão é um plano por parte de Terra para promover a geração olímpica no domínio do cosmo em detrimento da ordem titânica de Crono: pelos "planos" ou "conselhos" de Terra, Zeus e os demais filhos de Reia e Crono libertam os Centímanos (v. 626), que os auxilia na vitória contra os Titãs, permitindo que a ordem olímpica se estabeleça; pelos "planos" ou "conselhos" de Terra, os deuses olímpicos fizeram de Zeus seu governante (v 884), depondo Crono; e pelos "planos"

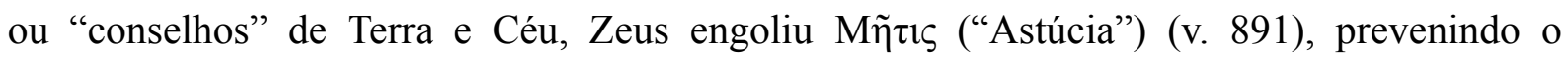
nascimento do filho que seria gerado por ela em união com Zeus, um possível usurpador do poder do cronida. Valendo-se do mesmo expediente de Terra na Teogonia, Hera tenta evitar o nascimento de Apolo, filho de Leto com Zeus, porém, enquanto os planos de Terra são bemsucedidos naquele poema e evitam o nascimento do filho de Astúcia, no h.Ap.3 os "planos" de

11 Isso costuma ser apontado como uma incoerência em relação à tradição de poesia hexamétrica e também serve como argumento em favor do episódio do nascimento de Tifeu no h.Ap.3 ser considerado uma interpolação. Cf. Clay (2006 [1989], p. 64, n. 145) para uma lista de comentadores que condenaram a passagem. Esta tese, contudo, é partidária da manutenção do episódio tanto em razão do argumento da composição anelar, pois o episódio está no interior de um anel (cf. Thalmann, 1984, p. 70-73), como em virtude da amplificação que o episódio opera no caráter danoso da serpente. Clay (2006 [1989], p. 65-66), seguindo Miller (1985, p. 85), acredita que o poeta do h.Ap.3 é familiarizado com a versão hesiódica bem como com outras versões. Para eles, o poeta junta elementos diversos adensando a narrativa presente no h.Ap.3.

12 A passagem entre os versos 300-374, em que se encontram a descrição da serpente e sua morte e o nascimento de Tifeu, está reproduzida no Apêndice G.

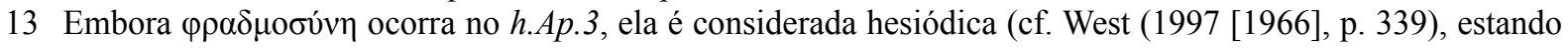
ausente dos épicos homéricos. 
Hera não conseguem impedir o nascimento de Apolo.

Embora seus conselhos conduzam à vitória de Zeus na Teogonia, Terra quase sempre traz um novo governante para o cosmo, primeiro com Crono, depois com Zeus e, por fim, Tifeu, momento em que o princípio gerador de mudança representado por Terra é suspenso ou temporariamente neutralizado. No h.Ap.3, esse princípio parece ter sido resgatado por Hera ao pedir a Terra, a Céu e aos Titãs no Tártaro que permitam a ela produzir um filho sozinha que supere Zeus em força na medida em que este supera Crono (v. 334-339). Diante do pedido de Hera, selado quando a deusa fustiga o solo com a mão (v. 340-341), Terra estremece em sinal de que a deusa será atendida. ${ }^{14}$ Desse modo, o papel de Terra continua sendo crucial na geração de Tifeu mesmo no h.Ap.3, ainda que sua progenitora direta seja Hera.

Além disso, a evocação dessas divindades primeiras para que propiciem o nascimento de Tifeu o torna, como seu nascimento na Teogonia, um prolongamento dessa era ou um regresso a ela, como propuseram Détienne e Vernant (2008 [1974], p. 107) e Clay (2003, p. 25) para o poema hesiódico. Portanto, ao receber Tifeu das mãos de Hera e ao nutri-lo, a serpente se torna parte da tentativa da deusa de produzir um filho que supere Zeus, concluindo assim a cadeia Terra-Hera-serpente na qual cada uma das três figuras femininas cumpre seu papel na existência de Tifeu bem como na resistência à ordem de Zeus. ${ }^{15}$

Todavia, não é exatamente por ter nutrido Tifeu que Apolo aniquila a serpente, e sim por ela se encontrar no local que ele escolheu para estabelecer seu templo. Logo após ser

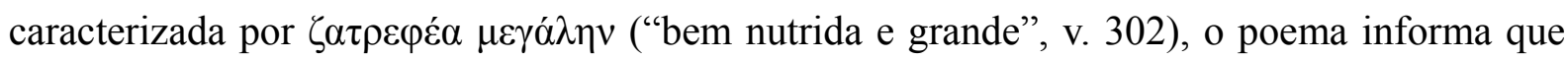
ela causa males aos humanos e a seus rebanhos, sendo bastante possível que tal adjetivação encontre razão no fato de se alimentar destes. ${ }^{16}$ Outro adjetivo que indica o aspecto selvagem da serpente nesse mesmo verso é óxpıs (“selvagem”, v. 302). ${ }^{17}$ Portanto, ao destruí-la, Apolo não apenas elimina o impedimento para estabelecer seu templo, possibilitando o trânsito de pessoas, mas torna possível também que elas lhe ofertem hecatombes (v. 363-366), aniquilando a predadora de rebanhos instalada naquele local.

Embora a tradição posterior se refira a essa serpente pelo nome de "Pitó", o verso 372 permite a leitura de ПvӨஸ́ como alcunha tanto da serpente quanto do local no qual Apolo a mata e estabelecerá seu santuário. Entretanto, Allen, Halliday e Sikes (1936) afirmam que o termo deve se referir ao lugar estritamente e não à serpente, pois ela não é nomeada no

14 Para outro exemplo de bater a mão no chão como um gesto de invocação de um poder ctônico, cf. Ilíada 9.568-569, em que a mãe de Meleagro invoca as Erínias no Érebo.

15 Cf. adiante a comparação entre o nascimento de Tifeu no h.Ap.3 e o nascimento de Apolo.

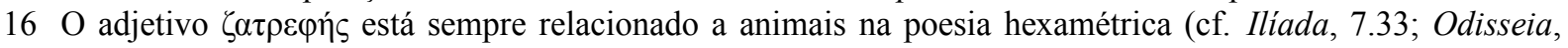
4.451, 14.19 e 106).

17 Cf. Escudo de Héracles v. 236 em que o adjetivo também está relacionado a serpentes. 
poema, enquanto o local é referido novamente como ПvӨஸ́ no verso 390. Richardson (2010, p. 133) reitera afirmando que ПvӨஸ́ é o nome do local do santuário de Apolo tanto em Homero como em Hesíodo. ${ }^{18}$

Defradas (1954, p. 66) observa que é a ausência de nome para a serpente que permite a Apolo nomear o local em que estabelecerá seu santuário. ${ }^{19}$ Depois de matá-la com suas flechas, o deus profere um pequeno discurso se dirigindo à própria serpente, imprecando para que ela ali "apodreça” (“ $\pi u ́ \theta \varepsilon v ", ~ v . ~ 363) .{ }^{20}$ Desse modo, o poeta fornece a razão pela qual tanto o santuário é chamado "Pitó" como Apolo é também chamado "Pítio", colocando a morte da serpente e seu apodrecimento como elementos cruciais na trajetória do deus para se tornar o fundador do santuário e do oráculo pítico. Veja-se que em seu discurso dirigido à serpente moribunda, Apolo declara que "eles, que comem o fruto da mui nutriz terra, / aqui me trarão perfeitas hecatombes" (v. 365-366), evidenciando o caráter cultual que aquele local assumirá.

Ao aniquilar a serpente e imprecar pelo seu apodrecimento, o deus afirma que ela não

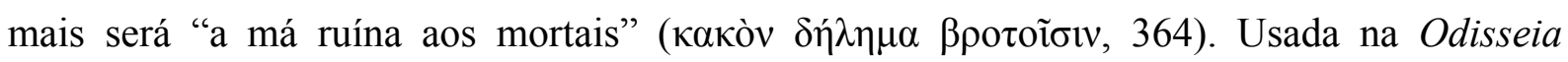
(12.286) por Euríloco, um dos companheiros de Odisseu, em relação aos ventos que sopram no mar à noite e que são capazes de destruir as embarcações, o substantivo $\delta \eta ́ \lambda \eta \mu \alpha$ não é um

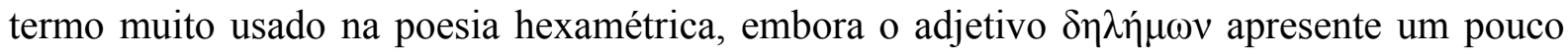
mais de ocorrências. É curioso que no início do canto 24 da Ilíada, na fala de Apolo aos demais deuses olímpicos, indignado por permitirem que Aquiles degrade o corpo de Heitor, ele chama seus pares de " $\delta \eta \lambda \eta ́ \mu o v \varepsilon \varsigma "$ ("malévolos", 24.33). O mesmo adjetivo está no verso

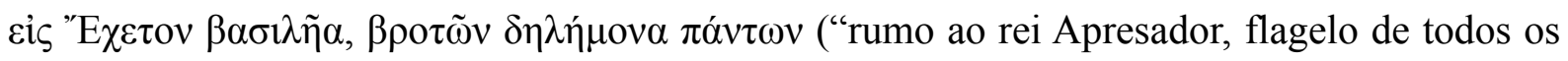
mortais"), proferido três vezes por Antínoo na Odisseia (18.85, 18.116 e 21.308) ao ameaçar seu interlocutor: primeiro Iro (18.85 e 18.116), outro pretendente, que perde na luta para Odisseu-mendigo; e depois o próprio Odisseu-mendigo (21.308). A ameaça de Antínoo se constitui em dizer que vai enviar seu interlocutor para o rei "Apresador", que cortava o nariz, as orelhas, arrancava os genitais de sua vítima e os dava aos cães (18.86-87).

O caráter destruidor e ruinoso da serpente é expresso também pela expressão $\pi \tilde{\eta} \mu \alpha$

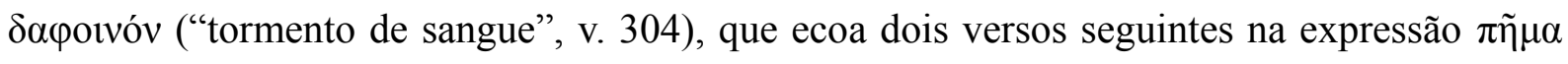

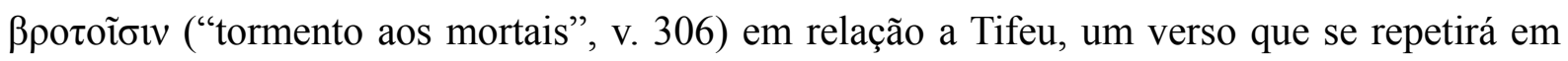
352, ao fim da narrativa de seu nascimento. Semelhante a $\delta \eta \dot{\lambda} \eta \mu \alpha$ em seu campo semântico, o substantivo $\pi \tilde{\eta} \mu \alpha$ também expressa aquilo que causa ruína e destruição, marcadamente aos

18 Ilíada 9.405; Odisseia 8.80 e Teogonia v. 499.

19 Defradas (Les thèmes de la propaganda delphique (Paris, 1954, p. 66), apud Strolonga, 2011, p. 547, n. 62).

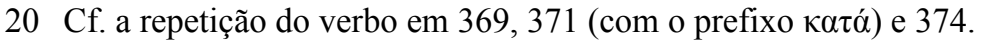




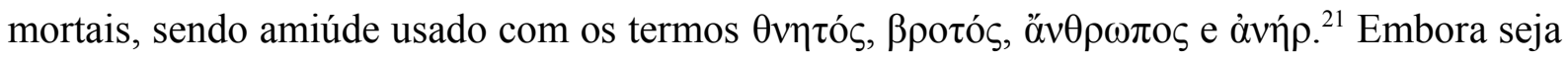
ainda mais comumente usado sem esses complementos, ele sempre denota algo que causa desgraça. $^{22}$ A enunciação desse substantivo no verso 304, caracterizando a serpente, e sua repetição logo em seguida para Tifeu no verso 306 e novamente no verso 352 parecem estar estrategicamente colocadas. A descrição da serpente entre os versos 300-306 e a cena de sua morte pelas flechas de Apolo, entre 358-374, delimitam em um arranjo de composição anelar o início e o fim do episódio do nascimento de Tifeu. De um lado, a enunciação de seu caráter ruinoso seguida da narrativa do nascimento de Tifeu dado à luz por Hera aproxima a figura da deusa antagonista de Apolo ao mal que tanto seu filho quanto a serpente que o criou fazem aos mortais. De outro, quando essa narrativa se aproxima do fim e Tifeu é novamente caracterizado como uma ruína aos mortais, o poema declara que quem deparasse com a serpente encontraria o dia fatal. Isso é seguido imediatamente pela atitude do deus de eliminála com suas flechas, associando a figura de Apolo à eliminação de males que afligem os homens. Portanto, ainda que Apolo e Tifeu não se enfrentem no h.Ap.3, a narrativa do nascimento deste último, composta de quase cinquenta versos, cercada no início e no fim pela serpente ruinosa que o nutriu, amplifica a capacidade destruidora da serpente em sua associação com Tifeu. Sendo ela um mal que nutriu outro mal (v. 353-355), ao ser morta por Apolo, este tem amplificados, por consequência, sua vitória e seu caráter favorável aos mortais.

Esse papel benéfico do deus, contudo, contrasta enormemente com sua atitude no início da Ilíada, em que ele envia suas setas como pragas para dizimar o exército aqueu (Ilíada 1.43-53). O caráter ameaçador de Apolo também é um aspecto colocado pelo próprio h.Ap.3, conforme Clay (2006 [1989], p. 19-20) explicita em relação a seus versos iniciais: ${ }^{23}$

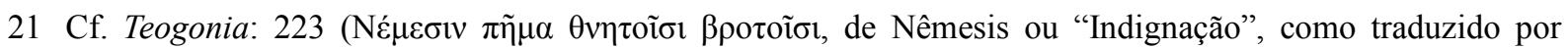

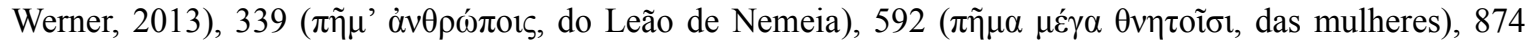

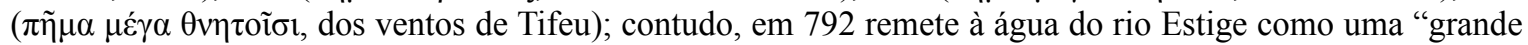

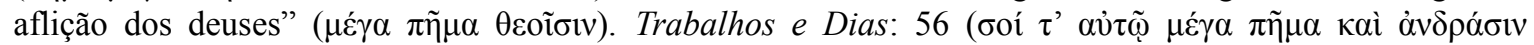

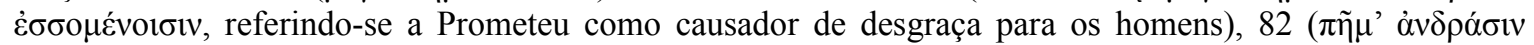

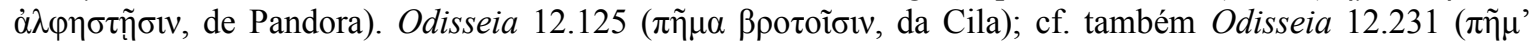

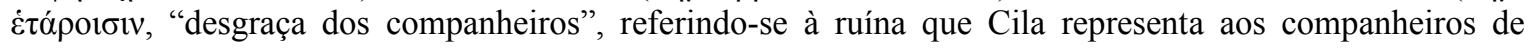
Odisseu.

22 Cf. Trabalhos e Dias: 242 (sobre as pestes que Zeus envia aos injustos); 346 (dito do vizinho ruim); 366 (de precisar daquilo que está distante); 691 (desgraças no mar); 804 (referindo-se à Jura ou à Disputa como desgraça aos perjuros). Ilíada: 3.50, 3.160, 5.886, 6.282, 8.176, 9.229, 10.453, 11.347, 11.413, 15.110, 15.721, 17.99, 17.688, 22.288, 22.421, 24.547; Odisseia: 1.49, 1.190, 2.163, 3.100, 3.152, 4.243, 4.330, $5.33,5.179,5.187,7.152,7.195,8.81,8.411,9.535,10.300,10.344,11.115,11.555,12.27,12.125,12.231$, $14.275,14.312,14.338,15.345,17.444,17.446,17.524,17.597$ e 21.305.

23 "The hymn opens with a violent and dramatic scene that vividly portrays the terrifying power of Apollo through his effect on the gods assembled on Olympus. They tremble at his approach, then leap up from their chairs, not so much from respect, but rather out of uncontrollable fear at the sight of the god brandishing his bow. The awesome apparition of Apollo on the threshold of Olympus is, as many scholars have noted, reminiscent of the plague god of the first book of Iliad. [...]". 
O hino abre com uma cena violenta e dramática que retrata vividamente o poder terrificante de Apolo por meio do efeito que causa nos deuses reunidos no Olimpo. Eles tremem diante de sua aproximação, então se levantam de seus assentos, não tanto por respeito, mas pelo medo incontrolável diante da visão do deus brandindo seu arco. A impressionante aparição de Apolo à soleira do Olimpo é, como muitos pesquisadores notaram, reminiscente do deus da peste no primeiro livro da Ilíada. $[\ldots]$

Diferente de Apolo, contudo, em nenhum momento do poema a serpente é colocada sob uma luz favorável. Causadora de muitos males à raça humana, ela é uma "desgraça

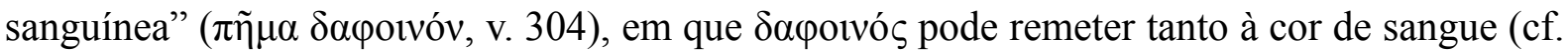
a variante Sapotveós na Ilíada 18.538) como a um caráter sanguinário (cf. Escudo de

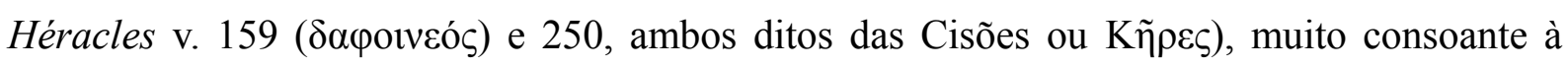
declaração, cinquenta versos adiante, de que "quem com ela deparasse encontraria morte certa" (v. 355). ${ }^{24}$

É digno de nota que a serpente seja o animal aniquilado por Apolo no local em que estabelecerá seu oráculo, já que ela é um animal associado à atividade da divinação na poesia hexamétrica arcaica. Observe-se que no canto 2 da Ilíada, na passagem em que Odisseu relata a profecia de Calcas, o adivinho faz sua previsão partindo do aparecimento de um "uma

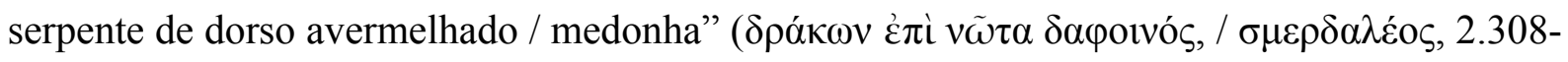
309), que devora os filhotes de pardal mais a mãe. ${ }^{25}$ No canto 12 (195-250), uma serpente, designada adicionalmente pelo termo őpı (v. 208, de onde, "ofídio" em português), é o objeto de um augúrio proferido não por um adivinho, mas pelo herói troiano Polidamante diante dos muros que protegem as embarcações dos aqueus. ${ }^{26}$

É notável também que, em ambos os augúrios, o resultado é desfavorável aos troianos. No primeiro, Calcas prediz que as nove vítimas da serpente representam os nove anos de guerra contra os troianos, entretanto, o fato de a serpente tê-los devorado indica que os aqueus, ao fim e ao cabo, destruirão a cidade de Troia, em uma identificação direta entre aqueus e a serpente. No segundo augúrio, os troianos estão a ponto de destruir os muros que

24 As edições de Allen (1912) e de Càssola (1975) leem ö ৎ no verso 355, fazendo o verso remeter a Tífon; mas West (2003) lê ท̄, o que o faz remeter à serpente. Prefere-se esta última opção porque ela torna menos brusca a transição dos versos anteriores, que se referem a Tífon, para os seguintes, que se referem à serpente (cf. Richardson, 2010, p. 131).

25 Note-se que nessa passagem da Ilíada, já discutida no capítulo 2, p. 66, a serpente é referida como $\mu \varepsilon ́ \gamma \alpha$

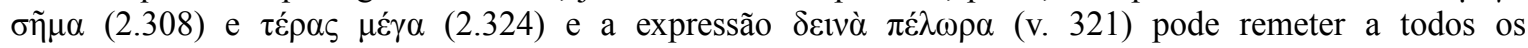
componentes do prodígio, o que inclui a serpente.

26 Nessa passagem, o intercâmbio entre $\delta \rho \alpha ́ \kappa \omega \nu$ e ǒ $\varphi$ ı parece indicar a equivalência entre ambos. Na Teogonia esse intercâmbio também acontece (v. 322-323, 825). A passagem também foi discutida no capítulo 2, p. 6869. 
protegem as embarcações dos aqueus quando uma ave, sobrevoando à esquerda do exército,

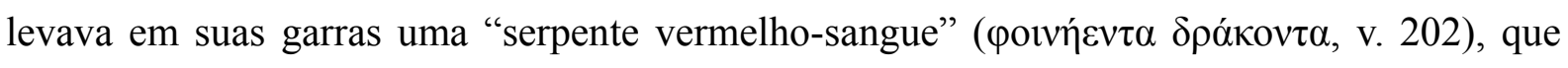

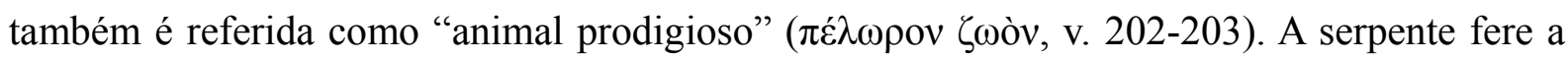
ave na garganta, que a solta, caindo no meio do exército. Os troianos estremecem ao ver a

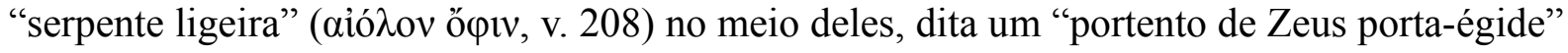

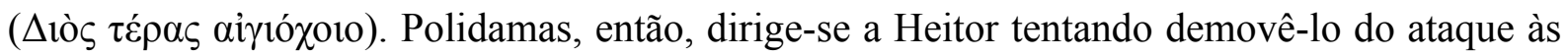
embarcações, interpretando o ocorrido como mau agouro. ${ }^{27}$ Enquanto no primeiro augúrio está colocado o sinal de que Troia será destruída, no segundo, o sinal é de que o exército troiano será malsucedido no ataque aos aqueus, como a ave foi mal sucedida em aprisionar a serpente.

Essa relação de aproximação entre aqueus e serpente encontra outras instâncias na Ilíada e é preciso apontar para o fato de que Apolo é não somente uma divindade aliada dos troianos, como teve seu sacerdote ofendido pelo chefe do exército aqueu, o Atrida Agamêmnon, no início da Ilíada. Veja-se que a figura da serpente está em duas peças do armamento de Agamêmnon: sua couraça (11.19-28) e a alça de seu escudo (11.38-40). ${ }^{28}$ Hainsworth (1993, p. 219) sugere que a presença da serpente em dois itens do armamento de Agamêmnon deve ser mais que meramente decorativa, talvez tendo algum simbolismo especial relativo ao Atrida. Além disso, na Ilíada, a serpente aparece em um símile para a covardia de Páris diante do outro Atrida: ao ver Menelau em meio ao exército aqueu, Páris é comparado a alguém que encontra uma serpente em vales entre montanhas e salta para trás, amedrontado. Opostamente a Apolo no h.Ap.3, que enfrenta e mata uma serpente enorme e ameaçadora, a figura de Páris, nesse símile, remete justamente à reação contrária: alguém que, diante de uma serpente, amedronta-se e recua. É oportuno lembrar que Apolo e Páris compartilham o arco como arma de excelência e é justamente essa a arma com a qual Apolo mata a serpente, o que torna o contraste entre Apolo e o herói troiano ainda maior e o aspecto covarde de Páris ainda mais evidente.

Por fim, na Ilíada, em 22.93, é a vez de Heitor ser comparado a uma serpente em outro símile. Dentro dos muros da cidade, Príamo e Hécuba tentam convencer o fillho a não duelar com Aquiles, e o símile compara Heitor a uma serpente que, depois de ter ingerido veneno (acreditava-se que serpentes conseguiam seu veneno a partir do que comiam, [Richardson,

27 Em sua fala, o v. 220 repete o verso 202. Esse verso é formular, cf. $O d$. xv.161 (Hainsworth, 1993, p. 340).

28 Eles são descritos apresentando três cabeças de serpentes de ciano que saem de apenas um pescoço. Nessa

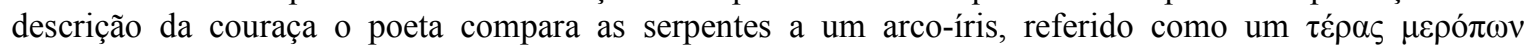
$\dot{\alpha} v \theta \rho \omega ́ \pi \omega v$ ("portento aos mortais", v. 28) (cf. capítulo 2, p. 67). Cf. as doze cabeças de serpente presentes no

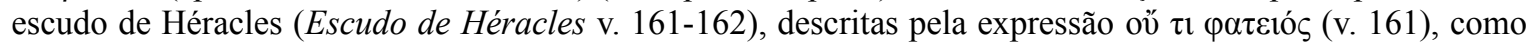
Cérbero na Teogonia (v. 310) (cf. capítulo 3, p. 116-117 e 147). 
1993, p. 116]), contorce-se à espreita, cheia de ira, em seu covil, a fim de atacar um homem, proporcionando uma imagem horrível de se ver. De Jong (2012, p. 81) notou como a comparação de Heitor a uma serpente preparada para atacar Aquiles é a perspectiva reversa da apresentada no canto 3.33-37 quando Páris recua ao ver Menelau como alguém recuaria diante de uma serpente. ${ }^{29}$

O sentimento de medo frequentemente associado à figura da serpente na Ilíada dá lugar, no h.Ap.3, à impotência humana diante dos males que ela causa aos mortais e seus rebanhos (v. 302-304 e 364-366). ${ }^{30} \mathrm{~A}$ ameaça que ela representa no h.Ap.3 aos mortais é um impedimento para que Apolo seja reverenciado ali, sendo, portanto, uma ameaça ao próprio deus (cf. Strolonga, 2011, p. 546 e ss.). A reverência ao deus e o desrespeito a essa reverência também é um elemento colocado na Ilíada, logo no início, com Agamêmnon enxotando o sacerdote que porta as insígnias do deus, levando Apolo a interceder em favor daquele que lhe presta culto e dizimar o exército aqueu por meio da peste que envia. ${ }^{31}$

Na cena de aniquilação da serpente, Apolo declara que nem Tifeu nem Quimera virão afastá-la da morte (v. 367-368). Embora a relação da serpente com Tifeu no h.Ap.3 seja praticamente de mãe e filho, a evocação da Quimera é uma instância única no poema e provoca certo estranhamento. Por que Quimera? Por que não outra criatura? A resposta talvez resida em uma tradição subjacente à da Teogonia (v. 304-306), na qual Tifeu e Équidna se uniram e geraram filhos, dentre os quais Quimera. ${ }^{32}$ Portanto, apesar de o h.Ap.3 revelar para Tifeu progenitores diversos daqueles da Teogonia, a menção à Quimera pode remeter, se não ao texto hesiódico, a uma tradição comum a ele, com a fala de Apolo explicitando no h.Ap.3 que nem Tifeu ou mesmo sua progênie virá socorrê-la, enfatizando a impotência da criatura diante do deus. Outro elemento possível é a natureza em parte ofídica de Quimera, que na Teogonia tem uma de suas cabeças de serpente (v. 321-324).

Como aniquilador da serpente, o papel de Apolo é geralmente associado ao papel de

29 Werner (2010, p. 20) aponta para o desequilíbrio de forças expresso no símile: a pequenez da serpente diante de um homem espelharia a dimensão de Heitor diante de Aquiles.

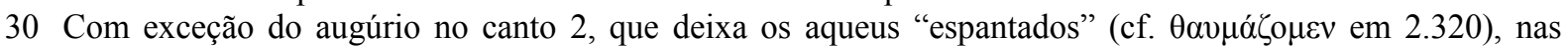
outras passagens o sentimento que predomina é o medo. Páris sente medo (cf. $\delta \varepsilon i ́ \sigma \alpha \varsigma$, "amedrontado", em 3.37) diante de Menelau bem como seus conterrâneos, que estremecem diante da serpente que cai no meio

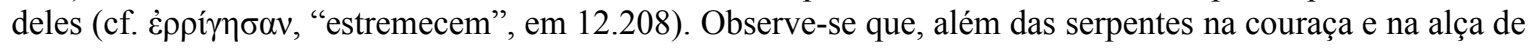
seu escudo, este último item apresenta a cabeça da Górgona posicionada entre as personificações $\Delta \varepsilon \tilde{u} \mu \circ \mathrm{S}^{\mathrm{e}}$ Фóßos ("Medo" e "Pavor", ou "Afugentador" e "Susto", conforme traduzidos por Werner em sua tradução da Teogonia, 2013). O medo que as serpentes podem provocar acaba por torná-las um elemento que afugenta o inimigo e, por afastar esse mal, podem assumir também uma função apotropaica nas armas de Agamêmnon. Compare-se a descrição do escudo de Agamêmnon com a do escudo de Palas Atena em 5.73842. Veja-se também a descrição do escudo de Héracles em Escudo de Héracles (v. 144-167).

31 Já na Odisseia, há apenas uma menção a serpente e ela ocorre no canto 4.457, com o termo $\delta \rho \alpha ́ k \omega v$ designando um dos animais dentre os quais Proteu se transforma.

32 Cf. capítulo 3 (p. 148-150) acerca dos possíveis progenitores de Quimera. 
Zeus como aniquilador de Tifeu na Teogonia. Thalmann (1984, p. 208, n. 116) considera os dois episódios como "duplos" (“doublets"), ou mesmo "variantes cognatas de um único protótipo" relacionado ao "ataque de forças da ordem contra as forças da desordem". ${ }^{33}$ Chappell (2006, p. 341) declara que o episódio da serpente é um exemplo do motivo "combate com um monstro antes de fundar uma cidade", do qual a história de Cadmo seria o exemplo mais óbvio, pois como Apolo, ele parte em busca de um local e tem de derrotar uma serpente nas proximidades de uma fonte. Como "libertador da humanidade" em relação a alguma ameaça que se apresenta contra ela, Chappell considera que Apolo se assemelharia a Héracles e a Teseu. Segundo Richardson (2010, p. 125), a narrativa da morte da serpente (v. 357-374) "segue o padrão das cenas homéricas em que heróis menores são mortos: detalhes da origem da vítima (etc.), o combate e a morte (às vezes com uma descrição gráfica da morte), o discurso do vencedor". Embora todas essas comparações sejam pertinentes, já que evocam temas que se repetem nas narrativas míticas de cunho heroico ou um padrão narrativo tradicional que é seguido pelo poeta, a que se mostra mais diretamente ligada ao episódio no h.Ap.3 é, sem dúvida, aquela do combate entre Zeus e Tifeu na Teogonia, principalmente sob a perspectiva da história do cosmo (Graziosi e Haubold, 2005), na qual Apolo se insere como sucessor de Zeus, não no domínio sobre o cosmo, mas dando continuidade à ordem estabelecida por seu pai. Para Thalmann $(1984$, p. 72$):{ }^{34}$

[...] Como Zeus, Apolo livra o mundo de um monstro e preserva a humanidade especificamente os que peregrinam a Delfos - de suas [do monstro] destruições. Esse paralelo diz muito sobre a natureza de Apolo. Ele está do lado da ordem e contra as forças monstruosas e violentas com as quais Hera, para satisfazer sua inveja, alinha-se.

Clay (2006 [1989, p. 74]) reitera o papel de Apolo como "um componente crítico na constituição e preservação da ordem olímpica". Contudo, ela acaba sendo mais feliz em sua análise justamente por apontar outro aspecto do deus (cf. supra), que será explorado adiante. Por ora, vejamos como Tifeu se insere nessa história.

33 " [...] It seems that the myths of Zeus and Typhaon and of Apollo and the Python are doublets, perhaps cognate variants of a single prototype (both originally combat myths concerned with the attack of the forces of disorder upon the forces of order) [...]".

34 " [...] Like Zeus, Apollo rids the world of a monster and preserves mankind - specifically the pilgrims to Delphi - from her ravages. This parallel says much about Apollo's nature. He is on the side of order and against the monstrous and violent forces with which Hera, to satisfy her jealousy, aligns herself." 


\subsection{TÍFON/TIFEU}

De acordo com o que foi dito anteriormente, o episódio do nascimento de Tifeu no h.Ap.3 é frequentemente considerado espúrio, encontrando poucos defensores de sua manutenção, dentre eles Thalmann (1984) e Clay (2006 [1989]), que a justificam em razão principalmente da conexão do episódio com a primeira parte do h.Ap.3, como será visto.

Também de acordo com o que já foi exposto, Tifeu não é descrito no h.Ap.3 nos moldes em que o fora pelo poeta da Teogonia (v. 823-835). Sua caracterização no h.Ap.3 se resume à sua índole, que é descrita em poucos versos $(306,351-352,354)$. Primeiro, assim que a serpente é descrita (v. 302-304), o poeta afirma que Hera entregou a ela "o assombroso

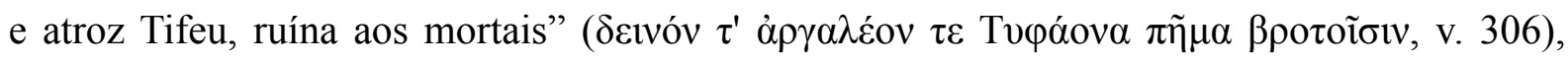
verso que será repetido ao final da narrativa de seu nascimento (v. 352), uma repetição que contribui não apenas para a reiteração do caráter ruinoso de Tifeu e da serpente, que o recebeu da deusa Hera e o nutriu, como também para o arranjo em estrutura anelar no qual o episódio de seu nascimento é composto.

Embora exígua, a caracterização de Tifeu e da serpente os coloca em uma relação de considerável semelhança concernente a seus papéis, pois ambos são retratados como uma "ruína" ou "desgraça" $(\pi \tilde{\eta} \mu \alpha)$ e ambos são considerados um "mal” (cf. v. 354). A serpente,

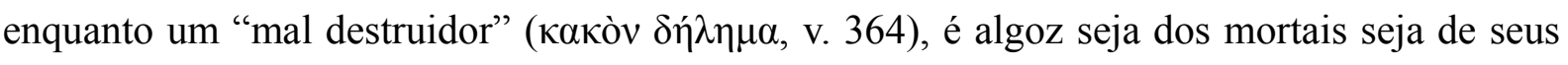

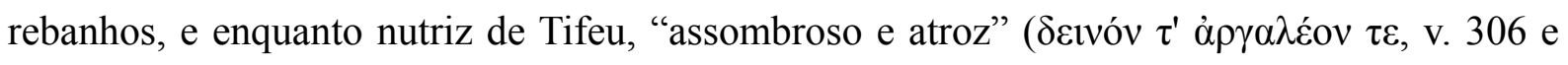
352), gerado com o intuito de superar Zeus (v. 338-39), ela é alçada ao estatuto de algo que é capaz de atingir os próprios deuses.

Contudo, a função de Tifeu no h.Ap.3 não é a de se opor diretamente a Apolo, como tem sido visto. Gerado de Hera no h.Ap.3, é a própria deusa que se configura como uma das principais opositoras de Apolo no h.Ap.3. Contrariada pelo nascimento de Atena gerada por Zeus sozinho, Hera dirige-se aos deuses todos com um discurso que revela sua indignação

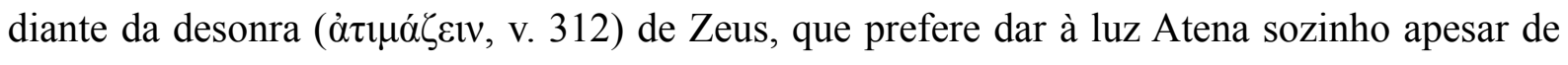
tê-la como esposa. A deusa estabelece uma comparação entre o destaque que Atena tem entre os deuses e seu filho Hefesto, manco e de pés deformados, que ela gerou sozinha e com as próprias mãos lançou ao mar (v. 305-321). Ao pedir outro filho só seu a Terra, a Céu e aos Titãs no Tártaro, Hera deixa claro que quer um filho que exceda Zeus na mesma medida em que Zeus supera Crono (v. 334-339).

Depois de decorrido o tempo em que Hera se isolou em seus templos, deleitando-se com as oferendas que recebia, ela gera Tifeu, "nem aos deuses semelhante nem aos mortais" 


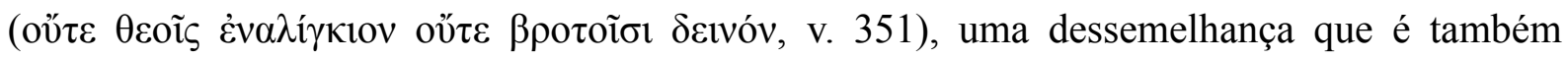
explicitada para Équidna na Teogonia (v. 295-296), sua consorte no poema hesiódico. Por outro lado, essa disparidade contrasta fortemente com a similitude traçada entre os Ciclopes e os deuses (Teogonia, v. 142). A despeito de sua configuração anatômica não normatizada, que colocaria Tifeu e Ciclopes dentro de uma mesma categoria "monstro", estes são colocados como parelhos dos deuses enquanto Tifeu e Équidna são colocados à parte, indicando que mais relevante é a atitude em relação aos outros deuses e aos mortais do que sua anatomia. ${ }^{35}$

A narrativa do nascimento de Tifeu, emoldurada pelo episódio da serpente, apresenta uma forte conexão com a primeira parte do h.Ap.3, ou seção deliana, em apresentar o tema do ciúme de Hera. Na seção deliana é em virtude desse ciúme que a deusa tenta evitar que Leto dê à luz os irmãos Apolo e Ártemis, seus filhos com Zeus, e na seção pítica é em virtude dele que Hera dá à luz Tifeu: ${ }^{36}$

[...] O ciúme de Hera quando Leto está prestes a dar a Zeus "um filho impecável e poderoso" (v. 100-101) corresponde à sua raiva contra Zeus porque ele deu à luz Atena sozinho em vez de em parceria com ela, sua esposa (v. 323-325). Agora Apolo, cujo nascimento Hera tentou obstruir, subjuga um monstro que era aliado de Hera em outra disputa com Zeus envolvendo uma criança. A querela de Hera com seu marido e seu plano contra ele recebem destaque especial por estarem no centro da estrutura. $\mathrm{O}$ episódio que eles iniciam é claramente parte do mito de sucessão: Hera suplica a Terra, Céu e aos Titãs (as duas gerações mais antigas no mito) para que ela dê à luz um filho "longe de Zeus, de modo algum inferior a ele em força, mas que seja mais forte, tanto quanto Zeus longevidente era mais forte que Crono" (v. 334-339). Tifeu ameaça depor Zeus e governar em seu [lugar], como na Teogonia. Naquele poema, a vitória de Zeus sobre ele preserva a ordem no mundo. $\mathrm{O}$ mesmo deve ser implicado aqui, ainda que o hino não mencione explicitamente a derrota de Tifeu ou sua importância. Diz-se que Tifeu, no mínimo, prejudicou homens (v. 355), e a história inteira era certamente familiar. O desenrolar do episódio dentro da narrativa de Apolo matando Pitó relaciona as duas histórias entre si, especialmente porque no verso 355 o mesmo linguajar é usado para os danos de Tifeu aos homens que aquele usado anteriormente para as de Pitó (v. 302-303). $[\ldots]^{37}$

35 Embora a deformidade de Hefesto desaponte sua mãe, Tétis e suas irmãs o acolhem e o cercam de cuidados. Hefesto, como os Ciclopes, também se ocupa da forja, exercendo uma atividade metalúrgica.

36 Thalmann (1984, p. 72): “[...] Hera's jealousy when Leto is about to bear to Zeus "a blameless and mighty son" (11. 100-101) corresponds to her anger at Zeus because he has given birth to Athena by himself rather than in partnership with her, his wife (11. 323-25). Now Apollo, whose birth Hera tried to obstruct, overcomes a monster who was Hera's ally in another dispute with Zeus involving childbirth. Hera's quarrel with her husband and her plot against him are given special prominence by their place at the center of the structure. The episode that they initiate is clearly part of the succession myth; Hera prays to Gaia, Ouranos, and the Titans (the two earlier generations in that myth) that she bear a son "apart from Zeus, in no way inferior to him in strength, but let him be mightier, by as much as wide-seeing Zeus was mightier than Kronos" (11. 334-39). Typhaon threatens to depose Zeus and rule in his [place] stead, as in the Theogony. In that poem, Zeus victory over him preserves order in the world. The same must be implied here, even though the hymn does not explicitly mention Typhaon's defeat or its importance. Typhaon is at least said to have harmed men (1.355), and the whole story was surely a familiar one. The enfolding of this episode within the account of Apollo's killing of the Python relates these two stories to each other, especially since in line 355 the same language is used of Typhaon's injuries to men as is used earlier of the Python's (1l. 302-3). [...]".

37 Diferente da leitura seguida aqui e da de West (2003), Thalmann considera que o pronome no verso 355 seja 
O contraste operado na fala de Hera entre Atena e Hefesto faz lembrar também o contraste entre o filho que ela vai gerar, Tifeu, e o filho que é gerado no início do poema, o próprio deus Apolo. Veja-se que Tifeu, apesar de filho de uma deusa, não é semelhante nem aos mortais nem aos imortais, enquanto Apolo será reconhecido pelo comandante da embarcação cretense como deus em razão de sua aparência (v. 464-465). Como afirma Clay (2006 [1989], p. 65): ${ }^{38}$

[...] O tema central do poema, a emergência de Apolo, recebe sua definição total por meio do retrato daquilo que pode ser chamado de seu homólogo. O filho legítimo e poderoso que promove a agenda olímpica de seu pai se estabelece em um forte contraste ao rebento antinatural, potencial usurpador e destruidor da ordem olímpica.

Essa relação de homologia e contraste entre Apolo e Tifeu se estende também para a relação entre Hera, a esposa ciumenta que entrega seu filho a uma serpente "imediatamente"

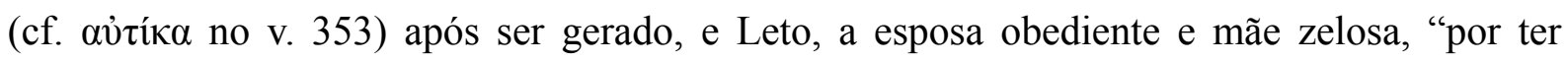
gerado um filho poderoso e portador do arco" (v. 125-126), alimentado não com o leite de sua mãe, mas por Têmis com néctar e ambrosia (v. 123-124), o alimento dos deuses. Portanto, ao trazer ao mundo um filho, que é "ruína aos mortais" ( $\pi \tilde{\eta} \mu \alpha$ $\theta \varepsilon$ cõ $\sigma ı v, ~ v . ~ 352)$, que nem a eles ou aos mortais se assemelha (v. 351), tendo se aliado aos poderes primordiais que acabaram de ser derrotados por Zeus (cf. Clay, 2006 [1989], p. 71), Hera, em um comportamento desafiador que assume proporções cósmicas, contrasta enormemente com Leto e sua conduta quer como mãe de Apolo quer como consorte de Zeus. ${ }^{39}$ Clay chama a atenção para as questões de gênero envolvidas no h.Ap.3:40

ö no lugar de $\dddot{\eta}$, ligando o verso a Tifeu em vez de à serpente. Sua leitura, no entanto, não prejudica a interpretação proposta aqui, ou seja, em ambos os casos o verso em questão reitera o caráter vil da criatura, seja ela a serpente ou Tifeu, já que a perversidade de um enfatiza a perversidade do outro.

38 " [...] The poem's central concern, the emergence of Apollo, receives its full definition through the portrayal of what may be called his opposite number. The legitimate and mighty son who furthers his father's Olympian agenda stands in powerful contrast to the unnatural offspring, would-be usurper, and destroyer of the Olympian order."

39 Strolonga (2011, p. 548, nota 68) aponta que "[n]o Hino, o poeta usa a genealogia da forma mais eficiente para apresentar Hera sob uma luz negativa enquanto mãe e assim a contrasta com a mãe ideal, Leto". Acerca disso, é notável a diferença estabelecida pelos sofrimentos de Leto em sua busca por um local onde pudesse dar à luz, na parte deliana do h.Ap.3, e o "deleite" (tદ́p $\pi \varepsilon \tau$, v. 348) de Hera ao se manter em seus templos recebendo oferendas durante a gravidez de Tifeu.

40 " [...] What Hera ultimately disputes - and what motivates her subsequent actions - is the subordination of the female to the male, of wife to husband. From this perspective, the portrayal of Leto in the two earlier Olympian scenes gains in significance. In the first, she displays maternal pride in her mighty son; in the second, she shares her husband's pleasure as both parents observe Apollo leading the concert of the gods. Leto thus exemplifies the conduct appropriate to the consort of Zeus, conduct characterized by quiet concord rather than rivalry and opposition. Once kindled, Hera's indignation goes beyond its immediate cause to a cosmic questioning of the natural hierarchy between the sexes and within the family. The violent, disorderly offspring she defiantly produces on her own will unambiguously demonstrate the validity of that hierarchy, a 
[...] O que Hera ao fim disputa - e o que motiva suas ações subsequentes - é a subordinação do feminino ao masculino, de esposa a marido. Dessa perspectiva, o retrato de Leto nas duas cenas olímpicas anteriores ganham em significância. $\mathrm{Na}$ primeira, ela demonstra orgulho maternal por seu poderoso filho; na segunda, ela compartilha o prazer do marido enquanto ambos os pais observam Apolo conduzir o concerto dos deuses. Leto, assim, exemplifica a conduta apropriada à consorte de Zeus, conduta caracterizada pelo assentimento silencioso em vez de rivalidade e oposição. Uma vez incitada, a indignação de Hera vai além de sua causa imediata atingindo um questionamento cósmico da hierarquia natural entre os sexos e no interior da família. O rebento violento, desordenado, que ela produz desafiadoramente por sua própria vontade demonstra sem ambiguidades a validade dessa hierarquia, uma hierarquia que se estende também à própria relação entre pai e filho, para a qual Apolo constitui um modelo.

Felson (2012), seguindo os parâmetros do que Fetterley (1798) designou "resisting reader", propôs uma leitura do h.Ap.3 que tenta levar em consideração a parte do público do poema que possivelmente não se identificaria com o "viril e vitorioso Apolo", como, por exemplo, as adoradoras de Hera ou os indivíduos de classes mais baixas ou mesmo as mulheres em geral. ${ }^{41}$ Felson considera que, embora o poeta claramente tome o lado de Apolo, ele dá voz a dissidência no poema, como a de Hera ou a de Telfussa, ou mesmo a de Delos em expor seu medo de abrigar Leto para que dê à luz Apolo (cf. adiante), com a qual uma parte da audiência pan-helênica do h.Ap.3 se identificaria. ${ }^{42}$ "Em um leitor relutante", diz Felson (2012, p. 277-278), ${ }^{43}$

essa voz divina de protesto fortalece as vozes da temerosa Delos (antes de ser apaziguada e vencida), da orgulhosa Telfussa (que não fica com a última palavra em seu agôn com Apolo) e da mortal Pitó (que não tem fala alguma, apenas uma morte inglória). Essa acumulação de vozes de protesto contestam a legitimidade mesma da história cósmica que a supremacia de Apolo em Delfos ajuda a completar.

Para essa parte da audiência que se identificaria com a reclamação de Hera em relação à desonra praticada contra ela por Zeus, ou com a atitude da fonte Telfussa de desviar a atenção do deus para Crisa, e até mesmo com o temor expresso por Delos, Tifeu talvez não seja uma figura da "desordem", mas um elemento que poderia vir a contrabalançar o

hierarchy that extends also to the proper relation between father and son, for which Apollo forms the model."

41 O conceito de "resisting reader", tal como proposto por Fetterley (1978), envolve a resistência e a recusa do leitor em se identificar com o ponto de vista masculino ou em aceitar como norma um sistema de valores masculino.

42 Acerca do caráter pan-helênico do h.Ap.3 e dos demais hinos, cf. Clay (2006 [1989, p. 10-11]).

43 "In a resisting reader, this divine voice of protest strengthens the voices of the fearful Delos (before she is placated and won over), the proud Telfussa (who does not get the last word in her agôn with Apollo), and the deadly Python (who has no speech at all, only an inglorious death). This accumulation of protest voices calls into question the very legitimacy of the cosmic history which Apollo's ascendancy at Delphi helps complete." 
desequilíbrio de forças na política de gênero praticada pela ordem olímpica.

\subsection{GOLFinHo}

Depois de matar a serpente (v. 356-374) e de se vingar da fonte Telfussa (v. 375-387), Apolo necessita de adoradores para seu novo templo e profetizadores para seu oráculo. A fim de obtê-los, o deus interpela uma embarcação cretense que estava a caminho de Pilos (v. $397-$ 399), transformando-se em um golfinho ( $\delta \varepsilon \lambda$ pís), que se atira para dentro da embarcação. ${ }^{44}$

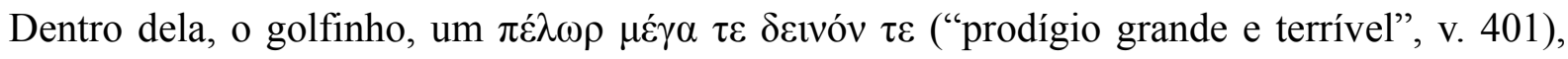
sacode-se e a chacoalha ao mínimo sinal de que os tripulantes querem mudar seu curso. ${ }^{45}$ Diante da inesperada invasão, a tripulação fica paralisada e emudecida de medo (cf. àkéஸv e

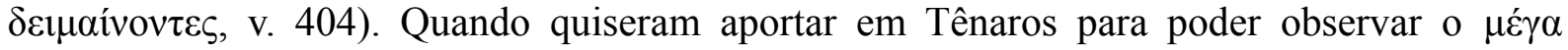
$\theta \alpha \tilde{u} \mu \alpha($ v. 415), a fim de ver se tal $\pi \varepsilon ́ \lambda \omega \rho o v(v .416)$ permaneceria na nau ou voltaria para o mar, o barco já não mais obedecia ao comando dos tripulantes, mas seguia até Crisa. Lá, o deus se transforma em um astro, lançando-se da embarcação rumo ao ádito do templo, onde a epifania de Apolo causa semelhante pavor nas mulheres críseas (v. 440-447).

Tal aspecto assustador de Apolo, conforme exposto anteriormente, é levado em consideração por Clay (2006 [1989]) em seu estudo do h.Ap.3 como parte da natureza do deus. Ao apontá-lo como uma figura "complexa, até mesmo ambígua, multifacetada em vez de monolítica" (1989, p. 19), Clay expõe como Apolo é também uma figura que incorpora a violência e a ameaça. Na cena, já mencionada, que inicia o h.Ap.3, os deuses estremecem e saltam de seus assentos ao ver Apolo adentrar o Olimpo (v. 1-4), reação comparável à dos tripulantes cretenses e das mulheres críseas. Como também já mencionado anteriormente, o potencial destrutivo do deus pode ser vislumbrado no início da Ilíada por meio da peste que envia para assolar os aqueus. No h.Ap.3, Clay aponta como os lugares percorridos por Leto,

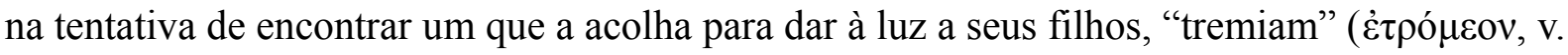

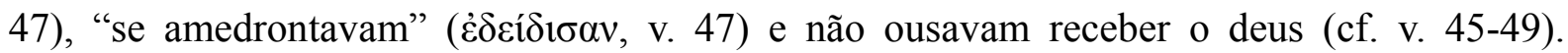
Mesmo Delos, que aceita, por fim, recebê-lo, revela em sua fala a Leto que "treme" ( $\tau \rho \rho \mu \varepsilon ́ \omega$,

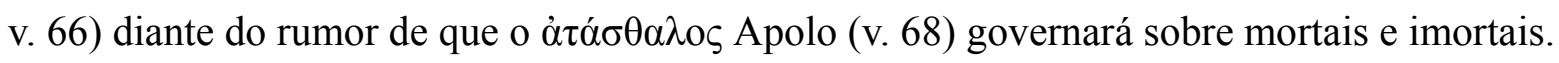

Essa atribuição do adjetivo áđá $\sigma \theta \alpha \lambda o \varsigma$ a Apolo é geralmente considerada uma

44 Cada um desses feitos justifica um epíteto ou aspecto do deus: matar a serpente permite a Apolo ser conhecido como "Pítio" (v. 373); vingar-se contra Telfussa lhe confere o epíteto "Telfússio" (v. 385-387); e, por fim, transformar-se em golfinho garante a Apolo o epíteto "Delfínio" (v. 495-496).

45 Clay (2006 [1989], p. 80) nota a "estranha" habilidade" do golfinho de ler a mente dos tripulantes (cf. v. 402). 
hipérbole por críticos e comentadores (cf. Clay, 2006 [1989], p. 35-36), que tentam amenizar essa característica atribuída a um deus, uma atitude que por si só revela uma concepção que não consegue conciliar a noção de divindade com uma natureza que pode ser iníqua e temerária. Além disso, proferido por Delos, o adjetivo está sendo usado sob a focalização da

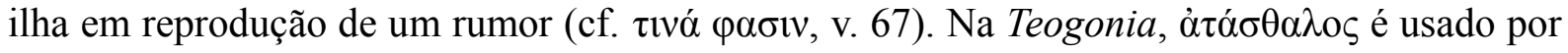
Terra para adjetivar Céu na fala que ela dirige a seus filhos (v. 164) na tentativa de convencêlos a auxiliá-la. Sob a focalização de Crono, a estes últimos também é atribuída $\alpha \tau \alpha \sigma \theta \alpha \lambda i ́ \alpha$ (v. 209), pela qual, segundo a imprecação de Céu, serão punidos. Fora da focalização de

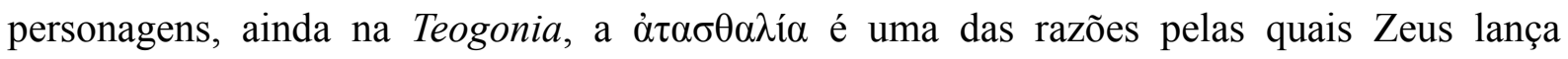
Menoitio (v. 516), irmão de Prometeu, ao Érebo, e também uma característica atribuída ao rei Pélias de Iolco (v. 996), que impôs duras provas a Jasão. A mesma característica é associada à Raça de Prata (v. 134) em Trabalhos e Dias, que Zeus destruiu porque não prestavam honras aos deuses e, no mesmo poema, é também atribuída aos reis que se desviam da Justiça (v. 261,

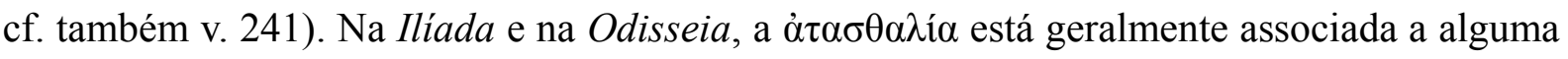
forma de ü $\beta \rho ı \varsigma^{46}{ }^{46}$ Portanto, o rumor de que o "iníquo" Apolo exercerá um domínio tirânico (cf. $\pi \rho v \tau \alpha v \varepsilon v \sigma \varepsilon ́ \mu \varepsilon v$, v. 68) sobre deuses e homens é o que provoca o terror não somente na ilha de Delos e, consequentemente, em outras localidades que se negam a acolher Leto, como também é potencialmente um dos motivos pelos quais os próprios deuses tremem e saltam ao ver Apolo adentrar a soleira do Olimpo sem saber, ainda, se ele será o destituidor da ordem olímpica ou o propagador dela.

A futura brutalidade de Apolo é evidenciada ainda mais pela continuidade da fala de Delos a Leto, que diz temer que o deus, tão logo nasça, a pisoteie e a faça afundar no mar, uma ação contra a qual ela pede uma garantia por meio da jura de Leto. Diante da promessa da deusa, Delos, então, aceita seu papel como local onde o deus nascerá e se rejubila (v. 8990). Tal júbilo, após tais manifestações da ilha, é comparado por Clay (2006 [1989], p. 41) ao modo como os deuses no Olimpo se acalmam após Leto receber seu filho e Zeus acenar com a cabeça. De modo semelhante, talvez, após seu terror inicial, os tripulantes da embarcação cretense aceitam, ao fim e ao cabo, a função que o deus lhes atribuiu como sacerdotes de seu templo. Essa progressão de um medo inicial para o júbilo final acaba por se constituir em uma das características essenciais do deus em suas epifanias (Clay, 2006 [1989], p. 40 e 56).

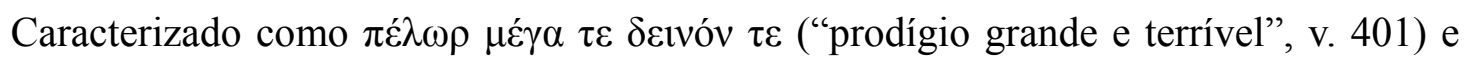
depois novamente por $\pi \varepsilon ́ \lambda \omega \rho$ (v. 416), termo que o poeta usou para a serpente em 375 , o golfinho compartilha com a serpente um caráter aterrorizante. É certo que a serpente é 46 Cf., por exemplo, Ilíada 23.633-634, Odisseia 16.86, 24.282 e 24.352. 
declaradamente um mal para os mortais, devorando seus rebanhos, enquanto o golfinho, posteriormente, revela-se um deus que, embora possa causar males aos mortais, como no início da Ilíada, estabelece com eles uma relação de reciprocidade (cf. h.Ap.3, v. 526 em diante). Ao eliminar a serpente, o deus elimina aquilo que impossibilitaria seu culto por devotos que the façam sacrifícios (cf. Strolonga, 2011, p. 546 e ss.), sendo o culto com sacrifícios um dos garantidores da existência do próprio deus. Veja-se que é baseada na reciprocidade a intervenção no início da Ilíada em prol de seu sacerdote.

Contudo, no momento em que são abduzidos pelo golfinho, nada sabe a tripulação cretense acerca daquele $\mu \varepsilon ́ \gamma \alpha \theta \alpha \tilde{v} \mu \alpha$ (v. 415) e o terror que sentem diante do animal é ainda mais compreensível se considerarmos um símile presente no canto 21 da Ilíada (v. 22-26): durante o combate entre Aquiles e os troianos no rio Xanto, agachados sob uma rocha no leito do rio, os troianos são comparados a peixes que fogem e se alojam próximo à margem do rio, aterrorizados (“ $\delta \varepsilon 1 \delta$ เó $\varepsilon \varepsilon \zeta ”, ~ 21.24)$ por um golfinho, que os devora. O símile é ainda mais aterrador quando sabemos que Aquiles em seguida tomará doze desses jovens para imolá-los em vingança a Pátroclo.

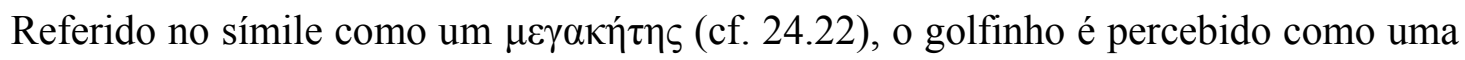
criatura marinha de grande porte, como é possível constatar em uma passagem da Odisseia (12.96-97), na qual é colocado dentre as "grandes criaturas marinhas" ( $\mu \varepsilon \tilde{i} \zeta o v \kappa \tilde{\eta} \tau o \varsigma)$, ao lado do "tubarão" ou da "foca" ( aterrorizadora, alimenta-se de animais que também o são. Veja-se que essa passagem coloca essas criaturas marinhas em relação direta com Anfitrite, uma das filhas de Nereu, que na Teogonia é gerado pelo Mar e dá origem às cinquenta virgens, ditas "peritas em trabalhos impecáveis" (v. 264). Golfinho e tubarão ou foca, estão dentre as incontáveis criaturas marinhas nutridas por Anfitrite (Odisseia, 12.95-96).

No Hino Homérico a Dioniso (hino 7, v. 48-53,) Dioniso transforma os tripulantes de uma nau tirrena em golfinhos como punição por tentarem capturá-lo. Vale dizer que a epifania de Dioniso nesse hino é bastante semelhante à de Apolo no h.Ap.3, já que os tripulantes da embarcação se aterrorizam diante de um leão, que é o deus transformado. O resultado, contudo, difere: os tripulantes da embarcação tirrena, aterrorizados, lançam-se ao mar e, como punição, são transformados em golfinhos. 


\subsection{CONCLUSÕeS}

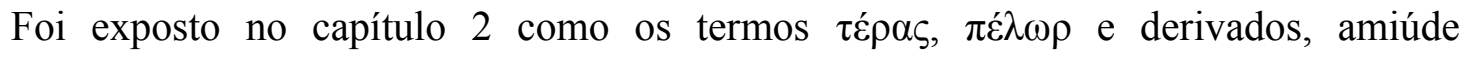
entendidos e traduzidos como "monstro", são palavras ligadas ao âmbito da adivinhação; também foi exposto que, para ser entendido como um sinal a ser interpretado, algo necessita se apresentar como extraordinário. No h.Ap.3 tanto a serpente morta por Apolo como o golfinho no qual ele se transforma são designados por $\pi \dot{\lambda} \lambda \omega \rho$ (serpente: v. 374; golfinho: v.

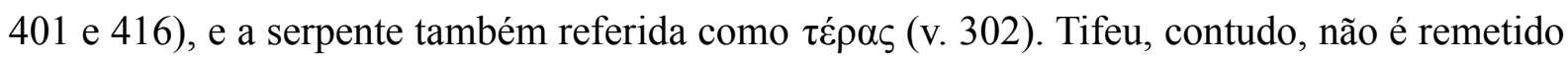
por qualquer desses dois termos no h.Ap.3.

Como os outros hinos homéricos, que narram a conquista das timāi de cada deus ao qual é dedicado, o h.Ap.3 também narra como Apolo, desde seu nascimento no início do h.Ap.3 até o primeiro oráculo proferido em Delfos ao final dele, conquista suas timāi, dentre as quais o oráculo délfico. Conforme nota Clay (2006 [1989], p. 92), após o medo inicial que acomete tanto mortais quanto imortais diante do deus, a nova divindade coloca sua timē tripla (o arco, o oráculo, a música) a serviço da humanidade, ${ }^{47}$

[...] ao liberá-la das criaturas monstruosas e destrutivas como Pitó e ao compartilhar com ela os prazeres da música, que liberta os homens - ainda que apenas momentaneamente - das preocupações humanas. Além disso, o oráculo de Apolo eleva os mortais de sua desamparada ignorância e, ao torná-los conscientes das consequências de suas ações, torna-os capazes de escolha moral.

Com o oráculo, portanto, Apolo assume um papel como mediador entre os decretos divinos de Zeus e a humanidade, diminuindo a distância entre os dois polos e inaugurando uma nova era nas relações entre deuses e mortais (Clay, 2006 [1989], p. 92).

É notável que a serpente aniquilada por Apolo, cuja morte possibilita que o deus funde seu oráculo e também lhe confere o epíteto de "Pítio", seja referida por dois termos associados à atividade oracular, atividade mesma à qual o oráculo fundado no local onde ela apodreceu será dedicado. É igualmente notável que o golfinho, animal no qual o deus se transforma a fim de angariar os sacerdotes de que necessita, seja também designado por $\pi \varepsilon ́ \lambda \omega \rho$. Ambos, serpente e golfinho, desempenham papéis fundamentais para que a atividade oracular seja instaurada pelo deus.

Se, como afirma Manetti (1993, p. 18), “a divinação surge, assim, na lacuna que

47 "[...] by liberating it from monstrous and destructive creatures like Pytho and by sharing with it the pleasures of music, which free men - if only momentarily - from the human cares. In addition, Apollo's oracle raises mortals up from their helpless ignorance and, by making them aware of the consequences of their actions, renders them capable of moral choice." 
separa o conhecimento da humanidade daquele dos deuses", o sinal ( $\sigma \tilde{\eta} \mu \alpha$ ou $\tau \dot{\varepsilon} \rho \alpha \varsigma)$ é

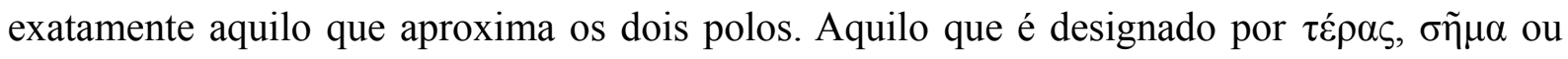
$\pi \varepsilon ́ \lambda \omega \rho$, enquanto o signo por meio do qual ocorre a comunicação dos deuses com os mortais, comprova a existência da divindade e de seu desejo de comunicação com os mortais, aproximando o universo divino do humano: ${ }^{48}$

[...] Longe de corresponder simplesmente a um acidente do mundo físico, os terata, os prodígios, são a garantia da existência dos seres sobre-humanos que manifestam sua atenção sobre as coisas do mundo.

A nossa concepção moderna e desencantada de "monstro" não consegue dar conta do que esses termos ou mesmo essas criaturas representam no hino a Apolo. Esse poema expressa um sistema de pensamento e de visão de mundo na qual aquilo que os leitores modernos traduzem como "monstro" é exatamente o que diminui o abismo entre deuses e humanos. Há uma dialética entre o divino e o humano na qual a comunicação é realizada por meio do prodígio, ou do que denominamos monstruoso, e este não compõe uma terceira categoria de seres por si sós que se interpõe ou se contrapõe às categorias de seres "mortais" e “imortais". O prodígio ou o " $\tau \varepsilon ́ \rho \alpha \varsigma$ ” não é uma categoria de seres, mas de fenômeno pelo qual os deuses se apresentam e se revelam (causando terror, espanto, maravilhamento) aos mortais.

48 Colombo (2012, p. 226): “[...] Loin de correspondre simplement à un accident du monde physique, les terata, les prodiges, sont garants de l'existence des êtres surhumains qui manifestent leur attention aux choses du monde.". 


\section{CApÍtulo 5}

\section{CRIATURAS CONSIDERADAS MONSTRUOSAS NA ODISSEIA DE HOMERO}

Sereia: hipotético animal marinho, lemos num dicionário brutal.

Jorge Luis Borges, O livro dos seres imaginários, p. 189. 


\section{CAPÍTULO 5}

Em conclusão aos capítulos de análise das criaturas consideradas monstruosas na poesia hexamétrica arcaica, o presente capítulo se dedica, por fim, ao estudo daquelas apresentadas pela Odisseia. Pela primeira vez na tese, deixamos a parte da história do cosmo centrada nas divindades para ingressar naquela que se foca nos heróis, "esses humanos (mortais) que estão no meio do caminho entre deuses e homens", como os define em poucas palavras Werner (2013, p. 17), em sua introdução à tradução da Teogonia.

As criaturas consideradas monstruosas da Odisseia estão concentradas entre os cantos 9 e 12, no contexto das narrativas de Odisseu aos feácios, denominadas apologoi. Nessas narrativas em primeira pessoa (com apenas uma interrupção, entre 11.333-384), Odisseu narra a Alcínoo, rei dos feácios, à esposa deste e aos demais convidados suas próprias aventuras desde a saída de Troia até a chegada a Esquéria, terra dos feácios, ponto final de suas perambulações marítimas antes de finalmente retornar a Ítaca. ${ }^{1} \mathrm{O}$ itinerário narrado por Odisseu compreende os episódios em que figuram os lotófagos, povo que se alimenta de flores de lótus, o ciclope Polifemo, o deus Eolo, que presenteia Odisseu com um saco de ventos, os lestrigões, povo canibal que se assemelha aos gigantes, a ninfa Circe, que transforma os companheiros de Odisseu em porcos, sua visita ao Hades, onde encontra o adivinho Tirésias, as Sirenas, que atraem os homens com seu canto, Cila, que destrói barcos e marinheiros e é dotada de doze pés e seis cabeças, Caríbdis, uma espécie de redemoinho que suga os barcos que passam próximos a ela, as vacas do deus Hélio na Trinácia, devoradas insensatamente pelos companheiros de Odisseu e, por fim, Calipso, a ninfa que acolhe Odisseu e em cuja companhia ele permanece por vários anos. ${ }^{2}$

De todos esses encontros de Odisseu durante sua errância pelo mar, apenas alguns são analisados aqui, com o foco sobre as criaturas descritas de modo a ser possível considerá-las monstruosas, como o ciclope Polifemo, os lestrigões, as Sirenas, Cila e Caríbdis. Os lotófagos não são descritos na Odisseia e a única característica que pode ser atribuída a eles é o hábito de comer flores de lótus, o que causa o esquecimento do retorno nos companheiros de

1 Acerca da estrutura geral dos apologoi, cf. Most (1989) e Bakker (2013, principalmente o capítulo 2, p. 13$35)$.

2 A ordem das aventuras narradas por Odisseu é: 1) cícones (9.39-66) e tempestade no mar (9.67-81); 2) lotófagos (9.82-105); 3) ciclopes (9.106-566); 4) Eolo (10.1-79); 5) lestrigões (10.80-134); 6a) Circe (10.135-574); 7) mundo dos mortos (11.1-332; 385-640); 6b) Circe (12.1-143); 8) Sirenas (12.144-200); 9a) Cila (e Caríbdis) (12.201-59); 10) Trinácia e tempestade (12.260-425); 9b) Cila e Caríbdis (12.426-46); 11) Calipso (12.447-50), que foi narrada na noite anterior e, portanto, Odisseu a retoma brevemente ao final dos apologoi. Lista baseada em De Jong, 2004 [2001], p. 222. 
Odisseu. Eolo, Hipérion, Circe e Calipso são referidos como deuses e também não recebem descrição. O episódio de Polifemo é o que receberá mais atenção, já que ocupa um canto praticamente inteiro (canto 9), enquanto as outras criaturas recebem pouco mais que uma dezena de versos.

Talvez seja desnecessário dizer que a história do cosmo de Graziosi e Haubold (2005) e a referencialidade tradicional de Foley (1991 e 1999) continuam a compor o instrumental de análise também para a Odisseia. Em relação a esse poema, contudo, faz-se aqui um uso mais frequente do arcabouço da narratologia, conforme proposto por De Jong (1992; 2004 [1987] e 2004 [2001]), muito em virtude de os episódios dos apologoi serem narrados por um narrador-personagem, tornando a distinção entre narrador principal e enunciação de personagem importante para a compreensão dos episódios.

Esse capítulo está organizado de acordo com as narrativas apresentadas por Odisseu aos feácios: primeiro a análise dos ciclopes com destaque para o episódio de Polifemo, seguida de uma breve exploração dos lestrigões, das Sirenas e, por fim, de Cila e Caríbdis. ${ }^{3}$

\subsection{OS APOLOGOI}

Por constituírem a mais longa narrativa embutida existente nos dois épicos homéricos, qualquer análise das criaturas que participam dos apologoi tem de necessariamente levar em consideração a posição de "narrativa dentro de uma narrativa" e suas implicações para ambas, a embutida e a principal. ${ }^{4}$ Quando Odisseu, protagonista da narrativa principal, passa a narrar suas próprias aventuras, tornando-se narrador e protagonista da narrativa embutida, há uma sobreposição de funções resultando em uma narrativa sob a focalização do narrador interno. ${ }^{5}$

3 O episódio de Polifemo é frequentemente considerado uma narrativa folclórica, com versões provenientes de diversos países. Contudo, essa característica não é relevante para a análise proposta aqui, que se centra no papel de Polifemo estritamente no contexto da Odisseia. Para o tratamento do episódio como narrativa folclórica, cf. Page (1955), o primeiro analisar o episódio de Polifemo como a junção de dois temas folclóricos: o ogro que devora seres humanos e que é, por fim, cegado e o tema do "Ninguém". Schein (1970) analisa as diferenças apontadas por Page entre a versão da Odisseia e as coletadas por folcloristas, defendendo a pertinência delas à trama odisseica. Cf. também Glenn (1971), que analisa 25 detalhes da narrativa de Polifemo comparando-a a versões folclóricas. Cf. recentemente Bakker (2013), que analisa a figura de Odisseu à luz do tipo "Mestre dos animais", uma espécie de status primordial proposto por Burkert (1979) e também assumido por Bremmer (2002).

4 A Ilíada também apresenta narrativas embutidas, entretanto, além de serem curtas se comparadas aos apologoi, que ocupam 2.140 versos, elas remetem a eventos passados em relação à narrativa principal, enquanto as narrativas de Odisseu são ancoradas nela (cf. De Jong, 2004 [2001], p. 221 e ss.) e assumem grande importância na construção do personagem protagonista, a ponto de o proêmio da Odisseia remeter em linhas gerais ao conteúdo dos apologoi em detrimento do conteúdo do poema como um todo (cf. Bakker, 2013, p. 4).

5 Para o conceito de focalização, cunhado por Gérard Genette ao final da década de 1960, e outros próprios da narratologia aplicados aos poemas homéricos, cf. De Jong (2004 [1987]) para a Ilíada e De Jong (2004 [2001]) para a Odisseia. 
Uma das consequências dessa focalização é a sobreposição, na performance, entre a figura de Odisseu e o poeta, que, narrando em primeira pessoa, coloca a plateia diante de si também diante do herói. Consequentemente, há a uma sobreposição entre o público interno da narrativa de Odisseu, ou seja, Alcínoo e os feácios, e o público externo, aquele que compõe a plateia do poeta da Odisseia e, em última instância, nós, os leitores desse poema. ${ }^{6}$ Assim, a sobreposição protagonista-narrador gera uma sobreposição que nos coloca temporariamente na posição dos próprios feácios. ${ }^{7}$

Desse modo, ao longo das onze aventuras narradas nos apologoi, os públicos interno e externo dessas narrativas acompanham Odisseu e seus companheiros até o herói chegar sozinho à ilha de Calipso. Sendo o único sobrevivente, Odisseu é a única testemunha do que lhe aconteceu, não havendo outros que pudessem corroborar ou negar o conteúdo de sua narrativa aos feácios. Essa posição privilegiada em relação à sua própria narrativa, por um lado, o redime da necessidade essencial dos aedos de invocar as Musas, limitando a responsabilidade delas em relação à narrativa de Odisseu (Pucci, 1998, p. 143), e, por outro, o coloca na posição do único garantidor da veracidade da narrativa que faz para os feácios, por meio do testemunho ocular em primeira pessoa. ${ }^{8}$ Usa-se o termo "veracidade" aqui não como sinônimo de "verdade" em oposição a "mentira", mas em sua relação de sinonímia com a verossimilhança. Evita-se neste capítulo tratar os apologoi ou mesmo os épicos homéricos como um todo enquanto narrativas sobre as quais se aplica o binômio "verdade", enquanto fato histórico, e "fantasia", enquanto criação da mente humana que nada tem a ver com a realidade. Para a análise proposta nesta tese, em que os elementos extraordinários, sejam eles ambientados na realidade empírica ou na realidade poética, são todos percebidos como indício da atividade divina no mundo humano, pouco importa uma distinção entre real e imaginário. ${ }^{9}$

$\mathrm{O}$ artifício de aproximação de narradores e de públicos também provoca efeitos sobre a relação entre o conteúdo daquilo que é narrado por Odisseu e o público, particularmente o externo. Em vez de ouvir os relatos em terceira pessoa, em que o narrador principal contaria a sua plateia sobre a errância do personagem, ela ouve um testemunho ocular em primeira

6 Essa aproximação entre público externo e interno pode estar indicada já no proêmio da Odisseia em que, no verso 10, o poeta pede para que a Musa cante acerca daquilo que está indicado no proêmio, ou seja, o conteúdo dos apologoi, "também para nós” (cf. Bakker, 2013, p. 6-9).

7 Cf. Bakker (2013, p. 7): "When the hero takes over the floor from the poet, his story is not merely 'embedded'; the boundary between the internal and the external audience begins to fade, and we are listening to Odysseus himself. [...]"'.

8 A propósito, o testemunho ocular é o mais forte critério de verdade para a Heródoto. Cf. Gagnebin (2005 [1997], p. 13-35).

9 Veja-se a proposta de compreensão de Gould (2001) para a Ilíada em que ele considera o universo do poema composto de "itens" reais ou imaginários selecionados e moldados de acordo com o interesse da ficção em sua integralidade. 
pessoa cujo efeito é a aproximação dela com o próprio conteúdo narrado. Isso é importante principalmente porque essas narrativas remetem a um momento na história do cosmo ainda mais distante no passado do que o mundo dos heróis da geração da guerra de Troia, à qual pertence Odisseu, ou seja, elas remetem a um tempo no qual viveram gerações de heróis como Héracles, Perseu, Jasão e Belerofonte, que aniquilaram criaturas não humanas, precedentes à geração de heróis na qual se insere Odisseu. ${ }^{10}$ Assim, o herói-narrador da Odisseia, ao se inserir em um espaço geográfico e temporal de gerações anteriores, aglutina o tempo no qual vive com aquele dessas gerações em que ainda figuram criaturas elegíveis para perecer pela mão de algum desses heróis do seu passado. Portanto, ao fundir narrador externo e interno, os apologoi fundem o tempo presente da performance com o tempo da guerra de Troia e, recuando ainda mais no passado, com o tempo dos chamados "heróis matadores de monstros". ${ }^{11}$

Uma importante consequência dos episódios em que figuram as criaturas consideradas monstruosas na Odisseia estarem em uma narrativa embutida é que a linguagem usada para descrevê-las tem de levar em consideração a focalização do narrador-personagem. De Jong (1992 e 2004 [2001]) aponta para o estilo mais subjetivo dos apologoi sob o qual o narrador faz uso de uma linguagem mais típica da enunciação de personagem. Desse modo, a caracterização dessas criaturas deve ser entendida primordialmente sob a perspectiva de Odisseu, o narrador secundário. Há, contudo, exceções a essa focalização, como aponta Scodel (2005): nas descrições feitas por Odisseu dos povos que encontra, o herói fornece informações que ele próprio não teria, conjugando a focalização de personagem com a do narrador principal e onisciente. Essa focalização mista estaria fundamentalmente presente nas chamadas "digressões etnográficas” de Odisseu.

Os apologoi têm início no canto 9, após o terceiro canto de Demódoco (8.497-519), que, a pedido de Odisseu (8.485-496), narrava o episódio do cavalo protagonizado por ele em Troia. Durante a performance do aedo, Odisseu chora e Alcínoo, tendo notado os gemidos de

10 Mackie (2008, p. 189) aponta para o caráter fundamentalmente "heracleano" da paisagem na qual Odisseu opera, embora seu livro se dedique à transição de gerações na conduta heroica da Ilíada, desde os períodos mais recuados da história do cosmo até a geração de Aquiles em Troia. Cf. também Nieto Hernández (2000), que coloca a ciclopeia em um tempo ainda mais recuado: "[...] The Cyclopeia locates us in an antique world, in which we relive, along with Odysseus, the overthrow of Cronus, the beginning of Zeus' sovereignty, and the division of the universe among the three brothers. In the course of the poem Odysseus will experience each of these realms: not only Poseidon's sea, but also the subterranean domain of Hades, and finally, his own homeland of Ithaca, over which Zeus is sovereign.". Contudo, prefere-se aqui manter a leitura que coloca os apologoi na época da geração de heróis anterior à da guerra de Troia em razão de Circe mencionar a Argo, a embarcação de Jasão, como a única a ter sido bem-sucedida em cruzar o estreito entre Cila e Caríbdis (12.69-72).

11 Odisseu, contudo, diferente da geração de heróis "matadores de monstros", não aniquila nenhuma das criaturas com as quais depara, apesar de ter cegado Polifemo, continuando à parte dessa geração. 
seu hóspede, ordena que Demódoco cesse o canto e se dirige a Odisseu inquirindo sobre sua identidade (8.531-584). O canto 9, então, tem início com a resposta de Odisseu, que revela sua identidade e começa a tecer sua narrativa com o episódio do saque aos cícones (9.39-61), habitantes de Ismaros, referidos na Ilíada como aliados dos troianos (2.846 e 17.73), contra os quais Odisseu e seus companheiros praticaram pilhagem, seguida da destruição da cidade, uma prática social comum ao universo da poesia hexamétrica heroica em geral. Contrariando o pedido do herói para partirem imediatamente, seus companheiros se embriagaram e permaneceram junto à costa, enquanto os cícones remanescentes se juntaram e rechaçaram Odisseu e sua tropa de lá. ${ }^{12}$ Diante de um resultado totalmente diferente do cerco a Troia, e enfrentando em seguida uma grande tempestade no mar (9.62-75), Odisseu vai abandonando o universo em que a Ilíada é ambientada e conduz o público interno e o externo a deixá-la também (cf. De Jong, 2004 [2001], p. 229, e Most, 1989, p. 22). ${ }^{13}$

Depois de enfrentar as tempestades e de quase chegar a Ítaca (9.67-81), Odisseu e seus companheiros desembarcam na terra dos lotófagos (9.84-105), que, como os cícones, não recebem descrição por parte de Odisseu, apenas a indicação de que se alimentam da flor de lótus. Segundo Scodel (2005, p.156-157), os cícones não são descritos porque não há nada de especial a respeito deles e os lotófagos aparentemente não apresentam nada que os distinga além de seu hábito alimentar. Odisseu, contudo, ao pedir a três de seus companheiros, dentre eles um mensageiro, que investiguem quem seriam os habitantes locais, refere-se aos eventuais habitantes daquela região como "varões, que sobre a terra comem pão" (бĩนov

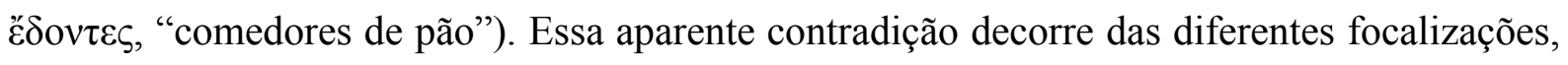
em que a referência aos varões que comem pão está sob a focalização de Odisseu como personagem da narrativa embutida e a descrição dos lotófagos como aqueles que se alimentam da flor de lótus, por sua vez, está sob a focalização de Odisseu enquanto narrador, que declara seu conhecimento post factum. ${ }^{14}$

Contudo, os enviados não retornam a Odisseu, nem sequer o mensageiro, não por terem sido abatidos, mas por não desejarem voltar após terem ingerido a flor de lótus. Uma

12 Odisseu teria prevenido grande parte das perdas sofridas se seus companheiros, em vez de terem se embriagado pelo vinho de Ismaros, tivessem seguido seu conselho de deixarem aquela terra imediatamente após o saque. Mas por terem permanecido ali, os cícones receberam ajuda de aliados que vieram em seu auxílio e subjugaram a frota de Odisseu (9.43-61). Essa atitude de Odisseu e a dos companheiros se repetirá ao longo dos apologoi e justificará a perda da totalidade de sua frota e a chegada solitária à terra dos feácios. Além disso, contribui para a caracterização de Odisseu, presente no proêmio, como aquele que almeja não só o seu retorno mas também o dos companheiros. No episódio de Polifemo, contudo, ocorre o contrário: os companheiros de Odisseu tentam demovê-lo da decisão de permanecer na gruta do ciclope (9. 224-229).

13 Para as tempestades no mar como demarcadores do início e do fim do que Most chama "aventuras fabulosas" de Odisseu, cf. Most (1989, p. 22).

14 Nessa breve introdução aos lotófagos como aqueles "que comem alimento floral”, nem é necessário evocar o recurso da focalização mista de narrador principal e narrador secundário, proposta por Scodel (2005). 
flor que provoca o esquecimento do retorno e a vontade de se manter onde está é o primeiro elemento da viagem de Odisseu que pode ser considerado exterior ao mundo militar da guerra de Troia. Assim, Odisseu tem a oportunidade de, ao ingerir a flor de lótus, esquecer-se de seu retorno para Ítaca; sem provar da planta, contudo, Odisseu embarca os companheiros à força. A terra dos lotófagos é, portanto, a porta de entrada para o universo dos episódios que constituirão o $\kappa \lambda \dot{\varepsilon}$ os (kleos) odisseico de Odisseu, dando início à sua jornada. ${ }^{15}$

\subsection{OS CICLOPES}

Antes de analisar a caracterização dos ciclopes feita por Odisseu aos feácios, é necessário levar em consideração duas coisas: a primeira é a diferença entre os Ciclopes da Teogonia e os ciclopes da Odisseia; a segunda é a caracterização dos ciclopes e de Polifemo na Odisseia fora dos apologoi. ${ }^{16}$

Como visto no capítulo 3, os Ciclopes da Teogonia são um grupo de três filhos de Terra e Céu, forjadores do raio de Zeus, que apresentam um olho circular na fronte. Embora essa característica não seja explicitada na Odisseia para a raça dos ciclopes, ela é geralmente pressuposta, sendo fundamental para o episódio em que Odisseu cega Polifemo, feito que o herói executa enfiando uma enorme estaca de oliveira no olho do ciclope (9.318-330 e 9.375397). Mondi (1983) defende que a raça dos ciclopes na Odisseia não apresenta essa

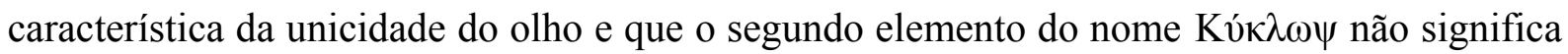

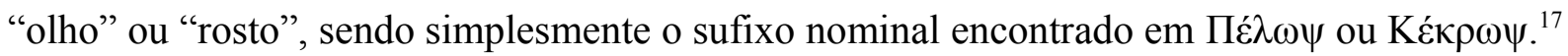
Para Mondi, a posse de um olho só atribuída aos ciclopes na Odisseia seria uma espécie de contaminação da característica presente nos Ciclopes teogônicos. Contudo, ainda que a Odisseia não explicite essa particularidade, Polifemo se declara cegado (்̇ $\xi \alpha \lambda \alpha ́ \omega \sigma \varepsilon, 9.453$;

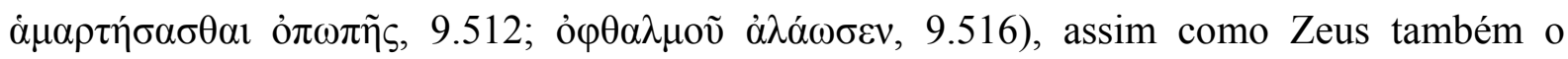

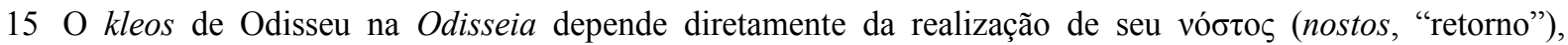
contrastando com o kleos de Aquiles na Ilíada, que tem a garantia de adquiri-lo ao decidir pelo não retorno da guerra de Troia. Para uma comparação entre o funcionamento do kleos na Ilíada e na Odisseia, cf. Duarte (2001) e Werner (2001). Duarte (2001, p. 92) lança mão da noção de uma "mais-valia heroica" produzida pelo árduo percurso de Odisseu em contraste com o retorno sem grandes obstáculos dos demais heróis que combateram em Troia: "[...] À glória troiana soma-se a advinda de suas viagens e do seu enfrentamento com os pretendentes.".

16 O uso de inicial maiúscula para os Ciclopes da Teogonia decorre de ser um nome próprio para um grupo de três seres e o uso de inicial minúscula para os ciclopes da Odisseia encontra razão em ser a denominação de um povo, que o português geralmente designa com inicial minúscula.

17 Bakker (2013, p. 69-70) recentemente adota a proposta da linguística comparada que propõe outra

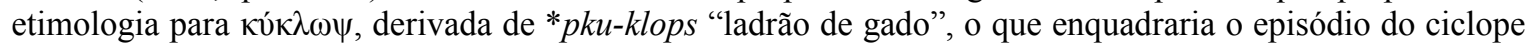
no mito do "Mestre dos Animais", em que animais são roubados e mantidos em uma caverna por um ladrão monstruoso e que serão resgatados por um herói, do qual Héracles seria o exemplo mais óbvio nas narrativas helênicas. 
declara (1.68-73), e seu olho é sempre referido no singular (9.383, 9.389-390, 9.394, 9.397, 9.453; cf. também 1.69 na fala de Zeus a Atena); ademais, Polifemo, após ter a estaca de oliveira enfiada em seu olho por Odisseu e os companheiros, tem de apalpar não somente a pedra antes de removê-la da entrada de sua gruta (9.416), como também as ovelhas, esperando apanhar os companheiros e o próprio Odisseu, que, escondidos sob elas, não são vistos pelo ciclope.

A única característica que a raça dos ciclopes da Odisseia compartilha com os Ciclopes da Teogonia é a unicidade do olho. É possível que a não explicitação desse traço na

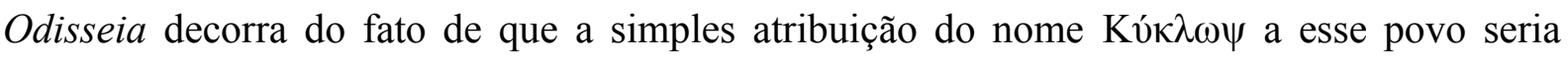
suficiente para evocar essa característica dentro da rede de ressonâncias da tradição de poesia hexamétrica, uma nomeação a partir da qual o público atribuiria prontamente tal característica, já que a tradição hexamétrica não emprega a alcunha para designar qualquer ser ou raça que não apresente essa característica. ${ }^{18}$

Conforme notado por outros estudiosos, os nomes na Odisseia carregam significados que indicam aspectos fundamentais, particularizadores, dos personagens. Veja-se, por

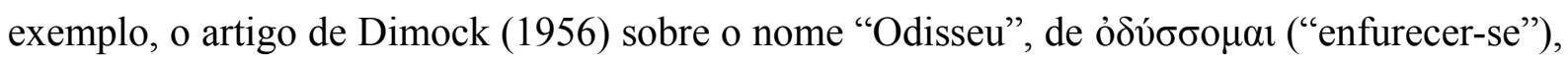
relacionando o sentimento que Odisseu desperta em Posêidon à capacidade do herói de causar problemas, para os outros e para si, ou o artigo de Bakker (2002), no qual ele explora a significação do nome "Polifemo", composto do prefixo $\pi$ o $\lambda v$ - e de $\varphi \eta ́ \mu \eta$, termo derivado da raiz $\varphi \eta$-, uma das raízes verbais que denota fala, propondo que na Odisseia $\varphi \eta ́ \mu \eta$ é uma "enunciação com propriedades proféticas das quais o falante não tem consciência" (essa significação será explorada adiante). ${ }^{19}$ Não há, portanto, razão suficiente para negar a

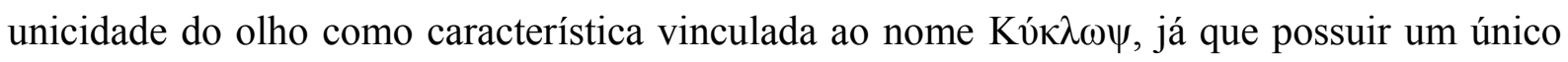
olho é o que vai permitir a Odisseu cegar Polifemo, assim conseguindo escapar de ser devorado por ele.

Quanto à caracterização dos ciclopes e de Polifemo fora dos apologoi, ou seja, fora da focalização de Odisseu como narrador secundário, ela ocorre brevemente em três momentos: no início do canto 1 (68-73), em que Polifemo é caracterizado por Zeus; no início do canto 2 (19-20), em que o narrador menciona que Antifo, filho de Egípcio, foi morto pelo ö $\gamma \rho 10 \varsigma$ ("selvagem") ciclope; e no início do canto 6 (4-6), em que os ciclopes são brevemente

18 Há, contudo, uma menção no comentário à Eneida de Virgílio ( $a d$. Aen. 3.636), atribuído a Sérvio, de que havia ciclopes com um, dois ou três olhos (apud Glenn, 1971, 154, n. 90). Sérvio, contudo, viveu no final do século IV e início do V da nossa era, e seu comentário possivelmente está levando em consideração versões posteriores à poesia hexamétrica arcaica.

19 Bakker (2002, p. 139): "Thus phêmê designates, in the Odyssey, an utterance with prophetic properties of which the speaker is unaware. [...]". 


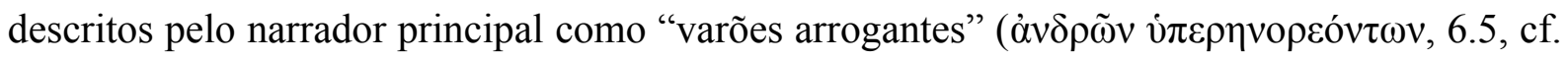
adiante), que lesavam os feácios, seus antigos vizinhos, por lhes serem superiores em "força" (ßín, 6.6).

No início do canto 1 (68-73), Zeus explicita a Atena o ódio de Posêidon por Odisseu como razão para manter o herói errando, longe de casa. Essa cólera de Posêidon, explica Zeus, deve-se ao fato de Odisseu ter cegado o ciclope Polifemo, que ele caracteriza como

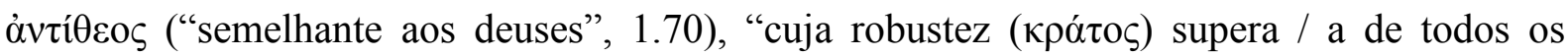
ciclopes" (1.70-71). Zeus também remete à origem de Polifemo, filho de Posêidon com Toossa, uma ninfa filha de Fórcis.

Essas três breves descrições situadas fora dos apologoi ancoram a narrativa acerca dos ciclopes e de Polifemo feitas por Odisseu aos feácios na narrativa principal e a fala de Zeus, além de prenunciar o fundamental episódio do cegamento de Polifemo, indica que esta é razão pela qual Odisseu não consegue voltar para casa.

A caracterização que Zeus faz de Polifemo, conquanto breve, é um tanto iluminadora. Embora ele use o epíteto não distintivo àvtí $\theta \varepsilon o \varsigma$, este é um epíteto de excelência, usado geralmente para heróis (cf. Ilíada 1.264, 3.186, 4.88, 4.377, 5.168 etc.), inclusive Odisseu (cf. Ilíada 11.140; Odisseia 1.21, 2.17, 4.741, 6.331 etc.). A focalização de Zeus, que atribui

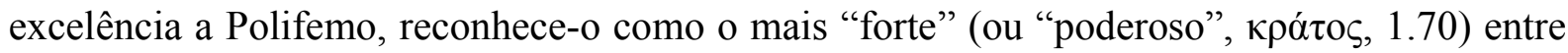
os ciclopes e explicita sua ascendência divina, não somente esclarecendo a razão da cólera de Posêidon contra Odisseu, como também intensificando a falta cometida pelo herói ao cegar o filho de um deus.

Mondi comenta que essa ascendência de Polifemo como neto de Fórcis faz com que ele seja considerado uma entidade monstruosa, como muitos outros dos "abomináveis netos de Fórcis" (1983, p. 28), uma decisão do poeta que ele considera adequada, já que a linhagem de Fórcis inclui várias criaturas aniquiladas heróis, como Medusa, Hidra, Quimera e Esfinge (1983, p. 28, n. 41). Thalmann (1984, p. 1) coloca os ciclopes e os feácios como extremos que se contrabalançam, um sendo necessário para a existência do outro, traçando um paralelo com as filhas de Nereu na Teogonia, que representam os aspectos benignos do mar, enquanto a progênie de Fórcis e Cetó revela seu lado ameaçador (Teogonia 240-264 e 270-336), ambos os grupos delineando o mar como um todo. Do mesmo modo, ciclopes e feácios seriam opostos complementares. Para Thalmann (1984, p. 1), ciclopes e feácios marcam os extremos entre "selvageria" e "civilização" no mundo pelo qual Odisseu vagueia, e também fornecem os limites geográficos desse mundo, no interior do qual Odisseu encontra mortais, monstros e deuses que nunca excedem esses limites. Como será visto adiante, os ciclopes, de um lado, 
sendo o primeiro povo com o qual Odisseu entra de fato em contato, marcam a inserção de Odisseu em um mundo que pertence a outro tempo na história do cosmo, e os feácios, de outro lado, marcam a saída de Odisseu desse mundo. Como já apontaram Clay (1980) e Pucci (1998), a dicotomia entre "selvageria" e "civilização", uma frequente chave de leitura para a compreensão de ciclopes e feácios, deve ser nuançada em uma leitura mais atenta do episódio de Polifemo.

\section{2.a) Os ciclopes nos apologoi}

Após mencionar brevemente o episódio do saque aos cícones (9.39-61), ainda calcado no universo da guerra de Troia, e a rápida passagem pela terra dos lotófagos (9.84-105), Odisseu começa a narrar sua estadia na terra dos ciclopes (9.106-566) e, como ocorre no início de cada episódio dos apologoi, ele oferece uma descrição do povo ou da figura que encontra. ${ }^{20}$ Essa descrição dos ciclopes por parte de Odisseu se constitui principalmente pela negação de aspectos de uma determinada organização social pressuposta para a sociedade à qual pertence, e que também é pressuposta para os feácios, sendo entendida com frequência em termos estruturalistas como uma oposição entre natureza e cultura (Kirk, 1970, p. 162 e ss.; Vidal-Naquet, 1970). ${ }^{21}$

Segundo Odisseu, os ciclopes não têm normas comuns (9.106 e 9.112), não cultivam a terra (9.107-111), não têm assembleias (9.112), não cuidam uns dos outros (9.115) e não praticam a navegação (9.125-129), o que, por sua vez, impossibilita que explorem ou habitem a ilha abundante em recursos nas proximidades, sobre a qual Odisseu discorre (9.116-141), percebendo prontamente as possibilidades de exploração de suas riquezas naturais. ${ }^{22}$

Essa descrição dos ciclopes feita sob a focalização de Odisseu enquanto narrador secundário contrasta com a dos feácios realizada pelo narrador principal no início do canto 6 (1-12), em que Nauveloz, então governante dos feácios (os ciclopes não têm governantes), após conduzir seu povo a Esquéria, fez construir um muro para cercar a cidade (os ciclopes não vivem em cidades), construiu casas (os ciclopes vivem em grutas) e templos (não mencionados para os ciclopes) e dividiu as terras aráveis (os ciclopes não cultivam a terra). Contudo, é nessa mesma passagem que o poema estabelece uma relação prévia de grande

20 Para os lotófagos em 9.84, para os ciclopes em 9.106-15 (para Polifemo especificamente em 9.187-92 e 9.214-15), para Eolo em 10.1-13, para os lestrigões em 10.82-6 e para Circe em 10.135-9.

21 Cf. também Kirk (1962), Schein (1970), Glenn (1971), Mondi (1982), Most (1989), Segal (1994) e Bremmer (2002).

22 Cf. De Jong, 2004 [2001], p. 233-235, que comenta acerca do olhar de colonizador por parte de Odisseu. 
proximidade entre feácios e ciclopes. Antes de serem conduzidos a Esquéria por Nauveloz, os feácios habitavam um local chamado Hipereia, próximo à terra dos ciclopes. ${ }^{23}$ Estes, referidos

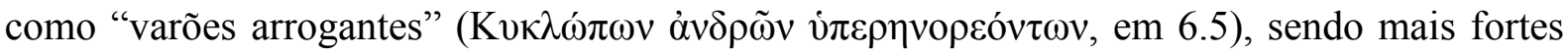
que os feácios, os pilhavam. Nauveloz os conduziu, então, para longe de "varões comemgrãos" (6.8, $\dot{\alpha} v \delta \rho \tilde{\omega} v \dot{\alpha} \lambda \varphi \eta \sigma \tau \alpha ́ \omega v)$ e Alcínoo, seu filho, o sucedeu ao trono. ${ }^{24}$

Alcínoo (7.199-206) deixa clara a relação de proximidade entre seu povo e os deuses, que sempre aparecem para os feácios em sua forma verdadeira e se sentam à mesa com eles quando estes fazem sacrifícios, e a equipara com a proximidade que ciclopes e gigantes também têm com os deuses. Conquanto tenham se afastado dos ciclopes, que apresentam uma organização social diferente, a ligação dos feácios com eles está para além da prévia proximidade territorial que se torna distância, porque Alcínoo e Polifemo compartilham uma ascendência comum: Polifemo é filho de Posêidon (1.71-73) e Alcínoo, seu neto (7.56-63). Certa proximidade também ocorre entre os feácios e os gigantes: segundo Atena (7.54-77), Periboia, mãe de Nauveloz e avó de Alcínoo e Arete, era filha de Eurimédon, "que um dia foi rei dos autoconfiantes gigantes" (7.59). Clay (1980, p. 264), diante dessa relação de proximidade entre feácios, deuses, ciclopes e gigantes, questiona a oposição simplista entre civilização e barbárie ou natureza e cultura. Pucci (1998, p. 123) comenta sobre essa fala de Alcínoo em 7.199-206:25

\begin{abstract}
Essa é uma passagem notável. A relação entre os feácios e os deuses é uma relação de proximidade e contiguidade, especificada apenas pela analogia com a relação que os ciclopes e as selvagens tribos dos gigantes têm com os mesmos deuses. De repente, a humanidade e o caráter civilizado dos feácios se tornaram problemáticos. Por um lado, a relação dos feácios com os deuses, análoga àquela gozada pelos ciclopes e gigantes, necessariamente descarta qualquer simples humanidade como a de Odisseu. Por outro lado, essa relação análoga coloca em questão a distinção estrita entre pio e ímpio, pois parece que os ciclopes (cuja "piedade" nos é familiar) e os gigantes (explicitamente descritos como selvagens, agria) compartilham igualmente essa contígua relação com os deuses.
\end{abstract}

23 Clay (1980) sugere que Hipereia e a ilha das cabras que Odisseu descreve sejam o mesmo lugar.

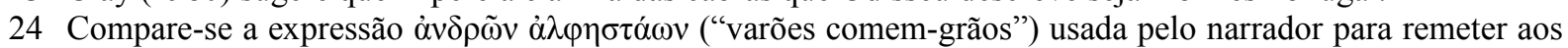
ciclopes e $\sigma \tilde{\tau} \tau o v ~ \varepsilon ̌ \delta o v \tau \varepsilon \varsigma$ ("comedores de pão"), usada por Odisseu no contexto de sua chegada à terra dos lotófagos. Observe-se que o narrador se refere aos ciclopes como "varões" ( $\alpha \not v \delta \rho \varepsilon \varsigma$ ) tanto em 6.5 como em 6.8 .

25 Pucci (1998, p. 123): "This is a remarkable passage. The relationship between the Phaeacians and the gods is a relationship of proximity and contiguity, specified only by analogy with the relationship that the Cyclopes and the savage tribes of the Giants have with those same gods. Suddenly the humanity and civilized character of the Phaeacians have become problematic. On the one hand, the Phaeacians relationship with the gods, analogous to that enjoyed by the Cyclopes and Giants, necessarily rules out any simple humanity like that of Odysseus. On the other hand, this analogous relationship calls into question the strict distinction between pious and impious, for it seems that the Cyclopes (whose 'piety' is familiar to us) and the Giants (explicitly described as savages, agria) are equal sharers in this contiguous relationship with the gods.". 
À parte a antropofagia praticada por Polifemo, um olhar mais atento à descrição da terra dos ciclopes e de seus habitantes pode não identificar tanto barbárie e selvageria, conquanto um mundo pastoril em contraste com um complexo rural-urbano, em que não há cidades muradas, nem espaço para assembleias deliberativas, ou organização social do trabalho, dentre os quais a agricultura, nem governantes ou até mesmo a navegação, crucial para a formação de centros de trocas culturais. Embora não cultive a terra, Polifemo apascenta cabras e ovelhas, faz queijo, tem cestos e recipientes que só podem ter sido manufaturados e seu gado é organizado por ordem de tamanho. ${ }^{26}$ Se os ciclopes devem ser considerados não civilizados dentro da poesia odisseica, essa não civilidade deve ser circunscrita a um modo de vida pastoril em contraposição ao urbano, não uma contraposição entre civilização e barbárie. Observe-se que Polifemo é não apenas provido de fala, mas se comunica com Odisseu, compartilhando, portanto, a mesma língua (que é o critério por excelência para determinar o bárbaro em contraposição ao heleno). ${ }^{27}$

Feácios, de um lado, e ciclopes e lestrigões, do outro, podem ser considerados povos que marcam os extremos da viagem de Odisseu em relação à xenia, instituição social da hospitalidade presidida por Zeus, com quem Polifemo diz que os ciclopes não se preocupam (9.275), declarando que são mais poderosos que os deuses (9.576). ${ }^{28}$ Esse desrespeito dos ciclopes pelos deuses e também pelas instituições que eles presidem não os exclui do favorecimento divino, que Odisseu nota ao descrever a abundância da terra em que habitam na qual tudo germina fomentado pela chuva de Zeus. Isso pode ser um indício de que os ciclopes prescindem da relação de reciprocidade com as divindades, já que, sendo próximos dos deuses, gozam de um estatuto não humano, ou sobre-humano, quase divino, ou, no caso de Polifemo, muito próximo do divino, já que é filho do deus Posêidon com a ninfa Toossa. Se os ciclopes prescindem da relação de reciprocidade com os deuses, não teriam razão para mantê-la com os mortais (reciprocidade é um aspecto fundamental da relação de xenia.

26 Cf. Scodel (2005, p. 148), que considera Polifemo "a hard-working shepherd".

27 Cf. Versnel (2011, p. 386-387): "[...] As to the Cyclopes, their most obvious positive quality, so obvious indeed that it is not noticed at all initially, is their excellent working knowledge of Greek. They are fluent in that language - that is: all other Cyclopes are, whereas Polyphemos must have cancelled his Greek course just before tackling the indefinite pronoun. No element of this Homeric excursus has received a more stepmotherly treatment. If noticed at all, scholars at most assign it a narratological inevitability: Germans in an English war film communicate in English which they speak fluently albeit with a funny accent. As for the Homeric epic, everybody speaks Greek: Trojans, Phaeacians, gods, nymphs. Is it a negligible feature for that reason? In many respects it is, in one respect it is highly meaningful: better than anything else it illustrates that the Other cannot be imagined nor communicated without the aid of elements of the self. And the most revealing thing is that as soon as otherness requires a reminder you can use the self by corrupting it and making a pun on a pronoun.".

28 Pucci (1998, p. 127, n. 24) coloca essa fala de Polifemo como um exemplo da esperteza retórica do ciclope, como a gozação que ele faz da etiqueta de hospitalidade. Essa jactância de Polifemo acerca de sua desconsideração pelos deuses, segundo Pucci, tem a provável intenção de aterrorizar seus prisioneiros. 
Contudo, como nota Scodel (2005, p. 150), ${ }^{29}$

[...] Mesmo que Polifemo afirme que os ciclopes não se importam com Zeus ou com os deuses (Od. 9.275-6), a resposta deles à fala de Polifemo de que 'ninguém' o está matando é dizer que não é possível escapar a uma doença que vem de Zeus ( $O d$. 9.410-12), e recomendar que ele rogue a Posêidon. Os outros ciclopes, de fato, poderiam ser um povo ordinariamente pio, até onde Odisseu sabe com base em sua própria experiência, pois ele não tinha razão para pensar que Polifemo é um informante confiável.

Se é possível confiar na descrição dos ciclopes feita por Odisseu, feácios e ciclopes apresentam diferenças em relação a sua organização social, mais precisamente, diferenças que expõem um contraste entre um mundo urbano (na medida em que se pode falar de "urbano" em Homero) e um mundo pastoril, em que o oikos é muito menor e mais restrito do que aquele em contexto urbano e no qual não há relação coletiva entre os habitantes, diferentemente da organização coletiva ou social das cidades, em que há governo, governante e governados. Polifemo, apontado por Zeus como o mais forte dos ciclopes, nem por isso impõe-se sobre seus conterrâneos. ${ }^{30}$ A organização social de subsistência na qual os ciclopes estão inseridos contrasta com o mundo urbano, cuja existência só é possível por causa de uma produção agrária que transcende esse nível de subsistência e permite trocas comerciais (embora não no caso dos feácios, que estão isolados do resto do mundo). Essas trocas, por sua vez, dependem da boa relação entre governantes; daí a importância da xenia para um mundo urbano e comercial. Embora a instituição da hospitalidade e da reciprocidade seja antropologicamente muito importante no contexto pastoril, o que se tem na narrativa odisseica é o que talvez se possa chamar de uma "caricatura" urbana da vida pastoril. ${ }^{31}$

A relação de xenia, que perpassa todo o poema, ${ }^{32}$ é certamente central na relação

29 Scodel (2005, p. 150): “[...] Even though Polyphemus asserts that the Cyclopes do not care about Zeus or the gods (Od. 9.275-6), their response to his saying that 'nobody' is killing him is to say that it is not possible to escape a disease that comes from Zeus (Od. 9.410-12), and to recommend that he pray to Poseidon. The other Cyclopes, in fact, could be ordinary pious folk, insofar as Odysseus knows from his own experience, for he had no reason to think that Polyphemus is a reliable informant.".

30 A suposição de Page (1955, p. 6) de que Polifemo é o "mestre e senhor" dos ciclopes já foi refutada por

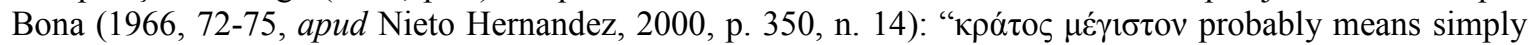
that he was the strongest and mightiest of the Cyclopes, without implying that he was their king or recognized leader.".

31 Acerca do pastoreio e da agricultura na composição da paisagem helênica, cf. Osbourne (1987). Pastoreio e agricultura coexistem no mundo helênico. Embora haja conflito, há também interação, e a ideia de que o pastoreio é inferior ou menos civilizado é uma caricatura criada pela elite da pólis que vê a agricultura como uma atividade mais honrada. Osbourne faz uma discussão sobre essa imagem retórica no século IV a.C. A Odisseia, apesar de estabelecer uma hierarquia de valores semelhante, apresenta uma diferença entre o pastor e o agricultor (que mora na cidade) menos matizada do que no século IV a.C. Ao final do livro, Osbourne mostra que a caricatura se inverte quando as elites urbanas se encontram distantes dos conflitos entre agricultura e pastoreio, e passam a valorizar este último, com o culto a Pã e com as poesias bucólicas.

32 E que está intimamente relacionada à questão do alimento, cf. Hernández (2000, p. 2) e Bakker (2013). 
Polifemo-Odisseu e Odisseu-pretendentes: Polifemo se recusa a estabelecê-la com Odisseu, enquanto os pretendentes têm estendido ao longo de dez anos sua permanência no oikos do herói, ignorando a reciprocidade demandada pela xenia. A negação dela por parte de Polifemo e a sua deturpação praticada pelos pretendentes são colocadas para a plateia externa como dois extremos comportamentais ultrajantes por se configurarem como desrespeito a uma instituição social presidida por Zeus.

Além da falta de xenia por parte de Polifemo, a ausência de "assembleias decisórias"

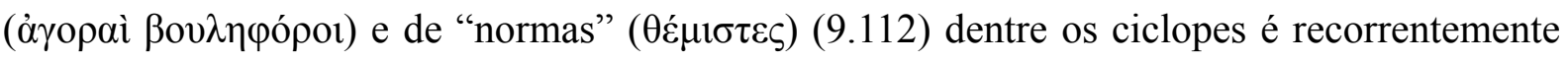
apontada como evidência de sua "selvageria", ou falta de civilidade. Contudo, ela também ressoa na Ítaca dominada pelos pretendentes, como aponta Bakker (2013, p. 56-57), que durante os anos de ausência de Odisseu sofre com a inexistência de assembleias, já que aquela convocada por Telêmaco no canto 2 é a primeira desde que Odisseu partiu para Troia (2.2627). Ademais, a observação de Odisseu de que cada ciclope "impõe normas" ( $\theta \varepsilon \mu 1 \sigma \tau \varepsilon v ́ \varepsilon ı v)$ sobre seus filhos e mulheres contrasta com a situação do herói, que, estando ausente, é impossibilitado de exercer o governo sobre seu próprio oikos, incluindo sua esposa e seu filho. Bakker (2002, p. 137) ainda coloca em termos de semelhança com os ciclopes a atitude do próprio Odisseu de aniquilar todos os pretendentes quanto retorna a Ítaca, ignorando as leis ou assembleias demandadas pela organização social da pólis.

Se, por um lado, a plateia externa pode reconhecer a semelhança entre a transgressão das regras de hospitalidade por parte dos ciclopes e dos pretendentes em Ítaca, ela também pode reconhecer a contraposição entre esses dois grupos, de um lado, e, do outro, a hospitalidade dos feácios, diante dos quais Odisseu está narrando o episódio de Polifemo em meio aos prazeres de um banquete. Os próprios feácios, enquanto plateia interna de Odisseu, também podem perceber o contraste entre a atitude de Polifemo e a sua em relação à hospitalidade proporcionada a Odisseu, constituindo-se em uma captatio benevolentiae, um recurso oportunamente usado por Odisseu como narrador secundário, já que é dos feácios que depende sua viagem de retorno a Ítaca. ${ }^{33}$

Ao chegar à sua terra natal, contudo, Odisseu terá de enfrentar os pretendentes, cuja associação com os ciclopes não se resume à relação de xenia, pois está colocada também em sua caracterização ao longo do poema. O verso (9.106) com o qual Odisseu introduz os ciclopes para as plateias interna e externa apresenta a justaposição dos adjetivos i $\pi \varepsilon \rho \varphi i ́ \alpha \lambda o \varsigma$ (“soberbos”) e $\dot{\alpha} \theta \dot{\varepsilon} \mu 1 \sigma \tau o \varsigma$ (“desregrados”), ambos utilizados para caracterizar também os

33 Interessante notar que Odisseu, almejando auxílio para seu retorno a Ítaca, narra sua viagem de retorno aos feácios e, quando disfarçado de mendigo em Ítaca, narra um episódio acerca de um manto almejando receber um manto do porqueiro Eumeu (14.462-506). 


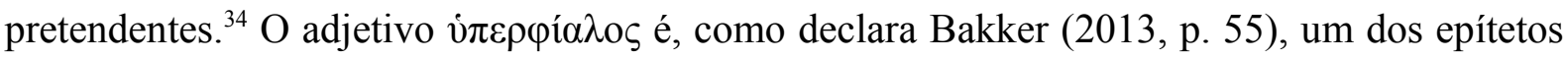
"quintessenciais" dos pretendentes e, ao ser usado para caracterizar os ciclopes na "descrição programática" realizada por Odisseu no início do episódio, enquadra-o como um todo. ${ }^{35} \mathrm{De}$ modo semelhante, a característica expressa por $\dot{\alpha} \theta \varepsilon \dot{\mu} \mu \iota \tau$ o e sua variante $\dot{\alpha} \theta \varepsilon \mu i ́ \sigma \tau \imath \varsigma \varsigma$, usada na

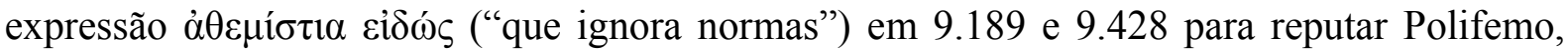
também se verifica em 20.287 qualificando Ctesipo, um dos pretendentes que, no momento em que é assim taxado, perverte as regras de hospitalidade atirando contra Odisseu-mendigo um pé de vaca que o pretendente chama de " $\delta \tilde{\omega} \xi \varepsilon$ cíviov" ("presente de hospitalidade"). Bakker

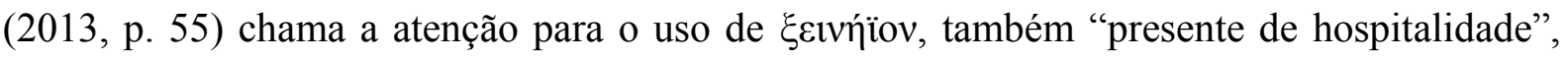
por Polifemo para designar o "direito" de Odisseu ser devorado por último como retribuição pelo vinho. Observe-se que, no canto 17 (v. 363), Atena pede a Odisseu, disfarçado de

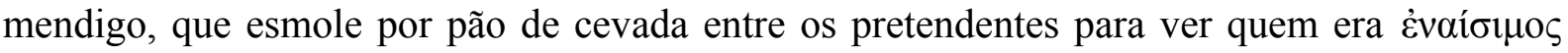

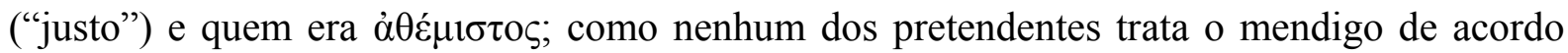
com as regras de hospitalidade, como o ciclope Polifemo também não o tratou, todos podem

34 O adjetivo vं $\varepsilon \varepsilon \rho \varphi i ́ \alpha \lambda o \zeta$ ocorre na Ilíada 3.106 em fala de Menelau acerca dos filhos de Príamo; em $5.881 \mathrm{em}$ fala de Ares a Zeus acerca de Diomedes; em 13.621 em fala de Menelau acerca dos troianos; em $15.94 \mathrm{em}$

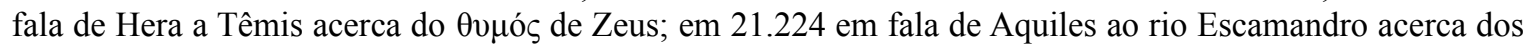
troianos; em 21.414 em fala de Palas Atena a Ares acerca dos troianos; em 21.459 em fala de Posêidon a Apolo acerca dos troianos; em 23.611 em fala de Menelau a Antíloco negando que seu coração seja

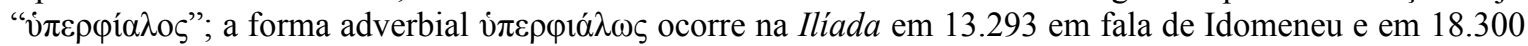
em fala de Heitor a Polidamante significando descomedimento e excesso. Na Odisseia, o termo ocorre predominantemente na caracterização dos pretendentes: em 1.134 em enunciação de narrador; em 1.227 (forma adverbial) em fala de Atenas-Mente a Telêmaco; em 2.310 em fala de Telêmaco a Antínoo; em 3.315 em fala de Nestor a Telêmaco; 4.790, em enunciação de narrador, primeira vez em que aparece a fórmula $\mu \nu \eta \sigma \tau \tilde{\eta} \rho \varepsilon \varsigma$ vं $\pi \varepsilon \rho \varphi \dot{\alpha} \alpha \lambda o l ;$ em 11.116 na fala de Tirésias a Odisseu; em 13.373 e 14.27 em enunciação do

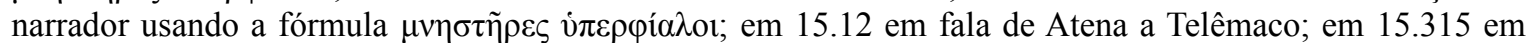

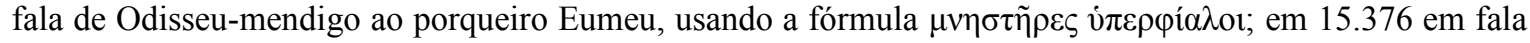

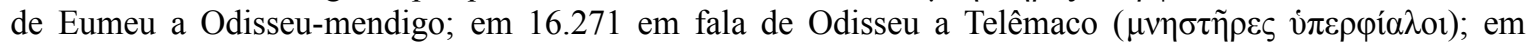
17.481 (forma adverbial) acerca dos pretendentes terem se indignado com o discurso de Antínoo; em 18.71 (forma adverbial) acerca do modo como se irritaram os pretendentes ao ver o corpo forte de Odisseumendigo; 18.167 em fala de Penélope a Eurínome ( $\mu \nu \eta \sigma \tau \tilde{\eta} \rho \varepsilon \varsigma$ vं $\pi \varepsilon \rho \varphi \dot{\alpha} \alpha \lambda$ ot); 20.12 e 20.291 em enunciação

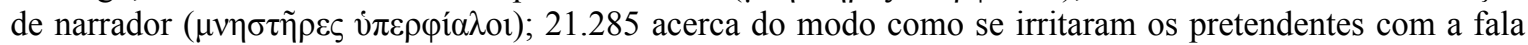
de Odisseu-mendigo; 21.289 em fala de Antínoo a Odisseu mendigo acerca dos demais pretendentes; 23.356

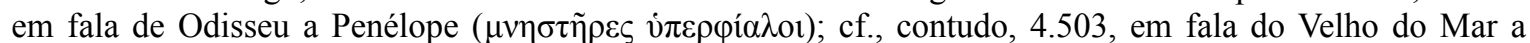
Menelau acerca do ह̈́noৎ de Ájax, que o levou à ruína; 4.663, em fala de Antínoo aos pretendentes a respeito da viagem de Telêmaco e 4.774 acerca dos discursos ( $\mu$ v́ $\theta$ o ) dos pretendentes; 6.274, em fala de Nausícaa a Odisseu acerca dos feácios; 16.346 (forma adverbial) em fala do pretendente Eurímaco acerca da viagem de Telêmaco. Como é possível perceber, vं $\pi \varepsilon \rho \varphi i ́ \alpha \lambda o \varsigma$ e $\dot{\pi} \varepsilon \rho \varphi \iota \dot{\alpha} \lambda \omega \varsigma$ se encontram predominantemente em enunciação de personagem, o que está em concordância com o estilo subjetivo dos apologoi, como demonstrado por De Jong (1992). Também de acordo com De Jong (2004 [2001]) o uso de termos característicos de enunciação de personagem feito pelo narrador contribui para o aumento do $\pi \dot{a} \theta 0 \varsigma$.

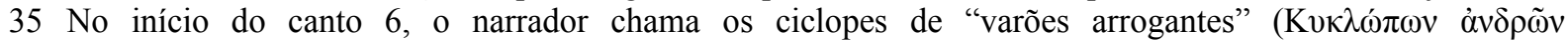

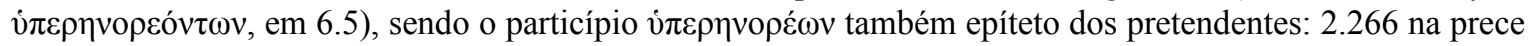
de Telêmaco a Atena; 4.766 na prece de Penélope a Atena; 17.581 em fala de Eumeu a Penélope; e $23.31 \mathrm{em}$ fala de Euricleia a Penélope. Ele é usado frequentemente pelo narrador no verso formular que anuncia a fala de um ou mais dos pretendentes: 2.324; 2.331; 4.769; 17.482; 20.375; 21.361 e 21.401. Cf. também Ilíada 4.176 em que é usado para os troianos na fala de Agamêmnon a Menelau e 13.258 na fala de Meríones acerca de Deífobo. 
ser considerados $\alpha \dot{\theta \varepsilon ́} \mu 1 \sigma \tau o{ }^{36}$

Outros elementos reforçam essa associação entre os ciclopes e os pretendentes, como a atitude em relação a seus respectivos sustentos. A descrição geral e inicial dos ciclopes por parte de Odisseu já foi apontada como semelhante à Era de Ouro, presente em Trabalhos e Dias (v. 109-118) de Hesíodo (cf., por exemplo, Hernández, 2000, p. 346 e ss.; Kirk, 1970), sendo a abundância de frutos providos sem o esforço do trabalho o elemento comum a ambos. ${ }^{37}$ Por confiarem nos deuses, os ciclopes não usam suas mãos para plantar nem para arar, porém tudo germina graças à chuva de Zeus: trigo, cevada e videiras que dão vinho. Embora os pretendentes não vivam, como os ciclopes, em território que parece pertencer à Era de Ouro de Hesíodo, eles também não se dedicam aos cuidados com a terra para que possam saciar sua fome, mas devoram os bens que lhes são providos pela casa de Odisseu, que, como é possível perceber em 19.112, são muito semelhantes aos produzidos espontaneamente na terra dos ciclopes: trigo, cevada e árvores carregadas de frutos. Desse modo, a situação dos pretendentes em Ítaca é associada por Bakker (2013, p. 56-57) a uma Era de Ouro "artificial" e "pervertida", na qual se tem a ilusão de que tudo, principalmente a carne, está disponível sem esforço. ${ }^{38}$

Não obstante a indicação de Odisseu de que os ciclopes não cultivam a terra, que, como nota Scodel (2005, p. 150), é uma informação que Odisseu não tinha como saber, pois não teve tempo de examinar os campos da ilha, a narrativa de sua permanência na gruta de Polifemo mostra que o ciclope trabalha, e muito, para seu próprio sustento, como será visto a seguir.

\section{2.b) Polifemo e Odisseu}

A caracterização de Polifemo por Odisseu tem início com elementos do local que o ciclope habita (9.182-186), em uma técnica de "zooming-in", como se a descrição de sua habitação preparasse o público interno e externo para a apresentação da criatura (De Jong, 2004, [2001], p. 235): a caverna é alta e o muro de pedra que cerca cabras e ovelhas também o

36 O adjetivo á $\theta \varepsilon ́ \mu ı \sigma \tau o \zeta$, contudo, não é usado apenas em relação ao desrespeito às regras de hospitalidade. Vejam-se os usos gnômicos na fala de Nestor a Diomedes na Ilíada 9.53-79 e de Odisseu a Anfínomo na Odisseia 18.141.

37 A Era de Ouro também é associada à terra dos feácios por Dougherty (2001, p. 87 e ss), que eram vizinhos dos ciclopes (Odisseia 6.4-6) e compartilham Posêidon como ancestral comum. Contudo, no início do canto 6, é dito que o pai do rei Alcínoo, Nauveloz, dividiu as glebas quando assentou seu povo em Esquéria, indicando que os feácios, diferente dos ciclopes, trabalham a terra.

38 Essa ressonância entre ciclopes e pretendentes é bem explorada por Bakker (2013, p. 53 e ss.), que dedica um capítulo inteiro para as semelhanças estruturais e temáticas entre esses dois conjuntos e, por fim, como Odisseu se torna semelhante a Polifemo ao rechaçar com violência os pretendentes. 
é, preconizando a enormidade de Polifemo, que será caracterizado duas vezes pelo adjetivo $\pi \varepsilon \lambda \omega ́ \rho ı \varsigma s ~(9.187,190)$ e referido duas vezes pelo substantivo $\pi \varepsilon ́ \lambda \omega \rho$ (9.257 e 9.428). O isolamento de sua caverna reflete diretamente seu isolamento em relação aos demais ciclopes (9.188-189) e a menção à ả $\theta \varepsilon \mu \iota \tau$ í́ (“falta de normas”, 9.189) parece não apenas recuperar essa característica atribuída por Odisseu ao povo ao qual Polifemo pertence (9.106), como também apontar que ele é à $\theta \varepsilon ́ \mu 1 \sigma \tau o \varsigma$ mesmo em relação aos outros ciclopes, já que vive isolado dos demais e nem mesmo um núcleo familiar ele tem para governar. Odisseu o compara a um pico isolado dentre as montanhas (9.190-191), o que conjuga ambos, a dimensão descomunal e o isolamento de Polifemo, e o relaciona diretamente a um elemento da natureza (cf. Kirk, 1970, p. 166).

Contudo, essa descrição inicial de Polifemo por parte de Odisseu também o caracteriza como ỏví ("homem”, "varão", 9.187). Observe-se que a raça dos ciclopes foi

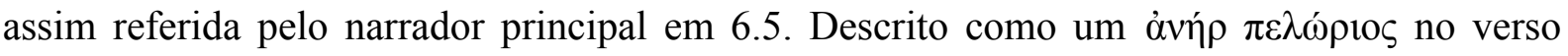
187, em que, como visto no capítulo $2, \pi \varepsilon \lambda \omega ́ p ı \varsigma \varsigma$ é um adjetivo que está relacionado à ideia de enormidade e de extraordinariedade, Polifemo exibe uma dimensão montanhesca, explicitada por Odisseu ao compará-lo com o pico de um monte. Em 9.190, Odisseu repete o adjetivo $\pi \varepsilon \lambda \omega ́ p ı$, que agora está qualificando o substantivo $\theta \alpha \tilde{\mu} \mu \alpha$ ("maravilha”), enfatizando o aspecto extraordinário de Polifemo em toda a sua enormidade. E é essa característica de

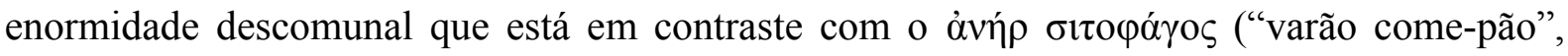
9.191), expressão utilizada por Odisseu ao declarar que Polifemo não parecia um "varão

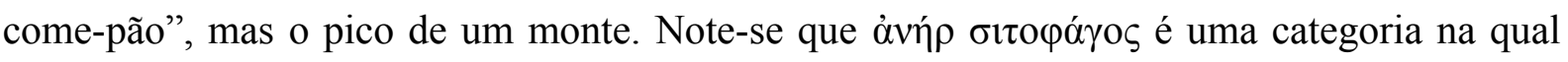
Odisseu se inclui, pois em 8.222 ele declara aos feácios que não há "varões comem-pão" que se equiparem a ele. Ironicamente, são "varões comem-pão" que ele espera encontrar na terra dos lotófagos (9.89), que, por sua vez, não comem pão, mas flor de lótus, e também na ilha dos lestrigões (10.101), que, como Polifemo, são caracterizados pela enormidade (10.112-113 e 10.120) e devoram alguns dos companheiros de Odisseu.

Ao adentrar a caverna de Polifemo e não encontrar ninguém em seu interior, Odisseu e seus doze companheiros deparam com queijos em cestos, cabritos e carneiros bem organizados, além de recipientes confeccionados ( $\varepsilon \varepsilon \tau \gamma \mu \varepsilon ́ v \alpha, 9.223$ ) para serem usados na ordenha. A descrição do interior da caverna de Polifemo e de suas atividades o colocam dentro de um modo de vida pastoril e de subsistência, conforme apontado anteriormente: Polifemo, após retornar à sua gruta trazendo um grande feixe de lenha com a finalidade de preparar o jantar, toca o rebanho de ovelhas para dentro, apartando os machos, que ele deixa

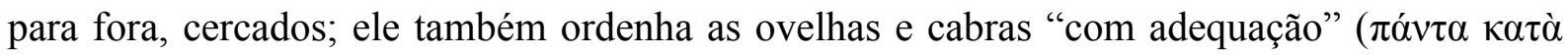




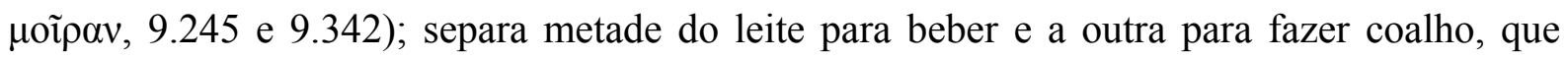
coloca em cestos trançados, ou seja, manufaturados; enfim, Polifemo, como o próprio Odisseu

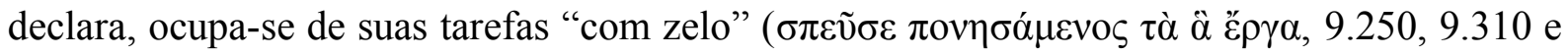
9.343).

Essa descrição do interior da caverna e das atividades de Polifemo não condiz com a pecha de selvagem. Como observado por Valgimigli (apud Pucci, 1998, p. 119, n. 9), "Esse imenso gigante, vislumbrado de modo intermitente em sua caverna, agachado para ordenhar seu rebanho e para tocar o cordeiro até sua mãe... não é tão diferente de um pastor comum; ele é um Eumeu agigantado, mas ainda um tipo de Eumeu.". ${ }^{39}$ Ademais, ao se introduzirem na gruta do ciclope, Odisseu e seus companheiros são os que transgridem a norma da hospitalidade, comendo do queijo e fazendo sacrifícios no interior da caverna sem a permissão de seu anfitrião, um tipo de abuso que o próprio Odisseu terá de combater quando retornar à Ítaca.

Ao notar a presença de estranhos em sua caverna, Polifemo se mostra provido de fala. É notável que os quatro versos que compõem a fala de Polifemo (9.252-255) sejam idênticos àqueles proferidos por Nestor (3.71-74) a Telêmaco e a Atena travestida de Mentor durante a visita a Pilos. Pucci (1998, p.117) considera essa repetição significativa, pois ela tem o efeito de indicar que Polifemo é familiar às "regras de uma sociedade educada". Observe-se a forma comovente com que Polifemo se dirige a um de seus carneiros, aquele que leva Odisseu, desejando que fosse capaz de pensar e ter linguagem como ele próprio a fim de que pudesse falar onde Odisseu se escondia (9.456-457). ${ }^{40}$ Glenn (1971) já tinha indicado que o poeta da Odisseia se utiliza de recursos ausentes em outras versões da suposta narrativa folclórica para, por um lado, ampliar a esperteza de Odisseu e, por outro, aumentar a simpatia por Polifemo.

Todavia, quando Polifemo dirige a palavra a Odisseu e seus companheiros, o herói

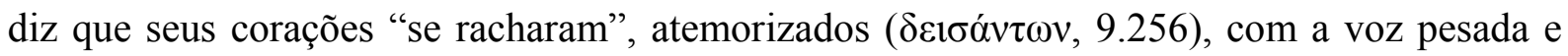

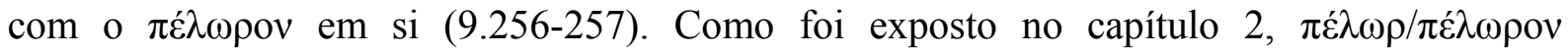
expressam uma enormidade fora do comum, uma característica que pode ou não infligir medo, conquanto o elemento do extraordinário provoque um sentimento mais geral de espanto

39 Valgimigli (apud Pucci, 1998, p. 119, n. 9): “This immense giant, glimpsed intermittently in his cave stooping to milk his flocks and to prod the lamb toward its mother... is not so different from an ordinary herdsman; he is an oversized Eumaeus, but still a Euameus of sorts.".

40 Cf. Nieto Hernández (2000, p. 354): "But if his exceptional size and his one eye (which is never actually specified as being single) make him rather strange, the Cyclops is, at the same time, humanized by his mastery of language or logos, which differentiates him from animals. So too, the affectionate way in which Polyphemus speaks to the sheep that carries Odysseus (not a motif in the folktales: cf. Glenn 1971, 171) brings him nearer to being human. He is not just a monster or a savage, not even a noble savage; he is deeply disconcerting and ambiguous, like the Golden Age and like Cronus himself. [...]". 
e de maravilhamento. No caso de Polifemo, o medo, expresso novamente em 9.396, é o sentimento dominante de Odisseu e de seus companheiros. A enormidade colossal de Polifemo, diante da qual Odisseu e sua tropa se aterrorizam, somada à atitude não temente a Zeus do ciclope, significando que este não partilha das instituições sociais presididas pelo deus, apresentam-se como ameaças iminentes à integridade física de Odisseu e de seus companheiros, expondo a fragilidade destes, que, ao fim e ao cabo, terão seis dos seus devorados pelo filho de Posêidon (9.287-298).

Certamente, a antropofagia ou o canibalismo de Polifemo é a principal razão para que ele, e por extensão a raça dos ciclopes, seja considerado um "selvagem” (ärpıs, cf. 2.19). Nieto-Hernández (2000, p. 350, n. 12) aponta a inadequação do termo "canibalismo" para designar o fato de Polifemo devorar os companheiros de Odisseu, pois "canibalismo" é definido pelo ato de se alimentar daqueles da própria espécie. Considerando-se os ciclopes uma raça diferente da dos humanos, Polifemo teria praticado antropofagia e não canibalismo. Contudo, tanto os ciclopes como Polifemo são referidos pelo termo " $\alpha \dot{v} \eta$ ", o que os coloca dentro de uma categoria comum com Odisseu e seus companheiros, e Polifemo é chamado

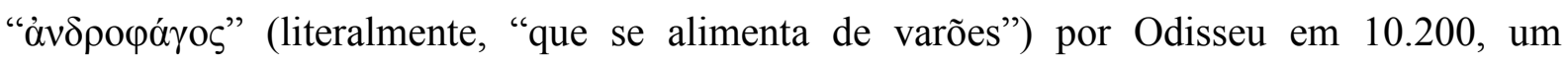
adjetivo composto de $\alpha v \eta ́ \rho$, que encontra apenas essa ocorrência na poesia hexamétrica arcaica, constituindo-se em um hapax. Como nota Versnel: ${ }^{41}$

\begin{abstract}
Os ciclopes homéricos, especialmente na pessoa de Polifemo, são retratados como antigregos e anti-humanos: eles não têm mercado, mecanismos de decisão política, conselhos, formas sociais de organização, barcos, religião. Eles são canibais bestiais e, mesmo quando não conseguem pôr as mãos em gregos que são ocasionalmente levados pela maré às suas paragens, eles permanecem "comedores de carne e bebedores de leite". Certamente, essas são matéria-prima para a construção da alteridade. Do mesmo modo, deve se ter em mente que os Ciclopes não são bestas, mas apenas compartilham um número de características assustadoras com bestas. No mais, eles exibem um meio de vida reconhecivelmente humano, pois estão equipados com pernas, braços, orelhas, tudo de tamanho agigantado, é verdade, mas sob a forma humana; $[\ldots]$
\end{abstract}

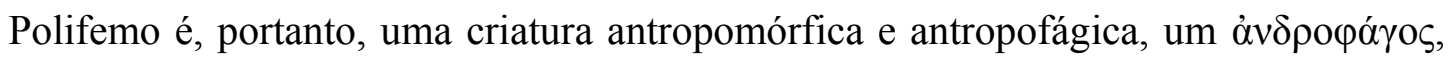
um "comedor de carne e bebedor de leite", na expressão utilizada por Versnel entre aspas, que faz referência à utilizada por Heródoto em suas Histórias para caracterizar uma parte dos

41 Versnel (2011, p. 386): “The Homeric Cyclopes, especially in the person of Polyphemos, are portrayed as anti-Greeks and anti-human: they do not know markets, political decision making, councils, social forms of organization, ships, religion. They are bestial cannibals, and even when they cannot lay hands on an occasional Greek washed ashore they still remain "eaters of flesh and drinkers of milk." Clearly, these are raw materials for the construction of otherness. All the same it is to be borne in mind that Cyclopes are no beasts but only share a number of frightening features with beasts. For the rest, they boast a fairly recognizable humanlike livelihood, for which they are equipped with legs, arms, ears, all of gigantic seize it is true, but of human form; [...]". 
citas, nome atribuído de modo genérico aos habitantes da região ao norte do Mar Negro, onde atualmente se localiza a Ucrânia. Ao caracterizar a parte dos citas que vivia na região mais ao

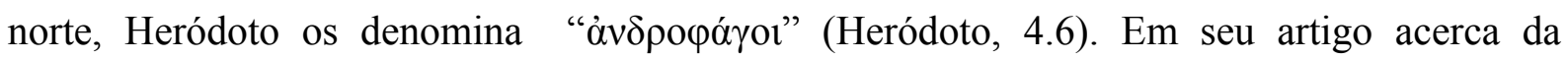
construção ideológica do pastoreio e do nomadismo, duas noções que não estão separadas em Heródoto, como opostas à noção de civilidade, Shaw (1982/1983, p. 12-13) explora a caracterização desses citas feita por Heródoto: ${ }^{42}$

[...] Eles são o tipo humano mais degradado da Cítia e a explicação de seu barbarismo, simbolizado de modo mais vívido em seu hábito de comer carne humana, é a ligação causal entre seus costumes e seu tipo de sociedade: "Os Androphagoi têm os costumes mais selvagens de todos os homens, não praticando qualquer forma de justiça ou não fazendo uso de quaisquer leis,... pois eles são

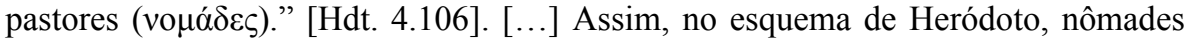
são definidos por características que estão no polo oposto da civilização (ou seja, sem leis ou sistema de justiça no caso dos Androphagoi). $\mathrm{O}$ nômade não poderia ter

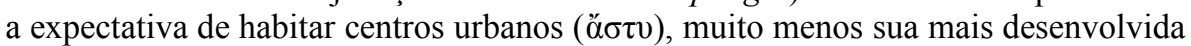
forma entre os homens civilizados, a pólis grega. Portanto, por definição o nômade é distanciado da civilização (cf. o latim civis, civitas), já que não pode formar sua instituição central e definidora, a cidade política. Acima de tudo, entretanto, é seu modo de consumo dos frutos de seu trabalho que marca o nômade. Ele é visto como

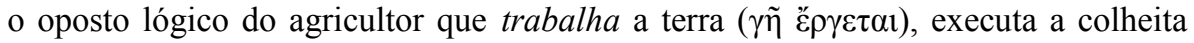

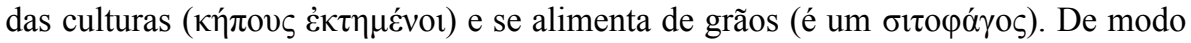
oposto, o nômade cita é caracterizado por Heródoto, como um "comedor de carne (geralmente carne crua)" e como um "bebedor de leite" [Hdt. 3.99.1].

Nomadismo à parte, que, embora se sobreponha ao pastoreio em Heródoto, não é uma característica atribuída aos ciclopes, a descrição do modo de vida dos cita do extremo norte por parte de Heródoto apresenta bastante em comum com a caracterização de Polifemo na Odisseia, o que talvez possa indicar sua inserção mais em um tópos de construção de alteridade em relação à organização social urbana do que uma percepção de Polifemo como um monstro canibal. Por outro lado, essa dicotomia entre pastores canibais e civilidade como sinônimo de organização social urbana não encontra validade para os lestrigões, que vivem em uma ǒ́ $\sigma v$ e devoram alguns dos companheiros de Odisseu, conforme será visto adiante.

A descrição gráfica da sanguinolenta cena em que Polifemo subitamente apanha os

42 Shaw (1982/1983, p. 12-13): "They are the most degraded human type in Skythia and the explanation for their barbarity, symbolized most vividly in their eating of human flesh, is the causal link between their customs and their type of society: 'The Androphagoi have the mos savage customs of all men, not practicing

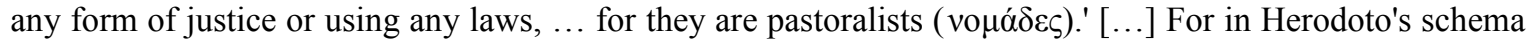
nomads are defined by characteristics which are the polar opposites of civilization (e.g. no laws or system of justice in the case of the Androphagoi). The nomad could no hope to attain to the habitation of urban centres

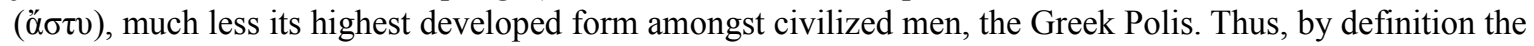
nomad is removed from civilization (cf. the Latin civis, civitas) since he cannot form its central defining institution, the political city. Above all, however, it is his mode of consumption of the fruits of his labour that mark out the nomad. He is seen as the logcal opposite of the farmer who works the land ( $\gamma \tilde{\eta}$ है $\rho \gamma \varepsilon \tau \alpha \mathrm{l})$, harvest

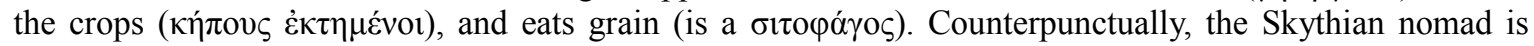
characterized by Herodotos as an 'eater of meat' (often raw flesh) and a 'drinker of milk'." 
companheiros de Odisseu e os esmaga, com os miolos escorrendo pelo chão, para depois cortá-los em pedaços e aprontar com eles o jantar, devorando tudo, incluindo as vísceras e os ossos, faz lembrar cenas cinematográficas de filmes do gênero "gore". Diante de tal espetáculo, Odisseu declara que seu ânimo foi detido pela ả $\mu \eta \chi \alpha v i ́ \eta$ (“falta de recursos”, "impotência”), um hapax na poesia homérica, ele, que tem em $\pi \mathrm{o} \lambda v \mu \eta \dot{\chi} \chi \alpha v o \varsigma$ ("de muitos recursos") um de seus epítetos (cf. Ilíada 2.173, 4.358 etc.; Odisseia 1.205, 5.203 etc.). Entretanto, em face a um ỏvท́ $\pi \varepsilon \lambda \omega ́ \rho ı v$, a quem é inútil apelar por respeito às instituições divinas, Odisseu não terá outra solução além de contar com sua própria esperteza e com a ajuda dos companheiros.

Há, contudo, uma instituição divina que Polifemo e os ciclopes conhecem: a da adivinhação (9.507-516). Quando Odisseu declara seu verdadeiro nome (9.502-505), Polifemo se dá conta de que o vaticínio do adivinho Telemo, que tinha vivido entre os ciclopes, tornou-se realidade. A profecia dizia que Polifemo perderia a visão pelas mãos de Odisseu. Como será visto a partir de agora, $\varphi \eta ́ \mu \eta$, presente no nome de Polifemo e entendida como "uma enunciação com propriedades proféticas das quais o falante não tem consciência" (Bakker, 2002, p. 139), é um elemento crucial para a compreensão do papel de Polifemo na aquisição do kleos odisseico de Odisseu, que ele só obtém com suas errâncias pelo mar e cuja causa fundamental é uma $\varphi \eta ́ \mu \eta$ proferida por Polifemo. ${ }^{43}$

Como dito anteriormente, o nome Polifemo é composto do prefixo $\pi \mathrm{o} \lambda v$ - com uma forma de $\varphi \eta ́ \mu \eta$, derivada de $\varphi \eta$-, uma das raízes que designam fala. Na Odisseia, o adjetivo $\pi \circ \lambda v ́ \varphi \eta \mu$ ○ qualifica a ágora ou assembleia (2.150) convocada por Telêmaco em Ítaca como “cheia de vozes"; ele é, ainda, usado por Odisseu em remissão a Fêmio (22.376), o aedo que canta para os pretendentes em Ítaca, significando "aquele que conhece muitas canções". ${ }^{44}$ LSJ oferece uma terceira acepção, posterior a Homero, de "famoso", "bastante falado". Contudo, o termo para "fama" em Homero não é $\varphi \eta ́ \mu \eta$, mas kleos. No início do canto 2, quando Telêmaco convoca a assembleia para anunciar que partirá em busca de notícias de seu pai, Egípcio, que ainda tinha um de seus filhos na companhia de Odisseu, profere um discurso elogiando a convocação da assembleia, já que não havia uma desde a partida de Odisseu para Troia (2.25-34). Além de elogiar a iniciativa, Egípcio roga que Zeus conceda o que deseja aquele que a convocou. Esse pequeno discurso, referido como $\varphi \eta \dot{\mu \eta}$ pelo narrador, agrada Telêmaco, que toma a palavra na assembleia. Ao final da troca de discursos entre Telêmaco e o pretendente Antínoo, o filho de Odisseu roga que Zeus conceda retribuição para a atitude

43 A leitura que segue é amplamente baseada na leitura de Bakker (2002). Para uma excelente apreciação dos

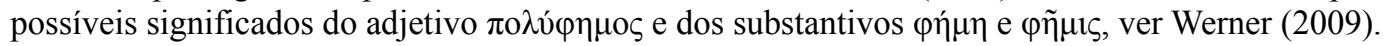

44 Esses dois significados são glosados por Cunliffe no verbete $\pi \circ \lambda \dot{\varphi} \varphi \eta \mu \circ \varsigma$. 
dos pretendentes (9.143-145). Nesse momento, Zeus envia um portento. Bakker (2002), investigando o significado de $\varphi \eta ́ \mu \eta$ e do nome Polifemo, faz um apontamento crucial para a compreensão de ambos: ${ }^{45}$

\begin{abstract}
O que significa phêmê? Egípcio termina seu discurso com um desejo que se tornará verdade, como leitores da Odisseia sabem. Zeus de fato cumprirá a "boa coisa" que Telêmaco "deseja em sua mente". A enunciação de Egípcio, assim, adquire em retrospectiva a força de uma profecia da qual ele próprio não tem consciência. Além disso, as duas águias são também um sinal apontando para o futuro como ainda não compreendido por todos. Um sentido semelhante se aplica à única outra enunciação na Odisseia que é explicitamente chamada phêmê (não há ocorrências da palavra na Ilíada). Exatamente antes do massacre final dos pretendentes, Odisseu roga a Zeus, pedindo por sinais concretos da presença e da benevolência do deus [...].
\end{abstract}

Bakker se refere à passagem em 20.100-101 na qual Odisseu pede a Zeus que alguém de sua casa pronuncie ( $\varphi \alpha ́ \sigma \theta \omega)$ uma $\varphi \eta ́ \mu \eta$ e que, fora dela, apareça um prodígio ( $\tau \dot{\varepsilon} \rho \alpha \varsigma)$ de Zeus para confirmá-la. O deus, que ouve as palavras de Odisseu, troveja do Olimpo e, da casa do herói, uma moleira profere uma $\varphi \eta ́ \mu \eta$ para Odisseu (9.105), também designada como " $\sigma \tilde{\eta} \mu \alpha "$. A moleira reconhece o trovão em um céu sem nuvens como um prodígio ( $\tau \dot{\varepsilon} \rho \alpha \varsigma$ )

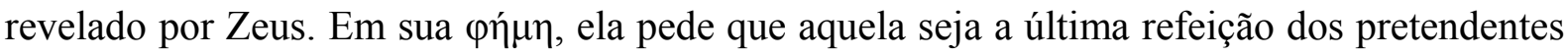
na casa de seu senhor (9.112-119). Bakker (2002, p. 139) nota que em ambas as vezes $\varphi \eta \dot{\mu \eta}$ está relacionada a eventos futuros e ambas estão acompanhadas por um portento de Zeus. Assim, ele conclui, $\varphi \eta ́ \mu \eta$, na Odisseia, designa "uma enunciação com propriedades proféticas das quais o falante não tem consciência". ${ }^{46}$

Em seu artigo, Bakker revela uma distinção entre a $\varphi \eta ́ \mu \eta$ e a $\varphi \tilde{\eta} \mu ı$ na Odisseia, um termo que compartilha a mesma raiz $\varphi \eta$-, conquanto não pareça haver tal distinção na poesia

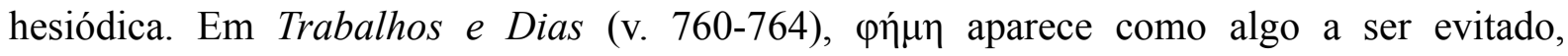
caracterizada como uma coisa ruim, muito fácil de ser erigida, muito difícil de ser suportada e de ser posta de lado, porque ela não morre se muitos a propagarem. Em oposição ao kleos, a $\varphi \eta ́ \mu \eta$ em Hesíodo é, como nota Bakker, $\varphi \tilde{\eta} \mu ı \varsigma$ na Odisseia. Ele exemplifica a distinção entre kleos e $\varphi \tilde{\eta} \mu 1 \varsigma$ com o discurso de Agamêmnon a Odisseu no Hades que contrasta Penélope, a esposa exemplar cujo kleos de sua virtude nunca perecerá, e a $\varphi \tilde{\eta} \mu ı \varsigma_{\text {de }}$ sua esposa,

45 Bakker (2002, p. 137-138): "What does phêmê mean? Aiguptios ends his speech with a wish that will come true, as readers of the Odyssey know. Zeus will indeed accomplish the 'good thing' that Telemachos 'wishes in his mind.' Aiguptios' utterance só acquires with hindsight the force of a prophecy of which he himself is unaware. Moreover, the two eagles are also a sign pointing to the future, as yet not understood by everyone. A similar sense applies to the only other utterance in the Odyssey that is explicitly called a pheme (there are no occurrences of the word in the Iliad). Just before the final massacre of the Suitors, Odysseus prays to Zeus, asking for concrete signs of the god's presence and goodwill [...]."

46 Bakker (2002, p. 139): "Thus phêmê designates, in the Odyssey, an utterance with prophetic properties of which the speaker is unaware. [...]". 
Clitemnestra, que se alastra para todas as mulheres. Como nota Bakker (2002, p. 141-142), “[...] [d]a boa esposa se ouve, da má se fala, e a $\varphi \tilde{\eta} \mu ı$ que se liga a ela está para além do controlável: ela toca todas as mulheres, inclusive as inocentes". ${ }^{47}$

Polifemo, assim, de acordo com Bakker (2002, p. 143), partilha do campo semântico no qual a raiz verbal $\varphi \eta$ - pode ser interpretada tanto como uma revelação profética quanto como algo que é melhor que não seja dito, e $\pi \mathrm{o} \lambda v$ - intensifica ambos os sentidos.

Quando Odisseu revela seu verdadeiro nome ao ciclope, evocando seu kleos na Ilíada pelo epíteto “arrasa-urbe” ( $\pi \tau \mathrm{o} \lambda \iota \pi$ ó $\theta$ เov, v. 505), tal revelação permitirá que o ciclope não só recorde a profecia de Telemo, referida como $\pi \alpha \lambda \alpha i ́ \varphi \alpha \tau \alpha \theta \dot{\varepsilon} \sigma \varphi \alpha \theta \alpha$ (9.507), ambos os termos apresentando a raiz $\varphi \eta$-, mas que rogue a seu pai pedindo que ou Odisseu não volte para casa ou que seu retorno seja retardado, uma espécie de $\varphi \eta ́ \mu \eta$ que transforma o kleos de Odisseu na Ilíada em $\varphi \tilde{\eta} \mu \iota \varsigma$, uma notoriedade indesejável: "[...] De um pedido furioso a seu pai imortal, a enunciação de Polifemo se transforma em um desejo", e como os desejos de Egípcio e da moleira em Ítaca, o de Polifemo também terá "uma força profética da qual o falante não tem consciência". ${ }^{48}$

Como é possível perceber das relações estabelecidas por Bakker (2002), até mesmo Polifemo, aquele que talvez possa ser considerado o "monstro" por excelência pelas leituras modernas das narrativas mitológicas da Antiguidade, sendo um $\pi \varepsilon ́ \lambda \omega \rho$ muita- $\varphi \eta ́ \mu \eta$, está, e muito, ligado ao campo semântico da divinação.

Todavia, a figura de Polifemo pode revelar outro "sinal não compreendido por todos" (Bakker, 2002, p. 137-138). Newton (1983) nota como Odisseu ao fim do canto 17 se torna ele mesmo uma espécie metafórica de Polifemo: ${ }^{49}$

ele retorna, como um homem pobre, a sua casa e a encontra ocupada por hóspedes não convidados que devoram seu gado e que acumulam abuso verbal e físico contra ele. Como Polifemo, Odisseu sofre a dor e a humilhação isolado de seus amigos e mesmo de seu animal de estimação. Ao transformar o palácio de Ítaca em uma

47 Bakker também sugere que essa noção de "má fama" expressa por $\varphi \tilde{\eta} \mu 1 \zeta$ elucida o nome do aedo Fêmio

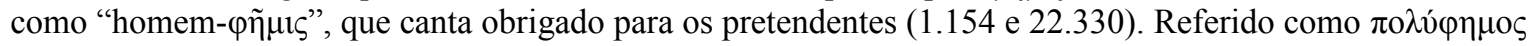

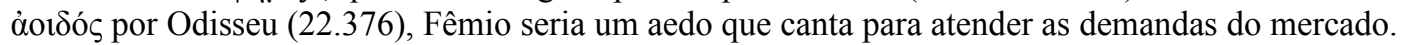

48 Bakker (2002, p. 147-148): “[...] From an angry request to his immortal father, Polyphemos' utterance turns into a wish. The confident imperative dos $m \hat{e}$ 'give that not' turns into the wishing optatives that we have already seen uttered by Aiguptios and the slave woman in Odysseus' house: wishes with a prophetic force of which the speaker is unaware. [...]".

49 Newton (1983, p. 142): “[...] Odysseus becomes himself a metaphorical Cyclops: he returns, a poor man, to his home and finds it occupied by uninvited guests who have been devouring his livestock and who heap verbal and physical abuse upon him. Like Polyphemus, Odysseus suffers the pain and humiliation in isolation from his friends and even from his pet animal. In making the Ithacan palace a Cyclopean cave, Homer sets the stage, emotionally and ethically, for the slaughter of the suitors. Odysseus has paid for his folly with Polyphemus by wandering the seas for ten years. Now that the suitors have committed the same crime, their punishment cannot be far off.". 
caverna ciclópica, Homero prepara o palco, emocional e eticamente, para o massacre dos pretendentes. Odisseu pagou por sua insensatez contra Polifemo ao vagar pelo mar por dez anos. Agora que os pretendentes têm cometido o mesmo crime, sua punição não pode estar muito longe.

Polifemo, $\pi \varepsilon ́ \lambda \omega \rho$ muita- $\varphi \eta ́ \mu \eta$ não é, portanto, apenas a causa das duras perambulações de Odisseu antes de conseguir completar seu nostos ("retorno"), é um indício profético, um prenúncio, do futuro do próprio Odisseu.

\subsection{LESTRIGõeS (10.80-134)}

Seguindo o padrão de dois episódios breves e um longo presente no canto 9, o canto 10 se inicia com a passagem de Odisseu pela ilha de Eolo (10.1-79), seguida da chegada à terra dos lestrigões (10.80-134) e, por fim, o episódio longo, que se constitui na permanência de Odisseu e os companheiros na ilha de Circe (10.135 e ss.). ${ }^{50}$ Diferente do que ocorre com a terra dos ciclopes, a passagem pela terra dos lestrigões é bastante breve e a descrição deles por parte de Odisseu que os torna "monstruosos" é sua enorme dimensão, característica que já foi atribuída aos ciclopes, somada ao fato de devorarem seis dos companheiros de Odisseu, atitude semelhante à realizada por Polifemo.

Inicialmente descritos por sua relação peculiar com o dia e a noite (10.80-86), os lestrigões recebem essa descrição por parte de Odisseu, embora, como nota Scodel (2005, p. 150-151), ele não tenha permanecido tempo suficiente para ter descoberto essa informação por si mesmo e não haja nada na narrativa que esclareça acerca da fonte de sua informação, fazendo parte das digressões introdutórias de Odisseu enquanto narrador secundário, que Scodel (2005) chama de "digressões etnográficas".

Diferente dos ciclopes, os lestrigões possuem um porto "glorioso" ( $\kappa \lambda v \tau o ́ v, 9.87$ ), descrito em oito versos (10.87-94), apesar de parecer não haver embarcações pertencentes aos lestrigões, já que Odisseu não as menciona. Note-se que os lestrigões lançam rochas contra as embarcações de Odisseu no porto sem receio de danificar as próprias (10.121-124). Como os ciclopes, contudo, não parece haver sinal de que os lestrigões praticavam a agricultura, já que Odisseu diz que lá não havia "campos arados por bois ou varões" (10.98).

Odisseu segue o procedimento para a investigação inicial da terra dos lestrigões que havia adotado para a terra dos lotófagos de enviar dois companheiros mais um arauto a fim de que investiguem "quem seriam os varões que sobre a terra comem pão" (9.89 e 10.101).

50 No canto 9, os dois episódios breves são o dos cícones e o dos lotófagos, e o longo é o dos ciclopes. Cf. Most (1989). 
Contudo, enquanto os lotófagos não se alimentam de pão, mas de flor de lótus, os lestrigões vão devorar alguns de seus companheiros. Observe-se que Odisseu usa a expressão similar àvท́ e compará-lo ao pico de uma montanha e, tanto no caso de Polifemo como no dos lestrigões, alguns dos companheiros de Odisseu acabam sendo devorados.

O ambiente urbano que os companheiros encontram na terra dos lestrigões, contudo, é muito distinto do habitat pastoril de Polifemo: note-se a reiterada repetição de ố $\tau$ ("cidade", $10.104,10.105,10.108$ e 10.118), a descrição da via plana que levava à cidade usada por

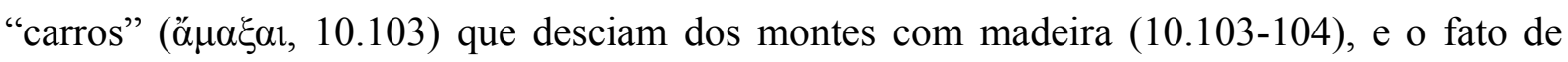
Antífates se encontrar na ágora (10.114). É na fonte, diante da cidade, que os companheiros

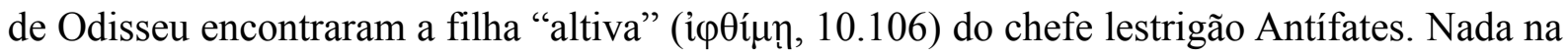
aparência dessa moça, entretanto, parece remeter inicialmente à enormidade dos lestrigões, e é somente quando chegam à casa de Antífates que encontram sua esposa "alta como o pico de um monte" (10.113), mesma analogia que Odisseu usou para Polifemo (9.191-192). ${ }^{51}$ Tanto os lestrigões como Polifemo são ditos serem dessemelhantes a varões (10.120 para os lestrigões e 9.190-191 para Polifemo) em relação à sua enormidade física especificamente, sendo os lestrigões comparados a "gigantes" (10.120). A enorme dimensão física também é medida pela capacidade tanto dos lestrigões como de Polifemo de levantarem rochas que são pesadas demais para os homens (9.240-243 e 10.121-122) ou atirarem penedos contra Odisseu e os companheiros. Diferente de Polifemo, contudo, os lestrigões atingem grande parte da frota de Odisseu, que consegue escapar com apenas um barco, aquele que ele tinha deixado à entrada do porto.

Apesar da marcada diferença entre o ambiente urbano dos lestrigões e o pastoril dos ciclopes, tanto Antífates quanto Polifemo devoram companheiros de Odisseu, que, em um caso, são comparados a cachorrinhos (9.289-290), e, em outro, com peixes em espetos (10.124). Segundo De Jong (2004 [2001], p. 254), essa comparação dos companheiros com peixes serve para ilustrar a diferença de tamanho entre presa e predador, mas também sublinha o aspecto horrível do canibalismo dos lestrigões que se alimentam de humanos como os humanos se alimentam de peixes. ${ }^{52}$ Note-se que o canibalismo ou antropofagia é praticada tanto no habitat pastoril de Polifemo como no ambiente citadino dos lestrigões e em ambos os casos não parece que os companheiros de Odisseu são devorados crus, como frequentemente se supõe (cf., por exemplo, Vidal-Naquet, 1970, p. 1286), mas há algum tipo de preparação da

51 Cf. Heubeck (em Heubeck e Hoekstra 1990, p. 49-50).

52 De Jong (2004 [2001], p. 254) também nota que o símile dos peixes é usado novamente na passagem em que Cila devora os companheiros de Odisseu (12.251-255). 
refeição, como indicam os versos 9.291 (“Após cortá-los em pedaços, aprontou o jantar",

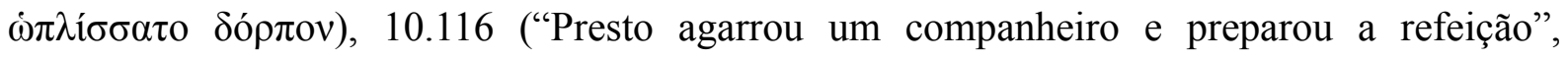

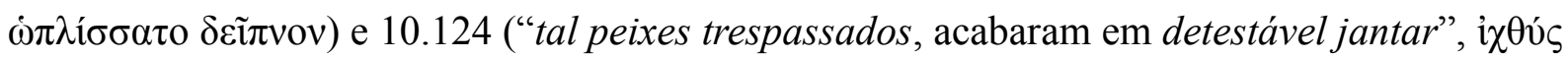

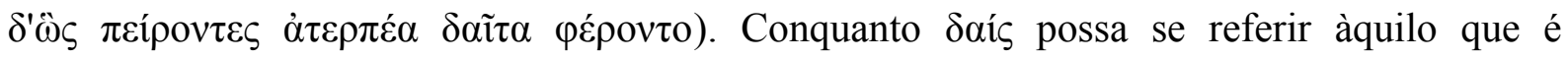
devorado por feras (cf. Ilíada 24.43) e $\delta \varepsilon i ̃ \pi v o v$ ao alimento dado a cavalos (Ilíada 2.383), o verbo ỏ $\pi \lambda i \zeta \omega$ na voz média envolve algum tipo de preparação.

Apesar da antropofagia e da enormidade dos lestrigões, os adjetivos í $\varphi$ $\theta \mu \mathrm{o} \varsigma$ ("altivo") e $\kappa \lambda v \tau$ ó ("glorioso"), epítetos de excelência, são usados com uma frequência de

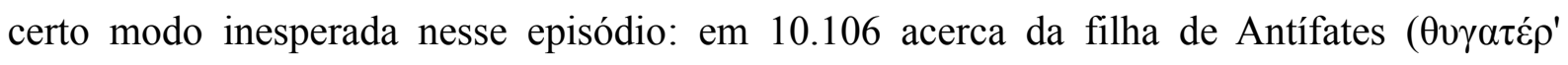

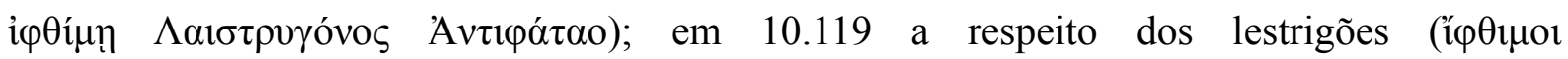

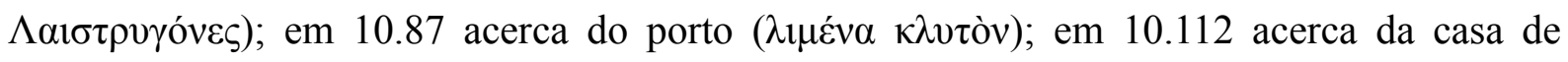

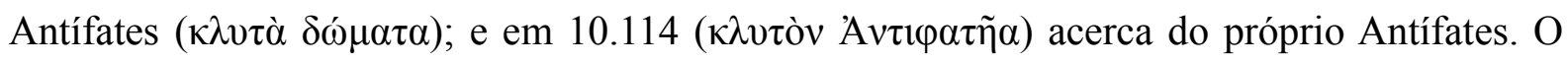
uso desses epítetos de excelência, somado ao ambiente urbano, torna a antropofagia dos lestrigões uma característica talvez mais surpreendente do que no caso de Polifemo. Ao colocar esse elemento em um ambiente urbano, diferente daquele pastoril do canto 9, o narrador principal não apenas trabalha com o elemento do inesperado em sua narrativa, como também sugere que a urbanidade ou "civilidade" não é garantia de hospitalidade. Os lestrigões, como predadores urbanos, não seriam mais "civilizados" que os ciclopes em relação às suas presas.

Heubeck (em Heubeck e Hoekstra, 1990, p. 47) consideram que o episódio dos lestrigões assume importância mais pela função do que pelo conteúdo da descrição dos lestrigões, que se organizam socialmente de modo bastante mundano. A função do episódio, porém, seria a de reduzir a frota de Odisseu de doze embarcações para apenas uma de modo que o status do herói também fosse reduzido de capitão de frota para capitão de apenas um barco. Em geral, tende-se nesta tese a não valorizar demais explicações mecanicistas, principalmente as do tipo que reduzem os episódios a uma função meramente pragmática dentro da narrativa, despindo-os daqueles elementos que os tornam cativantes e deleitam a público. Além disso, no proêmio da Odisseia, o poeta pede à Musa que cante acerca do varão que "de muitos homens viu urbes" (1.3), e, dada a grande repetição do caráter urbano do habitat dos lestrigões, sua cidade é certamente uma delas, junto com a dos cícones, a de Eolo e a dos feácios. 


\subsection{SIRENAS (12.39-56 E 12.158-200)}

A narrativa referente às Sirenas se divide em três partes: a primeira compõe a fala de Circe, reproduzida pelo narrador Odisseu (12.39-56), em que ela descreve ao herói os perigos que ele e os companheiros vão enfrentar até chegar à Trinácia, para onde o adivinho Tirésias disse que Odisseu deveria ir (canto 11); a segunda está presente na fala de Odisseu aos companheiros (12.158-164) em que ele os avisa do perigo representado pelas Sirenas e põe em prática o plano de Circe para que sobrevivam a elas; e a terceira está na narrativa da cena em que deparam com elas (12.165-200). Como será visto, não há uma descrição física das Sirenas nem por Circe, nem por Odisseu, sendo apenas caracterizadas por seu canto enfeitiçador. Sua descrição como seres híbridos, com cabeça de figura feminina e corpos de pássaros não se encontra na Odisseia, estando presente apenas em fontes escritas e iconográficas posteriores.

Após sua estadia no Hades para interpelar Tirésias, narrada no canto 11, Odisseu e os companheiros retornam à ilha de Circe e são avisados por ela dos perigos que ainda enfrentarão (12.37-110). A descrição que Circe faz das Sirenas se concentra na ameaça que elas representam em lugar de sua aparência ou de sua ascendência, sugerindo um estratagema para que Odisseu e os companheiros sobrevivam a elas. A primeira característica expressa por Circe é que as Sirenas enfeitiçam ( $\theta \dot{\lambda}$ yovoıv, 10.40 e 10.45) a todos que ouvirem seu canto, fazendo com que aquele que as ouve não mais retorne à casa (10.40-45). Embora não seja explicitado o "esquecimento do retorno", como no caso daquele que consome a flor de lótus (canto 9.82-105), o efeito do canto das Sirenas é semelhante por colocar em perigo o nostos de Odisseu.

Acerca de sua aparência é possível depreender muito pouco partindo-se apenas da Odisseia. Circe informa que elas ficam "sentadas no prado, tendo ao redor monte de putrefatos / ossos de varões e suas peles ressequidas" (12.45-46) e, pelo uso do dual em 12.52, é possível depreender que são duas. ${ }^{53}$ Por não remeter ao aspecto biforme com corpo de pássaro e cabeça de figura feminina, encontrado na iconografia, Buschor (apud Gresseth, 1970, p. 204) alegou que as Sirenas em Homero deviam ser antropomórficas, uma hipótese geralmente refutada fundamentalmente com base na iconografia bem como em descrições presentes em tragédias. Veja-se, por exemplo, o famoso Vaso das Sirenas, um stamnos ático de figuras vermelhas datado de c. 480-470 a.C. e que se encontra no British Museum

53 Nem se pode contar com a Teogonia, já que elas estão ausentes nesse poema. Veja-se, contudo, o fragmento do Catálogo das Mulheres MW Fr.150 v. 33 (Most 98, p. 172-173). 
(Museum Number: 1843,1103.31). Na face A do vaso, vê-se a figura de Odisseu amarrado ao mastro de uma nau sendo remada por seus companheiros e rodeada por três figuras com cabeça humana e corpos de aves. ${ }^{54}$ A fisionomia biforme é mencionada por Eurípides em Helena (v. 167-179), peça datada de 412 a.C., possivelmente a fonte literária mais antiga a descrever as Sirenas como metade pássaro metade mulher. Contudo, a informação de Circe na Odisseia de que elas tentam atrair os passantes em vez de voar até eles pode ser um indício contra a versão híbrida de pássaro. Esse silêncio em relação a seu aspecto biforme, contudo, conforme apontado por meu orientador, pode encontrar um paralelo na ausência de menção à unicidade do olho dos ciclopes ou, ainda, é possível que houvesse mais de uma forma de representá-las e o poeta se absteve de escolher, já que tal forma não é relevante para o episódio.

O leitmotif do episódio das Sirenas, entretanto, é o canto que elas emitem, dominando a cena como um todo. A capacidade de enfeitiçar com seu canto coloca o ouvinte em uma espécie de torpor, em que ele se esquece não apenas do retorno como também das necessidades básicas de sobrevivência, restando deles apenas os cadáveres com peles ressequidas (não há menção de que as Sirenas os ataquem ou os devorem, entretanto). ${ }^{55}$ Amarrado ao mastro da nau e com o ouvido dos companheiros tapado por cera, precauções sugeridas por Circe para que Odisseu pudesse ouvir e sobreviver ao canto das Sirenas, o herói é convidado por elas a ancorar a nau e a ouvi-las enunciar seu conhecimento acerca de tudo o que se passou em Troia (10.184-191).

Pucci (1998, p. 1-9) explora a dicção iliádica da fala das Sirenas, a começar pelo

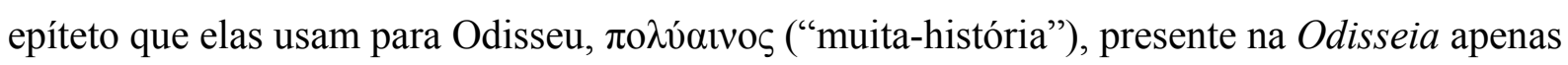
na fala das Sirenas (12.184) e duas vezes na Ilíada (9.673 e 10.544) em contextos que narram feitos importantes de Odisseu, um epíteto exclusivo do herói que o caracteriza como aquele

54 O tipo iconográfico de pássaro com cabeça humana é atestado desde o final do século VIII a.C. em ornamentos de caldeirões de bronze. Entretanto, as Sirenas encontradas por Odisseu são representadas assim a partir da primeira metade do século VI a.C., identificadas em dois frascos de perfume de produção coríntia: um aríbalo de figuras negras no estilo coríntio médio (c. 590 a.C., Basel, Antikenmuseum BS 425. LIMC s.v. Odysseus (Odette Touchefeu-Meynier) nr. 150 = s.v. Herakles (J. Boardman) nr. 1992; e outro aríbalo de figuras negras no estilo coríntio tardio (c. 575-550 a.C., Boston, Museum of Fine Arts 1901.8100. LIMC s.v. Odysseus nr. 151). Para as demais fontes iconográficas, cf. LIMC, Vol. 6, Odysseus et lês sirenes (Odette Touchefeu-Meynier), p. 962-964, com imagens em Vol 6.2, p. 632-637. Cf. também o verbete Seirenes (Eva Hofstetter) em LIMC Supplementum 2009, p. 448, com imagens em Supplementum vol. 2, p. 214. Para os problemas na identificação dessas figuras com as Sirenas, cf. Neils (1995, p. 178-180).

55 Pucci (1998, p. 8, n. 13) chama a atenção para o fato de a descrição das Sirenas feita por Circe mencionar a pilha de ossos em torno delas enquanto Odisseu nada menciona a respeito: "[...] It is reasonable that Odysseus fails to describe the huge pile of bones as he sees the Sirens on their meadow. The mention of bones and death would have emptied part of the charm Odysseus felt and wanted to describe. Yet the question remains: did a huge pile of bones in fact lie around the Sirens?". 
que se vale de histórias para obter sucesso e sobrevivência (Pucci, 1998, p. 2). ${ }^{56}$ Ao identificálo como o guerreiro partícipe do sítio a Troia em vez do herói da Odisseia, as Sirenas apelam para a nostalgia dos feitos gloriosos de Odisseu (Pucci, 1998, p. 5-6). Ao proclamar conhecimento sobre tudo o que ocorre, um conhecimento característico das Musas na poesia épica (Ilíada, 2.484 e ss. e Teogonia, v. 27-28), as Sirenas estariam se colocando oniscientes

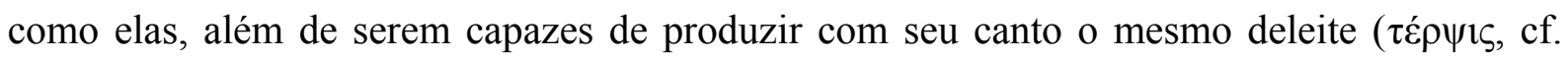
$\tau \varepsilon \rho \psi \alpha ́ \mu \varepsilon v o \varsigma$ em 12.188), um elemento característico na descrição que a poesia épica faz da canção e das Musas (cf. Pucci, 1998, p. 7).

Hopman (2012a, p. 85-86) aponta essa mesma semelhança temática entre Circe e as Sirenas, em que o canto destas (Odisseia 12.41, 12.44 e 12.52) ecoa o da feiticeira (Od. 10.220-228). Além disso, a droga de Circe e o canto das Sirenas produzem o mesmo efeito: a poção da feiticeira teria "enfeitiçado" Odisseu do mesmo modo que o canto das Sirenas

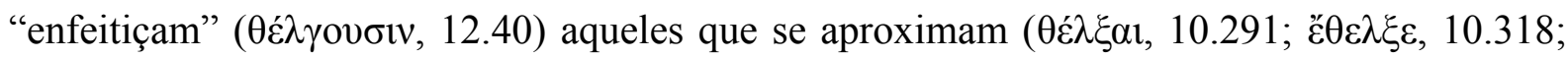
$\dot{\varepsilon} \theta \dot{\lambda} \lambda \chi \theta \eta s, 10.326)$.

Doherty (1995) considera que, ao proclamar uma competência que se equipara à das Musas sem que seja sancionada por Zeus, as Sirenas não estão alinhadas a qualquer autoridade masculina, seja humana ou divina (p. 88), constituindo-se em uma espécie de antiMusas. Desse modo, elas usurpariam o privilégio de Odisseu como narrador de sua própria história (p. 85), enquanto exemplo de uma voz feminina subversiva que desafia a focalização masculina do herói. Em termos de recepção pelo público do poema, essa leitura de Doherty faz lembrar a proposta de "resisting reader" de Fetterley (1978), exposta no capítulo anterior (p. 171), em que a leitora (ou a integrante da plateia) do poema se recusa a se identificar com o ponto de vista masculino ou a aceitar como norma um sistema de valores masculino. ${ }^{57}$

Embora o discurso das Sirenas esteja sob o controle de Odisseu enquanto narrador interno e evoque um poder que serve para reforçar uma imagem das Sirenas dentro de um sistema de valores dominado pelo gênero masculino, elas se imbuem (aparentemente por elas próprias) de uma atividade que, na poesia épica, é exclusivamente masculina: a do canto. Sua capacidade de enfeitiçar ( $\theta \varepsilon \dot{\lambda} \gamma \varepsilon \imath$ ) ou de deleitar ( $\tau \dot{\varepsilon} \rho \pi \varepsilon \imath$ ) não reside em seu potencial sexual,

56 Para as demais características iliádicas da fala das Sirenas, cf. Pucci (1998, p. 2-4).

57 Cf. Doherty (1995, p. 91-92, n. 37): “[...] In light of the late-twentieth-century awareness of audiences and their role in the production of artistic meaning, it is especially unfortunate that so little evidence survives for the composition of early epic audiences. This problem extends to the "audiences" for visual representations of the Sirens, which must have been understood quite differently by different groups and individuals in the range of artists, purchasers, and users of the surviving objects. The sheer numbers of Siren images on a wide variety of objects suggest the adaptability of the motif, and the fact that these objects included gems, amulets, and perfume bottles makes it unlikely that the Sirens were always imagined in purely negative terms. [...]". 
portanto, mas na capacidade que têm de produzir narrativas, prescindindo da figura masculina do aedo e, em última instância, das Musas, que, por sua vez, são sancionadas por Zeus: ${ }^{58}$

\begin{abstract}
[...] As Sirenas devem soar como Musas, inspiradoras da Ilíada, a fim de que sejam cantoras fiéis dos labores passados de Odisseu: portanto, estabelecem uma identificação genuína do herói odisseico com a Ilíada ao realçar seu glorioso pedigree literário; mas como Odisseu não deve abandonar o barco que o Cantor da Odisseia conduz por suas errâncias poéticas, então as Sirenas devem ser mostradas como destrutivas e um pouco patéticas, já que sua inocência é tão engenhosamente questionada pelo poeta da Odisseia.

Por fim, as Sirenas se provam cegas àquilo que ocorre diante de seus olhos: essas cantoras que têm o mesmo conhecimento das Musas da Ilíada estão realmente voltadas para o passado, vivem em um afastamento espacial e temporal que é assustador, e sua memória de museu se torna esquecimento do presente e lança apenas pesar, piedade e morte. Contra essa canção iliádica, a Odisseia assevera uma memória que preenche o presente, concede conhecimento próspero e assegura, ainda que controlados, prazeres possíveis.
\end{abstract}

Portanto, sob a superfície do deleite eterno enquanto dure que as Sirenas dizem proporcionar jaz o tão evitado esquecimento do retorno, semelhante àquele proporcionado pela flor de lótus, na terra dos lotófagos, elemento inicial das errâncias de Odisseu por esse passado distante do qual as Sirenas também são parte. Ao fim e ao cabo, a tentativa das Sirenas de fazer com que Odisseu permaneça nele encontra paralelos nas tentativas da feiticeira Circe e da ninfa Calipso, de quem, ausente o elemento da forma híbrida de pássaro e mulher, as Sirenas não se diferenciam tanto, a não ser pela grande pilha de ossos, que Odisseu, enfeitiçado ou não, nem se digna a mencionar. Vale lembrar que Circe transformou companheiros de Odisseu em porcos (cf. 10.282-283) e tencionava fazer o mesmo com ele, não fosse o deus Hermes lhe dar a droga benigna que agia como um contrafeitiço à poção de Circe (10.286-292).

Já que o poema não descreve as Sirenas, é possível supor que elas se diferenciam de Calipso e Circe não pela aparência mas de outro modo. Calipso é a ninfa que habita uma gruta tão distante que até mesmo Hermes reclama do infindável mar salgado que teve de cruzar para chegar até lá (5.100-102), mas quando adentra a gruta da ninfa, encontra a lareira acesa com a

58 Pucci (1998, p. 8-9): “[...] The Sirens must sound like Muses, inspirers of the Iliad, in order to be truthful singers of Odysseus's past toils: therefore they establish the genuine identification of the Odyssean hero with the Iliad by enhancing his glorious literary pedigree; but since Odysseus must not abandon the ship that the Singer of the Odyssey leads through his poetic wanderings, then the Sirens must be made to appear destructive and a little bit pathetic, in that their innocence is so adroitly questioned by the poet of the Odyssey.

Finally the Sirens prove to be blind to that which occurs before their eyes: these singers that have the same knowledge as the Muses of the Iliad are really turned to the past, live in a spatial and temporal remoteness which is frightening, since their musean memory becomes forgetfulness of the present, and spells only grief, pity, and death. Against this Iliadic song, the Odyssey asserts a memory that fulfills the present, grants succesful knowledge, and insures earthly, though controlled, pleasures. 
perfumada madeira de cedro e Calipso cantando junto ao tear; ao reconhecer o deus, a ninfa oferece a Hermes uma poltrona lustrosa para sentar e põe o jantar à mesa. Aliado a todo o bom arranjo do lugar em que habita, à sua ocupação ao tear e à presteza com que bem recebe seu visitante (cf. 55-95), elementos que revelam sua conformidade com o ideal feminino em uma sociedade patriarcal de mulher zelosa do ambiente doméstico, está sua obediência a Zeus ao consentir em deixar Odisseu partir diante da mensagem trazida por Hermes. Circe é também encontrada cantando junto ao tear (10.221-222), sua casa é bem construída (10.210), também oferece uma bela e artificiosa poltrona para Odisseu se sentar (10.314-315) e lhe prepara um mingau (10.316-317), no qual coloca a droga que transformaria o herói em porco. Apesar do ambiente doméstico muito semelhante àquele no qual encontramos Calipso, a atividade de feiticeira de Circe se constitui como uma ameaça ao status quo não apenas por neutralizar o domínio masculino mas por revertê-lo ao transformar os homens em animais e exercer o seu domínio sobre eles. Embora ambas desejassem que Odisseu se mantivesse com elas, oferecendo a ele a imortalidade em troca da união conjugal, Circe se distancia de Calipso porque, ao transformar "varões" (äv $\delta \rho \varepsilon \varsigma)$ em animais, reverte a ordem social na qual homens dominam mulheres. As Sirenas, por sua vez, estão distantes desse ambiente doméstico no qual Circe e Calipso estão imersas e sobre o qual reinam cada uma a seu modo; as Sirenas também não oferecem a imortalidade a Odisseu em troca de compartilhar seu leito com elas. A imortalidade que oferecem, ao menos superficialmente, constitui-se daquela que reside no canto épico, que, até onde se sabe, é uma atividade masculina por excelência. ${ }^{59}$ Como Musas e cantoras do próprio canto, sua ameaça não é apenas a do esquecimento do retorno, como a apresentada pela flor de lótus, nem a dos prazeres de compartilhar o leito de ninfas e deusas, como Calipso e Circe, mas a do irresistível deleite provocado pelo canto épico sendo produzido por vozes femininas.

59 Cf., contudo, Dalby (2006), que defende uma autoria feminina para a Ilíada e a Odisseia. Para ele, o ambiente doméstico ao qual as mulheres estavam confinadas era, na verdade, o mais propício para tamanho empreendimento (Dalby, 2006, p. 150): “[...] In some places women have been less likely than men to perform publicly as singers because the long journeys and the overnight stays cannot easily be combined with their traditional household roles. For this reason, women who have the necessary skills are in some societies more likely than men to be ablo to undertake the task of gradually creating a really long epic, since the work can - indeed, it must - be done at home.". 


\subsection{CiLA E CARÍBDis (12.72-126 E 12.234-259)}

Por comporem dois extremos de um estreito pelo qual a embarcação de Odisseu tem de passar, Cila e Caríbdis representam dois perigos que Odisseu deve enfrentar ao mesmo tempo. Cila é descrita por Circe com mais detalhes do que Caríbdis, sendo esta última a personificação de um elemento da paisagem enquanto Cila apresenta uma multiplicidade de braços e cabeças capazes de arrebatar vários tripulantes de uma nau ao mesmo tempo. Ambas são apresentadas como incombatíveis e imortais, portanto impossíveis de serem vencidas por Odisseu.

Como ocorre com as Sirenas, Cila e Caríbdis são também evocadas prolepticamente por Circe (12.85-126) antes do encontro ente elas e Odisseu (12.234-259). Para chegar à Trinácia, depois de sobreviver à Sirenas, ele e seus companheiros têm de atravessar as Plânctas, rochas salientes contra as quais quebram grandes ondas enviadas por Anfitrite (12.59-72), as quais apenas a nau de Jasão, Argó, foi capaz de atravessar, e o estreito onde ficam Cila, de um lado, e Caríbdis, do outro. ${ }^{60}$ De modo semelhante àquele empregado por Odisseu ao descrever o habitat dos ciclopes, particularmente, o de Polifemo, Circe descreve o local habitado por Cila com a técnica da descrição pela negação (12.72-84) e utiliza o recurso do zooming-in: primeiro o habitat com o foco se fechando sobre a criatura. Segundo a feiticeira, Cila habita um alto penedo impossível de ser escalado por um mortal, no meio do qual há uma gruta igualmente inatingível mesmo por uma flecha atirada do barco. Similarmente à rocha que cobre a entrada da gruta de Polifemo, impossível de ser movida mesmo por vinte e dois carros, o penedo habitado por Cila não pode ser escalado por um mortal mesmo que ele tivesse vinte pernas e braços.

A primeira característica de Cila apontada por Circe é relativa ao som que ela produz, um "assombroso som agudo" ( $\delta \varepsilon v$ òv $\lambda \varepsilon \lambda \alpha \kappa$ ĩ $\alpha, 12.85)$, que se assemelha àquele emitido por

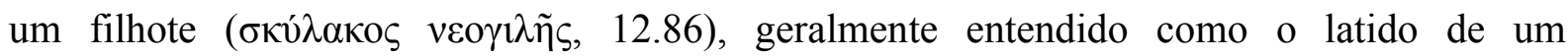

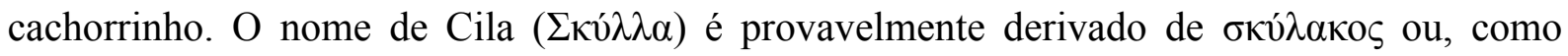

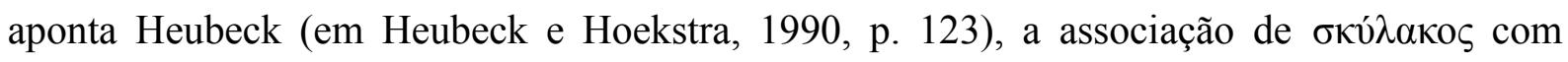
$\Sigma \kappa v ́ \lambda \lambda \alpha$ pode servir ao propósito de oferecer uma etimologização para o nome próprio,

60 Essa referência de Circe a Jasão e à Argó é considerada evidência de circulação de uma Argonáutica préhomérica (Heubeck em Heubeck e Hoekstra, 1990, p. 121). Cf. Hopman (2012a, p. 26-27), que coloca Odisseu como seguidor dos passos de Jasão, embora o herói odisseico não seja tão bem-sucedido quanto o herói da Argonáutica. Contudo, note-se que Jasão só conseguiu sobreviver às Plânctas porque Hera o guiou, enquanto Odisseu sobrevive sem o auxílio de Atena, ausente nas aventuras narradas nos apologoi, sendo ao mesmo tempo alvo do ódio de Posêidon em razão de ter cegado seu filho Polifemo. 
fornecendo uma interpretação para ele. ${ }^{61}$ Apesar da figuração de Cila junto com cães se tornar canônica na iconografia a partir do século VII a.C. (embora com mais frequência a partir do V a.C.), o texto que encerra sua descrição é um tanto problemático. O particípio perfeito $\lambda \varepsilon \lambda \alpha \kappa v i ̃ \alpha$ é um hapax na Odisseia, enquanto o verbo $\lambda \alpha ́ \sigma \kappa \omega$ pode designar na Ilíada sons agudos em geral, como o produzido pelo choque entre objetos de metal (cf. Ilíada 23.25). Portanto, não há nada em $\lambda \varepsilon \lambda \alpha \kappa v i ̃ \alpha$ que designe um latido propriamente. O substantivo $\sigma \kappa u ́ \lambda \alpha \xi$ designa filhotes de cachorro nas outras duas ocorrências na Odisseia (9.289 e 20.14), embora possa designar filhotes de animais em geral, apesar de esse sentido ocorrer apenas em

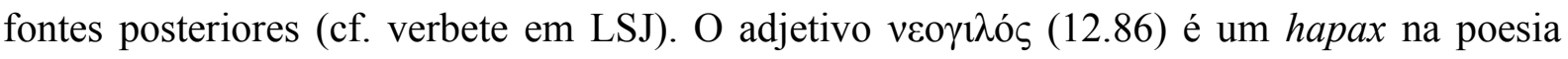
homérica e o segundo termo, que segue véos ("novo”) em sua composição, é desconhecido. Essa interpretação canina de Cila pode se complicar ainda mais se se levar em consideração

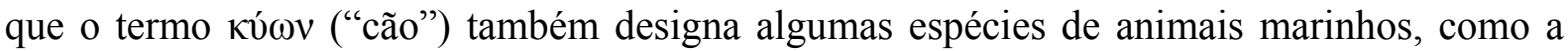
foca ou o tubarão (12.96; cf. verbete em Cunliffe e em LSJ), não havendo nada que impeça o termo $\sigma \kappa v ́ \lambda \alpha \xi$ de designar o filhote de uma dessas espécies marinhas.

De todo modo, o som, aparentemente inofensivo, produzido por Cila contrasta (cf. $\delta^{\prime}$

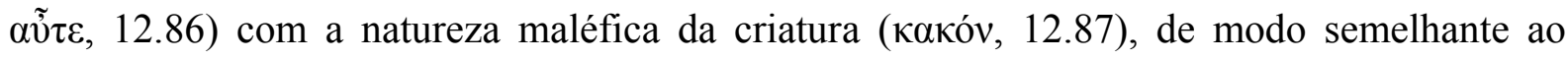

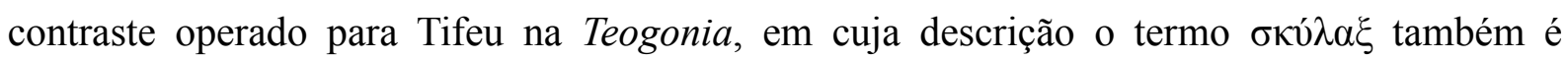
utilizado para um dos múltiplos sons que produz (v. 834), bem como o termo $\pi \varepsilon ́ \lambda \omega \rho / \pi \varepsilon ́ \lambda \omega \rho \circ v$ (para Cila em 12.87 e para Tifeu em 845 e 856). ${ }^{62}$ Como Tifeu, Cila possui uma multiplicidade de membros: doze pés e seis pescoços que portam, cada um, uma cabeça

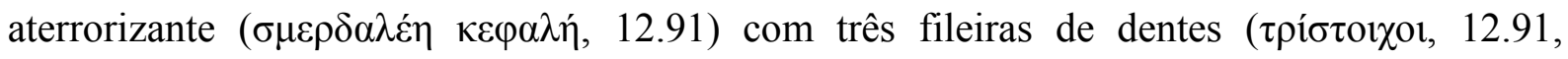
também um hapax na poesia homérica). A capacidade destrutiva desses dentes é enfatizada em 12.92 que os declara como "cerrados e múltiplos, cheios de negra morte".

A descrição de Cila propriamente também não é isenta de problemas de ordem

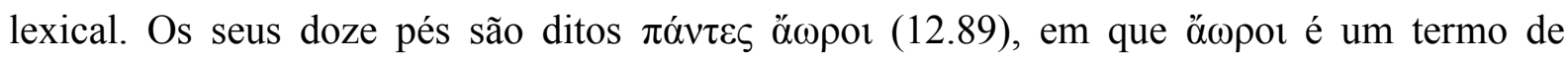

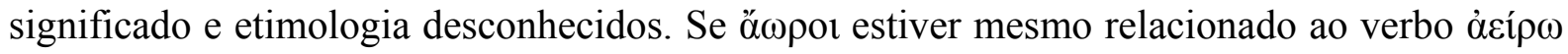
“erguer”, "suspender”, como propõe Cunliffe, a expressão pode indicar que os pés ficavam

61 Essa associação entre Cila e a figura canina se reflete na iconografia desde o final do século VII a.C., período em que é datada uma píxis de marfim etrusca (c. 620-570), proveniente da necrópole de Pania, em Chiusi, em que um barco com uma figura masculina ao remo está ao lado de três longos pescoços com cabeças de cachorro (Florença, Museo Archeologico, 73846 (apud Hopman, 2012a, p. 35-36)). Tal associação recebe grande atenção por parte de Hopman (2012a) em seu livro dedicado à figura da Cila, principalmente na relação metafórica, nos termos estabelecidos por Lakoff e Johnson (2003 [1980]), em que Cila é a realização de duas metáforas conceituais que compõem a compreensão do mar: de um lado a metáfora em que o mar é percebido como um animal, e, do outro, a metáfora em que ele é percebido como uma mulher (Hopman, 2012a, p. 18). A figura do cão não é, contudo, um elemento de identificação iconográfica de Cila, pois também é usado em figurações da deusa Hécate (cf. LIMC s.v. Hekate (H. Sarian), v. 6, p. 985-1018) e também das Erínias (LIMC s.v. Erinys (H. Sarian), v. 3, p. 825-843).

62 O termo é também usado para Polifemo em 9.257 e 9.428 e o adjetivo $\pi \varepsilon \lambda \omega ́ p ı \iota \varsigma$ em 9.187 e 9.190. 
erguidos ou suspensos, talvez como os tentáculos de um polvo. Essa singularidade da linguagem usada para Cila lembra, de certo modo, aquela da linguagem empregada na descrição dos Ciclopes e dos Centímanos na Teogonia (cf. capítulo 3, p. 113-114). Heubeck (em Heubeck e Hoekstra, 1990, p. 123) aponta, contudo, que Cila, com seus doze pés e suas seis cabeças, pertence ao rol de "monstros" descritos na Teogonia entre os versos 270-336, ou seja, aqueles do assim chamado "catálogo de monstros", filhos de Fórcis e Cetó. Contudo, tanto Tifeu na Teogonia como algumas das criaturas mencionadas no catálogo são derrotadas por Zeus, como é o caso de Tifeu, ou por heróis, como Medusa, Hidra de Lerna, Leão de Nemeia e Quimera, o que não ocorre com Cila. Ao contrário, ela devora seis dos companheiros de Odisseu e não há nada que o herói possa fazer contra ela ou em benefício dos companheiros. Além disso, a imortalidade de Cila é enfatizada por Circe (12.118) quando Odisseu pergunta se é possível se desviar de Caríbdis e ao mesmo tempo combater Cila, caso ela tentasse atacar os companheiros.

Sua enorme dimensão e capacidade destrutiva também é evidenciada pela menção aos animais marinhos dos quais se alimenta: golfinhos ( $\delta \varepsilon \lambda \varphi \tilde{v} v \alpha \varsigma, 12.96)$, focas ou tubarões

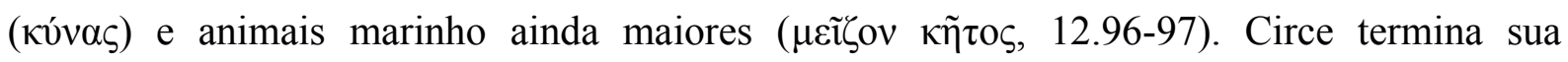
descrição de Cila afirmando a Odisseu que nunca se ouviu dizer que algum marinheiro escapou incólume, arrancando da embarcação um marinheiro com cada uma de suas cabeças (12.98-100), exatamente o que vai acontecer com alguns dos companheiros de Odisseu.

Tendo avisado Odisseu dos perigos representados por Cila, Circe passa a descrever Caríbdis (12.101-110). A pouca distância de Cila, sob uma figueira no outro penedo que compõe o estreito, a "divina” ( $\delta \tilde{a} \alpha, 12.104$ e 12.235) Caríbdis sorve a água negra e a esguicha três vezes por dia. Circe aconselha Odisseu a não estar por lá no momento do sorvo e a passar longe dela se aproximando de Cila, já que é melhor lastimar a perda de seis de seus companheiros do que de todos. O conselho de Circe, portanto, é tal que visa minimizar as perdas de Odisseu, que, por sua vez, dirige-se a ela perguntando se poderia se desviar de Caríbdis e ao mesmo tempo resistir a Cila. A resposta da deusa enfatiza a imortalidade de Cila (12.118) e também seu aspecto fatal em um verso que acumula quatro adjetivos: "assombrosa,

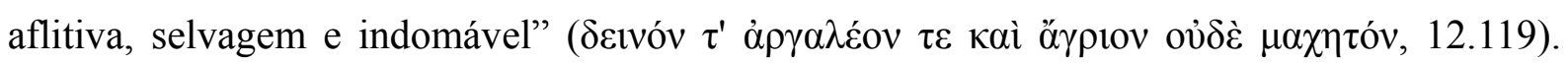
Circe coloca o perigo representado por Cila em termos sob os quais a bravura ou o combate são ineficazes: ainda que Odisseu esteja armado, se ele se demorar, é possível que Cila o agarre. Por isso, ele deve passar rápido por ela e gritar por Crátaiis, mãe de Cila, "que a gerou

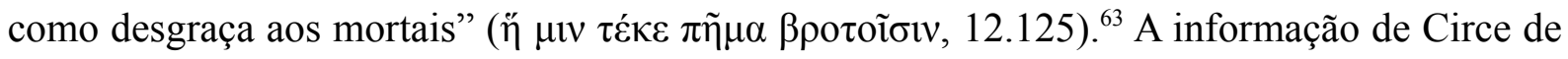


que apenas Crátaiis pode impedir um segundo ataque novamente pressupõe a minimização dos prejuízos de Odisseu, mas não a prevenção total das perdas.

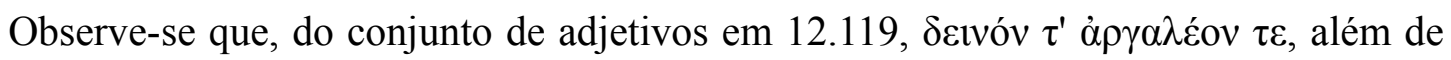
ter sido usado no canto 5 por Odisseu para caracterizar o mar, é também usado no Hino Homérico a Apolo para Tifeu (v. 306=352), bem como a expressão $\pi \tilde{\eta} \mu \alpha \beta \beta \rho \tau$ ßо̃ 12.125, também presente nesses dois versos do h.Ap.3. Note-se também que a serpente morta por Apolo é caracterizada pelo adjetivo ö $\gamma p ı \varsigma$ (v. 302) e pelo substantivo $\pi \tilde{\eta} \mu \alpha$ (v. 304). Tanto a serpente como Tifeu, este na Teogonia, só foram aniquilados pelas mãos de deuses, e a atribuição dessas mesmas características a Cila delineia a impossibilidade de ela ser aniquilada pelo mortal Odisseu, que a chama de "flagelo invencível” (ä $\pi \rho \eta \kappa \tau o v ~ \alpha v i ́ \eta v$,

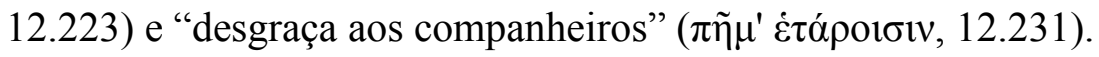

Se as Sirenas são um perigo contra o qual Circe consegue prevenir a perda dos companheiros por meio de um estratagema, Cila se configura como um perigo contra o qual a única solução é fugir (12.120). Diante de tal advertência, Odisseu prefere não relatar aos companheiros acerca de Cila ou Caríbdis (12.223-225) com receio de que parassem de remar e se escondessem, porém, na iminência de passar por elas, ele os exorta (12.207-221) a confiarem em sua capacidade estratégica ("excelência, plano e mente", 12.211), que já garantira a sobrevivência deles na gruta de Polifemo (12.209-2012). E como no caso do ciclope, Odisseu perde seis de seus companheiros, devorados por Cila. A cena em que Cila os arrebata enquanto eles gritam e estendiam os braços para Odisseu é declarada pelo herói como a pior de todas as coisas que teve de aguentar cruzando o mar. Além dessa terrível visão, a aparência da própria criatura é tal que Circe declara que nem mesmo um deus se alegraria em vê-la (12.88).

Hopman (2012a, p. 31-34) chama a atenção para a possibilidade de que a semelhança entre Tifeu e Cila evocasse no público o episódio da Tifonomaquia, já que tanto Odisseu como Zeus compartilham a mesma característica da astúcia. O fato de Odisseu se armar contra Cila, embora inutilmente, também evocaria as cenas de armamento da Ilíada, que precedem cenas de combate e por vezes a aristeia de um herói, como Diomedes, Aquiles, Pátroclo e Agamêmnon. Com a inexistência do combate contra Cila ou de uma possível aristeia de Odisseu, a Odisseia coloca o encontro de Cila e Odisseu como um combate cosmogônico frustrado e Cila como uma versão indestrutível dos monstros hesiódicos. O episódio de Cila, para Hopman, é, portanto, colocado como um desastre no qual Odisseu falha em comparação com os guerreiros da Ilíada e com Zeus, o momento mais desanimador de 
suas perambulações. Hopman (2012a, p. 34-41) também aponta que a derrota de Odisseu contra Cila contrasta com a vitória dele sobre Polifemo e indica outras semelhanças entre as duas criaturas, como habitarem uma gruta, a descrição como $\pi \dot{\lambda} \lambda \omega \rho$, as ações contra Odisseu, as descrições pela negação e o fato de ambos devorarem seis companheiros de Odisseu. A despeito dessas considerações de Hopman, não considero que o episódio de Cila represente uma derrota para Odisseu, afinal, o herói é capaz de sobreviver a ela, mesmo com a perda de seis de seus companheiros. Cila, de um lado, e Caríbdis, do outro, compõem um tipo de perigo contra o qual não há combate, elas são um tipo de ameaça que Odisseu não pode vencer ou destruir. A inevitável perda de seis de seus companheiros é o mínimo que Odisseu pode sofrer diante delas. Prefiro entendê-las como duas das "muitas aflições" que o proêmio do poema (1.4-5) bem como o proêmio de Odisseu no canto 9 (9.15) declaram que o herói sofreu, "tentando garantir sua vida e o retorno dos companheiros". Longe de representar uma derrota de Odisseu, o episódio de Cila e Caríbdis, dois perigos extremos que ele tem não exatamente que enfrentar mas superar, contribui, e muito, para a realização do herói como colocado desde início pelo poeta da Odisseia.

Os termos usados para descrever Cila e Caríbdis, principalmente os adjetivos pelos quais são evocadas, coloca as duas criaturas, principalmente Cila, como uma das mais aterradoras e nefastas da poesia hexamétrica. Como a serpente no Hino Homérico a Apolo,

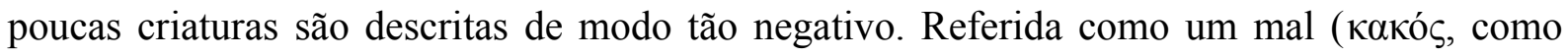
adjetivo em 12.87 e como substantivo 12.118), ela é também “assombrosa e aflitiva” ( $\delta \varepsilon ı v o ́ v$ $\tau^{\prime} \dot{\alpha} \rho \gamma \alpha \lambda \varepsilon \dot{o}$ v , 12.119). O adjetivo $\alpha \rho \gamma \alpha \lambda \varepsilon \varepsilon_{0} \varsigma$ tem o sentido de algo difícil de suportar, penoso e seu uso é bastante frequente tanto em Hesíodo como em Homero. Cila é também referida no

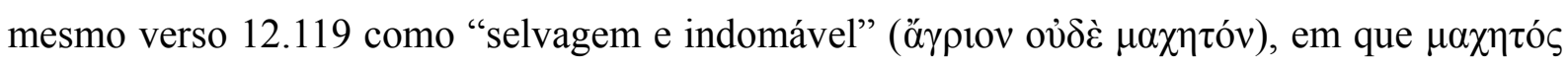

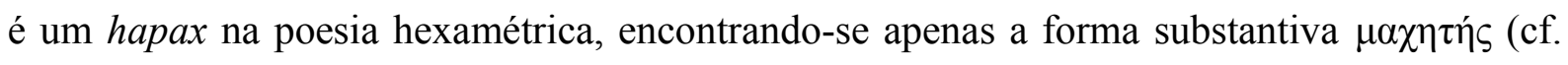
Ilíada 8.102, 16.186 e 4.202; Odisseia 18.261) que designa o "combatente". Ao dizer a

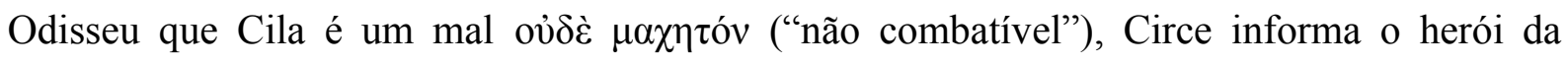
impossibilidade de se vencer Cila em combate, conselho que ele ignora ao se armar. Todavia, ao contrário do que Hopman defende, se Odisseu não é capaz de sobrepujar Cila, tampouco é derrotado por ela, pois tal derrota se constituiria em um fim para Odisseu tal qual o de seus companheiros, ou seja, serem devorados por ela como peixes, uma analogia já utilizada ao fim do episódio dos lestrigões. De Jong (2004 [2001]) aponta que nessa passagem o símile é desencadeado pelo hábito de Cila de "pescar" criaturas marinhas e tem a função primeira de ilustrar as convulsões dos companheiros arrebatados por ela; como segunda função está o 
aumento do pathos, já que a imagem sugere o desamparo dos companheiros. ${ }^{64}$

Quanto a Caríbdis, cujo nome é de etimologia desconhecida, sua descrição se centra em sua atividade e nos perigos que representa: ao sorver a água, ela pode sorver a embarcação de Odisseu, e ao regurgitar, ela lança a água como um caldeirão fervente (12.104-107 e 12.235-243). A visão de seu fundo arenoso deixa os companheiros de Odisseu com um "medo amarelo" ( $\chi \lambda \omega \rho o ̀ v ~ \delta \varepsilon ́ o \zeta, ~ 12.243)$ e seu caráter nefasto, já explicitado por Circe, é reiterado por

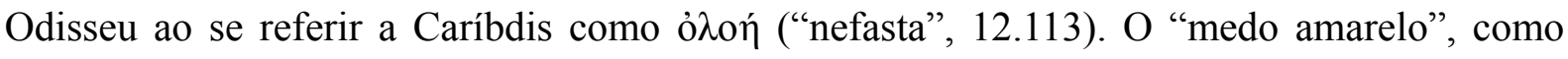
nota Foley (1999, p. 216-218), é uma expressão que indica uma situação na qual o medo é provocado por algo estritamente sobrenatural. Na Ilíada, ele toma conta dos troianos quando Zeus planeja maldades e troveja a noite toda (7.478-479) e dos aqueus quando Zeus troveja e lança um relâmpago no meio do exército. Na Odisseia, Odisseu é tomado pelo medo amarelo quando as sombras no Hades se juntam para beber o sangue do sacrifício (11.43) e também quando ele imagina que Perséfone poderia enviar contra ele a cabeça da Górgona (11.633). No canto 23, o medo amarelo toma conta dos pretendentes diante da fala de Medonte dizendo que Odisseu tem ajuda dos deuses, tendo percebido um imortal ao lado dele (23.450). Adiante no mesmo canto (23.533), o medo amarelo acomete novamente os pretendentes diante da fala de Atena. Para Foley, esse medo amarelo designa uma força sobre-humana e indomável, uma emoção incapacitante, sendo um $\sigma \tilde{\eta} \mu \alpha$ para algo que está além do controle de um mortal. Mesmo na ocorrência em que aparentemente não há o elemento do sobrenatural (22.42), ou seja, o medo provocado nos pretendentes diante do retorno de Odisseu, Foley considera que o fato do herói ser auxiliado por Atena, ainda que os pretendentes não saibam, somado à acusação por parte de Odisseu de que os pretendentes não demonstram temor aos deuses (22.39-40), é suficiente para a referencialidade estabelecida pelo $\sigma \tilde{\eta} \mu \alpha$ como um medo diante

64 Cf. a análise desse símile proposta por Werner (2005, p. 16): “As imagens utilizadas por Odisseu para descrever o evento aos feácios são grotescas: a comparação com uma bucólica cena de pesca; o aceno das mãos dos homens que são devorados; o guerreiro solitário no convés do navio, armado inutilmente. Se no caso de Polifemo Odisseu desconhecia tudo a respeito de seu oponente, aqui ele desconsidera o que Circe lhe havia dito anteriormente. Odisseu parece ainda não ter percebido que se encontra num mundo diferente, onde certas táticas e discursos são completamente inúteis. A primeira impressão é de estarmos diante de uma situação trágica na qual um herói enfrenta um obstáculo inominável, ação da qual ele sai engrandecido e derrotado ao mesmo tempo. Em nenhum dos episódios que compõem os cantos ix-xii, todavia, encontramos algo de trágico, justamente porque não podemos afirmar que Odisseu perca seus companheiros por ser um comandante excessivamente consciencioso: são os seus limites como líder que os colocam a todos em situações difíceis ou que não conseguem livrá-los completamente de tais situações.

Nesse sentido, é significativo o símile usado (xii.251-255) no episódio em questão. Descreve-se um pescador, parado sobre um rochedo, com as longa vara (xii.252); as semelhanças com Odisseu, armado com suas duas lanças, sobre a proa, não são insignificantes (xii.228-30). O pescador está lançando pedaços de comida com dolos ("isca": xii.252). Portanto, como imediatamente antes (xii.247-50) falava-se de Odisseu e dos homens que foram agarrados, é só com o desenvolvimento do símile que percebemos que o pescador é, de fato, Cila. Por um instante, temos a impressão de que Odisseu está usando seus companheiros como isca para que possam escapar do monstro. No final das contas, tendo em vista o modo como se dá a narração e o resultado da ação, as duas interpretações não se superpõem?”. 
do sobrenatural..$^{65}$ Note-se, ainda, que esse sobrenatural é circunscrito predominantemente a uma divindade, com exceção apenas dos corpos no Hades e de Cila.

Uma das interpretações de Cila e Caríbdis propostas por Hopman (2012a) é a de que elas se constituem enquanto criaturas e espaço ao mesmo tempo. Enquanto o que pode tornar Cila um elemento da paisagem é apenas o adjetivo "rochosa" ( $\pi \varepsilon \tau \rho \alpha i ́ \eta v, 12.231)$, isso é mais evidente no caso de Caríbdis, que, segundo a autora, está na fina linha que separa metáfora e personificação (Hopman 2012a, p. 68): "Simultaneamente um redemoinho e uma garganta engolfadora, Caríbdis é talvez o exemplo homérico mais extremo de uma configuração orgânica da paisagem". ${ }^{66}$ Polifemo e Antífates, a rainha dos lestrigões, foram comparados a picos de montanha pela sua enormidade, mas Caríbdis e também Tifeu, tanto na Teogonia como na passagem da Ilíada, são figuras que se imiscuem com a paisagem, tornando difícil a separação de um e de outro, uma separação que, na verdade, não parece existir. Talvez seja oportuno notar que isso não é uma exclusividade de Caríbdis e Tifeu, pois Terra, Céu, Mar, Oceano, Montanhas etc. são todas personificações de elementos da paisagem. Talvez, o que separe Caríbdis e Tifeu dos demais é que não são representados como benéficos aos mortais, enquanto os outros podem sê-lo e podem não sê-lo.

\subsection{CONCLUSÕES}

As narrativas apresentadas por Odisseu aos feácios entre os cantos 9 e 12 são frequentemente consideradas como tendo origem em narrativas folclóricas. Como já referido acima, vários estudiosos têm se dedicado ao estudo dos apologoi enquanto uma junção de diferentes narrativas do folclore, encontradas em diferentes partes do mundo, embora seu registro escrito date do século XIX com Wilhelm Grimm. Essa perspectiva, contudo, tem sido evitada aqui. A razão dessa relutância em aceitá-la se deve fundamentalmente a essa distinção, muito clara para alguns estudiosos (como para Hansen, 1997, por exemplo), entre mito e folclore. O problema de tal separação é o juízo de valor em geral envolvido nela, como se o mito tivesse uma aura divina, superior e etérea, enquanto o folclore se reduz ao reles cotidiano popular, uma distinção falsa com pressuposições perigosas, pois o mito, em sua conexão com a poesia, com a religião, com os preceitos políticos da pólis, é parte da realidade cotidiana imediata daqueles que partilhavam o modo de vida na região que eles próprios denominavam

65 A única ocorrência não endereçada por Foley está em 17.67, em um símile que compara Menelau a um leão, que não parece remeter a uma conotação sobrenatural.

66 "[...] Simultaneously a whirlpool and a swalloing throat, Charybdis is perhaps the most extreme Homeric example of an organic figuration of landscape." 
"Hélade".

Hansen (1997, p. 444-445), por exemplo, opera uma distinção tripartite entre folclore, lenda e mito: ${ }^{67}$

\begin{abstract}
Contos folclóricos são ficções tradicionais, ou seja, são contos que entretêm, são instrutivos ou consoladores, nos quais a questão da historicidade não é importante. Geralmente, tais contos são ambientados em um passado indefinido, ocorrem em locais vagamente definidos ou genéricos, e apresentam personagens humanos ou animais que não são nomeados ou têm nomes genéricos. [...]

Lendas diferem notavelmente de contos folclóricos, embora elas não precisem ter qualquer base histórica, porque são recontadas como relatos de eventos históricos ou, ao menos, como relatos que convidam a uma avaliação de sua própria historicidade. Por consequência, elas são geralmente situadas em um tempo definido na história humana ou acontecem em um local definido ou ambos, e apresentam seres humanos alegadamente reais. [...]

Finalmente, mitos são narrativas tradicionais sobre deuses e monstros. Elas são ambientadas em locais definidos, às vezes no passado distante quando o mundo estava recebendo suas características básicas, às vezes em um passado mais recente, e são relatos de eventos alegadamente reais.
\end{abstract}

Como é possível perceber, a classificação de Hansen se baseia fortemente não na distinção entre ficção e realidade, mas entre ficção e o "alegadamente" real, entre o ficcional e aquilo ao qual é conferido alguma historicidade. No tratamento da poesia hexamétrica arcaica, essa distinção está fadada ao fracasso, porque essas distinções não são operantes, ao menos não desse modo mecanicista. Rotular o episódio de Polifemo como proveniente do conto folclórico, os trabalhos de Hércules como lenda e a derrota de Tifeu por Zeus como mito é atribuir distinções que são fruto do mesmo processo de desencantamento do mundo pelo qual passou a figura do monstro, em que as diversas narrativas, coletadas inicialmente por viajantes e depois por antropólogos e estudiosos de narrativas orais, passaram a ser cada vez mais objeto da dissecação científica. Além disso, tal classificação decorre fundamentalmente do processo de escrita pelo qual passaram essas narrativas coletadas nos séculos XIX e XX. ${ }^{68}$

Ao tratar do poema anglo-saxão Beowulf, Tolkien (2006 [1983], p. 15-16) faz uma

67 "Folktales are traditional fictions, that is, entertaining, instructive, or consolatory tales in which the issue of historicity is unimportant. Generally such tales are set in the indefinite past, transpire in vaguely defined or generic locales, and feature human or animal characters who are unnamed or bear generic names. [...] Legends differ notably from folktales in that, although they need not have any historical basis, they are recounted as reports of historical events or at least as reports that invite an evaluation of their own historicity. Accordingly, they usually are situated in a definite time in human history or transpire in a definite locale or both, and feature purportedly real human beings. [...]

Finally, myths are traditional narratives about gods and monsters. They are set in definite locales, sometimes in the distant past when the world was receiving its basic character, sometimes in the more recent past, and are accounts of allegedly true events."

68 Para um breve mas eficiente tratamento da poesia épica como um gênero "guarda-chuva", ou seja, que incorpora vários gêneros, cf. Bakker (2013, p. 1-12). 
consideração relevante e perspicaz que serve bastante ao propósito deste capítulo e desta tese como um todo: ${ }^{69}$

[...] But I will not here enter into debate, nor attempt at length a defense of the mythical mode of imagination, and the disentanglement of the confusion between myth and folk-tale into which these judgements appear to have fallen. The myth has other forms than the (now discredited) mythical allegory of nature: the sun, the seasons, the sea, and such things. The term 'folk-tale' is misleading; its very tone of depreciation begs the question. Folk-tales in being, as told - for the 'typical folktale', of course, is merely an abstract conception of research nowhere existing - do often contain elements that are thin and cheap, with little even potential virtue; but they also contain much that is far more powerful, and that cannot be sharply separated from myth, being derived from it, or capable in poetic hands of turning into it: that is of becoming largely significant - as a whole, accepted unanalysed. The significance of a myth is not ealisy to be pinned on paper by analytical reasoning. It is at its best when it is presented by a poet who feels rather than makes explicit what his theme portends; who presents it incarnate in the world of history and geography, as our poet has done [Beowulf's poet]. Its defender is thus at a disadvantage: unless he is careful, and speaks in parables, he will kill what he is studying by vivisection, and he will be left with a formal or mechanical allegory, and, what is more, probably with one that will not work. For myth is alive at once and in all its parts, and dies before it can be dissected. It is possible, I think, to be moved by the power of myth and yet to misunderstand the sensation, to ascribe it wholly to something else that is also present: to metrical art, style, or verbal skill. Correct and sober taste may refuse to admit that there can be an interest for $u s$ - the proud we that includes all intelligent living people - in ogres and dragons; we then perceive its puzzlement in face of the odd fact that it has derived great pleasure from a poem that is actually about these unfashionable creatures. Even though it attributes 'genius', as does Mr. Girvan, to the author, it cannot admit that the monsters are anything but a sad mistake.

Acredito que esse capítulo não poderia encontrar palavras melhores para sua conclusão, principalmente no tocante à distinção prosaica entre mito e folclore que parte dos estudiosos da Odisseia insiste em fazer, como mais recentemente West (2014). Contudo, há ainda outros aspectos a serem tratados à guisa de conclusão, para os quais o ensaio de Tolkien ainda será de grande auxílio.

Este capítulo teve início com uma breve introdução acerca dos apologoi e as implicações de se ter o protagonista da narrativa principal como narrador e protagonista da narrativa embutida. Ao ceder o palco (e a plateia) a Odisseu entre os cantos 9 a 12, o poeta da Odisseia, um poema sobre o nostos de Odisseu, coloca o herói na posição daquele que narra grande parte desse retorno à sua casa, uma viagem que constituirá o kleos odisseico de Odisseu. Portanto, o poeta da Odisseia coloca Odisseu como agente e narrador do seu próprio kleos: os perigos que ele diz enfrentar são justamente as seções da Odisseia mais lembradas e reproduzidas na atualidade, elas são emblemáticas do poema. É pela narrativa de Odisseu aos

69 Mantenho a citação em inglês a fim de evitar que se perca o impacto e a genialidade imbuída de grande humildade que perpassam o estilo de Tolkien. 
feácios que conhecemos Polifemo, as Sirenas, Cila e Caríbdis, criaturas que não figuram nos outros poemas da tradição de poesia hexamétrica arcaica. Ainda que essas narrativas tenham circulado em outras formas de transmissão oral ou apresentem sua origem em narrativas separadas que foram unidas pelo poeta da Odisseia, elas não chegaram até a modernidade, a não ser por versões coletadas mais recentemente na história. Como observa Tolkien (2006 [1983], p. 17): “[...] The same heroic plot can yield good and bad poems, and good and bad sagas. The recipe for the central situations of such stories, studied in the abstract, is after all as 'simple' and as 'typical' as that of folk-tales. There are in any case many heroes but very few good dragons.". Se o poeta da Odisseia transformou um plote heroico em um poema de grande excelência, prezado por antigos e modernos, foi por meio do narrador Odisseu que ele conseguiu dar vida e - por que não? - kleos a "bons dragões".

Foram expostas ao longo do capítulo as descrições feitas por Odisseu desses "bons dragões" que ele encontra. Vimos que Polifemo é caracterizado primordialmente por sua enorme dimensão física e a posse de um único olho tem de ser pressuposta a bem da narrativa. Como Polifemo, os lestrigões também se caracterizam pela enormidade e por se alimentarem dos companheiros de Odisseu. As Sirenas não são descritas a não ser pela sua voz que é capaz de enfeitiçar ao emitir o canto daquelas que tudo conhecem, colocando seu ouvinte em uma espécie de torpor sob o qual ele de tudo se esquece até que lhe reste apenas os ossos e a pele ressequida. Cila com sua multiplicidade de membros e cabeças arrebata seis dos companheiros de Odisseu, uma perda inevitável para o herói. E, por fim, Caríbdis, o redemoinho que sorve tudo o que se aproxima. Todos são ameaças ao retorno do herói à Ítaca e todos podem ser facilmente colocados sob a categoria "monstro" de acordo com os nossos critérios modernos. Outros seres e situações, contudo, colocam-se como ameaças ao nostos de Odisseu: as deusas Calipso e Circe, por exemplo, que preferiam manter Odisseu junto delas, ou Posêidon, motivo declarado por Zeus da demora do herói, por este ter lhe cegado o filho, Polifemo.

Aqui, faço novamente uso de Tolkien (2006 [1983], p. 46, n. 23):

There is actually no final principle in the legendary hostilities contained in classical mythology. [...] The gods, Cronian or Olympian, the Titans, and other great natural powers, and various monsters, even minor local horrors, are not clearly distinguished in origin or ancestry. [...]

Polifemo é filho de um deus olímpico, Cila e Caríbdis são ditas divinas e imortais, Circe, que transforma os companheiros de Odisseu em porcos e já tinha o hábito de 
transformar homens em animais, também é referida como uma deusa. Apesar do antropomorfismo os deuses também são capazes de atitudes bastante desumanas.

Por vivermos em um mundo pós-cristianismo, mas ainda muito cristão, temos dificuldades imensas, talvez montanhescas como Polifemo, ou abissais como Caríbdis, em nos livrarmos da dicotomia "deus=bom" versus "diabo=mau". Os deuses da tradição de poesia hexamétrica podem ser benéficos ou hostis ao homem; podem engendrar heróis ou criaturas que lhes são igualmente hostis. É inestimável o fato de podermos contar com essa tradição de poesia hexamétrica como parte do nosso arcabouço literário e do nosso imaginário, pois ela engendrou igualmente bons heróis e bons "dragões". Por narrar acerca das "maravilhas de se ver" $(\theta \alpha \tilde{v} \mu \alpha$ ` $\delta \varepsilon \sigma \theta \alpha \imath)$, dentre as quais essas criaturas que nós denominamos "monstros", a performance dessa poesia hexamétrica devia ser a oportunidade que a plateia tinha de estar diante de um aedo que cantava, arrisco-me a dizer sem medo de me equivocar, maravilhas de se ouvir, principalmente quando chegava o momento em que ele iniciava os apologoi. Quanto à plateia interna, ou seja, os feácios, talvez Pucci (1998, p. 136) tenha colocado muito bem a questão: "[...] eles certamente nunca esperaram que um monstro sagrado como Odisseu aportaria em suas praias", ${ }^{70}$

70 "[...] they dertainly never expected a sacred monster like Odysseus to land on their shores." 


\section{CApítulo 6}

\section{CONCLUSÕES: \\ O MONSTRO COMO CATEGORIA \\ E SUA INEXISTÊNCIA NA \\ POESIA HEXAMÉTRICA ARCAICA}

The universe is a very big place, but as far as we know it's mainly empty, boring, and cold. If we exterminate the last magnificent scary beasts on planet Earth, as we seem bent on doing, then no matter where we go for the rest of our history as a species - for the rest of time - we may never encounter any others. The only thing more dreadful than arriving on $1 v-426$ and finding a nest of aliens, I suspect, would be to arrive there, and on the next unexplored planet, and on the next after that, and find nothing.

David Quammen, Monster of God. 
Conforme exposto no primeiro capítulo, é frequente se deparar com a ausência de definição do que vem a ser "monstro" na bibliografia que se dedica ao assunto, e a postura mais comum é a de que o monstro é indefinível (por exemplo, Mittman, 2013; Cohen, 1996; etc.). A multiplicidade e a complexidade subjacentes a essa categoria no mundo contemporâneo tornam, de fato, o esforço para sua delimitação uma tarefa inglória, já que qualquer definição que tente ser universalizante não dará conta dessa multiplicidade e imporá sobre a categoria "monstro" um caráter imanente, transcultural e atemporal, que falseia a compreensão contextualizada da categoria em si. Uma solução encontrada por parte dessa bibliografia é lidar com determinados aspectos da monstruosidade ou do que é monstruoso, conforme explicitado no primeiro capítulo, definindo seu objeto de acordo com alguma delimitação, como, por exemplo, a monstruosidade de corpos não normatizados, monstros mitológicos, a monstruosidade psicológica de assassinos em série etc.

Muito em razão dos estudos de antropólogos como Mary Douglas, principalmente em seu Pureza e Perigo (2012 [1966]), e de estudiosos da cognição, como Dan Sperber (1975), que nas décadas de 1960 e 1970 estavam refletindo a respeito do simbolismo animal e do caráter marginal de certos animais em determinadas culturas, as criaturas híbridas e fantásticas passaram a ser vistas como um construto conceitual que infringe as regras envolvidas nos processos taxonômicos ou como pertencentes a uma categoria simplesmente exterior ao sistema taxonômico de determinada sociedade. Um dragão, por exemplo, sendo uma serpente com patas e asas, infringe as regras taxonômicas que separam a serpente do pássaro. Híbridos, animais fantásticos e monstros seriam, portanto, aberrações taxonômicas engendradas no discurso por contradições dos princípios que regem a taxonomia dessa dada sociedade (Sperber, 1975, p. 7 e 15). Eles seriam, assim, engendrados contra a taxonomia e não por ela.

Tomando-se ainda os dragões como exemplo, eles podem assumir sentidos diversos em diferentes sistemas culturais. Frequentemente um inimigo de heróis, deuses e santos, na história ocidental, o dragão apresenta um sentido totalmente diverso no sistema cultural chinês, celebrado como um símbolo de poder e força, tendo sido o emblema imperial por séculos. ${ }^{1}$ Enquanto construtos culturais, os seres fantásticos devem, portanto, ser sempre

1 A propósito, durante minha estadia em Oxford, entre setembro de 2015 e março de 2016, tive a oportunidade de ficar hospedada em um núcleo para estudantes estrangeiros, onde conheci pesquisadores de vários países, inclusive da China. Surpreendeu-me muito que o termo chinês para "monstro", transliterado como "guàitái", 
entendidos de acordo com a sociedade que os criou, ou deles se apropriou e os ressignificou. Como nota a classicista Catherine Atherton $\left(1998\right.$, p. x): ${ }^{2}$

[...] Monstros (para resumir) são definidos em relação às comunidades e aos padrões do que é bom, aceitável, normal ou natural, de modo que somos nós que decidimos - em certo sentido de "decidir" - o que conta como monstruoso; e assim, em tempos, lugares e culturas diferentes, ou de pontos de vista diferentes dentro de uma única cultura, respostas diferentes emergirão.

Desse modo, por ser o monstro uma categoria cultural, sua definição é sempre culturalmente determinada e, ainda dentro de um mesmo sistema cultural, ela pode variar de acordo com as sensibilidades estéticas, com o sistema de crenças religiosas etc., resultando de múltiplas e diversas percepções. Por isso a impressão que se tem de que o monstro é indefinível: porque ele varia, em última instância, de acordo com as sensibilidades e percepções humanas. Os esforços para elaborar uma definição que abranja a totalidade das culturas e sociedades que os criam ou imaginam são, portanto, em vão: não há uma categoria "monstro", há tantas quantas diferentes perspectivas sociais, históricas, culturais, teóricas, permitirem e esses contextos não são prescindíveis quando a categoria é levada em consideração. Além das particularidades que ela pode assumir, é possível, ainda, que uma dada cultura não a tenha formulado enquanto tal, embora conceba criaturas que nós, modernos, percebemos como monstruosas. É o que esta tese defende em relação à poesia hexamétrica arcaica: que não há nela uma categoria "monstro", como a compreendemos no mundo contemporâneo, apesar de toda a elasticidade que a atualidade lhe confere; e que as criaturas que consideramos "monstros da mitologia" não são pensadas como pertencentes a uma categoria única pelo discurso mito-poético que as produziu, reelaborou e veiculou. O que ocorre é a projeção de uma categoria "monstro" plenamente articulada sobre a existência anterior e diferenciada de elementos que vieram a compor essa categoria em dado momento.

Há, ainda, outro aspecto que julgo estar no cerne da dificuldade em definir "monstro", que é a própria noção de "categoria". Em anos recentes, tanto a filosofia quanto a linguística e a psicologia cognitivas têm mostrado que o modo como categorizamos é muito mais

seja o mesmo para "estranho" e para "feto deformado", apresentando muita semelhança com o $\tau \dot{\varepsilon} \rho \alpha \varsigma$ aristotélico e com o "monstro" de Saint-Hillaire. Agradeço a Yanchang Li, historiador da medicina da Peking University, em Beijing, pela preciosa elucidação. Quando perguntado se o dragão era um monstro para os chineses, sua resposta veio acompanhada de uma expressão de espanto no rosto: "No, no. It is not a monster. It is fantastical, mythological.”.

2 Catherine Atherton (1998, p.x): “[...] Monsters (to summarise) get defined in relation to communities and to their standards of what is good, acceptable, normal, or natural, so that it is we who decide - in some sense of "decide" - what counts as monstrous; and so that in different times, places and cultures, or from different viewpoints within a single culture, different answers will emerge.". 
complexo do que geralmente se assume. A assunção comum é de que as categorias são definidas por um conjunto de propriedades que todos os seus membros compartilham, como caixas nas quais se coloca aquilo que cumpre os requisitos para estar dentro dela e se exclui aquilo que não os cumpre, tendo limites bem definidos. ${ }^{3}$ Contudo, Wittgenstein (2009 [1953]) propôs em obra publicada postumamente na década de 1950 e, mais recentemente, a psicologia cognitiva de Eleanor Rosch (1976) e suas ramificações têm demonstrado que, em vez disso, as categorias não apresentam delimitações tão fixas.

A visão tradicional do processo de categorização, também comumente chamada "clássica" ou "aristotélica", considera que uma categoria é geralmente definida por um conjunto de propriedades compartilhadas por todos os seus membros. Essa concepção tradicional encontra, não sua origem, mas sua formulação mais consolidada, no texto Categorias, parte da obra Organon, de Aristóteles. Nele, Aristóteles categoriza tudo o que existe em dez "praedicamenta", ou seja, em dez predicados que compreendem a totalidade do que pode ser dito a respeito de qualquer objeto passível de apreensão. Essa visão aristotélica de categorias e da categorização é atualmente considerada por Lakoff (1987, p. 121) como "folk theory", ou seja, o modo como em geral as pessoas comuns no mundo ocidental percebem o processo de categorização no cotidiano. Assim, por exemplo, um objeto tem de cumprir um conjunto de condições necessárias e suficientes para pertencer à categoria "cadeira"; para que o objeto pertença à categoria "mesa", outro conjunto de condições necessárias e suficientes teriam de ser cumpridas por ele.

$\mathrm{O}$ argumento mais contundente contra essa visão clássica de como uma categoria se define partiu de Wittgenstein. Ele observou que na categoria "Spiel" (termo alemão que pode significar tanto "jogo" quanto "brincadeira") não havia propriedades comuns compartilhadas por tudo o que se considera jogos/brincadeiras (e aqui há um caso de diferença de categorização, pois a língua portuguesa, diferente da alemã, distingue esses dois tipos de atividade). ${ }^{4}$ Ao se propor o exercício de tentar definir "Spiel", percebe-se que não há uma característica comum entre tudo o que pode ser classificado como tal: alguns “'jogos/brincadeiras” podem envolver competição mas nem todos, outros, envolver a sorte/azar, como aqueles em que há dados, outros, ainda, envolvem a mera fruição, como a ciranda de roda. Isso acontece não apenas com a noção de "jogos/brincadeiras", mas com o processo de categorização em geral. Jogos/brincadeiras não compartilham um mínimo de características comuns que possibilitem ser classificados como tais, o que eles apresentam são semelhanças, afinidades entre si, como os membros de uma família. Assim, Wittgenstein 
propôs que as categorias são, na verdade, organizadas em uma lógica de "Familienähnlichkeiten" (traduzido para o inglês como "family resemblance"), ou seja, partindo-se daquelas semelhanças que fazem as pessoas reconhecerem as outras como pertencentes a uma mesma família. Além disso, as categorias não têm limites bem definidos, pois, como na categoria "Spiel", não é possível traçar um limite no qual a noção de jogo começa ou termina.

Durante a década de 1970, Eleanor Rosch, em uma série de publicações na área de psicologia cognitiva, propôs a teoria dos protótipos. ${ }^{5}$ Seguindo o raciocínio de Wittgenstein e experimentos conduzidos por ela própria e um time de pesquisadores, Rosch notou que as categorias em geral apresentam exemplos mais emblemáticos e menos emblemáticos. Os exemplos que são mais emblemáticos da categoria, ou "melhores", ela denominou "protótipos". Com seus experimentos replicáveis, ela e sua equipe conseguiram identificar o que foi denominado "efeito prototípico": para a categoria "pássaros" (“birds"), o "pardal" ("sparrow") é um exemplo melhor do que coruja e águia, que, por sua vez, são melhores exemplos do que avestruz, ema e pinguim.

Outra grande contribuição de Rosch (1976) e sua equipe de pesquisadores é a demonstração de que há uma hierarquia no sistema de categorização. Por exemplo, "cadeira" e "cachorro" são categorias de "nível básico" ("basic level"), enquanto "de balanço" e "golden retriever" são categorias "subordinadas" ("subordinate") às categorias "cadeira" e "cachorro", respectivamente; do mesmo modo, "animal" e "mobília" são categorias "supraordenadoras" ("supraordinate") das categorias "cachorro" e "cadeira", respectivamente. As categorias de nível básico, como "cadeira" e "cachorro" são o nível mais alto na hierarquia na qual uma única imagem mental reflete a categoria inteira. É também o nível em que os indivíduos identificam mais rápido os membros da categoria e no qual a maior parte do nosso conhecimento é organizado. ${ }^{6}$ Seguindo a lógica dessa hierarquia proposta por Rosch e sua equipe, é possível concluir que "monstro" não é uma "categoria de nível básico", como "cachorro" ou "cadeira". Para nós, ela é uma categoria supraordenadora em que não há uma imagem mental única que reflete a categoria inteira.

A essas duas noções, de que categorias não têm limites rígidos e de que há uma hierarquia no processo de categorização, vem se juntar a de que categorias não são dados da realidade, mas construções culturais e linguísticas baseadas tanto na relação do indivíduo com o meio quanto no universo das percepções sociais e individuais. Além disso, as categorias não

5 Para uma lista das publicações de Rosch mais relevantes para a questão da teoria dos protótipos, ver Lakoff (1987), p. 597.

6 Para uma boa síntese do trabalho de Rosch, ver Lakoff (1987), p. 39-57. 
apenas classificam dados da realidade empírica, mas há todo um sistema de conceitos e abstrações que são classificados e categorizados, como sentimentos, números, seres abstratos etc., de modo que a ação de categorizar tem de levar em consideração necessariamente aquele que a realiza. $^{7}$

Essa exposição é importante por algumas razões. Primeiro, porque quando se pensa a categoria "monstro" como indefinível, tem-se em mente a concepção clássica ou aristotélica de categoria, sob a qual há um conjunto mínimo de características necessárias a serem cumpridas para que uma criatura seja considerada um "monstro". Todavia, "monstro" é uma categoria que não tem limites bem definidos e não há uma condição necessária e suficiente que possa ser apontada como cumprida por todos os indivíduos que eventualmente venham compor a categoria "monstro": um corpo não normatizado é uma característica que pode ser suficiente para classificar algo como um "monstro", conquanto não seja uma característica necessária; um comportamento violento e ameaçador pode, igualmente, ser um elemento suficiente para inserir algo nessa categoria, embora também não seja uma característica imprescindível. Como para "Spiel", é difícil precisar onde a noção de monstro começa e onde ela termina.

Essas duas características, a da inexistência de limites bem definidos a de condições necessárias e suficientes, estão no cerne da dificuldade em se definir o que é um "monstro", somando-se ao fato de este ser culturalmente definido. O modelo de "parentesco" ("family resemblance") de Wittgenstein ou o de protótipo de Rosch, portanto, parecem ser mais adequados para entender a categoria "monstro" do que a teoria clássica. Desse modo, as dificuldades em definir "monstro" também residem na inadequação das ferramentas classificatórias utilizadas e não em ser uma categoria "indefinível por definição", como apontam, por exemplo, Cohen (1996), Asma (2011) e Mittman (2013). Ademais, a complexidade não reside somente no que quer que venha a ser "monstro", mas na própria sociedade da qual fazem parte os estudiosos que estão tentando defini-lo. Está-se tentando entender e circunscrever uma categoria conceitual nos séculos XX e XXI com ferramentas próprias do XIX.

Em um artigo de 2010, o linguista africano Swanepoel explora o verbete "monstro" em vários dicionários de língua inglesa e mostra como as características apresentadas por eles que seriam definidoras da categoria não são nem necessárias nem suficientes para defini-la.

7 A obra de Lakoff (1987) apresenta um grande resumo dos estudos de cognição que foram realizados no século XX e defende principalmente que o processo cognitivo está calcado na "mente corporificada" ("embodied mind") em sua relação com o ambiente no qual estão inseridos essa mente e esse corpo. A noção de mente corporificada ressalta que a mente não existe sem um corpo, e este, por sua vez, influencia no modo como a mente funciona. 
Embora esse seja um critério bastante aristotélico de definição de uma categoria, é uma constatação importante de como ele é falho no caso dessa categoria especificamente. Swanepoel propõe que o Modelo Cognitivo Idealizado ou ICM ("Idealized Cognitive Model") do qual a categoria "monstro" faz parte no mundo ocidental é o da "Grande Cadeia de Seres" (“Great Chain of Being”), um modelo cultural que organiza o mundo em categorias de seres dentro de uma hierarquia de acordo com suas propriedades. ${ }^{8}$ Nesse modelo cultural, seres que estão mais acima dominam as formas que estão mais abaixo em virtude de suas naturezas superiores. Lakoff (1989, p. 166 e ss.) distingue duas versões da Grande Cadeia de Seres: uma básica e uma estendida. A que ele chama "básica" compreende a relação dos seres humanos com as formas de existência que lhe são "inferiores", como os animais, as plantas e substâncias inanimadas; a estendida, por sua vez, compreende a relação dos seres humanos com a sociedade, com Deus e com o universo ou cosmo. ${ }^{9}$ Enquanto a básica é mais centrada em discriminar a natureza dos diferentes níveis, a estendida é uma extensão metafórica que cria esses diferentes níveis que, por sua vez, também são entendidos metaforicamente como "seres": uma sociedade "doente" é uma expressão metafórica que exemplifica o modo de compreendermos a noção de sociedade enquanto um corpo vivo. Cada um dos níveis dentro da Grande Cadeia de Seres tem sua hierarquia interna, e como exemplo da hierarquia interna no nível cósmico, Lakoff (1989, p. 209) utiliza os deuses olímpicos com Zeus acima dos demais deuses, embora acima dele estejam "forças cósmicas sobrenaturais mais fortes”, como as Moiras, mencionando que Zeus foi obrigado a obedecê-las na determinação de que seu filho Sarpédon tinha de morrer.

A Teogonia, por exemplo, é um poema da tradição hexamétrica arcaica que se concentraria em expor o ICM da Grande Cadeia estendida, porque se propõe a explicitar a hierarquia acima dos seres humanos. As categorias fundamentais que formam a Grande Cadeia exposta nesse poema, e na poesia hexamétrica arcaica como um todo, são as de "mortal" (expressa principalmente pelos termos öv $\theta \rho \omega \pi o \varsigma, \beta \rho o \tau o ́ \varsigma$ ou $\theta v \eta \tau o ́ \varsigma)$ e "imortal"

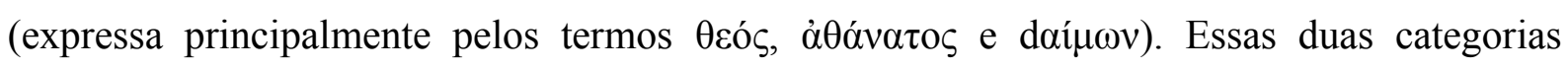
marcam a distinção entre o que compõe a Cadeia estendida e o que está abaixo dela. Os humanos que denominamos "heróis" estão quase todos na Cadeia básica porque são mortais, contudo, são humanos que, por terem ascendência divina, são considerados superiores aos mortais em geral. Embora tenham uma origem híbrida, tendo nascido da união de deuses com mortais humanos, os heróis se mantêm como parte da Cadeia básica, já que sua ascendência

8 Para ICMs, ver Lakoff (1987), p. 68 e ss. Para a Grande Cadeia de Seres ("Great Chain of Beings"), ver Lakoff e Turner (1989), p. 166 e ss. e p. 208 e ss.

9 Cf. Apêndice I. 
divina não os torna imortais, sendo Héracles um dos únicos casos de ascensão à categoria de imortal. Ainda que heróis recebam culto, uma prática florescente entre 750-650 a.C., este está fundamentalmente ligado à formação da pólis que o cultua, e tem sua origem, muito possivelmente, no culto aos ancestrais. ${ }^{10}$ A propósito, a categoria "herói" na poesia hexamétrica arcaica também apresenta complicações semelhantes à categoria "monstro", já

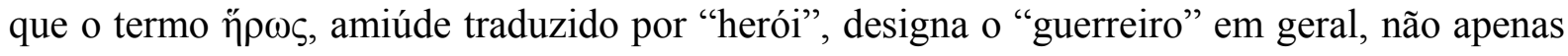
aqueles que têm origem divina, conquanto designe o guerreiro em um época da história dos cosmo em que os homens eram considerados superiores. ${ }^{11}$ De todo modo, a nossa categoria

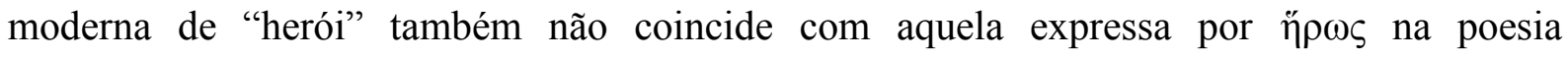
hexamétrica arcaica.

Quanto àquelas criaturas que consideramos monstruosas, algumas são declaradas imortais, como Estenó e Euríale (Teog., v. 274-278), as duas Górgonas irmãs de Medusa, Équidna (Teog., v. 304-305) e Cila (Od., 12.118), outras são mortais, já que foram abatidas por heróis: Medusa por Perseu (Teog., v. 274-281), Gerioneu, Orto (Teog., v. 287-294), Hidra de Lerna (Teog., v. 313-318) e Leão de Nemeia (Teog., v. 326-332) por Héracles e Quimera por Belerofonte (Teog., v. 319-325). Essa variação mostra que nem mesmo a distinção fundamental "mortal" e "imortal" é válida para colocar essas criaturas em uma categoria única. Algumas fazem parte da Cadeia estendida, outras não. Na verdade, dentro da parte da história do cosmo sendo narrada na Teogonia, o conjunto de descendentes de Fórcis e Cetó é o único a apresentar essa variação mortal/imortal, introduzindo os primeiros seres mortais do poema. Clay (1993, p. 106) aponta que esse conjunto de descendentes apresenta elementos que violam categorias fundamentais como "mortal/imortal", "velho/jovem", "masculino/feminino". Parece-me, contudo, o contrário: nesse grupo é que aparece pela primeira vez a distinção "mortais" em relação às outras entidades nascidas nessa narrativa; já a "velhice", que também é uma característica definidora dos mortais, aparece com Nereu, filho do Mar, e irmão de Fórcis e Cetó, e é tornada a característica principal das Velhas, suas sobrinhas. Quanto à violação do "masculino/feminino", Clay a atribui à progênie de Fórcis e Cetó muito possivelmente pelo fato de a parte masculina do casal gerar um descendente, como Espadouro gera Gerioneu (Teogonia, v. 287). Contudo, Nereu já fora gerado pelo Mar sozinho e Afrodite surgiu da espuma (ó $\alpha \varphi \rho o ́ \varsigma$ ) ejaculada pelo pênis de Céu depois de ter sido atirado no Mar. Portanto, essa violação “masculino/feminino” não pode ser considerada uma

10 Para questões concernentes ao culto funerário, culto heroico e culto aos ancestrais, cf. Snodgrass (2000 [1971]), Morris (1991), Alcock (1991) e Antonaccio (1994 e 1995). Discuti brevemente essas questões em minha dissertação de mestrado (cf. Zanon, 2009, p. 88 e ss.).

11 Cf. Nagy (2013). 
característica particular do catálogo; acrescente-se ainda o nascimento de Atena a partir da cabeça de Zeus.

É com os descendentes de Fórcis e Cetó, portanto, que a mortalidade é introduzida no poema, característica que separa fundamentalmente homens e deuses, e a velhice é introduzida por seu irmão Nereu e personificada por suas filhas, as Velhas, uma característica que não chega a separar homens e deuses, como a imortalidade, mas que passa a ser atribuída quase que exclusivamente aos mortais. Dentre os descendentes de Fórcis e Cetó é que estão também os primeiros exemplares do reino animal a serem apresentados no poema. ${ }^{12}$ Dentre eles estão o cavalo Pégaso, os cães Orto e Cérbero, Quimera, uma mistura de cabra, leão e serpente, o Leão de Nemeia e a serpente que guarda um rebanho de ouro. Alguns dos descendentes de Fórcis e Cetó, sendo imortais, fariam parte da Cadeia estendida, e os mortais começariam a compor a Cadeia básica, da qual fazem parte também os heróis. Os descendentes de Fórcis e Cetó, portanto, dariam início na Teogonia à formulação da Cadeia básica, com a introdução da mortalidade e da animalidade.

Segundo Versnel (2011, p. 384), ${ }^{13}$

[...] Uma das mais celebradas noções introduzidas pela École de Paris, especialmente por Marcel Detienne, é a de que, de acordo com os gregos, o status do homem se situa "entre os animais e os deuses" ("entre bêtes et dieux"). Ele tinha um predecessor em Aristóteles, que, em seu Ética a Nicômaco, refere-se com frequência a deuses e a animais como os dois extremos opostos que definem a existência humana. $[\ldots]$

Há uma questão, contudo, totalmente envolvida nos critérios de monstruosidade que é a do antropomorfismo, ou seja, a projeção de características humanas. O antropomorfismo é uma noção que traz consigo inúmeras dificuldades porque é difícil estabelecer seus limites. A projeção de características humanas se estende desde expressões metafóricas que atribui traços da anatomia humana a objetos, como "o braço da cadeira", até a atribuição de características psicológicas como a de volição quando se diz algo como "o carro não quer ligar". ${ }^{14}$ Como critério para se estabelecer o que é monstruoso, o antropomorfismo é

12 Talvez o primeiro elemento da fauna seja introduzido pelas Harpias, filhas de Taumas (ou "Espanto"), também descendentes do Mar, já que apresentam asas e acompanham pássaros e rajadas de vento. Embora o poema nada informe acerca do restante de sua anatomia, elas têm belos cabelos (Teogonia, v. 267), o que aponta para uma forma não somente de pássaro, mas minimamente antropomórfica. Acerca do antropomorfismo, cf. adiante.

13 Versnel (2011, p. 384): “[...] One of the most celebrated notions introduced by the École de Paris, especially by Marcel Detienne, is that according to the Greeks man's status was "between beasts and gods" ("entre bêtes et dieux"). He had a predecessor in Aristotle, who, in his Ethica Nicomachaea, often refers to gods and beasts as the two opposite extremes defining human existence. [...]".

14 Para um resumo das perspectivas de Pascal Boyer e Steven Mithen, dois pesquisadores que investigam acerca das origens do pensamento antropomórfico, cf. Knight e Power (1988). Para uma discussão entre Boyer e Mithen acerca de suas propostas, cf. Mithen e Boyer (1996). Cf. em Boyer (1996) a distinção entre a 
certamente um problema quando a monstruosidade é vista em termos psicológicos em detrimento da deformidade física, como no caso de assassinos em série, ou quando o monstro pode ser, na verdade, um vírus mortal, uma forma de vida que pode se constituir de uma única molécula de DNA e RNA capaz de dizimar milhares de pessoas, como o vírus do ebola, por exemplo. ${ }^{15}$ Debatida atualmente dentro do âmbito da robótica, a questão do antropomorfismo encontra problemas ontológicos acerca dos limites do que vem a ser humano e do quanto essa humanidade pode ser replicada. ${ }^{16}$

No caso das divindades presentes na poesia hexamétrica arcaica, o antropomorfismo é um elemento variável em sua caracterização. A deusa Terra, por exemplo, é e não é antropomórfica. ${ }^{17}$ Mesmo quando os deuses da poesia hexamétrica arcaica assumem uma forma antropomórfica, eles não estão limitados às características humanas: eles são maiores, seu talhe e sua força são amplificados, seu corpo emite uma luminosidade que impossibilita os mortais de olharem para eles diretamente, tornam-se frequentemente invisíveis e podem viajar com a velocidade do pensamento, como o faz Hera na Ilíada (15.80-83) e Apolo no h.Ap (v. 182-188). Mudam também de forma para atingir seus objetivos, transformando-se inclusive em animais, como Apolo no h.Ap. ${ }^{18}$

Versnel (2011, p. 379 e ss.) lida muito bem com essa questão, consciente da amplitude

projeção de características anatômicas daquela de características psicológicas. Acerca das metáforas usadas cotidianamente ligadas à personificação como resultado de uma mente corporificada, cf. Lakoff e Johnson (2003 [1980]).

15 Na ficção, essa capacidade destrutiva que um vírus pode possuir foi extrapolada no filme Contágio, de 2011, dirigido por Steven Soderbergh.

16 Cf. Vidal (2007), para um estudo comparativo entre a antropomorfização das divindades cultuadas atualmente na região de Himachal Pradesh no norte da Índia com a praticada pela robótica. Cf. p. 922, na qual Vidal faz a intrigante comparação entre o modo concreto com o qual as divindades interferem na vida dessa comunidade e os papéis assumidos pelos deuses na Ilíada e na Odisseia.

17 Graziosi $(2014$, p. 27): “[...] Hesiod's Earth is clearly the actual earth - with mountains, rivers, caves and valleys - but she is also the Earth Mother, the goddess Gaia, an anthropomorphic deity ready to castrate her partner in order to nurture her children. Modern editors have great trouble deciding when to capitalise Earth's name and when to leave it lower case, treating the term as referring simply to matter. The ancient Greeks did not have that problem, because they had only one letter size, but the real issue is not typographical but conceptual: Hesiod does not distinguish between cosmic principles, anthropomorphic deities and material realities. The power of his gods resides precisely in a mixture of different apprehensions. Earth is the physical earth, but also a 'broad-breasted' goddess. A cave is a cave, and it is also her womb: monsters and gods are nurtured there. Athena, for her part, is both an anthropomorphic goddess and rational thought.".

18 Acerca dos corpos dos deuses, cf. Vernant em Malamoud e Vernant (2003 [1986], p. 19-58). Na mesma obra, cf. Frontisi-Ducroux (p. 259-286) a respeito dos limites do antropomorfismo das divindades gregas, principalmente em relação aos deuses Hermes e Dioniso. Para uma crítica do antropomorfismo dos deuses em Homero e Hesíodo, não poderia deixar de citar os famosos fragmentos de Xenófanes: "Homero como Hesíodo atribuíram aos deuses tudo / quanto entre os homens é infâmia e vergonha / roubar, raptar e enganar mutuamente." (frag. 11)"; "Mas os mortais creem que os deuses são gerados, / e que têm roupas como as suas, e têm voz e têm corpo." (frag. 14); "Os etíopes < dizem que seus deuses> são negros de nariz chato / os trácios <dizem serem $>$ de olhos verdes e ruivos." (frag. 16); "Mas se tivessem mãos os bois, <os cavalos $>$ e os leões, / quando pintassem com as mãos e compusessem obras como os homens, / cavalos como cavalos, bois semelhantes aos bois / pintariam a forma dos deuses e fariam corpos / tais como fosse o próprio aspecto $<$ de cada um>." (frag. 15). Tradução de Santoro (2011), com alterações. 
da noção de antropomorfismo, que não se restringe à forma humana: ${ }^{19}$

O pisco-de-peito-ruivo que pensa ser dono do nosso jardim está com fome. Ele bate na janela. "Escute, o passarinho quer entrar, ele quer nossa companhia", diz minha esposa. "É, ele quer um pedacinho disso ou daquilo", respondo. E ficamos felizes: se um passarinho nos ama, isso certamente prova que somos boas pessoas. Meu problema, contudo, é que na verdade eu sei mais que isso desde que li uns livros escritos por essa aterrorizante raça de pesquisadores geralmente referida como behavioristas. Lá, aprendi que nossa interpretação dos motivos do passarinho é uma instância típica de "antropomorfismo": "a atribuição de experiências mentais e motivos humanos a animais. [...]"

Como um dos poucos classicistas conscientes dessa amplitude, Versnel está também a par de sua inevitabilidade: ${ }^{20}$

[...] se por natureza e criação o homem não consegue deixar de projetar motivos, afeições e emoções antropomórficos sobre o comportamento animal, embora animais como o nosso pisco-de-peito-ruivo se apresentem sob aparências bastante não humanas, quão infinitamente mais natural, autoevidente e inevitável não é a antropomorfização dos deuses, que o homem criou à sua própria imagem, e que, quando quer que se apresente visível, como por exemplo em uma epifania, tende a corroborar em vez de desmentir tal imagem? [...] Somos simplesmente incapazes de conceber um deus completamente não antropomórfico, já que não conseguimos falar dele/dela em termos não antropomórficos. Um problema chave é a linguagem. A religião se comunica em linguagem humana; também o homem quando fala sobre ou ora a seus deuses e também os deuses (na maioria das vezes) quando eles oferecem uma resposta. E também os pesquisadores das Clássicas. [...]

Adiante, Versnel (2011, p. 388) conclui::

Deuses são piscos-do-peito-ruivo. Ou pior. Piscos-do-peito-ruivo existem sem a iniciativa ou intervenção humana. Eles formam uma das numerosas telas vivas sobre

19 Versnel (2011, p. 379): "The robin who thinks he owns our garden is hungry. She taps at the window. "Listen, the robin wants to come in, he seeks our company," says my wife. "Yes she wants a bite of this or that" say I. And we are happy: if even a robin loves us, this surely proves us to be nice people. My problem, however, is that actually I know better since I read a few books written by that terrifying race of scholars generally referred to as behaviourists. There I learned that our interpretation of the robin's motives is a typical instance of 'anthropomorphism': "the ascription of human mental experiences and motives to animals. [...]"

20 Versnel (2001, p. 381-382): “[...] if by nature and nurture man cannot but project anthropomorphic motives, affects and emotions onto animal behaviour, although animals like our robin present themselves in very unhuman appearances, how infinitely more natural, self-evident and unavoidable is the anthropomorphization of gods, whom man created in his own image, and who, whenever visually available, as for instance in an epiphany, tend to corroborate rather than to falsify that image? [...] We simply are unable to conceive a completely non-anthropomorphic god since we cannot speak about him/her in nonanthropomorphic terms. One key problem is language. Religion speaks human language; so does man when he speaks about or prays to his gods and so do the gods (mostly) when they grant an answer. And so do classical scholars. [...]"

21 Versnel (2011, p. 388): "Gods are robins. Or worse. Robins exist without human initiative or intervention. They form one of the numerous live screens upon which man projects his human characteristics. Gods do not exist without man. They are projections because they are human creations. Hence, they are like mortals in form and behaviour. [...]". 
as quais o homem projeta suas características humanas. Deuses não existem sem o homem. Eles são projeções porque são criações humanas. Portanto, eles são como mortais em forma e comportamento. [...]

Se pensarmos nas criaturas às quais essa tese se dedica, poucas podem ser consideradas não antropomórficas ou totalmente teriomórficas. ${ }^{22}$ Os Ciclopes, semelhantes aos deuses em tudo com exceção da unicidade de seu olho, forjam o raio para Zeus, exercendo a atividade humana da metalurgia. Centímanos, com seus cem braços e cinquenta cabeças, são capazes de combater contra os Titãs lançando pedras contra eles, sendo também providos de fala. Tifeu, com suas cem cabeças de serpente, tem braços, pernas, ombros e, dentre os vários sons que emite, às vezes soava de modo a ser entendido pelos deuses. Algumas criaturas, contudo, parecem ser estritamente teriomórficas: os cães Orto e Cérbero, Quimera, Esfinge, de quem nada é dito acerca de sua anatomia, e a serpente do rebanho de ouro; estas não apresentam elementos antropomórficos, podendo ser agrupadas junto com a serpente no h.Ap. Na Odisseia, Polifemo é denominado ơví $\rho$ ("varão") e as Sirenas cantam matéria épica. Cila e Caríbdis, contudo, são casos particulares: Cila recebe uma descrição que a coloca na posição de um implacável animal caçador e Cila é a personificação de um

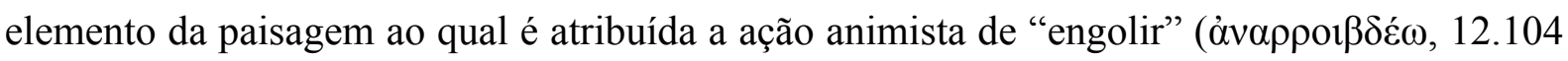

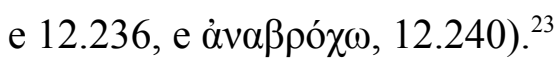

Portanto, o antropomorfismo, por sua ubiquidade, não serve como critério fundamental para designar o lugar ocupado por essas criaturas na Grande Cadeia de Seres. ${ }^{24}$ Antropomórficos ou teriomórficos, aqueles que são ditos imortais fazem parte da Cadeia estendida, sendo capazes de ações (sobre)humanas como os Ciclopes, que forjam o raio para Zeus, ou os Centímanos, que combatem os Titãs, ou mesmo Tifeu, que quase usurpa o trono

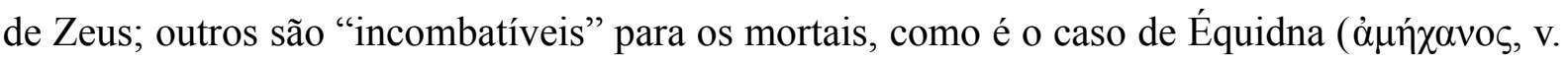

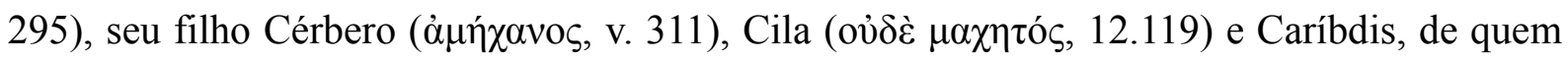
nem mesmo o deus Posêidon poderia proteger Odisseu (12.107). O que está em jogo, mais do

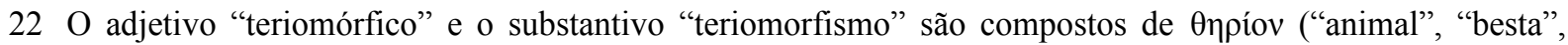
"fera") + português, o termo "theriomorphic" é mais comum em inglês (cf., por exemplo, Versnel, 2009, p. 381), sendo usado com certa frequência pela bibliografia que trata do assunto da monstruosidade e também por aquela acerca de divindades que apresentam forma híbrida de animal e ser humano, como os deuses egípcios, por exemplo.

23 Cf. a leitura de Versnel (2011, p. 386), já mencionada no capítulo 5, em relação ao modo como os ciclopes são descritos na Odisseia: "[...] they boast a fairly recognizable humanlike livelihood, for which they are equipped with legs, arms, ears, all of gigantic seize [sic] it is true, but of human form; [...].

24 A propósito, talvez seja oportuno levantar a questão da, por vezes, limitada noção de antropomorfismo apresentada pelos estudiosos da Antiguidade e se perguntar por que essa noção é considerada de modo tão estrito quando em outras áreas do conhecimento científico ela é tão mais abrangente e problematizadora. Acredito que tal "defasagem" teórica mascara os pressupostos eurocêntricos que dão base às ideias de exclusivismo ou milagre grego e refreia a incorporação de perspectivas mais amplas e multiculturais no campo do mito. 
que qualquer configuração anatômica, é o comportamento benéfico ou não em relação aos mortais e em relação ao poder de Zeus como o governante do cosmo. Como dito pelo capitão Flint, em um episódio da série Black Sails, "todo mundo é um monstro para alguém”, uma frase que tornei epígrafe da "Introdução". Em sua fala, "monstro" assume o sentido amplo de "antagonista", "algoz", e seria possível pensar em Zeus como o "monstro" para Tifeu e Odisseu como o "monstro" para Polifemo, tivéssemos um poema que relatasse sua perspectiva da narrativa. Adicionalmente, o aspecto benéfico aos mortais pode ainda ser relativizado, já que Zeus envia Pandora como um mal aos mortais (Teogonia 585-612 e Trabalhos e Dias 54-105 e 373-378) e Apolo é capaz de enviar pestes, como no canto 1 da Ilíada.

Ao fim e ao cabo, a mortalidade/imortalidade é o elemento essencial, na poesia hexamétrica arcaica, que distingue o que é parte da Cadeia de Seres estendida da Cadeia de Seres básica. Dentre as criaturas que se encontram na Cadeia básica por serem mortais, o critério é o do teriomorfismo mais do que o do antropomorfismo. Para Medusa, seu filho Espadouro e seu neto Gerioneu, há um antropomorfismo envolvido em sua concepção, embora não explicitado: Medusa se deitou com o deus Posêidon e teve sua cabeça cortada por Perseu, originando Pégaso e Espadouro, este nascido com uma espada de ouro nas mãos; Gerioneu apresenta três cabeças que, por falta de descrição, podem ser inferidas como antropomórficas. Contudo, Orto, Hidra de Lerna, Quimera, Esfinge, Leão de Nemeia e a serpente que guarda um rebanho de ouro são todos animais, ainda que Quimera seja um animal múltiplo. Com exceção de Espadouro e da serpente, todos estes outros são abatidos por heróis ou porque se interpõem entre eles e um objetivo a ser cumprido, ou porque se apresentam como ameaça à vida humana. Para combater esses animais que se destacam pela capacidade destrutiva, seja de aniquilar mortais e seus rebanhos, seja de mantê-los longe de algo que não deve ser adquirido por eles, são necessários mortais superiores em força e também em capacidade destrutiva, homens que são favorecidos pelos deuses imortais.

Contudo, apesar dessa separação contundente entre "mortais" e "imortais", os poemas hesiódicos e a poesia homérica épica e hínica mostram que o ICM (Modelo Cognitivo Idealizado) subjacente a esses poemas considera que o que estou chamando de "Grande Cadeia estendida" e o nível humano estão em frequente interação: os deuses estão constantemente presentes nos assuntos humanos e as ações humanas também impactam as decisões divinas. Uma das modalidades dessa interação é a comunicação da divindade com os mortais por meio do presságio, amiúde designado pelo termo $\tau \dot{\varepsilon} \rho \alpha \varsigma$ na poesia hexamétrica arcaica. Portanto, conforme demonstrado no capítulo 2, diferente do que ocorre em 
Aristóteles, $\tau \varepsilon ́ p \alpha \varsigma$ enquanto um $\sigma \tilde{\eta} \mu \alpha$ enviado pelos deuses, não designa nessa poesia uma categoria de seres, mas de fenômenos pelos quais se observa a interação entre as duas esferas, a divina com a humana. Desse modo, $\tau \dot{\varepsilon} \rho \alpha \varsigma$ não designa um monstro, e sim o elemento reconhecível pelos mortais do ato comunicativo da divindade.

Foi explicitado também no capítulo 2 que, para ser reconhecido enquanto uma mensagem divina, o elemento do extraordinário é imprescindível. Compartilhando grande parte de seu campo semântico com $\tau \dot{\varepsilon} \rho \alpha \varsigma, \pi \varepsilon ́ \lambda \omega \rho$ e derivados expressam essa extraordinariedade amiúde em termos de enormidade. Nem mesmo aí, com essa ideia de enormidade expressa por $\pi \varepsilon ́ \lambda \omega \rho$ e derivados, nossa noção moderna de monstro coincide com a expressa pelos termos usados na poesia hexamétrica arcaica, pois neles, habitam deuses, e nos nossos, uma infinidade de monstros "desendeusados", para me apropriar da expressão de Pierucci (2013).

Antes de partir para Oxford para fazer o doutorado sanduíche, meu companheiro Uiran carinhosamente me presenteou com a bela edição de "Onde Vivem os Monstros", publicada em 2009 pela recentemente extinta Cosac Naif, com tradução de Heloisa Jahn. O ilustrador americano Maurice Sendak escreveu e ilustrou o livro destinado ao público infantil chamado originalmente de "Where the Wild Things Are", publicado em 1963. Essa obra de Sendak foi adaptada para o cinema sob a direção de Spike Jonze em 2009, e seu título em português é o mesmo da tradução do livro. Como tanto a tradução de Heloisa Jahn quanto o filme foram lançados em 2009, é difícil saber quem inspirou quem. De todo modo, a expressão "wild things" virou "monstros" na tradução brasileira, seja do livro, seja do filme. A propósito, o livro acaba de ganhar uma tradução para o latim, intitulada Ubi fera sunt, realizada por Richard A Lafleur (2016). A história tem início quando Max, o menino protagonista, veste uma fantasia de lobo e sai fazendo bagunça pela casa, razões pelas quais sua mãe o chama de "wild", traduzido como "monstro" por Heloisa Jahn. Como resposta à mãe, Max diz "Olha que eu te como!", e ela o manda para a cama sem comer nada. Em seu quarto, então, Max presencia o surgimento de uma floresta e um oceano pelo qual ele navega "noite e dia / semana vai semana vem / durante quase um ano / para onde vivem os monstros (to where the wild things are)". Lá, o menino se torna rei e "dá início à bagunça geral", mas depois de pôr um fim à bagunça que ele mesmo começou, Max sente o cheiro de comida, navega de volta "por mais de um ano / semana vai semana vem / e um dia inteiro" e encontra o jantar 
esperando por ele, ainda quentinho.

Nessa pequena aventura odisseica de Max, em que ele domina as criaturas selvagens com o olhar e ao retornar para casa encontra o jantar servido, não há uma ocorrência sequer da palavra "monstro". Ao se deter nas ilustrações de Sendak, contudo, é possível compreender a escolha feita pela tradutora. "The wild things", ou as criaturas selvagens que Max encontra, parecem-se mais com humanos vestindo fantasias, alguns são híbridos de diferentes animais, outros, de animais com humanos. Eles têm dentes para fora, garras e chifres. Como manifestações da imaginação de Max, que foi mandado para cama por ser "wild", termo que é usado em inglês em relação ao comportamento agitado e incorrigível de algumas crianças, essas criaturas que ele imagina estão relacionadas à sua compreensão do que seja "wild" e não do que seja "monstro": elas indicam a capacidade de Max de relacionar, por meio do que a palavra "wild" pode significar, o ambiente selvagem de uma floresta e seus animais com o ambiente doméstico em que ele está inserido com sua fantasia de lobo.

Enquanto Max, em sua breve odisseia, encontra "wild things", torna-se rei delas e pode, saciado de bagunça, voltar e aproveitar seu jantar ainda quentinho, eu, por outro lado, não encontrei os monstros prometidos no título do livro. Algo semelhante ocorreu ao investigar os monstros da poesia hexamétrica arcaica. Em ambas as situações, porém, encontrei algo maior até mesmo do que os monstros, encontrei o elemento do extraordinário, do maravilhoso. Às vezes, olhar embaixo da cama e perceber que não há nada lá além de pó pode ser mais assustador do que encontrar o pior dos pesadelos. Mas a nossa imaginação pode sempre dar um jeito nisso: ainda há o guarda-roupa, atrás da porta, aquele cantinho escuro do quarto que não dá para enxergar. Quando ainda não conseguimos encontrar nada lá, podemos procurar em obras de literatura, cinematográficas, nas artes plásticas e nos quadrinhos. Não tenho dúvida de que a poesia hexamétrica arcaica era um desses "lugares" onde residia o extraordinário para aqueles que puderam presenciar sua performance e usufruir de suas narrativas. Nela, os deuses, antropomórficos ou não, tinham sempre algo extraordinário ou maravilhoso a revelar. 


\section{REFERÊNCIAS}


BAGNALL, R. S. et al. (eds.). (2013). The Encyclopedia of Ancient History. Oxford: WileyBlackwell.

BAILLY, Anatole. (2000). Le Grand Bailly: Dictionnaire Grec Francais. Paris: Hachette.

BEEKS, Robert. (2010). Etymological Dictionary of Greek. Leiden and Boston: Brill.

CANCIK, Hubert; SCHNEIDER, Helmut; PAULY, August F. von; LANDFESTER, Manfred; EGGER, Brigitte; \& DERLIEN, Jochen. (1996-2003). Der neue Pauly: Enzyklopädie der Antike. Stuttgart: J.B. Metzler.

; __ SAlAZAR, C. F. (2002). Brill's New Pauly: encyclopaedia of the ancient world (English ed. / managing editor, Christine F. Salazar.). Leiden: Brill.

CHANTRAINE, Pierre. (1958). Grammaire Homérique. Tome 1: Phonétique et Morphologie. Paris: Librarie C. Klincksieck.

Éditions Klincksieck.

(1968-1977). Dictionnaire etymologique de la langue grecque. Tomes I-IV. Paris:

CUNLIFFE, Richard John. (1963). A Lexicon of the Homeric Dialect. University of Oklahoma Press.

FINKELBERG, Margalit (ed.). (2011). The Homer Encyclopedia. 3 vols. Malden and Oxford: Wiley-Blackwell.

GAGARIN, M.; FANTHAM, E. (2010). The Oxford encyclopedia of ancient Greece and Rome. New York; Oxford: Oxford University Press.

GRIMAL, Pierre. (2000). Dicionário da Mitologia Grega e Romana. $4^{\mathrm{a}}$ ed. Rio de Janeiro: Bertrand Brasil.

HOFINGER, M. (1975-1978). Lexicon Hesiodeum cum indice inverso (Tomes I-IV). Leiden: Brill.

HORNBLOWER, Simon; SPAWFORTH, Antony. (eds.). (1998). The Oxford Companion to Classical Civilization. Oxford: Oxford University Press.

LIDDELL, Henry George. SCOTT, Robert. (1940). A Greek-English Lexicon. Revised and augmented throughout by Sir JONES, Henry Stuart with the assistance of MCKENZIE, Roderick. Oxford: Clarendon Press, 1940.

LIMC. (1981-1999). Lexicon Iconographicum Mythologiae Classicae. Zürich-München, Düsseldorf: Artemis \& Winkler Verlag.

NEVES, Maria Helena de Moura; DEZZOTTI, Maria Celeste C.; MALHADAS, Daisi. (coord.). (2006-2010). Dicionário Grego-Português. 5 vols. Cotia: Ateliê Editorial. 
PAULY, August F. Von.; WISSOWA, Georg; KROLL, Wilhelm; WITTE, Kurt. (1894). Paulys Real-Encyclopädie der classischen Altertumswissenschaft. (Neue Bearbeitung / unter Mitwirkung zahlreicher Fachgenossen herausgegeben von Georg Wissowa.). Stuttgart; Munchen: J.B. Metzler; Alfred Druckenmuller.

SHIPLEY, Graham et. al. (eds.). (2006). The Cambridge dictionary of classical civilization. Cambridge: Cambridge University Press.

SNELL, Bruno (ed.). (1955-2010). Lexikon des frühgriechischen Epos (LfgrE). 25 vols. Göttingen: Vandenhoeck und Ruprecht.

WILSON, Nigel G. (ed.). (2006). Encyclopedia of ancient Greece. New York ; London: Routledge.

ZIEGLER, K.; SONTHEIMER, W. (1964-1975). Der Kleine Pauly: Lexikon der Antike. (5 vols.). Stuttgart: ADruckenmüller. 
FONTES:

EDIÇÕES, TRADUÇÕES E COMENTÁRIOS

ALEXANDRE JR., Manuel. (Trad.). (2006). Aristóteles: Retórica. Lisboa: Imprensa Nacional-Casa da Moeda.

ALLEN, Thomas. (1917). W. Homeri: Opera. Tomo III: Odisseia I-XII. 2nd ed. Oxford. . (1919). Homeri: Opera. Tomo IV: Odisseia XIII-XXIV. 2nd ed. Oxford. ; (1920). MONRO, D. B. Homeri: Opera. Tome I: Iliad I-XII. 3rd ed. Oxford. . (1920). Homeri: Opera. Tome II: Iliad XIII-XXIV. 3rd ed. Oxford.

Clarendon Press.

; HALLIDAY, W.; SIKES, E. (1936). The Homeric Hymns. 2nd ed. Oxford:

ARRIGHETTI, Graziano. (1998). Esiodo: Opere. Intr., trad. e comentário. Torino: Einaudi-Gallimard.

ASHERI, David; LLOYD, Alan B; CORCELLA, Aldo; MURRAY, Oswyn; MORENO, Alfonso; GRAZIOSI, Barbara. (2007). A commentary on Herodotus books I-IV. Oxford: Oxford University Press.

BARNEY, Stephen A. (2006). The etymologies of Isidore of Seville. Cambridge: Cambridge University Press.

BENVENISTE, Émile. (1995). O Vocabulário das Instituições Indo-europeias. Vol. II. Campinas: Editora da Unicamp.

BOUlAngER, André, \& WUILlEUMIER, Pierre. (1959). Cicéron: Discours. Tome $X I X$ : Philippiques I-IV. Paris: Les Belles Lettres.

BUTLER, Samuel. (1898). The Iliad of Homer. Rendered into English prose for the use of those who cannot read the original. London, New York, and Bombay: Longmans, Green and Co.

. (1900). The Odyssey of Homer. Rendered into English prose for the use of those who cannot read the original. London: A. C. Fifield.

CABRAL, Luiz A. M. (trad.). (2004). O Hino Homérico a Apolo. Cotia: Ateliê Editorial; Campinas: Editora Unicamp.

CAMPOS, Haroldo de (trad.). (2001). Ilíada de Homero (Volume I) (2a ed.). São Paulo: Editora Mandarim. . (trad.). (2002). Ilíada de Homero (Volume II). São Paulo: Arx.

CÀSSOLA, Filippo. (1975). Inni Omerici. Verona: Lorenzo Valla - Mondadori.

CLARK, Albert Curtis; PETERSON, William (Eds.). (1905-1918). M. Tulli Ciceronis Orationes. (Vols. 1-6). Oxonii: Typographeo Clarendoniano. 
CURTIS, P. (2011). Stesichoros's Geryoneis. Leiden ; Boston: Brill.

DAVIES, Malcolm. (1991). Poetarum Melicorum Graecorum Fragmenta 1. Oxford: University Press.

DE SOUZA, Luciano Ferreira (trad.). (2010). Platão, Crátilo: estudo e tradução (Dissertação de mestrado). Universidade de São Paulo, São Paulo.

DI GREGORIO, Lambertus (recensuit). (1975). Scholia vetera in Hesiodi Theogoniam. Milano: Vita e Pensiero.

DYCK, Adrew R. (2010). Cicero: Pro Sexto Roscio. New York: Cambridge University Press.

ERBSE, Hartmut (recensuit). (1969). Scholia Graeca in Homeri Iliadem (Scholia Vetera) (Vols. 1-7). Berlin: W. de Gruyter.

EVELYN-WHITE, Hugh G. (trans.). (1982 [1914]). Hesiod, the Homeric Hymns and Homerica. Cambridge, Mass.; London, England: Harvard University Press.

FALCONER, William Armistead (trans.). (1923). Cicero: De Senectute, De Amicitia, De Divinatione. Cambridge, Mass., London: Harvard University Press.

FRAENKEL, Hermann. (ed.). (1961). Apollonii Rhodii Argonautica. Oxford: Clarendon Press. [Repr. 1970 (1st ed. corr.)].

FRAZER, James G. (trans.). (1921) Apollodorus: The Library. 2 vols. London: William Heinemann; New York: G. P. Putnam's Sons.

GOW, A. S. F. (ed.). (1952) Theocritus. vol. 1. 2nd ed. Cambridge: Cambridge University. [Repr. 1965.]

HAINSWORTH, Bryan; KIRK, G. S. (ed.). 1993. The Iliad: A Commentary. Volume III: Books 9-12. Cambridge: Cambridge University Press.

HAMILTON, Richard. (1990). Hesiod's Theogony. Bryn Mawr: Bryn Mawr College.

HEUBECK, Alfred; WEST, Stephanie; HAINSWORTH, J. B. (1998). A commentary on Homer's Odyssey. Vol. I (Introduction and Books I-VIII). Oxford: Clarendon Press.

; HOESKTRA, Arie. (1990). A commentary on Homer's Odyssey. Vol. II (Books IX-XVI). Oxford: Clarendon Press.

; RUSSO, Joseph; FERNÁNDEZ-GALIANO, Manuel. (1992). A commentary on Homer's Odyssey. Vol. III (Books XVII-XXIV). Oxford: Clarendon Press.

HOROWITZ, Mary Ann C. (1976). Aristotle and Woman. Journal of the History of Biology, 9(2), pp. 183-213.

LAFER, Mary de Camargo Neves. (2006). Hesíodo: Os trabalhos e os dias (primeira parte) (5a ed.). São Paulo: Iluminuras. 
LINDSAY, W. M. (1911). Isidori Hispalensis Episcopi Etymologiarvm sive originvm libri XX. (2 vols.). Oxonii: E Typographeo Clarendoniano.

LOURENÇO, Frederico (trad.). (2013a). Ilíada. São Paulo: Penguin Companhia. . (2013b). Odisseia. São Paulo: Penguin Companhia.

MAIR, A. W. (ed.). (1928). Oppian, Colluthus, Tryphiodorus. Cambridge, Mass.: Harvard [Repr. 1963.]

MAYHEW, R. (2010). The Female in Aristotle's Biology: Reason or Rationalization. Chicago and London: University of Chicago Press.

MAZON, Paul (texte établi et traduit par). (1928). Hésiode: Théogonie, Les Travaux et les Jours, Le Bouclier. Paris: Les Belles Lettres.

MCCRINDLE, John Watson. (1882). Ancient India as described by Ktesias the Knidian: being a translation of the abridgement of his "Indika" by Photios, and of the fragments of that work preserved in other writers. London: Trübner; Calcutta.

MENDES, Manuel Odorico (trad.); RODRIGUES, Antonio Medina (ed.). (1996). Odisseia. $2^{\mathrm{a}}$ ed. (Coleção Texto \& Arte, n. 5). São Paulo: Ars Poética; Editora da Universidade de São Paulo.

; Nienkötter, Sálvio (pref. e notas). (2008). Ilíada. Cotia: Ateliê Editorial; Campinas: Editora Unicamp.

MERKELBACH, R.; WEST, M.L. (eds.). (1967). Fragmenta Hesiodea. Oxford: Clarendon Press.

MOST, Glenn W. (ed. and trans.). (2006). Hesiod: Theogony, Works and Days, Testimonia (Vol. 1). Camdridge, Mass.; London, Eng.: Harvard University Press.

. (ed. and trans.). (2007). Hesiod: The Shield, Catalogue of Women, Other

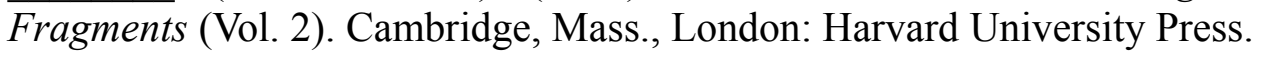

MOURA, Alessandro Rolim de (ed., trad., intro. e notas). (2012). Hesíodo: Os trabalhos e os dias. Curitiba: Segesta.

MÜLLER, Karl Otfried et al. (1841-1883) Fragmenta Historicorum Graecorum. 5 vols. Parisiis: Editore Ambrosio Firmin Didot.

MURRAY, A. T. (trans.). (1919). Homer. The Odyssey (in two volumes). Cambridge, Mass.; London: Harvard University Press; William Heinemann.

. (trans.). (1924). Homer: The Iliad (in two volumes). Cambridge, Mass., London: Harvard University Press; William Heinemann.

MURRAY, Gilbert. (1913). Euripides: Euripidis Fabulae. Vol. 3. Oxford: Clarendon Press, Oxford. 
NICHOLS, Andrew. (2011). Ctesias on India and fragments of his minor works. London: Bristol Classical.

NUNES, Carlos Alberto (trad.). (1996). Homero: Ilíada (6a ed.). Rio de Janeiro: Ediouro. . Odisseia. Rio de Janeiro: Ediouro, 2001.

PECK, A. L. (trans.). (1943). Aristotle: Generation of Animals. London: William Heinemann; Cambridge, Mass.: Harvard University Press.

PFEIFFER, Rudolfus. (ed.). (1953). Callimachus. vol. 2. Oxford: Clarendon Press.

PLASBERG, O. (Ed.). (1917). M. Tullius Cicero: De natura deorum. Leipzig: Teubner.

RACKHAM, Harris (Trans.). (1967). Cicero: De natura deorum; Academica. Cambridge, Mass.; London: Harvard University Press; William Heinemann.

RIBEIRO JR., Wilson A. (ed. e org.). (2010). Hinos homéricos. São Paulo: Editora da Unesp.

RICHARDSON, Nicholas J. (2010). Three Homeric hymns: to Apollo, Hermes, and Aphrodite. Introduction, edition and commentary. Cambridge: Cambridge University Press.

ROSS, W. D. (ed.). (1959). Aristotelis ars rhetorica. Oxford: Clarendon Press. [Repr. 1964].

SANTORO, Fernando. (2011). Filósofos Épicos I: Parmênides e Xenófaneems. Framentos. Rio de Janeiro: Fundação Biblioteca Nacional; Hexis Editora.

SCHÜLER, Donaldo (trad.). (2007). Odisseia. 3 vols. Porto Alegre: L\&PM.

SCHULTZ, C. E. (2014). A commentary on Cicero, De divinatione I. Ann Arbor: University of Michigan Press.

SERRA, Ordep. (2006). Hino Homérico IV: A Hermes. São Paulo: Odysseus.

SNELL, Bruno; MAEHLER, Herwig (eds.). (1975). Pindari carmina cum fragmentis. Pars II. Leipzig: BSB B. G. Teubner Verlagsgesellschaft.

SOLMSEN, F., MERKELBACH, R., \& WEST, M. L. (1990). Hesiodi: Theogonia; Opera et Dies; Scutum; Fragmenta Selecta (3a ed.). New York: Oxford University Press.

TORRANO, Jaa (trad. e estudo). (1995). Hesíodo: Teogonia - A origem dos deuses. (3a ed.). São Paulo: Iluminuras.

. (2000). Escudo de Héracles: Poema de Hesíodo. HYPNOE, Ano 5, n. 6. $2^{\circ}$ semestre, p. 185-221.

VERDENIUS, W. J. (1972). Notes on the proem of Hesiod's Theogony. Mnemosyne, 25, Fasc. 3, pp. 225-260.

VIEIRA, Trajano (trad.). (2011). Odisseia. São Paulo: Editora 34. 
WERNER, Christian (trad. e intro.). (2013a). Hesíodo: Teogonia. São Paulo: Hedra. . (trad. e intro.). (2013b) Hesiodo: Trabalhos e Dias. São Paulo: Hedra. . (2014). Odisseia: Homero. São Paulo: Cosac Naify.

WEST, Martin L. (1978). Hesiod, Works \& Days: edited with prolegomena and commentary. Oxford: Clarendon Press.

Oxford: Clarendon Press.

(1997 [1966]). Hesiod, Theogony: edited with prolegomena and commentary. (ed. \& trans.). (2003). Homeric Hymns, Homeric Apocrypha, Lives of Homer. Harvard UP (Loeb): Cambridge and London.

YONGE, C. D. (trans.). (1913-1921). The Orations of Marcus Tullius Cicero (Vols. 1-4). London: George Bell \& Sons. 
ADKINS, A. W. H. (1972). Homeric Gods and the Values of Homeric Society. The Journal of Hellenic Studies, 92, pp. 1-19.

ALCOCK, Susan E. (1991). Tomb Cult and Post-Classical Polis. American Journal of Archaeology, v. 95, n. 3, pp. 447-467.

ALLAN, William. (2006). Divine Justice and Cosmic Order in Early Greek Epic. Journal of Hellenic Studies, 126, pp. 1-35.

ALONI, Antonio. (1989). L'aedo e i tiranni: Ricerche sull'Inno omerico a Apollo. Roma: Ateneo.

ANTONACCIO, Carla M. (1994). Contesting the Past: Hero Cult, Tomb Cult, and Epic in Early Greece. American Journal of Archaeology, v. 98, no. 3, pp. 389-410.

. (1995). Archaeology of Ancestors: tomb cult and hero cult in early Greece. Lanham, Maryland: Rowman and Littlefield.

ARNOULD, Dominique. (2009). Les noms des dieux dans la Théogonie d'Hésiode: étymologies et jeux de mots. REG 122, pp. 1-14.

ARRIGHETTI, Graziano (a cura di). (1975). Esiodo: letture critiche. Milano: Mursia.

. (1975). Introduzione: Esiodo fra epica e lirica. In: ARRIGHETTI, G. (a cura di). Esiodo: Letture critiche (p. 5-36). Milano: Mursia.

. (1975). Cosmologia mitica di Omero e Esiodo. In: ARRIGHETTI, G. (org.). Esiodo: Letture critiche. Milano: Mursia.

ARTHUR, Marilyn B. (1982). Cultural Strategies in Hesiod's Theogony: Law, Family, Society. Arethusa 15.

ASMA, Sephen T. (2011). On Monsters: An Unnatural History of Our Worst Fears. Oxford; New York: Oxford University Press.

ASSUNÇÃO, T. R. (1997). Le mythe iliadique de Béllerophon. Gaia 1/2: 41-66. . (2004). Nota sobre o gastêr funesto e "ultra-cão" na Odisseia. Kleos 7-8: 55-69.

ATHERTON, Catherine (ed.). (1998). Monsters and Monstrosity in Greek and Roman Culture. Bari: Levante Editori.

AUFRERE, Sydney. (2007). Aperçu de quelques ophidiens fantastiques de l'Egypte pharaonique. In: MAZOYER, Michel; PÉREZ REY, Jorge (Orgs.). Monstres et monstruosités dans le monde ancien (Vol. IX, p. 11-36). Paris: L'Harmattan.

AUSTIN, N. (1983). Odysseus and the Cyclops: who is who? In: RUBINO, Carl A.; 
SHELMERDINE, Cynthia W. (eds.). Approaches to Homer. Austin: University of Texas Press.

BAGLIONI, Igor. (2012). Echidna e i suoi discendenti: Studio sul carattere ibrido e mostruoso nella stirpe di Pontos. (Dottorato di Ricerca in Storia Religiosa XXIV ciclo). Roma.

- (a cura di). (2013). Monstra: costruzione e percezione delle entità ibride e mostruose nel Mediterraneo antico. Vol. 1: Egitto, Vicino Oriente Antico, Area Storicocomparativa. Vol. 2: L’Antichità classica. Roma: Edizioni Quasar.

BAKKER, Egbert J.; KAHANE, Ahuvia. (eds.). (1997). Written Voices, Spoken Signs: Tradition, Performance, and the Epic Text. Cambridge, MA: Harvard University Press.

. (2002). Polyphemos. Colby Quarterly, vol. 38, n.2, pp. 135-150.

. (2013). The Meaning of Meat and the Structure of the Odyssey. Cambridge:

University Press.

BARKER, E.; CHRISTENSEN, J. (2014). Even Heracles Had to Die: Homeric "Heroism", Mortality and the Epic Tradition. Trends in Classics 6(2): pp. 249-277.

BEAL, Timothy K. (2002). Religion and its Monsters. New York / London: Routledge.

BEERDEN, Kim. (2013). Worlds Full of Signs: Ancient Greek Divination in Context. Leiden: Brill.

BENVENISTE, Émile. 1995. O vocabulário das instituições indo-europeias. Vol. II. Campinas: Editora da Unicamp.

BIERLEIN, John F. (1994). Parallel Myths. New York: Ballantine Books.

BILES, J. (2007). Ecce Monstrum: Georges Bataille and the sacrifice of form. New York: Fordham University Press.

BLAISE, Fabienne. (1992). L'épisode de Typhée dans la Théogonie d'Hésiode (v. 820-885): la stabilisation du monde. Revue des Études Grecques, tome 105, fascicule 502-503, p. 349370 .

; JUDET DE LA COMBE, Pierre; ROUSSEAU, Philippe (eds.). (1995). Le métier $\overline{d u ~ m y t h e: ~ l e c t u r e s ~ d ' H e ́ s i o d e . ~ L i l l e: ~ P r e s s e s ~ U n i v e r s i t a i r e s ~ d u ~ S e p t e n t r i o n . ~}$

BONNAFÉ, Annie. (1985). Eros et Eris: mariages divins et mythe de succession chez Hésiode. Lyon: Presses universitaires de Lyon.

BONIFAZI, Anna. (2008). Memory and Visualization in Homeric Discourse Markers. In: MACKAY, E. A. (ed.), Orality, Literacy, Memory in the Ancient Greek and Roman World, Leiden / Boston, p. 34-64.

. (2012). Homer's Versicolored Fabric: The Evocative Power of Ancient Greek Epic Word-Making. Washington, DC: Center for Hellenic Studies, trustees for Harvard University 
Press.

BORGES, Jorge L. (1995). O livro dos seres imaginários. São Paulo: Companhia das Letras.

BOUCHON, Richard; BRILLET-DUBOIS, Pascale; LE MEUR-WEISSMAN, Nadine (eds.). (2012). Hymnes de la Grèce Antique: Approches Littéraires et Historiques. Lyon: Maison de l'Orient et de la Méditerranée.

BOYER, Pascal. (1996). What Makes Anthropomorfism Natural: Intuitive Ontology and Cultural Representations. Journal of the Royal Anthropological Institute, 2, Issue 1, pp. 8397.

BREMMER, Jan N. (1988). Interpretations of Greek Mythology. London: Routledge.

. (2002). Odysseus versus the Cyclops. In: Myths and Symbols, vol. 1, ed. S. des Bouvrie. Athens: Norwegian Institute, pp. 135-152.

. (2012). Greek Demons of the Wilderness: the case of the Centaurs. In: FELDT, Laura. (ed.). Wilderness in Mythology and Religion: Approaching Religious Spatialities, Cosmologies, and Ideas of Wild Nature. Boston / Berlin: Walter de Gruyter, pp. 25-54.

; ERSKINE, A. (2010). The Gods of Ancient Greece: Identities and Transformations. Edinburgh: Edinburgh University Press.

BRILlANTE, C.; CANTILENA, M; PAVESE, C. (orgs.). (1981). I poemi rapsodici non omerici e la tradizione orale. Padua: Antenore.

BROWN, C. G. (1996). In the Cyclop's cave. Mnemosyne 49, pp. 1-29.

BURGESS, Jonathan S. (2001). The Tradition of the Trojan War in Homer and the Epic Cycle. Baltimore / London: The Johns Hopkins University Press.

BURKERT, W. (1979). Structure and History in Greek Mythology and Ritual. Berkeley: University of California Press.

. (1993). Religião grega na época arcaica e clássica. Lisboa: Calouste Gulbenkian.

BUSSANICH, John. (1983). A Theoretical Interpretation of Hesiod's Chaos. Classical Philology, 78, No. 3, 212-219.

BUXTON, Richard. (1994). Imaginary Greece: The contexts of Mythology. Cambridge: Cambridge University Press.

University Press.

. (2009). Forms of astonishment: Greek myths of metamorphosis. Oxford: Oxford . (2012). The Complete World of Greek Mythology. New York: Thames \& Hudson.

CAIRNS, Douglas L. (1993). Aidōs: the psychology and ethics of honour and shame in ancient Greek literature. Oxford: Clarendon Press. 
CALAME, Claude. (1985). Les figures grecques du gigantesque. Communications, 42, Le gigantesque, pp. 147-172.

(1994). . Les Hymnes Homériques: Modalités énonciatives et fonctions. Mètis 9: 391-400 . Poétiques des mythes dans la Grèce antique. Paris: Hachette, 2000.

CALHOUN, G. M. (1937). Homer's gods: Prolegomena. Transactions and Proceedings of the American Philological Association, 68, pp. 11-25.

CANGUILHEM, Georges. (1962). La monstruosité et le monstrueux. Diogène, 40, pp. 29-43.

CARLISLE, Miriam; LEVANIOUK, Olga. (1999). Nine Essays on Homer. Lanham, MD: Rowman and Littlefield.

CASEVITZ, M. (1998). Quelques remarques sur le style et la langue de l'Hymne Homerique à Apollon. RP 72, pp. 205-212.

CASKEY, John L. (1960). The Early Helladic Period in the Argolid. Hesperia 29.3 (July), pp. 285-303.

CÉARD, Jean. (1977). La nature et les prodiges: l'insolite au XVIe siècle, en France. Genève: Librairie Droz.

CHAPPEL, Mike. (2006). Delphi and the Homeric Hymn to Apollo. Classical Quarterly 56.2, pp. 331-348.

CHRISTOPOULOS, Menelaos; KARAKANTZA, Efimia D.; LENAVIOUK, Olga (eds.). (2010). Light and Darkness in Ancient Greek Myth and Religion. Lanham: Lexington Books.

CINGANO, Ettore. (2009). The Hesiodic corpus. In: MONTANARI, F.; RENGAKOS, A.; TSAGALIS, C. (ed.). Brill's Companion to Hesiod. Leiden and Boston: Brill, p. 91-130.

CLARK, Matthew. (2012). Exploring Greek Myth. Malden / Oxford / West Sussex: WileyBlackwell.

CLARKE, Michael. (1999). Flesh and Spirit in the Songs of Homer: A Study of Words and Myths. Oxford: Clarendon Press.

CLAY, Diskin. (1992). The world of Hesiod. Ramus 21, pp. 131-155.

CLAY, Jenny Strauss. (1993). The Generation of Monsters in Hesiod. Classical Philology, 88, no.2, 105-116.

. (1997). The Wrath of Athena: Gods and Men in the Odyssey. Lanham, Boulder, New York, London: Rowman \& Littlefield. . (2003). Hesiod's Cosmos. Cambridge: Cambridge University Press. 
Hymns. $2^{\text {nd }}$ Edition. London: Bristol Classical Press.

COHEN, Beth. (1995). The distaff side: representing the female in Homer's Odyssey. New York: Oxford University Press.

COHEN, Jeffrey Jerome (ed.). (1996). Monster Theory: Reading Culture. Minneapolis and London: University of Minnesota Press.

COLOMBO, Ileana Chirassi. (2012). Teras ou les modalités du prodige dan le discours divinatoire grec: une perspective comparatiste. In: GEORGOUDI, Stella, KOCH PIETTRE, Renée; Schmidt, Francis. La raison des signes : présages, rites, destin dans les sociétés de la Méditerranée ancienne. Leiden: Brill. pp. 221-251.

COOK, Erwin F. (1995). The Odyssey in Athens: Myths of Cultural Origin. Ithaca and London: Cornell University Press.

CORREIA, Beatriz C. de P. (2015). A advinhação na tragédia de Ésquilo. São Paulo: Universidade de São Paulo. Tese de doutorado.

CREED, Barbara. (1993). The monstrous-feminine : film, feminism, psychoanalysis. London: Routledge.

CSAPO, Eric. (2005). Theories of Mythology. Malden / Oxford / Victoria: Blackwell.

CUNY-LE CALLET, Blandine. (2005). Rome et ses monstres: Naissance d'un concept philosophique et rhétorique. Grenoble: Editions Jérôme Millon.

DALBY, Andrew. (2006). Rediscovering Homer: Inside the origins of the epic. New York; London: W. W. Norton \& Company.

DAVIES, M. (1987). Description by Negation: History of a Thought-Pattern in Ancient Accounts of Blissful Life. Prometheus 13, pp. 265-284.

. (2007). Hesiod's Theogony and the folk-tale. In: FINGLAS, P. J.; COLLARD, C.; RICHARDSON, N. J. Hesperos: studies in ancient Greek poetry presented to M. L. West on his seventieth birthday. Oxford: Oxford University Press.

DAVIES, Surekha. (2013). The Unlucky, the Bad and the Ugly: Categories of Monstrosity from the Renaissance to Enlightenment. In: MITTMAN, Asa Simon; DENDLE, Peter J. (Orgs.), The Ashgate Research Companion to Monsters and the Monstrous. Farnham, Surrey, England; Burlington, Vt.: Ashgate Pub Co.

DE JONG, Irene J. F. (1992). The subjective style in Odysseus wanderings. The Classical Quarterly, New Series, vol. 42, n.1, pp.1-11.

. (2004 [1987]). Narrators and focalizers: the presentation of the story in the Iliad. London: Bristol Classical Press.

. (2004 [2001]). A Narratological Commentary on the Odyssey. Cambridge: Cambridge University Press.

; Nünlist, René; Bowie, Angus (2004). Narrators, Narratees and Narratives in 
ancient Greek literature. Lieden and Boston: Brill.

DEBIASI, Andrea. (2008). Esiodo e l'Occidente. Roma: L'Erma di Bretschneider.

DEE, James H. (n.d.). (2001). Epitheta Deorum Apud Homerum: The Epithetic Phrases for the Homeric Gods. A Repertory of the Descriptive Expressions for the Divinities of the Iliad and the Odyssey. Hildesheim: Olms-Weidmann.

DEL PRIORI, Mary. (org.). (1998). Monstros e Monstrengos do Brasil. São Paulo: Companhia das Letras.

DEPEW, Mary. (2000). Enacted and represented dedications: genre and Greek Hymn. In: DEPEW, Mary; OBBINK, Dirk (orgs.) Matrices of genre: authors, canons, and society. Cambridge, MA: Harvard University Press.

DETIENNE, Marcel. (1988). Os mestres da verdade na Grécia Arcaica. Rio de Janeiro: Jorge Zahar Editor.

. (1997). “J'ai l'intencion de bâtir ici un temple magnifique". RHR 214, pp. 23-55.

; VERNANT, Jean Pierre. (2008 [1974]). Métis: As astúcias da inteligência. São Paulo: Odysseus Editora.

DERRIDA, Jacques. (1995). Points...: Interviews, 1974-1994. (WEBER, Elisabeth, Org.). Stanford: Stanford University Press.

. (2011). A Estrutura, o Signo e o Jogo no Discurso das Ciências Humanas. In: $A$ Escritura e a Diferença. São Paulo: Perspectiva. p. 229-249.

DIHLE, Albrecht. (1975). Gli inizi dell'epica scritta. In: ARRIGHETTI, G. (a cura di). Esiodo: letture critiche (p. 37-59). Milano: Mursia.

DOHERTY, Lillian E. (1995). Sirens, Muses, and Female Narrators in the Odyssey. In: COHEN, Beth. The distaff side: representing the female in Homer's Odyssey. New York: Oxford University Press. pp. 81-92.

DOUGHERTY, Carol. (2001). The raft of Odysseus: the ethnographic imagination of Homer's Odyssey. Oxford: Oxford University Press.

DOUGLAS, Mary. (2007). Thinking in circles: an essay in ring composition (Terry Lecture Series). New Haven and London: Yale University Press. . (2012 [1966]). Pureza e Perigo. (2 $2^{\text {a }}$ ed). São Paulo: Perspectiva.

DOWDEN, Ken. (1994). Os usos da mitologia grega. Campinas: Papirus.

DUARTE, Adriane da Silva. (2001). As relações entre retorno e glória na Odisseia. Letras Clássicas, v. 5, p. 89-97.

ECO, Umberto. (2014). Baudolino. Rio de Janeiro: BestBolso.

EDWARDS, G. P. (1971). The language of Hesiod in its traditional context. Oxford: 
Published for the Philological Society by Basil Blackwell.

EDWARDS, Anthony T. (1993). Homer's ethical geography: country and city in the Odyssey. Transactions of the American Philological Association, 123, pp. 27-78.

EMLYN-JONES, Chris. (1996 [1992]). The Homeric Gods: poetry, belief and authority. In: EMLYN-JONES, Chris; HARDWICK, L.; PURKIS, J. (eds.). Homer: Readings and Images. London: Duckworth.

EVANS-PRITCHARD, Edward E. (1956). Nuer religion. New York; Oxford: Oxford University Press.

FARAONE, Christopher A. (2013). The Poetics of the Catalogue in the Hesiodic Theogony. Transactions of the American Philological Association, 143, pp. 293-323.

FARKAS, A. E.; HARPER, P. O.; HARRISON, E. B. (1987). Monsters and demons in the ancient and medieval worlds: papers presented in honor of Edith Porada. P. von Zabern.

FAULKNER, Andrew. (2011). The Homeric Hymns: Interpretative Essays. Oxford: Oxford University Press.

FELSON, Nancy. (2012). Victory and Virility in the Homeric Hymn to Apollo: at whose expense? In BOUCHON, Richard; BRILLET-DUBOIS, Pascale; LE MEUR-WEISSMAN, Nadine (eds.). Hymnes de la Grèce Antique: Approches Littéraires et Historiques. Lyon: Maison de l'Orient et de la Méditerranée. pp. 269-280.

FELTON, Debbie. (2013). Rejecting and Embracing the Monstrous in Ancient Greece and Rome. In: MITTMAN, A. S.; DENDLE, P. J. (eds.). The Ashgate Research Companion to Monsters and the Monstrous. Farnham, Surrey, England; Burlington, Vt.: Ashgate Pub Co.

FERRARA, Marianna. (2013). Teste animaili, lingue infuocte, corpi anguiformi. A riguardo di pericoli e rimedi nell'esegesi vedica dei rituali. In: BAGLIONI, I. (a cura di). Monstra: costruzione e percezione delle entità ibride e mostruose nel Mediterraneo antico. Vol. 1: Egitto, Vicino Oriente Antico, Area Storico-comparativa. Roma: Edizioni Quasar. pp. 191209.

FERRARI, Franco. (2007). Orality and textual criticism: the Homeric Hymns. In: COOPER, Craig (org.) Politics of orality. Orality and Literacy in Ancient Greece, vol. 6. Leiden, New York, Köln: Brill.

FETTERLEY, Judith (1978). The resisting reader: a feminist approach to American fiction. Bloomington: Indiana University Press.

FINGLASS, P. J.; KELlY, Adrian. (2015). Stesichorus in Context. Cambridge: Cambridge University Press.

FLORENZANO, Maria B. B. (1995). Anotações sobre as representações de monstros nas moedas da Grécia antiga. Revista do Museu de Arqueologia e Etnologia - USP: São Paulo, v. 5, pp. 223-234.

FOLEY, J. M. (1991). Immanent Art: From Structure to Meaning in Traditional Oral Epic. Bloomington, Ind.: Indiana University Press. 
. (1999). Homer's Traditional Art. University Park: Penn State Press.

. (ed.). (2005). A Companion to Ancient Epic. Oxford: Blackwell Publishing.

FONTENROSE, J. E. 1980 (1959). Python: A Study of Delphic Myth and Its Origins. Berkeley, Los Angeles, London: University of California Press.

FOUCALT, Michel. (2003). Abnormal: lectures at the Collège de France 1974-1975. (MARCHETTI, Valerio \& SALOMONI, Antonella, Eds., BURCHELL, Graham, Trad.). London: Verso.

FOX, Robin L. (2008). Traveling Monsters. In: Travelling Heroes: Greeks and Their Myths in the Epic Age of Homer. London: Penguin Books, p. 295-318.

FRÄNKEL, Hermann F. (1975). Early Greek Poetry and Philosophy: a history of Greek epic, lyric, and prose to the middle of the fifth century. Oxford: B. Blackwell.

FRIEDMAN, John Block. (1981). The Monstrous Races in Medieval Art and Thought. Camdridge, Mass.; London, Eng.: Harvard University Press.

GAGNEBIN, Jeanne Marie. (2005 [1997]). Sete aulas sobre linguagem, memória e história. $2^{\mathrm{a}}$ ed. Rio de Janeiro: Imago.

GEORGOUDI, Stella, KOCH PIETTRE, Renée; Schmidt, Francis. (2012). La raison des signes : présages, rites, destin dans les sociétés de la Méditerranée ancienne. Leiden: Brill.

GILMORE, David D. (2003). Monsters, Evil Beings, Mythical Beasts, and All Manner of Imaginary Terrors. Philadelphia: University of Pennsylvania Press.

GLENN, Justin. (1971). The Polyphemus Folktale and Homer's Kyklopeia. Transactions and Proceedings of the American Philological Association 102, pp.133-81.

GOULD, John. (2001). Myth, ritual, memory, and exchange: essays in Greek literature and culture. Oxford: Oxford University Press.

GRANT, Edward. (2009). História da filosofia natural: Do mundo antigo século XIX. São Paulo: Madras.

GRAZIOSI, B., \& HAUBOLD, J. (2005). Homer: the resonance of epic. London: Duckworth. . (2014). The Gods of Olympus: a history. London: Profile Books.

GRESSETH, Gerald K. (1970). The Homeric Sirens. Transactions and Proceedings of the American Philological Association, Vol. 101, pp. 203-218.

GRIFFIN, Jasper. (1977). The Epic Cycle and the Uniqueness of Homer. The Journal of Hellenic Studies, Vol. 97, pp. 39-53.

57. . (1986). Words and speakers in Homer. Journal of Hellenic Studies 106, pp. 36- 
GRUBE, G. M. A. (1951). The gods of Homer. Phoenix, Vol. 5, No. 3/4, pp. 62-78.

GUARINELLO, Norberto L. (2003). Uma Morfologia da História: As Formas da História Antiga. Politeia: História e Sociedade, Vol. 3, No 1, p. 41-61.

. (2004). História científica, história contemporânea e história cotidiana. Revista Brasileira de História. São Paulo, v. 24, nº 48, p.13-38.

HANSEN, William. (1997). Homer and the Folktale. In: MORRIS, Ian; POWELL, Barry. (Eds). A New Companion to Homer. Leiden: Brill. pp. 442-462.

. (2002). Ariadne's Thread: A Guide to International Tales Found in Classical Literature. Ithaca and London: Cornell University Press.

HARTOG, François. (1999). Memoria de Ulises: relatos sobre la frontrera en la antigua Grecia. Buenos Aires: Fondo de Cultura Económica.

HAUBOLD, Johannes. (2013). Greece and Mesopotamia: Dialogues in Literature. Cambridge: University Press.

. (2014). Ethnography in the Iliad. In: SKEMPIS, Marios; ZIOGAS, Ioannis. Geography, Topography, Landscape: Configurations of Space in Greek and Roman Epic. Berlin / Boston: De Gruyter, p. 19-36.

HOEKSTRA, Alfred. (1975). Esiodo e la tradizione orale: Contributo allo studio dello stile formulare. In: Esiodo: letture critiche (p. 60-88). Milano: Mursia.

HÖLSCHER, Uvo. (1975). Eredità di concezioni cosmogoniche in Esiodo. In: Esiodo: letture critiche (p. 127-145). Milano: Mursia.

HOPMAN, Marianne Govers. (2012a). Scylla: Myth, Metaphor, Paradox. New York: Cambridge University Press.

. (2012b). Narrative and Rhetoric in Odysseus' Tales to the Phaeacians. American Journal of Philology, Volume 133, Number 1 (Whole Number 529) (Spring), pp. 1-30.

HOROWITZ, Mary A. C. (1976). Aristotle and Woman. Journal of the History of Biology, 9(2), pp. 183-213.

HUNTER, Richard. (ed.). (2005). The Hesiodic Catalogue Of Women: Constructions and Reconstructions. Cambridge: University Press.

IANNUCCI, Alessandro. (2012). L' Odissea' e il racconto fantastico. LEXIS: Poetica, retorica e comunicazione nella tradizione clássica, 30. Venezia: Adolf M. Hakkert Editore, pp. 87-104.

JACKSON, Kimberly. (2013). Technology, monstrosity, and reproduction in twenty-first century horror. Basingstoke: Palgrave Macmillan.

JANKO, Richard. (1982). Homer, Hesiod, and the Hymns: diachronic development in epic diction. Thesis (Ph.D.), University of Cambridge. 
JEHA, Julio (Org.). (2007). Monstros e monstruosidades na literatura. Belo Horizonte: Editora UFMG.

. (Org.) (2009). Da Fabricação de Monstros. Belo Horizonte: Editora UFMG.

KAPLAN, Matt. (2012). Medusa's Gaze and Vampire's Bite: The Science of Monsters. New York: Scribner Book Company.

KEARNEY, Richard. (2003). Strangers, Gods and monsters : interpreting otherness. London: Routledge.

KELLY, Adrian. (2007). A Referential Commentary and Lexicon to Homer, Iliad VIII. Oxford: University Press.

. (2010). Tradição na épica grega arcaica. Letras Clássicas, vol. 14, p. 3-20.

. (2015). Stesichorus in Context. Cambridge: University Press.

KIRK, G. S. (1962). The Songs of Homer. Cambridge: University Press.

. (1970). Myth: Its Meaning and Functions in Ancient and Other Cultures.

Cambridge: University Press.

KNIGHT, Chris; POWER, Camilla. (1988). The origins of anthropomorphic thinking. Journal of the Royal Anthropological Institute 4(1) March, pp. 129-32.

KNOPPERS, Laura L.; LANDES, Joan B. (eds.). (2004). Monstrous Bodies / Political Monstrosities in Early Modern Europe. Ithaca and London: Cornell University Press.

KRISTEVA, J. (1984). Powers of Horror: An Essay on Abjection. New York: Columbia University Press.

KULLMAN, Wolfgang. (1985). Gods and Men in the Iliad and the Odyssey. Harvard Studies in Classical Philology, 89, pp. 1-23.

LADA-RICHARDS, Ismene. (1998). 'Foul Monster or good saviour'? Reflections on ritual monsters. In: ATHERTON, Catherine (ed.). (1998). Monsters and Monstrosity in Greek and Roman Culture. Bari: Levante Editori. pp. 41-82.

LAFLEUR, Richard A. (trad.). (2016). Ubi fera sunt: fabula et picturae ab Maurice Sendak. Mundelein, IL: Bolchazy-Carducci Publishers, Inc.

LAKOFF, George. (1987). Women, Fire, and Dangerous Things. Chicago and London: University of Chicago Press.

; JOHNSON, Mark. (2003 [1980]). Metaphors we live by. (Updated ed.). Chicago, Ill.; London: University of Chicago Press.

; TURNER, Mark. (1989). More than Cool Reason: A Field Guide to Poetic Metaphor. Chicago and London: The University of Chicago Press. 
LANDIS, John. (2011). Monsters in the Movies. London: DK.

LECLERC, M.-C. (1993). La parole chez Hésiode: à la recherche de l'harmonie perdue. Paris: Belles Lettres.

LÉVI-STRAUSS, Claude. (1955). The Structural Study of Myth. The Journal of American Folklore, Vol. 68, No 270, pp. 428-444.

LENFANT, Dominique. (1999). Monsters in Greek Ethnography and Society in the Fifth and Fourth Centuries BCE. In: BUXTON, Richard (Org.), From Myth to Reason? Studies in the Development of Greek Thought (p. 197-214). Oxford: Oxford University Press.

LLOYD, A. B. (1997). What is a God? Studies in the Nature of Greek Divinity. London: Duckworth.

LÓPEZ-RUIZ, Carolina. (2014). Gods, Heroes, and Monsters: A Sourcebook of Greek, Roman, and Near Eastern Myths in Translation. New York: Oxford University Press.

LORD, Albert B. (1971 [1960]). The singer of tales. New York: Atheneum.

LOWE, Dunstan. (2015). Monsters and Monstrosity in Augustan Poetry. Ann Arbor: University of Michigan Press.

MACKIE, Chris J. (1997). Achilles' teachers: Chiron and Phoenix in the Iliad. G\&R 44, pp. 110.

. (1999). Scamander and the rivers of Hades in Homer. AJP 120, pp. 485-501.

. (2008). Rivers of fire: mythic themes in Homer's Iliad. Washington, DC: New Academia Publishing.

. (2011). Monsters. In: FINKELBERG, M. (ed.). Homeric Encyclopedia. Vol. 2. Chichester; Malden, MA: Wiley-Blackwwell.

MALAMOUD, Charles, \& VERNANT, Jean-Pierre (Orgs.). (2003 [1986]). Corps des dieux (Collection Folio/Histoire). Paris: Gallimard.

MANDER, Pietro. (2013). Mischwesen nella religione mesopotamica. In: BAGLIONI, Igor. (a cura di). Monstra: costruzione e percezione delle entità ibride e mostruose nel Mediterraneo antico. Vol. 1: Egitto, Vicino Oriente Antico, Area Storico-comparativa. Roma: Edizioni Quasar. pp. 149-159.

MANETTI, Giovanni. (1993). Theories of the Sign in Classical Antiquity. Bloomington and Indianapolis: Indiana University Press.

MARCONI, Momolina. (1952). Il Mito di Gaia nella Teogonia Esiodea. Acme: annali della Facoltà di lettere e filosofia dell'Università degli studi di Milano, 5, n. 3, p. 561-72.

MARTIN, Ernest. (1880). Histoire des monstres: depuis l'antiquité jusqu'à nos jours. Paris: C. Reinwald et Cie. 
MARTIN, Richard P. (1983). Healing, Sacrifice and Battle: Amechania and Related Concepts in Early Greek Poetry. Innsbruck: Inst. für Sprachwiss. d. Univ. Innsbruck.

. (2000). Synchronic Aspects of Homeric Performance: The Evidence of the Hymn to Apollo, em González de Tobia, Ana M. (ed.), Una nueva visión de la cultura griega antigua, p. 403-432. La Plata.

. (2013). The "myth before the myth began". In: NAGY, Joseph Falaky, Writing down the myths (p. 45-66). Turnhout: Brepols.

MATTHIS, Eugénie. (2007). Aristote, l'incomplet, le monstrueux et l'inachevé. In: MAZOYER, Michel; PÉREZ REY, Jorge (Orgs.). Monstres et monstruosités dans le monde ancien (Vol. IX). Paris: L'Harmattan. p. 203-217.

MAYHEW, Robert. (2010). The Female in Aristotle's Biology: Reason or Rationalization. University of Chicago Press.

MAYOR, Adrienne. (2000). The First Fossil Hunters: Paleontology in Greek and Roman Times. Princeton and Woodstock: Princeton University Press.

MAZOYER, Michel; PÉREZ REY, Jorge (Orgs.). (2007). Monstres et monstruosités dans le monde ancien (Vol. IX). Paris: L'Harmattan.

MELLINK, Machteld J. (1998). Homer, Lycia, and Lukka. In: Carter, J. B., \& Morris, S. P. The Ages of Homer: A Tribute to Emily Townsend Vermeule. University of Texas Press. pp. $33-43$

MILLER, Andrew M. (1985). From Delos to Delphi: A Literary Study of the Homeric Hymn to Apollo. Leiden: Brill.

MINTON, William W. (1970). The Proem-Hymn of Hesiod's Theogony. Transactions and Proceedings of the American Philological Association, 101, pp. 357-377.

MITHEN, Stephen; BOYER, Pascal. (1996). Anthropomorphism and the Evolution of Cognition. The Journal of the Royal Anthropological Institute, Vol. 2, No. 4 (Dec., 1996), pp. 717-721.

MITTMAN, Asa Simon; DENDLE, Peter J. (Orgs.). (2013). The Ashgate Research Companion to Monsters and the Monstrous. Farnham, Surrey, England; Burlington, Vt.: Ashgate Pub Co.

MONDI, Robert. (1983). The Homeric Cyclopes: Folktale, Tradition, and Theme. Transactions of the American Philological Association 113, pp. 17-38.

(1986). Tradition and Innovation in the Hesiodic Titanomachy. Transactions of the American Philological Association 116, pp. 25-48.

. (1989). Xaos and the Hesiodic Cosmogony. Harvard Studies in Classical Philology, Vol. 92, pp. 1-41.

MONTANARI, Franco; RENGAKOS, Antonios; TSAGALIS, Christos (eds.). (2009). Brill's 
Companion to Hesiod. Leiden, Boston: Brill.

MORAIS, Cynthia. (2004). Maravilhas do Mundo Antigo: Heródoto, pai da hitstória? Belo Horizonte: Editora UFMG.

MOREAU, Erwan. (2014). Le Monstre: figure de l'eschatologie occidentale - Étude sur sa sécularisation (Mémoire (Master)). Université Montpellier III - Paul-Valéry, Montpellier.

MORRIS, Ian. (1991). The Archaeology of Ancestors: The Saxe-Goldstein Hypothesis Revisited. Cambridge Archaeological Journal 1, pp. 147-169.

; POWELL, Barry. (Eds). (1997). A New Companion to Homer. Leiden: Brill.

MOST, Glenn W. (1989). The Structure and Function of Odysseus' Apologoi. Transactions of the American Philological Association, 119, pp. 15-30

MUELLNER, Leonard. (1996). The Anger of Achilles: Mênis in Greek Epic. Ithaca: Cornell University Press.

MUREDDU, Patrizia. (1983). Formula e tradizione nella poesia di Esiodo. Roma: Edizioni dell'Ateneo.

MURGATROYD, Paul. (2007). Mythical Monsters in Classical Literature. London: Duckworth.

NAGY, Gregory. (2009a). Hesiod and the Ancient Biographical Traditions. In MONTANARI, Franco; RENGAKOS, Antonios; TSAGALIS, Christos (eds.). Brill's Companion to Hesiod. Leiden, Boston: Brill.

NAGY, G. (2009b). Ancient Greek elegy. In: WEISMAN, K. (org.) The Oxford handbook of the elegy. Oxford: Oxford University Press, 2009.

. (2013). The Ancient Greek Hero in 24 hours. Cambridge, Mass: The Belknap Press of Harvard University Press.

NEILS, Jenifer. (1995). Les Femmes Fatales: Skylla and the Sirens in Greek Art. In: COHEN, Beth. The distaff side: representing the female in Homer's Odyssey. New York: Oxford University Press. pp. 175-184.

NENCI, Giuseppe. (1957). La concezione del miracoloso nei poemi omerici. Atti Della Academia delle Scienze Di Torino (Classe di Scienze Morali, Storiche e Filologiche), 92, pp. 275-311.

NEWTON, Rick M. (1983). Poor Polyphemus: Emotional Ambivalence in Odyssey 9 and 17. The Classical World, 76 (3), pp. 137-142.

NIETO HERNÁNDEZ, Pura. (2000). Back in the cave of the Cyclops. American Journal of Philology, 121, pp. 345-66.

OGDEN, Daniel. (2013). Dragons, serpents and slayers in the classical and early Christian 
Worlds: a sourcebook. Oxford: Oxford University Press.

O’BRIEN, Joan V. (1990-1991). Homer’s savage Hera. CJ 86, pp. 105-25.

O’SULLIVAN, James N. (1987). Observations on the Kykloppeia. SO 62, pp; 5-24.

OLIVEIRA, Gustavo J. D. (2015). Tradição épica, circulação da informação e integração cultural nos poemas homéricos. Tese de doutoramento em História Social. Universidade de São Paulo.

O'MALEY, James. (2014). Homer's Footnotes: storytelling and the representation of the past in the Iliad. Ph.D. Thesis. University of Melbourne.

ORMAND, K. (2014). The Hesiodic Catalogue of women and archaic Greece. New York: Cambridge University Press.

OSBORNE, Robin. (1987). Classical Landscape with Figures: the ancient Greek cities and its countryside. London: George Philip.

OTTO, Walter F. (2005). Os deuses da Grécia: a imagem do divino na visão do espírito grego. São Paulo: Odysseus.

PAGE, Denys L. (1955). The Homeric Odyssey. Oxford: Clarendon Press.

PARÉ, Ambroise. (1971). Des monstres et prodiges. (CÉARD, Jean, éd. critique e comm.). Genève: Librairie Droz.

. (1982). On monsters and marvels. (PALLISTER, Janis L., trad., intr., notes). Chicago; London: University of Chicago Press.

PARK, Katharine, \& DASTON, Lorraine J. (1981). Unnatural Conceptions: The Study of Monsters in Sixteenth- and Seventeenth-Century France and England. Past \& Present, 92 (Aug., 1981), pp. 20-54.

PARRY, M. (1987 [1971]). The making of Homeric verse: the collected papers of Milman Parry. New York; Oxford: Oxford University Press.

PAVESE, Carlo Odo; VENTI, Paolo. (2000). A complete formular analysis of the Hesiodic poems : introduction and formular edition. Amsterdam: AMHakkert.

PELLIZER, Ezio. (1995). Réflexions sur les combats de la Théogonie. In BLAISE, Fabienne; JUDET DE LA COMBE, Pierre; ROUSSEAU, Philippe (eds.). Le métier du mythe: lectures d'Hésiode. Lille: Presses Universitaires du Septentrion. p. 235-249.

PENGLASE, Charles. (1994). Greek Myth and Mesopotamia: Parallels and Influence in the Homeric Hymns and Hesiod. London: Routledge.

PHILIPPSON, P. (1936). Genealogie als mythische Form: Studien zur "Theogonie" des Hesiod. Oslo: Symbolae Osloenses, supp. 7.

PIERUCCI, Antônio Flávio. (1999). Ciladas da Diferença. São Paulo: Editora 34. 
. (2013). O desencantamento do mundo: Todos os passos do conceito em Max Weber (3a ed). São Paulo: Editora 34.

PIZZANI, U. (1997). I monstra nella cultura classica. In: I monstra nell'Inferno dantesco: tradizione e simbologie. Spoleto: Centro italiano di studi sull'alto medioevo. p. 1-26.

. (2000). Qualche osservazione sulla terminologia "teratologica" in Omero. In: FERA, Maria Cannatà; GRANDOLINI, Simonetta (a cura di). Poesia e religione in Grecia: studi in onore di G. Aurelio Privitera. Napoli: Ed. Scientifiche Italiane. p. 526-539.

PODBIELSKI, H. (1986). Le Chaos et les confins de l'univers dans la Théogonie d'Hésiode. Les Études Classiques, 54, pp. 253-263.

PORTER, James I. (2015). Homer and the sublime. Ramus, 44 (1\&2), 184-189.

PUCCI, Pietro. (1977). Hesiod and the language of poetry. Baltimore: Johns Hopkins University Press.

. (1998). The Song of the Sirens: Essays on Homer. Lanham: Rowman \& Littlefield Publishers, Inc.

. (2007). Inno alle Muse (Esiodo, Teogonia, 1-115): Testo, Introduzione, Traduzione e Commento. Pisa, Roma: Fabrizio Serra Editore.

. (2009). The poetry of the Theogony. In MONTANARI, Franco; RENGAKOS, Antonios; TSAGALIS, Christos (eds.). Brill's Companion to Hesiod. Leiden, Boston: Brill. p. 37-70.

RABEL, Robert J. (ed.). (2005). Approaches to Homer: Ancient \& Modern. Swansea: The Classical Press of Wales.

RAMNOUX, C. (1986). La Nuit et les enfants de la Nuit. 2a ed. Paris.

RAUTENBACH, Susan (1984). Cyclopes (I). Acta Classica 27, 41-55.

RENGAKOS, Antonios. (2009). Hesiod's Narrative. In: MONTANARI, Franco (et al.). Brill's Companion to Hesiod. Leiden-Boston: Brill, p. 203-218.

RIJKSBARON, Albert. (2009). Discourse Cohesion in the Proem of Hesiod's Theogony. In: BAKKER, Stéphanie \& WAKKER, Gerry (Eds.). Discourse Cohesion in Ancient Greek. Leiden. Boston: Brill. pp. 241-265.

ROAS, David. (2014). A ameaça do fantástico: aproximações teóricas. São Paulo: Editora Unesp.

ROSA, Guimarães. (1994). Grande Sertão: Veredas. Rio de Janeiro: Editora Nova Aguilar.

ROSE, Peter W. (1992). Sons of the Gods, Children of Earth: Ideology and Literary Form in Ancient Greece. Ithaca; London: Cornell University Press. 
.(2012). Class in Archaic Greece. Cambridge: Cambridge University Press.

ROSCH, Eleanor et alii. (1976). Basic Objects in Natural Categories. Cognitive Psychology 8, pp. 382-439.

ROWE, C. J. (1983). "Archaic Thought” in Hesiod. The Journal of Hellenic Studies, 103, pp. 124-135.

RUDHARDT, J. (1995). Le préambule de la Théogonie: la vocation du poete; le langage des Muses. In: BLAISE, F., JUDET DE LA COMBE, P., \& ROUSSEAU, P. (Orgs.), Le métier du mythe: lectures d'Hésiode. Lille: Presses Universitaires du Septentrion. pp. 25-40.

RUTHERFORD, Ian. (2009). Hesiod and the Literary Traditions of the Near East. In: MONTANARI, Franco (et al.). Brill's Companion to Hesiod. Leiden-Boston: Brill, pp. 9-35.

SAINT-HILAIRE, Isidore Geoffroy. (1837-1838). Histoire générale et particulière des anomalies de l'organisation chez l'homme et les animaux, ou traité de tératologie (Vols. 1-3). Bruxelles: Établissement Encyclographique.

SAUSSURE, Ferdinand de. (2008). Curso de Linguística Geral. São Paulo: Cultrix.

SAX, Boria. (2013). Imaginary Animals: The Monstrous, the Wondrous and the Human. London: Reaktion Books.

SCHEIN, Seth L. (1970). Odysseus and Polyphemus in the Odyssey. Greek, Roman and Byzantine Studies, vol. 11, n. 2.

SCHULTZ, Celia E. (2014). A commentary on Cicero, De divinatione I. Ann Arbor: University of Michigan Press.

SCODEL, Ruth. (2005). Odysseus' Ethnographic Digressions. In: RABEL, Robert J. (ed.). Approaches to Homer: Ancient \& Modern. Swansea: The Classical Press of Wales. pp. 147165.

SEGAL, Charles. (1983). Kleos and its Ironies in the Odyssey. L'antiquité Classique, 52, pp. $22-47$.

. (1994). Singers, Heroes, and Gods in the Odyssey. Ithaca: Cornell University

Press.

SENDAK, Maurice. (2009). Onde vivem os monstros. (Trad. de Heloisa Jahn). São Paulo: Cosac Naif.

SHAW, Brent. (1982/1983). "Eaters of Flesh, Drinkers of Milk": The Ancient Mediterranean Ideology of the Pastoral Nomad. Ancient Society, 13/14, pp. 5-31.

SHEAR, Ione M. (1998). Bellerophon Talets from the Mycenaean World? A Tale of Seven Bronze Hinges. The Journal of Hellenic Studies, Vol. 118, pp. 187-189.

. (2000 [1971]). The Dark Age of Greece: An Archaeological Survey of the 
Eleventh to Eighth Centuries B.C. Edinburgh: University Press.

SISSA, Giulia; DETIENNE, Marcel. (1990). Os deuses gregos. (A vida cotidiana). São Paulo: Companhia das Letras.

SKEMPIS, Marios; ZIOGAS, Ioannis. (2014). Geography, Topography, Landscape: Configurations of Space in Greek and Roman Epic. Berlin / Boston: De Gruyter.

SMITH, Warren. (1988). The Disguises of the Gods in the Iliad. Numen (Brill), 35, fasc. 2, pp. 161-178.

SOURVINOU-INWOOD, Christiane. 1988 [1987]. "Myth as History: The Previous Owners of the Delphic Oracle". In BREMMER, J. (ed.), Interpretations of Greek Mythology. London: Routledge. p. 215-241.

SPERBER, Dan. (1975). Pourquoi les animaux parfaits, les hybrides et les monstres sont-ils bons à penser symboliquement? L'Homme, Tomme 15, n. 2, pp. 5-34.

. (1975 [1974]). Rethinking Symbolism. Cambridge: Cambridge University Press.

(1996). Explaining Culture: A naturalistic approach. Oxford: Blackwell.

STODDARD, Kathryn. (2004). The narrative voice in the Theogony of Hesiod. Leiden: Brill.

STROLONGA, Polyxeni. (2011). The Foundation of the Oracle at Delphi in the Homeric Hymn to Apollo. Greek, Roman, and Byzantine Studies, 51, pp. 529-551.

SWANEPOEL, Piet. (2010). On defining the category MONSTER - using definitional features, narrative categories and Idealized Cognitive Models (ICM's). Euralex (European Association for Lexicography) Proceedings, pp. 1411-1427.

TEIXEIRA, Ivana Lopes. (2013). Romanidade em Plínio, o Antigo, e a Naturalis História como um 'projeto' político-pedagógico. Universidade de São Paulo: Tese de doutorado.

THALMANN, William G. (1984). Conventions of Form and Thouth in Early Greek Epic Poetry. Baltimore and London: The Johns Hopkins University Press.

TOLKIEN, J. R. R. (2006 [1983]). The Monsters and the Critics and Other Essays. (Edited by Christopher Tolkien). London: Harper Collins Publishers.

TORRANO, Jaa. (2012). A noção mítica de Kháos na Teogonia de Hesíodo. Ide, 35, n.54, p. 29-38.

TSAGALIS, Christos C. (2006). Poet and audience: From Homer to Hesiod. In: MONTANARI, Franco; RENGAKOS, Antonios (orgs.). La poésie épique grecque: métamorphoses d'un genre littéraire. Genève: Fondation Hardt. pp. 79-134.

TURNER, Victor. (1969). The ritual process: Structure and anti-structure. Chicago: Aldine. . (1974). Dramas, Fields, and Metaphors: Symbolic Action in Human Society. Ithaca and London: Cornell University Press. 
ULLMANN, Reinholdon Aloysio. (1989). O significado de theós em grego. Clássica, 2, pp. $135-152$.

VERDERAME, Lorenzo. (2013). Osservazioni a margine dei concetti di "ibrido" e "mostro" in Mesopotamia. BAGLIONI, Igor. (a cura di). (2013). Monstra: costruzione e percezione delle entità ibride e mostruose nel Mediterraneo antico. Vol. 1: Egitto, Vicino Oriente Antico, Area Storico-comparativa. Roma: Edizioni Quasar. pp. 161-172.

VERGADOS, Athanassios. (2013). The Cyclopes and the Hundred-handers in Hesiod "Theogony" 139-53. Hermes, 141(1), pp. 1-7.

VERMEULE, Emily. (1979). Aspects of death in early Greek art and poetry. Berkeley; London: University of California Press.

VERNANT, Jean-Pierre. (1988). A morte nos olhos: Figuração do outro na Grécia antiga, Ártemis e Gorgó. Rio de Janeiro: Jorge Zahar Editor.

. (1991). Mortals and Immortals: Collected Essays. (F. I. Zeitlin, ed.). Princeton: Princeton University Press.

VERSNEL, H. S. (2011), Coping with the Gods: wayward readings in Greek theology. Leiden: Brill.

VEYNE, Paul. (2014). Os gregos acreditavam em seus mitos? São Paulo: Editora UNESP.

VIDAL, Denis (2007). Anthropomorphism or Sub-Anthropomorphism? An Anthropological Approach to Gods and Robots. The Journal of the Royal Anthropological Institute, Vol. 13, No. 4 (Dec., 2007), pp. 917-933.

VIDAL-NAQUET, Pierre. (1970). Valeurs religieuses et mythiques de la terre et du sacrifice dan l'Odyssée. Annales. Économies, Societés, Civilisations, vol. 25, n. 5, p. 1278-1297.

(1981). Le Chasseur noir. Formes de pensée et forme de societé dans le monde grec. Paris: La Découverte (François Maspero).

. (2002). O mundo de Homero. São Paulo: Companhia das Letras.

WALCOT, Peter. (1966). Hesiod and the Near East. Cardiff: Wales UP.

WEBSTER, T. B. L. (1954). Personification as a Mode of Greek Thought. Journal of the Warburg and Courtauld Institutes, 17(1/2), pp. 10-21.

WENGROW, David. (2014). The Origins of Monsters: Image and Cognition in the First Age of Mechanical Reproduction. Princeton and Oxford: Princeton University Press.

WERNER, Christian. (2001). A ambiguidade do kléos na Odisseia. Letras Clássicas, n. 5, p. 99-108. 
. (2009). Reputação e presságio na assembleia homérica: poluphemos em Odisseia 2, 150. PhaoS, n.9, p. 29-52.

. (2010). A deusa compõe um 'mito': o jovem Odisseu em busca de veneno (Odisseia I, 255-68). Nuntius Antiquus, v. 6, 2010, p. 7-27.

- (2011). O mito do retorno dos heróis de Troia e as funções narrativas dos presságios na Odisseia de Homero. História, imagem e narrativas, n. 12, p. 1-23.

. (2014). O mundo dos heróis na poesia hexamétrica grega arcaica. Romanitas, v. 2, p. 20-41.

. (Publicação prevista para 2016). O discurso etnográfico e as vozes narrativas na Odisseia. In: MORAES, A. S. (org.). Homero, etnicidade e os olhares da Antiguidade sobre a identidade helênica.

; LOPES, Caroline E. (2014). Poeta-adivinho em Teogonia e Trabalhos e dias: o futuro no discurso poético Hesiódico. Revista ARCHAI. As origens do pensamento ocidental, v. 13, p. $25-33$.

WEST, Martin L. (1997). The East Face of Helicon: west Asiatic elements in Greek poetry and myth. Oxford: Clarendon Press.

WEST, Martin. L. (2014). The Making of the Odyssey. Oxford: Oxford University Press.

WILLIAMS, David (1999). Deformed Discourse: The Function of the Monster in Mediaeval Thought and Literature. Montreal Que.: Mcgill-Queens University Press.

WILLIAMS, Wes (2011). Monsters and their Meanings in Early Modern Culture. Oxford: Oxford University Press.

WILSON, Dudley B. (1993). Signs and portents : monstrous births from the Middle Ages to the Enlightenment. London: Routledge.

WITTGENSTEIN, Ludwig. (2009 [1953]). Philosophical Investigations. John Wiley \& Sons.

WITTKOWER, Rudolf. (1942). Marvels of the East: A Study in the History of Monsters. Journal of the Warburg and Courtauld Institute, 5, pp. 159-197.

WOODWARD, Roger D. (org.). (2007). The Cambridge Companion to Greek Mythology. Cambridge: Cambridge University Press.

WOYSCH-MÉAUTIS, Daphné. (1982). La representation des animaux e des êtres fabuleux sur les monuments funéraires grecs de l'époque archaïque à la fin du IVe siècle av. J.-C. Lausanne: Bibliothèque Historique Vaudoise.

WRIGHT, Alexa. (2013). Monstrosity: the human monster in visual culture. London: IBTauris.

ZANON, Camila A. (2009). A Ilíada de Homero e a Arqueologia. Universidade de São Paulo: Dissertação de Mestrado. 
- (2014a). Cyclopes, Hundred-Handers, Typhon and the Mechanisms of Monstrosity in Hesiod's Theogony. In: REHLING, Petra; BOUET, Elsa. Monstrous Reflections. Oxford: Inter-Disciplinary Press. pp. 215-222.

(2014b). Resenha: WENGROW, D. The Origins of Monsters: Image and Cognition in the First Age of Mechanical Reproduction. Princeton and Oxford: Princeton University Press, 2014. Revista Mare Nostrum: Estudos sobre o Mediterrâneo Antigo, 5, p. 197-200.

ZIZEK, S., MILIBANK, J., \& DAVIS, C. (2011). The Monstrosity of Christ: Paradox or Dialectic? Cambridge, Mass.; London: MIT Press. 
APÊNDICES 


\section{VERBETES}

\section{A.1 Extraídos do dicionário grego-inglês LSJ, acompanhados de tradução própria.}

$\pi \varepsilon ́ \lambda \omega \rho, \tau o ́$, portent, prodigy, monster, Ep. Noun, only nom. and acc., in early writers always of

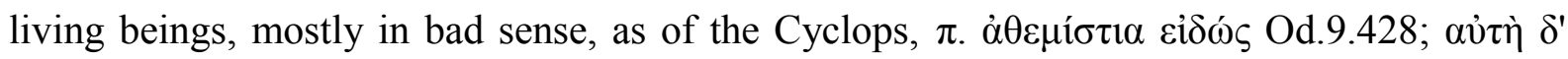

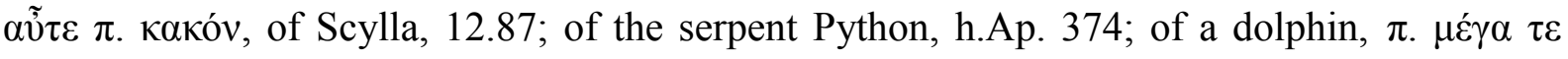

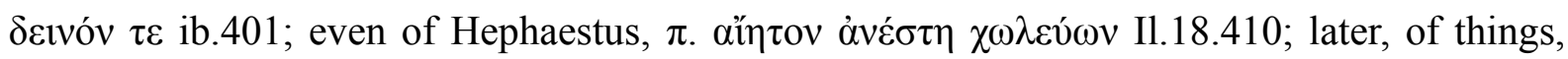

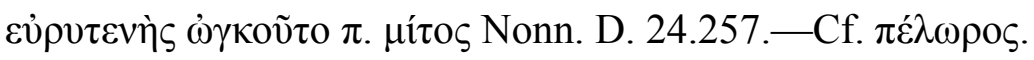

$\pi \varepsilon ́ \lambda \omega \rho, \tau o ́$, portento, prodígio, monstro, Subst. Ép., somente nom. e ac., em autores mais antigos sempre acerca de seres vivos, na maioria no mau sentido, como acerca dos Ciclopes,

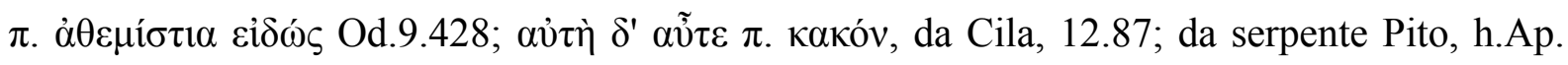

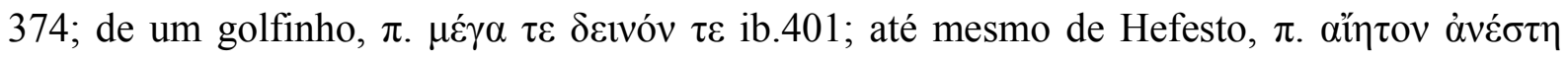

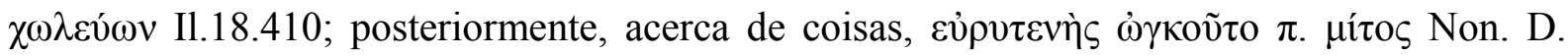
24.257.—Cf. $\pi \dot{\lambda} \lambda \omega \rho \circ \varsigma$.

$\pi \varepsilon \dot{\lambda} \omega \rho-\mathrm{ov}, \tau$,,$=\pi \varepsilon \dot{\lambda} \omega \rho$, of the Gorgon, Il.5.741, Od. 11.634; of the offspring of the earth, Hes. Th. 295, cf. 845, 856; of a large stag, Od.10.168; of the enchanted animals of Circe, ib. 219; $\pi \varepsilon ́ \lambda \omega \rho \alpha \theta \varepsilon \tilde{\omega} \nu$ portents sent by the gods, I1.2.321.- Prop. neut. from sq.

$\pi \varepsilon ́ \lambda \omega \rho-o v, \tau o ́,=\pi \varepsilon ́ \lambda \omega \rho$, acerca da Górgona, Il.5.741, Od. 11.634; do rebento da terra, Hes. Th. 295, cf. 845, 856; de um grande cervo, Od.10.168; dos animais encantados de Circe, ib. 219; $\pi \varepsilon \dot{\lambda} \omega \rho \alpha \theta \varepsilon \tilde{\omega} v$ portentos enviados pelos deuses, Il.2.321.— Prop. [propriamente] neut. [neutro] baseando-se na sq. [sequentia, ou "nos itens listados"].

$\pi \varepsilon ́ \lambda \omega \rho-o \varsigma, \eta$, ov, also os, ov Od. 15.161 (the only example of the fem. in Hom.):- monstrous, prodigious, huge, with collat. notion of terrible, in Hom. much rarer than the form $\pi \varepsilon \lambda \omega \operatorname{\rho ios}$, 


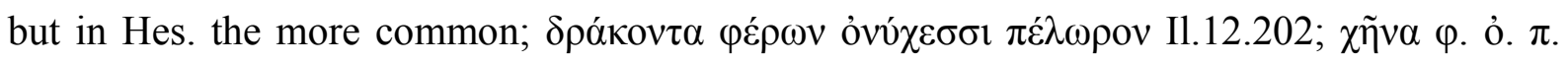

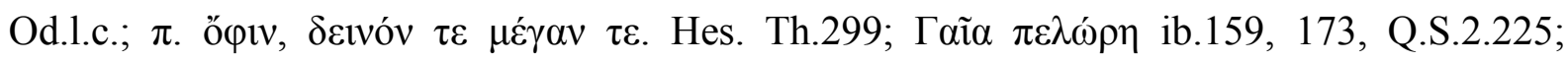

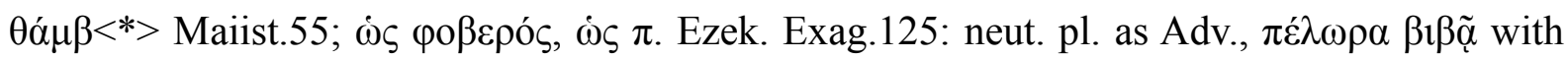

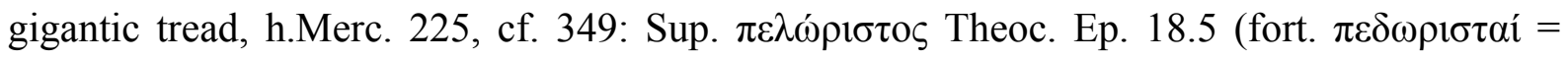

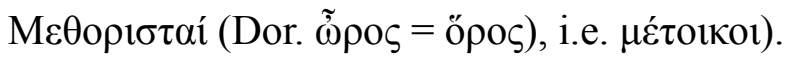

$\pi \varepsilon ́ \lambda \omega \rho-o \varsigma, \eta$, ov, também os, ov Od. 15.161 (o único exemplo de fem. em Hom.): monstruoso, prodigioso, enorme, com sentido colat. [colateral, "derivado"] de terrível, em

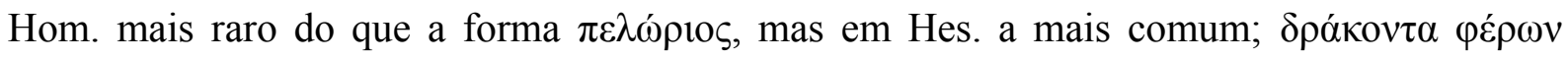

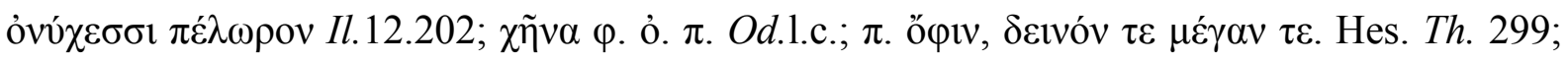

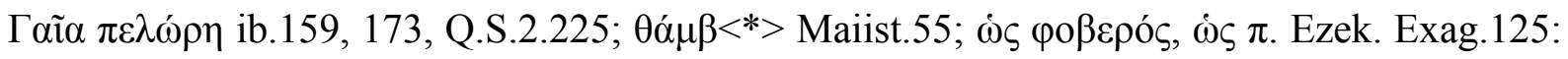
neut. pl. como adv., $\pi \dot{\lambda} \lambda \omega \rho \alpha \beta 1 \beta \tilde{\alpha}$ com enormes passos, h.Merc. 225, cf. 349: sup. $\pi \varepsilon \lambda \omega ́ \rho ı \sigma \tau \varsigma$

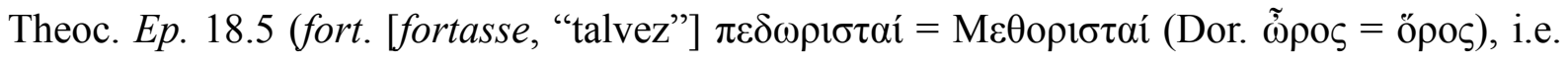

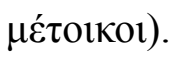

$\pi \varepsilon \lambda \omega ́ \rho-10 \varsigma$ (also $\tau \varepsilon \lambda \omega ́ \rho 1 o \varsigma$ (q. v.)), ov, fem. (not in Hom.) -1os Hes. Th. 179, -ín A.R.4.1682 : =

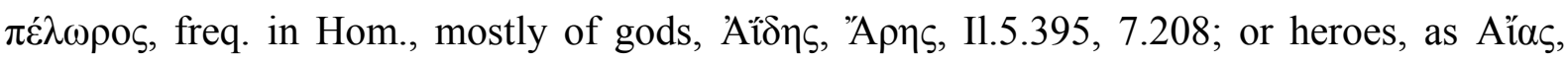

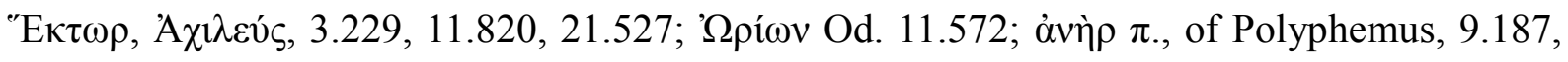

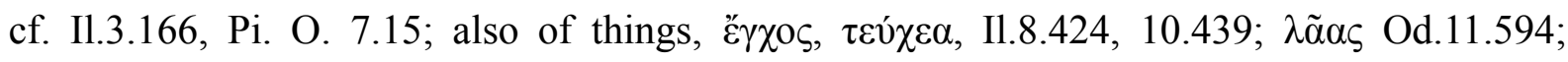

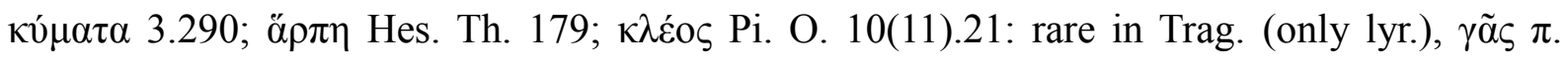

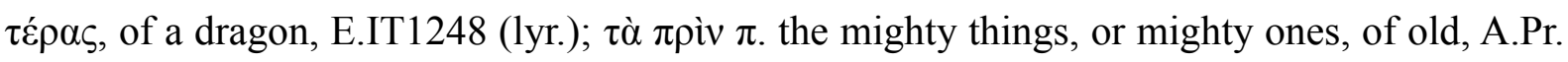
151 (lyr.); used by Com. in mockheroicstyle, Ar.Av. 321; in exaggerated language, Arist. Rh. 1408b13: in later Prose, Ath. 3.84e.

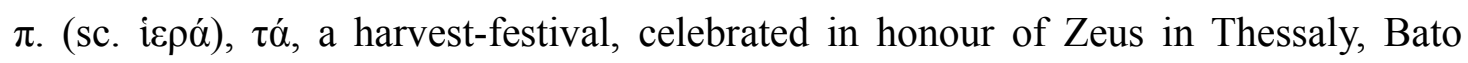

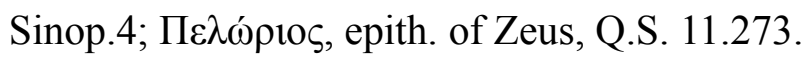

$\pi \varepsilon \lambda \omega ́ \rho-10 \varsigma$ (também $\tau \varepsilon \lambda \omega ́ \rho ı \varsigma$ (q. v. [quod vide, “consulte o termo"])), ov, fem. (não em Hom.)

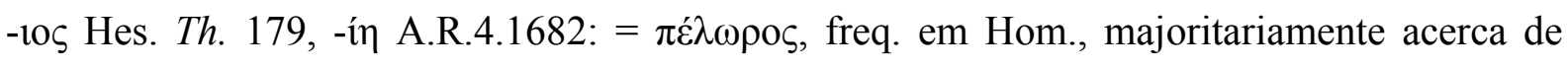

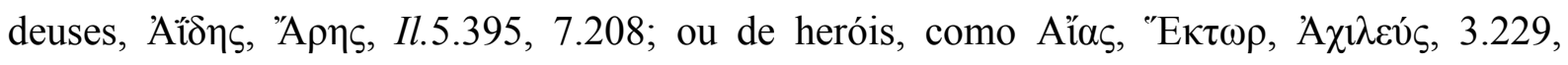

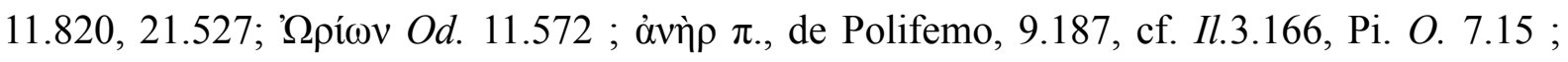

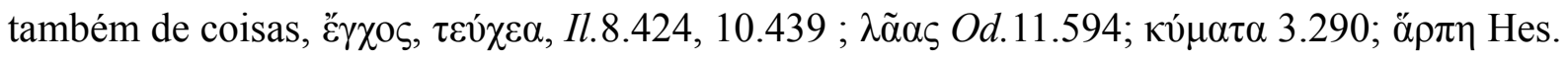

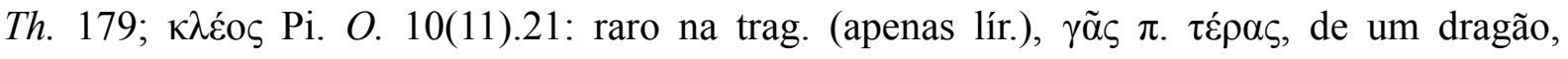




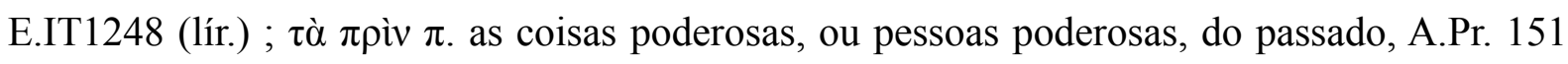
(lír.); usado pela com. no estilo heroico-cômico, Ar. $A v$. 321; em linguagem exagerada, Arist. Rh. 1408b13: na prosa tardia, Ath. 3.84e.

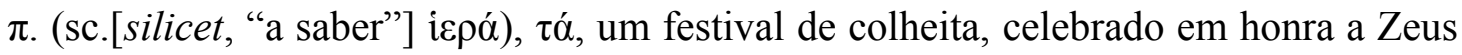

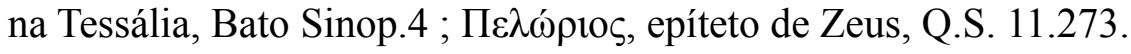

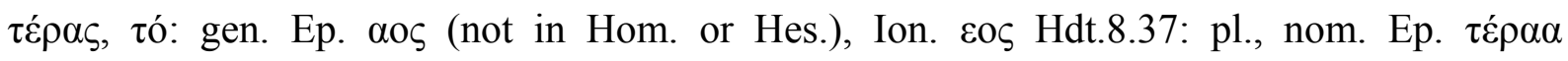

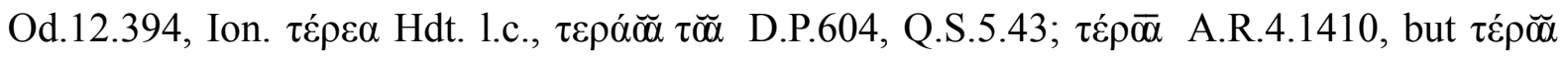

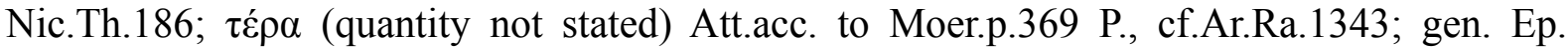
$\tau \varepsilon \rho \alpha ́ \omega v$ Il.12.229, $\tau \varepsilon \rho \varepsilon ́ \omega v$ Alc.155; Att. $\tau \varepsilon \rho \tilde{\omega} v$ acc. to Moer.1.c., Thom.Mag.p.348 R.; dat. Ep.

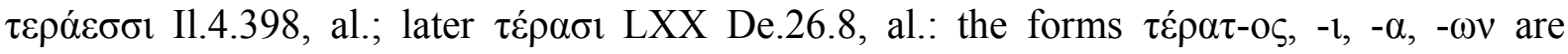
Hellenistic, Moer.pp.366,369 P., Thom.Mag.p.348 R. ( $\varepsilon \dot{\varepsilon} \rho \alpha \tau \alpha$ LXX Ex.4.21, al., $\tau \varepsilon \rho \alpha ́ \tau \omega v$

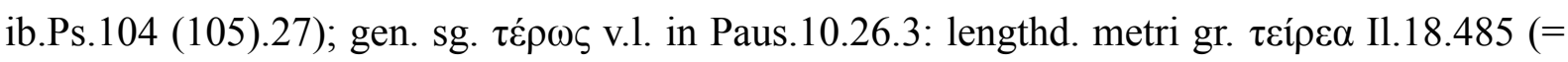

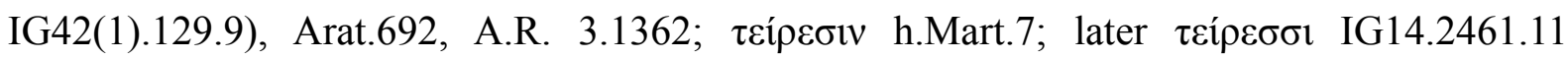

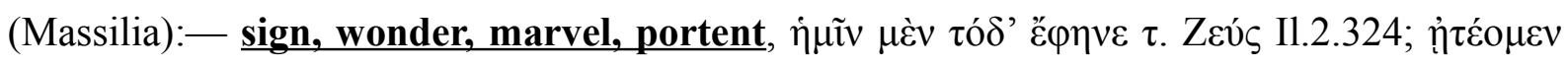

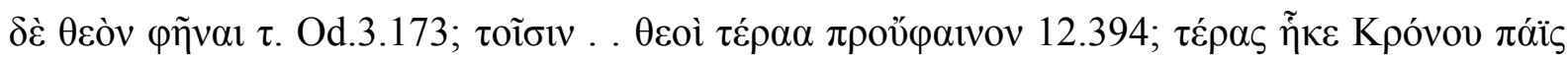

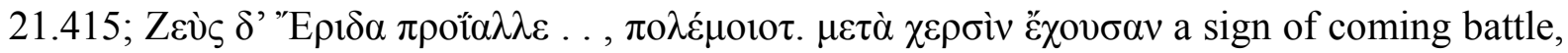

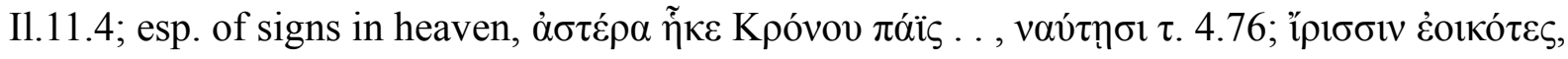

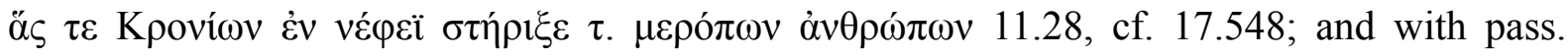
Verbs, $\tau$. $\varphi \alpha v \eta ́ \tau \omega ~ O d .20 .101:-$ so always when the first syll. is lengthd., v. supr.:-also in

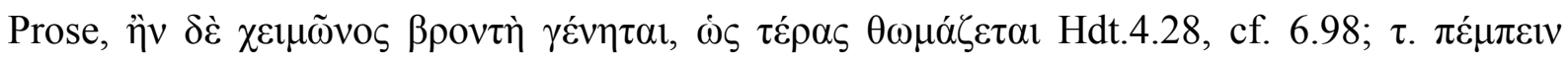

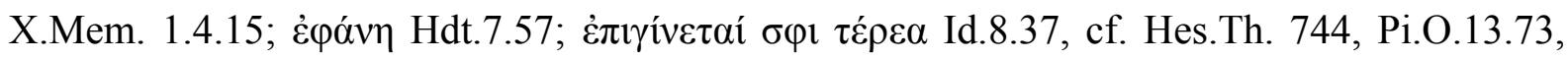

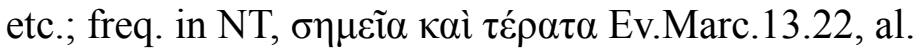

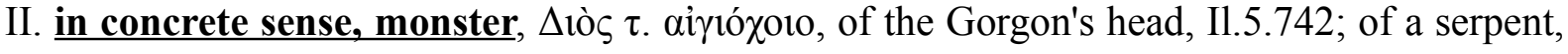

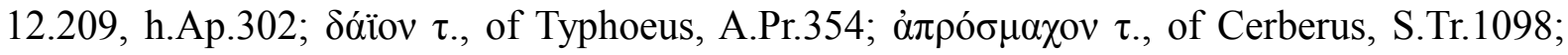

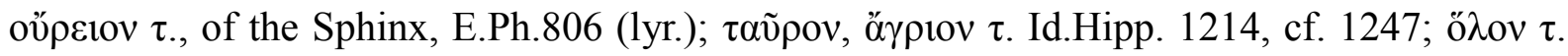

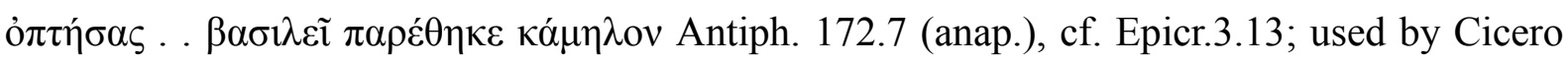
of Caesar, Att.8.9.4.

2. monstrous birth, monstrosity, P1.Cra.393b, 394a, Aeschin.3.111, Arist.GA769b30, 773a3,

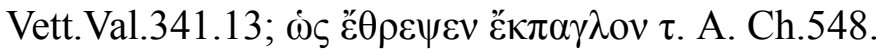

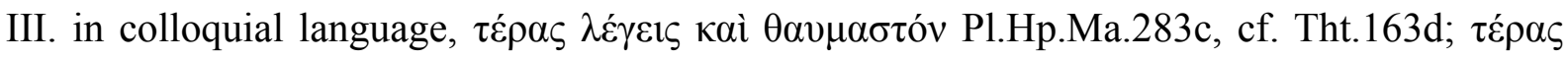
$\lambda \varepsilon \dot{\gamma \varepsilon ı \varsigma}$, , $\varepsilon \dot{~ . ~ . ~ I d . M e n .91 d ; ~ ' a ~ m a r v e l ' ~ o f ~ a ~ c u p, ~ T h e o c .1 .56: ~ p l ., ~ o f ~ i n c r e d i b l e ~ s t a t e m e n t s, ~ P h l d . ~}$ Mus.p.74 K. 


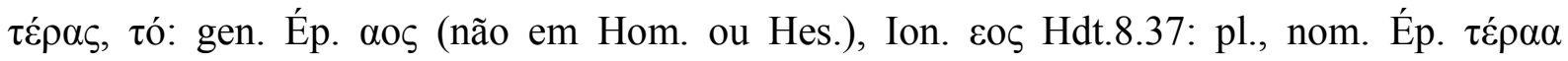

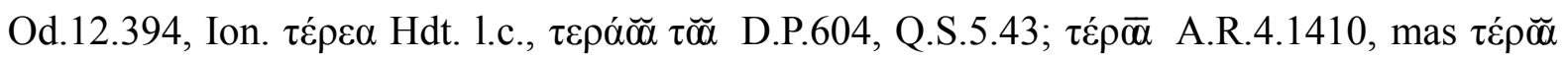
Nic.Th.186; $\tau \dot{\varepsilon} \rho \alpha$ (quantidade não especificada) Ac. át. para Moer. p.369 P., cf.Ar.Ra.1343; gen. Ép. $\tau \varepsilon \rho \alpha ́ \omega v$ Il.12.229, $\tau \varepsilon \rho \varepsilon ́ \omega v$ Alc.155; Át. $\tau \varepsilon \rho \tilde{\omega} v$ ac. para Moer. 1.c., Thom.Mag.p.348

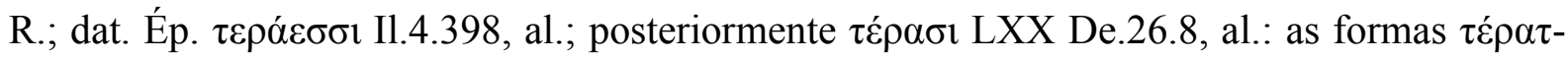

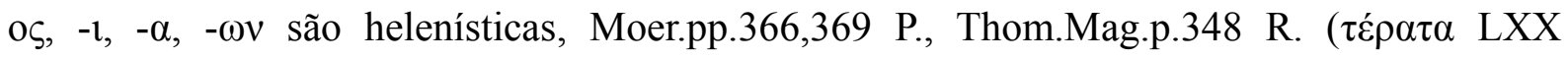

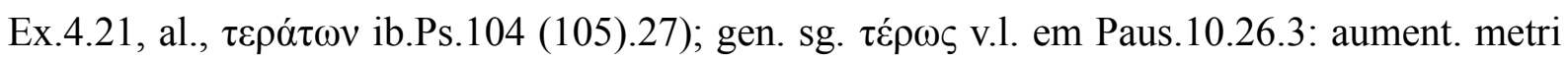

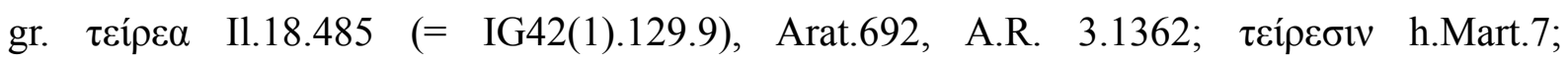
posteriormente $\tau \varepsilon i ́ p \varepsilon \sigma \sigma \mathrm{l}$ IG14.2461.11 (Massília):- sinal, prodígio, maravilha, portento,

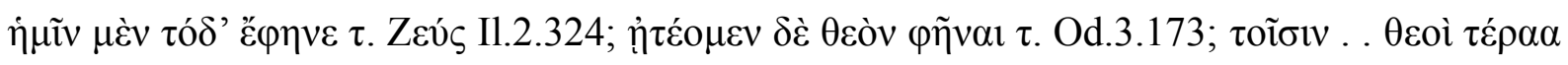

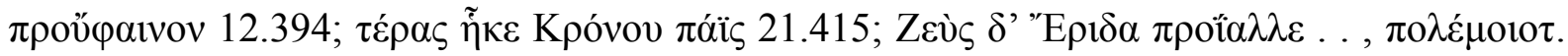

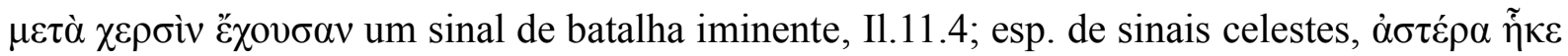

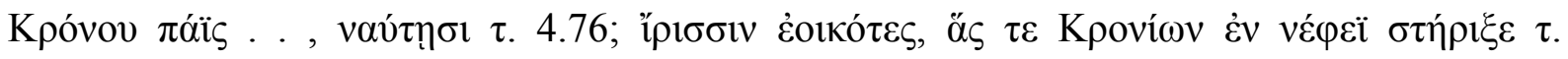

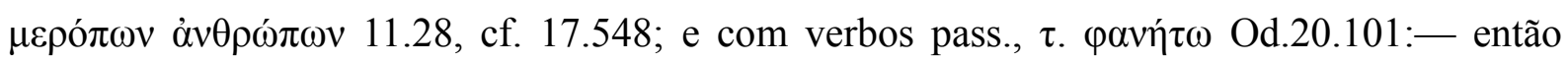
sempre quando a primeira sílaba é alongada, v. supr.:- também em Prosa, ìv $\delta \varepsilon \grave{\varepsilon} \chi \varepsilon \mu \tilde{\omega} v o \varsigma$

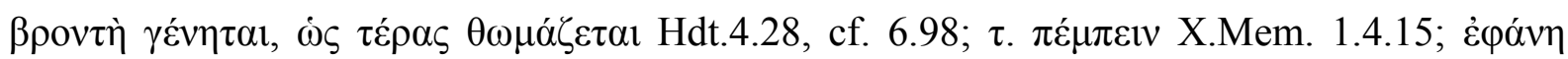

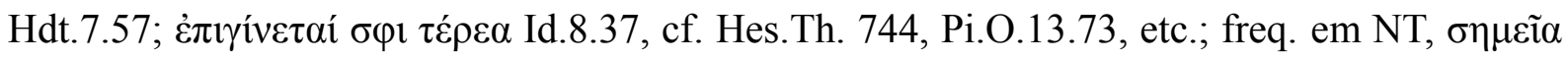

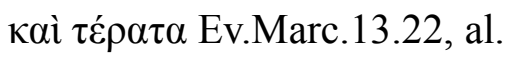

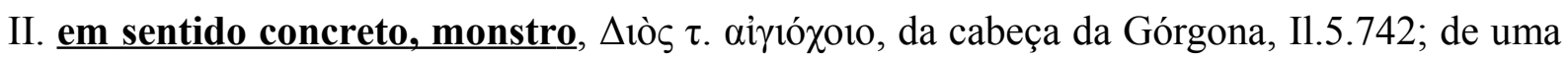

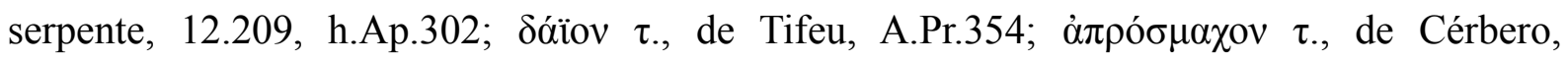

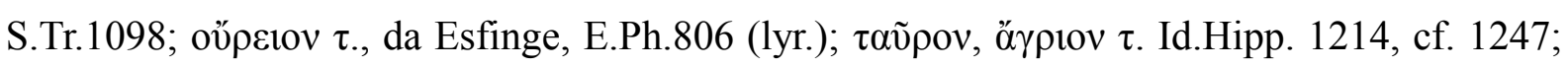

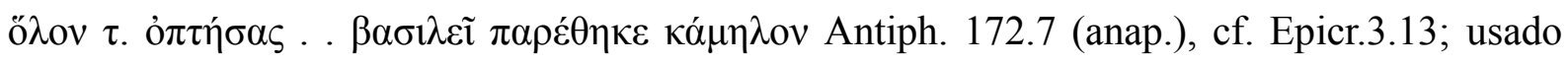
por Cícero acerca de César, Att.8.9.4.

2. nascimento monstruoso, monstruosidade, P1.Cra.393b, 394a, Aeschin.3.111,

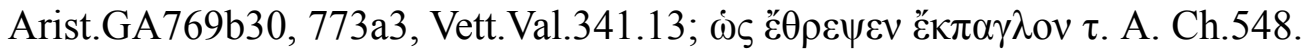

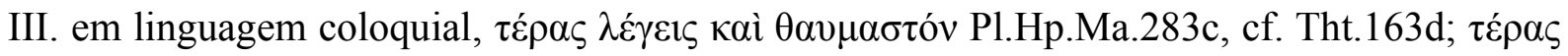

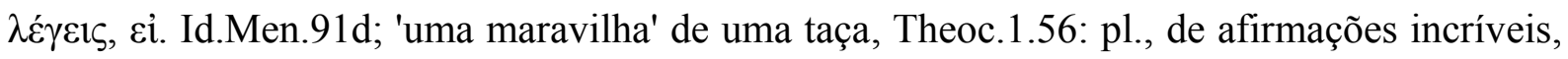
Phld. Mus.p.74 K. 


\section{A.2 Extraídos de $A$ Lexicon of the Homeric Dialect de Cunliffe (1963), acompanhados de tradução própria.}

$\pi \varepsilon ́ \lambda \omega \rho, \tau$, . A being of uncommon size or strength or of peculiarly daunting or portentous aspect (cf. $\pi \varepsilon \dot{\lambda} \lambda \omega \rho o v)$. Of Hephaestus $\Sigma$ 410.--Of the Cyclops 1 428.--Of Scylla $\mu 87$.

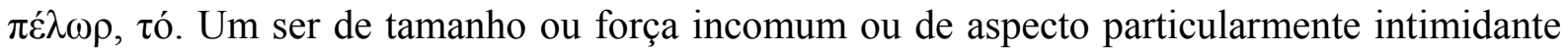
ou portentoso (cf. $\pi \varepsilon ́ \lambda \omega \rho o v)$. De Hefesto [Ilíada] 18.410. --Do Ciclope [Odisseia] 9.428. - Da Cila [Odisseia] 12.87.

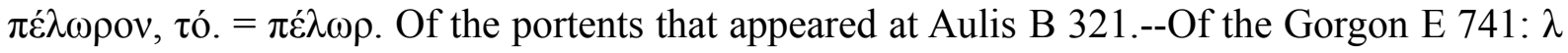
634.--Of the Cyclops 1257 .--Of the deer taken by Odysseus in Circe's island $\kappa$ 168.--Of the creatures transformed by Circe $\kappa 219$.

$\pi \varepsilon ́ \lambda \omega \rho o v, \tau o ́ .=\pi \varepsilon ́ \lambda \omega \rho$. Dos portentos que apareceram em Áulis [Ilíada] 2.321.--Da Górgona [Ilíada] 5.741: [Odisseia] 11.634.--Do Ciclope [Odisseia] 9.257.--Do capturado por Odisseu na ilha de Circe [Odisseia] 10.168.--Das criaturas transformadas por Circe [Odisseia]10.219.

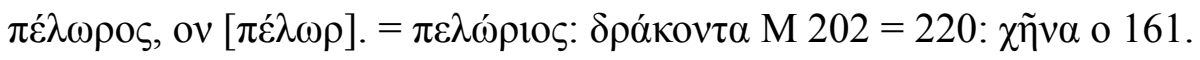

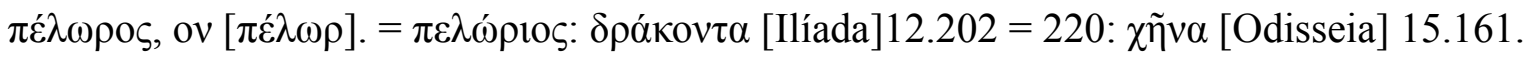

$\pi \varepsilon \lambda \omega ́ \rho 1 o \varsigma$ [ $\pi \varepsilon \dot{\varepsilon} \omega \rho]$. Of uncommon size or strength, great, huge, prodigious, wondrous: ö $v \delta \rho \alpha$

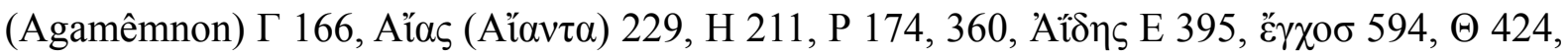

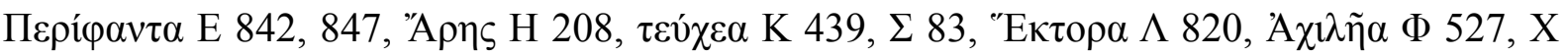

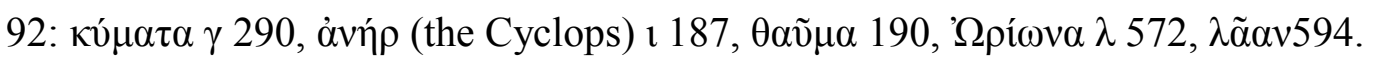

$\pi \varepsilon \lambda \omega ́ \rho ı \varsigma \zeta ~[\pi \varepsilon ́ \lambda \omega \rho]$. De tamanho ou força incomum, grande, enorme, prodigioso, extraordinário: őv $\delta \rho \alpha$ (Agamemnon) [Ilíada] 3.166, Aỉas (Aï $\alpha v \tau \alpha)$ 3.229, 7.211, 17.174,

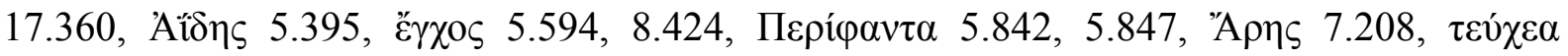

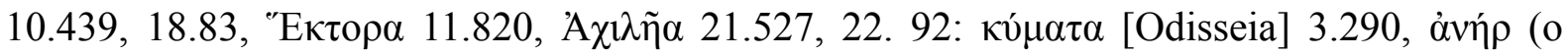

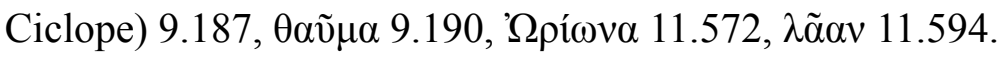




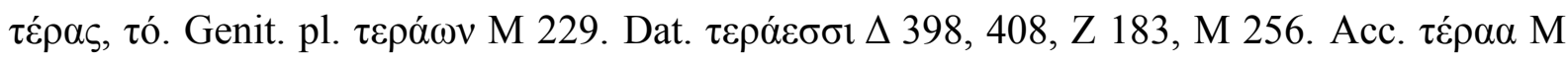
394.

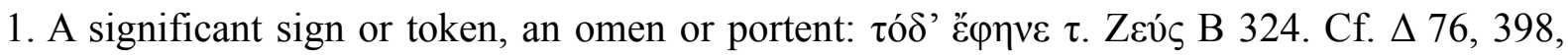

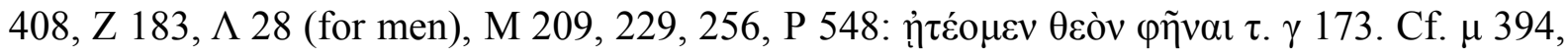
o $168, \pi 320$, v 101, 114, $\varphi 415$.

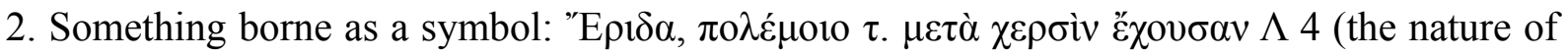
the object seems to be beyond conjecture).

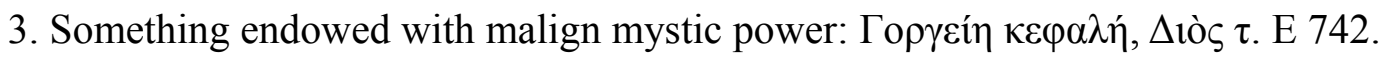

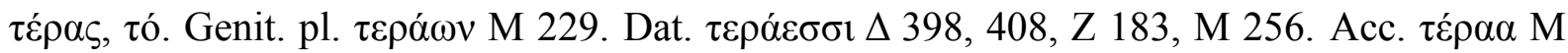
394.

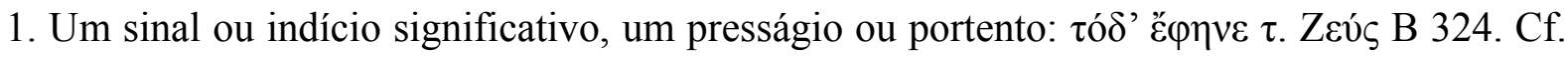

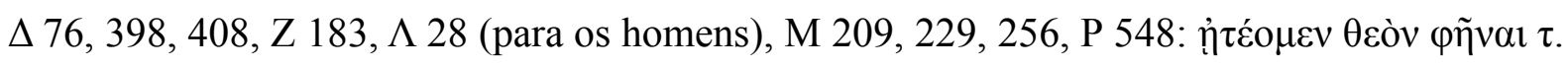
$\gamma$ 173. Cf. $\mu$ 394, o 168, $\pi$ 320, v 101, 114, $\varphi 415$.

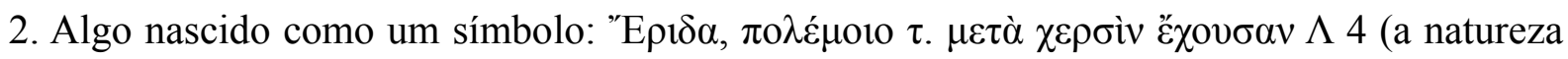
do objeto parece estar além de conjectura).

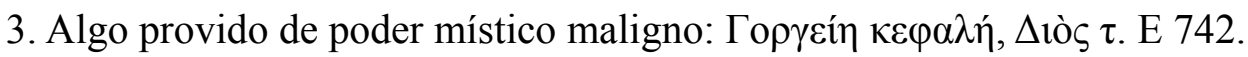


APÊNDICE B

\section{TABELA DE OCORRÊNCIAS

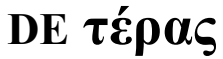

\begin{tabular}{|c|c|c|c|c|}
\hline $\begin{array}{l}\text { Poema e } \\
\text { verso }\end{array}$ & Verso & Enunciador & $\begin{array}{l}\text { Interlocutor } \\
\text { interno }\end{array}$ & Referente \\
\hline $\begin{array}{l}\text { Ilíada, } \\
2.324\end{array}$ & 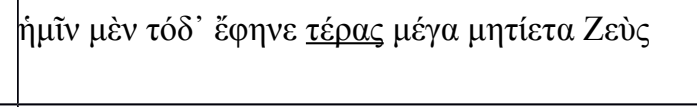 & Odisseu & aqueus & $\begin{array}{l}\text { portento mostrado } \\
\text { por Zeus }\end{array}$ \\
\hline $\begin{array}{l}\text { Ilíada, } \\
4.76\end{array}$ & 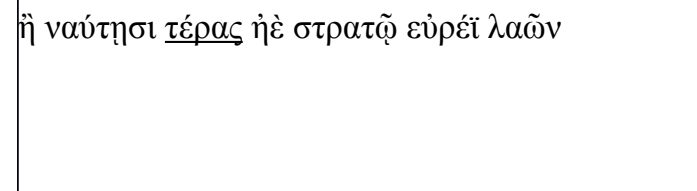 & narrador & não há & $\begin{array}{l}\text { estrela como } \\
\text { portento enviado } \\
\text { por Zeus (símile } \\
\text { de Palas Atena) }\end{array}$ \\
\hline $\begin{array}{l}\text { Ilíada, } \\
4.398\end{array}$ & 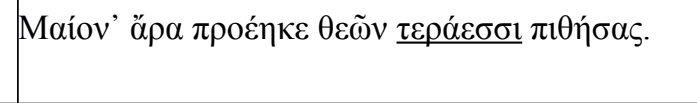 & Agamêmnon & Diomedes & $\begin{array}{l}\text { portentos dos } \\
\text { deuses }\end{array}$ \\
\hline $\begin{array}{l}\text { Ilíada, } \\
4.408\end{array}$ & 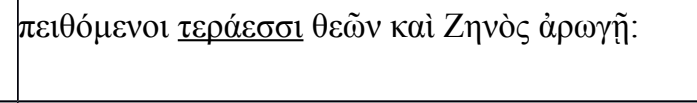 & Estênelo & Agamêmnon & $\begin{array}{l}\text { portentos dos } \\
\text { deuses }\end{array}$ \\
\hline $\begin{array}{l}\text { Iliada, } \\
5.742\end{array}$ & 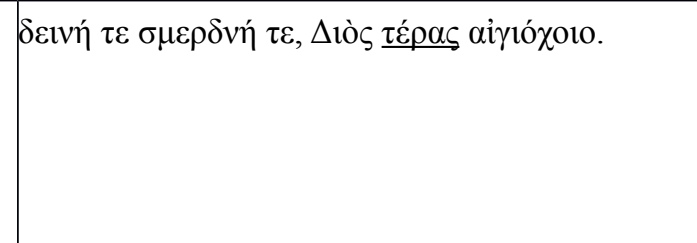 & narrador & não há & $\begin{array}{l}\text { cabeça da } \\
\text { Górgona como } \\
\text { portento de Zeus } \\
\text { detentor do } \\
\text { escudo }\end{array}$ \\
\hline Ilíada, & 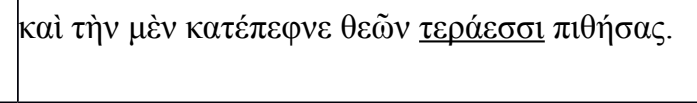 & Glauco & Diomedes & $\begin{array}{l}\text { portento dos } \\
\text { deuses }\end{array}$ \\
\hline $\begin{array}{l}\text { Ilíada, } \\
11.4\end{array}$ & 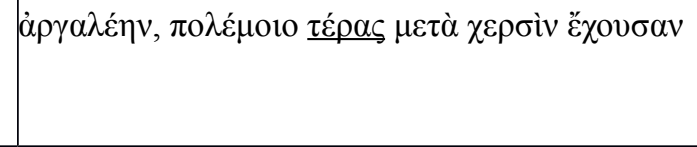 & narrador & não há & $\begin{array}{l}\text { portento de guerra } \\
\text { que Discórdia } \\
\text { segura nas mãos }\end{array}$ \\
\hline $\begin{array}{l}\text { Ilíada, } \\
11.28\end{array}$ & 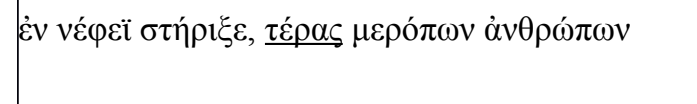 & narrador & não há & $\begin{array}{l}\text { arco-íris como } \\
\text { portento de Zeus }\end{array}$ \\
\hline $\begin{array}{l}\text { Ilíada, } \\
12.209\end{array}$ & 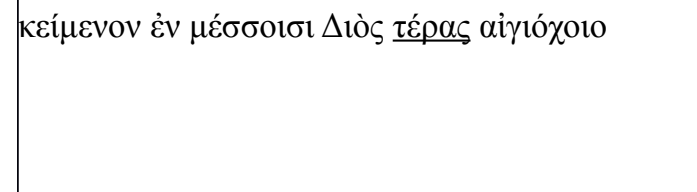 & narrador & não há & $\begin{array}{l}\text { cobra como } \\
\text { portento de Zeus } \\
\text { portador do } \\
\text { escudo }\end{array}$ \\
\hline $\begin{array}{l}\text { Ilíada, } \\
12.229\end{array}$ & 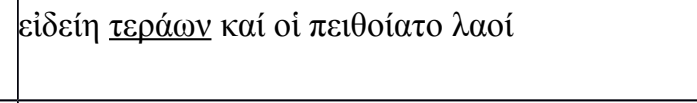 & Polidamante & Heitor & portentos \\
\hline $\begin{array}{l}\text { Ilíada, } \\
12.256\end{array}$ & 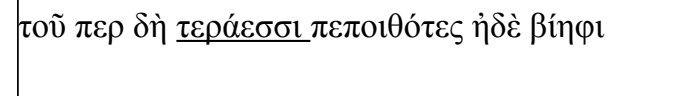 & narrador & não há & portentos \\
\hline $\begin{array}{l}\text { Ilíada, } \\
17.548\end{array}$ & 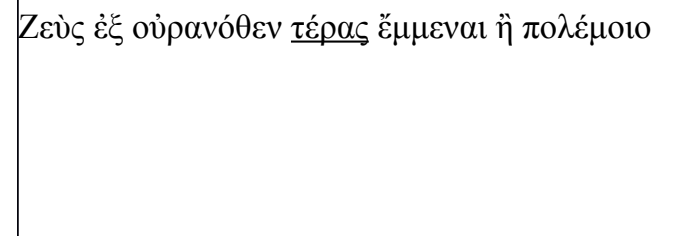 & narrador & não há & $\begin{array}{l}\text { arco-íris como } \\
\text { portento de guerra } \\
\text { ou da tempestade } \\
\text { gélida (símile de } \\
\text { Atena) }\end{array}$ \\
\hline $\begin{array}{l}\text { Odisseia, } \\
3.173\end{array}$ & 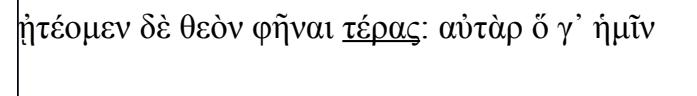 & Nestor & Telêmaco & portento \\
\hline
\end{tabular}




\begin{tabular}{|c|c|c|c|c|}
\hline $\begin{array}{l}\text { Odisseia, } \\
12.394\end{array}$ & 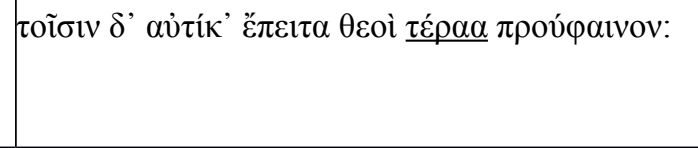 & Odisseu & feácios & $\begin{array}{l}\text { portento como } \\
\text { algo } \\
\text { extraordinário }\end{array}$ \\
\hline $\begin{array}{l}\text { Odisseia, } \\
15.168\end{array}$ & 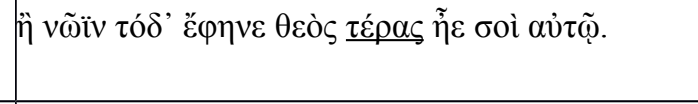 & Pisístrato & Menelau & portento \\
\hline $\begin{array}{l}\text { Odisseia, } \\
16.320\end{array}$ & 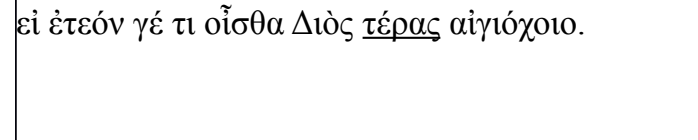 & Telêmaco & Odisseu & $\begin{array}{l}\text { portento de Zeus } \\
\text { portador do } \\
\text { escudo }\end{array}$ \\
\hline $\begin{array}{l}\text { Odisseia } \\
20.101\end{array}$ & 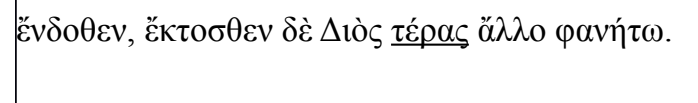 & $\begin{array}{l}\text { Odisseu } \\
\text { (prece) }\end{array}$ & Zeus & portento de Zeus \\
\hline $\begin{array}{l}\text { Odisseia, } \\
20.114\end{array}$ & 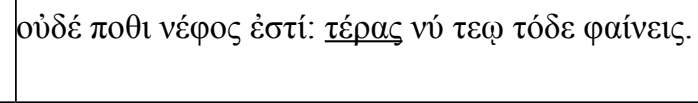 & $\begin{array}{l}\text { moendeira } \\
\text { (prece) }\end{array}$ & Zeus & portento de Zeus \\
\hline $\begin{array}{l}\text { Odisseia, } \\
21.415\end{array}$ & 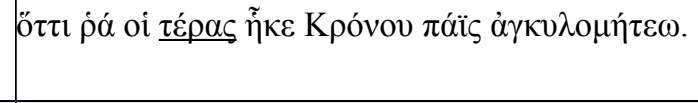 & narrador & não há & $\begin{array}{l}\text { portento de Zeus } \\
\text { a Odisseu }\end{array}$ \\
\hline $\begin{array}{l}\text { h.Ap., v. } \\
302\end{array}$ & 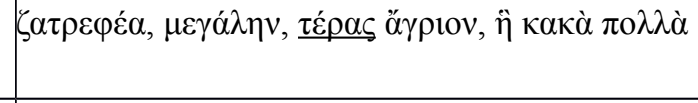 & narrador & não há & $\begin{array}{l}\text { serpente morta } \\
\text { por Apolo }\end{array}$ \\
\hline $\begin{array}{l}\text { Teogonia, } \\
\text { v. } 744\end{array}$ & 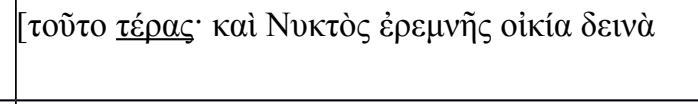 & narrador & não há & Tártaro \\
\hline $\begin{array}{l}\text { Cat. 141, } \\
\text { linha } 28\end{array}$ & [ ] $\Delta \Delta_{\mathrm{tó} \theta \varepsilon v} \underline{\tau \varepsilon \dot{\varepsilon} \rho \varsigma \tilde{\eta} \varepsilon v .}$ & $\begin{array}{l}\text { possivel } \\
\text { narrador }\end{array}$ & poss. não há & $\begin{array}{l}\text { poss. portento de } \\
\text { Zeus }\end{array}$ \\
\hline
\end{tabular}




\section{EXCERTOS COM AS OCORRÊNCIAS

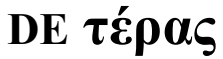

Ilíada, 2.324

Enunciador: Odisseu [Calcas] Interlocutor interno: aqueus Referente: prodígio enviado por Zeus

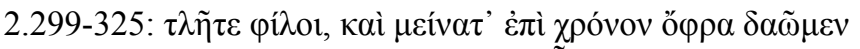

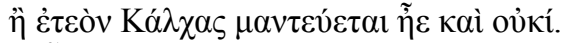

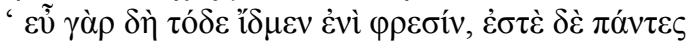

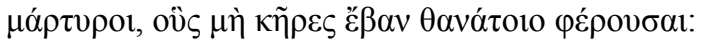

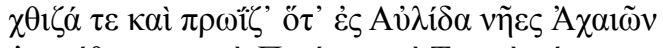

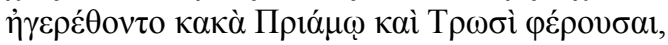

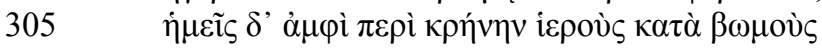

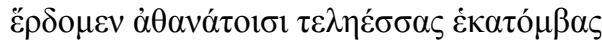

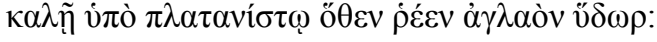

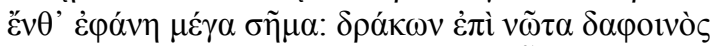

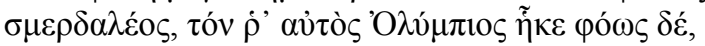

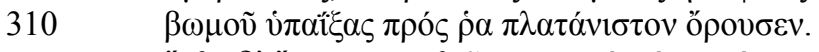

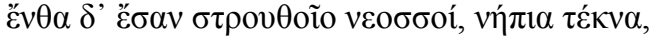

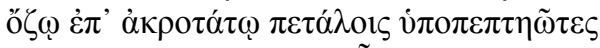

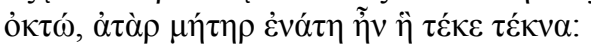

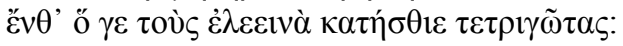

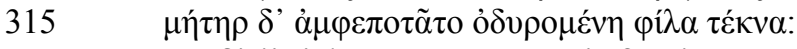

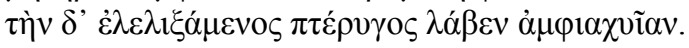

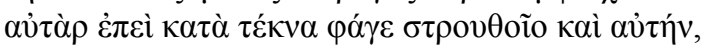

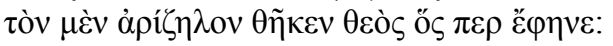

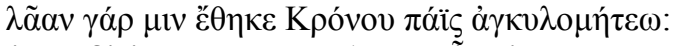

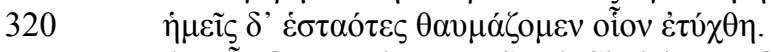

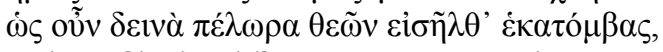

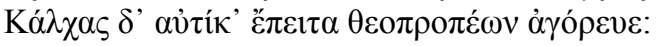

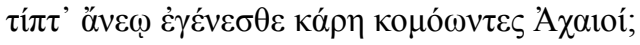

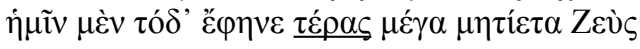

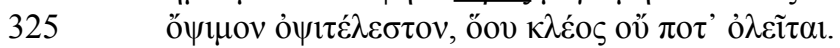

Allen-Monro (1920).

Aguentai, amigos, e permanecei mais um tempo, para sabermos se com verdade ou sem ela Calcas vaticinou. Pois todos sabemos isso nos corações - e todos vós sois testemunhas, todos que as divindades da morte não levaram ontem ou antes de ontem -: quando as naus dos Aqueus se reuniram em Áulis, trazendo desgraças a Príamo e aos troianos

305 e nós em torno de uma fonte nos sagrados altares sacrificávamos aos imortais e oferecíamos hecatombes debaixo de um belo plátano, donde fluía água transparente, foi então que apareceu um grande portento. Uma serpente de dorso avermelhado, medonha, que o Olímpio mostrara

310 à luz do dia, deslizou debaixo do altar e atirou-se ao plátano, onde estavam as crias de um pardal, crias inocentes!, no ramo mais alto, aterrorizadas sob as folhas: eram oito; com a mãe que as gerara eram nove. Então a serpente devorou as crias, que piavam de modo 
315 confrangedor, enquanto a mãe esvoaçava, chorando pelos filhos. Porém a serpente enrolando-se apanhou a chorosa pela asa.

Mas depois que devorou as crias e o próprio pardal, invisível fez a serpente o deus que a fizera visível: em pedra a transformou o Crônida de retorcidos conselhos. E nós ali em pé nos espantamos com o que acontecera. Quando o portento terrível interrompeu a hecatombe, imediatamente nos deu Calcas o seguinte vaticínio:

'Por que vos mantendes em silêncio, ó Aqueus de longos cabelos? A vós mostrou este grande prodígio Zeus conselheiro,

325 que veio tarde, que tarde se cumprirá, mas cuja fama nunca morrerá.

Lourenço (2013a).

Ilíada, 4.76 Enunciador: narrador Interlocutor interno: não há Referente: uma estrela, símile de Palas Atena

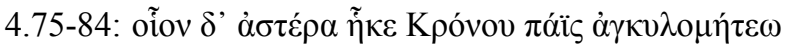

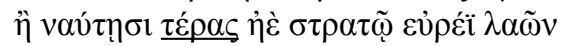

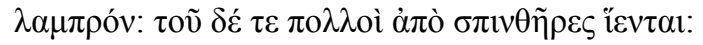

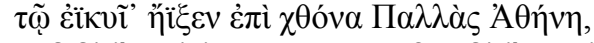

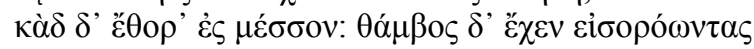

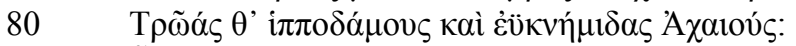

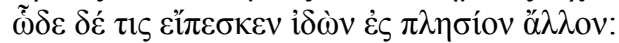

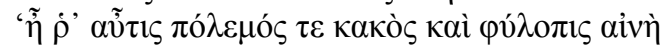

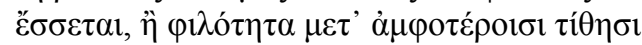

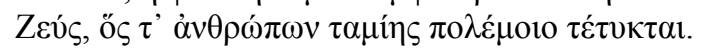

Tal como o astro enviado pelo Crônida de retorcidos conselhos como portento a marinheiros ou ao vasto exército de povos, estrela brilhante, de que se projetam abundantes centelhas assim se lançou em direção à terra Palas Atena, aterrando no meio deles com um salto; e o espanto dominou quem olhava,

80 Troianos domadores de cavalos e Aqueus de belas cnêmides. E assim dizia um deles, olhando de soslaio para o outro: "Virá de novo a guerra maligna e o fragor tremendo da refrega, ou então entre ambas as partes estabelece Zeus a amizade, ele que dispensa a guerra aos homens."

Ilíada, 4.398 Enunciador: Agamêmnon Interlocutor interno: Diomedes Referente: portentos dos deuses

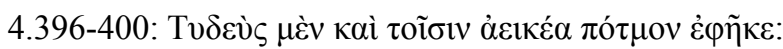

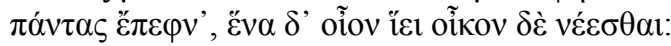

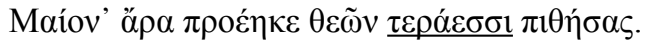

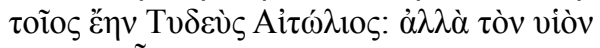

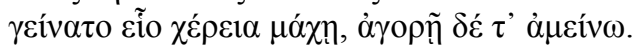

Mas Tideu fez desabar sobre eles um destino vergonhoso e matou-os a todos; só a um deixou que regressasse a casa mandou embora Méon, obedecendo aos portentos dos deuses. Tal era Tideu da Etólia; mas o filho que gerou é pior que ele na guerra, embora seja melhor na conversa.

Ilíada, 4.408 Enunciador: Estênelo Interlocutor interno: Agamêmnon Referente: portentos dos deuses

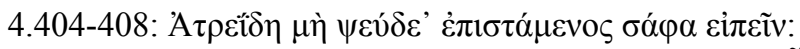

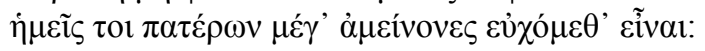

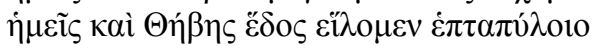




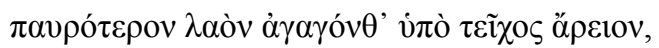

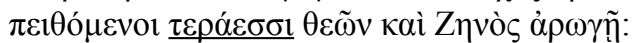

Atrida, não profiras mentiras, quando sabes dizer a verdade. Nós declaramo-nos de longe melhores que os nossos pais. Conquistamos a sede da heptápila Tebas, quando ambos juntamos uma hoste menor sob uma muralha mais forte, tendo acreditado nos portentos divinos e na ajuda de Zeus.

Ilíada, 5.742 Enunciador: narrador Interlocutor interno: não há Referente: cabeça da Górgona como portento de Zeus detentor do escudo (descrição do escudo de Atena)

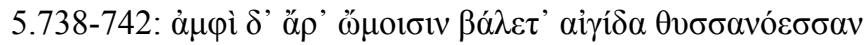

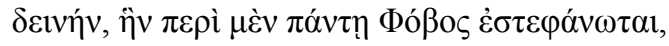
$\dot{\varepsilon} v \delta$ ' 'Е

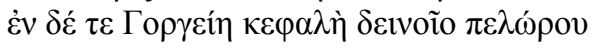

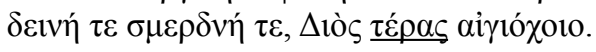

Em torno dos ombros atirou a égide borlada terrível, toda ela engalanada de Pânico: nela está a Discórdia, está a Sanha, está o gélido Assalto, está a cabeça monstruosa da Górgona, terrível e medonha, portento de Zeus detentor da égide.

Ilíada, $6.183 \quad$ Enunciador: Glauco Interlocutor interno: Diomedes Referente: portento dos deuses no contexto da morte da Quimera por Belerofonte

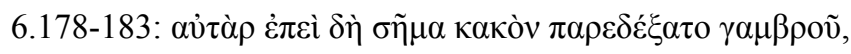

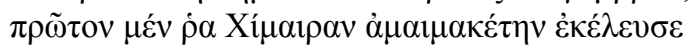

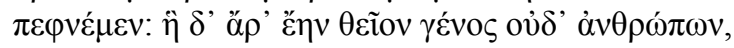

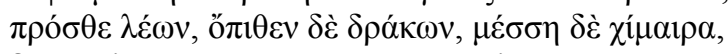

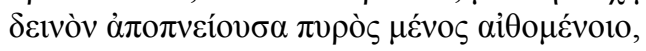

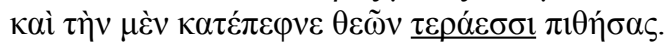

Porém quando recebeu o sinal maligno de seu genro, primeiro mandou-o matar a terrífica Quimera.

Ela é de raça divina - não pertence à dos homens:

à frente tem forma de leão, atrás de dragão, no meio de cabra; seu sopro é a fúria terrível do fogo ardente.

Mas Belerofonte matou-a, obedecendo aos portentos dos deuses.

Ilíada, 11.4 Enunciador: narrador Interlocutor interno: não há Referente: portento de guerra que Discórdia segura nas mãos

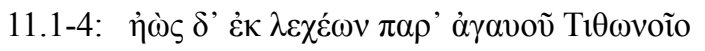

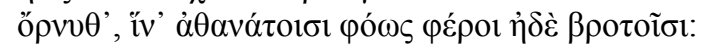

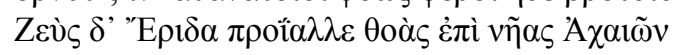

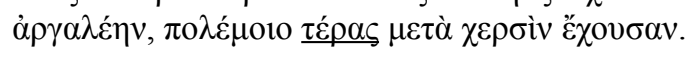

Do leito onde se deitava junto do orgulhoso Titono surgiu a Aurora, para trazer luz aos homens.

Zeus enviou a Discórdia para junto das naus velozes dos Aqueus, a medonha Discórdia, que segurava nas mãos um portento de guerra.

Ilíada, $11.28 \quad$ Enunciador: narrador Interlocutor interno: não há Referente: portento para os mortais, referente ao arco-íris (descrição de couraça de Agamêmnon

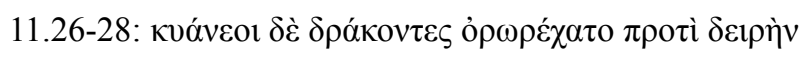




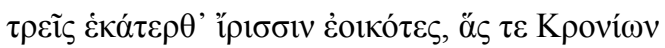

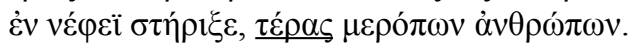

Serpentes azuis entrelaçavam-se até o pescoço, três de cada lado, semelhantes ao arco-íris que o Crônida põe no meio das nuvens, como portento para os mortais.

Ilíada, 12.209 Enunciador: narrador Interlocutor interno: não há Referente: portento de Zeus detentor do escudo (em relação à cobra que se contorcia no meio dos troianos)

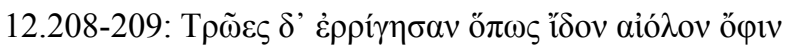

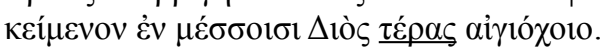

Os Troianos horrorizaram-se ao ver a cobra a contorcer-se, ali jazente no meio deles - portento de Zeus detentor da égide!

Ilíada, 12.229 Enunciador: Polidamante Interlocutor interno: Heitor Referente: portentos

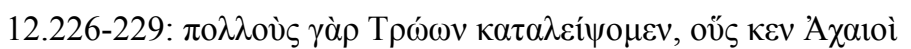

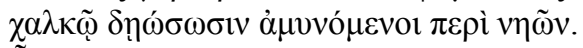

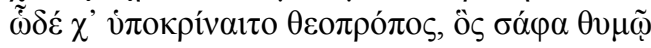

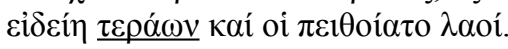

Pois muitos troianos lá deixaremos, a quem os Aqueus matarão com o bronze em defesa das naus. Esta seria a interpretação de um adivinho, que no ânimo tem conhecimento de portentos e no qual o povo confia.

Ilíada, 12.256 Enunciador: narrador Referente: portentos

Interlocutor interno: não há

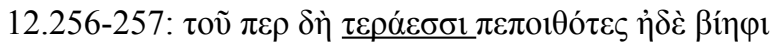

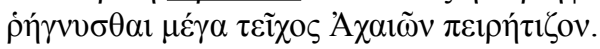

Confiando em portentos e na sua força, os Troianos procuravam arrasar a grande muralha dos Aqueus.

Ilíada, 17.548 Enunciador: narrador Interlocutor interno: não há Referente: arco-íris como portento de guerra ou da tempestade gélida (símile de Atena)

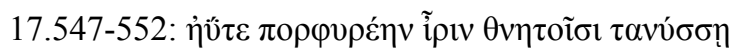

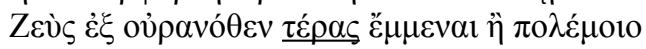

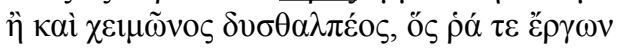

$550 \quad \dot{\alpha} v \theta \rho \omega ́ \pi 00 \varsigma$

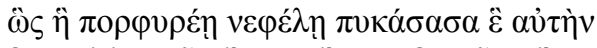

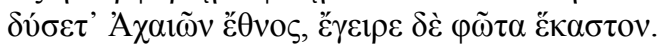

Allen (1920).

Tal como quando um purpúreo arco-íris para os mortais Zeus estica do céu, como portento quer da guerra, quer da gélida tempestade que obriga os homens

550 a parar a lavoura nos campos e prejudica rebanhos assim Atena, envolta numa nuvem purpúrea, entrou na chusma dos Aqueus e encorajou cada homem. 
Odisseia, 3.173

Enunciador: Nestor

Interlocutor interno: Telêmaco

Referente: prodígio do deus

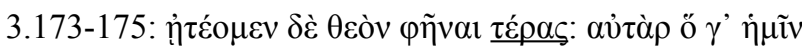

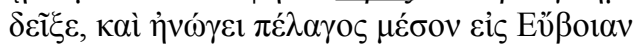

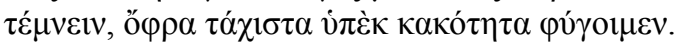

\section{Allen (1917).}

Pedimos ao deus que exibisse um prodígio, e ele a nós mostrou e ordenou que, rumo a Euboia, o meio do mar cortássemos, para bem rápido escapar do nefasto.

\section{Werner (2014).}

Odisseia, 12.394

Enunciador: Odisseu

Interlocutor interno: feácios

Referente: prodígio dos deuses

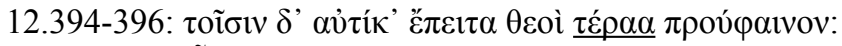

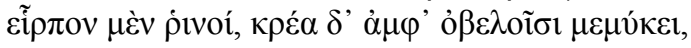

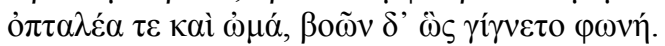

Logo os deuses exibiram-lhes um prodígio:

as peles caminhavam, as carnes nos espetos mugiam,

cozidas ou cruas; e o som era como o das vacas.

Odisseia, 15.168

Enunciador: Pisístrato

Interlocutor interno: Menelau

Referente: presságio

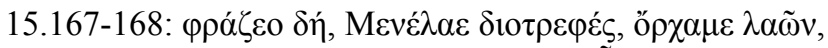

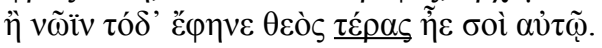

Allen (1919)

Analisa, Menelay criado-por-Zeus, líder de tropa, se o deus mostrou o presságio a nós dois, ou a ti”.

Odisseia, 16.320

Enunciador: Telêmaco

Interlocutor interno: Odisseu

Referente: prodígio de Zeus

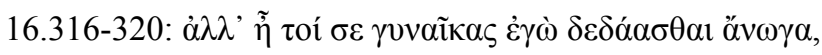

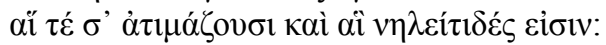

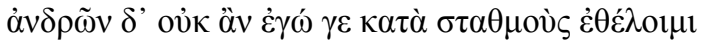

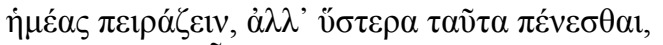

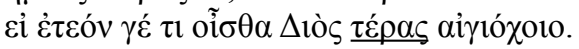

Mas eu peço que examines as mulheres, as que te desonram e as que são inocentes; aos varões eu não quereria, pela quinta, que os testássemos, isso faremos depois, se de verdade sabes de prodígio de Zeus porta-égide.

Odisseia, $20.101 \quad$ Enunciador: Odisseu (prece) Interlocutor interno: Zeus Referente: prodígio de Zeus

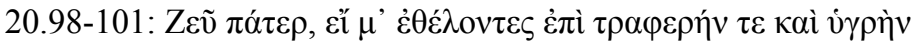

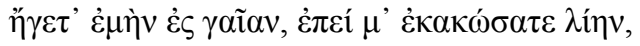

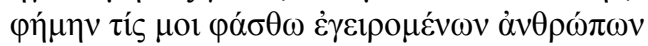

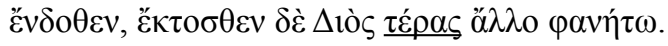


Zeus pai, se a mim, com intenção, à firme e úmida terra, à minha, trouxestes, após me lesardes demais, prenúncio pronuncie um dos homens que desperta dentro, e, fora, prodígio de Zeus, ademais, apareça.

Odisseia, 20.114 Enunciador: moendeira (prece) Interlocutor interno: Zeus Referente: prodígio de Zeus

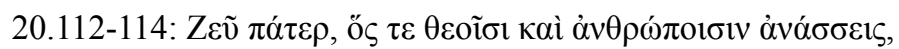

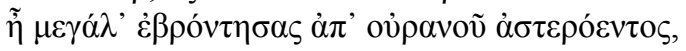

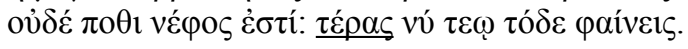

Zeus pai, que aos deuses e homens reges, com vigor trovejaste do páramo estrelado, onde nuvem não há; é prodígio que mostras a alguém.

Odisseia, 21.415

Enunciador: narrador Interlocutor interno: não há Referente: prodígio de Zeus

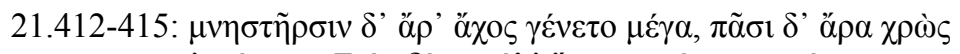

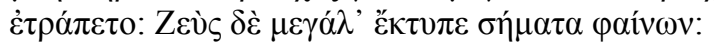

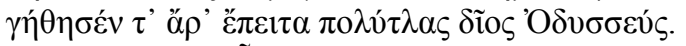

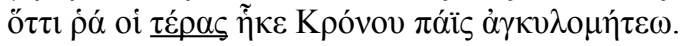

Grande angústia se apossou dos pretendentes, e sua cor mudou. E Zeus ribombou forte, revelando sinais. Então alegrou-se o muita-tenência, divino Odisseu, pois prodígio enviou-lhe o filho de Crono curva-astúcia.

h.Ap., v. $302 \quad$ Enunciador: narrador Interlocutor interno: não há Referente: serpente

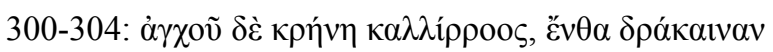

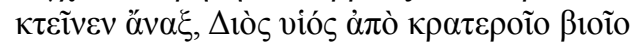

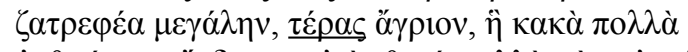

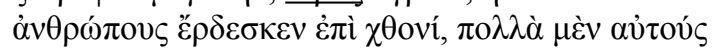

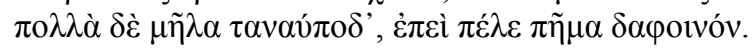

Càssola (1975).

Perto há uma fonte de bela corredeira, ali o senhor filho de Zeus, matou, com seu arco enérgico, uma serpente robusta, grande, um monstro feroz que fazia muitos males aos homens sobre a terra; muitos males a eles, e muitos males aos carneiros de patas finas. Era um tormento de sangue.

Massi (em Ribeiro Jr., 2010). Referente: Tártaro

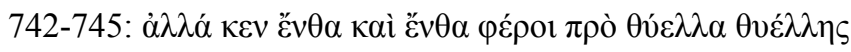

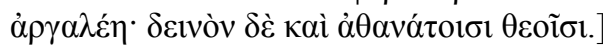

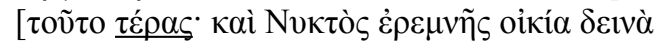

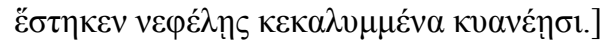

$$
\text { West (1997 [1966]). }
$$

mas p'ra lá e p'ra cá o levaria rajada após rajada aflitiva. Assombroso é também para deuses imortais 
esse prodígio; também a morada assombrosa de Noite encontra-se escondida em nuvem cobalto.

Werner (2013a).

Catálogo das Mulheres, frag.141, linha 28

28-29: [ ] ]

[ ] $\Delta \mathrm{ió} \theta \varepsilon v \underline{\tau \varepsilon ́ p \alpha \varsigma} \tilde{\eta} \varepsilon v$.

Merkelbach e West (1967). 
APÊNDICE D

\section{TABELAS DE OCORRÊNCIAS DE $\pi \hat{\varepsilon} \lambda \omega \rho$ e derivados}

\section{D.1 Variantes do substantivo $\tau$ ò $\pi \varepsilon ́ \lambda \omega \rho$ e $\tau$ ò $\pi \varepsilon ́ \lambda \omega \rho o v$}

\begin{tabular}{|c|c|c|c|c|}
\hline $\begin{array}{l}\begin{array}{l}\text { Poema e } \\
\text { verso }\end{array} \\
\end{array}$ & Verso & Enunciador & $\begin{array}{l}\text { Interlocutor } \\
\text { interno }\end{array}$ & Referente \\
\hline $\begin{array}{l}\text { Ilíada, } \\
2.321\end{array}$ & 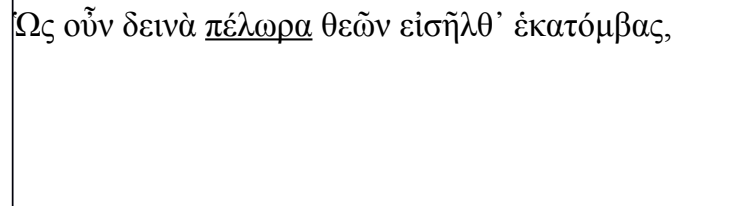 & Odisseu & aqueus & $\begin{array}{l}\text { manifestações } \\
\text { divinas que } \\
\text { serão } \\
\text { interpretadas por } \\
\text { Calcas }\end{array}$ \\
\hline $\begin{array}{l}\text { Ilíada, } \\
5.741\end{array}$ & 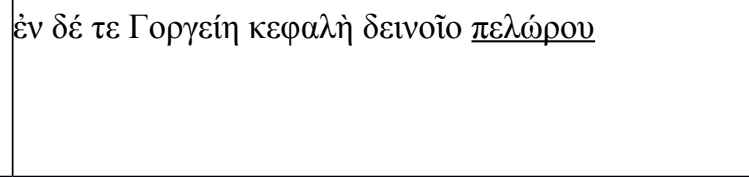 & narrador & não há & $\begin{array}{l}\text { cabeça da } \\
\text { Górgona, na } \\
\text { descrição do } \\
\text { escudo de Atena }\end{array}$ \\
\hline $\begin{array}{l}\text { Ilíada, } \\
18.410\end{array}$ & 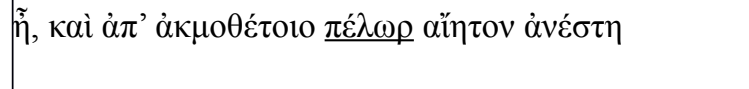 & narrador & não há & Hefesto \\
\hline $\begin{array}{l}\text { Odisseia, } \\
9.257\end{array}$ & 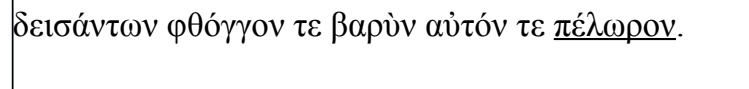 & Odisseu & feácios & $\begin{array}{l}\text { ciclope } \\
\text { [Polifemo] }\end{array}$ \\
\hline $\begin{array}{l}\text { Odisseia, } \\
9.428\end{array}$ & 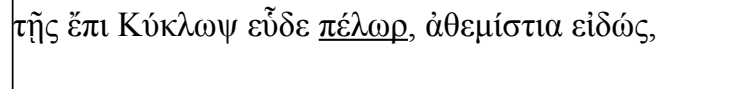 & Odisseu & feácios & $\begin{array}{l}\text { ciclope } \\
\text { [Polifemo] }\end{array}$ \\
\hline $\begin{array}{l}\text { Odisseia, } \\
10.168\end{array}$ & 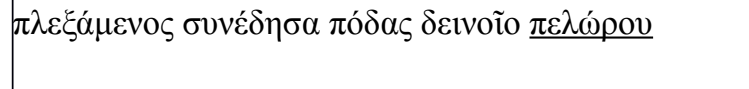 & Odisseu & feácios & cervo \\
\hline $\begin{array}{l}\text { Odisseia } \\
10.219\end{array}$ & 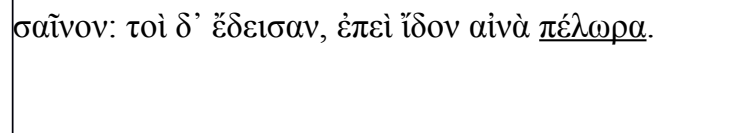 & Odisseu & feácios & $\begin{array}{l}\text { animais } \\
\text { encantados de } \\
\text { Circe }\end{array}$ \\
\hline \begin{tabular}{|l} 
Odisseia \\
11.634
\end{tabular} & 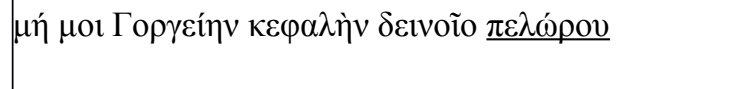 & Odisseu & feácios & $\begin{array}{l}\text { cabeça da } \\
\text { Górgona }\end{array}$ \\
\hline $\begin{array}{l}\text { Odisseia } \\
12.87\end{array}$ & 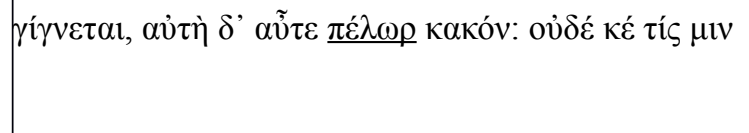 & $\begin{array}{l}\text { Circe } \\
\text { (Odisseu) }\end{array}$ & $\begin{array}{l}\text { Odisseu e } \\
\text { companheiros } \\
\text { (feácios) }\end{array}$ & Cila \\
\hline $\begin{array}{l}\text { Odisseia } \\
15.161\end{array}$ & 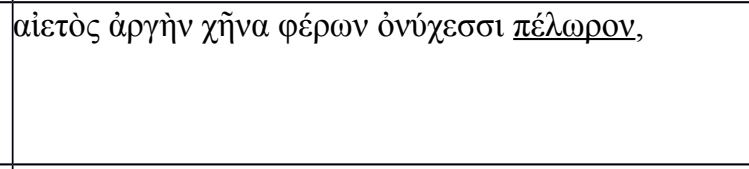 & narrador & não há & $\begin{array}{l}\text { vaticínio: uma } \\
\text { águia voa com } \\
\text { uma gansa nas } \\
\text { garras }\end{array}$ \\
\hline $\begin{array}{l}\text { h. } A p ., \\
\text { v. } 374\end{array}$ & 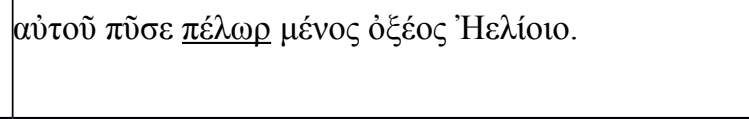 & narrador & não há & $\begin{array}{l}\text { serpente morta } \\
\text { por Apolo }\end{array}$ \\
\hline $\begin{array}{l}\text { h. } A p \cdot, \\
\text { v. } 401\end{array}$ & 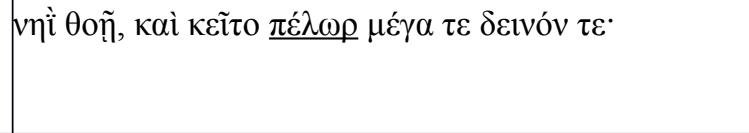 & narrador & não há & $\begin{array}{l}\text { golfinho no qual } \\
\text { Apolo se } \\
\text { transforma }\end{array}$ \\
\hline $\begin{array}{l}\text { h. } A p ., \\
\text { v. } 416\end{array}$ & 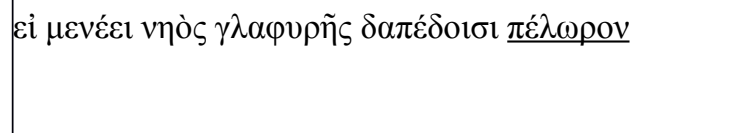 & narrador & não há & $\begin{array}{l}\text { golfinho no qual } \\
\text { Apolo se } \\
\text { transforma }\end{array}$ \\
\hline $\begin{array}{l}\text { h.Merc., } \\
\text { v. } 225\end{array}$ & 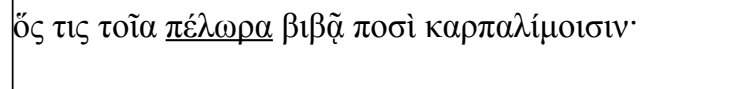 & Apolo & $\begin{array}{l}\text { não há } \\
\text { (interjeição) }\end{array}$ & $\begin{array}{l}\text { pegadas de } \\
\text { Centauro }\end{array}$ \\
\hline
\end{tabular}




\begin{tabular}{|c|c|c|c|c|}
\hline $\begin{array}{l}\text { h.Merc., } \\
\text { v. } 349\end{array}$ & 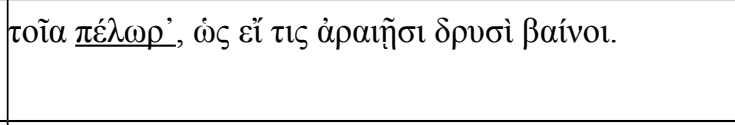 & Apolo & Zeus & $\begin{array}{l}\text { pegadas } \\
\text { deixadas por } \\
\text { Hermes }\end{array}$ \\
\hline $\begin{array}{l}\text { Teogonia, } \\
\text { v. } 295\end{array}$ & 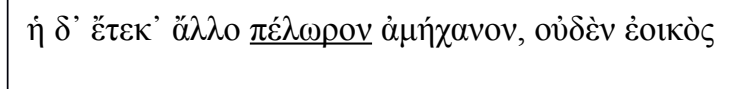 & narrador & não há & Équidna \\
\hline \begin{tabular}{|l} 
Teogonia, \\
v. 845
\end{tabular} & 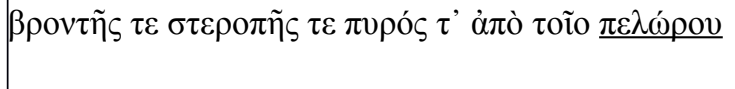 & narrador & não há & Tifeu \\
\hline \begin{tabular}{|l} 
Teogonia, \\
v. 856
\end{tabular} & 856: ё & narrador & não há & Tifeu \\
\hline $\begin{array}{l}\text { Scutum, } \\
\text { v. } 223\end{array}$ & 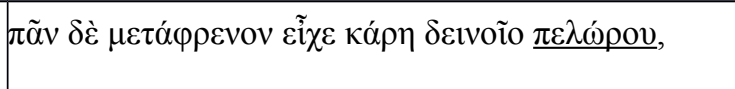 & narrador & não há & $\begin{array}{l}\text { cabeça da } \\
\text { Górgona }\end{array}$ \\
\hline
\end{tabular}

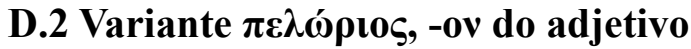

\begin{tabular}{|c|c|c|c|c|}
\hline $\begin{array}{l}\begin{array}{l}\text { Poema e } \\
\text { verso }\end{array} \\
\end{array}$ & Verso & Enunciador & \begin{tabular}{|l|}
$\begin{array}{l}\text { Interlocutor } \\
\text { interno }\end{array}$ \\
\end{tabular} & Referente \\
\hline $\begin{array}{l}\text { Iliada, } \\
3.166\end{array}$ & 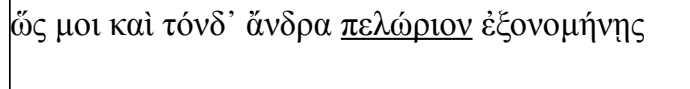 & Príamo & Helena & Agamêmnon \\
\hline $\begin{array}{l}\text { Ilíada, } \\
3.229\end{array}$ & 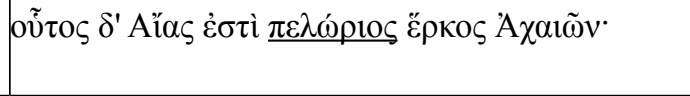 & Helena & Príamo & Ájax \\
\hline $\begin{array}{l}\text { Ilíada, } \\
5.395\end{array}$ & 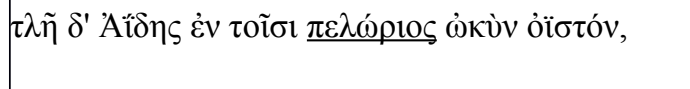 & Dione & Afrodite & Hades \\
\hline $\begin{array}{l}\text { Iliada, } \\
5.594\end{array}$ & 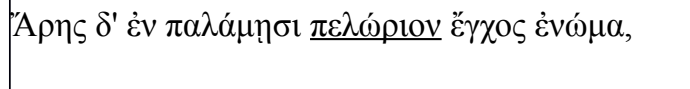 & narrador & não há & lança de Ares \\
\hline $\begin{array}{l}\text { Iliada, } \\
5.842\end{array}$ & 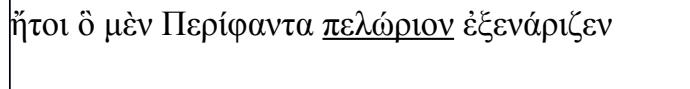 & narrador & não há & Perifante \\
\hline $\begin{array}{l}\text { Iliada, } \\
5.847\end{array}$ & 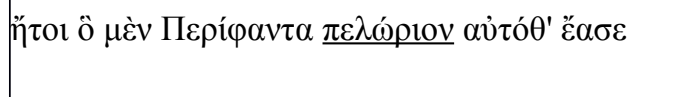 & narrador & não há & Perifante \\
\hline $\begin{array}{l}\text { Ilíada, } \\
7.208\end{array}$ & 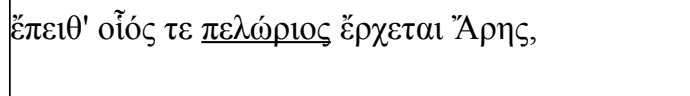 & narrador & não há & Ares \\
\hline $\begin{array}{l}\text { Ilíada, } \\
7.211\end{array}$ & 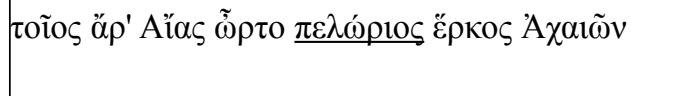 & narrador & não há & Ájax \\
\hline $\begin{array}{l}\text { Ilíada, } \\
8.424\end{array}$ & 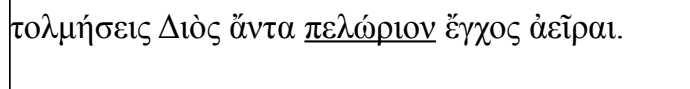 & Íris & Hera e Atena & lança de Atena \\
\hline $\begin{array}{l}\text { Ilíada, } \\
10.439\end{array}$ & 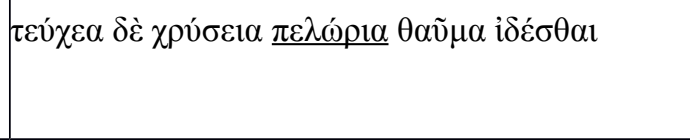 & Dólon & Diomedes & $\begin{array}{l}\text { armas de ouro de } \\
\text { Reso, rei dos } \\
\text { Trácios }\end{array}$ \\
\hline $\begin{array}{l}\text { Iliada, } \\
11.820\end{array}$ & 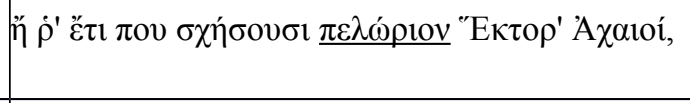 & Pátroclo & Eurípilo & Heitor \\
\hline $\begin{array}{l}\text { Ilíada, } \\
17.174\end{array}$ & 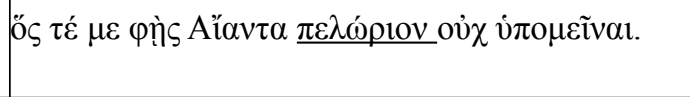 & Heitor & Glauco & Ájax \\
\hline $\begin{array}{l}\text { Ilíada, } \\
17.360\end{array}$ & 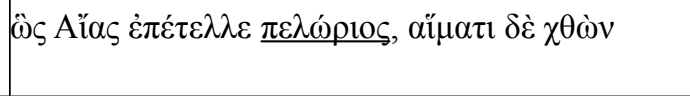 & narrador & não há & Ájax \\
\hline $\begin{array}{l}\text { Iliada, } \\
18.83\end{array}$ & $\delta \eta \omega ́ \sigma \alpha \varsigma \dot{\alpha} \pi \varepsilon \dot{\delta} \delta v \sigma \varepsilon \underline{\pi \varepsilon \lambda \omega ́ \rho 1 \alpha} \theta \alpha \tilde{v} \mu \alpha$ i $\delta \varepsilon \varepsilon^{\prime} \sigma \theta \alpha$ & Aquiles & Tétis & $\begin{array}{l}\text { armas de Aquiles } \\
\text { vestidas por } \\
\text { Pátroclo }\end{array}$ \\
\hline
\end{tabular}




\begin{tabular}{|c|c|c|c|c|}
\hline $\begin{array}{l}\text { Iliada, } \\
21.527\end{array}$ & 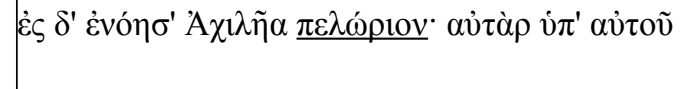 & narrador & não há & Aquiles \\
\hline $\begin{array}{l}\text { Iliada, } \\
22.92\end{array}$ & 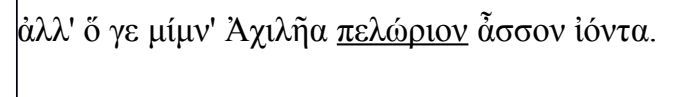 & narrador & não há & Aquiles \\
\hline $\begin{array}{l}\text { Odisseia, } \\
3.290\end{array}$ & 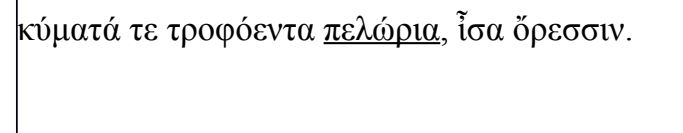 & Nestor & $\begin{array}{l}\text { Telêmaco e } \\
\text { Atena- } \\
\text { Mentor }\end{array}$ & ondas \\
\hline $\begin{array}{l}\text { Odisseia, } \\
9.187\end{array}$ & 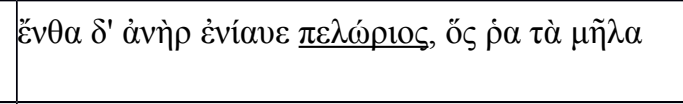 & Odisseu & feácios & Polifemo \\
\hline $\begin{array}{l}\text { Odisseia, } \\
9.190\end{array}$ & 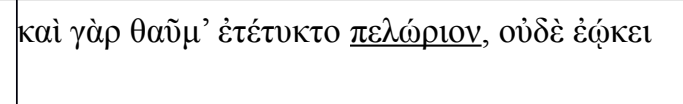 & Odisseu & feácios & Polifemo \\
\hline $\begin{array}{l}\text { Odisseia, } \\
11.572\end{array}$ & 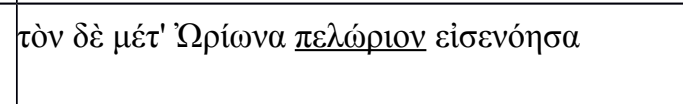 & Odisseu & feácios & Órion \\
\hline $\begin{array}{l}\text { Odisseia, } \\
11.594\end{array}$ & 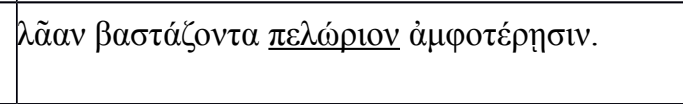 & Odisseu & feácios & $\begin{array}{l}\text { pedra carregada } \\
\text { por Sísifo }\end{array}$ \\
\hline $\begin{array}{l}\text { Teogonia, } \\
\text { v. } 179\end{array}$ & 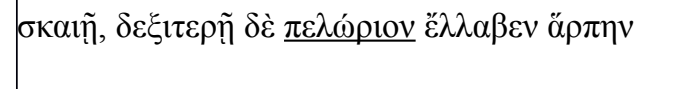 & narrador & não há & Foice \\
\hline
\end{tabular}

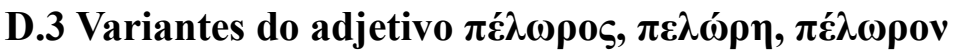

\begin{tabular}{|c|c|c|c|c|}
\hline $\begin{array}{l}\text { Poema e } \\
\text { verso }\end{array}$ & Verso & Enunciador & $\begin{array}{l}\text { Interlocutor } \\
\text { interno }\end{array}$ & Referente \\
\hline $\begin{array}{l}\text { h.Merc., v. } \\
342\end{array}$ & 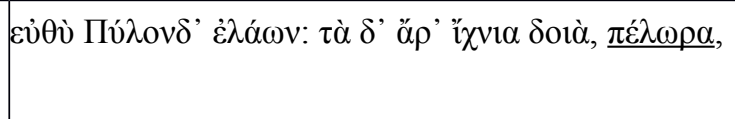 & Apolo & Zeus & $\begin{array}{l}\text { pegadas } \\
\text { deixadas por } \\
\text { Hermes }\end{array}$ \\
\hline $\begin{array}{l}\text { Teogonia, } \\
\text { v. } 159\end{array}$ & 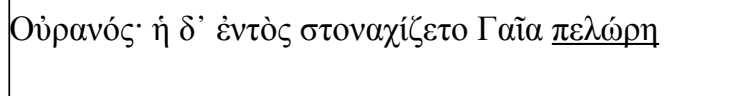 & narrador & não há & Terra \\
\hline $\begin{array}{l}\text { Teogonia, } \\
\text { v. } 173\end{array}$ & 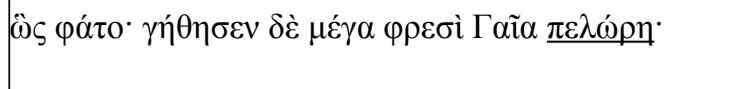 & narrador & não há & Terra \\
\hline $\begin{array}{l}\text { Teogonia, } \\
\text { v. } 299\end{array}$ & 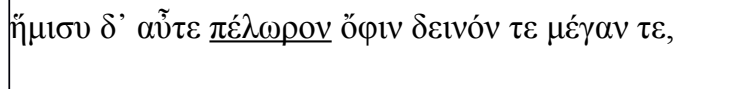 & narrador & não há & Équidna \\
\hline $\begin{array}{l}\text { Teogonia, } \\
\text { v. } 479\end{array}$ & 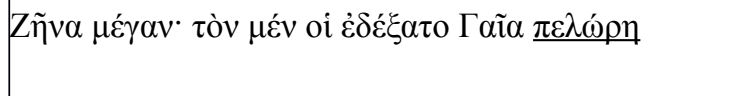 & narrador & não há & Terra \\
\hline $\begin{array}{l}\text { Teogonia, } \\
\text { v. } 505\end{array}$ & 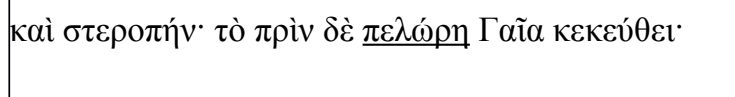 & narrador & não há & Terra \\
\hline $\begin{array}{l}\text { Teogonia, } \\
\text { v. } 731\end{array}$ & 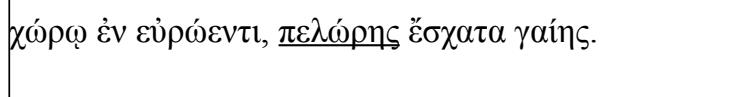 & narrador & não há & Terra \\
\hline $\begin{array}{l}\text { Teogonia, } \\
\text { v. } 821\end{array}$ & 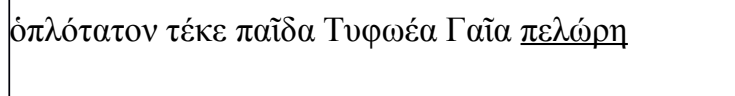 & narrador & não há & Terra \\
\hline $\begin{array}{l}\text { Teogonia, } \\
\text { v. } 858\end{array}$ & 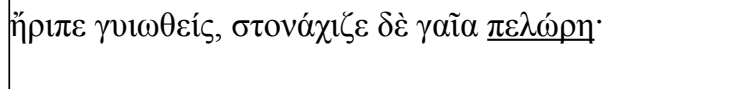 & narrador & não há & Terra \\
\hline $\begin{array}{l}\text { Teogonia, } \\
\text { v. } 861\end{array}$ & 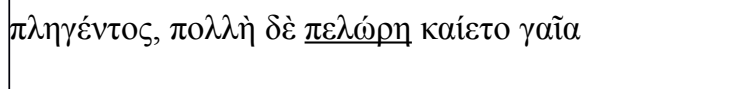 & narrador & não há & Terra \\
\hline $\begin{array}{l}\text { Cat. frag. } \\
150, \text { v. } 11\end{array}$ & 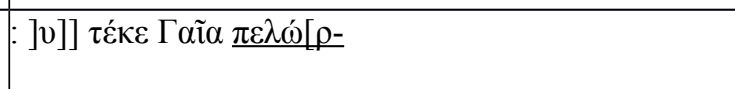 & $\begin{array}{l}\text { poss. o } \\
\text { narrador }\end{array}$ & poss. não há & Terra \\
\hline
\end{tabular}




\section{EXCERTOS COM AS OCORRÊNCIAS DE $\pi \hat{\varepsilon} \lambda \omega \rho$ E DERIVADOS}

\section{E.1 Ilíada}

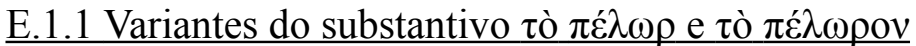

Ilíada, 2.321

$$
\begin{aligned}
& \text { Enunciador: Odisseu Interlocutor interno: aqueus } \\
& \text { Referente: manifestações divinas que serão interpretadas por Calcas }
\end{aligned}
$$

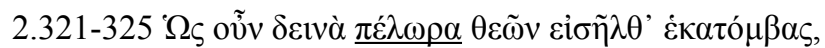

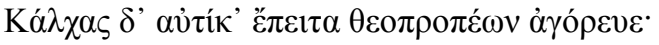

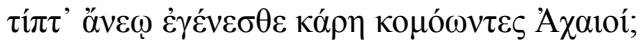

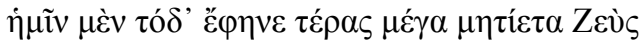

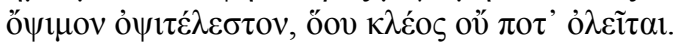

\section{Allen-Monro (1920).}

Quando o portento terrível interrompeu a hecatombe imediatamente nos deu Calcas o seguinte vaticínio: 'Por que vos mantendes em silêncio, ó Aqueus de longos cabelos? A vós mostrou este grande prodígio Zeus conselheiro, que veio tarde, que tarde se cumprirá, mas cuja fama nunca morrerá.

$$
\text { Lourenço (2013a). }
$$

Ilíada, 5.741

Enunciador: narrador $\quad$ Interlocutor interno: não há
Referente: cabeça da Górgona, na descrição do escudo de Atena

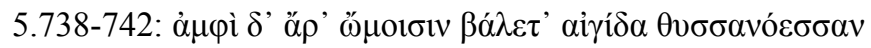

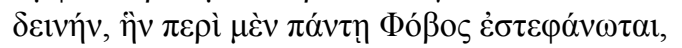

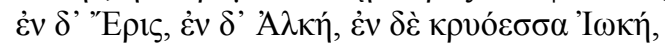

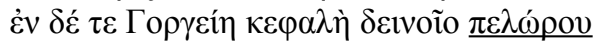

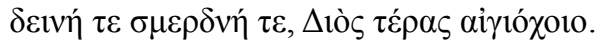

Em torno dos ombros atirou a égide borlada terrível, toda ela engalanada de Pânico: nela está a Discórdia, está a Sanha, está o gélido Assalto, está a cabeça monstruosa da Górgona, terrível e medonha, portento de Zeus detentor da égide.

Ilíada, 18.410 Enunciador: narrador
Referente: Hefesto

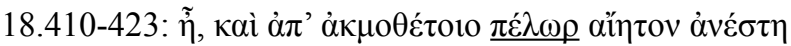

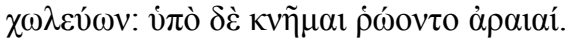

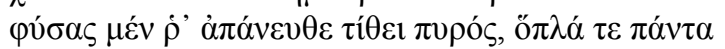

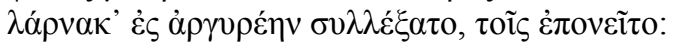

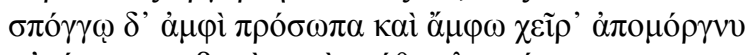

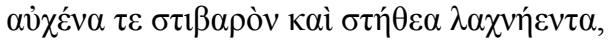
$\delta \tilde{v} \delta \dot{\varepsilon} \chi \imath \tau \tilde{\omega} v^{\prime}$, हैं $\lambda \varepsilon \delta \dot{\varepsilon} \sigma \kappa \tilde{\eta} \pi \tau \rho \circ v \pi \alpha \chi v ́, \beta \tilde{\eta} \delta \dot{\varepsilon} \theta u ́ \rho \alpha \zeta \varepsilon$

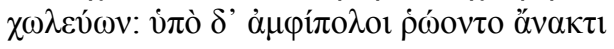




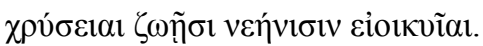

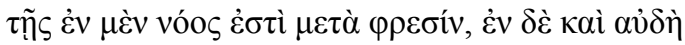

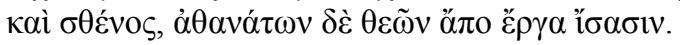

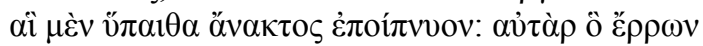

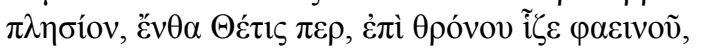

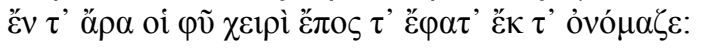

Falou; e levantou-se da bigorna, qual colosso ofegante, coxeando, mas as pernas por baixo dele eram ágeis.

Colocou os foles longe do fogo e toso os instrumentos reuniu numa arca de prata, todos de que se servira.

Com uma esponja limpou a cara e os dois braços, assim como o pescoço possante e o peito hirsuto; depois vestiu uma túnica e agarrou num cetro robusto; saiu porta fora a coxear. Para dar apoio ao soberano correram duas servas douradas, semelhantes a moças vivas.

Nelas há entendimento no espírito; são dotadas de voz e de força e conhecem os trabalhos dos deuses imortais.

Foram estas que se apressaram a apoiar o amo, que foi a coxear até onde estava Tétis e sentou-se num trono luzente.

Acariciando-a com a mão assim lhe disse, tratando-a pelo nome.

\section{E.1.2 Variante $\pi \varepsilon \lambda \omega_{0} \rho c_{2}$-ov do adjetivo}

Ilíada, 3.166

Enunciador: Príamo

Interlocutor interno: Helena

Referente: Agamêmnon

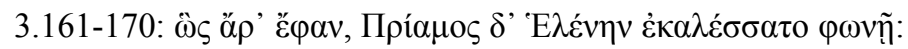

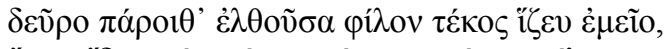

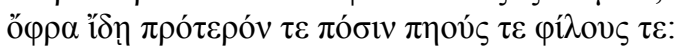

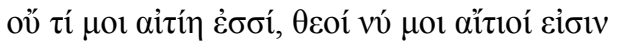

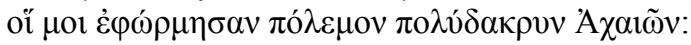

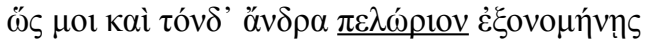

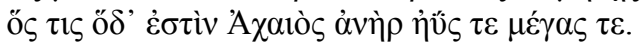
ทँं

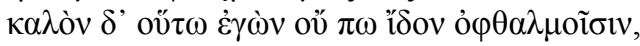

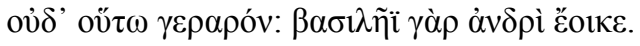

Assim falaram. Mas Príamo com sua voz chamou Helena. "Chega aqui, querida filha, e senta-te ao meu lado, para veres o teu primeiro marido, teus parentes e teu povo pois no meu entender não tens culpa, mas têm-na os deuses, que lançaram contra mim a guerra cheia de lágrimas dos Aqueus e para me dizeres quem é este homem guerreiro ele que é um aqueu tão alto e tão forte; na verdade outros haverá uma cabeça mais altos, mas nunca com os olhos vi homem mais belo, nem de aspecto tão nobre: pois parece um rei."

Ilíada, 3.229

$$
\begin{aligned}
& \text { Enunciador: Helena } \\
& \text { Referente: Ájax }
\end{aligned}
$$

Interlocutor interno: Príamo

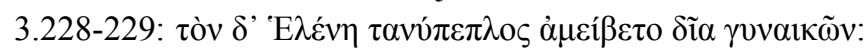

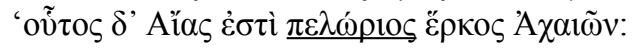

A ele deu resposta Helena de longos vestidos, a mulher divina:

"Este é o enorme Ájax, baluarte dos Aqueus. 
Ilíada, 5.395

Enunciador: Dione

Interlocutor interno: Afrodite

Referente: Hades

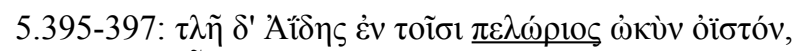

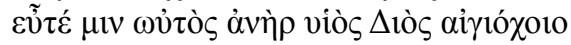

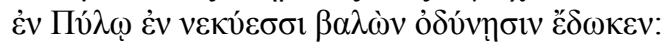

Além destes sofreu uma seta veloz o monstruoso Hades, quando o mesmo homem, filho de Zeus detentor da égide, $\mathrm{o}$ atingiu em Pilos no meio dos mortos, entregando-o à dor.

Ilíada, 5.594

Enunciador: narrador

Interlocutor interno: não há Referente: lança de Ares

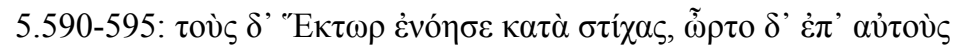

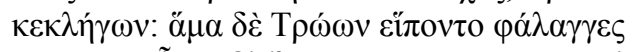

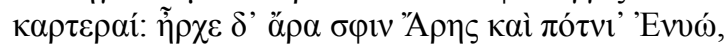

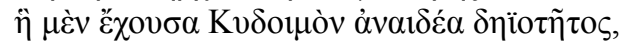

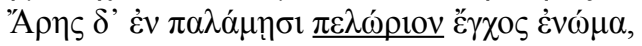

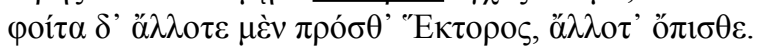

Viu-os Heitor por entre as fileiras e investiu contra eles, gritando. Com ele seguiram as falanges dos Troianos, vigorosas. Conduziu-os Ares e a soberâna Ênio, ela traz o Tumulto ignominioso da chacina; e Ares segurava nas mãos uma lança monstruosa, deslocando-se ora à frente, ora atrás, de Heitor.

Ilíada, 5.842

Enunciador: narrador

Interlocutor interno: não há Referente: Perifante

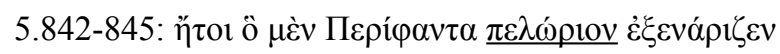

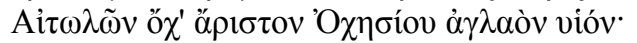

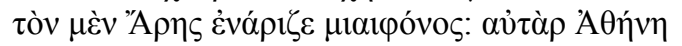

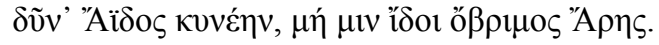

Ora Ares estava a despir das suas armas o musculoso Perifante de longe o melhor dos Etólios, glorioso filho de Oquésio: era a ele que despia Ares, coberto de sangue. Mas Atena pôs na cabeça o gorro de Hades, para que Ares poderoso não a visse.

Ilíada, 5.847

Enunciador: narrador

Interlocutor interno: não há Referente: Perifante

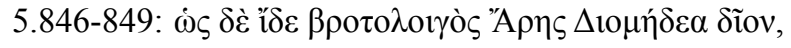

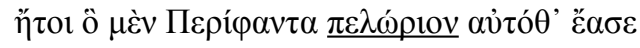

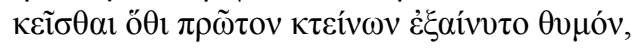

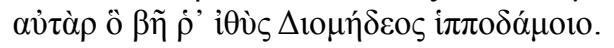

E quando Ares, flagelo dos mortais, viu o divino Diomedes, deixou jazente onde estava o musculoso Perifante, no mesmo local onde $o$ abatera e lhe tirara a vida, e foi direto contra Diomedes domador de cavalos.

Ilíada, 7.208

Enunciador: narrador Interlocutor interno: não há Referente: Ares

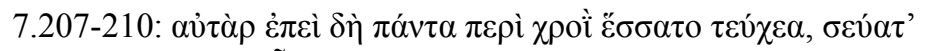

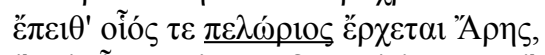

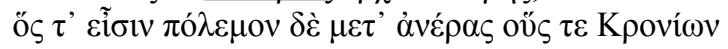




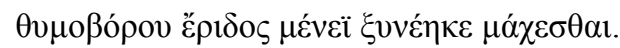

Depois que sobre o corpo [Ájax] vestira todas as armas avançou tal como caminha o enorme Ares quando entra na guerra entre os homens que o Crônida juntou, para combaterem na fúria do conflito devorador da alma.

Ilíada, 7.211

$$
\begin{aligned}
& \text { Enunciador: narrador } \\
& \text { Referente: Ájax }
\end{aligned}
$$

Interlocutor interno: não há

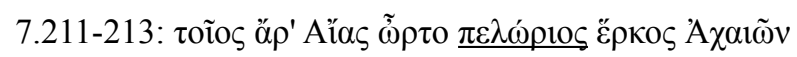

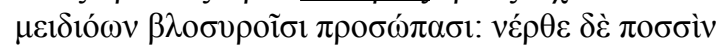

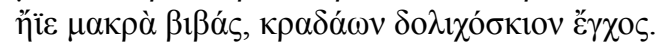

De tal modo avançou o enorme Ájax, baluarte dos aqueus, sorrindo com expressão medonha. Com grandes passadas dos seus pés caminhou, brandindo a lança de longa sombra.

Ilíada, 8.424

Enunciador: Íris Referente: lança de Atena

Interlocutor interno: Hera e Atena

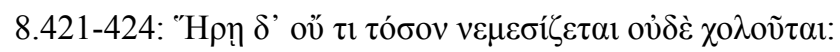

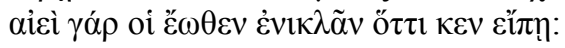

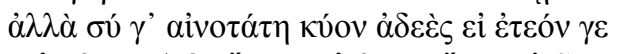

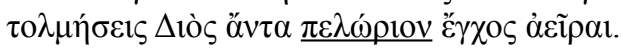

Contra Hera [Zeus] não se zanga tanto nem se encoleriza, visto que sempre o queres frustar no que determina. Mas sobremaneira danada serias, ó cadela desavergonhada [Atena], se na verdade te atrevesses a levantar a forte lança contra Zeus.

Ilíada, 10.439 Enunciador: Dólon Interlocutor interno: Diomedes Referente: armas de ouro de Reso, rei dos Trácios

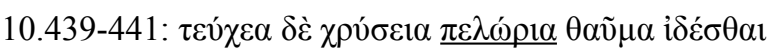

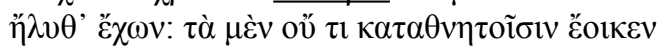

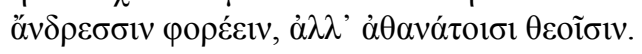

E enormes armas de ouro, maravilha de se ver!, trouxe ele; armas que a homens mortais não fica bem envergar, mas tão somente aos deuses imortais.

Ilíada, 11.820

$$
\begin{aligned}
& \text { Enunciador: Pátroclo } \\
& \text { Referente: Heitor }
\end{aligned}
$$

Interlocutor interno: Eurípilo

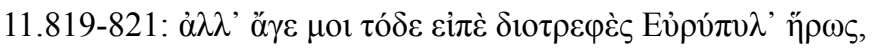

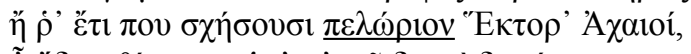

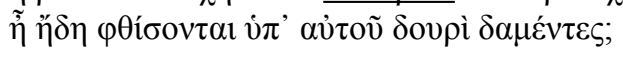

Mas diz-me tu agora, ó herói Eurípilo, criado por Zeus, se os Aqueus retêm ainda o possante Heitor, ou se morrem subjugados pela sua lança?

\author{
Ilíada, 17.174

$$
\text { Referente: Ájax }
$$$$
\text { Enunciador: Heitor }
$$ \\ Interlocutor interno: Glauco
}

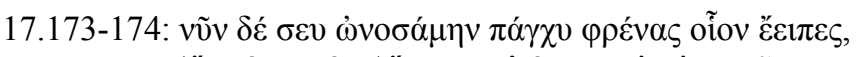

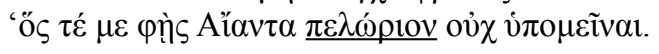

Mas agora desprezo completamente o teu juízo pelo que disseste: 
tu que afirmas não ter eu enfrentado na luta o enorme Ájax!

Ilíada, 17.360

Enunciador: narrador

Interlocutor interno: não há Referente: Ájax

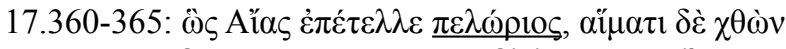

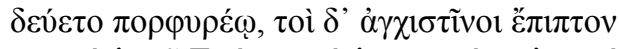

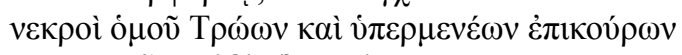

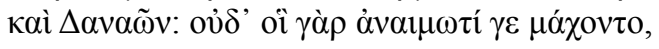

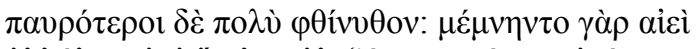

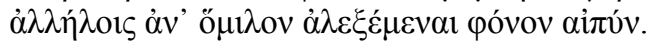

Enquanto o possante Ájax dava estas ordens, de sangue purpúreo se umedecia a terra; uns atrás dos outros tombavam os mortos, tanto do lado dos Troianos e seus orgulhosos aliados, como da parte dos Dânaos. Pois estes não lutaram sem derrame sangue, embora tombassem em menor número. Só pensavam em afastar dos outros no meio da turba o íngreme morticínio.

Ilíada, 18.83

Enunciador: Aquiles Interlocutor interno: Tétis Referente: armas de Aquiles, vestidas por Pátroclo

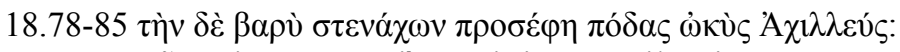

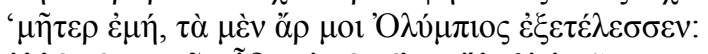

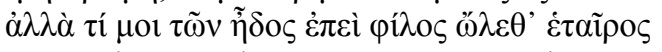

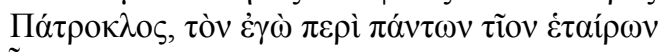

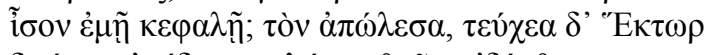

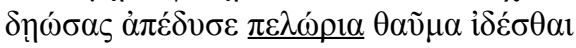

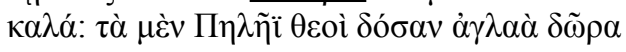

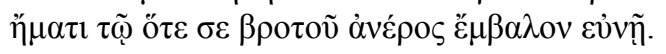

Suspirando profundamente lhe respondeu Aquiles de pés velozes: "Minha mã, na verdade essas coisas cumpriu para mim o Olímpio. Mas que satisfação tenho eu nisso, se morreu o companheiro amado, Pátroclo, a quem eu honrava acima de todos os outros, como a mim próprio? Perdi-o! E Heitor, que o matou, despiu-lhes as armas, grandes e belas (maravilha de se ver), presentes gloriosos que os deuses deram a Peleu no dia em que te empurraram para a cama de um homem mortal.

Ilíada, 21.527 Enunciador: narrador Interlocutor interno: não há Referente: Aquiles

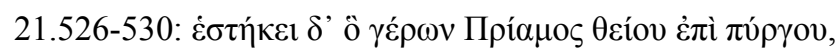

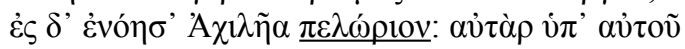

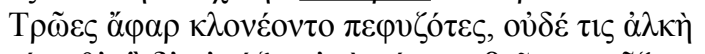

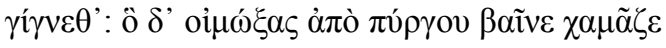
ỏ

Ora Príamo, o ancião, estava de pé em cima da muralha. Discerniu o portentoso Aquiles. Também viu que por ele os Troianos eram perseguidos em fuga e não havia auxílio possível. Com um gemido desceu ao chão da muralha e gritou aos ilustres guardiões ao longo do muro:

Ilíada, 22.92 Enunciador: narrador Interlocutor interno: não há Referente: Aquiles

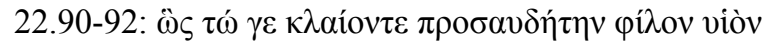

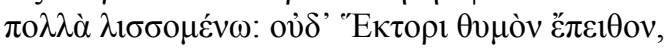




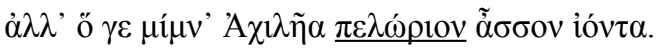

Assim ambos choraram, implorando seu filho amado com muitas súplicas. Mas não persuadiram o coração de Heitor, que aguardou até se aproximar o enorme Aquiles.

\title{
E.2 Odisseia
}

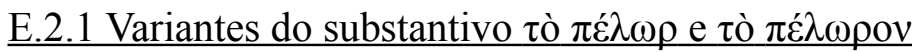

Odisseia, 9.257

\author{
Enunciador: Odisseu
}

Interlocutor interno: feácios

Referente: Polifemo

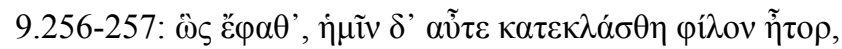

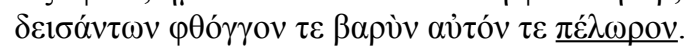

Assim falou, e nosso coração rachou-se, atemorizados com a voz pesada e o portento em si.

Odisseia, 9.428

$$
\begin{aligned}
& \text { Enunciador: Odisseu } \\
& \text { Referente: ciclope (Polifemo) }
\end{aligned}
$$

Interlocutor interno: feácios

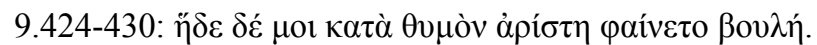

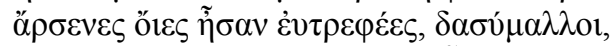

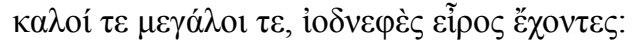

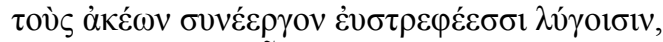

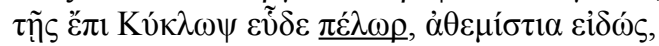

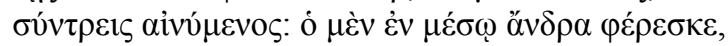

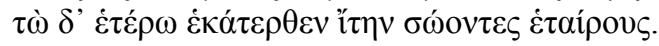

Este, em meu ânimo, mostrou-se o plano melhor: havia carneiros machos, bem-nutridos, de espesso velo, belos e grandes, carregados de roxa lã; eles, quieto, juntos eu prendia com vime bem-trançado, sobre o qual dormia o portento ciclope que ignorava regras e tomava três a três: o do meio levava um homem, os outros iam de cada lado, salvando os companheiros.

Odisseia, 10.168

$$
\begin{aligned}
& \text { Enunciador: Odisseu } \\
& \text { Interlocutor interno: feácios }
\end{aligned}
$$

Referente: grande cervo, enviado por um deus, provavelmente um homem transformado por Circe (cf. 10.156-159), caçado por Odisseu e levado para

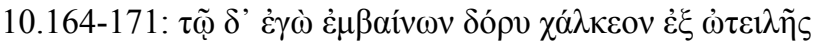

Com o pé sobre ele, a lança brônzea do ferimento arranquei. Após depô-la aí mesmo no chão, deixei-a de lado; apanhei galhos e vime, e com corda de uma braça, bem-trançada, nos dois lados tendo torcido, prendi os pés do assombroso prodígio e me dirigi à negra nau, levando-o nas costas apoiado na lança, pois impossível sobre o ombro, 
levar com um, braço: bastante grande era o animal.

Odisseia, 10.219

Enunciador: Odisseu

Interlocutor interno: feácios

Referente: animais encantados de Circe

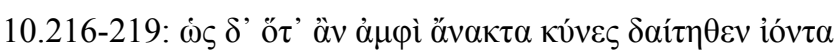

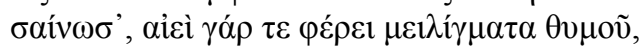

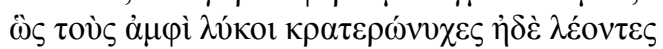

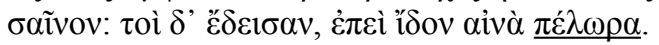

Tal cães que junto ao senhor que sai da mesa rabeiam: sempre lhes traz o que agrada o ânimo assim, em torno deles, lobos garra-potente e leões rabeavam. E eles temeram ao ver os terríveis portentos.

Odisseia, 11.634

Enunciador: Odisseu

Interlocutor interno: feácios

Referente: cabeça da Górgona

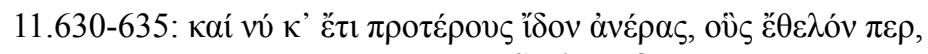

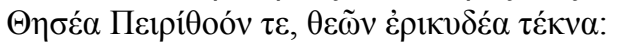

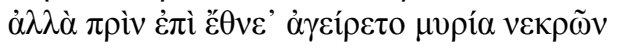

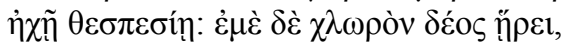

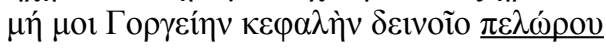

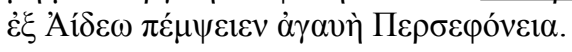

Teria ainda visto os varões de antanho que desejava,

Teseu e Perítoo, filhos bem majestosos de deuses;

mas grupos de mortos, milhares, perto juntaram-se

com ruído prodigioso; um medo amarelo atingiu-me,

que a cabeça de Gorgô, portento assombroso,

da casa de Hades me enviaria a ilustre Perséfone.

Odisseia, 12.87

Enunciador: Odisseu

Interlocutor interno: feácios

Referente: ciclope (Polifemo)

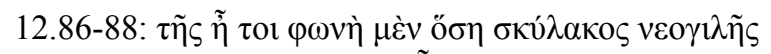

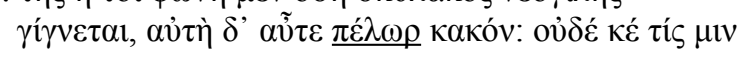

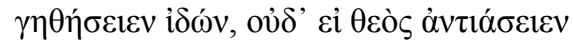

Sua voz [de Cila] ao ladrar de um filhote de cão equivale, mas ela mesma é portento vil; ninguém se jubilaria ao vê-la, nem mesmo um deus.

Odisseia, 15.161

Enunciador: narrador

Interlocutor interno: não há Referente: vaticínio

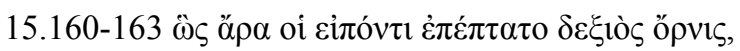

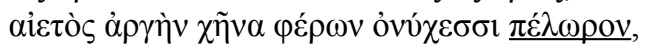

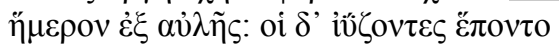

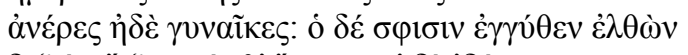

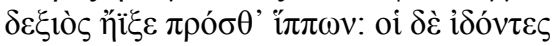

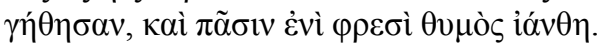

Depois de ter falado, em sua direção voou à direita uma águia com cintilante gansa doméstica do pátio nas garras, um prodígio: seguiam-na, berrando, varões e mulheres. Ela dele se aproximou, $\mathrm{e}$, à direita, adejou diante dos cavalos. Aqueles, vendo-a alegraram-se, e no peito de todos o ânimo esquentou. 


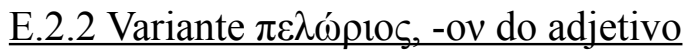

(Mentor)

Odisseia, 3.290

Enunciador: Nestor

Interlocutor interno: Telêmaco e Atenas

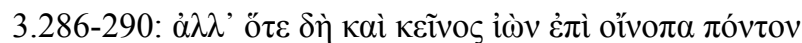

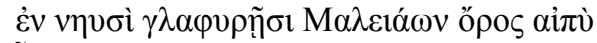

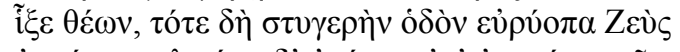

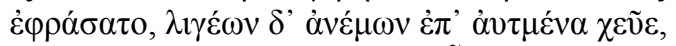

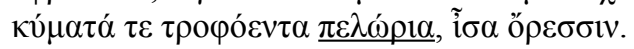

Mas quando também ele, célere, indo sobre o mar vinoso em côncavas naus, o escarpado monte Maleia alcançou, então rota hedionda Zeus ampla-visão planejou e verteu sopro de ventos sibilantes e ondas inchadas, portentosas, feito morros.

Odisseia, 9.187 Enunciador: Odisseu Interlocutor interno: feácios Referente: Polifemo

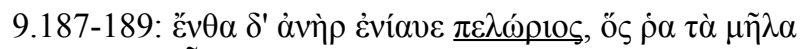

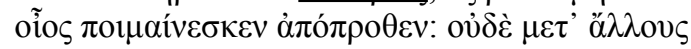

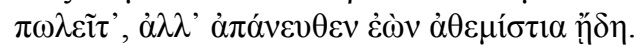

Lá pernoitava um varão, portentoso, ele que o rebanho, sozinho, apascentava, afastado: aos outros não visitava, mas, longe vivendo, normas ignorava.

Odisseia, 9.190 Enunciador: Odisseu
Referente: Polifemo Interlocutor interno: feácios

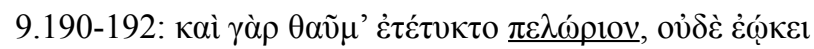

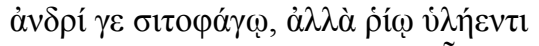

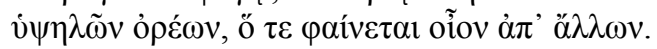

De fato, era um assombro portentoso, não parecia um varão come-pão, mas um pico matoso dos altos montes, que surge só, longe dos outros.

Odisseia, 11.572

$$
\begin{aligned}
& \text { Enunciador: Odisseu } \\
& \text { Referente: Órion }
\end{aligned}
$$

Interlocutor interno: feácios

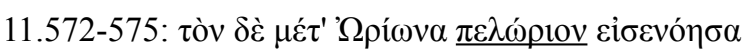

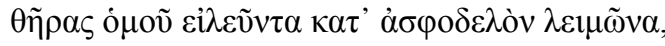

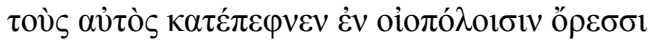

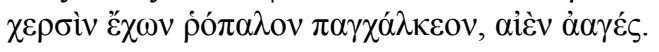

Depois dele, percebi o portentoso Órion agrupando feras pelo prado de asfódelos, as que ele mesmo matou em montanhas solitárias, com estaca toda de brônzea nas mãos, inquebrável.

Odisseia, 11.594

$$
\begin{aligned}
& \text { Enunciador: Odisseu Interlocutor interno: feácios } \\
& \text { Referente: pedra carregada por Sísifo }
\end{aligned}
$$

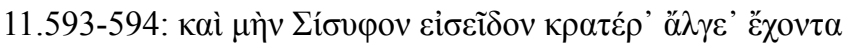

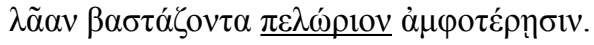

E, sim, vi Sísifo com seu duro sofrimento carregando pedra portentosa com as duas mãos. 


\title{
E.3 Hino Homérico a Apolo
}

\author{
h.Ap., 374 \\ Enunciador: narrador \\ Interlocutor interno: não há \\ Referente: serpente morta por Apolo

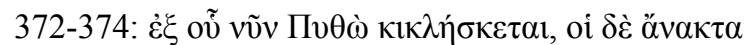

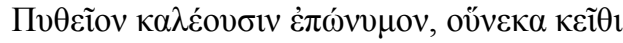 \\ $\alpha$ \\ A partir disso, o lugar é chamado Pitô, e eles chamam \\ o senhor pelo sobrenome Pítio, porque lá mesmo \\ a força aguda de Hélio fez o monstro apodrecer. \\ h.Ap., 401 \\ Enunciador: narrador \\ Interlocutor interno: não há \\ Referente: golfinho no qual Apolo se transforma

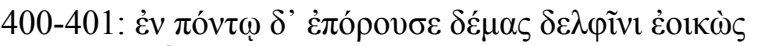

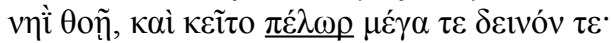 \\ No alto-mar, no corpo semelhante a um delfim, Apolo se lançou

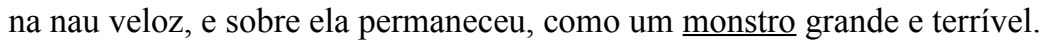 \\ h.Ap., 416 \\ Enunciador: narrador \\ Interlocutor interno: não há \\ Referente: golfinho no qual Apolo se transforma

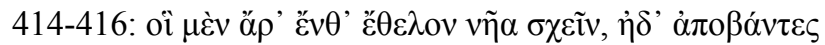

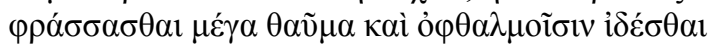

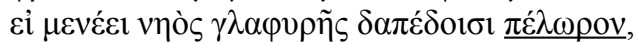

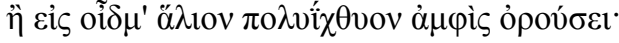 \\ Ali, eles quiseram deter a nau, para desembarcar \\ observar o grande prodígio, e ver, com os próprios olhos, \\ se o monstro permaneceria no piso da cava nau \\ ou se lançar-se-ia sobre as ondas do mar piscoso.
}

\section{E.4 Hino Homérico a Hermes}

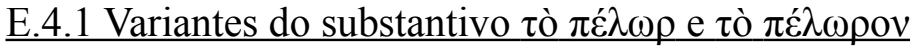

h.Merc., 225 Enunciador: Apolo

Referente: pegadas de Centauro

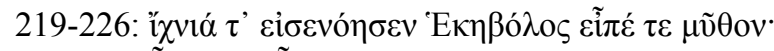

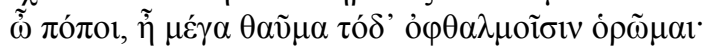

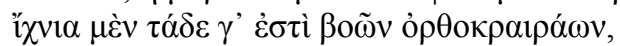

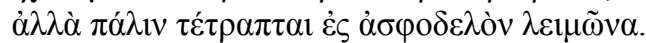

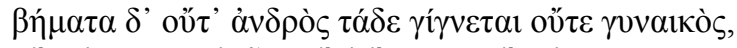

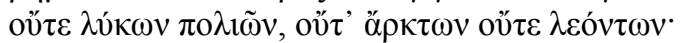

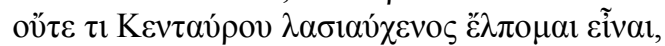

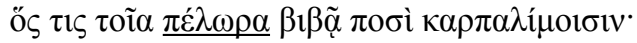

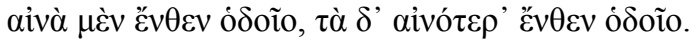

Nas pegadas atentou o Arqueiro e disse estas palavras: "Deuses! Grande assombro este que vejo com meus olhos! Estas pegadas são mesmo de bois de chifres retos, mas estão invertidas, de volta ao prado de asfódelos! Mas estes passos não são nem de homem, nem de mulher, nem de lobos cinzentos, nem de ursos, nem de leões! 
Nem penso que sejam de um Centauro de peludo colo, que dá tão prodigiosas passadas com pés ligeiros; são medonhas, neste lado do caminho, e mais medonhas nesse outro".

h.Merc., 349

Enunciador: Apolo Interlocutor interno: Zeus

Referente: pegadas deixadas por Hermes

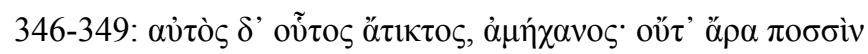

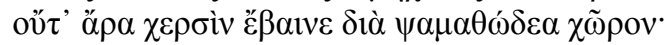

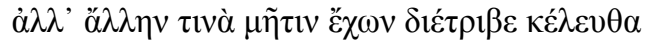

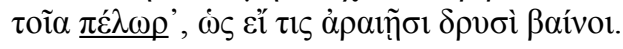

Mas esse aí em pessoa era intocável, surpreendente! Nem com pés nem sequer com mãos ele caminhava pelo terreno arenoso; antes, usando de algum outro artifício, deixava marcas no percurso tamanho prodígio! - como se alguém que calçasse ramos de carvalho.

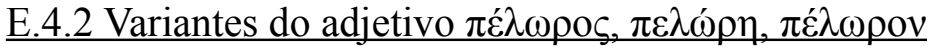

h.Merc., 342

Enunciador: Apolo

Referente: pegadas deixadas por Hermes

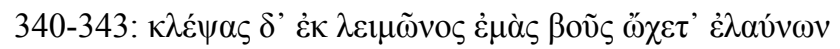

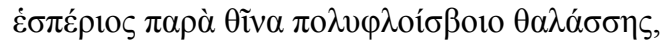

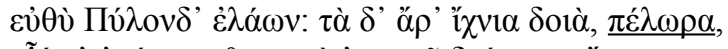

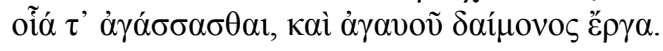

Roubou do prado minhas vacas e foi-se, ao entardecer, tangendo-as ao longo da praia do mar fragoroso; tocava reto para Pilos. Eram pegadas duplas, medonhas, capazes de espantar, obras mesmo de admirável deidade.

\section{E.5 Teogonia}

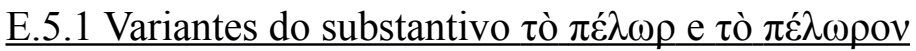

Teogonia, 295

Enunciador: narrador

Interlocutor interno: não há Referente: Équidna

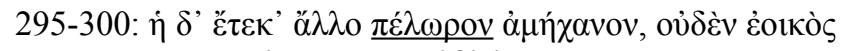

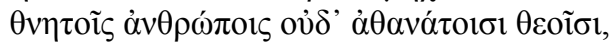

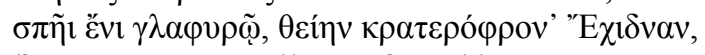

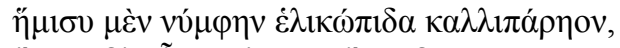

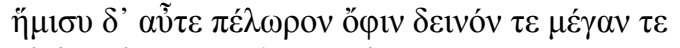

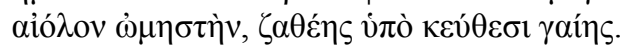

Ela gerou outro ser portentoso, impossível, nem parecido com homens mortais nem com deuses imortais, em cava gruta, a divina Équidna juízo-forte, metade moça olhar luzente, bela-face metade serpente portentosa, terrível e grande, dardejante come-cru, sob os confins da numinosa terra.

Teogonia, 845

Enunciador: narrador Interlocutor interno: não há Referente: Tifeu

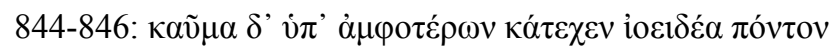

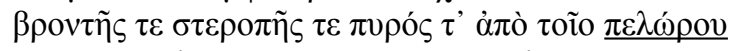

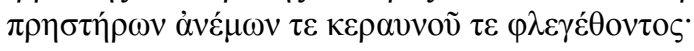


Queimada abaixo dos dois tomou conta do mar violeta vinda do trovão, do raio e do fogo desse portento, dos ventos de ígneos tornados e do relâmpago ardente.

Teogonia, 856

$$
\begin{aligned}
& \text { Enunciador: narrador } \\
& \text { Referente: Tifeu }
\end{aligned}
$$

Interlocutor interno: não há

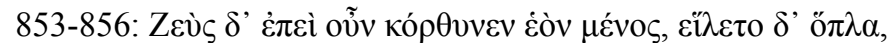

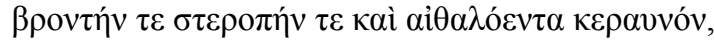

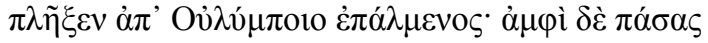

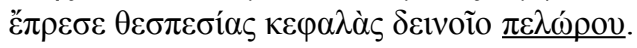

Zeus, após rematar seu ímpeto, pegou as armas, trovão, raio e o chamejante relâmpago, e golpeou-o arremetendo do Olimpo; em volta, todas as cabeças prodigiosas do terrível portento queimou.

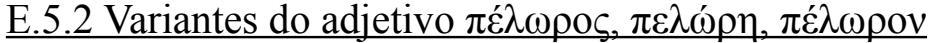

Teogonia, 159

Enunciador: narrador

Interlocutor interno: não há Referente: Terra

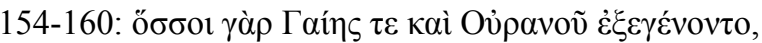

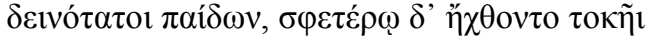

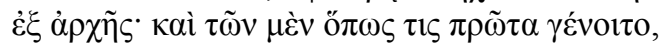

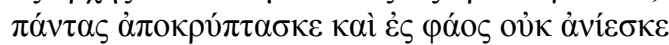

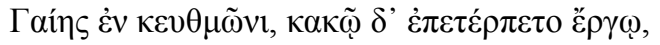

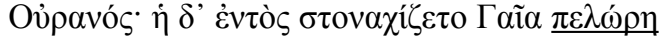

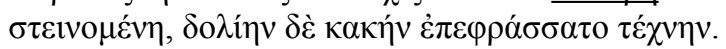

Pois tantos quantos de Terra e Céu nasceram, os mais feros dos filhos, por seu pai foram odiados desde o princípio: assim que nascesse um deles, a todos ocultava, não os deixava para a luz subir, no recesso de Terra, e com o feito vil regozijava-se Céu. Ela dentro gemia, a portentosa Terra, constrita, e planejou ardiloso, nocivo estratagema.

Teogonia, 173 Enunciador: narrador Interlocutor interno: não há Referente: Terra

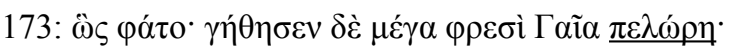

Assim falou; muito alegrou-se no juízo a portentosa Terra.

Teogonia, 299 Enunciador: narrador
Referente: Équidna Interlocutor interno: não há

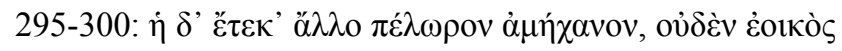

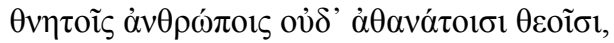

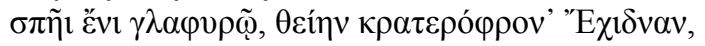

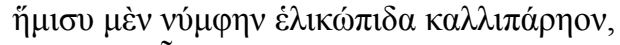

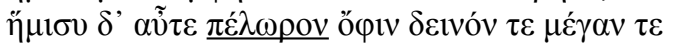

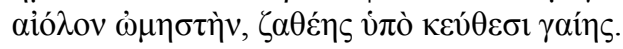

Ela gerou outro ser portentoso, impossível, nem parecido com homens mortais nem com deuses imortais, em cava gruta, a divina Équidna juízo-forte, metade moça olhar luzente, bela-face 
metade serpente portentosa, terrível e grande, dardejante come-cru, sob os confins da numinosa terra.

Teogonia, 479

Enunciador: narrador

Interlocutor interno: não há Referente: Terra

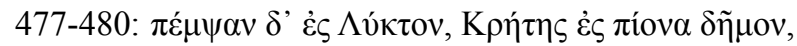

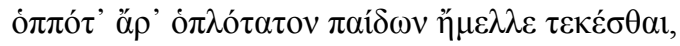

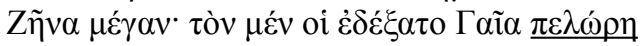

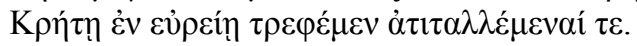

Enviaram-na a Lictos, à fértil região de Creta, quando iria parir o mais novo dos filhos, o grande Zeus. Recebeu-o a portentosa Terra na ampla Creta para criar e alimentar.

Teogonia, 505 Enunciador: narrador Interlocutor interno: não há Referente: Terra

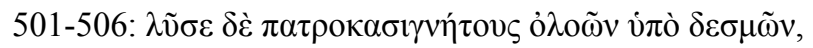

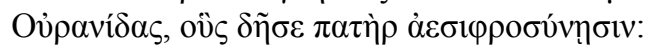

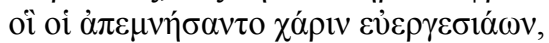

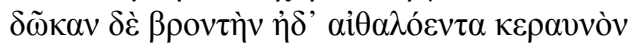

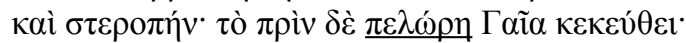

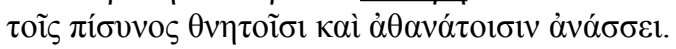

E soltou os irmãos do pai de seus laços ruinosos, filhos de Céu, que prendera o pai por conta de cego juízo: eles [os Ciclopes] pela boa ação retribuíram com um favor e deram-lhe trovão, raio chamejante e relâmpago. Antes portentosa Terra os mantivera ocultos; com o apoio deles, rege sobre mortais e imortais.

Teogonia, 731 Enunciador: narrador Interlocutor interno: não há Referente: Terra

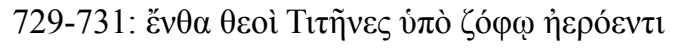

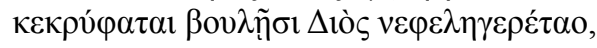

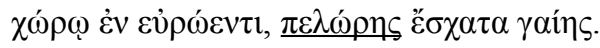

Para lá os deuses Titãs, sob brumosa escuridão, foram removidos pelos planos de Zeus junta-nuvem, em região bolorenta, extremos da terra portentosa.

Teogonia, 821

$$
\text { Enunciador: narrador }
$$
Referente: Terra

Interlocutor interno: não há

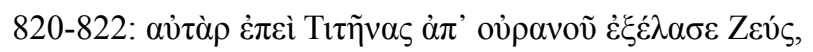

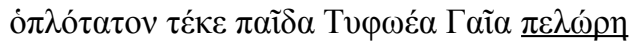

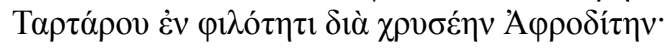

Mas depois que Zeus expulsou os Titãs do céu, pariu Tifeu, o filho mais novo, a portentosa Terra em amor por Tártaro através da dourada Afrodite:

Teogonia, 858 Enunciador: narrador
Referente: Terra Interlocutor interno: não há

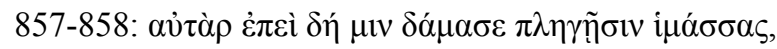

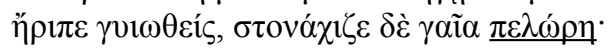


Após subjugá-lo, tendo-o com golpes fustigado, o outro tombou, aleijado, e gemeu a portentosa Terra.

Teogonia, 861

Enunciador: narrador

Interlocutor interno: não há

Referente: Terra

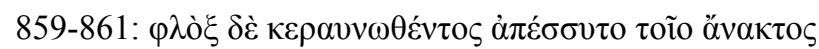

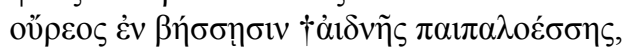

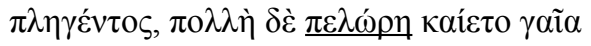

E a chama fugiu desse senhor, relampejado, nos vales da montanha escura, escarpada, ao ser atingido, e a valer queimou a terra portentosa.

\section{E.5.3 Variante $\pi \varepsilon \lambda \omega ́ \rho 10 \varsigma$, -ov do adjetivo}

Teogonia, 179

Enunciador: narrador

Interlocutor interno: não há

Referente: foice

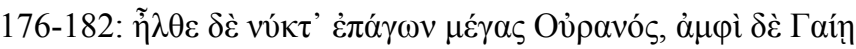

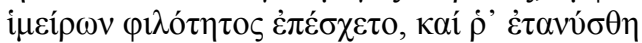

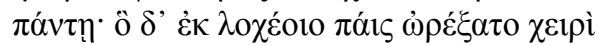

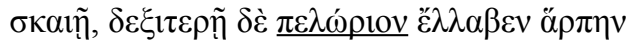

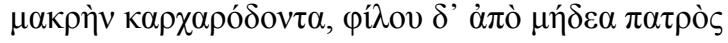

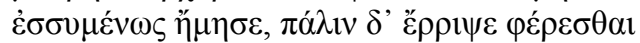

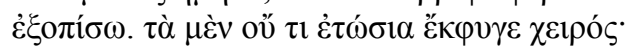

Veio, trazendo a noite, o grande Céu, e em torno de Terra estendeu-se, desejoso de amor, e estirou-se em toda direção. O outro, o filho, da tocaia a mão esticou, a esquerda, e com a direita pegou a foice portentosa, grande, serridêntea, os genitais do caro pai com avidez ceifou e lançou para trás, que fossem embora. Mas, ao escapar da mão, não ficaram sem efeito:

\section{E.6 Catálogo das mulheres}

frag. 150, v. 11

Enunciador: possivelmente o narrador Interlocutor interno: possivelmente não há Referente: Terra

]v]] $\tau \varepsilon ́ \kappa \varepsilon ~ \Gamma \alpha \tilde{\alpha} \alpha \varepsilon \lambda \omega ́[\rho-$

\section{E.7 Escudo de Héracles}

Sc., v. 223
Enunciador: narrador
Interlocutor interno: não há
Referente: cabeça da Górgona no escudo de Perseu, representado no escudo de Héracles

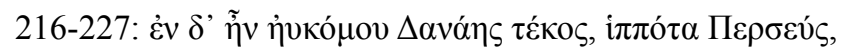

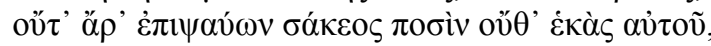

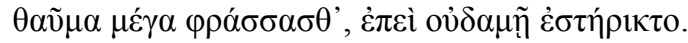

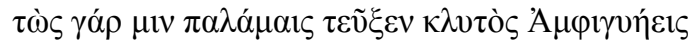

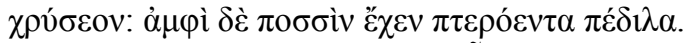

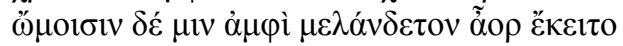

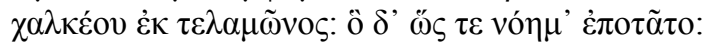




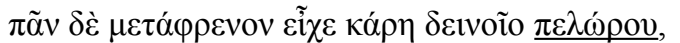

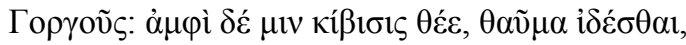

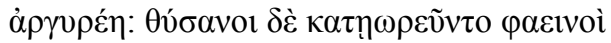

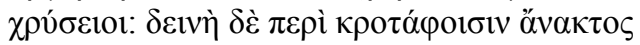

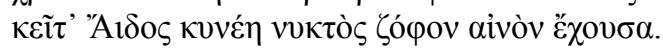

Aí o filho de Dânae pulcrícoma cavaleiro Perseu, sem tocar o escudo com os pés, nem longe dele, grande prodígio de ver, que em nada se apoiava: assim o ínclito Ambidestro o fez com as mãos, áureo, tinha nos pés aladas sandálias, nos ombros espada com bainha negra pendia de brônzeo cinturão: pairava como pensamento; cobria-lhe as costas o crânio de terrível monstro Górgona, envolto por bolsa, prodígio de ver, argêntea e as franjas pediam rutilantes, áureas; terrível cingia as têmporas do rei o elmo de Hades com terríveis trevas noturnas. 
APÊNDICE F

\section{EXCERTOS DA TEOGONIA}

\section{v. 126-160 (filhos de Céu e Terra: Titãs, Ciclopes e Centímanos)}

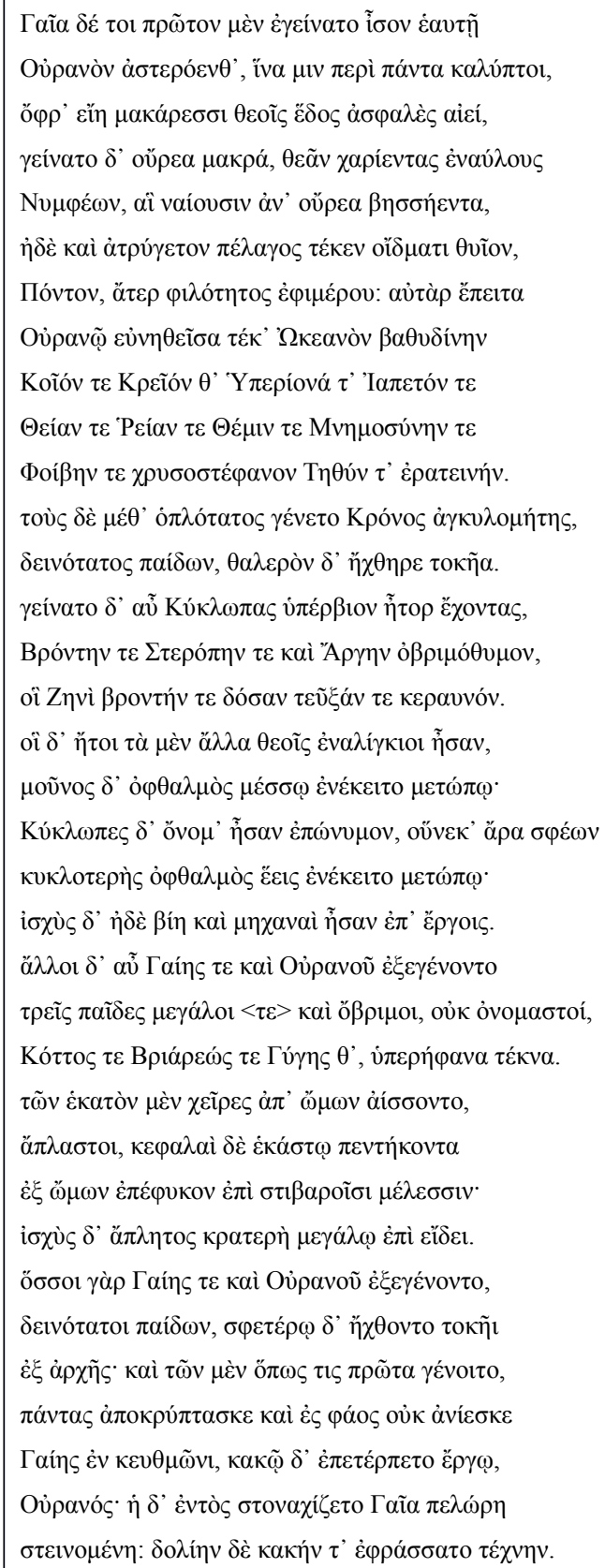

Terra primeiro gerou, igual a ela, o estrelado Céu, a fim de cobri-la por inteiro para ser, dos deuses venturosos, assento sempre estável. Gerou as enormes Montanhas, refúgios graciosos de deusas, as Ninfas, que habitam as montanhas matosas.

Pariu também o ruidoso pélago, furioso nas ondas, Mar, sem amor desejante; e então deitou-se com Céu e pariu Oceano funda-corrente, Coio, Creio, Hipérion, Jápeto, Teia, Reia, Norma, Memória,

Febe coroa-dourada e a atraente Tetís.

Depois deles, o mais novo nasceu, Crono curva-astúcia, o mais fero dos filhos; e odiou o viçoso pai. Então gerou os Ciclopes, que têm brutal coração, Trovão, Relâmpago e Clarão ânimo-ponderoso, eles que o trovão deram a Zeus e fabricaram o raio. Quanto a eles, de resto assemelhavam-se aos deuses, mas um só olho no meio da fronte jazia; Ciclopes era seu nome epônimo, porque deles circular o olho, um só, que na fronte jazia; energia, força e engenho havia em seus feitos. E outros então de Terra e Céu nasceram, três filhos grandes e ponderosos, inomináveis, Coto, Briareu e Giges, rebentos insolentes.

Deles, cem braços dos ombros lançavam-se, inabordáveis, e cabeças, em cada um, cinquenta dos ombros nasceram sobre os membros robustos e a energia imensa era brutal na grande figura. Pois tantos quantos de Terra e Céu nasceram, os mais feros dos filhos, por seu pai foram odiados desde o princípio: assim que nascesse um deles, a todos ocultava, não os deixava para a luz subir, no recesso de Terra, e com o feito vil regozijava-se Céu. Ela dentro gemia, a portentosa Terra, constrita, e planejou ardiloso, nocivo estratagema. 


\section{v. 270-336 (Progênie de Fórcis e Cetó)}

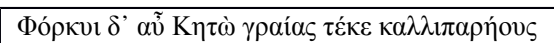

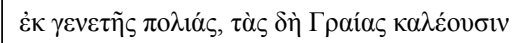

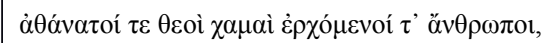

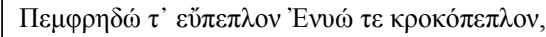

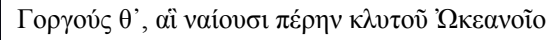

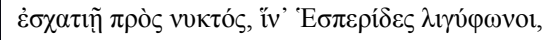

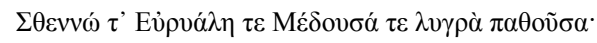

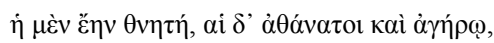

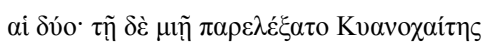

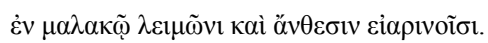

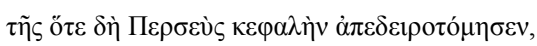

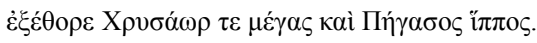

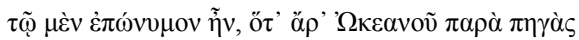

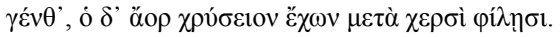

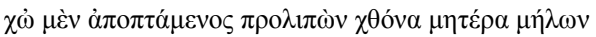

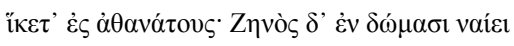

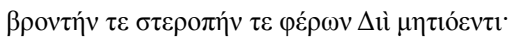

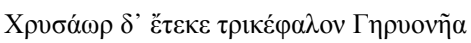

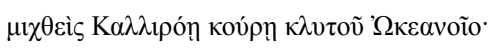

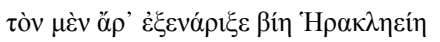

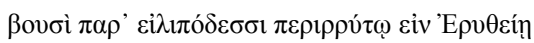

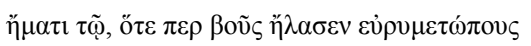

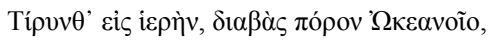

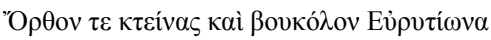

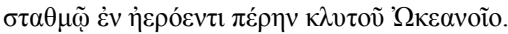

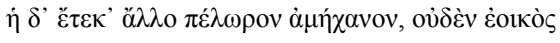

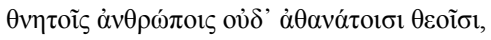

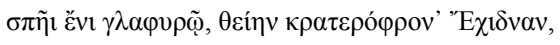

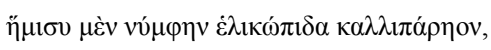

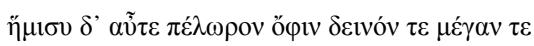

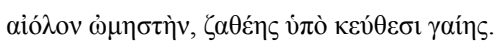

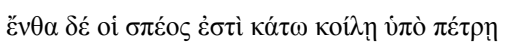

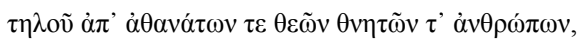

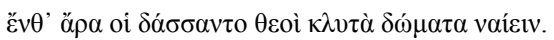

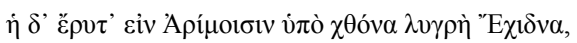

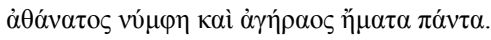

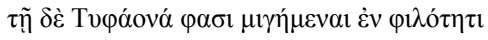

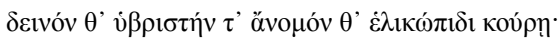

$\dot{\eta} \delta$ '

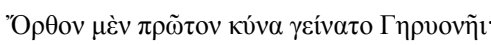

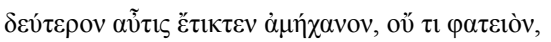

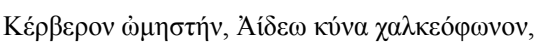

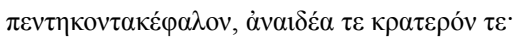

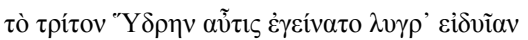

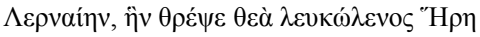

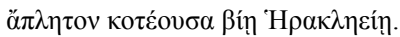

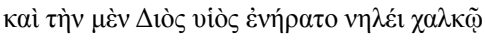

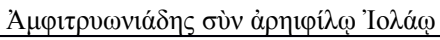

270 E Cetó pariu para Fórcis Velhas bela-face,

grisalhas de nascença, que chamam Velhas

os deuses imortais e homens que andam na terra,

Penfredó belo-peplo, Enió peplo-açafrão

e as Górgonas, que habitam pra lá do glorioso Oceano

no limite, rumo à noite, onde Hespérides clara-voz

Estenó, Euríale e Medusa, que sofreu o funesto:

ela era mortal, as outras, imortais e sem velhice,

as duas; e só junto a ela deitou-se Coma-cobalto

numa prado macio com flores primaveris.

Dela, quando Perseu a cabeça cortou do pescoço,

p'ra fora pularam o grande Espadouro e o cavalo Pégaso.

Tinha esse epônimo pois pegado às fontes de Oceano

nasceu, e aquele, com dourada espada nas caras mãos.

Pégaso alçou voo, após deixar a terra, mãe de ovelhas,

e dirigiu-se aos imortais; a casa de Zeus habita

e leva trovão e raio ao astucioso Zeus.

E Espadouro gerou o três-cabeças Gerioneu,

unido a Bonflux, filha do famoso Oceano.

E eis que a esse matou a força heráclida,

junto a bois passo-arrastado na oceânica Eriteia

naquele dia em que tangeu os bois fronte-larga

até a sacra Tirinto, após cruzar o estreito de Oceano

e ter matado Orto e o pastor Euritíon

na quinta brumosa pra lá do famoso Oceano.

Ela gerou outro ser portentoso, impossível, nem parecido com homens mortais nem com deuses imortais, em cava gruta, a divina Équidna juízo-forte, metade moça olhar-luzente, bela-face metade serpente portentosa, terrível e grande, dardejante come-cru, sob os confins da numinosa terra. Lá fica sua caverna, para baixo, sob cava pedra, longe de deuses imortais e homens mortais, onde os deuses lhe atribuíram casa gloriosa pr'a morar. E ela fica nos Arimos sob a terra, a funesta Équidna, moça imortal e sem velhice para todos os dias.

Com ela, dizem, Tifeu uniu-se em amor, o violento, terrível e ímpio com a moça olhar-luzente: ela, após engravidar, gerou rebentos juízo-forte. Orto primeiro gerou um cão para Gerioneu; depois, pariu o impossível, de todo impronunciável, Cérbero come-cru, o cão bronzissonante de Hades, cinquenta-cabeças, insolente e brutal; como terceiro, gerou Hidra, versada no funesto, de Lerna, a quem nutriu a divina Hera alvo-braço, com imenso rancor da força heráclida.

A ela matou o filho de Zeus com bronze impiedoso, o filho de Anfitríon com Iolau caro-a-Ares - 


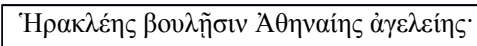

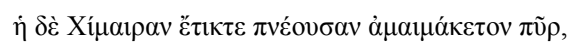

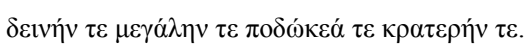

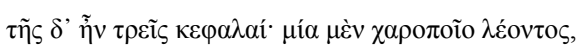

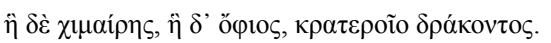

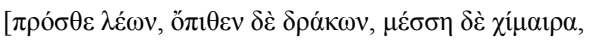

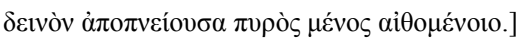

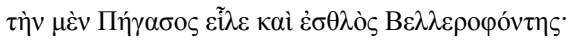

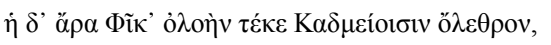

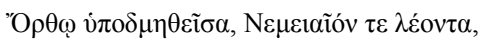

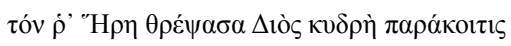

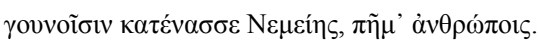

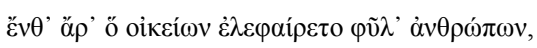

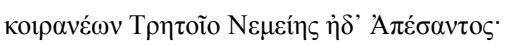

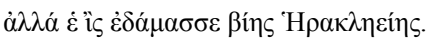

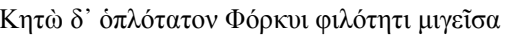

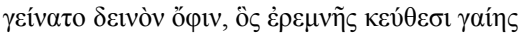

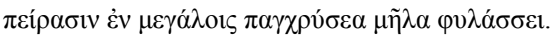

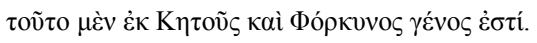

Héracles - pelos planos de Atena guia-tropa.

E ela pariu Quimera, que fogo indômito soprava, terrível, grande, pé-ligeiro, brutal.

Tinha três cabeças: uma, de leão olhar-cobiçoso,

outra, de cabra, a terceira, de cobra, brutal serpente.

Na frente, leão, atrás, serpente, no meio, cabra, soprando o fero ímpeto do fogo chamejante.

A ela pegou Pégaso e o valoroso Belerofonte.

E ela pariu a ruinosa Esfinge, ruína dos cadmeus, após ser subjugada por Orto, e o leão de Nemeia, do qual Hera cuidou, a majestosa consorte de Zeus, e o alocou nos morros de Nemeia, desgraça dos homens.

E ele, lá habitando, encurralava a raça de homens,

dominando Tretos, na Nemeia, e Apesas;

mas a ele subjugou o vigor da força heráclida.

Cetó, unida em amor a Fórcis, como o mais jovem gerou terrível serpente, que nos confins da terra lúgubre, nos grandes limites, guarda um rebanho todo de ouro.

E essa é a linhagem de Cetó e Fórcis.

\section{v. 501-506 (libertação dos Ciclopes)}

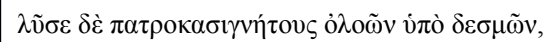

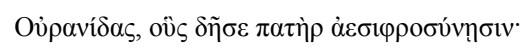

oî oi $\dot{\alpha} \pi \varepsilon \mu v \eta ́ \sigma \alpha \nu \tau o ~ \chi \alpha ́ \rho ı v ~ \varepsilon v ̉ \varepsilon \rho \gamma \varepsilon \sigma i \alpha ́ \alpha v$,

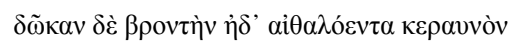

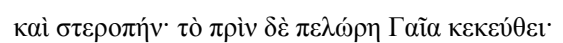

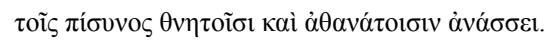

E soltou os irmãos do pai de seus laços ruinosos, filhos de Céu, que prendera o pai por conta de cego juízo: eles pela boa ação retribuíram com um favor, e deram-lhe trovão, raio chamejante e relâmpago. Antes, portentosa Terra os mantivera ocultos; com o apoio deles, rege sobre mortais e imortais.

\section{v. 617-628 (libertação dos Centímanos)}

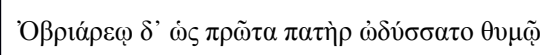

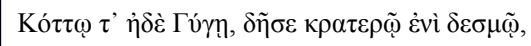

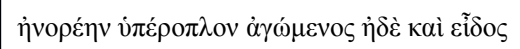

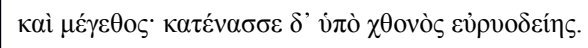

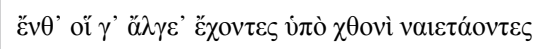

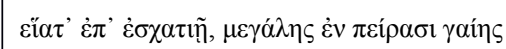

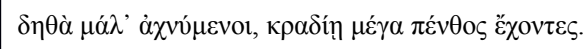

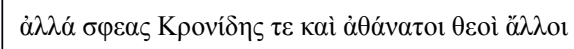

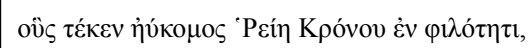

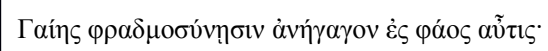

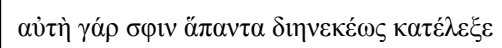

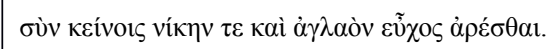

Assim que o pai teve ódio no ânimo por Obriareu,

Coto e Giges, prendeu-os em laço forte,

irritado com a virilidade insolente, a aparência

e a altura; e alocou-os embaixo da terra largas-rotas.

Lá eles, que sofriam sob a terra habitando,

estavam sentados na ponta, nos limites da grande terra,

há muito angustiados com grande pesar no coração.

Mas a eles o Cronida e outros deuses imortais,

os que Reia bela-coma pariu em amor por Crono,

graças ao conselho de Terra, levaram de volta à luz:

ela tudo lhes contara, do início ao fim,

como com aqueles vitória e triunfo radiante granjear. 


\section{v. 639-735 (Titanomaquia) e 815-819}

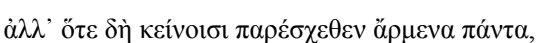

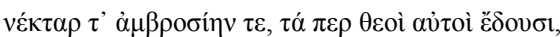

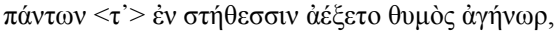

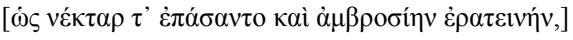

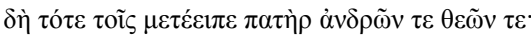

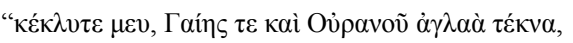

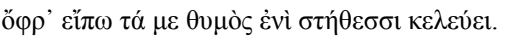

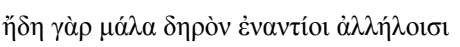

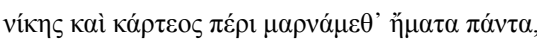

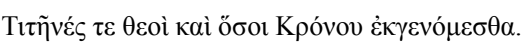

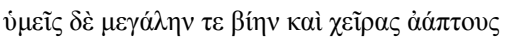

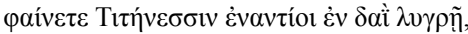

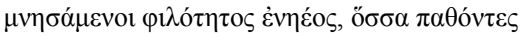

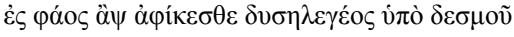

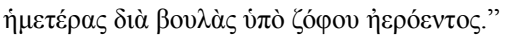

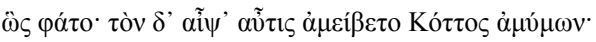

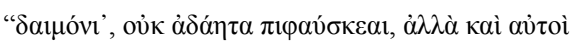

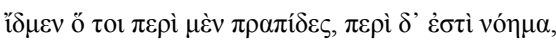

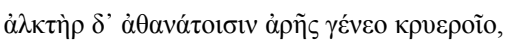

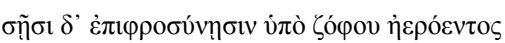

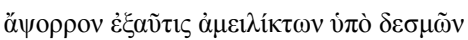

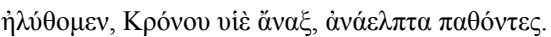

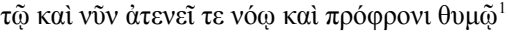

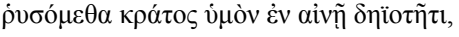

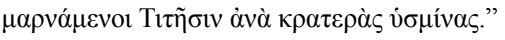

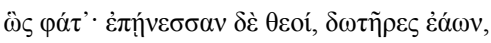

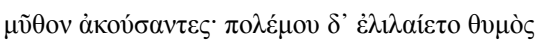

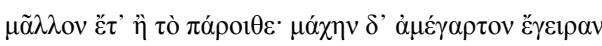

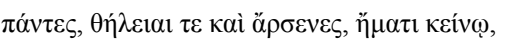

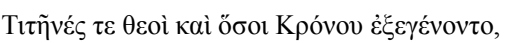

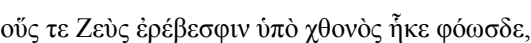

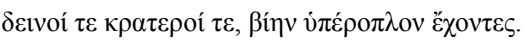

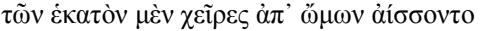

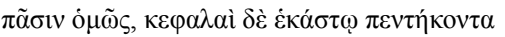

غ̇ं

oî

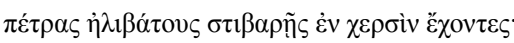

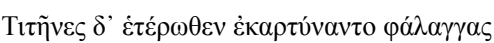

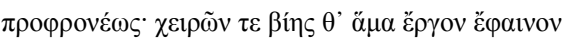

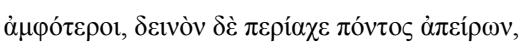

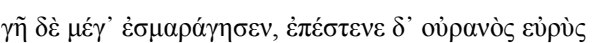

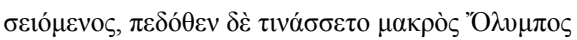

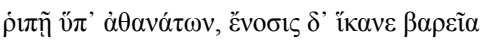

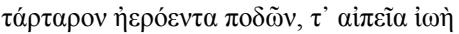

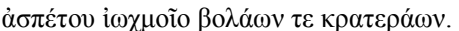

Mas quando, vê, ofertou-lhes tudo que é adequado,

640

645 néctar e ambrosia, o que comem os próprios deuses,

e no íntimo de todos avolumou-se o ânimo arrogantes quando comeram o néctar e a encantadora ambrosia, nisso então entre eles falou o pai de deuses e varões:

"Ouvi-me, radiantes filhos de Terra e Céu,

para eu dizer o que o ânimo no peito me ordena.

Já muito tempo uns contra os outros

pela vitória e poder combatemos todo dia,

os deuses Titãs e tantos quantos de Crono nasceram.

Vós grande força e mãos intocáveis

mostrai em oposição aos Titãs no prélio funesto

ao se lembrar da amizade afável, quanto sofreram

e de novo a luz alcançaram, soltos do laço tenebroso

graças a nossos desígnios, vindos das trevas brumosas".

Assim falou; e logo respondeu-lhe o impecável Coto:

“Honorável, não anuncias algo ignoto, mas também nós

sabemos que sobressais no discernimento e na ideia

e te tornaste protetor dos imortais contra dano gelado,

e com tua sagacidade, vindos das terras brumosas,

de volta de novo, dos laços inamáveis,

viemos, senhor filho de Crono, após sofrer o inesperado.

Assim também agora com espírito tenso e juízo solícito protegeremos vosso poder na refrega terrível,

combatendo os Titãs nas batalhas brutais".

Assim falou; e louvaram os deuses oferentes de bens

o discurso após o ouvir. E à peleja almejou o ânimo

mais ainda que antes; e à luta não invejável acordaram

todos, fêmeas e machos, naquele dia,

Titãs e deuses, tantos quantos de Crono nasceram,

e o que Zeus do Érebo, sob a terra, à luz enviou,

terríveis e brutais, com força insolente.

Deles, cem braços dos ombros lançavam-se,

igual para todos, e cabeças, em cada um, cinquenta,

dos ombros nasceram sobre os membros robustos.

Contra os Titãs então se postaram no prélio funesto

com rochas alcantiladas nas mãos robustas;

os Titãs, do outro lado, revigoraram suas falanges

com afã: ação de braços e de força, juntos, mostraram

ambos, e o mar sem fim em volta rugia, terrível,

e a terra, alto ribombava, e gemia o amplo céu

sacudido, e tremia do fundo o enorme Olimpo

com o arremesso dos imortais, e tremor atingia, pesado,

dos pés, o Tártaro brumoso, bem como zunido agudo

do fragor indizível e dos arremessos brutais.

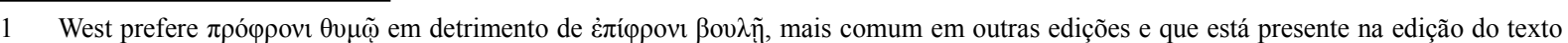
utilizado em Werner (2013a). 


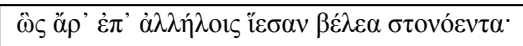

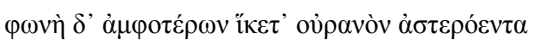

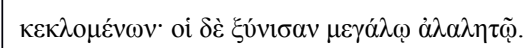

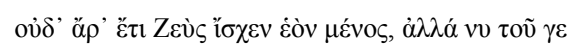

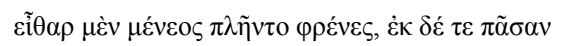

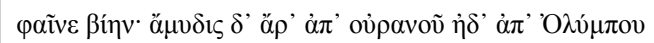

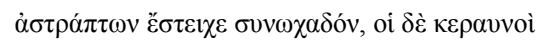

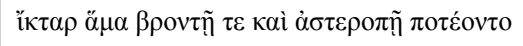

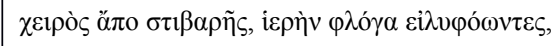

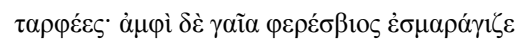

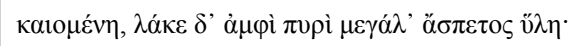

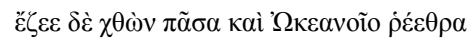

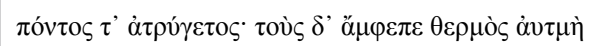

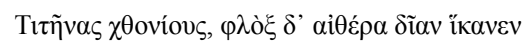

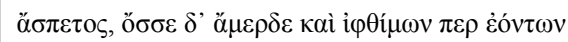

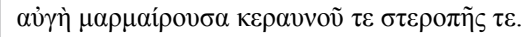

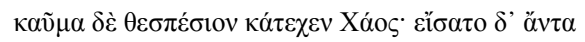

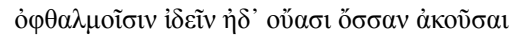

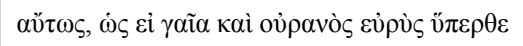

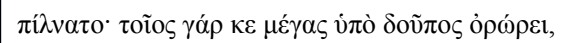

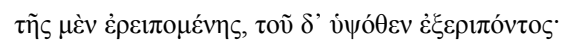

$\tau$

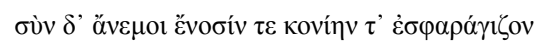

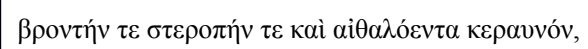

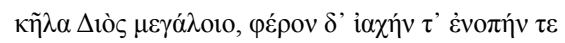

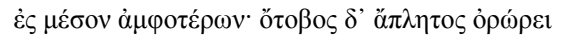

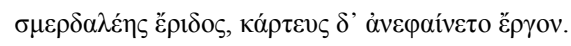

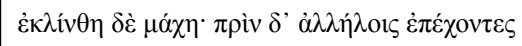

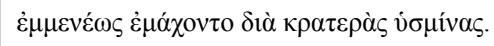

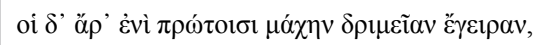

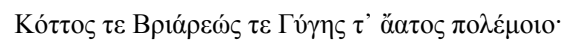

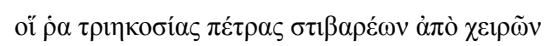

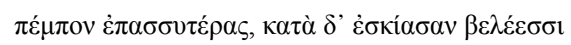

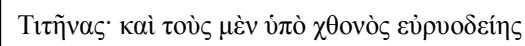

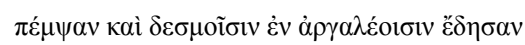

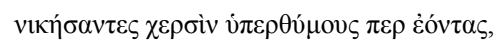

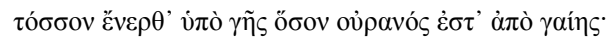

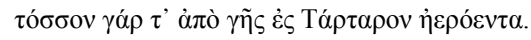

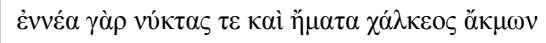

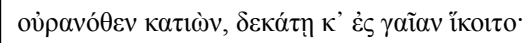

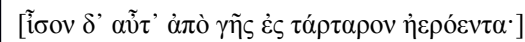

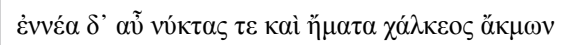

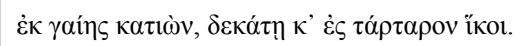

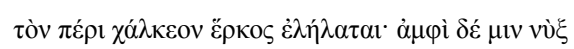

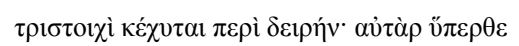

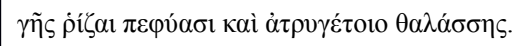

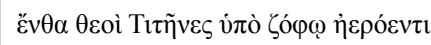

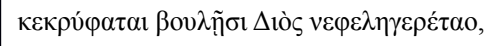

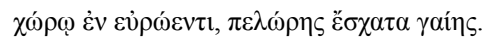

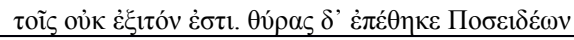

Assim uns nos outros lançavam projéteis desoladores;

alcançava o céu estrelado o som de ambas as partes,

das exortações; e se chocaram com grande algaraviada.

E Zeus não mais conteve seu ímpeto, mas dele agora

de pronto o peito encheu-se de ímpeto, e toda

a força mostrou. Ao mesmo tempo, do céu e do Olimpo

690

relampejando, progrediu sem parar, e os raios

em profusão, com trovão e relâmpago, voavam

de sua mão robusta, revolvendo a sagrada chama,

em massa. Em volta, ribombava a terra traz-víveres,

queimando, e, no entorno, alto chiava o mato incontável.

Todo o solo fervia, as correntes de Oceano

e o mar ruidoso. A eles rodeava quente bafo,

aos terrestres Titãs, e chama alcançou a bruma divina,

indizível, e aos olhos deles, embora altivos, cegou

a luz cintilante do raio e do relâmpago.

700

Prodigiosa queimada ocupou o abismo; parecia, em face

olhando-se com olhos e com ouvidos ouvindo-se o rumor,

assim como quando Terra eu largo Céu acima

se reuniram; tal baque, enorme, de baixo veio,

ela pressionada e ele, do alto, pressionando -

tamanho baque veio da briga de deuses se atracando.

Junto, ventos engrossavam o tremor, a poeira,

trovão, raio, relâmpago em fogo,

setas do grande Zeus, e levavam grito e assuada

ao meio de ambas as partes. Veio imenso clangor

da briga aterrorizante, e o feito do poder se mostrou.

E a batalha se inclinou; antes com avanços recíprocos,

pelejavam sem cessar em batalhas audazes.

Eles, entre os da frente, acordaram peleja lancinante,

Coto, Briareu e Giges, insaciável de guerra;

esses trezentas pedras de suas mãos robustas

enviavam em sucessão, e com os projéteis sombrearam

os Titãs; e a eles para baixo da terra largas-rotas

enviaram e com laços aflitivos prenderam,

após vencê-los, no braço, embora autoconfiantes,

720

tão longe abaixo da Terra quanto o céu está da terra.

Tal a distância da Terra até o Tártaro brumoso.

Pois por nove noites e dias bigorna de bronze,

caindo do céu, no décimo a terra alcançaria

$723 \mathrm{a}$

(por sua vez, igual da terra até o Tártaro brumoso.)

De novo, por nove noites e dias bigorna de bronze,

da terra caindo, no décimo o Tártaro alcançaria. 725

Em volta dele, corre muro de bronze; no entorno, noite

camada-tripla derrama-se em volta da garganta; acima,

crescem as raízes da terra e do mar ruidoso.

Para lá os deuses Titãs, sob brumosa escuridão,

730

foram removidos pelos planos de Zeus junta-nuvem,

em região bolorenta, extremos da terra portentosa.

É-lhes impossível sair, Poseidon fixou portões 


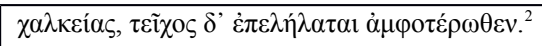

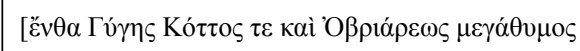

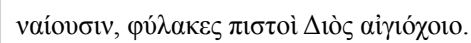

$[\ldots]$

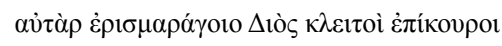

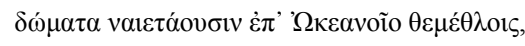

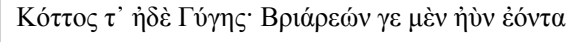

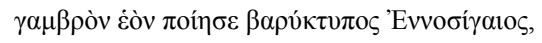

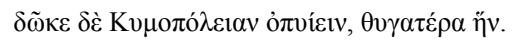

de bronze, e muralha corre para os dois ladosLá Giges, Coto e o animoso Obriareu habitam, fiéis guardiões de Zeus porta-égide. $[\ldots]$

E os gloriosos aliados de Zeus troveja-alto

habitam casas nos fundamentos de Oceano,

Coto e Giges; quanto a Briareu, sendo valoroso,

fez dele genro o Agita-a-Terra grave-ressoo.

Deu-lhe Flanonda, sua filha, para desposar.

\section{v. 820-880 (Tifeu/Tífon)}

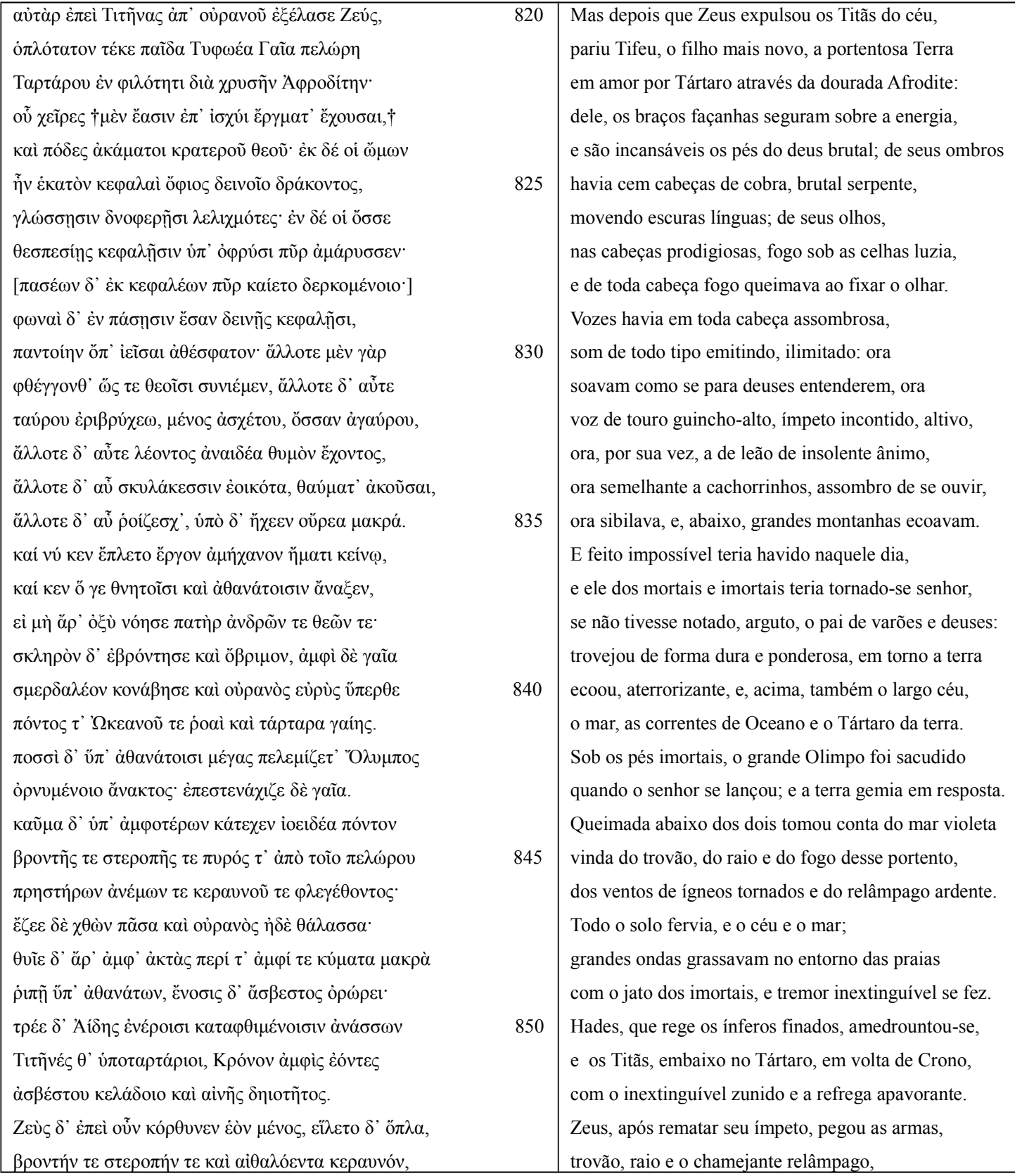
ecoou, aterrorizante, e, acima, também o largo céu, o mar, as correntes de Oceano e o Tártaro da terra. Sob os pés imortais, o grande Olimpo foi sacudido quando o senhor se lançou; e a terra gemia em resposta. Queimada abaixo dos dois tomou conta do mar violeta vinda do trovão, do raio e do fogo desse portento, dos ventos de ígneos tornados e do relâmpago ardente.

Todo o solo fervia, e o céu e o mar; grandes ondas grassavam no entorno das praias com o jato dos imortais, e tremor inextinguível se fez. Hades, que rege os ínferos finados, amedrountou-se, e os Titãs, embaixo no Tártaro, em volta de Crono, com o inextinguível zunido e a refrega apavorante. Zeus, após rematar seu ímpeto, pegou as armas, trovão, raio e o chamejante relâmpago,

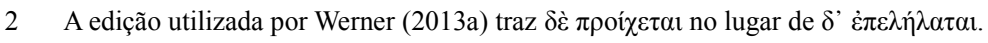




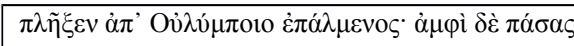

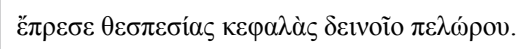

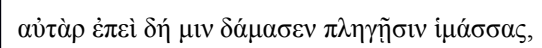

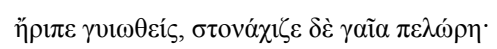

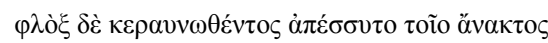

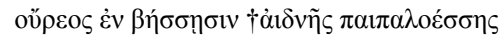

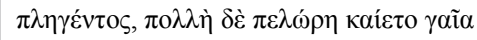

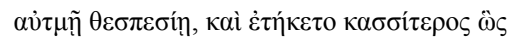

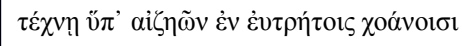

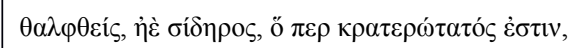

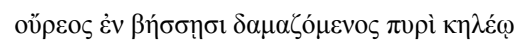

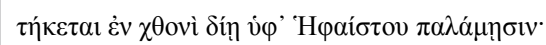

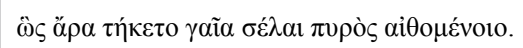

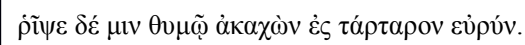

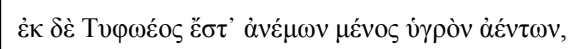

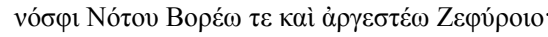

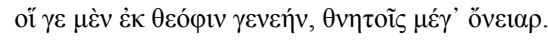

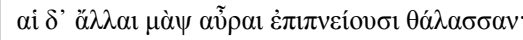

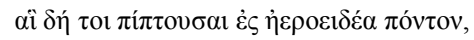

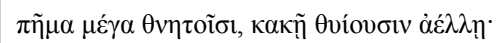

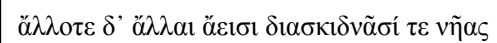

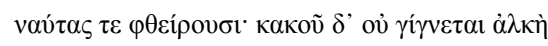

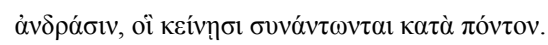

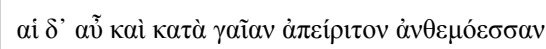

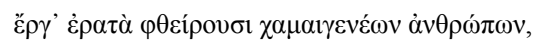

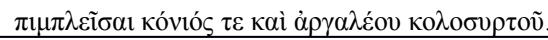

855

e golpeou-o arremetendo do Olímpo; em volta, todas as cabeças prodigiosas do terrível portento queimou.

Após subjugá-lo, tendo-o com golpes fustigado,

o outro tombou, aleijado, e gemeu a portentosa Terra.

E a chama fugiu desse senhor, relampejado,
860

.

nos vales de montanha escura, escarpada,
ao ser atingido, e a valer queimou a terra portentosa
com o bafo prodigioso, e fundiu-se como estanho,
em cadinhos bem furados, com arte por varões
aquecido, ou ferro, que é a coisa mais forte,
nos vales de montanha subjugado por fogo ardente
funde-se em solo divino pelas mãos de Hefesto -
assim fundiu-se a terra com a fulgência do fogo chamejante.
E arremessou-o, atormentado no ânimo, no largo Tártaro.
De Tifeu é o ímpeto dos ventos de úmido sopro,
exceto Noto, Bóreas e o clareante Zéfiro:
que são de cepa divina, grande ajuda aos mortais.
As outras brisas à toa sopram no oceano;
quanto a elas, caindo no mar embaciado,
grande desgraça aos mortais, correm com rajada má:
sopram p'ra cá depois p'ra lá, despedaçam naus
e nautas destróem; contra o mal não há defesa
para homens que com elas se deparam no mar.
Essas também, na terra sem fim, florida,
campos amados destróem dos homens na terra nascidos,
enchendo-os de poeira e confusão aflitiva.




\section{EXCERTOS do Hino Homérico a Apolo}

\section{v. 300-374 (serpente e Tifeu)}

\begin{tabular}{|c|c|c|}
\hline 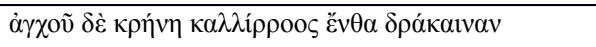 & 300 & Perto há uma fonte de bela corredeira, ali o senhor \\
\hline 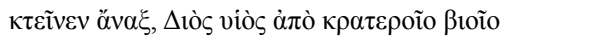 & & filho de Zeus, matou, com seu arco enérgico, uma serpente \\
\hline 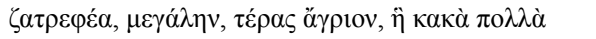 & & robusta, grande, um monstro feroz que fazia muitos males \\
\hline 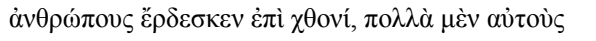 & & aos homens sobre a terra; muitos males a eles, \\
\hline 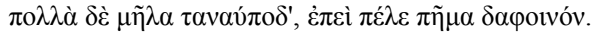 & & e muitos males aos carneiros de patas finas. Era um tormento de sangue. \\
\hline 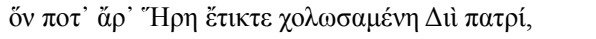 & & que Hera, um dia, pariu irada com Zeus pai, \\
\hline 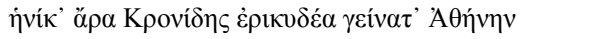 & & porque o Cronida deu à luz a gloriosa Atena \\
\hline 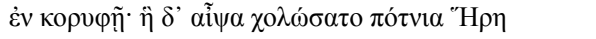 & & de sua cabeça. Prontamente, a soberana Hera irou-se, \\
\hline 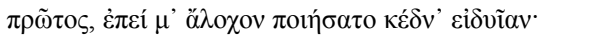 & & após me ter feito esposa e devotada mulher. \\
\hline 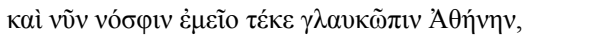 & & Agora, longe de mim, pariu Atena de olhos glaucos, \\
\hline 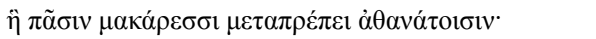 & 315 & distinta de todos os bem-aventurados imortais. \\
\hline 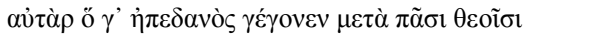 & & No entanto, meu filho Hefesto, entre todos os deuses, \\
\hline 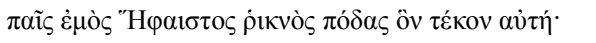 & & nasceu deficiente, deformado nos pés, ele que eu pari sozinha. \\
\hline 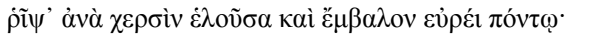 & & De imediato, agarrando-o com minhas mãos, lancei-o no vasto mar, \\
\hline 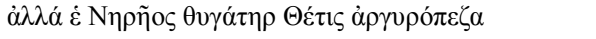 & & mas Tétis de pés prateados, filha de Nereu, \\
\hline 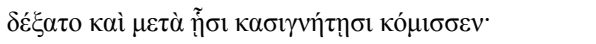 & 320 & recebeu-o, e o criou com suas irmãs.” \\
\hline 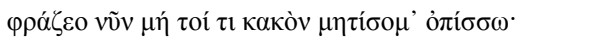 & $325 \mathrm{a}$ & Toma cuidado! Que um mal contra ti mais tarde não trame! ${ }^{1}$ \\
\hline 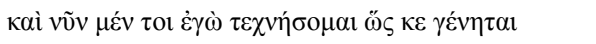 & & Agora, também eu empregarei minha arte para que nasça \\
\hline 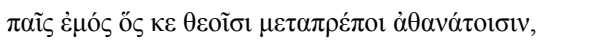 & & meu filho, que seja distinto entre os deuses imortais, \\
\hline 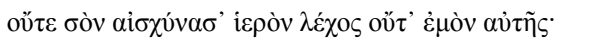 & & sem macular teu leito sagrado nem o meu próprio. \\
\hline 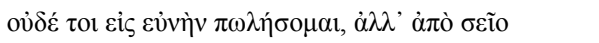 & & Não irei para tua cama, mas longe de ti estando \\
\hline 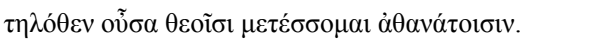 & 330 & estarei entre os deuses imortais". \\
\hline 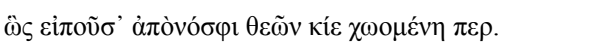 & & Assim falando, completamente irritada, ia para longe dos deuses. \\
\hline 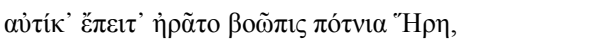 & & Em seguida, a soberana Hera de olhos grandes suplicou; \\
\hline 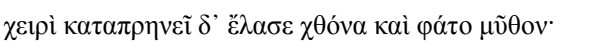 & & com a palma da mão bateu na terra, e falou esta palavra: \\
\hline 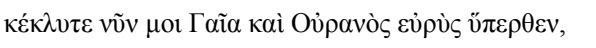 & & "Ouvi-me, agora, Gaia e o vasto Urano, do alto, \\
\hline 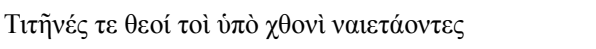 & 335 & e vós, deuses Titãs, que habitais sob a terra \\
\hline 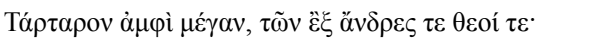 & & ao redor do grande Tártaro, a partir de quem há homens e deuses. \\
\hline 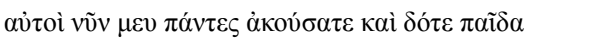 & & Vós todos que me escutai agora, dai-me um filho, \\
\hline 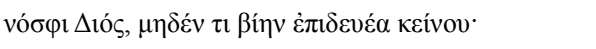 & & longe de Zeus, que na força não seja inferior àquele, \\
\hline 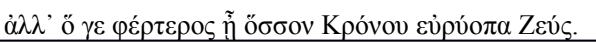 & & mas que seja forte como o longividente Zeus, filho de Crono". \\
\hline
\end{tabular}

1 O verso 325a não foi considerado pela tradução de Massi (em Ribeiro Jr., 2010). A tradução é de Cabral (2004). 


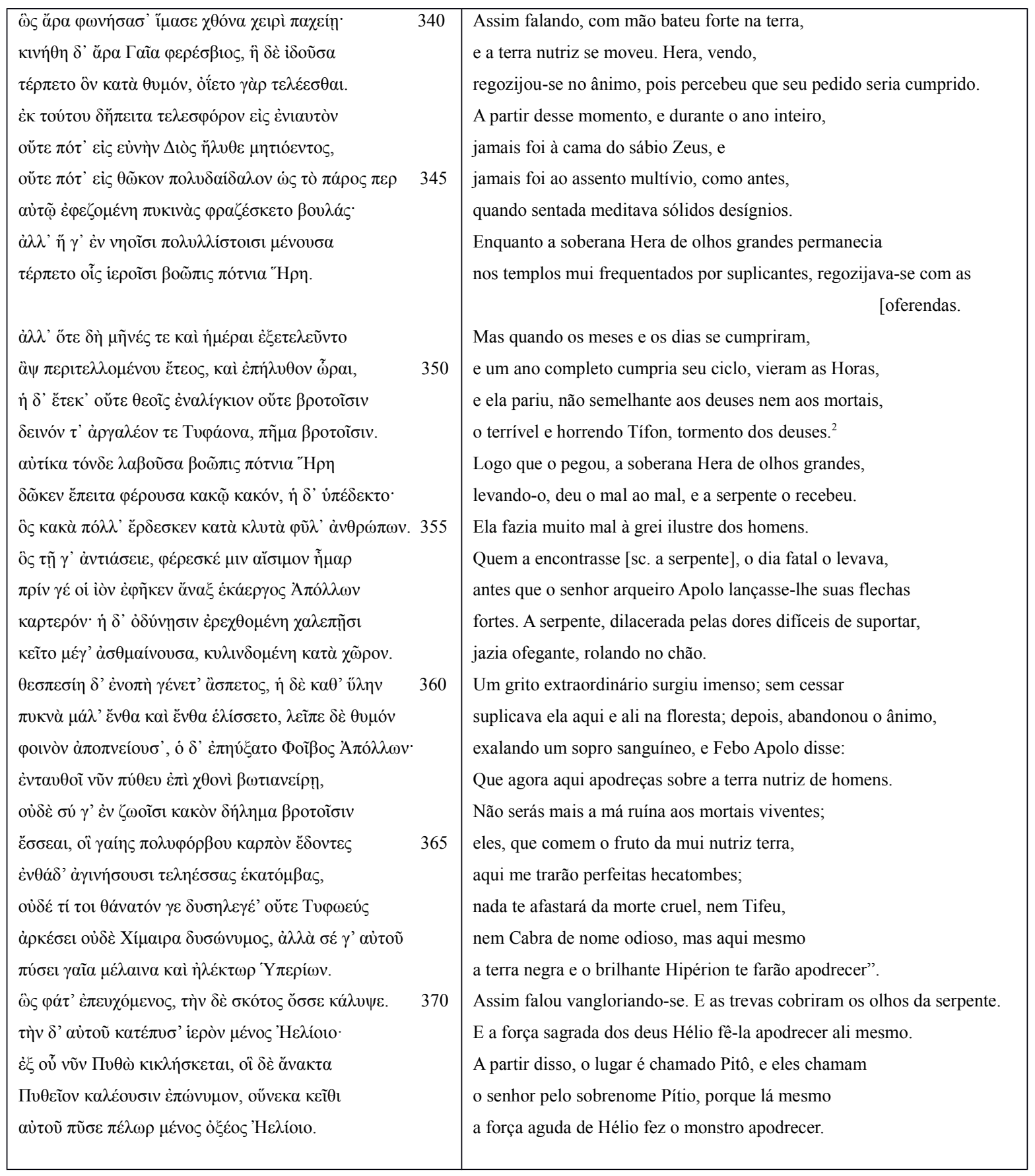

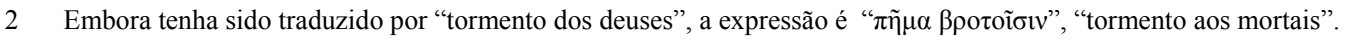




\section{v. 400-404; 414-416 (golfinho)}

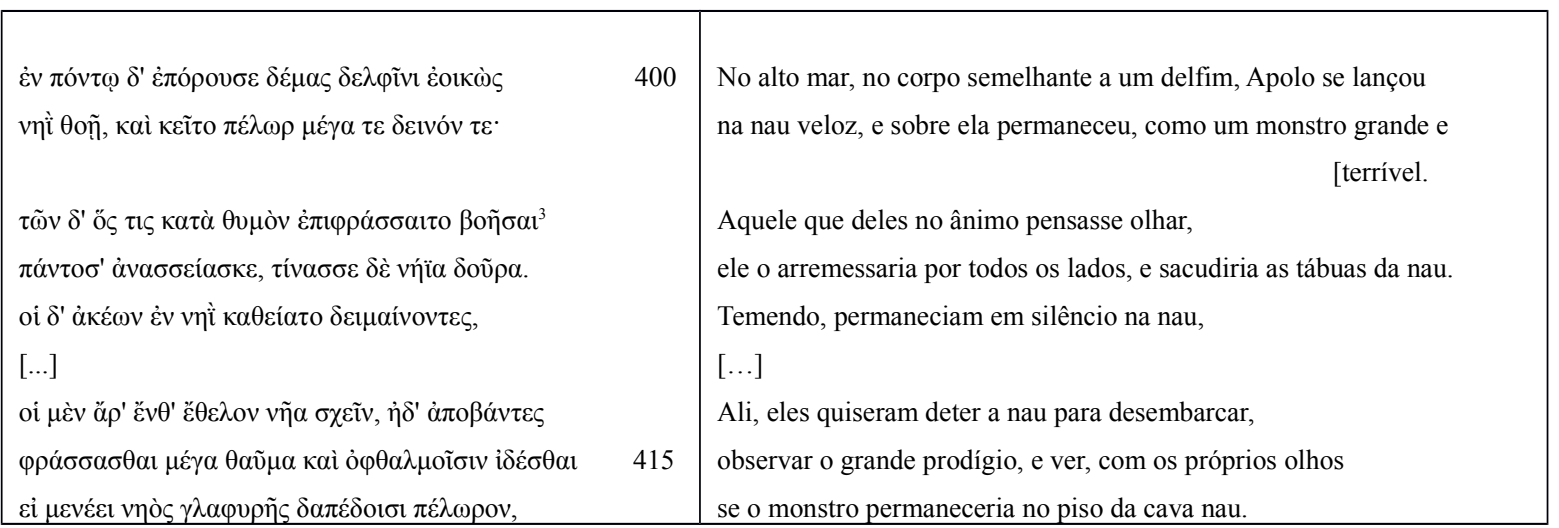

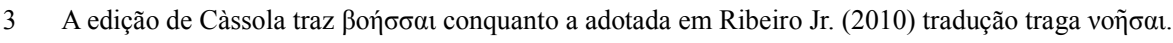


APÊNDICE H

\section{EXCERTOS DA ODISSEIA}

\subsection{6-117 (ciclopes)}

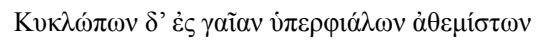

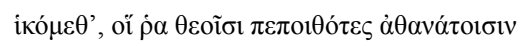

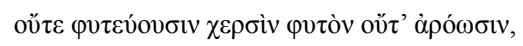

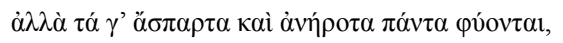

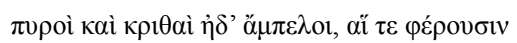

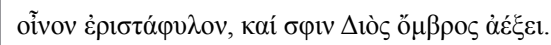

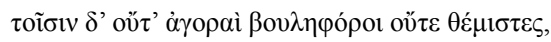

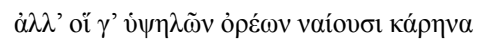

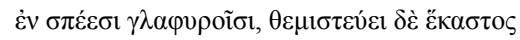

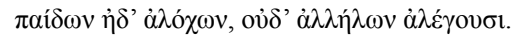

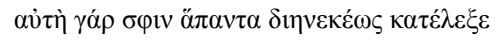

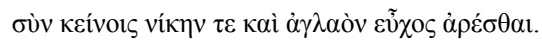

E à terra dos ciclopes, soberbos, desregrados, chegamos, eles que, confiantes nos deuses imortais, não plantam árvores com as mãos nem aram, mas, sem semear nem arar, isso tudo germina, trigo, cevada e videiras, que produzem vinho de grandes uvas que a chuva de Zeus lhes fomenta. Eles não têm assembleias decisórias nem normas, mas habitam os cumes de montes elevados em cavas grutas, e cada um impõe normas sobre filhos e mulheres, e não cuidam uns dos outros. ela tudo lhes contara, do início ao fim, como com aqueles vitória e triunfo radiante granjear.

\subsection{1-192 (Polifemo)}

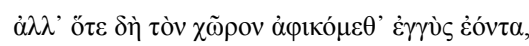

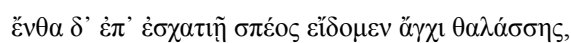

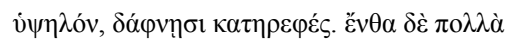

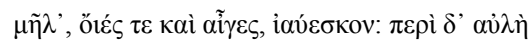

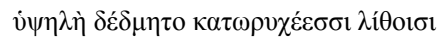

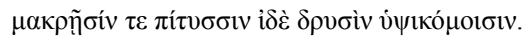

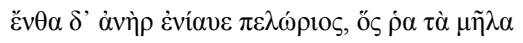

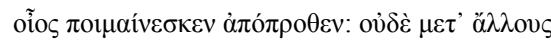

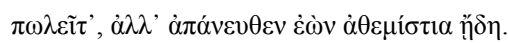

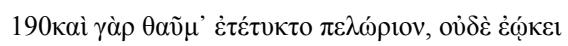

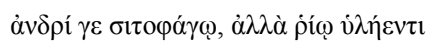

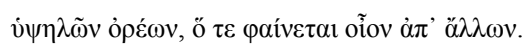

Mas ao chegarmos a esse lugar que perto ficava, lá vimos, no extremo, uma caverna junto ao mar, alta, à sombra de loureiros. Lá, grande rebanho, ovelhas e cabras, pernoitava; em torno, cerca alta se construíra com blocos de uma pedreira, com grandes pinheiros e carvalhos alta-copa.

Lá pernoitava um varão, portentoso, ele que o rebanho, sozinho, apascentava, afastado: aos outros não visitava, mas, longe vivendo, normas ignorava. De fato, era um assombro portentoso, não parecia um varão come-pão, mas um pico matoso dos altos montes, que surge só, longe dos outros.

\subsection{0-134 (Lestrigões)}

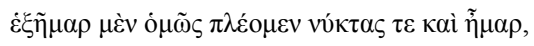

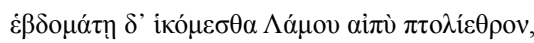

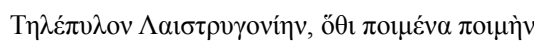

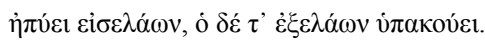

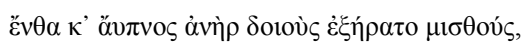

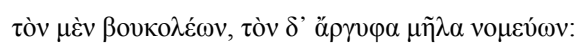

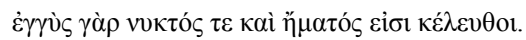
' '
Seis dias navegamos sem parar, de noite e de dia, no sétimo chegamos à escarpada cidade de Lamos, a lestrigônia Telépilos, onde pastor a pastor chama, trazendo o rebanho, e o outro, levando, responde. Lá o varão insone conquistaria dupla paga, uma, apascentando bois, outra, vigiando brancas ovelhas: próximos são os caminhos da noite e do dia. Lá fomos ao porto glorioso, que circunda rochedo 


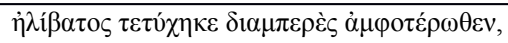

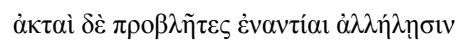

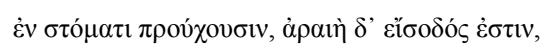

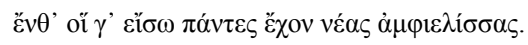

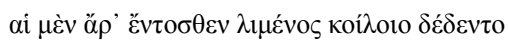

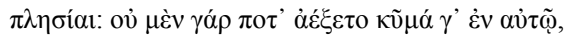

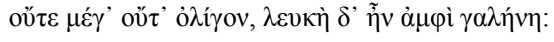

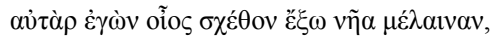

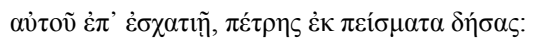

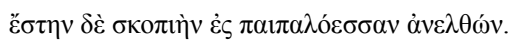

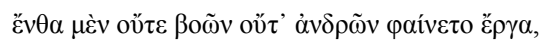

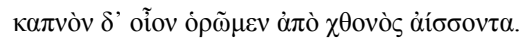

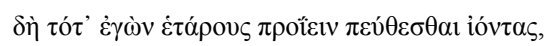

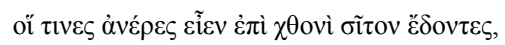

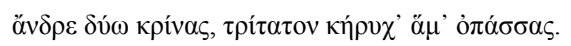

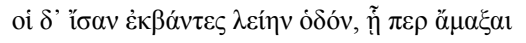

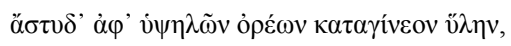

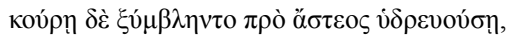

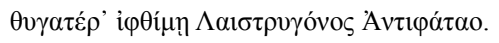

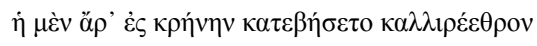

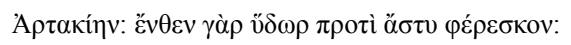

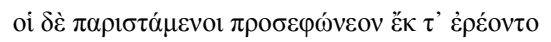

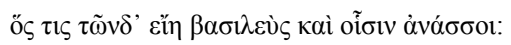

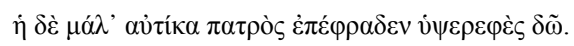

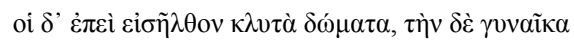

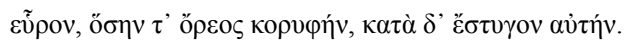

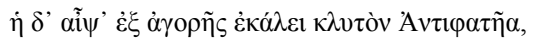

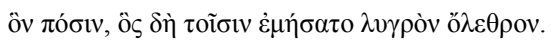

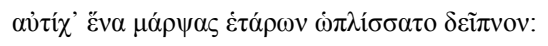

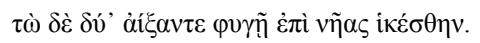

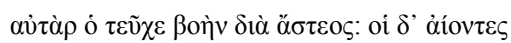

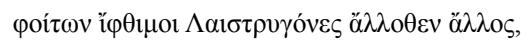

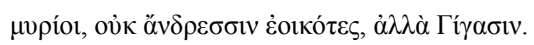

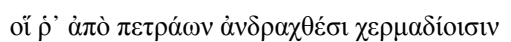

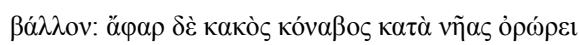

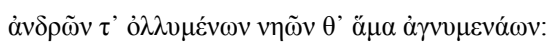

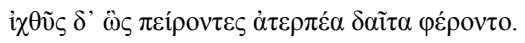

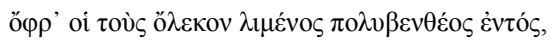

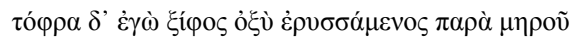

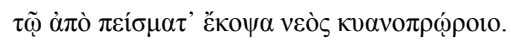

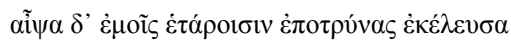

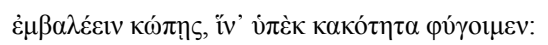

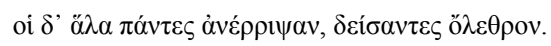

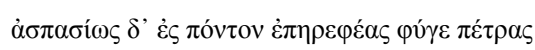

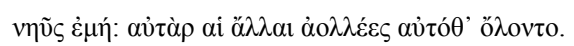

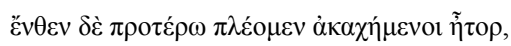

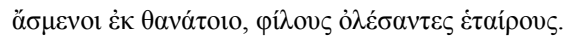

alcantilado por toda a extensão, de ambos os lados,

e cabos salientes, um defronte ao outro,

90

na boca projetam-se, e a entrada é estreita -

lá dentro eles aportaram, todos, as naus ambicurvas.

Eis que elas, dentro do cavo porto, foram presas

lado a lado; de fato, nele nunca crescia uma onda,

grande ou pequena, e havia luzidia calmaria.

Somente eu contive fora a negra nau,

aí mesmo no extremo, e com cabos prendi à rocha.

Pus-me de pé após subir à escarpada atalaia;

lá não havia campos arados por bois ou varões,

vimos somente fumaça irrompendo da terra.

Então ordenei que companheiros investigassem

quem seriam os varões que sobre a terra comem pão;

dois escolhi e um terceiro, arauto, enviei com eles.

Desembarcaram e foram à urbe por via plana,

de onde carros, dos altos montes, desciam com madeira.

Uma moça encontraram diante da urbe pegando água,

a filha altiva do lestrigão Antífates.

Ela descera até a fonte, a belas-correntes

Artácia: de lá até a urbe carregavam água.

Eles, de pé ao lado, interpelavam-na e inquiriam

quem era o rei deles e sobre quem regia.

De pronto ela indicou a grandiosa casa do pai.

Eles, após chegarem à gloriosa casa, a esposa

acharam, alta como o pico de um monte, e a abominaram.

Ela logo fez chamar da ágora o glorioso Antífates,

seu marido, que contra eles armou funesto fim.

Presto agarrou um companheiro e preparou a refeição;

os outros dois, fugindo em disparada, chegaram às naus.

E aquele lançou um grito pela urbe; tendo ouvido,

acorriam os altivos lestrigões, cada um de um lado,

miríades, não assemelhados a varões, mas a gigantes.

Dos rochedos, lançavam penedos pesados demais

para varões; logo nefasto estrondo as naus percorreu,

de homens destruídos e naus destroçadas:

tal peixes trespassados, acabaram em detestável jantar.

Enquanto eles os destruíam no porto mui profundo,

eu, após puxar da coxa a afiada espada,

com ela cortei os cabos da nau proa-cobalto;

logo pedi a meus companheiros, incitando-os,

que tocassem os remos para escaparmos do dano:

130

eles todos se apressaram, pois temeram o fim.

Com satisfação, mar adentro escapou das rochas salientes minha nau; as outras, em conjunto, lá ficaram destruídas.

Então navegamos para diante, atormentados no coração,

voltando da morte, após perder caros companheiros. 
12.39-54 e 12.158-200 (Sirenas)

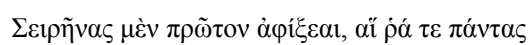

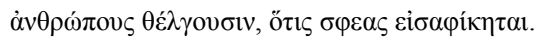

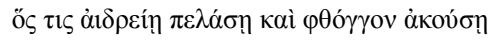

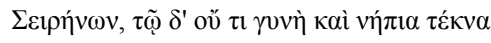

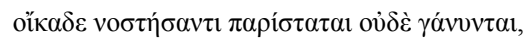

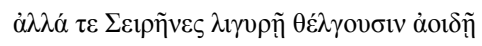

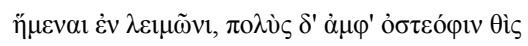

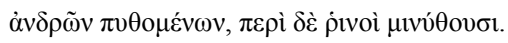

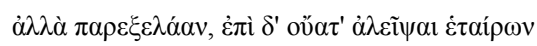

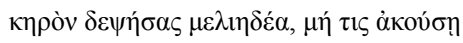

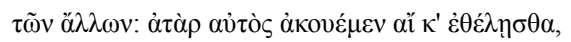

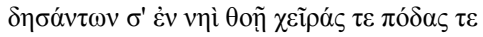

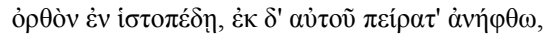

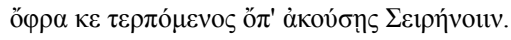

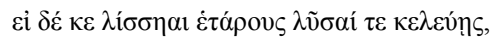

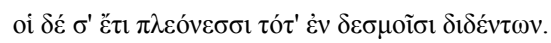

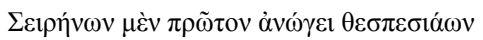

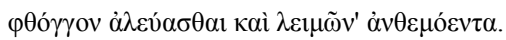

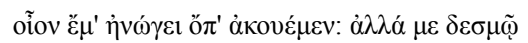

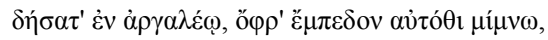

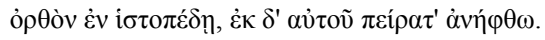

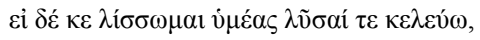

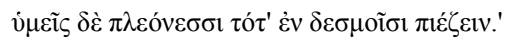

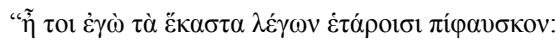

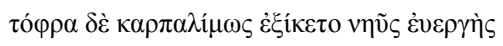

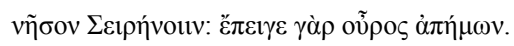

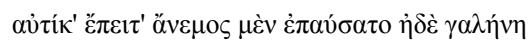

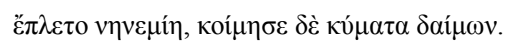

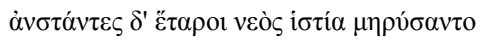

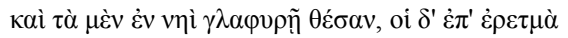

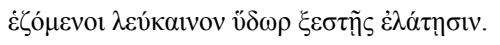

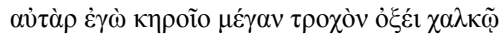

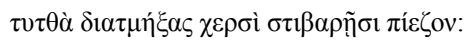

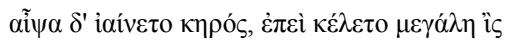

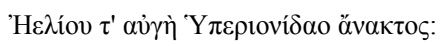

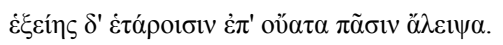

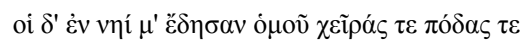

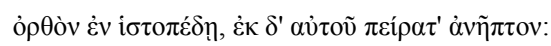

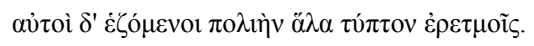

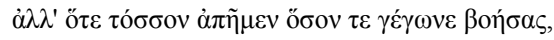

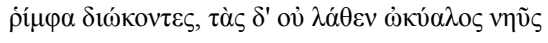

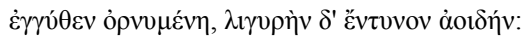

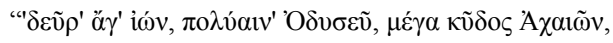

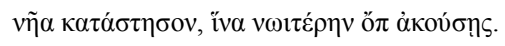

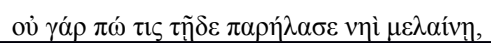

'Primeiro alcançarás as Sirenas, elas que a todos

40
'Das Sirenas prodigiosas, primeiro, mandou que evitemos sua voz e o prado florido. com nó apertado prendei, para, imóvel, eu aí mesmo quedar, reto no mastro, e nele fiquem amarrados os cabos. Se eu vos suplicar e solicitar que me soltem, que então vós com mais laços me amarreis'. Tudo isso relatei e expus aos companheiros; nisso a nau engenhosa, célere, alcançou a ilha das Sirenas; uma brisa favorável a impelia. Logo depois o vento parou, uma calmaria surgiu sem ventos, e a divindade amainou as ondas.

De pé, companheiros enrolaram a vela da nau.

Puseram-na na cava nau e eles, junto aos remos sentados, branquearam a água com os pinhos polidos. E eu a um grande naco de cera, com bronze afiado, fragmentei e apertava com mãos robustas.

Logo a cera amoleceu, pois impeliu-a a grande pressão e o raio de Sol, o senhor Hipérion; tampei os ouvidos de cada um dos companheiros. Na nau, prenderam-me mãos e pés, por igual, reto no mastro, e nele amarraram os cabos; sentados, golpeavam o mar cinzento com remos. Mas quando estávamos à distância de um grito, rápido viajando, elas não ignoraram a nau saltadora surgir próxima, e deram vazão a canto agudo: 'Vem cá, Odisseu muita-história, grande glória dos aqueus, ancora tua nau para ouvires nossa voz. Nunca ninguém passou por aqui, em negra nau, 


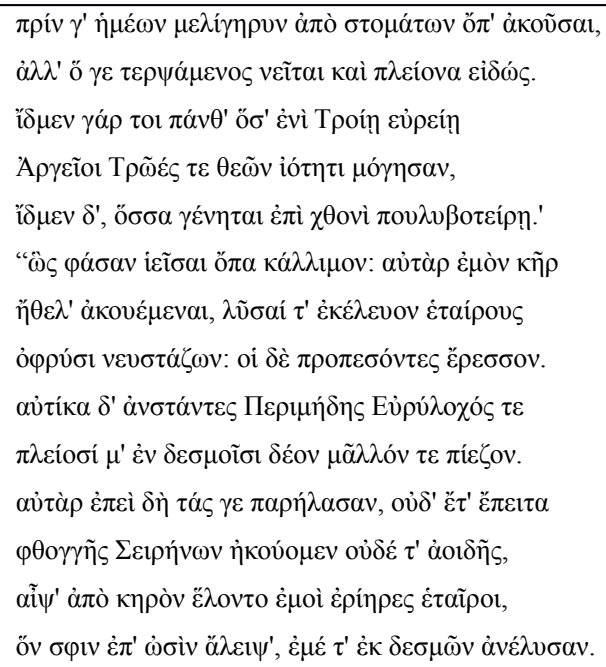

sem antes ouvir a melíflua voz que vem de nossa boca; mas ele se deleita e parte com mais saber.

De fato, sabemos tudo que, na extensa Troia,
190 aguentaram argivos e troianos por obra dos deuses.

Sabemos tudo que ocorre sobre a terra nutre-muitos'.

Assim falaram, lançando belíssima voz. Meu coração quis ouvir, e num movimento das celhas solicitei aos companheiros que me soltassem; eles remavam. De pronto, ergueram-se Perimedes e Euríloco, e com mais laços prenderam-me e apertaram bem. Depois que por elas passamos, então nem mais ouvimos o tom das Sirenas nem seu canto, e presto meus leais companheiros retiraram a cera que tampara seus ouvidos, e soltaram-me dos laços.

\subsection{0-110 (Cila e Caríbdis); 12.112-126 (Cila); 12.208-263 (Cila e Caríbdis)}

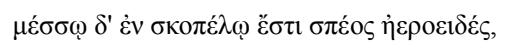

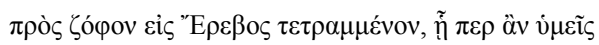

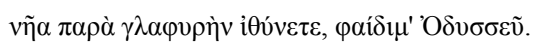

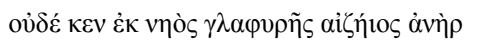

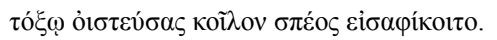

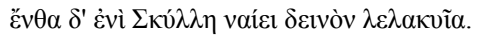

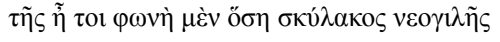

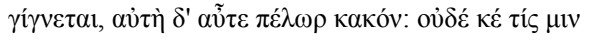

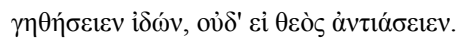

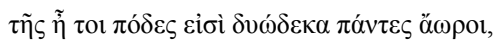

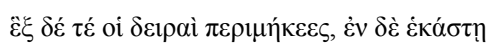

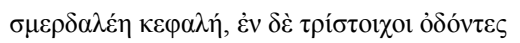

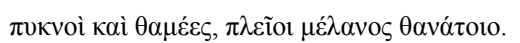

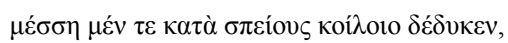

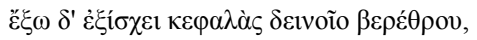

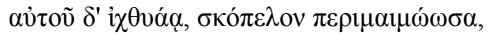

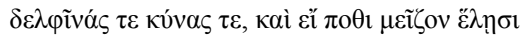

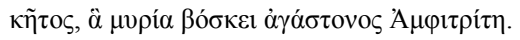

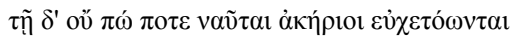

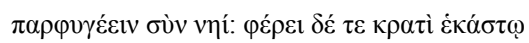

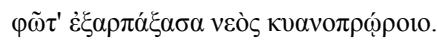

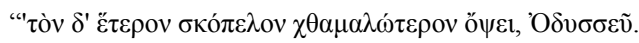

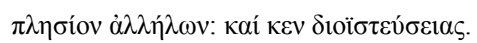

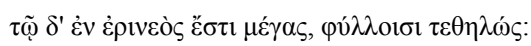

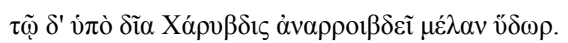

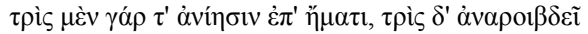

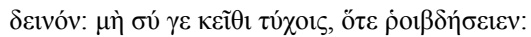

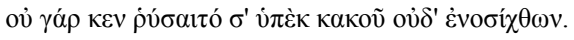

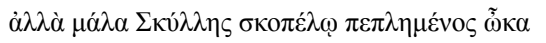

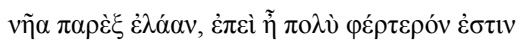

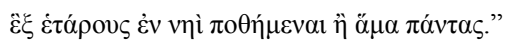

'No meio do penedo há uma gruta penumbrosa, voltada para oeste, rumo ao Érebo, e vós junto dela dirigireis a cava nau, ilustre Odisseu.

Da côncava nau nem um varão animoso, com arco flechando, alcançaria a cava gruta.

É aí que mora Cila de latido assombroso.

Sua voz ao ladrar de um filhote de cão equivale, mas ela mesma é portento vil; ninguém se jubilaria ao vê-la, nem mesmo um deus. Ela tem doze pés, todos sem panturrilha, e seis são os pescoços bem longos, e, em cada um, uma aterrorizante cabeça com dentes em três fileiras, cerrados e múltiplos, cheios de negra morte. Até a metade na cava gruta está embrenhada, e mantém as cabeças fora da furna assombrosa;

lá mesmo pesca, em volta do penedo, buscando delfins, focas e, se acaso pega, maior portento, dos que, milhares, cria Anfitrite alto-gemido. Nunca se ouviram nautas, incólumes, proclamar ter escapado com a nau; leva, em cada cabeça, um herói, após arrancá-lo da nau proa-cobalto. 'O outro penedo verás que é mais raso, Odisseu, os dois próximos entre si, à distância de uma flecha. Nele há uma grande figueira, abundante em folhas; abaixo dela, a divina Caríbdis sorve negra água.

Três vezes esguicha ao dia, três vezes sorve, assombrosa: que lá não te encontres durante o sorvo; do mal não te protegeria nem mesmo o treme-solo. Rápido, do penedo de Cila bem achegando a nau, passa ao largo, pois é muito melhor lastimar da nau seis companheiros que todos. 


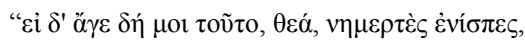

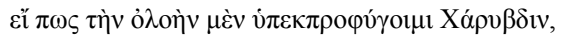

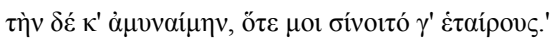

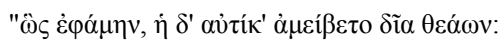

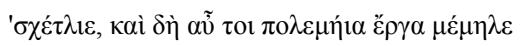

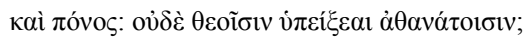

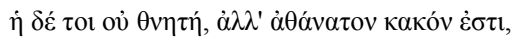

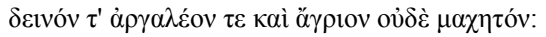

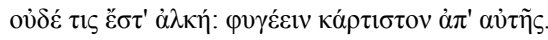

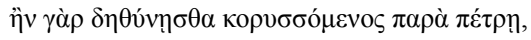

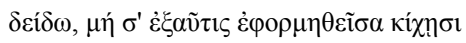

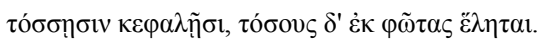

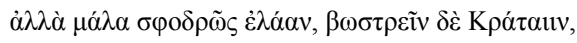

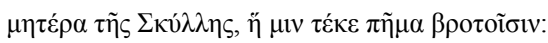

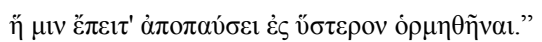

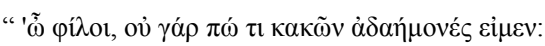

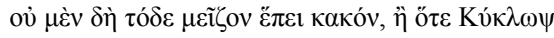

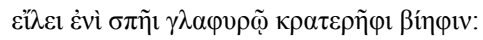

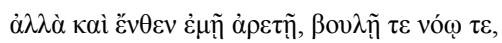

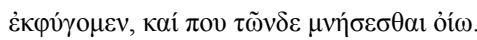

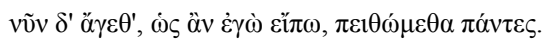

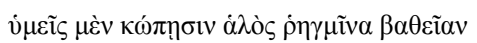

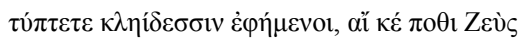

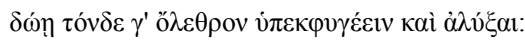

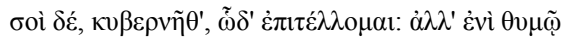

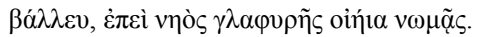

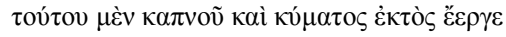

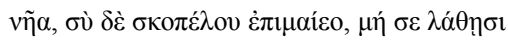

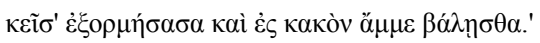

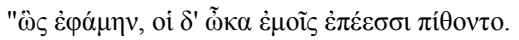

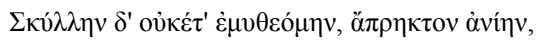

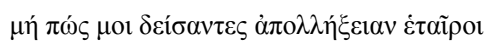

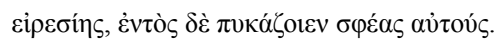

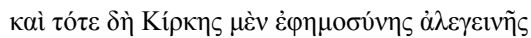

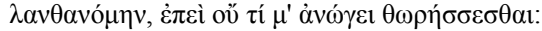
$\alpha$ ơ่น̀̀

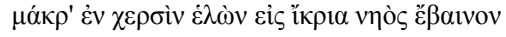

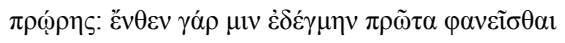

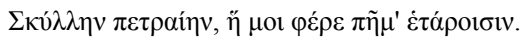

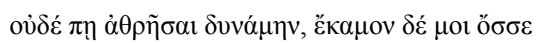

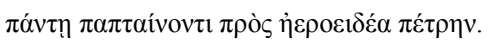

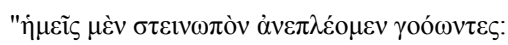

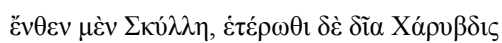

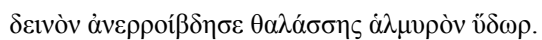

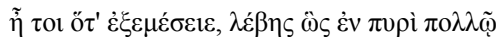

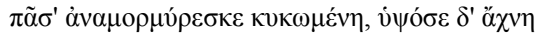

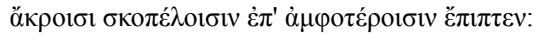

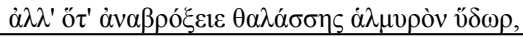

'Vamos, deusa, diga-me sem evasivas

se acaso poderia esquivar-me da nefasta Caríbdis

e resistir à outra quando ela tentar lesar meus companheiros'

Assim falei, e ela logo respondeu, deusa divina:

'Terrível! Não é que os feitos marciais te ocupam tanto,

o labor, que não te submetes a deuses imortais?

Ela não é mortal, vê, mas um mal imortal,

assombrosa, aflitiva, selvagem e indomável;

não é caso de bravura: o melhor é dela fugir.

Se te demoras, armado, junto à pedra,

temo que, de novo atacando, a ti alcance,

as cabeças todas, e agarre número igual de heróis.

Mas passa com todo ímpeto, grita por Crátaiis,

a mãe de Cila, que a gerou como desgraça aos mortais.

Ela então a impedirá de atacar uma segunda vez."

'Amigos, por certo não somos inexpertos em males.

Este mal, vede, não é maior que quando o ciclope

prendeu-nos na cava gruta com violência brutal;

mas também lá, com minha excelência, plano e mente,

escapamos, e creio que disso lembraremos.

Mas vamos, o que eu falar, obedeçamos todos.

Com os cabos, golpeai a profunda rebentação do mar,

sentados junto às correias, esperando Zeus

conceder que evadamos e escapemos desse fim;

e para ti, timoneiro, isto imponho, e no ânimo

lança-o, pois controlas o leme da cava nau:

a nau, afasta para longe daquela fumaça e da onda,

busca o penedo, e que a nau de ti não escape,

mudando de rumo, e nos lances no mal'.

Assim falei, e presto obedeceram minhas palavras.

De Cila não mais falei, flagelo invencível,

para que, temerosos, os companheiros não abdicassem

da remada e se abrigassem a si mesmos.

E então a ordem pungente de Circe

negligenciei, pois pedira que não me armasse;

eu entrei na armadura gloriosa e duas lanças

grandes peguei nas mãos e subi na plataforma da nau,

na proa: aí esperei que primeiro surgisse

Cila rochosa, que trazia desgraça aos companheiros.

Nenhures pude vislumbrá-la, e meus olhos cansaram,

esquadrinhando em toda direção a rocha embaciada.

E nós, entre lamentações, navegávamos o estreito:

de um lado, Cila, de outro, a divina Caríbdis,

terrível, sorvia água salina do mar.

Quando regurgitava, como caldeirão em fogo alto,

efervescia toda, agitada, e, para o alto, a espuma

tombava sobre os picos dos dois penedos.

Mas quando engolia água salina do mar. 


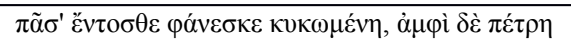

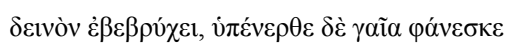

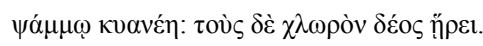

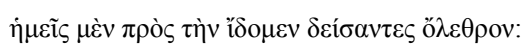
$\tau$

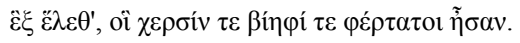

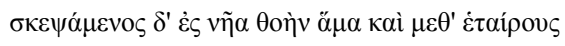

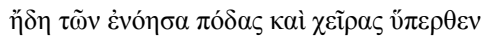

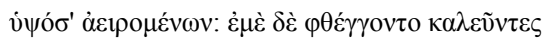

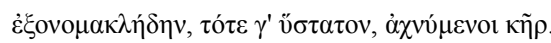

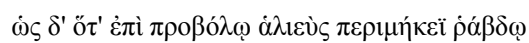

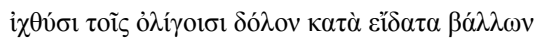

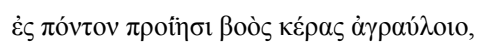

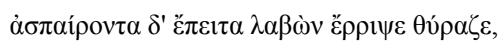

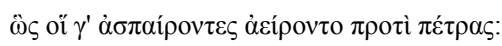

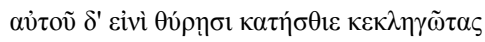

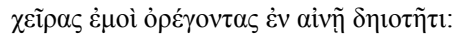

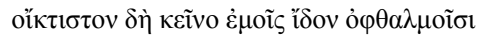

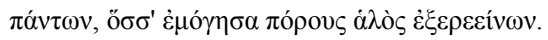

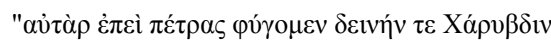

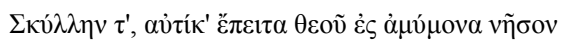

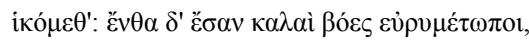

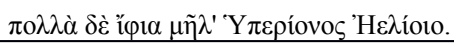

para dentro aparecia inteira, agitada, e ao redor as rochas fremiam, terríveis, e embaixo surgia a terra cobalto com areia; e um medo amarelo atingiu-os. Nós a miramos, temendo o fim; então Cila, da côncava nau, tomou-me seis companheiros, nos braços e força os melhores. Quando fitei a nau veloz e também os companheiros, já vislumbrei seus pés e braços acima, alçados ao alto; e gritavam, chamando-me pelo nome, a última vez, aflitos no coração. Como quando, de um cabo, pescador com longa vara lança petiscos como isca a peixes miúdos, ao mar arremessa um chifre de boi campestre, fisga um peixe, puxa-o para fora e ele se convulsiona assim eles, convulsionando-se, eram alçados à rocha.

Lá na entrada devorou-os enquanto guinchavam, e estendiam os braços a mim em terrível refrega. Foi a mais deplorável cena que vi com meus olhos, de tudo que aguentei, cruzando as rotas do mar. Mas após dos rochedos escaparmos, da fera Caríbdis e de Cila, logo depois à impecável ilha do deus chegamos; lá estavam as belas vacas larga-fronte e muitas ovelhas robustas de Sol Hipérion. 


\section{Grande Cadeia de SERES}

\section{I.1 ICM ("Idealized Cognitive Model") da Grande Cadeia de Seres no pensamento ocidental}

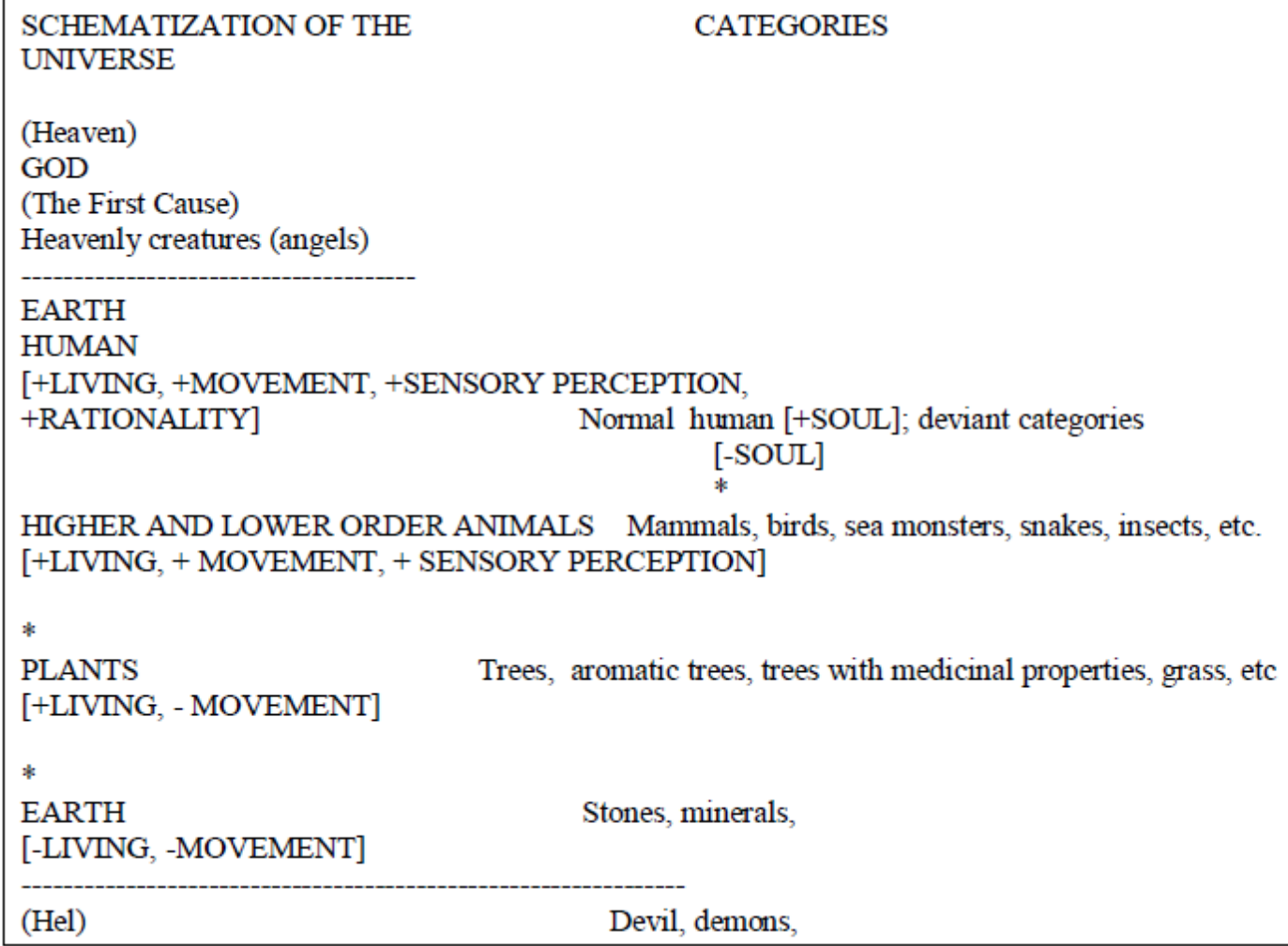

Fonte: Swanepoel (2010, p. 1421). 


\section{I.2 Esboço inicial do ICM (“Idealized Cognitive Model”) da Grande Cadeia de Seres na poesia hexamétrica arcaica}

O que segue é apenas um esboço inicial e geral do que seria a Grande Cadeia de Seres presente na poesia hexamétrica arcaica. Há uma lógica subjacente que diferencia os dois ICMs. No ICM do pensamento ocidental há uma separação entre Céu, Terra e Inferno que se constituem em expressões espaciais do critério fundamental da GCB ("Great Chain of Beings"): a proximidade com Deus. No Céu estão Deus e os anjos, na Terra todos os seres animados e inanimados que a habitam, no inferno os seres que voluntariamente se afastam de Deus. No ICM da poesia hexamétrica arcaica a separação fundamental entre a cadeia básica e a cadeia estendida é mortal e imortal. Dentro da cadeia estendida (imortais), o critério é a relação de proximidade com Zeus enquanto governante do cosmo. Na cadeia básica (mortais), o primeiro critério é o da proximidade com a esfera divina (acima dos humanos) e o segundo (abaixo dos humanos) é se são ou não seres providos de fala. No ICM da poesia hexamétrica não há uma separação rígida do local em que habitam, pois, embora o Olimpo seja o ambiente das divindades olímpicas e o Hades seja reservado aos mortos, o cosmo habitado pelos mortais se imiscui ao habitado pelas divindades, em razão de ser um mundo ainda não "desendeusado".

\section{ESQUEMATIZAÇÃO DO COSMO}

\section{CATEGORIAS}

IMORTAIS ( $\theta \varepsilon o i ́, \not ̋ \theta \alpha ́ v \alpha \tau o l, \delta \alpha i ́ \mu o v \varepsilon \varsigma)$

Divindades olímpicas (Zeus, Hera, Posêidon, Hades, Deméter, Hefesto, Atena, Apolo, Ártemis, Hermes, Ares e Afrodite)

Divindades e entidades não olímpicas e criaturas prodigiosas: Caos e sua linhagem, Terra e sua linhagem (incluindo Titãs, Ciclopes, Centímanos e Tifeu), Mar e sua linhagem (incluindo duas das Górgonas, Pégaso?, Équidna, Espadouro?), Cila e Caríbdis

Raça de ouro

MORTAIS ( $\theta v \eta \tau o i ́)$

Medusa e Gerioneu

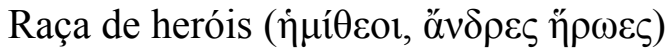

Raça de prata

Raça de bronze

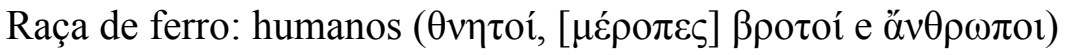

Animais extraordinários e/ou superpoderosos: Orto, Hidra de Lerna, Quimera,

Esfinge, Leão de Nemeia, serpente que guarda o rebanho de ouro

Animais em geral 